
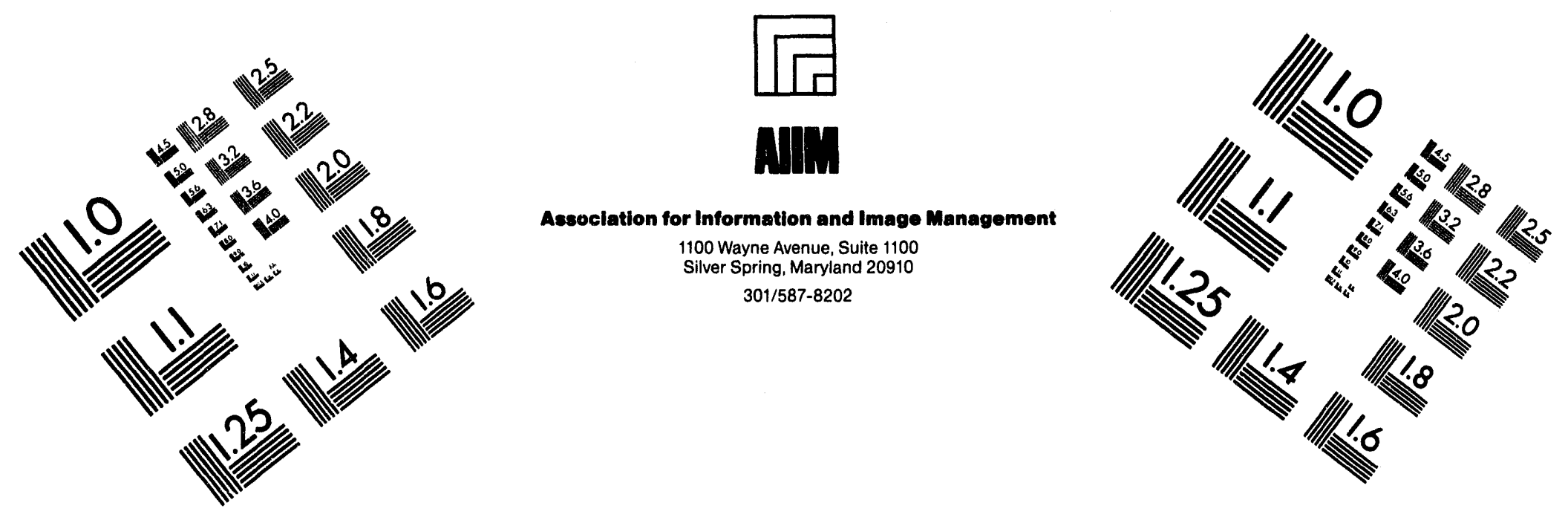

\title{
Centimeter
}

$\begin{array}{llllllllllllllll}1 & 2 & 3 & 4 & 5 & 6 & 7 & 8 & 9 & 10 & 11 & 12 & 13 & 14 & 15 & m m\end{array}$ $\left.\right|_{1}$ Inches
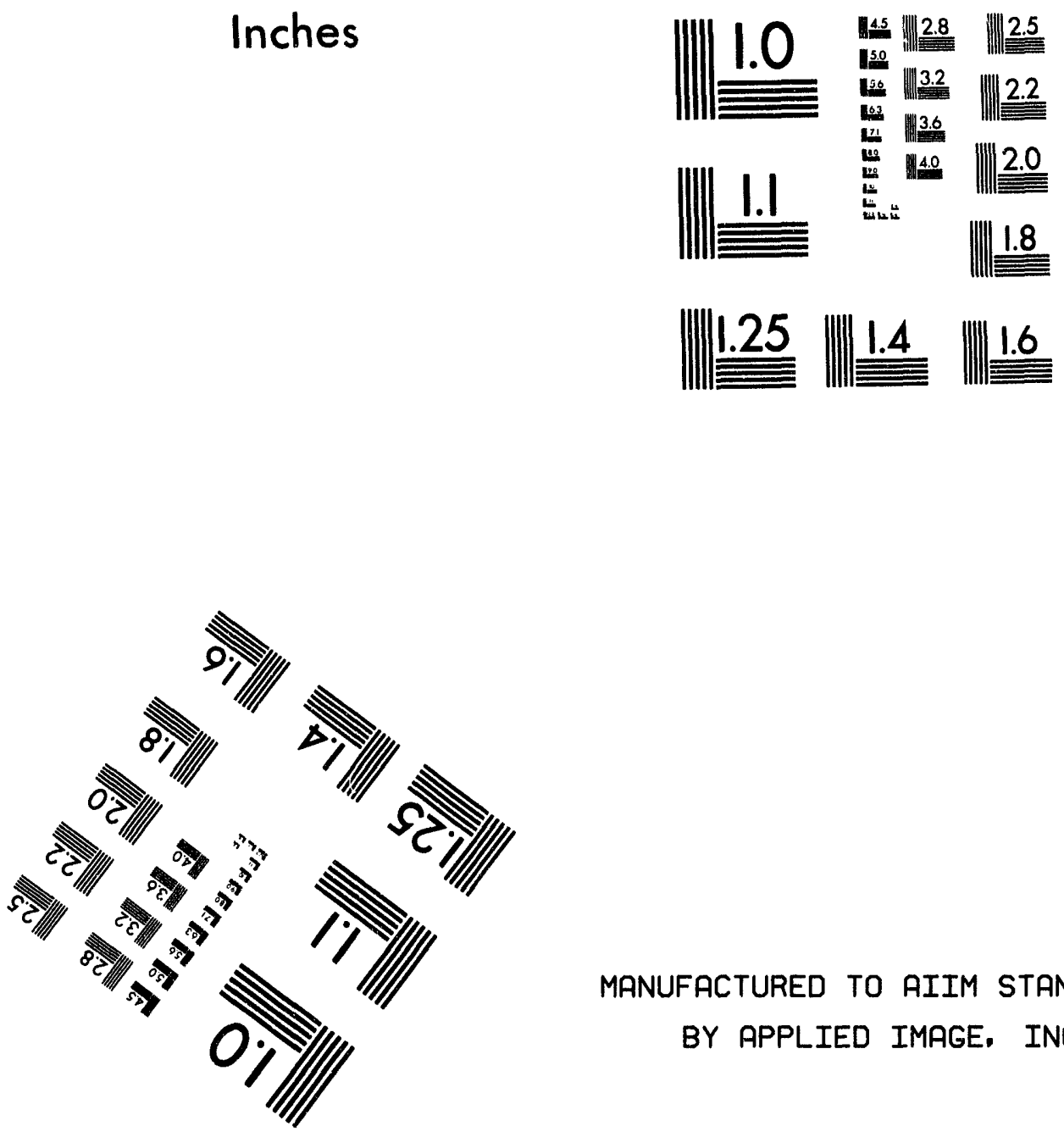

MANUFACTURED TO AIIM STANDARDS

BY APPLIED IMAGE, INC.

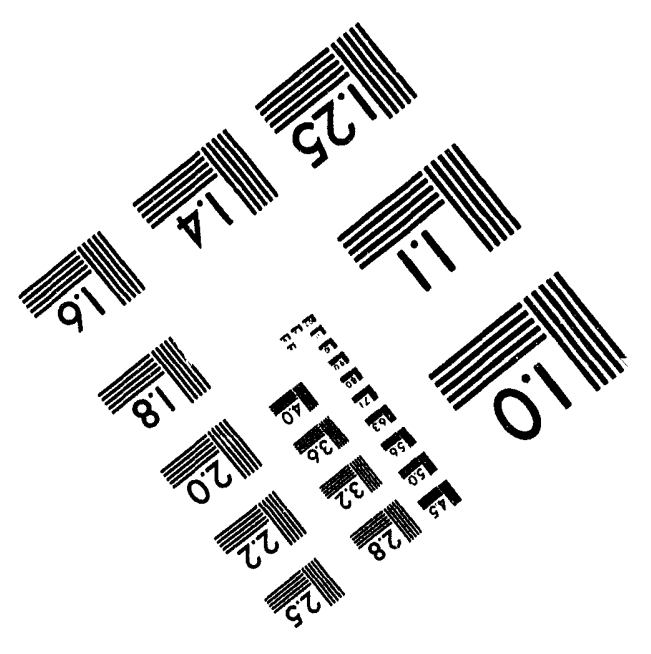



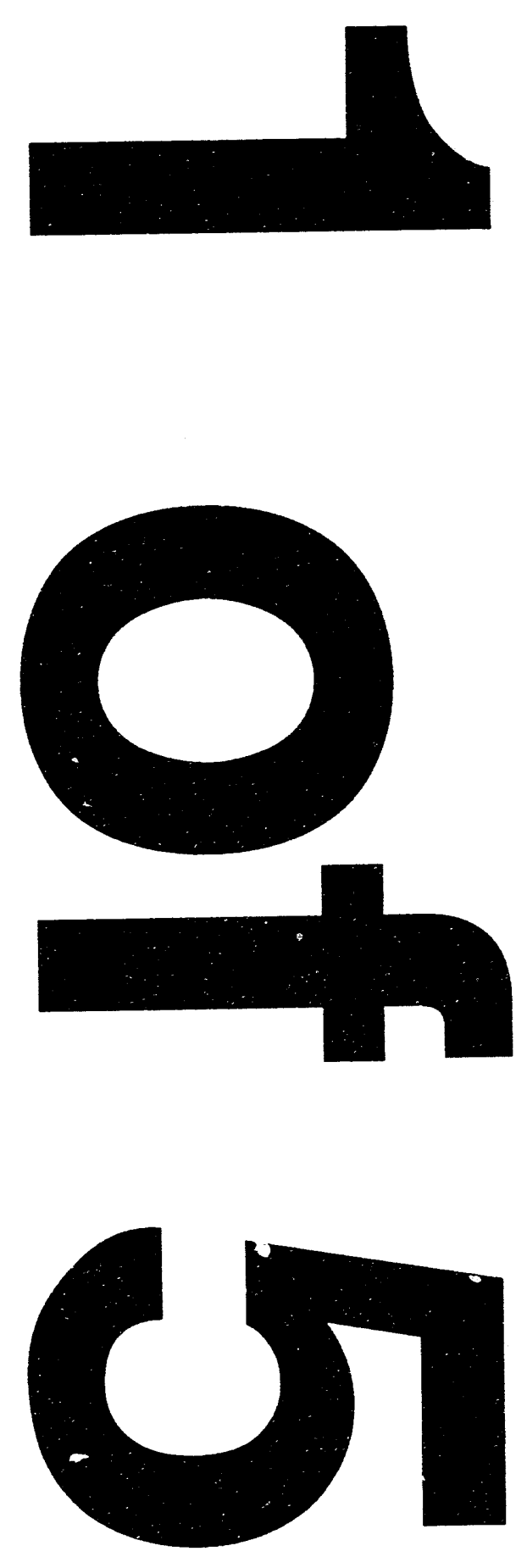


\section{Solid Waste Program Technical Baseline Description}

\section{List of Contributors:}

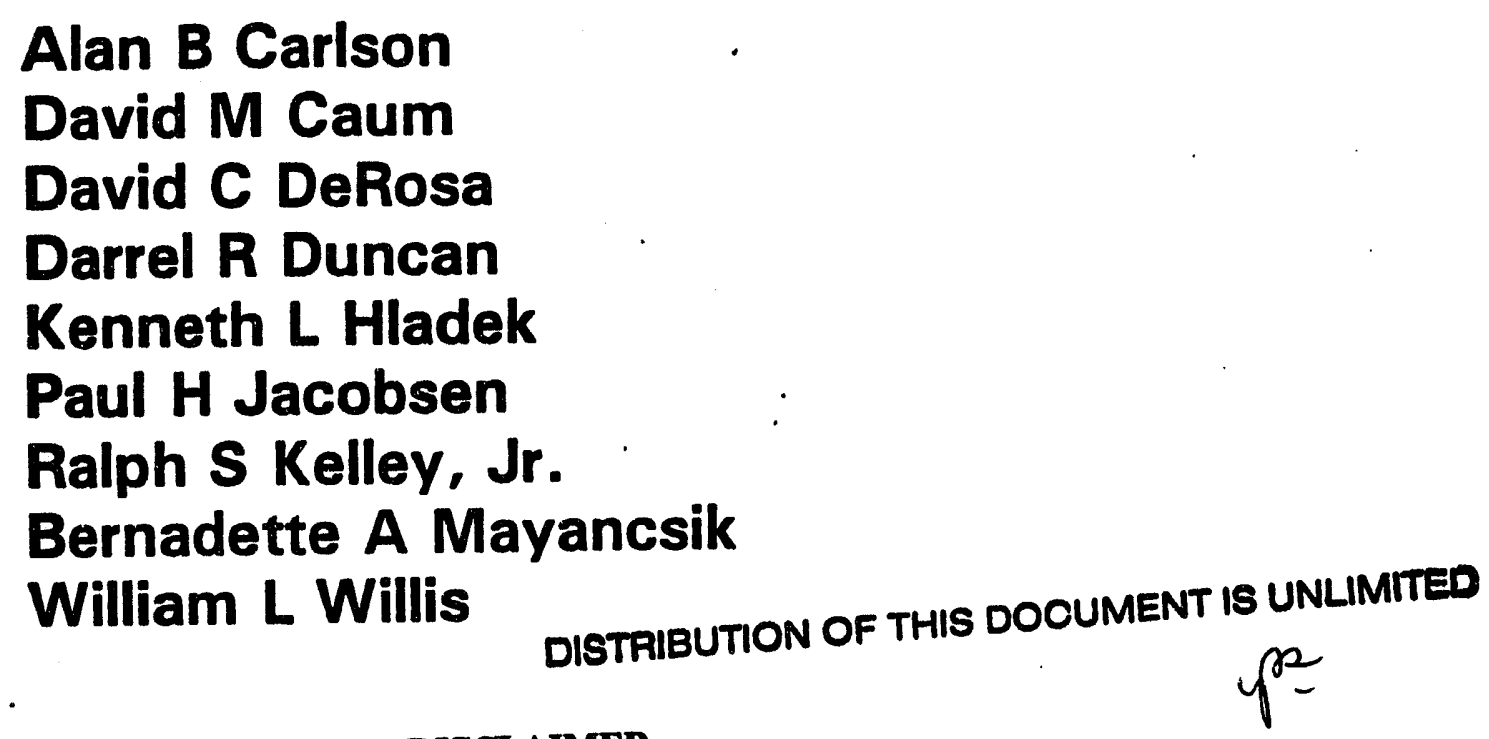

\section{DISCLAIMER}

This report was prepared as an account of work sponsored by an agency of the United States Government. Neither the United States Government nor any agency thereof, nor any of their employees, makes any warranty, express or implied, or assumes any legal liability or responsibility for the accuracy, completeness, or usefulness of any information, apparatus, product, or process disclosed, or represents that its use would not infringe privately owned rights. Referprocess disclosed, or represents the commercial product, process, or service by trade name, trademark, ence hercin to any specific con necessarily constitute or imply its endorsement, recommanufacturer, or otherwise does not necessarily constient or any agency thereof. The views mendation, or favoring by the United States Government or any agency thereor. The ref and opinions of authors expressed herein do not United States Government or any agency thereof. 


\section{Solid Waste Program \\ Technical Baseline Description}

\section{INDEX}

SUMMARY: Executive Summary

VOLUME 1: Mission Analysis

VOLUME 2: Functions and Requirements Analysis

VOLUME 3: System Description

VOLUME 4: Program Documentation

VOLUME 5: Facility and Project Bases

VOLUME 6: Uncertainties 
Solid Waste Program

Technical Baseline Description

\section{Executive Summary}




\section{WHC-SD-WM-RPT-060, REV 0 EXECUTIVE SUMMARY}

The Solid Waste Program Technical Baseline Description provides a detailed compilation of information that describes the current basel ine of the Solid Waste Program. The Snlid Waste Program Technical Baseline Description also provides the basis for the current baseline.

\section{PURPOSE}

The Solid Waste Program Technical Baseline Description employs a system engineering approach to establish the program's technical baseline. The purpose of this document is to view the program as a single system and document the external and internal interfaces necessary to successfully manage a program of this magnitude. By defining the progran's baseline, the effects of uncertainties and changes (internally and externally driven) to key elements of the program can be understood. Impacts of these changes to the mission and the functions of the program can be assessed and controlled.

\section{APPROACH}

The approach taken in developing the Solid Waste Program Technical Baseline Description is based on system engineering. System engineering is a generalized, systematic methodology for defining large, complex and/or firstof-a-kind problems, evaluating solutions to the problem, and implementing an appropriate solution. The methodology adopted by the Sol id Waste Program is provided in figure 1. The methodology consists of five iterative steps to establish the program technical baseline: 1). mission analysis, 2) functional analysis, 3) requirements analysis, 4) system synthesis and integration, and 5) al ternative evaluation/optimization.

Mission analysis defines what need the mission is fulfilling and provides a statement of the mission based on the need. The mission analysis also defines the objectives of the program, the scope of the mission, constraints placed on the program, and external interfaces necessary for completion of the mission.

Functional analysis identifies the functions that are performed to meet the mission. These functions can then be allocated at increasingly greater levels of detail in order to provide an increasingly explicit depiction of the mission statement. Requirements analysis identifies the requirements associated with each function. Requirements are al located to. each functional allocation in order to provide greater detail of the requirements.

System synthesis and integration (or system definition) depicts the system that satisfies the requirements in order to meet the mission. All elements of the system are to be considered in arriving at the integrated scheme. System definition is suitabiy described by illustrating system interfaces, permits traceability between system elements, and provides a means for change control of the system. 
Alternative evaluation and optimization has not formally been performed at the program level as part of the technical baseline description for the Solid Waste Program. Alternative evaluation has been addressed at the project level for each of the major projects under the Sol id Waste Program. Evaluation and optimization studies regarding specific issues and uncertainties facing the Solid Waste Program have also been undertaken to assess their impact on the program. -Alternative evaluation and optimization will be performed in the future to understand the impact of uncertainties currently facing the Solid Waste program.

\section{CONTENI}

The contents of the technical baseline description is segregated into six volumes describing: (1) mission analysis; (2) functions and requirements analysis, (3) system definition, (4) documentation, (5) facility and project bases, and (6) program uncertainties. 
Figure 1. System Engineering Process for System Dẹfinition of the Solid Waste Program

\section{Hanford Mission Statement}

- Mission Need

Mission Objectives

Mission Constraints

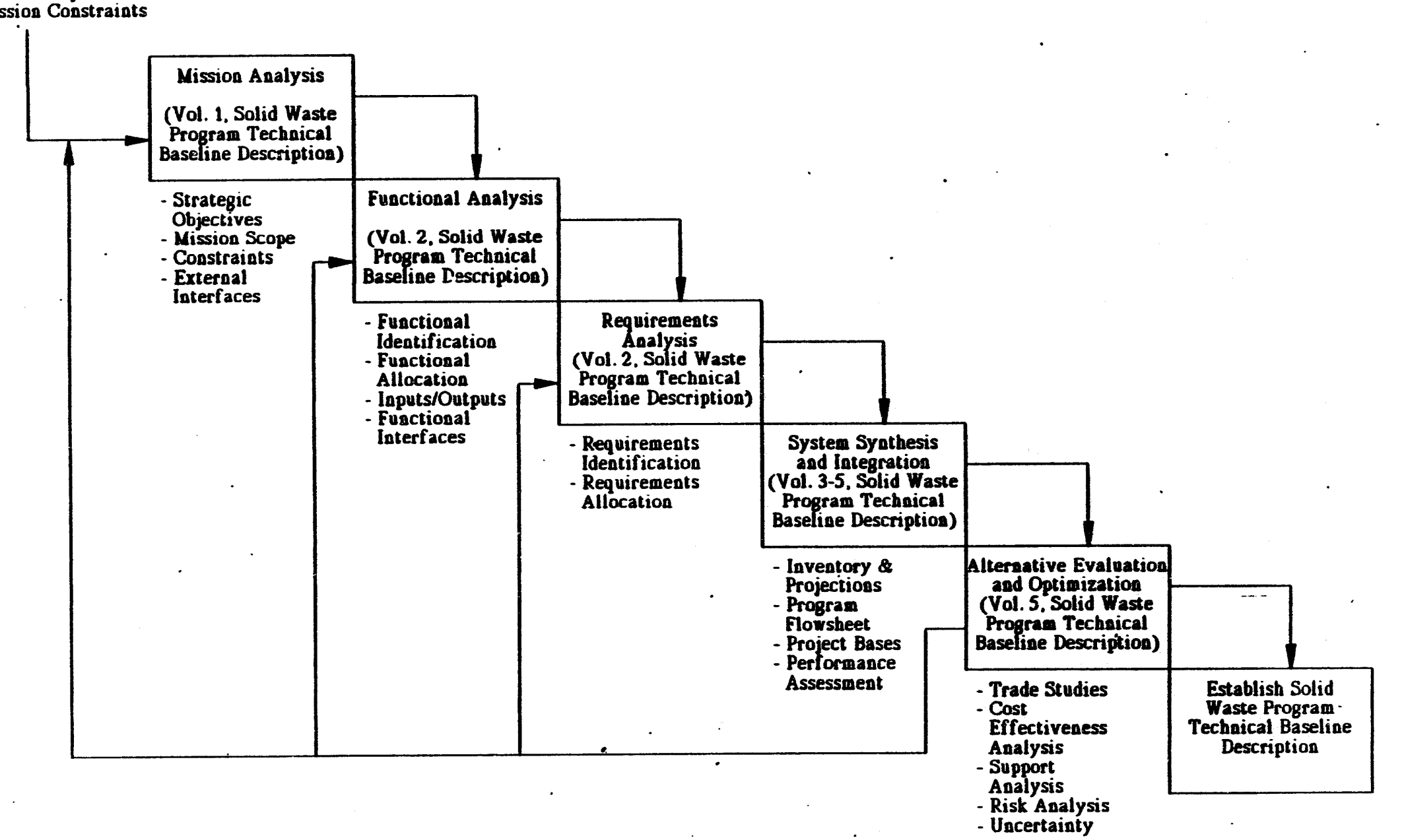




\section{MISSION ANALYSIS}

The Hanford Mission Plan, Volume 1, Site Guidance identifies the need for the Solid Waste Program to "treat, store, and dispose of a wide variety of solid material types consisting of multiple radioactive and hazardous waste classes". This includes "future Hanford Site activities (which) will generate new wastes that must be handled as cleanup activities are completed". Solid wastes are typically categorized as transuranic waste, low-level waste, lowlevel mixed waste, and hazardous waste.

To meet this need the Solid Waste Program has defined its mission as the following - receive, store, treat, and dispose of solid radioactive and nonradioactive wastes in a safe and environmentally compliant manner.

\section{Iransuranic Waste}

Management of all retrieved, stored, and newly generated transuranic (TRU) waste shall be the responsibility of the Solid Waste Program with the TRU waste prepared for offsite disposal at the Waste Isolation Pilot Plant (WTPP). The program is responsible for providing onsite TRU waste storage until an offsite disposal system is prepared to accept Hanford Site material. The program is also responsible for arranging for transportation of the TRU waste to WIPP for disposal.

Low-Level/Low-Level Mixed Waste

The Solid Waste Program is responsible for the receipt, treatment, interim storage, and disposal of multiple categories of low-level and lowlevel mixed waste assigned to the Hanford Site for disposition. Final disposition may include a combination of onsite, RCRA permitted onsite, and offsite disposal systems. Where onsite disposal is required, the program responsibility includes closure of the disposal system. Where offsite disposal is required, program responsibility includes onsite storage and arranging for transport to the offsite location.

\section{Hazardous Waste}

The Solid Waste Program provides for disposition of nonradioactive hazardous wastes generated by onsite programs. The program is responsible for arranging for tranisportation of hazardous waste to an offsite treatment, storage or disposal site.

Figure 2 graphically summarizes the Solid Waste Program boundaries, the waste that is included in the Solid Waste Program, the waste products from the Sol id Waste Program, interfaces with other programs, and the programmatic interfaces within which the Solid Waste Program operates. 
Figure 2. Solid Waste Program Interfaces and Boundaries

Programmatic Interfaces of the Solid Waste Program

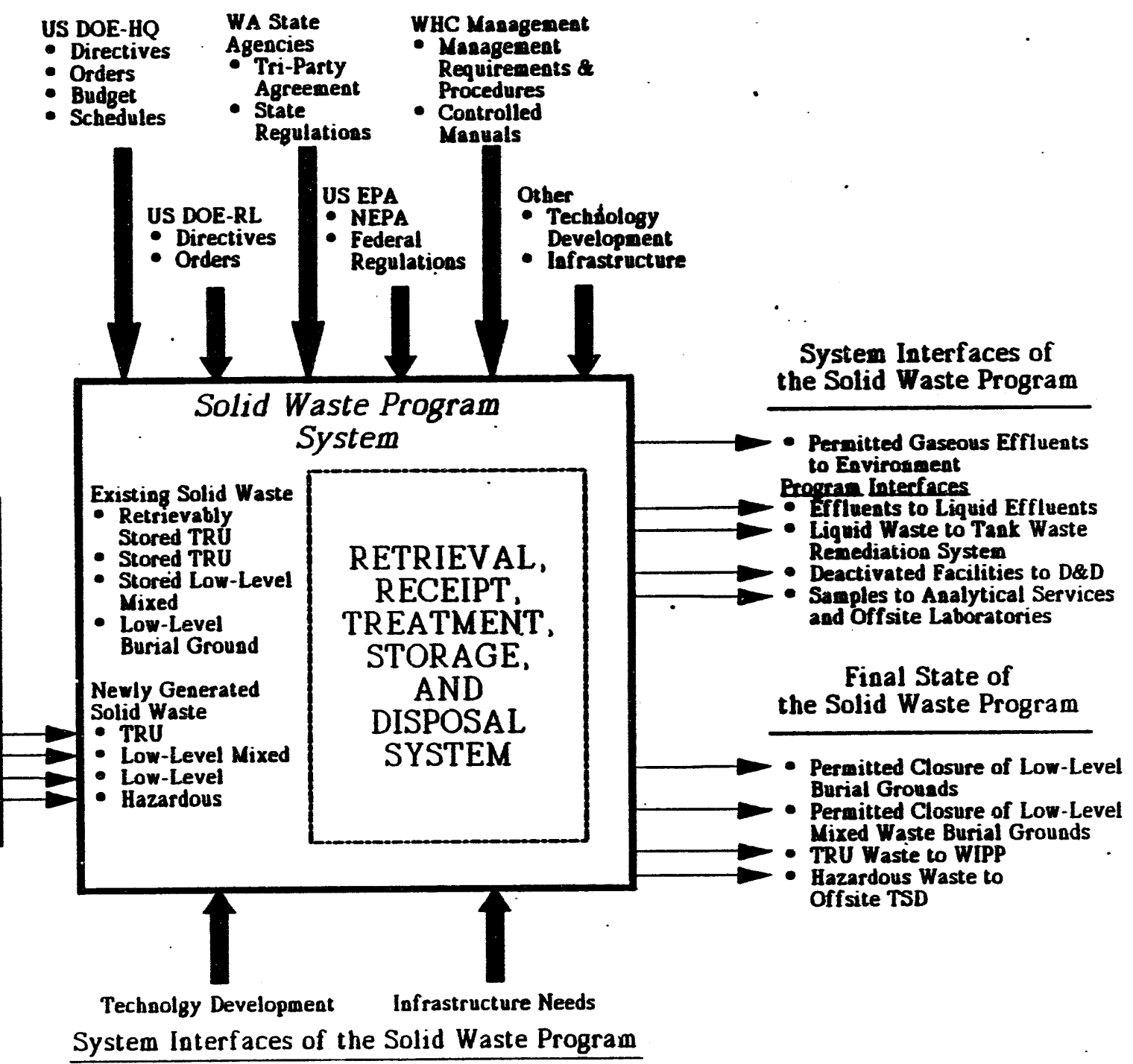

- Tank Waste Remediation System Solid Waste

- Liquid Effluents Solid Waste

- Waste \& Decontamiaation

Services Solid Waste

- Facility Operations Solid Waste

Solid Waste

- Environmental Restoration

Remedial Actions Solid Waste

- Decontamination and

Decommissioning Solid

- Onsite Contractors Solid Waste

- Analytical Services

Saste

WA State

HC Manageneat

Requirements

Offsite Generators Solid Waste

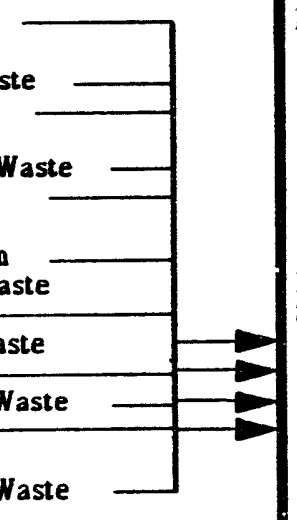

RETRIEVAL

REATMENT AND

DISPOSAL

- Tech

Development

Iafrastructure

ystem Interfaces of the Solid Waste Program 


\section{WHC-SD-WM-RPT-060, REV 0 EXECUTIVE SUMMARY}

\section{EUNCTION AND REOUIREMENT ANALYSIS}

The function and requirements analysis establishes the Solid Waste Program functions and requirements baseline by defining the functions, requirements, and interfaces necessary to meet the Solid Waste Program mission. Functions are specific actions, activities, or processes that achieve or support the achievement of the Solid Waste Program's technical mission. This functional analysis is limited only to technical functions and does not include programmatic functions (program management, project management, etc.). Requirements define how well a function must perform. Requirements set 1 imits on functions and also limits on the outputs from functions. Requirements include, but are not limited to, mission specifications, regulatory constraints, external policies, and internal policies.

Figure 3 shows the integration of the Solid Waste Program functional analysis as part of the site-wide system engineering function analysis. The site-wide system engineering effort has assigned 4.3 to the function Remedy Solid Waste. The Solid Waste Program functions have been numbered here based on this numbering scheme for traceability of Solid Waste Program functional analysis to the site-wide effort.

As part of the functional analysis the Solid Waste Program is in the processing of developing specific definition regarding interfaces between itself and other programs throughout the Hanford Site. To date an Interface Control Document has been issued specifying the interfaces between the Solid Waste Disposal and Environmental Division programs in conjunction with the remediation of past practice sites at Hanford. The Interface Control Document includes a baseline description of the waste that will be remediated, treated, and disposed in new and existing facilities. It also includes the roles of each program during remediation and disposal, the basis for determining disposal cost per cubic yard, and the strategies for integration of existing Hanford waste management capabilities with the remediation process.

The Solid Waste Program is pursuing Interface Control Documents with other programs at the Hanford Site that provide a similar definition for interfaces between programs. As these Interface Control Documents are completed they will be added to the baseline documentation for the Sol id Waste Program. Listed below are other programs with which the Solid Waste Program is either developing or planning to develop Interface Control Documents:

- Tank Waste Remediation System

- Liquid Effiuents Treatment Program

- PUREX

- Plutonium Finishing Plant

- Advanced Reactor Programs. (Fast Flux Test Facility)

- Analytical Services

- Decontamination and Decommissioning

- General Site Support 


\section{WHC-SD-WM-RPT-060, REV 0 EXECUTIVE SUMMARY}

Figure 3. Solid Waste Program Eunctional Analysis

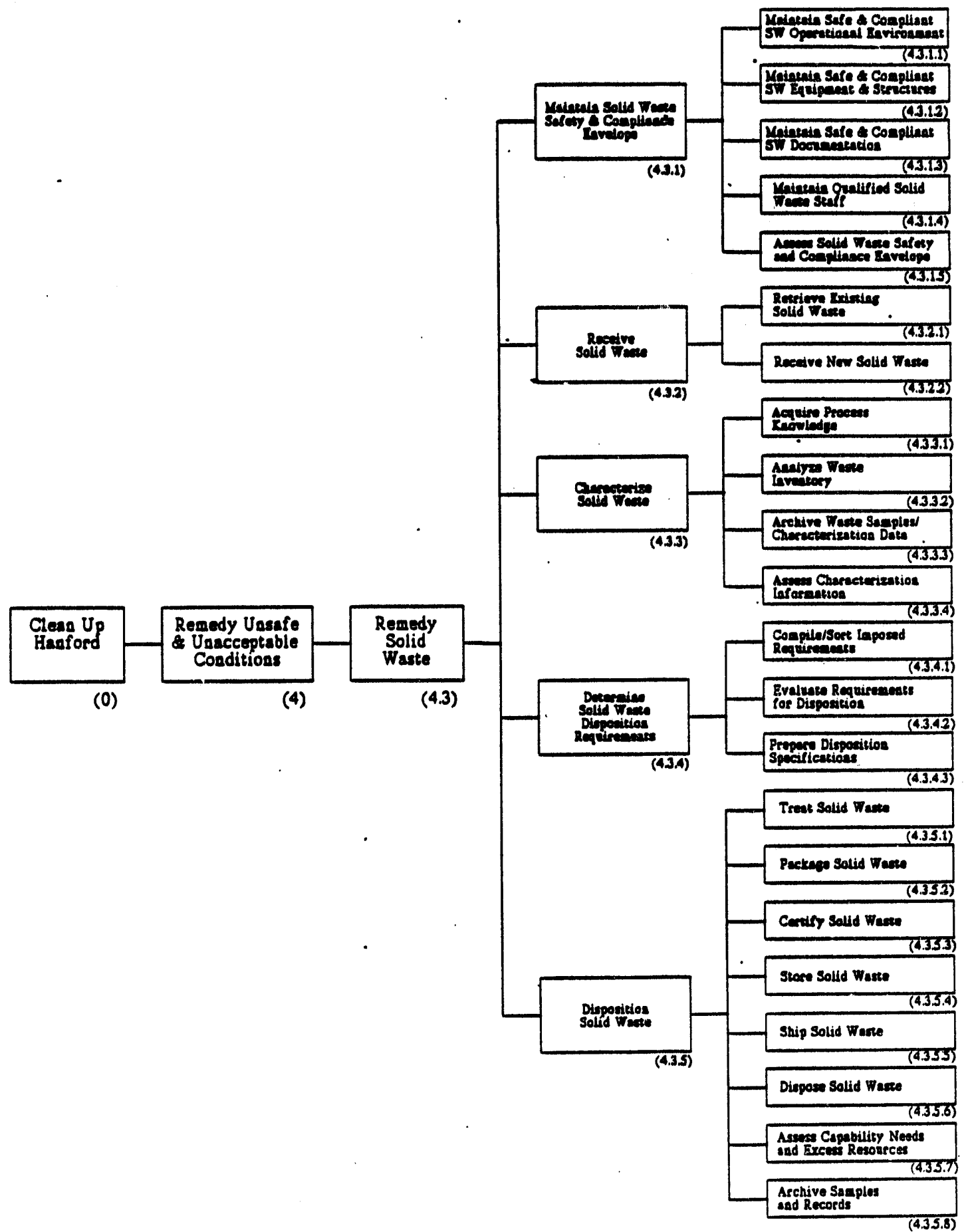




\section{SYSTEM DEFINIIION}

Each type of waste (transuranic and transuranic mixed waste, low-level mixed waste, low-level waste, and hazardous waste) managed by the Solid Waste Program has distinctive characteristics. Some of this waste (e.g., retrievabiy stored TRU) will be retrieved. Storage for waste awaiting treatment will be required for existing and projected transuranic and transuranic mixed waste and low-level mixed waste. Treatment will be required for almost all waste categories (a large volume of Category 1 low-level waste will not be treated prior to disposal) managed by Solid Waste. Disposal will be required for all solid waste managed, but the Solid Waste Program does not provide TRU or Greater Than Category 3 Waste disposal since these are DOE complex-level issues.

The Solid Waste Projgram plans for the retrieval of TRU waste stored in burial ground trenches an'd caissons since May 1, 1970. Retrieval will be accomplished through three projects: Solid Waste Retrieval Phase I (Project W113), Alpha Caisson Retriaval (Project W-156), and Solid Waste Retrieval Phase 2, (Project W-221). Solid Waste Retrieval Phase I will retrieve the 9,989 retrievably stored containers $\left(2,400 \mathrm{~m}^{3}\right)$ from Trench 4 of Burial Ground 218-W-4C. This accounts for roughly one-third of the containers and one-sixth of the volume of retrieyably stored TRU waste. Alpha Caisson Retrieval will involve removal of $23 \mathrm{~m}^{3}$ remote-handled TRU waste stored in the four alpha caissons located in the 218-W-4B burial ground. Sol id Waste Retrieval Phase 2 will involve retrieval of the entire inventory of retrievably stored TRU waste (less that retrieved in Phase 1 and Alpha Caisson Retrieval).

The Solid Waste Program plans for treatment of inventories of currently managed and/or projected TRU and TRU mixed, low-level mixed, and low-level waste. The treatment function has been separated into a number of projects the most significant being: WRAP Module 1 (Project W-026), WRAP Module 2A (Project $W-100$ ), WRAP Module 2B (Project $W-255$ ), Thermal Treatment Facility (Project $W-242$ ). WRAP Module 1 has been designed to sort, process and repackage retrievably stored and newly generated TRU solid waste for shipment ro the Waste Isolation Pilot Plant. WRAP Module $2 A$ will be designed to provide treatment to stored and projected contact-handled low-level mixed waste that does not require thermal treatment. Low-level mixed waste is lowlevel radioactive waste contaminated with dangerous waste under the Washington Administrative Code subject to regulation by the Department of Energy and Washington State. WRAP Module $2 B$ will be designed to receive retrieved and newly generated solid remote-handled radioactive wastes and will also receive oversized contact-handled radioactive wastes. WRAP Module 2B will be operated as a size reduction and repackaging facility for these wastes. The waste processing facility known as the Thermal Treatment Facility provides treatment for that portion of the low-level and TRU mixed waste that will require incineration as the technology-based standard for treatment. 


\section{WHC-SD-WM-RPT-060, REY 0 EXECUTIVE SUMMARY}

Storage functions will encompass both interim and long term storage capabilities. The individual storage requirements are outlined by the specific waste types to be stored. Storage is necessary for contact-handled radioactive solid wastes received from offsite and onsite generators as well as waste recovered from retrieval operations. Storage facilities and projects under the Solid Waste Program include: Transuranic Storage and Assay Facility (224-T), Radioactive Mixed Waste Storage Facilities at the Hanford Central Waste Complex, and the Enhanced Radioactive and Mixed Waste Storage Phase V Module (Project W-112). The Transuranic Storage and Assay Facility primarily stores TRU waste that meets the Hanford Site Soifd Waste Acceptance Criteria. The Radioactive Mixed Waste Storage Facilities consist of a number of buildings, storage modules, and projects. Included among these facilities are twelve small radioactive mixed waste storage buildings (2402W, 2402WB, 2402WC, 2402WD, 2402WE, 2402WF, 2402WG, 2402WH, 2402WI, 2402WJ, 2402WK, 2402WL), 10W-flash-point mixed waste storage modules, one Plutonium/Polychlorinated Biphenyl Mixed Waste Storage Building (2401W), Phase I-IV Radioactive Mixed Waste Storage (2403WA, 2403WB, 2403WC, 2403WD) and a mixed waste storage pad. The Enhanced Radioactive Mixed Waste Storage Phase V Module will be designed to store wastes and distribute waste to various radioactive solid waste treatment facilities.

Disposal functions provide for the ultimate disposition of the radioactive solid waste both on and off the Hanford Site. Disposal facility performance is based on the level of containment required for the particular type of radioactive solid waste being dispositioned. Separate disposal functions are identified for TRU waste, low-level mixed waste, and low-level waste. The disposal function for TRU waste and Greater Than Category 3 lowlevel waste is outside of the scope of the Solid Waste Program. The Solid Waste Program provides disposal for inventories of currentiy managed and/or projected low-level mixed and low-level waste. Radioactive Mixed Waste Disposal (Project W-025) will provide permanent disposal capability for low-level mixed waste. The Low-Level Burial Grounds provide permanent disposal capability for low-level waste.

Figure 4 is a flowsheet which identifies the projected direction of the current Sol id Waste Program. This direction is based on the current and forecasted (for fiscal years 1993 through 2022) inventory of solid waste to be managed by the Solid Waste Program, and the functions that have been identified to properly.manage this inventory. The Solid Waste Program manages the existing inventory of solid waste located in active burial grounds and Solid Waste Program managed facilities. The program also plans for management of the forecasted solid waste. 


\section{WHC-SD-WM-RPT-060, REV 0 EXECUTIVE SUMMARY}

The flowsheet offers the reader an understanding of the solid waste mission by connecting functions through waste stream paths and providing an overall volume flow associated with each of the particular types of waste. The flowsheet is broken into the four top level program functions outlined previous 1y: retrieval, treatment, storage, and disposal. The waste - categories covered in the flowsheet are TRU, low-level mixed, low-level waste, special case waste and environmental restoration waste. Special case waste is waste requiring storage awaiting a final decision regarding its ultimate disposition. Environmental restoration waste is waste which will be generated by remedial actions at the Hanford site which is destined for a separate disposal facility specifically designed to accommodate the particular waste expected from remedial actions. 


\section{Figure 4. Hanford Solid Waste Program Flowsheet}

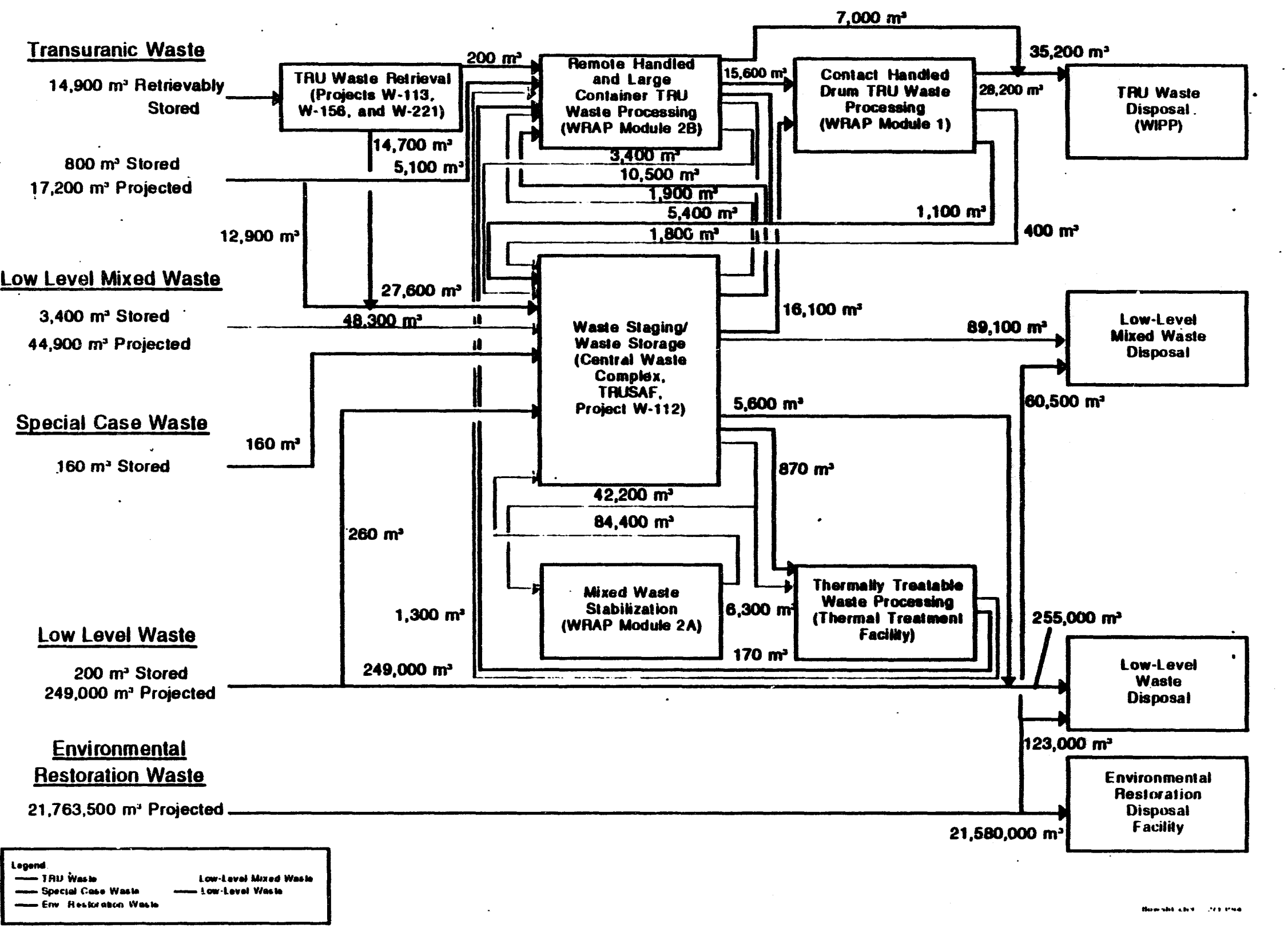


WHC-SD-WM-RPT-060, REV 0 EXECUTIVE SUMMARY

This page intentionally left blank. 


\section{WHC-SD-WM-RPT-060, REV 0 EXECUTIVE SUMMARY}

\section{DOCUMENTATION}

A vast amount of analysis, study, design, evaluation, planning, etc. is required for the Solid Waste Program to satisfactorily meet its mission. This information is documented to meet requirements placed on the Solid Waste Program and to substantiate the technical baseline of the program. The following figure identifies the hierarchy of documentation under which the Solid Waste Program operates to accomplish its mission. External (to the Solid Waste Program) requirements are placed on the Solid Waste Program by regulatory considerations $11 k e$ the Tri-Party Agreement and site-wide integration as described in thie Hanford Mission Plan.

The Solid Waste Program identifies its role relative to other on site programs through interface control documents. The Solid Waste Program identifies its own role at a summary level through the Sol id Waste Program Plan. The Solid Waste Program Plan describes at a summary level the current activities, strategy, schedule, and cost associated with solid waste management.

Each project and facility under control of the Solid Waste Program must develop a number of documents in order to satisfy the requirements placed on that project or facility. Depending on the scope of the project these requirements may include project management, system integration, environmental permitting and regulatory requitrements, safety analysis, design, engineering. and construction management, -environmental, safety, health and quality assurance, operational interface, transportation, analytical requirements, among other requirements. Facilities likewise have requirements for operation such as safety analysis, permits, and operational safety requirements. The level of completion of this documentation is dependent upon the status and schedule of each project and facility. A matrix showing the status of major documents for each project and facility is provided in Figure 5. 


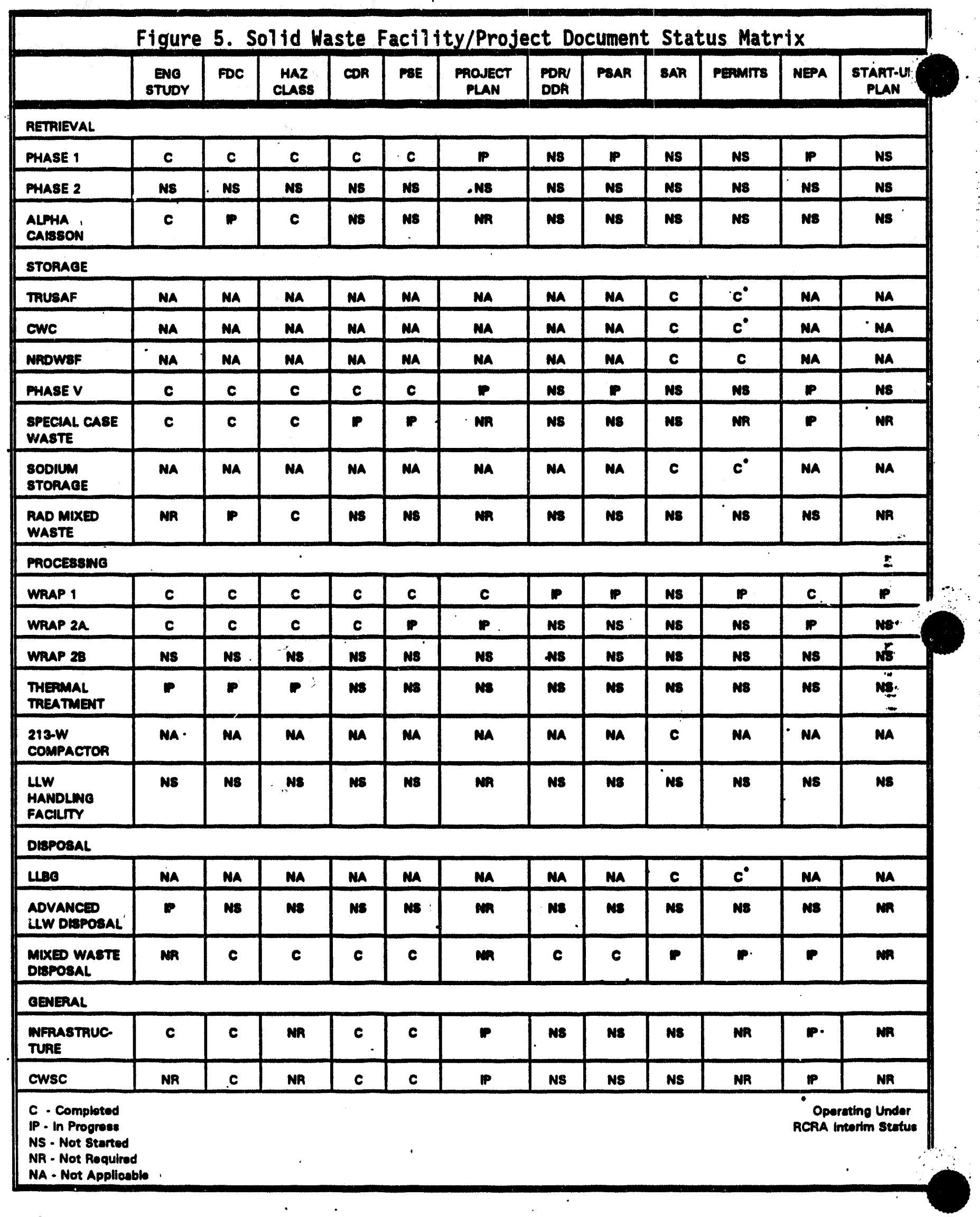




\section{WHC-SD-WM-RPT-060, REV 0 EXECUTIVE SUMMARY •}

\section{EACILITY AND PROJECT BASES}

The facility and project bases describe the bases and summary justification for the configuration of the projects and facilities which provide the capability for the Solid Waste Program to accomplish its mission.

The projects and facilities have been categorized according to the primary function they provide, namely retrieval, storage, treatment, or disposal. For each factlity and project the following information is provided:

- identified purpose (what does the particular project or facility fulfill in meeting the Solid Waste mission)

- scope (what waste types are handled, the interfaces with the project or facility, the physical characteristics, project schedule, capacities, etc.)

- functions performed (specific functions the project or facility carries out to provide the necessary capability [i.e., retrieval, storage, treatment, or disposal])

a

\section{disposal} projects and facilities. The retrieval projects covered are: Waste Retrieval Phase 1, Solid Waste Retrieval Phase 2, and Alpha Caisson Retrieval. The storage facilities and projects covered are: the Hanford Central Waste Complex - Radioactive Mixed Waste Storage Facility (consisting of the Mixed-Waste Storage Buildings, Large Mixed-Waste Storage Facility Phases I-IV, Plutonium/Polychlorinated Biphenyl Mixed Waste Storage Builiting, Flammable-Mixed-Waste Storage Modules, Waste Receiving and Staging Area, and Mixed-Waste Storage Pad), the Enhanced Radioactive Mixed Waste Storage. Phase V Project, and the Transuranic Storage and Assay Facility. The treatment projects covered are: WRAP Module 1, WRAP Module 2A, WRAP Module 2B, and the Thermal Treatment Facility. Disposal facilities and projects covered are the Low-Level Waste Burial Grounds and the Low-Level Mixed Waste Disposal project. 


\section{PROGRAM UNCERTAINTIES}

Program uncertainties are identified to highlight key areas of potential change that could impact the system defined by the Solid Waste Program to accomplish its mission. It should be noted that "uncertainties" includes "unknowns" as well as "alternatives" on which a decision has not yet been made. Uncertainties have been categorized as to the level at which the uncertainty will have to be reconciled. Uncertainties exist at a DOE Complex level, at the Hanford Site level, and at the Solid Waste Program level.

DOE Complex level uncertainties are related to the overall DOE solid waste complex problems as they may impact Solid Waste Program planning. For the most part, the Solid Waste Program cannot control these uncertainties, but must react to changes to current assumptions, laws, regulations and guidelines. Some of the DOE Complex level uncertainties include: policy on thermal treatment versus alternative treatments, low-level. mixed waste integrated demonstration, WIPP waste emplacement, TRU waste generation after WIPP closure, availability of certified laboratories, and effects of future National Environmental Policy Act decisions. Uncertainties associated with WIPP waste emplacement include: opening date and initial acceptance of Hanford waste, volume allocation for Hanford waste, acceptance rates, changes to waste acceptance criteria, and remote-handled waste uncertainties.

Hanford Site level uncertainties are within the control of the Hanford Site, but cross current organizational boundaries. Effort will be required by the Solid Waste Program and other site organizations to resolve these uncertainties. Some of the Hanford Site level uncertainties include: integration of remote-handled waste and materials management, management of double-shell and single-shell tank long-length equipment, accuracy of waste forecasts, and use of a commercial thermal treatment facility for low-level mixed waste treatment.

Solid Waste Program level uncertainties are related to areas within the Solid Waste Program operational scope. Effort will be required by the Solid Waste Program to resolve these uncertainties. Some of the Solid Waste Program level uncertainties include: results of performance assessment for Category 3 low-level waste disposal, storage for special case waste that has no final disposition identiffed to date, and total storage capacity required to accommodate projections of waste generated in the future. 
WHC-SD-WM-RPT-06O, REV O

Solid Waste Program

Technical Baseline Description

\section{Volume 1: Mission Analysis}




\section{WHC-SD-WM-RPT-060, REV 0 VOLUME 1}

VOLUME 1. MISSION ANALYSIS

\section{Table of Contents}

1.0 INTRODUCTION

1.1 BACKGROUND

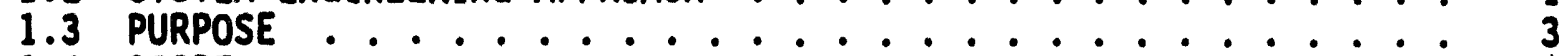

1.4 SCOPE

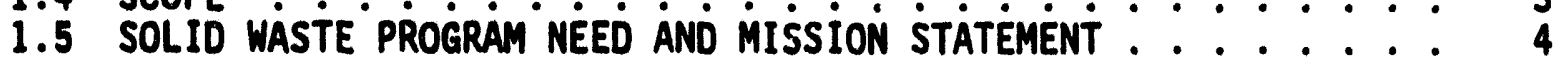

2.0 SOLID WASTE MISSION ANALYSIS RESULTS . . . . . . . . . . . . 6

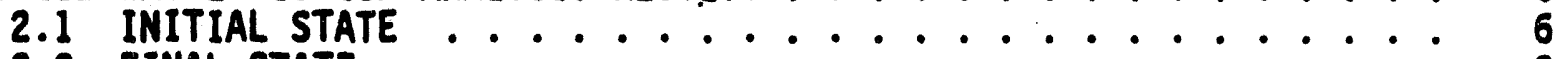

2.2 FINAL STATE

2.3 PROGRAMMATIC INTERFACES/BOUNDARIES $\ldots \ldots$

2.4 SYSTEM INTERFACES/BOUNDARIES . . . . ....... 10

2.5 MEASURES OF SUCCESS ................. 11

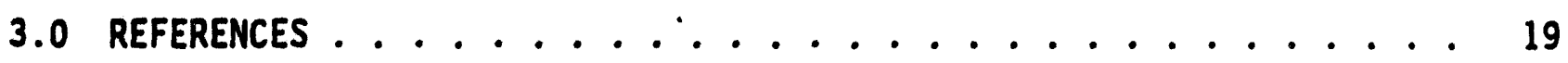




\section{WHC-SD-WM-RPT-060, REV 0 VOLUME 1}

\section{List of Tables}

Table 2-1. Initial State of the Solid Waste Program ......... 12

Table 2-2. Final State of the Solid Waste Program ........... 15

Table 2-3. Programmatic Interfaces, of the Solid Waste Program . . . . 16

Table 2-4. System Interfaces of the Solid Waste Program ........ 17

Table 2-5. Measures of Success for the Solid Waste Program . . . . . 18

\section{List of Figures}

Figure 1-1. System Engineering Process for System Definition of the

Figure 2-1. Sol Sold Waste Program Interfaces and Boundaries . . . . . . ${ }_{7}^{2}$

Figure 2-2. Hanford Site Radioactive Sol id Waste Current and

Projected Inventory . . . . . . . . . . . . . 8 


\section{WHC-SD-WM-RPT-060, REV 0 VOLUME 1}

\subsection{INTRODUCTION}

\subsection{BACKGROUND}

The Hanford Mission Plan, Volume 1, Site Guidance (Reference 1) states "The primary Hanford mission is to clean up the Hanford Site, eliminate potential risks to the public and our workers, and serve as the DOE mode1 in environmental restoration." As part of the Hanford mission the Solid Waste Program is responsible for management and final disposition of solid wastes in a safe manner. The Hanford Mission Plan, Volume 1 Site Guidance (Reference 1) provides specific guidance for the Sol id Waste Program regarding the program's mission, material management responsibilities, and material disposition responsibilities. This guidance is incorporated into the Solid Waste Program intssion analysis effort.

\subsection{SYSTEM ENGINEERING APPROACH}

The approach taken in developing the Solid Waste Program Technical Baseline Description is based on system engineering as outlined in DOE Order 4700.1 (Reference 2). System engineering is a generalized, systematic methodology for defining large, complex and/or first-of-a-kind problems, evaluating solutions to the problem, and implementing the solution. The methodology adopted by the Solid Waste Program is provided in figure 1-1. The methodology consists of five iterative steps to establish the program technical baseline: 1) mission analysis, 2) functional analysis, 3) requirements analysis, 4) system synthesis and integration, and 5) al ternative evaluation/optimization. Execution of these five steps develops the technical basel ine for the Solid Waste Program.

Mission analysis defines the mission of the program in a specific context. It defines what need the mission is fulfilling and provides a statement of the mission based on the need. The analysis also defines the objectives of the program in meeting the mission. The mission analysis identifies the scope of the mission, constraints placed on the program, and external interfaces necessary for completion of the mission.

Functional analysis identifies the functions that must be performed in order to meet the mission. These functions can then be allocated at increasingly greater levels of detail in order to provide an increasingly explicit depiction of the mission statement.

Requirements analysis identifies the requirements associated with each function. Requirements are allocated to each functional allocation in order to provide greater detail of the requirements. 
Figure 1-1. System Engineering Process for System Definition of the Solid Waste Program

Hanford Mission Statement

- Mission Need

- Missiun Objectives

Mission Constraints

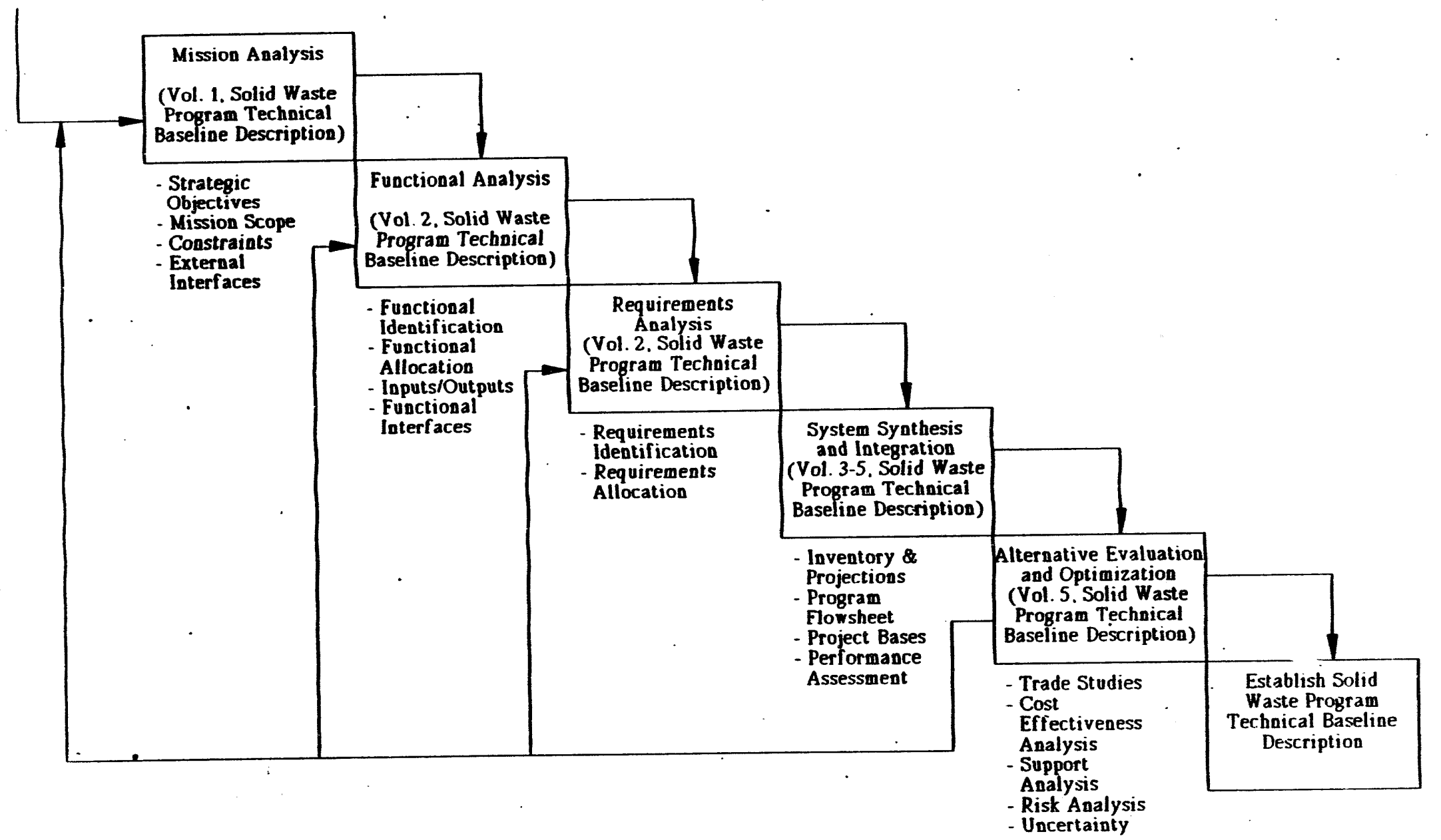


WHC-SD-WM-RPT-060, REV 0 VOLUME 1

System synthesis and integration depicts the concept that satisfies the requirements in order to meet the mission. All elements of the system are to be considered in arriving at the integrated scheme. Definition of the system is suitably described by illustrating system interfaces, permitting traceability between system elements, and providing a means for change control of the system. The system definition is illustrated by the program flowsheet which is based on the functions and requirements of the program.

Alternative evaluation and optimization has been performed at the project level but has not formally been performed at the program level as part of the technical baseline description for the Solid Waste Program. Evaluation and optimization studies at the project level include tradeoff analyses, cost effectiveness studies, value engineering studies, support (infrastructure, laboratory, etc.) needs, and risk analyses. Alternative evaluation and optimization at the project level is provided by the description of the project bases. Alternative evaluation and optimization at the program level will be performed in the future to understand the impact of uncertainties currentiy facing the Solid Waste Program.

\subsection{PURPOSE}

The purpose of the Solid Waste Mission Analysis is to establish the baseline technical mission of the Solid Waste Program. This is accomplished by defining the scope of the mission, objectives of the program, constraints placed on the program, and external interfaces necessary for completion of the mission.

\subsection{SCOPE}

The imission analysis documents:

- Initial conditions (initial or current state) of the system under the auspices of the Solid Waste Program (Table 2-1, Section 2.1)

- Final conditions (final state) to be achieved by the Solid Waste Program system (Table 2-2, Section 2.2)

- Solid Waste Progran system programmatic interfaces (Table 2-3, Section 2.3)

- Solid Waste Program system technical interfaces (Table 2-4, Section 2.4)

- measures of success to determine the effectiveness of the current system in achieving the final condition (Table 2-5, Section 2.5).

The mission analysis identifies the Solid Waste Programs baseline strategy or working position. The mission analysis also identifies the scope of the program based on initial conditions, and requirements associated with 
the final state, technical interfaces, programmatic interfaces, and measures of success.

\subsection{SOLID WASTE PROGRAM NEED AND MISSION STATEMENT}

The Hanford Mission Plan, Volume 1, Site Guidance (Reference 1) identifies the need for the Solid Waste Program to "treat, store, and dispose of a wide variety of solid material types consisting of multiple radioactive and hazardous waste classes". This includes "future Hanford Site activities (which) will generate new wastes that must be handled as cleanup activities are completed".

To meet this need the Solid Waste Program has defined its mission as the following - receive, store, treat, and dispose of solid radioactive and nonradioactive wastes in a safe and environmentally compliant manner. (Reference 3)

As part of the Hanford Site's current mission of cleaning up the site, the Solid Waste Program is responsible for: 1) buried waste located in RCRA regulated burial grounds (burial grounds $218-E-10,218-E-12 B, 218-W-3 A, 218-W-$ $3 A E, 218-W-4 B, 218-W-4 C, 218-W-5$, and 218-W-6 [future site]), 2) stored solid waste mainly in buildings which are part of the Hanford Central Waste Complex, and the Transuranic Storage and Assay Facility (TRUSAF), 3) managing receipts of newly generated solid waste from onsite programs and offsite generators. The mission does not include management of solid waste buried in inactive burial grounds that will be remediated by the Environmental Restoration Mission Area.

\section{Iransuranic Waste}

Management of all retrieved, stored, and newly generated TRU waste shall be the responsibility of the Solid Waste Program with the TRU waste prepared for offsite disposal at the Waste Isolation Pilot Plant (WIPP). The program is responsible for providing onsite TRU waste storage until an offsite disposal system is prepared to accept Hanford Site material. The program is al so responsible for arranging for transportation of the TRU waste to WIPP for disposal.

\section{Low-Leve]/Low-Leve] Mixed Waste}

The Solid Waste Program is responsible for the receipt, treatment, interim storage, and disposal of multiple categories of low-ievel and lowlevel mixed waste assigned to the Hanford Site for disposition. Final disposition may include a combination of onsite, RCRA pernitted onsite, and offsite disposal systems. Where onsite disposal is required, the program responsibility includes closure of the disposal system. Where offsite disposal is required, program responsibility includes onsite storage and arranging for transport to the offsite location. 
WHC-SD-WM-RPT-060, REV 0 VOLUME 1

Hazardous Waste

The Solid Waste Program provides for disposition of hazardous wastes generated by onsite programs. The program is responsible for arranging for transportation of hazardous waste to an offsite treatment, storage or disposal site. 
WHC-SD-WM-RPT-060, REV 0 VOLUME 1

\subsection{SOLID WASTE MISSION ANALYSIS RESULTS}

Figure 2-1 graphically summarizes the Solid Waste Program boundaries, the waste that is included in the Solid Waste Program, the waste products from the Solid Waste Program, interfaces with other programs, and the programmatic interfaces within which the Solid Waste Program operates. Sections 2.1 through 2.5 and Tables 2-1 through 2-5 contain the details of the information shown in Figure 2-1.

\subsection{INITIAL STATE}

Figure 2-2 graphically represents the existing inventory of solid waste currently at the Hanford site and the projected inventory of solid waste for the period fiscal year 1993 through fiscal year 2022. The Solid Waste Program manages the existing inventory of solid waste located in active burial grounds and Solid Waste Program managed facilities. The program also plans for management of projected solid waste forecasts.

The existing inventory of solid waste consists of: stored TRU waste generated since 1970, stored low-level mixed waste generated since 1987, and buried solid waste placed in seven burial grounds (218-E-10, 218-E-12B, 218-W$3 A, 218-W-3 A E, 218-W-4 B, 218-W-4 C, 218-W-5$, and 218-W-6 [future site, no waste placed]) which, are active burial grounds operating under RCRA interim status. Figure 2-1 shows the projected solid waste forecast to be managed by the Solid Waste Program comes from a number of sources: Tank Waste Remediation System, Liquid Effluents Program, Waste and Decontamination Services Program, Facility Operations Program, Advanced. Reactor (FFTF) Program, Environmental Restoration Remedial Actions and Decontamination and Decommissioning Programs, Landlord Program, Onsite Contractors, Analytical Services, and Offsite Generators.

The Solid Waste Program in addition to managing solid waste, manages the solid waste treatment, storage and disposal facilities necessary to execute its mission. Projects have also been identified by the Solid Waste Program to provide necessary treatment, storage and disposal capabilities which currently are not available for the program to execute its mission.

The active burial grounds in the 200 Areas also contain irradiated nuclear fuel from a number of experimental reactors. The disposition of this irradiated nuclear fuel will be addressed in the Hanford Irradiated FuelsEnvironmental Impact Statement. The Solid Waste Program may provide functions required to implement the record of decision of this EIS. In the interim, the Solid Waste Program will continue its existing storage management of the special case waste and may complete interim actions to continue safe management. 


\section{Figure 2-1. Solid Waste Program Interfaces and Boundaries}

Programmatic Interfaces of the Solid Waste Program

System Interf aces of

\begin{tabular}{|c|c|c|}
\hline $\begin{array}{l}\text { US DOE-HQ } \\
\text { Directives } \\
\text { - Orders } \\
\text { - Budget } \\
\text { - Schedules }\end{array}$ & $\begin{array}{l}\text { WA State } \\
\text { Agencies } \\
\text { Tri-Party } \\
\text { Agreement } \\
\text { - State } \\
\text { Regulations }\end{array}$ & $\begin{array}{l}\text { WHC Management } \\
\text { - Management } \\
\text { Requirements \& } \\
\text { Procedures } \\
\text { - Controlled } \\
\text { Manuals }\end{array}$ \\
\hline
\end{tabular}
the Solid Waste Program

- Tank Waste Remediation System Solid Waste

Liquid Effluents Solid Was Waste \& Decontamination Services Solid Waste

- Facility Operations Solid Waste Advanced Reactor (FFTF) Solid Waste

Environmental Restoration Remedial Actions Solid Waste - Decontamination and

Decommissioning Solid Wast

- Landlord Solid Waste

- Onsite Contractors Solid Waste

- Analytical Services

Solnd Waste

- Off ite Generators Solid Waste
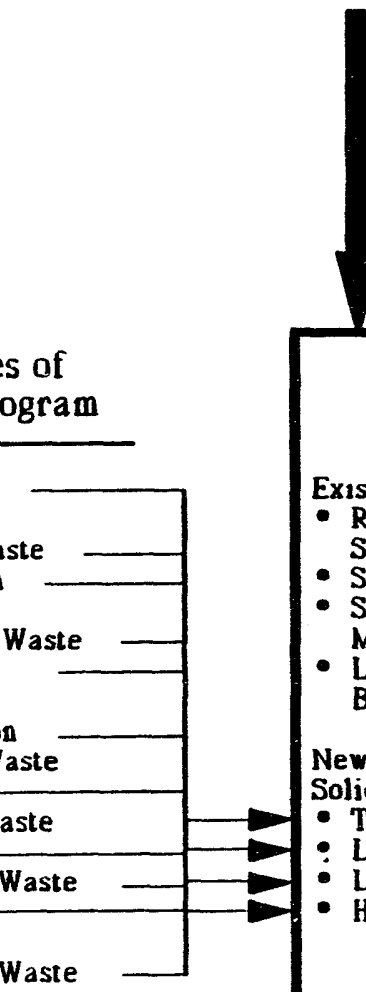

US DOE-RL

US DOE-RL

- Directives

US EPA

- NEPA

Federal

Regulations
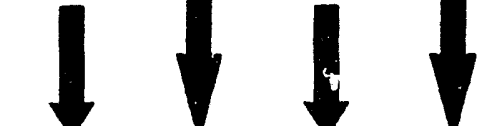

Stored Low-Level
Other

Development

- Infrastructure

ystem Interf aces of the Solid Waste Program

Pernitted Gaseous Effluents to Environment

\section{Program Interfaces}

Erom Interfaces
Exısting Solıd Waste

Retrievably

Stored TRU

Stored TRU

Mixed

Low-Level

Burial Ground

Newly Generated

Solid Waste

- TRU

- Low-Level Mixed

- Low-Level

- Hazardou

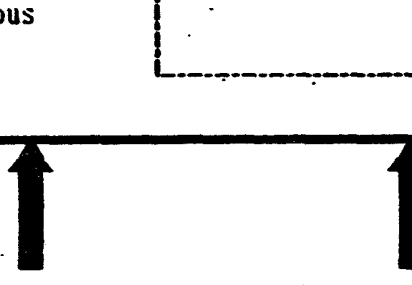

Technolgy Development Infrastructure Needs

System Intertaces of the Solid Waste Program 
Figure 2-2. Hanford Site Radioactive Solid Waste Current and Projected Inventory

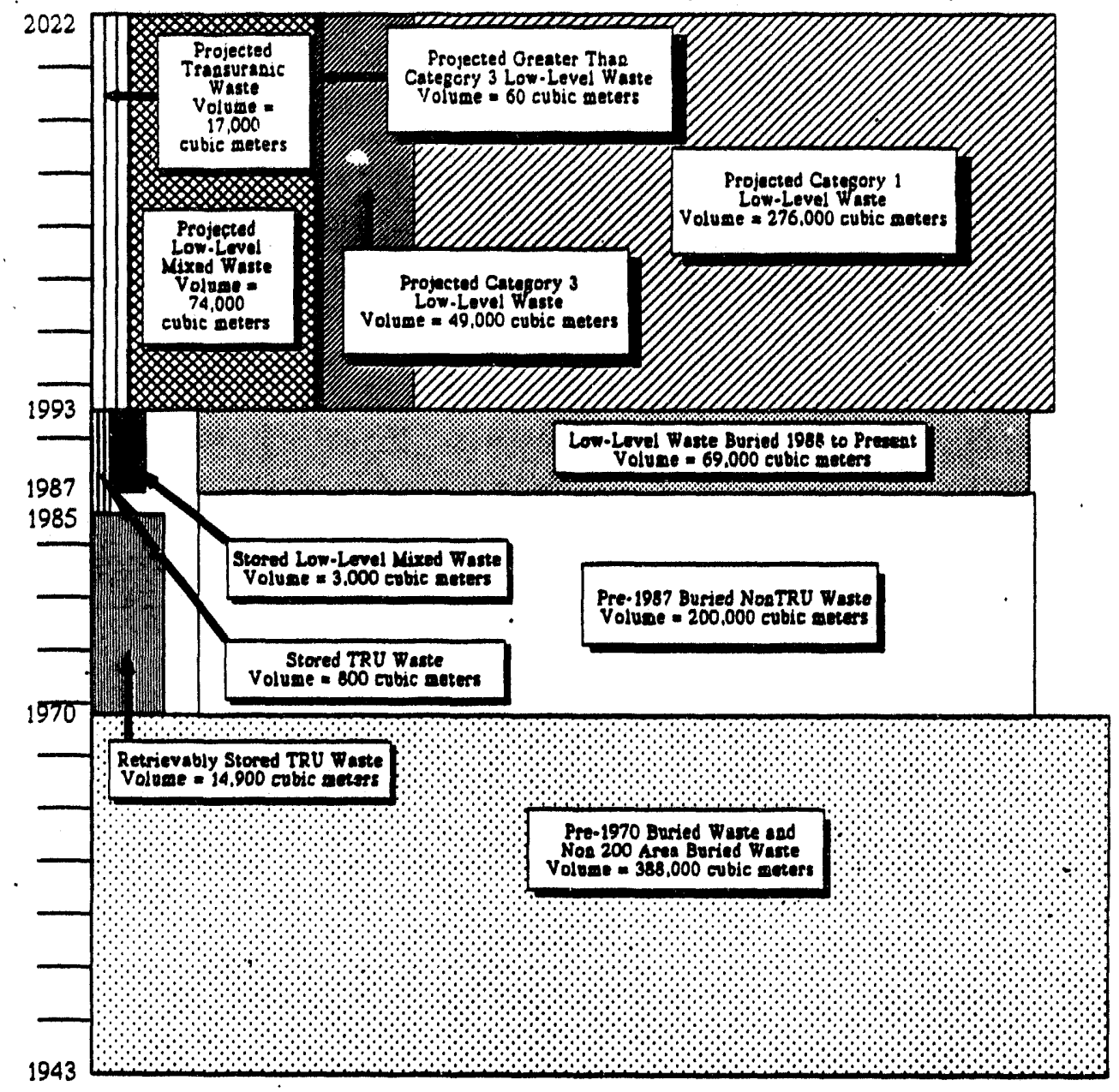

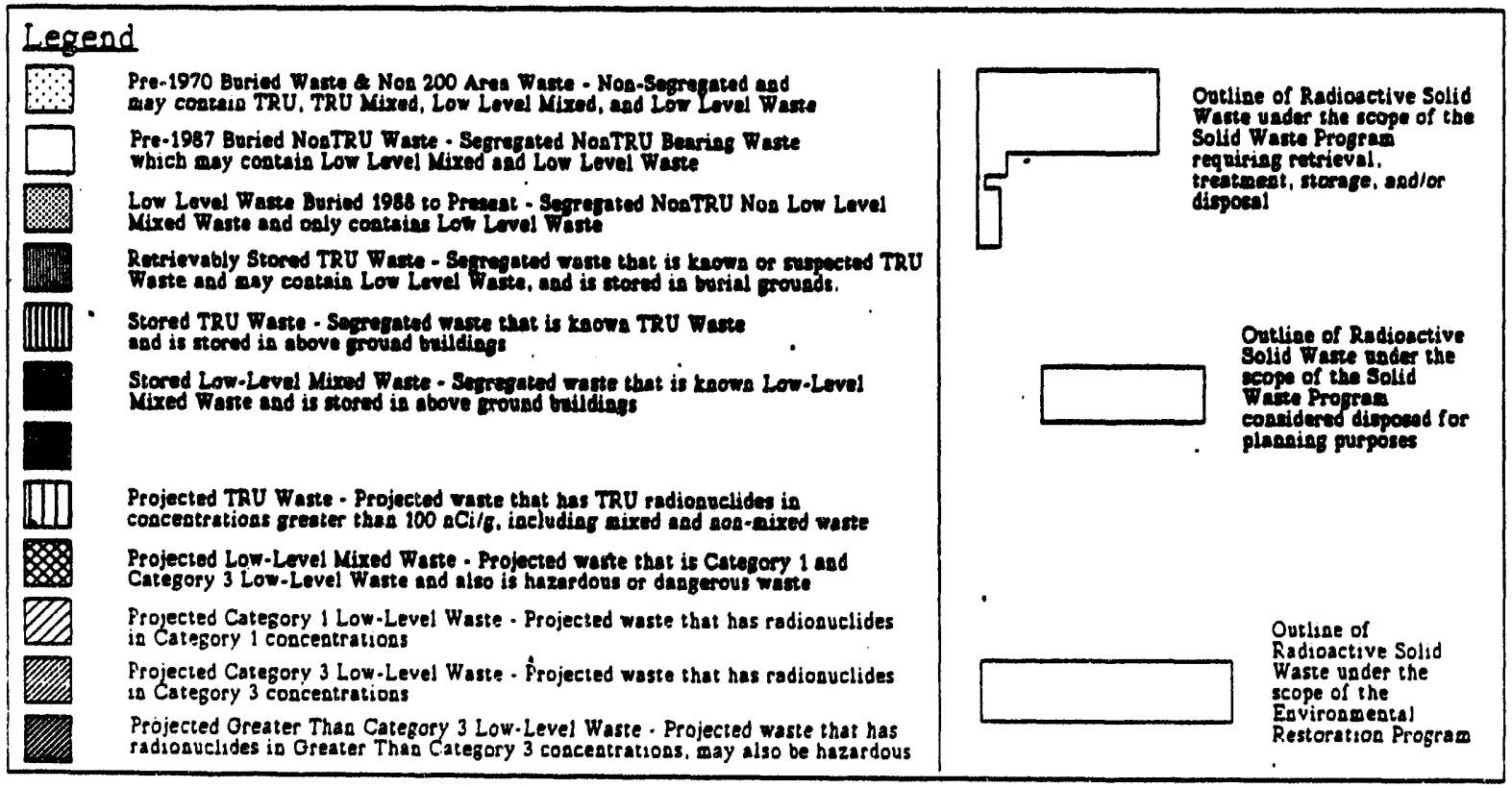




\section{WHC-SD-WM-RPT-060, REV 0 VOLUME 1}

Figure 2-2 includes solid waste Buried at the Hanford Site in inactive burial grounds that will be remediated by the Hanford Site Environmental Restoration (ER) Mission Area. The solid waste in the ER Mission Area is included in figure 2-2 to portray the entire inventory of existing solid waste buried at the Hanford site. In May 1987, DOE no longer regulated radioactive solid materials as byproduct materials and began to regulate radioactive and hazardous mixed waste under the Resource Conservation and Recovery Act (RCRA). The U.S. Department of Energy, Richland Field Office was required to submit RCRA Part A permit applications for those factlities (including burial grounds) that treated, stored, or disposed of RCRA regulated waste. The decision was made at that time to file permit applications for only a 1 imited number of burial grounds: 218-E-10, 218-E-12B, 218-W-3A, 218-W-3AE, 218-W-4B, 218-W-4C, 218-W-5, and 218-W-6 [future site, no waste placed]. All remaining burial grounds at the Hanford site would not receive any additional waste and would be regulated under the Comprehiensive Environmental Response, Compensation, and Liability Act (CERCLA). Remediation of CERCLA sites, including burial grounds, is under the direction of the Environmental Restoration Mission Area.

A memorandum of understanding exists between the Office of Waste Management (DOE-HQ) and the Office of Environmental Restoration (DOE-HQ) regarding integrated planning, siting, and management of waste treatment, storage, and disposal factitities. This memorandum of understanding states that the Office of Waste Management will be responsible for the planning and implementation of site-wide waste management and regulatory compliance activities at an installation, unless otherwise agreed to by a site-specific agreement. An Interface Control Document between Hanford Site Environmental Restoration (ER) and Solid Waste states that ER will be responsible for managing the design and construction of treatment, storage, and disposal facilities for waste from ER activities and Solid Waste will manage operations of these facilities (Reference 4 ).

Table 2-1 tabulates the current state of the Solid Waste Program concerning solid waste materials, facilities, and projects.

\subsection{FINAL STATE}

Figure 2-1 identifies the waste products from execution of the Solid Waste mission. The Solid Waste Program will deal with: transuranic waste, low-level waste, low-level mixed waste, and hazardous waste. The inventory of solid waste managed by the program will fall into one of these categories of waste. These four categories of waste each have final disposal requirements and will be disposed separately. Transuranic waste will be processed for disposal at WIPP. Hazardous waste will be transported to off site hazardous waste treatment, storage, and disposal facilities. Low-level waste will be disposed near-surface on the Hanford site. Low-level mixed waste will also be disposed near-surface on the Hanford site in a disposal system separate from low-level waste disposal. 
WHC-SD-WM-RPT-060, REV 0 VOLUME 1

When execution of the Solid Waste Program mission is completed the waste treatment and storage facilities will be deactivated and turned over to the Decontamination and Decommissioning Program for decommissioning. Disposal facilities will be closed in accordance with applicable regulations. Table 2-2 provides description of the final state of the Solid Waste Program.

\subsection{PROGRAMMATIC INTERFACES/BOUNDARIES}

Figure 2-1 shows the Solid Waste Program has a number of interfaces with external and internal programs which set requirements for performance of the Solid Waste Program system. These interfaces (U. S. Department of Energy Headquarters, U.S. Department of Energy - Richland Field Office, U. S. Environmental Protection Agency, Washington Department of Ecology, Westinghouse Hanford Company management, etc.) set constraints and requirements under which the program must execute its mission. These interfaces are continually being defined and refined by the program.

Table 2-3 provides internal and external programmatic interfaces of the Solid Waste Program and the types of requirements placed on the program.

\subsection{SYSTEM INTERFACES/BOUNDARIES}

The projected inventory portrayed in Figure 2-2 is based on those onsite programs and offsite generators planning to send solid waste to the Solid Waste Program for management and disposition. The projected solid waste forecast to be managed by the Solid Waste Program comes from a number of sources: Tank Waste Remediation System, Liquid Effluents Program, Waste and Decontamination Services Program, Facility Operations Program, Advanced Reactor (FFTF) Program, Environmental Restoration Remedial Actions and Decontamination and Decomissioning Programs, Landlord Program, Analytical Services Program, Onsite Contractors, and Offsite Generators.

The Solid Waste Program also relies on other onsite programs for completion of the Solid Waste Program mission. The Solid Waste Program will send liquid effluents to the Liquid Effluent Program, radioactive liquid wastes to the Tank Waste Remediation System, some samples will be sent to Analytical Services Program, deactivated facilities will be turned over to Decontamination and Decommissioning Program, and infrastructure needs such as transportation, electricity, water, etc. wili be furnished by the Landiord Program.

The Solid Waste Program will also rely on off site interfaces for execution of the program's mission. TRU waste will be disposed off site at the Waste Isolation Pilot Plant in Carlsbad, New Mexico. Hazardous waste is sent off site for treatment, storage and disposal. Offsite laboratories will provide a portion of the sample analysis requirements.

Table 2-4 provides details regarding the system interfaces of the Solid Waste Program with waste receipts, and on site and off site interfaces. 
WHC-SD-WM-RPT-060, REV 0 . VOLUME 1

\subsection{MEASURES OF SUCCESS}

Application of measures of success has not been formally established for the Solid Waste Program. Measures of success are quantifiable characteristics for assessing program performance and forming a basis for decision making for the program. The Solid Waste Program measures of success are: worker and public health and safety, environmental impact, technical assurance, schedule, and cost. Table 2-5 provides details regarding the measures of success for the Solid Waste Program. 
Table 2-1. Initial State of the Solid Waste Program

\begin{tabular}{|c|c|c|c|}
\hline $\begin{array}{l}\text { Tople } \\
\text { Number }\end{array}$ & Topie Deseription & $\begin{array}{l}\text { Inotude/Exatude } \\
\text { trom Soope }\end{array}$ & Solld Wusto Program strutegy \\
\hline 1.1 & Waste and Materide & & \\
\hline 1.1 .1 & Solvd Weots & & \\
\hline 1.1 .1 .1 & $\begin{array}{l}\text { Pre } 1970 \text { and Non } 200 \text { Anes Burled solld Werte } \\
\text { Including Buriod TRU Comtaminated Woote }\end{array}$ & Exchude & $\begin{array}{l}\text { Thle weoto is beling dleppoltioned by the } \\
\text { Environmented Restoration Miledion Ares }\end{array}$ \\
\hline 1.1 .1 .2 & $\begin{array}{l}\text { Post } 1970 \text { Retribvebly stored TRU Wasto in } \\
\text { Trenohes }\end{array}$ & molude & $\begin{array}{l}\text { Thie waste will be retrloved for proceseaing } \\
\text { and TRU wate will be eent to WPP }\end{array}$ \\
\hline 1.1 .1 .3 & 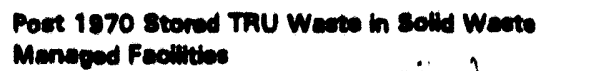 & melnes & $\begin{array}{l}\text { This weste will be procesead for dieposed } \\
\text { of Whip }\end{array}$ \\
\hline 1.1 .1 .4 & Poet 1987 stored Lowlevel Mixed Westo & methede & 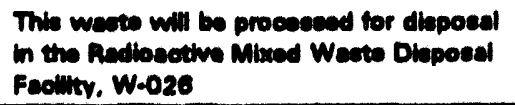 \\
\hline 1.1.1.5 & 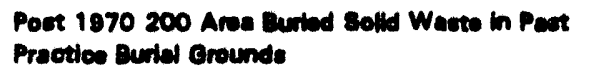 & Exchude & 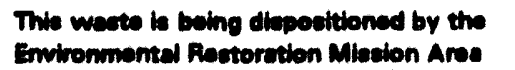 \\
\hline 1.1 .1 .6 & 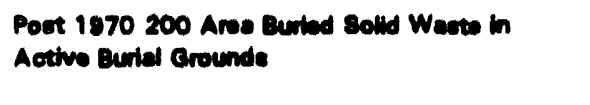 & melude & 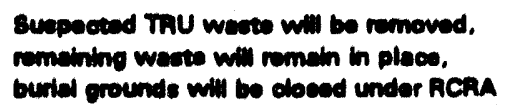 \\
\hline 1.1.1.7 & Projected Onates Genernsed solid Warte & meluede & Inolude in Solld Weats Mbelon \\
\hline 1.1 .1 .8 & Projoctiod Otfatte Benoreted solld Woste & molude & Inohude in solid Westo Mleaion \\
\hline 1.1 .2 & Tank Weate & . & \\
\hline 1.1.2.1 & Doublo-sholl Tenk Weots & Exalude & Exchede from Solld Waste Miseibn \\
\hline 1.1.2.2 & Sinele-shell Tenk Weoto & Exchude & Exclude from Solld Wats Mibeion \\
\hline 1.1 .3 & Nucher Motorlede & & \\
\hline 1.1.3.1 & Irrediated Fual & & \\
\hline 1.1.3.1.1 & N Rasotor Fual & Exchelude & Exchedo trom soldd Warte Miacion \\
\hline 1.1.3.1.2 & Fast Flux Teat Foellity Fual: & Exolude & Exolude from solid Weste Mikalon \\
\hline 1.1.3.1.3 & 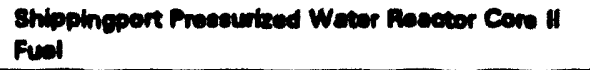 & Exelude & Exchede from selid Wects Mlecion \\
\hline 1.1.3.1.4 & Singla Paws Rasever Fund & Exchens & Exchude trom solld Westo Minalon \\
\hline 1.1.3.1.6 & Mibealleneous stoned Fual & Exalude & Exalude trom solid Werto Milealon \\
\hline 1.1.3.1.6 & Mbcalleneour Fuel in Actwo Buidal Grounds & 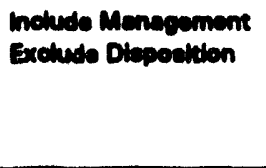 & 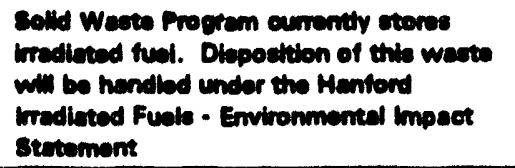 \\
\hline 1.1.3.2 & Spocial Nucher Matrerial & Exchude & Exolude from solid Weate Misalon \\
\hline 1.1.3.3 & Cosium/Strontium Capsules: & Exeludo & Exclude from Solld Wasto Misaion \\
\hline 1.1.3.4 & Unirradiated Uranium & Exclude & Exclude from Solid Weste Mission \\
\hline
\end{tabular}


Table 2-1. Initial State of the Solid Waste Program

\begin{tabular}{|c|c|c|c|}
\hline $\begin{array}{l}\text { Toplo } \\
\text { Number }\end{array}$ & Tople Deseription & $\begin{array}{l}\text { Inolude/Exolude } \\
\text { from Soope }\end{array}$ & Solld Waste Program Strategy \\
\hline 1.1 .4 & Emironmened Conteminciden & & \\
\hline 1.1 .4 .1 & 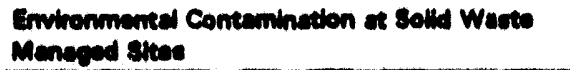 & Inolude & To bu detamined \\
\hline 1.1 .4 .2 & 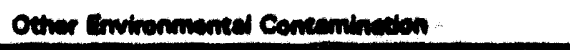 & Exalude & Exalude from solld Wasts Minglon \\
\hline 1.1 .8 & Laques Emumase & & \\
\hline 1.1.5.1 & 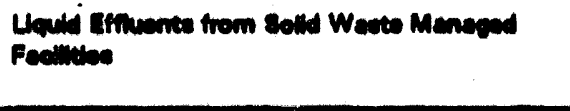 & 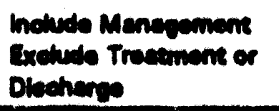 & 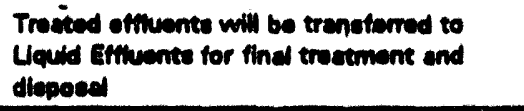 \\
\hline 1.1.8.2 & Other Luevid emume & Exelude & Exelvede from solld Waste Mlasion \\
\hline 1.2 & Solld Weots Proprem Meneced Fecillides & & \\
\hline 1.2.1 & 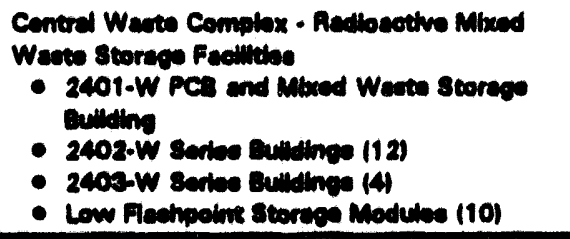 & inotude & Provide solld waete etorage \\
\hline 1.2.2 & 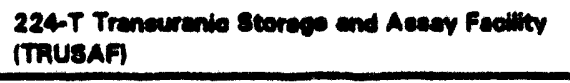 & include & Provide TRU weote eterege and cesesy \\
\hline 1.2.3 & 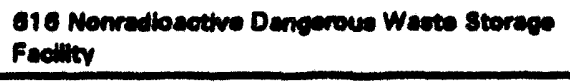 & Inchude & Provide hazerdous wares atorage \\
\hline 1.2 .4 & 213-W Compector Facimity & Include & 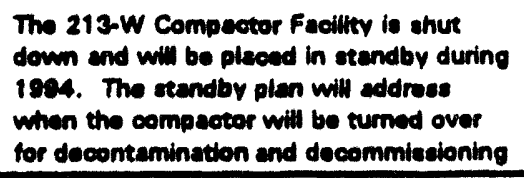 \\
\hline 1.2 .8 & 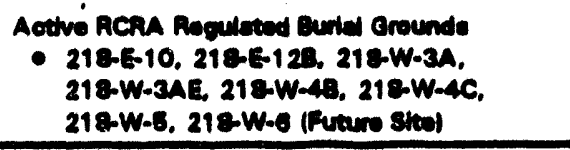 & include & Provide dieposed for solld wasto \\
\hline 1.3 & Solld Weste Projectes & & \\
\hline 1.3.1 & 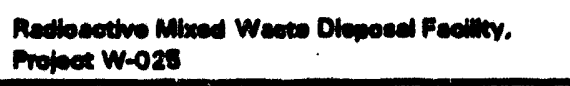 & moluce & Provide dbepoed for low lovel mixed wasto \\
\hline 1.3.2 & $\begin{array}{l}\text { Wasto Recoiving and Proceesing (WRAPI } \\
\text { Module 1. Project W-028 }\end{array}$ & inotude & $\begin{array}{l}\text { Procoee TRU and euispected TRU weete } \\
\text { for diaposel at WIPp }\end{array}$ \\
\hline 1.3.3 & WRAP Module 2A, Projet W-100 & Inctuda & $\begin{array}{l}\text { Process lomblovel mixed weote requiring } \\
\text { steblllzation for disposed }\end{array}$ \\
\hline 1.3 .4 & $\begin{array}{l}\text { Enhenoed Aedbeotivo Mixed Weate storege } \\
\text { Faclltity. Phace V. Projeot W-112 }\end{array}$ & Inctude & $\begin{array}{l}\text { Provide storage and inventory control for } \\
\text { weate being procoseced for diepoeal }\end{array}$ \\
\hline 1.3 .5 & Solld Warto Rotrievel Faciltity, Project W-113 & Include & $\begin{array}{l}\text { Provide retrioval for retrievabiy rtored TRU } \\
\text { wamte in Tronch } 04 \text { of burial ground } 218 \text { - } \\
\text { W.4C }\end{array}$ \\
\hline
\end{tabular}




\section{WHC-SD-WM-RPT-060, REV 0 VOLUME 1}

Table 2-1. Initial State of the Solid Waste Program

\begin{tabular}{|c|c|c|c|}
\hline $\begin{array}{l}\text { Tople } \\
\text { Number }\end{array}$ & Topte Desentotion & $\begin{array}{l}\text { molude/Exolude } \\
\text { trom soope }\end{array}$ & Solld Weoto Program Struteor \\
\hline 1.3 .6 & Alpha Culesen Rotrioval, Project W-186 & inolude & $\begin{array}{l}\text { Provide rotribval for remoto-hendiod ThU } \\
\text { wasto in elpha odiacons of burlal ground } \\
218-W=48\end{array}$ \\
\hline 1.3 .7 & 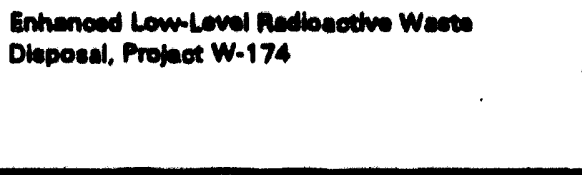 & meluede & 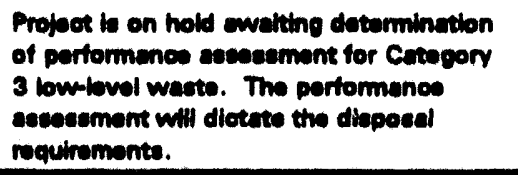 \\
\hline 1.3.8 & 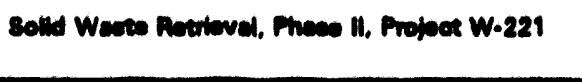 & melueves & $\begin{array}{l}\text { Provido mulovel for motrievebly atored TRU } \\
\text { weeto in burtel grounde }\end{array}$ \\
\hline 1.3 .8 & Thermel Tresument Fecillyy, Prejest W-242 & moluese & 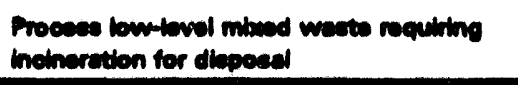 \\
\hline 1.3 .10 & $\begin{array}{l}\text { Low Lovel West Hending Feciury. } \\
\text { Projegt W-247 }\end{array}$ & melude & 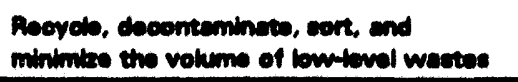 \\
\hline 1.3 .11 & WRAP Modul 28, Propoet W-28s - & molude & 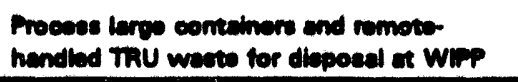 \\
\hline 1.3 .12 & Spodel Cen Weate storige, Projed W-272 & molude & $\begin{array}{l}\text { Provide trorese for Greater Then Cotepory } \\
3 \text { lowtovel weess }\end{array}$ \\
\hline 1.3.13 & Alkellno Metel storneg, Project W-300 & molues & 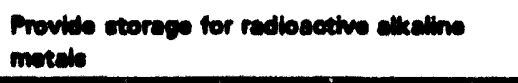 \\
\hline 1.3 .14 & $\begin{array}{l}\text { Phace } 6 \text { Mbred Weate storage, Project W.318 } \\
\text {. }\end{array}$ & motude & 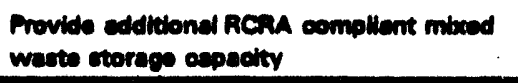 \\
\hline 1.3 .15 & Low Lovel Burial Bround Cbours, Projere W-329 & melude & 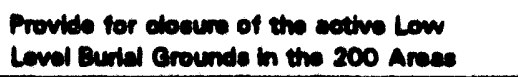 \\
\hline
\end{tabular}




\section{WHC-SD-WM-RPT-060, REV 0 VOLUME 1}

Table 2-2. Final State of the Solid Waste Program

\begin{tabular}{|c|c|c|c|}
\hline $\begin{array}{l}\text { Tople } \\
\text { Number }\end{array}$ & Toplo Description & Final Condition & Solld Waoto Program Strategy \\
\hline 2.1 & Olepoditaned Weote & & \\
\hline 2.1 .1 & mu Weots & 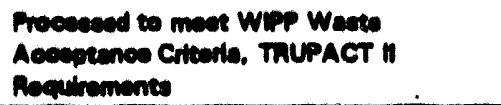 & $\begin{array}{l}\text { Weote shipeced to WiPP for } \\
\text { divioed }\end{array}$ \\
\hline 2.1 .2 & 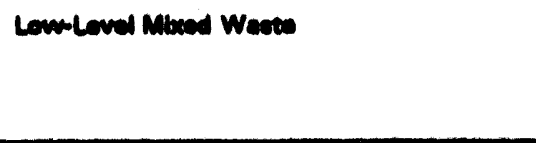 & 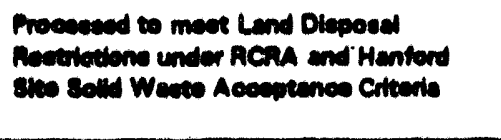 & 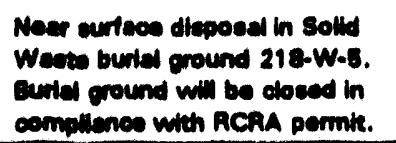 \\
\hline 2.1 .3 & Lonflovel Weas & & \\
\hline $2.1 .3 .1^{\prime}$ & Cotreven 1 Lowlevel Weots & 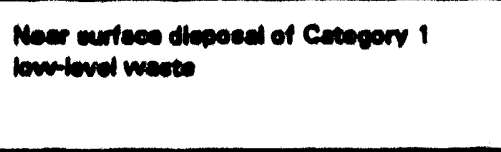 & 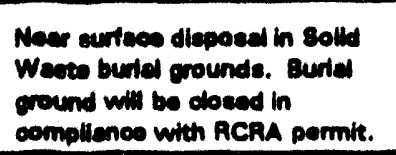 \\
\hline 2.1.3.2 & Crtaceory 3 Loullovel Westo & 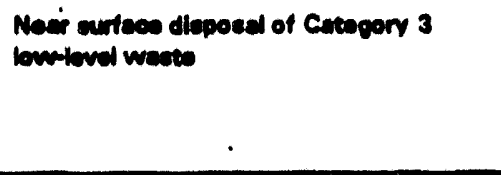 & 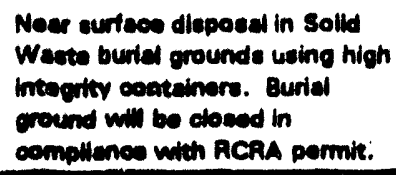 \\
\hline 2.1.3.3 & 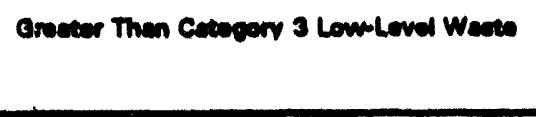 & To be decerminned & $\begin{array}{l}\text { Provide continued otorage } \\
\text { eweiting doterminution of } \\
\text { dienoed requirements. }\end{array}$ \\
\hline 2.1 .4 & High Lovel Weoto & Nor in solld Weato Program scopo & $\begin{array}{l}\text { Evelude trom solva Wasto } \\
\text { milealon }\end{array}$ \\
\hline 2.1.5 & Spent fuel & Not in solld Wasto Proprani soopes & $\begin{array}{l}\text { Exetude from Solld Wasto } \\
\text { Miladion }\end{array}$ \\
\hline 2.1 .6 & Heardous Weats & 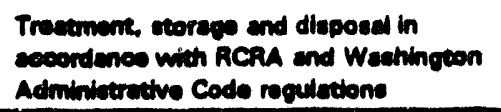 & $\begin{array}{l}\text { Waets ahloped off atte for } \\
\text { treatumeme and dispoed }\end{array}$ \\
\hline 2.1 .7 & 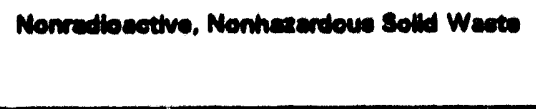 & Not in solid Wasto Progrem soope & $\begin{array}{l}\text { Dieposes in Henford Site } \\
\text { nonrediosetive, nonhazardous } \\
\text { lendfin }\end{array}$ \\
\hline 2.2 & Freanderese & & \\
\hline 2.2 .1 & 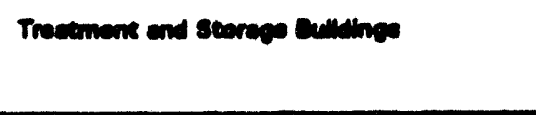 & 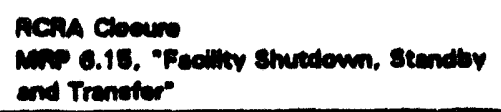 & 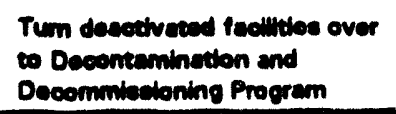 \\
\hline 2.2.2 & Burlat Broundo & RCAn Clomers & $\begin{array}{l}\text { Cloeure under requiremente of } \\
\text { RCRA }\end{array}$ \\
\hline
\end{tabular}


Table 2-3. Programmatic Interfaces of the Solid Waste Program

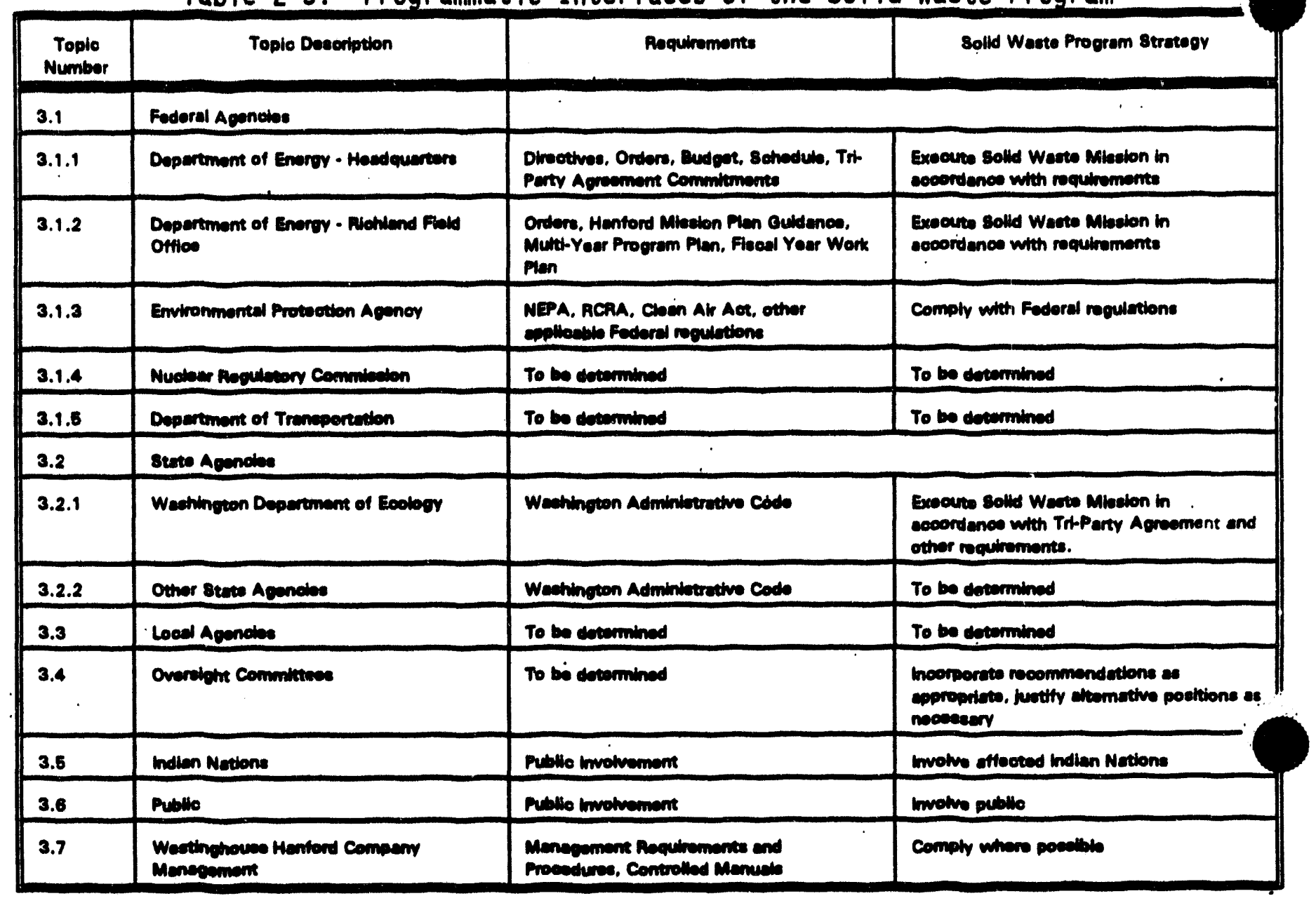


Table 2-4. System Interfaces of the Solid Waste Program

\begin{tabular}{|c|c|c|c|}
\hline $\begin{array}{l}\text { Topio } \\
\text { Number' }\end{array}$ & Tople Description & Requiremente & Solld Wasto Program Strategy \\
\hline 4.1 & Weots Pocelpte & & \\
\hline 4.1 .1 & $\begin{array}{l}\text { Tenk Werto Remedietion } \\
\text { Syetem }\end{array}$ & Weate Volume Projectiona & Recive woste \\
\hline 4.1 .2 & Llapud Efthuento Proverem & Weots Volveme Projections & Roceive Waste \\
\hline 4.1 .3 & $\begin{array}{l}\text { Weste und Decomteminedion } \\
\text { Serviose Properm }\end{array}$ & Wecte Vohmo Propetions & Recentwo Weste \\
\hline 4.1 .4 & Faciney Opermelone Progrem & Weote Velume Projections & Recenve Weate \\
\hline 4.1 .8 & Adveneed Racetwor Progrem & Westo Volwum Projoctonse & Roeche Weote \\
\hline 4.1 .6 & $\begin{array}{l}\text { Envisenmented Recteretion } \\
\text { Remediel Actions Progrion }\end{array}$ & Werte Volume Projsodions & Recaive Warts \\
\hline 4.1 .7 & $\begin{array}{l}\text { Decomtamination end } \\
\text { Decommiadoning Progrem }\end{array}$ & Werto Volume Projectiona & Receive Weots \\
\hline 4.1 .8 & Landlord Program & Weatp Volume Projectione & Rocoive Waste \\
\hline 4.1 .0 & Anchritoul senviose & Wese Vohmo Projections & Roceive Weots \\
\hline 4.1 .10 & On site Contrectere & Waets Vohmo Projectione & Recaive Waste \\
\hline 4.1 .11 & Off stwe Genveraters & Weste Volume Projoctione & Rocoive Weote \\
\hline 4.2 & Oncite Interfaces & & $\cdot$ \\
\hline 4.2 .1 & $\begin{array}{l}\text { Tenk Waots Remediedten } \\
\text { Syotem }\end{array}$ & $\begin{array}{l}\text { Tranofer hlohily comteminated liquid } \\
\text { weote }\end{array}$ & $\begin{array}{l}\text { Radioactive Hianid veasio to be received by TWAS. } \\
\text { neede to be defined }\end{array}$ \\
\hline 4.2 .2 & Liquid Emunme Progran & Tranoter liquid etmuentes & $\begin{array}{l}\text { Efmuente to be treated and discharged by the } \\
\text { Uquid Efmuenta Progrem }\end{array}$ \\
\hline 4.2 .3 & $\begin{array}{l}\text { Deconteminedion and } \\
\text { Docommiealoning Progrem }\end{array}$ & Trenefer descetivisad fecillides & $\begin{array}{l}\text { Desctivated fecilltioe recelved by Decontemination } \\
\text { and Decommiecioning Progrem }\end{array}$ \\
\hline 4.2 .4 & Anetrieal Servicas Program & Send exmplese for enalyelo & Provide eample enalyaie, neede to be defined \\
\hline 4.2 .5 & Lendlond Program & 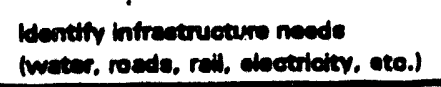 & 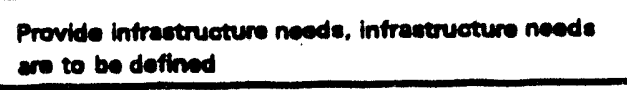 \\
\hline 4.3 & Orfice Interfaces & - & \\
\hline 4.3 .1 & Weats boledion Pllor Plant & Thu weste diepoed & Provide diepoeal of TRU Wate \\
\hline 4.3.2 & 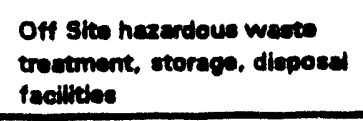 & $\begin{array}{l}\text { Heacardous wanto treatumens, } \\
\text { storace, and disposel }\end{array}$ & $\begin{array}{l}\text { Provide treatument. atorage, and dieposed of } \\
\text { haxardous wasto }\end{array}$ \\
\hline 4.3.3 & On stive leboratorive & Weate semplo andiycia & $\begin{array}{l}\text { Provide semplo analyalo as neoded, neode we to be } \\
\text { dofined }\end{array}$ \\
\hline 4.3.4 & Gascous efthemeste & $\begin{array}{l}\text { Gaccove efmuents diacharged to } \\
\text { the environment }\end{array}$ & $\begin{array}{l}\text { Disecherges in complience with regulatory } \\
\text { requirements }\end{array}$ \\
\hline 4.4 & Tochnology dovelopment & Technologr evailability & $\begin{array}{l}\text { Use exieting technology, develop now or emerging } \\
\text { technologies ac needed, needs to be detined }\end{array}$ \\
\hline
\end{tabular}


Table 2-5. Measures of Success for the Solid Waste Program

\begin{tabular}{|c|c|c|c|}
\hline $\begin{array}{l}\text { Topic } \\
\text { Number }\end{array}$ & Topic Desectiation & Requiremente & Solld Waste Program Strategy \\
\hline 5.1 & $\begin{array}{l}\text { Public and Worker Heath and } \\
\text { Sofety }\end{array}$ & $\begin{array}{l}\text { Minimize worter rediological exposure, } \\
\text { minimize worker inductrial haxards. } \\
\text { minimize public rediologieal expoeure. } \\
\text { minimbe public trensportation hazards }\end{array}$ & $\begin{array}{l}\text { Deleterious heafth effects will be as low } \\
\text { as rectonobly achiovable, worker and } \\
\text { public eafoty will be protected }\end{array}$ \\
\hline 5.2 & Environmontel impacts & $\begin{array}{l}\text { Minimize bong-term environmental. } \\
\text { contamination, maximize reovoling of } \\
\text { metorial, minimize cocondary wate } \\
\text { genoration }\end{array}$ & $\begin{array}{l}\text { Comply with regulatory mquinemente } \\
\text { whore practioally poselble, negotiate } \\
\text { greded compliance whore nocasesery }\end{array}$ \\
\hline 5.3 & Techmied Aceurenos & 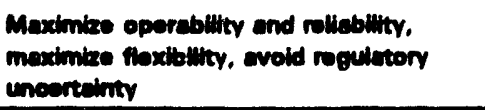 & 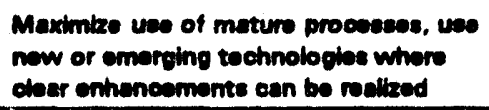 \\
\hline 5.4 & Schedula & $\begin{array}{l}\text { Triperty Agresmeme sehodule, other } \\
\text { sehedele requinimente to be determinind }\end{array}$ & Meet sobredule requirememts \\
\hline 5.5 & Cost & $\begin{array}{l}\text { Minimbe cost whils mesting } \\
\text { requiremonts }\end{array}$ & $\begin{array}{l}\text { Provide oyetems engineering, value } \\
\text { enginearing to detomine cost } \\
\text { effectivenose }\end{array}$ \\
\hline
\end{tabular}


WHC-SD-WM-RPT-060, REV 0 VOLUME 1 .

\subsection{REFERENCES}

1. DOE/RL-93-08, Hanford Mission Plan, Volume 1, Site Guidance, August, 1993.

2. DOE 4700.1, Project Management System, June 2, 1992.

3. WHC-SP-0989, Solid Waste Program FY 1994 Multi-Year Program Plan, Phase 1 WBS \#1.2.1, M. M. McCarthy, June 1993.

4. WHC-SD-ER-EE-002, REV 0, Hanford Restoration Baseline Approach Interface Control Document, M. A. Casbon, October, 1993. 


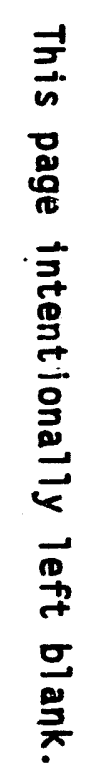


WHC-SD-WM-RPT-060, REV 0

Solid Waste Program

Technical Baseline Description

Volume 2: Functions and Requirements Analysis 
WHC-SD-WM-RPT-060, REV 0 VOLUME 2

Table of Contents

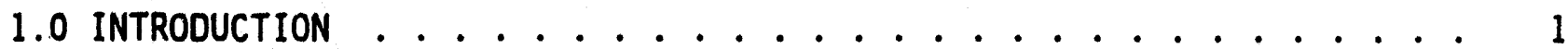

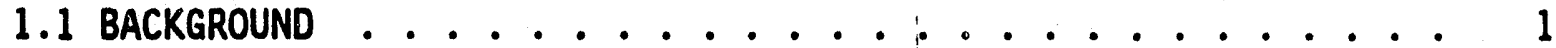

1.2 PURPOSE

2.0 FUNCTIONS AND REQUIREMENTS ANALYSIS . . . . . . . . . . . 5

2.1 FUNCTION HIERARCHY . . . . . ....... 5

2.2 FUNCTION DESCRIPTIONS AND REQUIREMENTS .......... 12

3.0 SOLID WASTE PROGRAM INTERFACES . . . . . . . . . . . 68

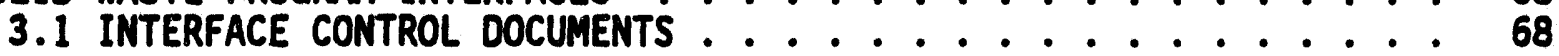

4.0 Definitions . . . . . . . . . . . . . . . . 75

5.0 REFERENCES ........................... 79 


\title{
WHC-SD-WM-RPT-060, REV 0 VOLUME 2
}

\author{
List of Tables
}

Table 1-1. Source Documents Reviewed for Solid Waste Program Requirements

Table 2-1. Function Definitions

Table 2-4.3 Function and Requirement Analys is for Function 4.3 , Remedy Solid Waste . . . . . . . . . .............

Table 2-4.3.1 Function and Requirement Analys is for Function 4.3.1, Maintain Solid Waste Safety And Compliance Envelope . . . . . . . 15

Table 2-4.3.1.1 Function and Requirement Analysis for Function 4.3.1.1, Maintain Safe and Compliant Solid Waste Operational Environment..

Table 2-4.3.1.2 Function and Requirement Analysis for Function 4.3.1.2,

Maintain Safe And Compliant Solid Waste Systems, Equipment and Structures

Table 2-4.3.1.3 Function and Requirement Analys is for Function $4.3 . i . j$, Maintain Safe And Compliant Solid Waste Documentation . . . . . . .

Table 2-4.3.1.4 Function and Requirement Analys is for Function 4.3.1.4, Maintain Qualified Solid Waste Staff ...............

Table 2-4.3.1.5 Function and Requirement Analysis for Function 4.3.1.5,

Maintain Safe And Compliant Solid Waste Documentation . . . . . . .

Table 2-4.3.2 Function and Requirement Analys is for Function 4.3.2,

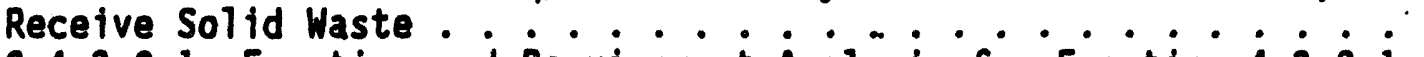

Table 2-4.3.2.1 Function and Requirement Analysis for Function 4.3.2.1, Retrieve Existing Solid Waste . . . . . . . . . . . . . . . .

Table 2-4.3.2.2 Function and Requirement Analys is for Function 4.3.2.2, Receive New Solid Waste . . . . . . . . . . . . . . . . .

Table 2-4.3.3 Function and Requirement Analys is for Function 4.3.3, Characterize Sol id Waste ...................

Table 2-4.3.3.1 Function and Requirement Analys is for Function 4.3.3.1, Acquire Solid Waste Process Knowledge . . . . . . . . . . . . . . .

Table 2-4.3.3.2 Function and Requirement Analys is for Function 4.3.3.2, Analyze Sol id Waste Inventory ................... . 40

Table 2-4.3.3.3 Function and Requirement Analysis for Function 4.3.3.3, Archive Sol id Waste Samples/Characterization Data . . . . .

Table 2-4.3.3.4 Function and Requirement Analys is for Function 4.3.3.4, Assess Solid Waste Characterization Information . . . . . . . .

Table 2-4.3.4 Function and Requirement Analys is for Function 4.3.4, Determine Sol id Waste Disposition Requirements . . . . . . . . . .

Table 2-4.3.4.1 Function and Requirement Analys is for Function 4.3.4.1, Compile Imposed Sol id Waste Requirements . . . . . . . . . .

Table 2-4.3.4.2 Function and Requirement Analysis for Function 4.3.4.2,

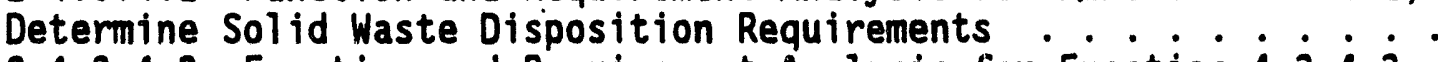

Table 2-4.3.4.3 Function and Requirement Analys is for Function 4.3.4.3, Prepare Solid Waste Disposition Specifications . . . . . . . . . 50

Table 2-4.3.5 Function and Requirement Analysis for Function 4.3.5, Disposition Solid Waste .................... .

Table 2-4.3.5.1 Function and Requirement Analys is for Function 4.3.5.1,

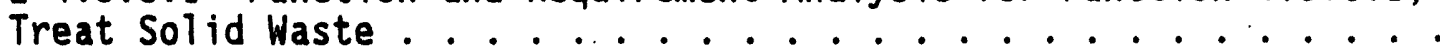

Table 2-4.3.5.2 Function and Requirement Analys is for Function 4.3.5.2, Package Solid Waste........................ 
Table 2-4.3.5.3 Function and Requirement Analys is for Function 4.3.5.3, Certify Solid Waste .................. 59

Table 2-4.3.5.4 Function and Requirement Analys is for Function 4.3.5.4, Store Sol id Waste . . . . . . . . . . . . . . . 61

Table 2-4.3.5.5 Function and Requirement Analys is for Function 4.3.5.5, Ship Solid Waste ....................... 63

Table 2-4.3.5.6 Function and Requirement Analys is for Function 4.3.5.6, Dispose Solid Waste .................... 64

Table 2-4.3.5.7 Function and Requirement Analys is for Function $4 . \dot{3} . \dot{5} . \dot{7}$, Assess Solid Waste TSD Capability Needs and Disposal Resources . . .65

Table 2-4.3.5.8 Function and Requirement Analysis for Function 4.3.5.8, Archive Solid Waste Process Samples and Records . . . . . . . . . 67 


\section{WHC-SD-WM-RPT-060, REV 0 VOLUME 2 \\ List of Figures}

Figure 2-1. Site-Wide System Engineering Functional Analysis . . . . . 6

Figure 2-2. Solid Waste Program Functional Analys is ....... 7

Figure 3-1. Functional Interface Diagram for Function 4.3, Remedy Solid

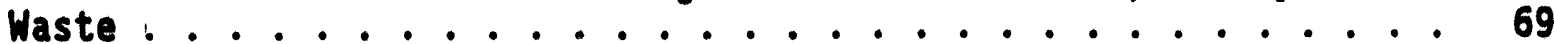

Figure 3-2. Functionai Interface Diagram for Function 4.3.1, Maintain Sol id Waste Safety And Compliance Envelope ........ 70

Figure 3-3. Functional Interface Diagram for Function 4.3.2, Receive Solid Waste. . . . . . . . . . 71

Figure 3-4. Functional Interface Diagram for Function 4.3.3, Characterize Solid Waste .............. . 72

Figure 3-5. Functional Interface Diagram for Function 4.3.4, Determine Solid Waste Disposition Requirements .......... . 73

Figure 3-6. Functional Interface Diagram for Function 4.3.5, Disposition Solid Waste ............... 74 
WHC-SD-WM-RPT-060, REV 0 VOLUME 2

\subsection{INTRODUCTION}

\subsection{BACKGROUND}

Since 1943, radioactive solid waste has been disposed in direct shallow 1 and burtal grounds at DOE's Hanford -Site. There are 75 burtal grounds located throughout the site in the 100 Areas, 200 Areas, 300 Area and 600 . Area. There are 28 burial grounds in the 100 Areas, 34 in the 200 Areas, and the remaining 13 are in the 300 and 600 Areas. Burial grounds have received radioactive solid wastes from all the various missions at the Hanford site over its fifty year history. The burial grounds also have received radioactive solid waste from off-site generators.

The Atomic Energy Commission directed in Immediate Action Directive 0511-21 (Reference 9) on March 20, 1970, that after April 30, 1970, al1 Atomic Energy Commission sites would segregate "waste with known or detectable. contamination of transuranium nuclides" from other types of wastes. Such wastes were to be segregated, packaged, and stored in readily retrievable, contamination-free packages for up to 20 years. After 20 years, retrievability was to continue to be possible. This policy was because of the high toxicity and long half-1ife periods of TRU isotopes. The 20-year interim storage perlod was to allow time to study the best disposal al ternative. The immediate action directive did not provide a detalled definition of TRU waste. Contractors to the Atomic Energy Commission implemented the policy as well as possible based upon analytical data, calculations, and process knowledge.

In 1973, the segregation 1 imit for TRU waste was given a value of 10 $\mathrm{nCi} / \mathrm{g}$. This did not change waste handling practices because the amount of TRU was based on calculations and/or estimates. In 1982, the segregation 1 imits were changed again, to $100 \mathrm{nCi} / \mathrm{g}$, reducing the volume of newiy generated wastes designated as TRU waste.

On May 18, 1987 the DOE issued an interpretive rule under the Atomic Energy Act of $1954 \mathrm{clarifying}$ DOE obligations under the RCRA, which is promulgated in Washington State by the "Dangerous Waste Regulations". Chapter 173-303 of the Washington Administrative Code (WAC). As a result, all lowlevel radioactive waste contaminated with dangerous waste under the WAC is termed low-level mixed waste and subject to regulation by the DOE and Washington State. This created categories of waste that require separate waste-management disposition and segregation.

In 1987, the Hanford Site stopped disposing of mixed waste in unlined trenches and began to store these wastes in above-ground facilities. In January 1988, an agreement with the State stipulated that mixed waste with a dose rate less than $200 \mathrm{mrem} / \mathrm{h}$ would be retrievably stored and $\mathrm{placed}$ in a building that meets all of the Washington State storage requirements. Mixed waste with greater than $200 \mathrm{mrem} / \mathrm{h}$ (remote-handled) would be disposed of below ground to satisfy as low as reasonably achievable radiation safety requirements, assuming successful waiver applications. 


\section{WHC-SD-WM-RPT-060, REV 0 VOLUME 2}

As part of the dangerouse waste regulations, the Hanford site was required to submit permits for operation of those burial grounds which would remain active. The burial grounds for which permits were submitted are: $218-E-10,218-E-12 B, 218-W-3 A, 218-W-3 A E, 218-W-4 B, 218-W-4 C, 218-W-5$, and 218-W-6 [future site]. All other burial grounds at the Hanford Site are considered inactive and w111 be remediated under the Comprehensive Environmental Response, Compensation, and Liability Act (CERCLA) as part of the Environmental Restoration Program mission.

\subsection{PURPOSE}

The purpose of this volume is to establish the Solid Waste Program functions and requirements baseline by defining the first three levels of functions, requirements, and interfaces necessary to meet the Solid Waste Program mission.

Functional analysis identifies the functions that must be performed in order to meet the mission. These functions can then be allocated at increasingly greater levels of detail in order to provide an increasingly explicit depiction of the mission statement. Requirements analys is identifies the requirements associated with each function. Requirements are allocated to each functional allocation in order to provide greater detall of the requirements.

The purpose of the functions and requirements analys is is to:

- Describe the first three levels of functions for the Solid Waste Program based on its role in the Hanford mission to clean up the site

- Identify the top-level requirements that govern the technical baseline system

- Identify the interfaces of. the Solid Waste Program whtch need to be defined to meet the progran's mission

- Provide the technical design basis for individual elements of the Solid Waste program's technical system. The technical system being defined by the integrated facilities and projects which will accomplish the Solid Waste program mission.

Functions are specific actions, activities, or processes that achieve or support the achievement of the Solid Waste program's technical mission. This functional analys is is limited only to technical functions and does not include programmatic functions (program management, project management, etc.).

Requirements define how well a function must perform. Requirements set limits on functions and also limits on the outputs from functions.

Requirements include, but are not 1 imited to, mission specifications, regulatory constraints, external policies, and internal policies. 
WHC-SD-WM-RPT-060, REV 0 VOLUME 2

\subsection{SOLID WASTE PROGRAM MISSION}

The Hanford Mission Plan, Volume 1, Site Guidance (Reference 1) identifies the need for the Solid Waste Program to "treat, store, and dispose of a wide varioty of solid material types consisting of multiple radioactive and hazardous waste classes". This includes "future Hanford Site activities (which) will generate new wastes that wust be handled as cleanup activities are completed".

To meet this need the Solid Waste Program has defined its mission as the following - recoive, store, treat, and dispose of solid radtoactive and nonradtoactive wastes in a safe and onvironentally compliant manner (Reference 2).

\subsection{SOLID WASTE PROGRAM EXTERNAL SYSTEM REQUIREMENTS}

Solid Waste Program external system requirements are 1 imits on the system design imposed from authority outside the mission. These requirements must be properly allocated to the functions to meet the mission. External system requirements cover a broad range of activities and a complete listing of all requirements. has not been developed to date for the Solid Waste Program functional analysis. Sources of requitrements include: Public Laws, the United States Code, Code of Federal Regulations and the Federal Register, Federal Consent Orders, Washington Administrative Code, Revised Code of Washington, Executive Orders, Secretary of Energy Notices, United States Department of Energy Orders, United States Department of Energy Notices, and Codes and Standards.

Table 1-1 identifies the sources documents that have been reviewed for requirements appificable to the Solid Waste Program functions. 


$$
\text { WHC-SD-WM-RPT-060, REV } 0 \text { VOLUME } 2
$$

Table 1-1. Source Documents Reviewed for Solid Waste Program Requirements

\begin{tabular}{|c|c|}
\hline Document Number & Document Title \\
\hline DOE 5400.1 & General Environmental Protection Program \\
\hline DOE 5400.3 & Hazardous and Radioactive Mixed Waste Program \\
\hline DOE 5400.5 & $\begin{array}{l}\text { Radiation Protection of the Public and the } \\
\text { Environment }\end{array}$ \\
\hline DOE 5480.11 & Radiation Protection for Occupational Workers \\
\hline DOE $5820.2 A$ & Radioactive Waste Management \\
\hline $\begin{array}{l}\text { Federal Register } \\
\text { Vol. 53, p. } 12449\end{array}$ & $\begin{array}{l}\text { Record of Decision, Hanford High-Leve1, } \\
\text { Transuranic, and Tank Wastes, Apri1 8, } 1988\end{array}$ \\
\hline DOE/WIPP-069, Rev 4 & $\begin{array}{l}\text { TRU Waste Acceptance Criteria for The Waste } \\
\text { Isolation Pilot Plant }\end{array}$ \\
\hline $\begin{array}{l}\text { TRUPACT II Shipping } \\
\text { Requirements }\end{array}$ & \\
\hline
\end{tabular}


WHC-SD-WM-RPT-060, REV 0 VOLUME 2

\subsection{FUNCTIONS AND REQUIREMENTS ANALYSIS}

Figure 2-1 shows the integration of the Solid Waste Program functional analysis to the site-wide system engineering function analysis. The site-wide system engineering effort has assigned 4.3 to the function Remedy Solid Waste and the Solid Waste Program functlons witil be numbered based on this numbering scheme for traceability of Solid Waste Program functional analysis to the site-wide effort.

\subsection{FUNCTION HIERARCHY}

As part of the site-wide systein engineering effort the Solid Waste Program developed a function hierarchy to further define function 4.3 , Remedy Solld Waste. This was accomplished through workshops which included representatives from the Solid Waste Program and other site programs affected by the Remedy Solid Waste function. The result of this effort by the Solid Waste Program is presented as a function hierarchy to the fourth level (where 4.3 is the second, 4.3.x is the third, and 4.3.x.y is the fourth level) shown in figure 2-2. A listing of each function and its definition is presented in Table 2-1. 


\section{WHC-SD-WM-RPT-060, REV 0 VOLUME 2}

Figure 2-1. Site-Wide System Engineering Functional Analysis

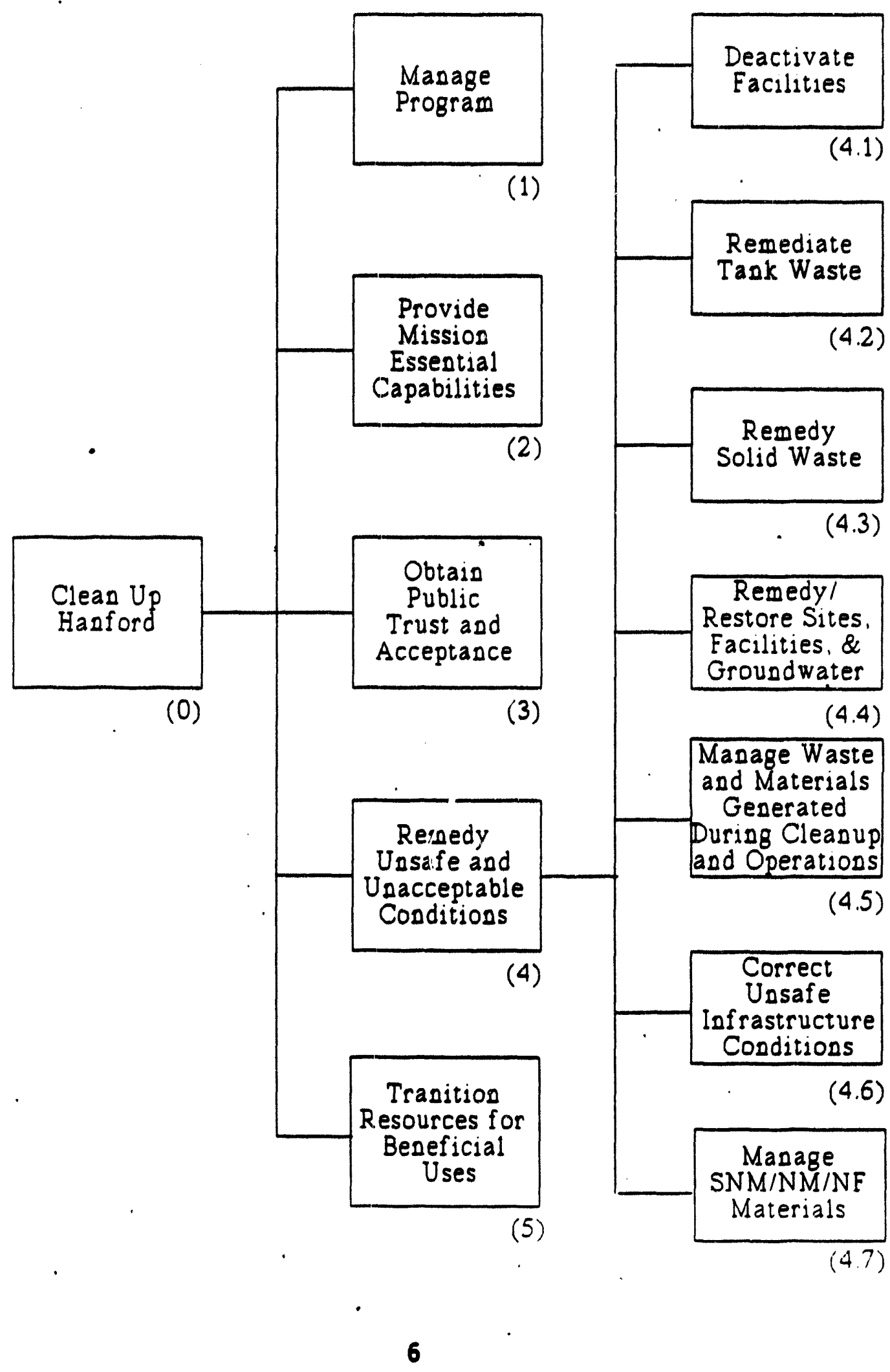




\section{WHC-SD-WM-RPT-060, REV 0 VOLUME 2}

Eigure 2-2. Solid Waste Program Eunctional A nalysis

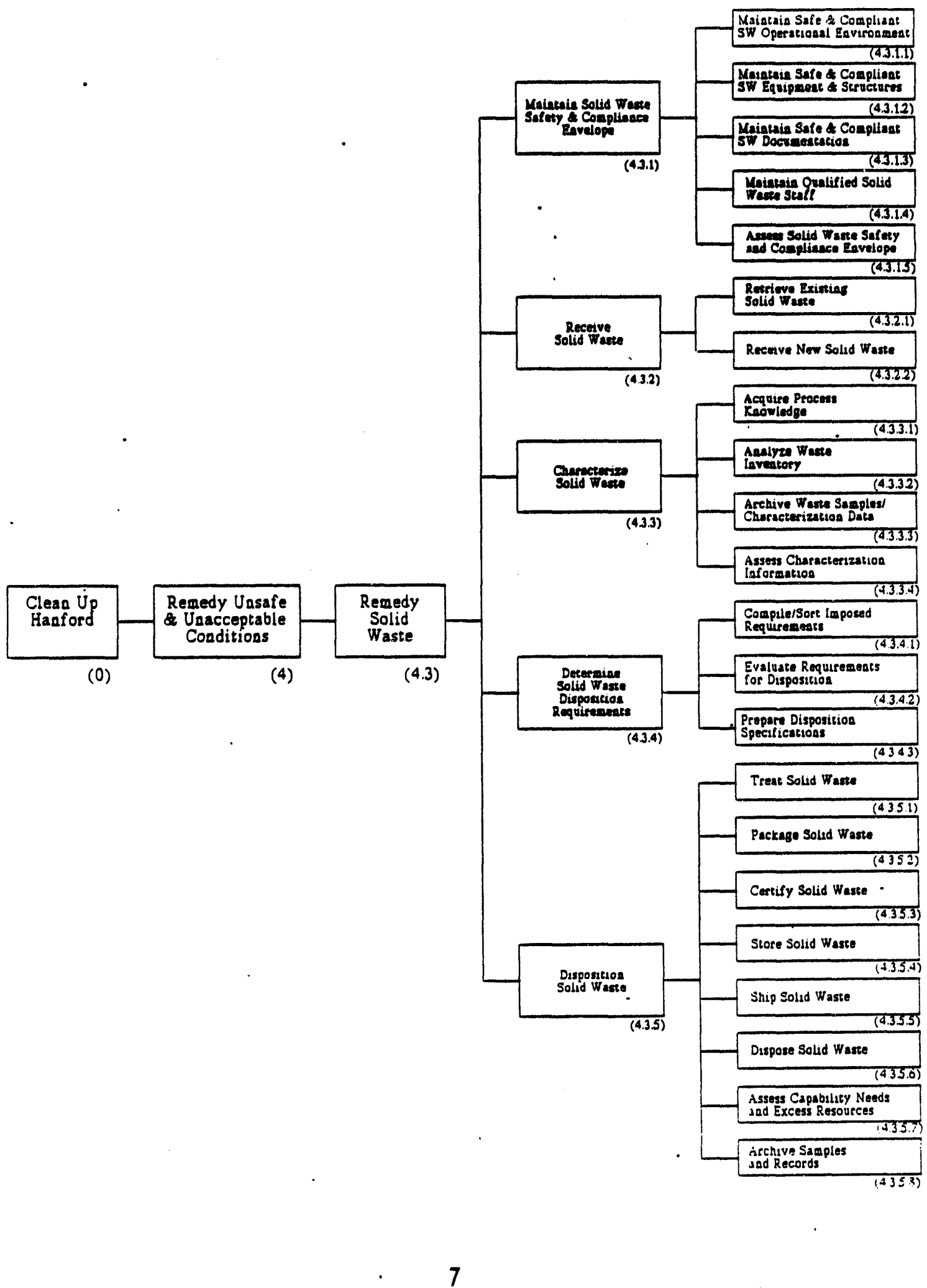


WHC-SD-WM-RPT-060, REV 0 VOLUME 2

Table 2-1. Function Definitions

\begin{tabular}{|c|c|}
\hline Function & Definition \\
\hline 4.3 & $\begin{array}{l}\text { Remedy Solid Waste } \\
\text { Provide the required treatment, storage and disposal of } \\
\text { solid. wastes involved in the Hanford cleanup mission. }\end{array}$ \\
\hline 4.3 .1 & $\begin{array}{l}\text { Maintzin Solid Waste Safety And Compliance Envelope } \\
\text { Continually assess and maintain the waste form and the } \\
\text { facility structures and operations in a safe and compliant } \\
\text { condition. Includes maintaining a qualified facility } \\
\text { staff, and maintaining required safety/compliance } \\
\text { documentation. }\end{array}$ \\
\hline 4.3 .1 .1 & $\begin{array}{l}\text { Maintain Safe And Compliant Solid Waste Operational Environment } \\
\text { Continually assess and maintain the solid waste } \\
\text { operational environment in a safe and compliant condition. }\end{array}$ \\
\hline 4.3 .1 .2 & $\begin{array}{l}\text { Maintain Safe And Compliant Solid Waste Systems, Equipment and } \\
\text { Structures } \\
\text { Continually assess and maintain the solid waste facility } \\
\text { systems, equipment, and structures, and their operations } \\
\text { in a safe condition. Maintain a qualified solid waste } \\
\text { staff, and maintain required solid waste facility and } \\
\text { operating documentation. }\end{array}$ \\
\hline 4.3 .1 .3 & $\begin{array}{l}\text { Maintain Safe And Compliant Solid Waste Documentation (SARs, } \\
\text { OSRs, etc.) } \\
\text { Maintain required solid waste facility and operating } \\
\text { documentation related to safe and compliant operations. }\end{array}$ \\
\hline 4.3 .1 .4 & $\begin{array}{l}\text { Maintain Qualified Solid Waste Staff } \\
\text { Maintain qualified and certified solid waste staff. }\end{array}$ \\
\hline 4.3 .1 .5 & $\begin{array}{l}\text { Assess Solid Waste Safety And Compliance State } \\
\text { Assess state of solid waste for safety and compliance. }\end{array}$ \\
\hline 4.3 .2 & $\begin{array}{l}\text { Receive Solid Waste } \\
\text { Retrieve legacy solid waste and receive solid waste } \\
\text { generated during cleanup operations and solid waste from } \\
\text { other missions. }\end{array}$ \\
\hline 4.3 .2 .1 & $\begin{array}{l}\text { Retrieve Existing Solid Waste } \\
\text { Retrieve legacy solid waste; includes retrieval planning } \\
\text { and solid waste access and removal, obtains waste } \\
\text { characterization samples, generates waste information, } \\
\text { establishes retrieval capability requirements, and } \\
\text { forecasts future retrieval operations. }\end{array}$ \\
\hline
\end{tabular}


WHC-SD-WM-RPT-060, REV 0 VOLUME 2

Table 2-1. Function Definitions

\begin{tabular}{|c|c|}
\hline Function & Definition \\
\hline 4.3 .2 .2 & $\begin{array}{l}\text { Receive New Solid Waste } \\
\text { Receives solid waste generated during Hanford Cleanup } \\
\text { mission operations and from other missions; includes solid } \\
\text { waste receipt planning, characterization information } \\
\text { verification for acceptance, establishes receipt } \\
\text { capability requirements, and forecasts future receipt } \\
\text { operations. }\end{array}$ \\
\hline 4.3 .3 & $\begin{array}{l}\text { Characterize Solid Waste } \\
\text { Identify, inventory, and characterize the waste by } \\
\text { reviewing the process operations (current and historical), } \\
\text { by reviewing new waste information and by sampling and } \\
\text { analyzing the waste inventory. Assess the current } \\
\text { condition of the waste. Archive the results of these } \\
\text { investigations. }\end{array}$ \\
\hline 4.3 .3 .1 & $\begin{array}{l}\text { Acquire Solid Waste Process Knowledge } \\
\text { Review the solid waste processing records, process } \\
\text { documentation, and submitted documentation to acquire } \\
\text { knowledge about the solid waste generation process. } \\
\text { Conduct interviews with sol id waste generators as needed } \\
\text { to obtain such knowledge and perform a safety review of } \\
\text { the solid waste. Provide this process knowledge to enable } \\
\text { the solid waste characterization assessment. }\end{array}$ \\
\hline 4.3 .3 .2 & $\begin{array}{l}\text { Analyze Solid Waste Inventory } \\
\text { Receive the solid waste samples and perform analysis } \\
\text { thereof to obtain required characterization data. Provide } \\
\text { this analysis information to enable the solid waste } \\
\text { characterization assessment. Transfer the solid waste } \\
\text { samples and accompanying characterization data to solid } \\
\text { waste archives. Send any excess solid waste samples on to } \\
\text { the Receive Solid Waste function to facilitate } \\
\text { disposition. }\end{array}$ \\
\hline 4.3 .3 .3 & $\begin{array}{l}\text { Archive Solid Waste Samples/Characterization Data } \\
\text { Provide archival storage and retrieval operations for the } \\
\text { analyzed solid waste samples and the accompanying } \\
\text { characterization data. }\end{array}$ \\
\hline
\end{tabular}


WHC-SD-WM-RPT-060, REV 0 VOLUME 2

Table 2-1. Function Definitions

\begin{tabular}{|c|c|}
\hline Function & Definition \\
\hline 4.3 .3 .4 & $\begin{array}{l}\text { Assess Solid Waste Characterization Information } \\
\text { Evaluate the solid waste characterization information, } \\
\text { consisting of generator request information, process } \\
\text { knowledge information, and waste sample characterization. } \\
\text { data, against the solid waste disposition requirements and } \\
\text { provide validation of meeting the disposition } \\
\text { requirements. Determine any additional sol id waste } \\
\text { process knowiedge needs to support disposition. }\end{array}$ \\
\hline 4.3 .4 & $\begin{array}{l}\text { Determine Solid Waste Disposition Requirements } \\
\text { Compile and sort imposed requirements, define requirements } \\
\text { that result from proposed solutions and required } \\
\text { capabilities, and assess constraints under which the } \\
\text { function must operate. }\end{array}$ \\
\hline 4.3 .4 .1 & $\begin{array}{l}\text { Compile Imposed Solid Waste Requirements } \\
\text { Collect state, federal, DOE and any other regulatory } \\
\text { documents which pertain to transport, handling, packaging } \\
\text { and disposition of solid waste. }\end{array}$ \\
\hline 4.3 .4 .2 & $\begin{array}{l}\text { Evaluate Solid Waste Requirements For Disposition } \\
\text { Review. and evaluate list of solid waste disposition } \\
\text { requirements to verify applicability and completeness for } \\
\text { disposition categories. }\end{array}$ \\
\hline $4.3 .4: 3$ & $\begin{array}{l}\text { Prepare Solid Waste Disposition Specifications } \\
\text { Generate specifications for solid waste operations } \\
\text { includingtreatment, packaging, certification, storage, } \\
\text { shipping, disposition, and archiving samples and records. }\end{array}$ \\
\hline 4.3 .5 & $\begin{array}{l}\text { Disposition Solid Waste } \\
\text { Package and certify the solid waste, store or ship it.as } \\
\text { needed, treat and/or immobilize it, and accomplish final } \\
\text { disposition. }\end{array}$ \\
\hline 4.3 .5 .1 & $\begin{array}{l}\text { Treat Solid Waste } \\
\text { Provide treatment of solid waste to neutralize, } \\
\text { immobilize, and stabilize it for storage and fina? } \\
\text { disposition. }\end{array}$ \\
\hline 4.3 .5 .2 & $\begin{array}{l}\text { Package Solid Waste } \\
\text { Containerize the treated solid waste in a container } \\
\text { suitable for the waste type. Provide solid waste } \\
\text { packaging documentation inciuding packaging certifications } \\
\text { and solid waste feedstock traceability. Provide } \\
\text { appropriate labeling and inspection of the containers of } \\
\text { solid waste. }\end{array}$ \\
\hline
\end{tabular}


WHC-SD-WM-RPT-060, REV 0 VOLUME 2

Table 2-1. Function Definitions

\begin{tabular}{|c|c|}
\hline Function & Definition. \\
\hline 4.3 .5 .3 & $\begin{array}{l}\text { Certify Solid Waste } \\
\text { Certify that the solid waste was treated according to the } \\
\text { disposition requirements and that the documentation is in } \\
\text { order to allow release of the solid waste package for } \\
\text { storage and disposition. }\end{array}$ \\
\hline 4.3 .5 .4 & $\begin{array}{l}\text { Store Solid Waste } \\
\text { Store the solid waste before shipment to the disposal } \\
\text { stte. }\end{array}$ \\
\hline 4.3 .5 .5 & $\begin{array}{l}\text { Ship Solid Waste } \\
\text { Receive the certified solid waste package and prepare the } \\
\text { necessary shipment requests and documentation. Coordinate } \\
\text { the solid waste package shipment with shippers and } \\
\text { receivers to verify that the final waste disposition was } \\
\text { accomplished. Document the final solid waste disposition } \\
\text { status. }\end{array}$ \\
\hline 4.3 .5 .6 & $\begin{array}{l}\text { Dispose Solid Waste } \\
\text { Schedule the solid waste package disposal and prepare the } \\
\text { waste transport package and disposal documentation. } \\
\text { Provide final inspection of the solid waste package load } \\
\text { and place in disposal site. close the disposal site in } \\
\text { regulatory compliance and provide institutional controls } \\
\text { and closure security to maintain the disposal site } \\
\text { security and integrity. }\end{array}$ \\
\hline 4.3 .5 .7 & $\begin{array}{l}\text { Assess Solid Waste TSD Capability Needs And Disposal Resources } \\
\text { Assess the solid waste treatment, storage, and disposal. } \\
\text { (TSD) capability needs and resources based on required } \\
\text { versus design throughput and capacities. }\end{array}$ \\
\hline 4.3 .5 .8 & $\begin{array}{l}\text { Archive Solid Waste Process Samples and Records } \\
\text { Provide archival storage and retrieval operations for the } \\
\text { analyzed solid waste process samples and the accompanying } \\
\text { analysis data. }\end{array}$ \\
\hline
\end{tabular}




\subsection{FUNCTION DESCRIPTIONS AND REQUIREMENTS}

Each function is designed to transform given inputs inco desired outputs. Technical requirements which define performance are necessary to adequately define each input, function, and output. This section describes each function, its inputs and outputs, and the requirements for each function, input, and output. Allocation of the first three levels of functions of Remedy Solid Waste and the associated inputs and outputs for each function are tabulated. The requirements allocated for each function, input, and nutput are also tabulated below.

The naming convention for the following tables is based on the function number from the site wide system engineering effort. For example the function and requirement description for function 4.3, Remedy Solid Waste, would be Table 2-4.3 and the function and requirement description for function 4.3.5.6, Dispose Solid Waste would be Table 2-4.3.5.6. The 2 at the beginning of the table number signifies this section of the document. 
WHC-SD-WM-RPT-060, REV 0 VOLUME 2

Table 2-4.3 Function and Requirement Analysis for Function 4.3, Remedy Solid Waste

Function 4.3 Remedy Solid Waste

Definition: Provide the required treatment, storage and disposal of solid wastes involved in the Hanford cleanup

Requirement( $\dot{s})$ : mission.

Input 1 Legacy Solid Waste

Definition: Existing waste resulting from Hanford's defense

Requirement( $s$ ): material production and energy production missions.

Input 2 Cleanup Wastes

Definition: Solid waste generated during cleanup operations or from other missions.

Requirement(s):

Input 3 Solid Wastes from Other Missions

Definition: Solid waste that comes from other DOE missions outside Requirement(s): of the Hanford Cleanup Mission.

Input 4 Non-Compliant Conditions

Definition: Conditions that do not pose an imminent threat to the public, to Hanford workers or to the environment, but that violate imposed requirements specified in laws, regulations, DOE Orders or other requirements

Requirement( $s$ ): promulgated by authorized jurisdictions.

Output 1. Transferrable Resources

Definition: Physical and intellectual resources; e.g., facilities, equipment, materials, infrastructure, land, technology, sclentific data, personnel expertise; that are developed during facility deactivation and can be transferred to other areas in the public or private

Requirement(s): domains. 
WHC-SD-WM-RPT-060, REV 0 VOLUME 2

Table 2-4.3 Function and Requirement Analys is for

Function 4.3, Remedy Solid Waste (Continued)

Output 2 Dispositioned Solid Waste.

Definition: Solid waste that is ready for disposal or transfer to a useful function within or outside the Cleanup Hanford mission.

Requirement (s):

Output 3 Rejected Non-Compliant Solid Waste

Definition: This is solid waste material received from solid waste operations, cleanup operations, and other missions that cannot be resolved without evaluation by the

Requirement(s): generator.

Output 4 Non-Solid Waste Generated During Cleanup Operations

Definition: Incidental gaseous and liquid wastes that are not

Requirement(s):

treated as part of solid waste treatment operations.

Output 5 Requirements Requiring Reconciliation

Definition: These are waste disposition requirements that require reconciliation.

Requirement(s):

Output 6 Solid Waste Remedy Needs/Information

Definition: In the course of solid waste remediation, needs and information may be discovered which may impact

direction \& control, mission requirements, and defined

Requirement(s): work packages.

Output 7 Excess Solid Waste Facilities

Definition: Facilities that have had a mission in the Hanford Cleanup Mission. It includes excess sites for disposition (e.g. potentially contaminated retrieved

Requirement(s): trench). 
WHC-SD-WM-RPT-060, REV 0 VOLUME 2

Table 2-4.3.1 Function and Requirement Analysis for Function 4.3.1, Maintain Solid Waste Safety And Compliance Envelope

Function 4.3.1 Maintain Solid Waste Safety And Compliance Envelope

Definition: Continually assess and maintain the waste form and the facility structures and operations in a safe and compliant condition. Includes maintaining a qualified facility staff, and maintaining required

Requitrement(s): safety/compli ance documentation.

Input 1 NonCompliant Conditions

Definition: Conditions that do not pose an imminent threat to the public, to Hanford workers or to the environment, but that violate imposed requirements specified in laws, regulations, DOE Orders or other requirements

Requirement(s): promulgated by authorized. jurisdictions.

Input 2 Solid Waste Characterization Information

Definition: This is characterization data consisting of current or historical process operation knowledge pertaining to the solid waste, its current condition, and sampling and analysis results required to determine its final

Requirement(s): disposition.

Input 3 Waste Disposition Status Information

Definition: As the physical status of the solid waste changes, the safety and compliance envelope changes. This is all information regarding the disposition state of the Requirement(s): solid waste.

Output I Acutely Unsafe Conditions Information

Definition: Nuclear or chemically unsafe conditions and information, does not include OSHA, for example. These are conditions detected during the cleanup operations which need to be immediately fed back to the program management function for consideration which may result in new direction \& control, defined Requirement(s): work packages, and/or mission requirements. 
WHC-SD-WM-RPT-060, REV 0 VOLUME 2

Table 2-4.3.1 Function and Requirement Analysis for Function 4.3.1, Maintain Solid Waste Safety And Compliance Envelope (Continued)

Output 2 Non-Solid Waste Generated During Cleanup Operations

Definition: Incidental gaseous and liquid wastes that are not Requirement(s): treated as part of solid waste treatment operations.

Output 3 Operations and Capability Needs

Definition: Capabilities and needs discovered while operating the Requirement( $s)$ : systen. As we operate the system, we got smarter.

Output 4 Solid Waste Generated During Solid Waste Cleanup Operations

Definition: Contaninated tools, equipment and materials generated as a direet result of cleanup operations; including used cleaning solvents, rags, stack filters and similar itens requiring processing prior to disposal or transfer to a useful function within or outside the

Requirement( $s$ : Cleanup Hanford mission.

Output 5 Solid Waste Safety/Compliance Envelope Constraints

Definition: These are constraints that follow the solid waste to ensure that the safety and compliance envelope is maintained during receipt, characterization, disposition requirement generation, and final

Requirement(s): disposition of solid waste.

Output 6 Transferrable Resources

Definition: Physical and intellectual resources; e.g., facilities, equipment, materials, infrastructure, land, technology, scientific data, personnel expertise; that are developed during facility deactivation and can be transferred to other areas in the public or private

Requirement( $s$ ): domains.

Output 7 Undocumented Wastes Information

Definition: While doing everyday operations we come upon waste previously undocumented. Information must be fed back Requirement(s): to the management function. 
WHC-SD-WM-RPT-060, REV. 0. VOLUME 2

Table 2-4.3.1.1 Function and Requirement Analysis for Function 4.3.1.1, Maintain Safe and Compliant Solid Waste Operational Environment

Function 4.3.1.1 Maintain Safe and Compliant Solid Waste Operational Environment

Definition: Continually assess and maintain the solid waste operational environment in a safe and compliant

Requirement(s): condition.

Input 1 NonCompliant Conditions

Definition: Conditions that do not pose an imminent threat to the pubile, to Hanford workers or to the environment, but that violate imposed requirements specified in laws, regulations, DOE Orders or other requirements

Requirement(s): promulgated by authorized jurisdictions.

Input 2 Solid Waste Characterization Information

Definition: This is characterization data consisting of current or historical process operation knowledge pertaining to the solid waste, its current condition, and sampling and analysis results required to determine its final

Requirement (s): disposition.

Input 3 Solid Waste Corrective Action Needs

Definition: Actions required to bring waste status into compliance with handing and disposition requirements.

Requirement(s):

Input 4 Waste Disposition Status Information

Definition: As the physical status of the solid waste changes, the safety and compliance envelope changes. This is all information regarding the disposition state of the solid waste.

Requirement(s):

Output 1 Non-Solid Waste Generated During Cleanup Operations

Definition: Incidental gaseous and liquid wastes that are not Requirement(s): treated as part of solid waste treatment operations. 
WHC-SD-WM-RPT-060, REV 0 VOLUME 2

Table 2-4.3.1.1 Function and Requirement Analysis for Function 4.3.1.1, Maintain Safe and Compliant Solid Waste Operational Environment (Continued)

Output 2 Operations and Capability Needs

Definition: Capabilities and needs discovered while operating the Requitrement (s): systen. As we operate the system, we get smarter.

Output 3 Solid Waste Operations and Maintenance Work Package

Definition: This is a work package that relates the solid waste Requitrement(s): operations and maintenance work to be performed.

Output 4 Solid Waste Operations Information

Definition: This is information related to the operations of the Requirement( $s$ ): solid waste systems, equipment, and structures.

Output 5 Transferrable Resources

Definition: Physical and intellectual resources; e.g., facilities, equipment, materials, infrastructure, 7 and, technology, scientific data, personnel expertise; that are developed during facility deactivation and can be transferred to other areas in the public or private

Requirement( $s$ ): domains. 
WHC-SD-WM-RPT-060, REV 0 VOLUME 2

T.able 2-4.3.1.2 Function and Requirement Analys is for Function 4.3.1.2, Maintain Safe And Compl tant Solid Waste Systems, Equipment and Structures

Function-4.3.1.2 Maintain Safe And Compliant Solid Waste Systems, Equipment and Structures

Definition: Continually assess and maintain the solid waste facility systems, equipment, and structures, and their operations in a safe condition. Maintain a qualified solid waste staff, and maintain required solid waste

Requitrement( $s$ ): factilty and operating documentation.

Input 1 Solid Waste Corrective Action Needs

Definition: Actions required to bring waste status into compliance Requirement( $s$ ): with handling and disposition requirements.

Output 1. Non-Solid Waste Generated During Cleanup Operations

Definition: Incidental gaseous and liquid wastes that are not Requitrement(s): treated as part of solid waste treatment operations.

Output 2 Solid Waste Equipment and Structure Information

Definition: This is information related to the solid waste equipment and structure safety and maintenance checks, covering core maintenance, preventative maintenance, ICRS, and minor facility and equipment

Requirement( $s$ ): modifications.

Output 3 Solid Waste Generated During Solid Waste Cleanup Operations

Definition: Contaninated tools, equipment and materials generated as a direct result of cleanup operations; including used cleaning solvents, rags, stack filters and similar items requiring processing prior to disposal or transfer to a useful function within or outside the Requirement(s): Cleanup Hanford mission. 
WHC-SD-WM-RPT-060, REV 0 VOLUME 2

Table 2-4.3.1.2 Function and Requirement Analys is for Function 4.3.1.2, Maintain Safe And Compliant Solid Waste Systems, Equipment and Structures (Continued)

Output 4 Transferrable Resources

Definition: Physical and intellectual resources; e.g., facilities, equipment, materials, infrastructure, iand, technology, scientific data, personnel expertise; that are-developed during facility deactivation and can be transferred to other areas in the public or private

Requirement(s): domains. 
WHC-SD-WM-RPT-060, REV 0 VOLUME 2

Table 2-4.3.1.3 Function and Requirement Analysis for Function 4.3.1.3, . Maintain Safe And Compliant Solid Waste Documentation

Function 4.3.1.3 Maintain Safe And Compliant Solid Waste Documentation

Definition: Maintain required solid waste facility and operating documentation related to safe and compliant operations.

Requirement(s):

Input 1 Solid Waste Corrective Action Needs

Definition: Actions required to bring waste status into compliance Requirement(s): with handling and disposition requirements.

Input 2 Solid Waste Equipment and Structure Information

Definition: This is information related to the solid waste equipment and structure safety and maintenance . checks, covering core maintenance, preventative

Requirement(s): maintenance, ICRS, and minor facility and equipment modifications.

Input 3 Solid Waste Operations Information

Definition: This is information related to the operations of the Requirement( $s$ ): solid waste systems, equipment, and structures.

Output 1 Acutely Unsafe Conditions Information

Definition: Nuclearr or chemically unsafe conditions and information, does not include OSHA, for example. These are conditions detected during the cleanup operations which need to be immediately fed back to the program management function for consideration which may result-in new direction \& control, defined

Requirement(s): work packages, and/or mission requirements.

Output 2 Solid Waste Documentation

Definition: This is documentation that shows that the safety and Requirement(s): compliance envelope of the solid waste is maintained. 
WHC-SD-WM-RPT-060, REV 0 VOLUME 2

Table 2-4.3.1.3 Function and Requirement Analys is for Function 4.3.1.3, Maintain Safe And Compliant Solid Waste Documentation. (Continued)

Output 3 Solid Waste Internal Safety Operations Constraint Documents

Definition: These are documents that relate the internal safety. operational constraints for the solid waste systems,

Requirement(s): equipment, and structures.

Output 4 Solid Waste Safety/Compliance Envelope Constraints

Definition: These are constraints that follow the solid waste to ensure that the safety and compliance envelope is maintained during receipt, characterization, disposition requirement generation, and final

Requirement (s): disposition of solid waste.

Output 5 Transferrable Resources

Definition: Physical and intellectual resources; e.g., facilities, equipment, materials, infrastructure, land, technology, scientific data, personnel expertise; that are developed during facility deactivation and can be transferred to other areas in the public or private

Requirement(s): domains. 


\section{WHC-SD-WM-RPT-060, REV 0 VOLUME 2}

Table 2-4.3.1.4 Function and Requirement Analys is for Function 4.3.1.4, Maintain Qualified Solid Waste Staff

Function 4.3.1.4 Maintain Qualified Solid Waste Staff

Definition: Maintain qualified and certified solid waste staff. Requirement(s):

Input 1 NonCompliant Conditions

Definition: Conditions that do not pose an imminent threat to the public, to Hanford workers or to the environment, but that violate imposed requirements specifiec in laws, regulations, DOE Orders or other requireme.: is

Requirement( $s$ ): promulgated by authorized jurisdictions.

Input 2 Solid Waste Corrective Action Needs

Definition: Actions required to bring waste status into compliance with handling and disposition requirements.

Requirement $(s)$ :

Input $3 \cdot$ Solid Waste Operations Information.

Definition: This is information related to the operations of the Requirement(s): solid waste systems, equipment, and structures.

Output 1 Solid Waste Qualified Staff

Definition: These are personnel that have been trained and qualified to perform the solid waste facility

Requirement ( $s$ ): operations.

Output 2 Transferrable Resources

Definition: Physical and intellectual resources; e.g., facilities, equipment, materials, infrastructure, 1 and, technology, scientific data, personnel expertise; that are developed during facility deactivation and can be transferred to other areas in the public or private domains.

Requirement (s): 
$\because$ WHC-SD-WM-RPT-060, REV 0 VOLUME 2

Table 2-4.3.1.5 Function and Requirement Analysis for Function 4.3.1.5, Maintain Safe And Compliant Solid Waste Documentation

Function 4.3.1.5 Assess Solid Waste Safety And Compliance State

Definition: Assess state of solid waste for safety and compliance. Requirement(s):

Input 1 Solid Waste Documentation

Definition: This is documentation that shows that the safety and Requirement (s): compliance envelope of the solid waste is maintained.

Output I Acutely Unsafe Conditions Information

Definition: Nuclear or chemically unsafe conditions and information, does not include OSHA, for example. These are conditions detected during the cleanup operations which need to be immediately fed back to the program management function for consideration which may result in new direction \& control, defined

Requirement(s): work packages, and/or mission requirements.

Output 2 Solid Waste Corrective Action Needs

Definition: Actions required to bring waste status into compliance Requirement(s): with handling and disposition requirements.

Output 3 Solid Waste Generated During Solid Waste Cleanup Operations

Definition: Contaminated tools, equipment and materials generated as a direct result of cleanup operations; including used cleaning solvents, rags, stack.filters and similar items requiring processing prior to disposal or transfer to a useful function within or outside the

Requirement(s): Cleanup Hanford mission.

Output 4 Transferrable Resources

Definition: Physical and intellectual resources; e.g., facilities, equipment, materials, infrastructure, land, technology, scientific data, personnel expertise; that are developed during facility deactivation and can be transferred to other areas in the public or private domains.

Requirement(s): 


\section{WHC-SD-WM-RPT-060, REV 0 VOLUME 2}

Table 2-4.3.1.5 Function and Requirement Analysis for Function 4.3 1.5, Maintain Safe And Compliant Solid Waste Documentation (Continued)

Output 3 Solid Waste Internal Safety Operations Constraint Documents

Definition: These are documents that relate the internal safety operational constraints for the solid waste systems,

Requirement(s): equipment, and structures.

Output 4 Solid Waste Safety/Compliance Envelope Constraints

Definition: These are constraints that follow the solid waste to ensure that the safety and compliance envelope is maintained during receipt, characterization,

Requirement (s): disposition requirement generation, and final disposition of solid waste.

Output 5 Transferrable Resources

Definition: Physical and intellectual resources; e.g., facilities, equipment, materials, infrastructure, iand, technology, scientific data, personnel expertise; that are developed during facility deactivation and can be transferred to other areas in the public or private

Requirement ( $s$ ): domains.

Output 6 Undocumented Wastes Information

Definition: While doing everyday operations we come upon waste previously undocumented. Information must be fed back to the management function.

Requirement (s): 
WHC-SD-WM-RPT-060, REV 0 VOLUME 2

Table 2-4.3.2 Function and Requirement Analysis for Function 4.3.2, Receive Solid Waste

Function 4.3.2 Receive Solid Waste

Definition: Retrieve legacy solid waste and receive solid waste generated during cleanup operations and solid waste

Requirement(s): from other missions.

Input I Cleanup Wastes

Definition: The solid waste material itself generated during cleanup operations or from continued waste receipts.

Requirement(s):

Input 2 Excess Waste Samples

Definition: These are excess solid waste samples that will be Requirement(s): received as solid waste requiring disposition.

Input 3 Legacy Solid Waste

Definition: It is existing waste resulting from Hanford's defense material production and energy production missions.

Requirement( $s$ ):

Input 4 NonCompliant Conditions

Definition: Conditions that do not pose en imminent threat to the public, to Hanford workers or to the environment, but that violate imposed requirements specified in laws, regulations, DOE Orders or other requirements

Requirement(s): promulgated by authorized jurisdictions.

Input 5 Solid Waste Characterization Information

Definition: This is characterization data consisting of current or historical process operation knowledge pertaining to the solid waste, its current condition, and sampling and analysis results required to determine its final disposition.

Requirement(s): 


\section{WHC-SD-WM-RPT-060, REV 0 VOLUME 2}

Table 2-4:3.2 Function and Requirement Analys is for Function 4.3.2, Receive Sol id Waste (Continued)

Input 6 Solid Waste From Other Missions

Definition: Solid waste that comes from.other DOE missions outside

Requirement(s):

of the Hanford Cleanup Mission.

Input 7 Solid Waste Generated During Solid Waste Cleanup Operations

Definition: Contaninated tools, equipment and materials generated as a direct result of cleanup operations; including used cleaning solvents, rags, stack filters and similar items requiring processing prior to disposal or transfer to a useful function within or outside the

Requirement(s): Cleanup Hanford mission

Output I Acutely Unsafe Conditions Information

Definition: Nuclear or chemically unsafe conditions and information, does not include OSHA, for example. These are conditions detected during the cleanup operations which need to be immediately fed back to the program management function for consideration which may result in new direction \& control, defined

Requirement(s): work packages, and/or mission requirements.

Output 2 Data/Samples for Characterization

Definition: This is new waste information and samples obtained during solid waste access and removal operations and through the verification process associated with

Requirement(s): acceptance.

Output 3 Excess Facilities, Equipment and Materials

Definition: Facilities no longer required for performance of Hanford cleanup mission functions.

Requirement(s):

Output 4 Non-Solid Waste Generated During Cleanup Operations

Definition: Incidental gaseous and liquid wastes that are not treated as part of solid waste treatment operations.

Requirement(s): 
WHC-SD-WM-RPT-060, REV 0 VOLUME 2

Table 2-4.3.2 Function and Requirement Analys is for Function 4.3.2, Receive Solid Waste (Continued).

Output 5 Operations and Capability Needs

Definition: Capabilities and needs discovered while operating the Requirement(s): system. As we operate the system, we get smarter.

Output 6 Recieved Waste

Definition: This is solid waste received from solid waste operations, cleanup operations, and other missions, including removed legacy waste, that is now ready for

Requirement(s): disposition.

Output 7 Retrieved Waste

Definition: Solid waste that has been received or retrieved and is Requirement(s): ready for disposition.

Output 8 Transferrable Resources

Definition: Physical and intellectual. resources; e.g., facilities, equipment, materials, infrastructure, 7 and, technology, scientific data, personnel expertise; that are developed during facility deactivation and can be transferred to other areas in the public or private

Requirement(s): domains. 
WHC-SD-WM-RPT-060, REV 0 VOLUME 2

Table 2-4.3.2.1 Function and Requirement Analysis for Function 4.3.2.1, Retrieve Existing Solid Waste

Function 4.3.2.1 Retrieve Existing Solid Waste

Definition: Retrieve legacy solid waste; includes retrieval planning and solid waste access and removal, obtains waste characterization samples, generates waste information, establishes retrieval capability requirements, and forecasts future retrieval

Requirement(s): operations.

Input $I^{\circ}$ Legacy Solid Waste

Definition: It is existing waste resulting from Hanford's defense Requirement.(s): material production and energy production missions.

Input 2 NonCompliant Conditions

Definition: Conditions that do not pose an imminent threat to the public, to Hanford workers or to the environment, but that violate imposed requirements specified in laws, regulations, DOE Orders or other requirements

Requirement ( $s$ ): promulgated by authorized jurisdictions.

Input 3 Solid Waste Characterization Information

Definition: This is characterization data consisting of current or historical process operation knowledge pertaining to the solid waste, its current condition, and sampling and analysis results required to determine its final

Requirement (s): disposition.

Output 1 Acutely Unsafe Conditions Information

Definition: Nuclear or chemically unsafe conditions and information, does not include OSHA, for example. These are conditions detected during the cleanup operations which need to be immediately fed back to the program management function for consideration which may result in new direction \& control, defined Requirement( $s)$ : work packages, and/or mission requirements. 
WHC-SD-WM-RPT-060, REV 0 VOLUME 2

Table 2-4.3.2.1 Function and Requirement Analys is for Function 4.3.2.1, Retrieve Existing Solid Waste (Continued)

Output 2 Data/Samples for Characterization

Definition: This is new waste information and samples obtained during solid waste access and removal operations and through the verification process associated with

Requirement ( $s)$ : acceptance.

Output 3 Excess Facilities, Equipment and Materials

Definition: Facilities no longer required for performance of Hanford cleanup mission functions.

Requirement(s):

Output 4 Non-Solid Waste Generated During Cleanup Operations

Definition: Incidental gaseous and liquid wastes that are not

Requirement(s): treated as part of solid waste treatment operations.

Output 5 Operations and Capability Needs

Definition: Capabilities and needs discovered while operating the

Requirement (s): system. As we operate the system, we get smarter.

Output 6 Retrieved Waste

Definition: Solid waste that has been received or retrieved and is Requirement(s): ready for disposition.

Output 7 Transferrable Resources

Definition: Physical and intellectual resources; e.g., facilities, equipment, materials, infrastructure, land, technology, scientific data, personnel expertise; that are developed during facility deactivation and can be transferred to other areas in the public or private

Requirement(s): domains. 
WHC-SD-WM-RPT-060, REV 0 VOLUME 2

Table 2-4.3.2.2 Function and Requirement Analys is for Function 4.3.2.2, Receive New Solid Waste

Function 4.3.2.2 Receive New Solid Waste

Definition: Receives solid waste generated during Hanford Cleanup mission operations and from other missions; includes solid waste receipt planning, characterization information verffication for acceptance, establishes

Requirement(s): recelpt capability requirements, and forecasts future receipt operations.

\section{Input 1 Cleanup Wastes}

Definition: The solid waste material itself generated during Requirement(s): cleanup operations or from continued waste receipts.

Input 2 Excess Waste Samples

Definition: These are excess solid waste samples that will be Requirement(s): received as solid waste requiring disposition.

Input 3 NonCompliant Conditions

Definition: Conditions that do not pose an imminent threat to the public, to Hanford workers or to the environment, but that violate imposed requirements specified in 1 aws, regulations, DOE Orders or other requirements

Requirement(s): promulgated by authorized jurisdictions.

Input 4 Solid Waste Characterization Information

Definition: This is characterization data consisting of current or historical process operation knowledge pertaining to the solid waste, its current condition, and sampling and analysis results required to determine its final

Requirement(s): disposition.

Input 5 Solid Waste From Other Missions

Definition: Solid waste that comes from other DOE missions outside Requirement (s): of the Hanford Cleanup Mission. 
WHC-SD-WM-RPT-060, REV 0 VOLUME 2

Table 2-4.3.2.2 Function and Requirement Analysis for Function 4.3.2.2, Receive New Solid Waste (Continued)

Input 6 Solid Waste Generated During Solid Waste Cleanup Operations

Definition: Contaminated tools, equipment and materials generated as a direct result of cleanup operations; including used cleaning solvents, rags, stack filters and similar items requiring processing prior to disposal

Requirement( $s$ ): or transfer to a useful function within or outside the Cleanup Hanford mission

Output 1 Acutely Unsafe Conditions Information

Definition: Nuclear or chemically unsafe conditions and information, does not include OSHA, for example. These are conditions detected during the cleanup operations which need to be immediately fed back to the program management function for consideration which may result in new direction \& control, defined Requirement(s): work packages, and/or mission requirements.

Output 2 Data/Samples for Characterization

Definition: This is new waste information and samples obtained during solid waste access and removal operations and through the verification process associated with

Requirement( $s$ ): acceptance.

Output 3 Excess Facilities, Equipment and Materials

Definition: Facilities no longer required for performance of Requirement(s): Hanford eleanup mission functions.

Output 4 Non-Sol id Waste Generated During-Cleanup Operations

Definition: Incidental gaseous and liquid wastes that are not Requirement(s): treated as part of solid waste treatment operations: 
WHC-SD-WM-RPT-060, REV 0 VOLUME 2

Table 2-4.3.2.2 Function and Requirement Analys is for Function 4.3.2.2, Receive New Solid Waste (Continued)

Output 5 Operations and Capability Needs

Definition: Capabilities and needs discovered while operating the Requitrement(s): system. As we operate the system, we get smarter.

Output 6 Recleved Waste

Definition: This is solid waste received from solid waste operations, cleanup operations, and other missions, including removed legacy waste, that is now ready for

Requitrement(s): dispostion.

Output 7 Transferrable Resources

Definition: Physical and intellectual resources; e.g., facilities, equipment, materials, infrastructure, 1 and, technology, scientific data, personnel expertise; that are developed during factlity deactivation and can be transferred to other areas in the public or private

Requirement(s): domains. 
WHC-SD-WM-RPT-060, REV 0 VOLUME 2

Table 2-4.3.3 Function and Requirement Analys is for Function 4.3.3, Characterize Solid Waste

Function 4.3.3 Characterize Solid Waste

Definition: Identify, inventory, and characterize the waste by reviewing the process operations (current and

historical), by reviewing new waste information and by sampling and analyzing the waste inventory. Assess the current condition of the waste. Archive the

Requirement(s): results of these investigations.

Input $1 \mathrm{Data} /$ Samples for Characterization

Definition: This is new waste information and samples obtained during solid waste access and removal operations and through the verification process associated with

Requirement(s): acceptance.

Input 2 Solid Waste Generator Request Information - Cleanup

Definition: Information rulated to a request from a solid waste generator for treatment, storage, and/or disposal of a particular solid waste package generated by Hanford

Requirement(s): cleanup operations.

Input 3 Solid Waste Generator Request Information - Other Missions

Definition: Information related to a request from a solid waste generator for treatment, storage, and/or disposal of a particular solid waste package generated by other

Requirement(s): missions.

Input 4 Solid Waste Generator Request Information - SW Cleanup

Definition: Information related to a request from a solid waste generator for treatment, storage, and/or disposal of a particular solid.waste package generated by solid

Requirement(s): waste operations.

Input 5 Legacy Waste Information

Definition: The information associated with the legacy solid waste.

Requirement(s): 
WHC-SD-WM-RPT-060, REV 0 VOLUME 2

Table 2-4.3.3 Function and Requirement Analys is for Function 4:3.3, Characterize Solid Waste (Continued)

Input. 6 Samples of Waste Requiring Additional Characterization

Definition: Solid waste that needs additional characterization

Requirement(s): data before final disposition can be made.

Output 1 Acutely Unsafe Conditions Information

- Definition: Nuclear or chemicaliy unsafe conditions and information, does not include OSHA, for example. These are conditions detected during the cleanup operations which need to be immediately fed back to the program management function for consideration which may result in new direction \& control, defined

Requirement(s): work packages, and/or mission requirements.

Output 2 Excess Solid Waste Samples

Definition: These are excess solid waste samples that will be received as solid waste requiring disposition.

Requirement(s):

Output 3 Non-Solid Waste Generated During Cleanup Operations

Definition: Incidental gaseous and liquid wastes that are not

Requirement(s):

treated as part of solid waste treatment operations.

Output 4 Operations and Capability Needs

Definition: Capabilities and needs discovered while operating the

Requirement(s): system. As we operate the system, we get smarter.

Output 5 Solid Waste Characterization Information

Definition: This is characterization data consisting of current or historical process operation knowledge pertaining to the solid waste, its current condition, and sampling and analysis results required to determine its final

Requirement(s): disposition. 
WHC-SD-WM-RPT-060, REV 0 VOLUME 2

Table 2-4.3.3 Function and Requirement Analys is for Function 4.3.3, Characterize Solid Waste (Continued)

Output 6 Transferrable Resources

Definition: Physical and intellectual resources; e.g., facilities, equipment, materials, infrastructure, 7 and, technology, scientific data, personnel expertise; that are developed during facility deactivation and can be transferred to other areas in the public or private

Requirement(s): domains. 
WHC-SD-WM-RPT-060, REV 0 VOLUME 2

Table 2-4.3.3.1 Function and Requirement Analysis for Function 4.3.3.1, Acquire Solid Waste Process Knowledge

Function 4.3.3.1 Acquire Solid Waste Process Knowledge

Definition: Review the solid waste processing records, process documentation, and submitted documentation to acquire knowledge about the solid waste generation process. Conduct interviews with solid waste generators as needed to obtain such knowledge and perform a safety review of the solid waste. Provide this process knowledge to enable the solid waste characterization

Requirement(s): assessment.

Input $1 \mathrm{Data} / \mathrm{Samples}$ for Characterization

Definition: This is new waste information and samples obtained during solid waste access and removal operations and through the verification process associated with

Requirement(s): accept ance.

Input 2 Solid Waste Generator Request Information - Cleanup

Definition: Information related to a request from a solid waste generator for treatment, storage, and/or disposal of a particular solid waste package generated by Hanford cleanup operations.

Requirement( $s$ ):

Input 3 Solid Waste Generator Request Information - Other Missions

Definition: Information related to a request from a solid waste generator for treatment, storage, and/or disposal of a particular solid waste package generated by other

Requirement( $s$ ): missions.

Input 4 Solid Waste Generator Request Information - SW Cleanup

Definition: Information related to a request from a solid waste generator for treatment, storage, and/or disposal of a particular solid waste package generated by solid waste operations.

Requirement(s): 


$$
\text { WHC-SD-WM-RPT-060, REV } 0 \text { VOLUME } 2
$$

Table 2-4.3.3.1 Function and Requirement Analysis for Function 4.3.3.1, Acquire Solid Waste Process Knowledge (Continued)

Input 5 Legacy Waste Information

Definition: The information associated with the legacy solid waste.

Requirement(s):

Input 6 Samples of Waste Requiring Additional Characterization

Definition: Solid waste that needs additional characterization data before final disposition can be made.

Requirement(s):

Output 1 Acutely Unsafe Conditions Information

Definition: Nuclear or chemically unsafe conditions and information, does not include OSHA, for example. These are conditions detected during the cleanup operations which need to be immediately fed back to the program management function for consideration which may result in new direction \& control, defined

Requirement(s): work packages, and/or mission requirements.

Output 2 Excess Solid Waste Samples

Definition: These are excess solid waste samples that will be received as solid waste requiring disposition.

Requirement (s):

Output 3 Non-Solid Waste Generated During Cleanup Operations

Definition: Incidental gaseous and liquid wastes that are not

Requirement (s): treated as part of solid waste treatment operations.

Output 4 Operations and Capability Needs

Definition: Capabilities and reeds discovered while operating the Requirement (s): system. As we operate the system, we get smarter. 


\section{WHC-SD-WM-RPT-060, REV 0 VOLUME 2}

Table 2-4.3.3.1 Function and Requirement Analys is for Function 4.3.3.1, Acquire Solid Waste Process Knowledge (Continued)

Output 5 Solid Waste Characterization Information

Definition: This is characterization data consisting of current or historical process operation knowledge pertaining to the solid waste, its current condition, and sampling and analysis results required to determine its final

Requirement(s): disposition.

\section{Output 6 Transferrable Resources}

Definition: Physical and intellectual resources; e.g., facilities, equipment, materials, infrastructure, land, technology, scientific data, personnel expertise; that are developed during facility deactivation and can be transferred to other areas in the public or private

Requirement(s): domains. 
WHC-SD-WM-RPT-060, REV 0 VOLUME 2

Table 2-4.3.3.2 Function and Requirement Analys is for Function 4.3.3.2, Analyze Solid Waste Inventory

Function 4.3.3.2 Analyze Solid Waste Inventory

Definition: Receive the solid waste samples and perform analysis thereof to obtain required characterization data. Provide this analysis information to enable the solid waste characterization assessment. Transfer the solid waste samples and accompanying characterization data to solid waste archives. Send any excess solid.waste samples on to the Receive Solid Waste function to

Requirement (s): facilitate disposition.

Input 1 Additional Analysis/Process Knowledge Needs

Definition: Needs for additional analysis of the solid waste samples or solid waste process knowledge to complete

Requirement(s): assessment of characterization information.

Input 2 Solid Waste Archive Samples

Definition: Solid waste samples retrieved from archival storage for further analysis.

Requirement(s):

Input 3 Data/Samples for Characterization

Definition: This is new waste information and samples obtained during solid waste access and removal operations and through the verification process associated with

Requirement (s): acceptance.

Input 4 Samples of Waste Requiring Additional Characterization

Definition: Solid waste that needs additional characterization Requirement (s): data before final disposition can be made. 
WHC-SD-WM-RPT-060, REV 0 VOLUME 2

Table 2-4.3.3.2 Function and Requirement Analys is for Function 4.3.3.2, Analyze Solid Waste Inventory (Continued)

Output 1 Acutely Unsafe Conditions Information

Definition: Nuciear or chemically unsafe conditions and information, does not include OSHA, for example. These are conditions detected during the cleanup operations which need to be immediately fed back to the program management function for consideration which may result in new direction \& control; defined

Requirement(s): work packages, and/or mission requirements.

Output 2. Solid Waste Analysis Information

Definition: Information from analysis of the solid waste samples. Requirement $(s)$ :

Output 3 Excess Solid Waste Samples

Definition: These are excess solid waste samples that will be Requirement(s): received as solid waste requiring disposition.

Output 4 Non-Sol id Waste Generated During Cleanup Operations

Definition: Incidental gaseous and liquid wastes that are not Requirement(s): treated as part of solid waste treatment operations.

Output 5 Solid Waste Samples

Definition: Solid waste samples that were used to analyze the waste inventory that now require archiving.

Requirement( $s$ ):

Output 6 Transferrable Resources

Definition: Physical and intellectual resources; e.g., facilities, equipment, materials, infrastructure, land, technology, scientific data, personnel expertise; that are developed during facility deactivation and can be transferred to other areas in the public or private domains.

Requirement(s): 
WHC-SD-WM-RPT-060, REV 0 VOLUME 2

Table 2-4.3.3.3 Function and Requirement Analys is for Function 4.3.3.3, Archive Solid Waste Samples/Characterization Data

Function 4.3.3.3 Archive Solid Waste Samples/Characterization Data

Definition: Provide archival storage and retrieval operations for the analyzed solid waste samples and the accompanying

Requirement(s): characterization data.

Input I Solid Waste Analysis Information

Definition: Information from analysis of the solid waste samples. Requirement(s):

Input 2 Solid Waste Samples

Definition: Solid waste samples that were used to analyze the Requirement $(s)$ : wiste inventory that now require archiving.

Output 1 Solid Waste Archive Data

Definition: Solid waste sample analysis data that is needed to complete the assessment of chara erization

Requirement(s): information.

Output 2 Solid Waste Archive Samples

Definition: Solid waste samples retrieved from archival storage Requirement(s): for further analysis. 
WHC-SD-WM-RPT-060, REV 0 VOLUME 2

Table 2-4.3.3.4. Function and Requirement Analys is for Function 4.3.3.4, Assess Solid Waste Characterization Information

Function 4.3.3.4 Assess Solid Waste Characterization Information

Definition: Evaluate-the solid waste characterization information, consisting of generator request information, process knowledge information, and waste sample characterization data, against the solid waste disposition requirements and provide validation of meeting the disposition requirements. Determine any additional solid waste process knowledge needs to

Requirement(s): support disposition.

Input 1 Solid Waste Analysis Information

Definition: Information from analysis of the solid waste samples. Requirement(s):

Input 2 Solid Waste Archive Data

Definition: Solid waste sample analysis data that is needed to complete the assessment of characterization

Requirement(s): information.

Input 3 Solid Waste Generator Request Information - Other Missions

Definition: Information related to a request from a solid waste generator for treatment, storage, and/or disposal of a particular solid waste package generated by other

Requirement(s): missions.

Input 4 Legacy Waste Information

Definition: The information associated with the legacy solid waste.

Requirement( $s$ ):

Input 5 Solid Waste Process Knowledge

Definition: This is knowledge of the process that generated the solid waste.

Requirement(s): 
WHC-SD-WM-RPT-060, REV 0 VOLUME 2

Table 2-4.3.3.4 Function and Requirement Analys is for Function 4.3.3.4, Assess Solid Waste Characterization Information (Continued)

Output 1 Acutely Unsafe Conditions Information

Definition: Nuclear or chemically unsafe conditions and information, does not include OSHA, for example. These are conditions detected during the cleanup operations which need to be immediately fed back to the program management function for consideration which may result in new direction \& control, defined

Requirement $(\dot{s})$ : work packages, and/or mission requirements.

Output 2 Additional Analysis/Process Knowledge Needs

Definition: Needs for additional analysis of the solid waste samples or solid waste process knowledge to complete

Requirement(s): assessment of characterization information.

Output 3 Operations and Capability Needs

Definition: Capabilities and needs discovered while operating the Requirement(s): system. As we operate the system, we get smarter.

Output 4 Solid Waste Characterization Information

Definition: This is characterization data consisting of current or historical process operation knowledge pertaining to the solid waste, its current condition, and sampling and analysis results required to determine its final

Requirement (s): disposition.

Output 5 Transferrable Resources

Definition: Physical and intellectual resources; e.g., facilities, equipment, materials, infrastructure, land, technology, scientific data, personnel expertise; that are developed during facility deactivation and can be transferred to other areas in the public or private

Requirement(s): domains. 


\section{WHC-SD-WM-RPT-060, REV 0 VOLUME 2}

Table 2-4.3.3.4 Function and Requirement Analys is for Function $4: 3.3 .4$, Assess Solid Waste Characterization Information (Continued)

Output 6 , Undocumented Wastes Information

Definition: While doing everyday operations we come upon waste previously undocumented. Information must be fed back Requirement(s): to the management function. 
WHC-SD-WM-RPT-060, REV 0 VOLUME 2

Table 2-4.3.4 Function and Requirement Analysis for Function 4.3.4, Determine Solid Waste Disposition Requirements

Function 4.3.4 Determine Solid Waste Disposition Requirements

Definition: Compile and sort imposed requirements, define requirements that result from proposed solutions and required capabilities, and assess constraints under Requirement(s): which the function must operate.

Input 1 NonCompliant Conditions

Definition: Conditions that do not pose an imminent threat to the public, to Hanford workers or to the environment, but that violate imposed requirements specified in laws, regulations, DOE Orders or other requirements

Requirement( $s$ ): promulgated by authorized jurisdictions.

Input 2 Solid Waste Characterization Information

Definition: This is characterization data consisting of current or historical process operation knowledge pertaining to the solid waste, its current condition, and sampling and analysis results required to determine its.final

Requirement( $s)$ : disposition.

Output 1 Operations and Capability Needs

Definition: Capabilities and needs discovered while operating the Requirement(s): system. As we operate the system, wo get smarter.

Output 2 Requirements Requiring Reconciliation

Definition: These are waste disposition requirements that require reconciliation.

Requirement(s):

Output 3 Solid Waste Archive Specifications

Definition: Solid waste archive specifications that have been Requirement(s): prepared during disposition specification development. 
WHC-SD-WM-RPT-060, REV 0 VOLUME 2

Table 2-4.3.4 Function and Requirement Analys is for Function 4.3.4, De.termine Solid Waste Disposition Requirements (Continued)

Output 4 Solid Waste Disposition Requirements

Definition: These are compiled and sorted solid waste disposition requirements determined from imposed requirements, results from proposed solutions and required

Requirement( $s$ ): capabilities; and operational constraints.

Output 5 Transferrable Resources

Definition: Physical and intellectual resources; e.g., facilities, equipment, materials, infrastructure, $l$ and, technology, scientific data, personnel expertise; that are developed during facility deactivation and can be transferred to other areas in the public or private

Requirement(s): domains. 
WHC-SD-WM-RPT-060, REV 0 VOLUME 2

Tablo 2-4.3.4.1 Function and Recilirement Analys is for Function 4.3.4.1, Compile Imposed Solid Waste Requirements

Function 4.3.4.1 Compile Imposed Solid Waste Requirements

Definition: Collect state, federal, DOE and any other regulatory documents which pertain to transport, handling,

Requirement(s): packaging and disposition of solid waste.

Input 1 Solid Waste Characterization Information

Definition: This is characterization data consisting of current or historical process operation knowledge pertaining to the solid waste, its current condition, and sampling and analysis results required to determine its final

Requirement(s): disposition.

Output 1 Solid Waste Disposition Requirements List

Definition: This is a list of disposition requirements generated during compilation. This list includes imposed regulatory requirements and operations requirements, Requirement(s): and are listed by disposition category. 

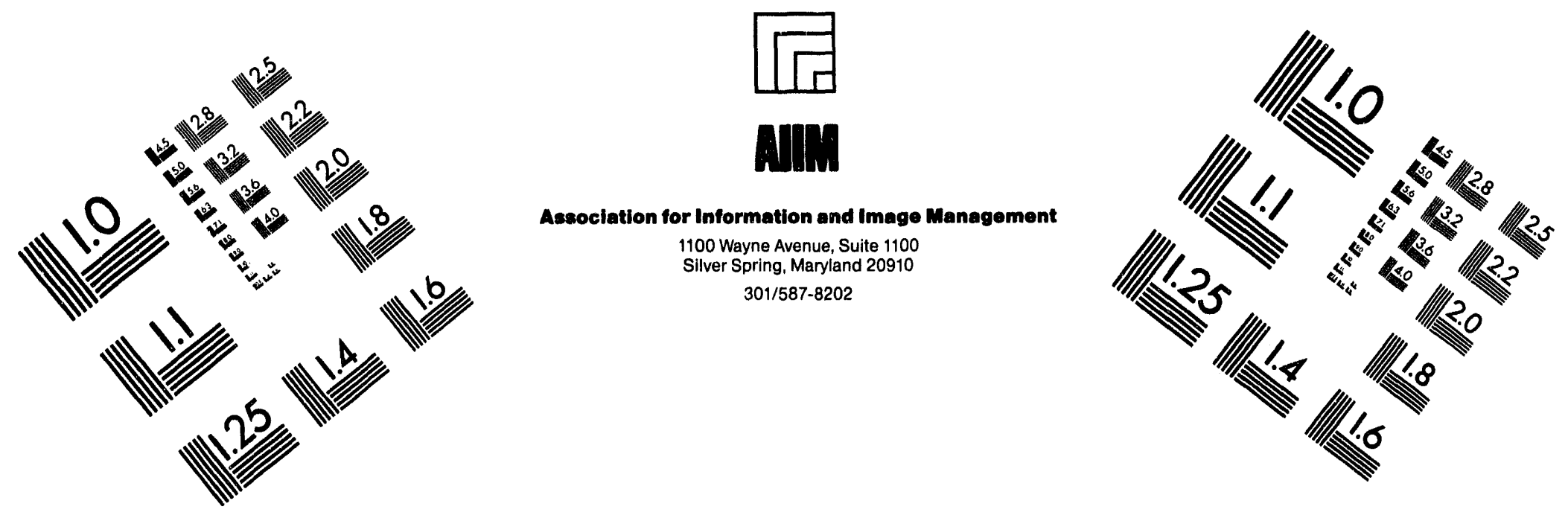

\section{Centimeter}

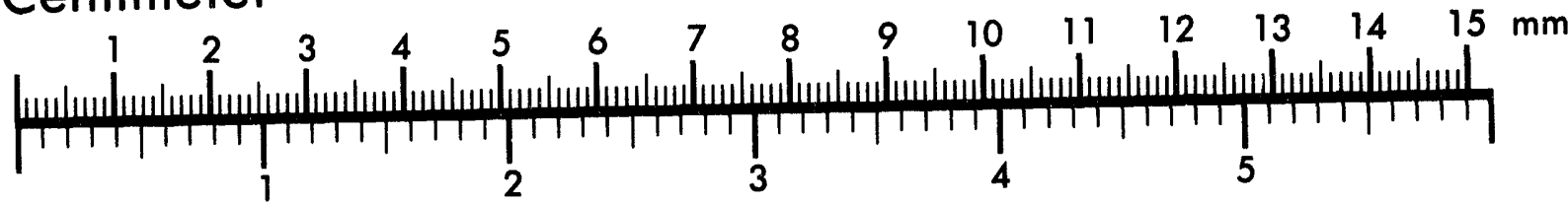
Inches
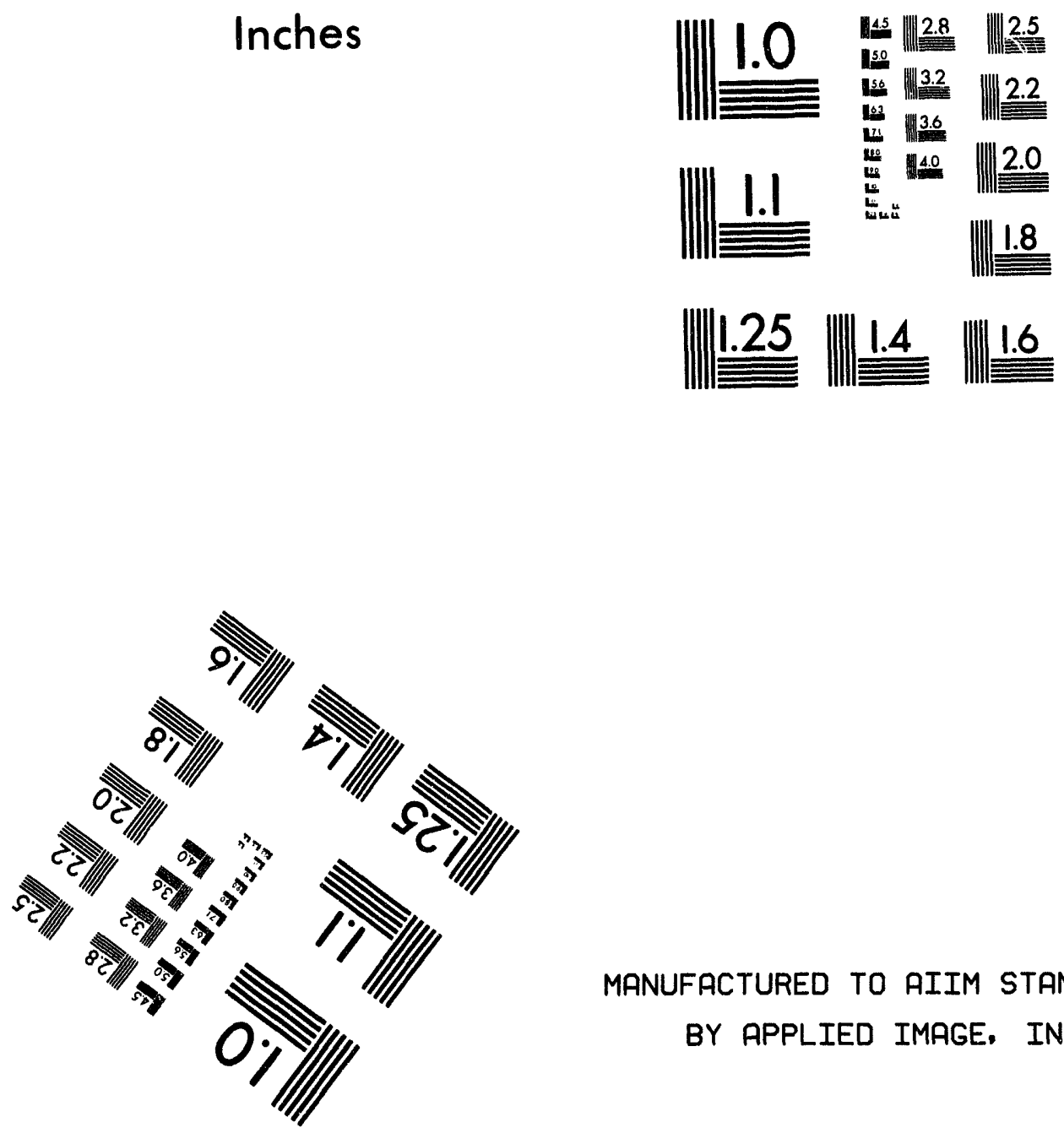

MANUFACTURED TO AIIM STANDARDS BY APPLIED IMAGE, INC.

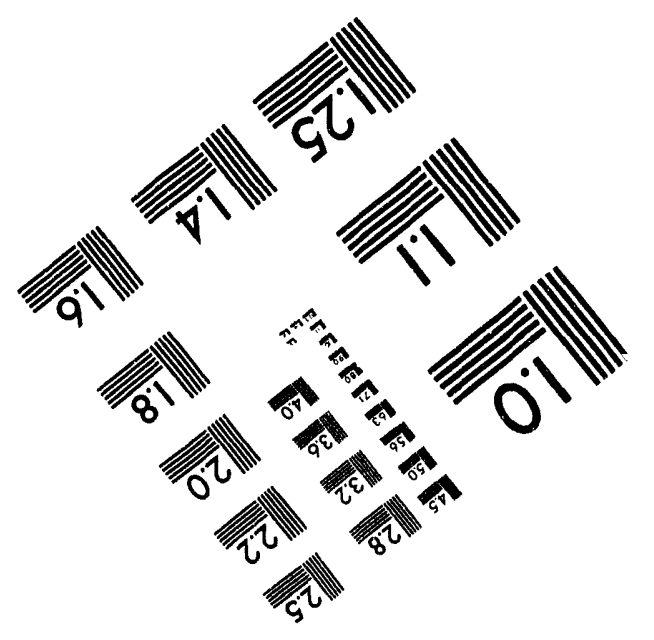



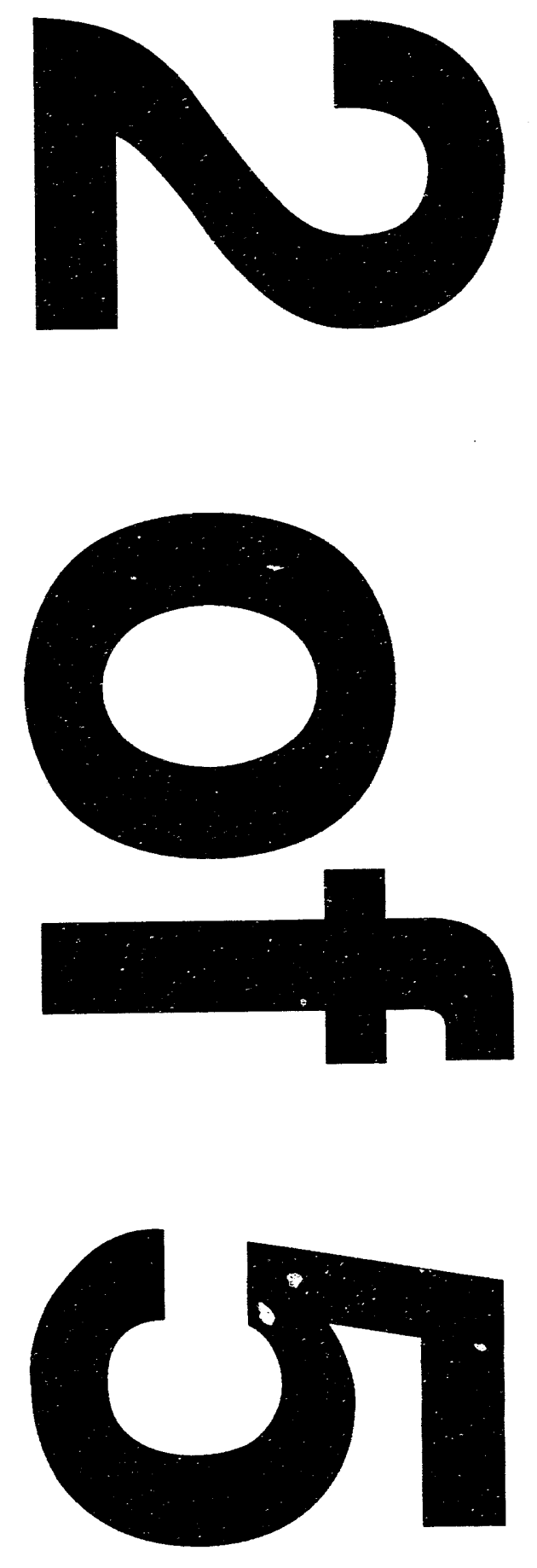
WHC-SD-WM-RPT-060, REV 0 VOLUME 2

Table 2-4.3.4.2 Function and Requirement Analys is for Function 4.3.4.2, Determine Solid Waste Disposition Requirements

Function 4.3.4.2 Evaluate Solid Waste Requirements for Disposition

Definition: Review and evaluate list of solid waste disposition requirements to verify applicability and completeness

Requirement(s): for disposition categories.

Input 1 NonCompliant Conditions

Definition: Conditions that do not pose an imminent threat to the public, to Hanford workers or to the environment, but that violate imposed requirements specified in laws, regulations, DOE Orders or other requirements

Requirement( $s$ ): promulgated by authorized jurisdictions.

Input 2 Solid Waste Disposition Requirements

Definition: These are compiled and sorted solid waste disposition requirements determined from imposed requirements, results from proposed solutions and required

Requirement(s): capabilities, and operational constraints.

Output 1 Operations and Capability Needs

Definition: Capabilities and needs discovered while operating the Requirement(s): system. As we operate the system, we get smarter.

Output 2 Recommended Requirement Resolutions

Definition: These are recommended resolutions of conflicting requirements influencing the final disposition of the solid waste. These resolutions must be approved by

Requirement( $s$ ): the "Manage Program" function.

Output 3 Solid Waste Disposition Specifications

Definition: These are disposition specifications for the solid waste.

Requirement(s): 


\section{WHC-SD-WM-RPT-060, REV 0 VOLUME 2}

Table 2-4.3.4.3 Function and Requirement Analysis for Function 4.3.4.3, Prepare Solid Waste Disposition Specifications

Function 4.3.4.3 Prepare Solid Waste Disposition Specifications

Definition: Generate specifications for solid waste operations includingtreatment, packaging, certification, storage, shipping, disposition, and archiving samples and

Requirement ( $s$ ): records.

Input 1 Solid Waste Disposition Specifiçations

Definition: These are disposition specifications for the solid Requirement(s): waste.

Output 1 Operations and Capability Needs

Definition: Capabilities and needs discovered while operating the

Requirement(s): system. As we operate the system, we get smarter.

Output 2 Solid Waste Archive Specifications

Definition: Solid waste archive specifications that have been Requirement(s): prepared during disposition specification development.

Output 3 Solid Waste Disposition Requirements

Definition: These are compiled and sorted solid waste disposition requi rements determined from imposed requirements, results from proposed solutions and required

Requirement( $s$ ): capabilities, and operational constraints.

Output 4 Transferrable Resources

Definition: Physical and intellectual resources; e.g., facilities, equipment, materials, infrastructure, $i$ and, technology, scientific data, personnel expertise; that are developed during facility deactivation and can be transferred to other areas in the public or private

Requirement.(s): domains. 
WHC-SD-WM-RPT-060, REV 0 VOLUME 2

Table 2-4.3.5 Function and Requirement Analysis for Function 4.3.5, Disposition Solid Waste

Function 4.3 .5

Disposition Solid Waste

Definition: Package and certify the solid waste, store or ship it as needed, treat and/or immobilize it, and accomplish

Requirement(s): final disposition.

Input I NonCompliant Conditions

Definition: Conditions that do not pose an imminent threat to the public, to Hanford workers or to the environment, but that violate imposed requirements specified in laws, regulations, DOE Orders or other requirements

Requirement(s): promulgated by authorized jurisdictions.

Input 2 Received Solid Waste

Definition: This is solid waste received from solid waste operations, cleanup operations, and other missions, including removed legacy waste, that is now ready for

Requirement(s): disposition.

Input 3 Solid Waste Characterization Information

Definition: This is characterization data consisting of current or historical process operation knowledge pertaining to the solid waste, its current condition, and sampling and analysis results required to determine its final

Requirement(s): disposition.

Output 1 Acutely Unsafe Conditions Information

Definition: Nuclear or chemically unsafe conditions and information, does not include OSHA, for example. These are conditions detected during the cleanup operations which need to be immediately fed back to the program management function for consideration which may result in new direction \& control, defined

Requirement(s): work packages, and/or mission requirements. 
WHC-SD-WM-RPT-060, REV 0 VOLUME 2

Table 2-4.3.5 Function and Requirement Analysis for Function 4.3.5, Disposition Solid Waste (Continued)

Output 2 Dispositioned Solid Waste

Definition: Solid waste that is ready for disposal or transfer to a useful function within or outside the Cleanup

Requirement(s): Hanford mission.

Output 3 Excess Solid Waste Facilities

Definition: Facilities that have had a mission in the Hanford Cleanup Mission. It includes excess sites for disposition (e.g. potentially contaminated retrieved

Requirement(s): trench).

Output 4 Non-Solid Wastes Generated During Cleanup Operations

Definition: Incidental gaseous and liquid wastes that are not

Requirement (s):

treated as part of solid waste treatment operations.

Output 5 Samples of Waste Requiring Additional Characterization

Definition: Solid waste that needs additional characterization data before final disposition can be made.

Requirement(s):

Output 6 Solid Waste Capability. Needs

Definition: These are the resource capability needs that are

Requirement(s): required to provide final solid waste dispostion.

Output $7^{\circ}$ Transferrable Resources

Definition: Physical and intellectual resources; e.g., facilities, equipment, materials, infrastructure, iand, technology, scientific data, personnel expertise; that are developed during facility deactivation and can be transferred to other areas in the public or private

Requirement(s): domains. 
WHC-SD-WM-RPT-060, REV 0 VOLUME 2

Table 2-4.3.5 Function and Requirement Analys is for Function 4.3.5, Disposition Solid Waste (Continued)

Output 8 Undocumented Wastes Information

Definition: While doing everyday operations we come upon waste previously undocumented. Information must be fed back

Requirement(s): to the management function.

Output 9 Waste Disposition Status Information

Definition: As the physical status of the solid waste changes, the safety and compliance envelope changes. This is all information regarding the disposition state of the

Requirement(s): solid waste. 
WHC-SD-WM-RPT-060, REV 0 VOLUME 2

Table 2-4.3.5.1 Function and Requirement Analys is for Function 4.3.5.1, Treat Solid Waste

Function 4.3.5.1 Treat Solid Waste

Definition: Provide treatment of solid waste to neutralize, immobilize, and stabilize it for storage and final

Requirement(s): disposition.

Input 1 NonCompliant Conditions

Definition: Conditions that do not pose an imminent threat to the public, to Hanford workers or to the environment, but that violate imposed requirements specified in laws,

Requirement(s): regulations, DOE Orders or other requirements promulgated by authorized jurisdictions.

Input 2 Received Solid Waste

Definition: This is solid waste received from solid waste operations, cleanup operations, and other missions, including removed legacy waste, that is now ready for

Requirement(s): disposition.

Input 3 Rejected Solid Waste

Definition: This is solid waste that. failed to meet the certification requirements that would have allowed disposition and, therefore, requires further

Requirement(s): treatment.

Input 4 Solid Waste Characterization Information

Definition: This is characterization data consisting of current or historical process operation knowledge pertaining to the solid waste, its current condition, and sampling and analysis results required to determine its final

Requirement(s): disposition. 
WHC-SD-WM-RPT-060, REV 0 VOLUME 2

Table 2-4.3.5.1 Function and Requirement Analys is for Function 4.3.5.1, Treat Sol id Waste (Continued)

Input 5 Solid Waste Process Quality Data

Definition:- This is solid waste treatment process quality data resulting from the solid waste certification function that determines if the treated waste product meets the solid waste disposition requirements. This data is

Requirement (s): provided as feedback to the treatment process to allow for process adjustments.

Output 1 Acutely Unsafe Conditions Information

Definition: Nuclear or chemically unsafe conditions and information, does not include OSHA, for example. These are conditions detected during the cleanup operations which need to be immediately fed back to the program management function for consideration which may result in new direction \& control, defined

Requirement(s): work packages, and/or mission requirements.

Output 2 Non-Solid Wastes Generated During Cleanup Operations

Definition: Incidental gaseous and liquid wastes that are not Requirement (s): treated as part of solid waste treatment operations.

Output 3 Quality Assurance Solid Waste Samples

Definition: This is solid waste treatment process quality samples used to certify that the treated waste product meets

Requirement(s): the solid waste disposition requirements.

Output 4 Solid Waste Disposition Capability Needs

Definition: These are capability needs to support treatment, Requirement(s): storage and disposal of the solid waste.

Output 5 Treated Sol id Waste

Definition: This is solid waste that has been treated so that it meets the disposition requirements and is ready for packaging.

Requirement(s): 
WHC-SD-WM-RPT-060, REV 0 VOLUME 2

Table 2-4.3.5.1 Function and Requirement Analysis for Function 4.3.5.1; Treat Solid Waste (Continued)

Output. 6 Undocumented Wastes Information

Definition: While doing everyday operations we come upon waste previously undocumented. Information must be fed back Requirement (s): to the management function. 
WHC-SD-WM-RPT-060, REV 0 VOLUME 2

Table 2-4.3.5.2 Function and Requirement Analysis for Function 4.3.5.2, Package Solid Waste

Function 4.3.5.2 Package Solid Waste

Definition: Containerize the treated solid waste in a container suitable for the waste type. Provide solid waste packaging documentation including packaging certifications and solid waste feedstock traceability. Provide appropriate labeling and inspection of the

Requirement(s): containers of solid waste.

Input 1 Solid Waste Process Quality Data

Definition: This is solid waste treatment process quality data resulting from the solid waste certification function that determines if the treated waste product meets the solid waste disposition requirements. This data is provided as feedback to the treatiment process to allow Requirement ( $s)$ : for process adjustments.

Input 2 Treated Solid Waste

Definition: This is solid waste that has been treated so that it meets the disposition requirements and is ready for

Requirement (s): packaging.

Output 1 Non-Solid Wastes Generated During Cleanup Operations

Definition: Incidental gaseous and liquid wastes that are not Requirement( $s$ ): treated as part of solid waste treatment operations.

Output 2 Packaged Solid Waste

Definition: This is solid waste that meets the certification Requirement(s): requirements that allow on-site disposition.

Output 3 Quality Assurance Solid Waste Samples

Definition: This is solid waste treatment process quality samples used to certify that the treated waste product meets the solid waste disposition requirements.

Requirement(s): 
WHC-SD-WM-RPT-060, REV 0 VOLUME 2

Table 2-4.3.5.2 Function and Requirement Analys is for Function 4.3.5.2, Package Solid Waste (Continued)

Output 4 Solid Waste Disposition Capability Needs

Definition: These are capability needs to support treatment, storage and disposal of the sulid waste.

Requirement (s): 
WHC-SD-WM-RPT-060, REV 0 VOLUME 2

Table 2-4.3.5.3 Function and Requirement Analys is for Function 4.3.5.3, Certify Sol id Waste

Function 4.3.5.3 Certify Solid Waste

Definition: Certify that the solid waste was treated according to the disposition requirements and that the documentation is in order to allow release of the

Requirement(s): solid waste package for storage and disposition.

Input 1 Certified Solid Waste Archive Data and Samples

Definition: This is archive data and samples that were part of the solid waste certification process that were requested Requirement(s): to support further certification work.

Input 2 Quality Assurance Solid Waste Samples

Definition: This is solid waste treatment process quality samples used to certify that the treated waste product meets

Requirement (s): the solid waste disposition requirements.

Input 3 Received Solid Waste

Definition: This is solid waste received from solid waste operations, cleanup operations, and other missions, including removed legacy waste, that is now ready for

Requirement(s): disposition.

Input 4 Solid Waste Characterization Information

Definition: This is characterization data consisting of current or historical process operation knowledge pertaining to the solid waste, its current condition, and sampling and analysis results required to determine its final

Requirement(s): disposition.

Output 1 Certified Solid Waste Data and Samples

Definition: This is data and samples that were part of the solid. waste certification process that require archival

Requirement(s): storage. 
WHC-SD-WM-RPT-060, REV 0 VOLUME 2

Table 2-4.3.5.3 Function and Requirement Analys is for Function 4:3.5.3, Certify Solid Waste (Continued)

Output 2 Non-Solid Wastes Generated During Cleanup Operations

Definition: Incidental gaseous and liquid wastes that are not Requirement(s): treated as part of solid waste treatment operations.

Output 3 Rejected Solid Waste

Definition: This is solid waste that failed to meet the certification requirements tiat would have allowed disposition and, therefore, requires further

Requirement(s): treatment.

Output 4 Solid Waste Disposition Capability Needs

Definition: These are capability needs to support treatment, Requirement(s): storage and disposal of the solid waste.

Output 5 Solid Waste Process Quality Data

Definition: This is solid waste treatment process quality data resulting from the solid waste certification function that determines if the treated waste product meets the solid waste disposition requirements. This data is provided as feedback to the treatment process to allow Requirement(s): for process adjustments. 


$$
\text { WHC-SD-WM-RPT-060, REV } 0 \text { VOLUME } 2
$$

Table 2-4.3.5.4 Function and Requirement Analys is for Function 4.3.5.4, Store Solid Waste

Function 4.3.5.4, Store Solid Waste

Definition: Store the solid waste before shipment to the disposal Requiremient(s):

Input 1 Certified Solid Waste Data

Definition: This is data related to the solid waste certification process that will allow storage and disposition of the solid waste and will be included in the waste

Requirement (s): disposition status information.

Input 2 Packaged Solid Waste

Definition: This is solid waste that meets the certification Requirement(s): requirements that allow on-site disposition.

Output 1 Acutely Unsafe Conditions Information

Definition: Nuclear or chemically unsafe conditions and information, does not include OSHA, for example. These are conditions detected during the cleanup operations which need to be immediately fed back to the program management function for consideration which may result in new direction \& control, defined

Requirement(s): work packages; and/or mission requirements.

Output 2 Certified Solid Waste

Definition: Certified solid waste consists of off-site certified solid waste that meets the certification requirements that allow off-site disposition and on-site certified solid waste that meets the certification requirements

Requirement(s): that allow on-site disposition.

Output 3 Non-Solid Wastes Generated During Cleanup Operations

Definition: Incidental gaseous and liquid wastes that are not Requirement( $s$ ): treated as part of solid waste treatment operations. 
WHC-SD-WM-RPT-060, REV 0 VOLUME 2

Table 2-4.3.5.4 Function and Requirement Analysis for Function 4.3.5.4, Store Solid Waste (Continued)

Output 4 Solid Waste Disposition Capability Needs

Definition: These are capability needs to support treatment, Requirement(s): storage and disposal of the solid waste.

Output 5 Waste Disposition Status Information

Definition: As the physical status of the solid waste changes, the safety and compliance envelope changes. This is all information regarding the disposition state of the

Requirement(s): solid waste. 
WHC-SD-WM-RPT-060, REV 0 VOLUME 2

Table 2-4.3.5.5 Function and Requirement Analysis for Function 4.3.5.5, Ship Solid Waste

Function 4.3.5.5 Ship Solid Waste

- Definition: Receive the certified solid waste package and prepare the necessary shipment requests and documentation. Coordinate the solid waste package shipment with shippers and receivers to verify that the final waste disposition was accomplished. Document the final

Requirement(s): solid waste disposition status.

Input 1 Off-site Certified Solid Waste

Definition: 'This is solid waste that meets the certification Requirement(s): requirements that allow off-site disposition.

Output 1 Dispositioned Solid Waste

Definition: Solid waste that is ready for disposal or transfer to a useful function within or outside the Cleanup

Requirement( $s)$ : Hanford mission.

Output 2 Solid Waste Disposition Capability Needs

Definition: These are capability needs to support treatment, Requirement( $s)$ : storage and disposal of the solid waste.

Output 3 Waste Disposition Status Information

Definition: As the physical status of the solid waste changes, the safety and compliance envelope changes. This is all information regarding the disposition state of the Requirement(s): solid waste. 
WHC-SD-WM-RPT-060, REV 0 VOLUME 2

Table 2-4.3.5.6 Function and Requirement Analysis for Function 4.3.5.6, Dispose Solid Waste

Function 4.3.5.6 Dispose Solid Waste

Definition: Schedule the solid waste package disposal and prepare the waste transport package and disposal

documentation. Provide final inspection of the solid waste package load and place in disposal site. Close the disposal site in regulatory compliance and provide institutional controls and closure security to

Requirement(s): maintain the disposal site security and integrity.

Input 1 On-site Certified Solid Waste

Definition: This is solid waste that meets the certification requirements that allow on-site disposition.

Requirement (s):

Output 1 Dispositioned Solid Waste

Definition: Solid waste that is ready for disposal or transfer to a useful function within or outside the Cleanup Hanford mission.

Requirement ( $s)$ :

Output 2 Solid Waste Disposition Capability Needs

Definition: These are capability needs to support treatment, Requirement(s): storage and disposal of the solid waste.

Output 3 Waste Disposition Status Information

Definition: As the physical status of the solid waste changes, the safety and compliance envelope changes. This is all information regarding the disposition state of the

Requirement(s): solid waste. 
WHC-SD-WM-RPT-060, REV 0 VOLUME 2

Table 2-4.3.5.7 Function and Requirement Analys is for Function 4.3.5.7, Assess Solid Waste TSD Capability Needs and Disposal Resources

Function $4 \cdot 3 \cdot 5.7$

Assess Solid Waste TSD Capability Needs and Disposal Resources

Definition: Assess the solid waste treatment, storage, and disposal (TSD) capability needs and resources based on

Requirement(s): required versus design throughput and capacities.

Input 1 NonCompliant Conditions

Definition: Conditions that do not pose an imminent threat to the public, to Hanford workers or to the environment, but that violate imposed requirements specified in laws, regulations, DOE Orders or other requirements

Requirement (s): promulgated by authorized jurisdictions.

Input 2 Received Solid Waste

Definition: This is solid waste received from solid waste operations, cleanup operations, and other missions, including removed legacy waste, that is now ready for

Requirement(s): disposition.

Input 3 Solid Waste Disposition Capability Needs

Definition: These are capability needs to support treatment, Requirement(s): storage and disposal of the solid waste.

Output 1 Assessed Solid Waste Capability Needs

Definition: These are assessed capability needs to support

Requirement (s):

treatment, storage and disposal of the solid waste.

Output 2 Excess Solid Waste Facilities

Definition: Facilities that have had a mission in the Hanford cleanup Mission. It includes excess sites for disposition (e.g. potentially contaminated retrieved trench).

Requirement (s): 


\section{WHC-SD-WM-RPT-060, REV 0 VOLUME 2}

Table 2-4.3.5.7 Function and Requirement Analys is for Function 4.3.5.7, Assess Solid Waste TSD Capability Needs and Disposal Resources (Continued)

Output $3^{\circ}$ Transferrable Resources

Definition: Physical and intellectual resources; e.g., facilities, equipment, materials, infrastructure, 7 and, technology, scientific data, personnel expertise; that are developed during facility deactivation and can be transferred to other areas in the public or private

Requirement(s): domains. 
WHC-SD-WM-RPT-060, REV 0 VOLUME 2

Table 2-4.3.5.8 Function and Requirement Analys is for Function 4.3.5.8, Archive Solid Waste Process Samples and Records

Function 4.3.5.8 Archive Solid Waste Process Samples and Records

Definition: Provide archival storage and retrieval. operations for the analyzed solid waste process samples and the

Requirement(s): accompanying analysis data.

Input 1 Certified Solid Waste Data and Samples

Definition: This is data and samples that were part of the solid waste certification process that require archival

Requirement(s): storage.

Output 1 Certified Solid Waste Archive Data and Samples

Definition: This is archive data and samples that were part of the solid waste certification process that were requested

Requirement(s): to support further certification work.

Output 2 Waste Disposition Status Information

Definition: As the physical status of the solid waste changes, the safety and compliance envelope changes. This is all information regarding the disposition state of the

Requirement(s): solid waste. 
WHC-SD-WM-RPT-060, REV 0 VOLUME 2

\subsection{SOLID WASTE PROGRAM INTÉRFACES}

Figures 3-1 through 3-6 illustrate the internal and external interfaces for function 4.3 and functions 4.3 .1 through 4.3 .5 , respectively. The external interfaces are defined as either inputs from or outputs to the environment external to the particular function. Internal interfaces are defined as an output from one function which inputs into another function within the same higher level function.

\subsection{INTERFACE CONTROL DOCUMENTS}

The Solid Waste Program is in the processing of developing specific definition regarding interfaces between itself and other programs throughout the Hanford Site. To date an Interface Control Document (ICD) has been issued specifying the interfaces between the Solid Waste Disposal and the Environmental Division programs in conjunction with the remediation of past practice sites at Hanford (Reference 8 ). The ICD includes a baseline description of the waste that will be remediated, treated, and disposed in new and existing facilities. It al so includes the roles of each program during remediation and disposal, the basis for determining disposal cost per cubic yard, and the strategies for integration of existing Hanford Waste Management capabilities with the remediation process..

The Solid Waste Program is pursuing ICDs with other programs at the Hanford Site that provide a similar definition for interfaces between programs. As these ICDs are completed they will be added to the baseline documentation for the Solid Waste Program. Listed below are other programs with which the Solid Waste Program is either developing or planning to develop ICDs:

- Tank Waste Remediation System

- Liquid Effluents Treatment Program

- PUREX

- Plutonium Finishing Plant

- Advanced Reactor Programs (Fast Flux Test Facility)

- Analytical Services

- Decontamination and Decommissioning

- General Site Support 
Figure 3-1. Functional Interface Diagram for

Function 4.3, Remedy Solid Waste

Inputs

\begin{tabular}{|c|c|c|c|c|c|}
\hline $\begin{array}{l}\text { NonCompliant } \\
\text { Conditions }\end{array}$ & $\begin{array}{c}\text { Maintain } \\
\text { Solid Waste } \\
\text { Safety and } \\
\text { Compliance } \\
\text { Envelope }\end{array}$ & $\begin{array}{l}\text { Solnd Waste Safety } \\
\text { and Compliance } \\
\text { Constraint } \\
\text { Envelope } \\
\text { Solid Waste } \\
\text { Generated During } \\
\text { Solid Waste } \\
\text { Cleanup Operations }\end{array}$ & $\begin{array}{l}\text { Solid Waste Safety } \\
\text { and Compliance } \\
\text { Constraint } \\
\text { Envelope } \\
\text { Generator Request } \\
\text { Information - } \\
\text { SW Cleanup }\end{array}$ & $\begin{array}{l}\text { Solid Waste Safety } \\
\text { and Compliance } \\
\text { Constraint } \\
\text { Envelope }\end{array}$ & $\begin{array}{l}\text { Solid Waste Safety } \\
\text { and Conpliance } \\
\text { Constraint } \\
\text { Eovelope }\end{array}$ \\
\hline $\begin{array}{l}\text { NonCompliant } \\
\text { Conditions } \\
\text { Legacy Solid Waste } \\
\text { Solid Waste from } \\
\text { Other Missions } \\
\text { Cleanup Wastes }\end{array}$ & & $\begin{array}{l}\text { Receive } \\
\text { Solid } \\
\text { Waste }\end{array}$ & $\begin{array}{l}\text { Data/Samples for } \\
\text { Characterization }\end{array}$ & & $\begin{array}{l}\text { Received Solid } \\
\text { Waste }\end{array}$ \\
\hline $\begin{array}{l}\text { Legacy Solid Waste } \\
\text { Solid Waste frow } \\
\text { Other Missions } \\
\text { Cleanup Wastes }\end{array}$ & $\begin{array}{l}\text { Solıd Waste } \\
\text { Characterization } \\
\text { Information }\end{array}$ & $\begin{array}{l}\text { Solid Waste } \\
\text { Characterization } \\
\text { Information } \\
\text { Excess Waste } \\
\text { Samples }\end{array}$ & $\begin{array}{c}\text { Characterize } \\
\text { Solid } \\
\text { Waste }\end{array}$ & $\begin{array}{l}\text { Solid Waste } \\
\text { Characterization } \\
\text { Information }\end{array}$ & $\begin{array}{l}\text { Solid Waste } \\
\text { Characterization } \\
\text { Information }\end{array}$ \\
\hline $\begin{array}{l}\text { NonCompliant } \\
\text { Conditions }\end{array}$ & & - & & $\begin{array}{c}\text { Determine } \\
\text { Solid Waste } \\
\text { Disposition } \\
\text { Requirements }\end{array}$ & $\begin{array}{l}\text { Solid Waste } \\
\text { Disposition } \\
\text { Requirements }\end{array}$ \\
\hline $\begin{array}{l}\text { NonCumpliant } \\
\text { Conditions }\end{array}$ & $\begin{array}{l}\text { Waste Disposition } \\
\text { Status Information }\end{array}$ & & $\begin{array}{l}\text { Samples of Waste } \\
\text { Requiriug } \\
\text { Additioua! } \\
\text { Characterization }\end{array}$ & & $\begin{array}{c}\text { Disposition } \\
\text { Solid } \\
\text { Waste. }\end{array}$ \\
\hline
\end{tabular}

Qutputs

NonSolid Waste Generated During Cleanup Operations Undocumented Waste Inio. Operation \& Capability Needs Acutely Unsafe Conditions Transferrable.Resources NonSolid Waste Generated During Cleasup Operations Excess Facilities. Equipment and Materials

Operation \& Capability Needs Acutely Unsafe Conditions cormation

Transferrable Resources

NonSolid Waste Generated

During Cleanup Operations Undocumented Waste Info Operation \& Capability Needs Operatio \& Capability Needs Information

Transferrable Resuurces

Operation \& Capabulity Needs

Requirements Requiring

Reconciliation

Transferrable Resuurces

NonSolid Waste Gener ated During Cleanup Operattuns Undocumented Waste Info Operation \& Capability Needs Acutely Unsafe Conditions Info. Excess Solid Wasté Facilitié

Dispositioned Solid Waste

Transferrable Resuurces 
Figure 3-2. Functional Interface Diagram for Function 4.3.1,

Maıntain Solid Waste Safety and Compliance Envelope

Inputs.

W:: :te Disposition Status Info Sulnd Waste Characterization Infurmation

Noncompliant Conditions

ป

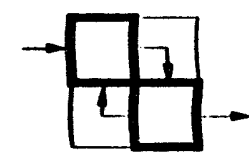

Qutputs

Non-Solid Waste Generated During Cleanup Operations Operations \& Capability Needs

\begin{tabular}{|c|c|c|c|}
\hline $\begin{array}{l}\text { Maintain Safe } \\
\text { and Compliant } \\
\text { Solid Waste }\end{array}$ & $\begin{array}{l}\text { Operations and } \\
\text { Maintenance } \\
\text { Work Package }\end{array}$ & $\begin{array}{l}\text { Operations and } \\
\text { Maintenance } \\
\text { Work Package } \\
\text { Solid Waste }\end{array}$ & $\begin{array}{l}\text { Operations } \\
\text { Information }\end{array}$ \\
\hline
\end{tabular}

Solid Waste

Solid Waste

Transferrable Resources

Environment

Solid Waste

Equipment and

Structure

and Compliant

Solid Waste

Equipment Q

Structures

\section{Solid Waste}

Internal Safety

Operations

Solid Waste

Internal Safety

Operations

Documents

Documents

and Compliant

Documentation

NonCompliant Conditions

Solid Waste

Qualified Staff

Solid Waste

Qnalified Staff

Solid Waste

Qualified Staff

$\cdot$

\begin{tabular}{|c|c|c|c|c|}
\hline$\cdot$ & & & $\begin{array}{l}\text { Qualified } \\
\text { Solid Waste } \\
\text { Staff }\end{array}$ & \\
\hline $\begin{array}{l}\text { Solid Waste } \\
\text { Corrective Action } \\
\text { Needs }\end{array}$ & $\begin{array}{l}\text { Solid Waste } \\
\text { Corrective Action } \\
\text { Needs }\end{array}$ & $\begin{array}{l}\text { Solid Waste } \\
\text { Corrective Actios } \\
\text { Needs }\end{array}$ & $\begin{array}{l}\text { Solid Waste } \\
\text { Corrective Action } \\
\text { Needs }\end{array}$ & $\begin{array}{c}\text { Assess Solid } \\
\text { Waste Safety } \\
\text { \& Compliance } \\
\text { State }\end{array}$ \\
\hline
\end{tabular}

Acutely Unsafe Conditions

Non-Solid Waste Generated During Cleanup Operations Solid Waste Generated

Duriag Solid. Waste

Cleanup Operations

Transferrable Resources

Acutely Unsafe Conditions

Information

Solid Waste Safety'

Compliance Envelope

Transferrable Resources

Transferrable Resources

Inf ormation

Solid Waste Generated During

Solid Waste Cleanup

Operations

ransferrable Resources

Undocumented Wastes

l.f ormation 
Figure 3-3. Functional- Interface Diagram for Funct10u 4.3.2, Receive Solid Waste

\section{Inputs}

NonCompliant Conditions

Solid Waste Characterization

lifiormation

Legacy Solıd Waste

4

NonCompliant Conditions

Solid Waste Characterization Intormation

Solnd Waste Generated During

Solid Waste Cleanup

Operations

Cleauup Wastes

Exce:ss Solnd Waste Samples

Sulnd Waste Erom Other

Missions

\begin{tabular}{|c|c|}
\hline $\begin{array}{c}\text { Retrieve. Existing } \\
\text { Solid Waste }\end{array}$ & \\
\hline & . \\
Receive New \\
Solid Waste
\end{tabular}

\section{Qutputs}

Acutely Unsafe Conditions

\section{Information}

Operations \& Capability

Needs

Excess Facilities

Equipment, and Materials

Data/Sampies for

Characterization

Transferrable Resources

Non-Solid Waste Generated

During Cleanup Operations

Retrieved Solid Waste

Acutely Unsafe Conditions

Information

Operations \& Capability

Needs

Excess Facilities

Equipment, and Materials

Data/Samples for

Characterization

Transferrable Resources

Non-Solid Waste Generated

During Cleanup Operatious

Recieved Solid Waste

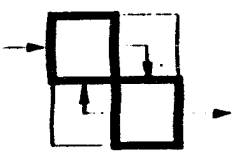


Figure 3-4. Functional Interface Diagram for Function 4.3.3, Characterize Solid Waste

Inputs

Data tor Characterization Lagacy Waste lnformation Infurmation on Samples of Waste Requiring. Additional Characterization SW Generator Request Info - Cleanup SW Generator Request Info - SW Clean SW Generator Request Info - Other Missions

Samples for Characterization Samples of Waste Requiring Additional Characterization

N

\section{- Solid Waste Archive Specifications}

Legacy Waste Information SW Generator Request Info - Cleanup SW Generator Request Iofo - SW Cleanup SW Gentrator Request Info - Other Missions

\begin{tabular}{|c|c|c|c|}
\hline $\begin{array}{c}\text { Acquire Solid } \\
\text { Waste } \\
\text { Process } \\
\text { Knowledge }\end{array}$ & $\begin{array}{l}\text { Solid Waste Safety } \\
\text { and Compliance } \\
\text { Constraint } \\
\text { Envelope } \\
\text { Solid Waste } \\
\text { Generated During } \\
\text { Solid Waste } \\
\text { Cleanup Operations }\end{array}$ & & $\begin{array}{l}\text { Solid Waste Process } \\
\text { Knowledge }\end{array}$ \\
\hline & $\begin{array}{c}\text { Analyze } \\
\text { Solid Waste } \\
\text { Inventory }\end{array}$ & $\begin{array}{l}\text { Solid Waste } \\
\text { Samples } \\
\text { Solid Waste } \\
\text { Analysis } \\
\text { Information }\end{array}$ & $\begin{array}{l}\text { Solid Waste } \\
\text { Analysis } \\
\text { Information }\end{array}$ \\
\hline & $\begin{array}{l}\text { Solid Waste } \\
\text { Archive Samples }\end{array}$ & $\begin{array}{c}\text { Archive } \\
\text { Solid Waste } \\
\text { Samples/ } \\
\text { Characterization } \\
\text { Data }\end{array}$ & $\begin{array}{l}\text { Solid Waste } \\
\text { Archive Data }\end{array}$ \\
\hline $\begin{array}{l}\text { Additional } \\
\text { Analysis/Process } \\
\text { Knowledge }\end{array}$ & $\begin{array}{l}\text { Additional } \\
\text { Analysis/Process } \\
\text { Knowledge }\end{array}$ & & $\begin{array}{c}\text { Assess } \\
\text { Solid Waste } \\
\text { Characterization } \\
\text { Information }\end{array}$ \\
\hline
\end{tabular}

\section{Qutputs}

Acutely Unsafe Conditions Ioformation Transferrable Resources

Acutely Unsafe Conditions Information Transferrable Resources

Solid Waste Samples

Non-Solid Waste Generated During Cleanup

Acutely Unsafe Conditions Information Operations and Capability Needs Solid Waste Characterization Information Transferrable Resources

Undocumented Wastes Information

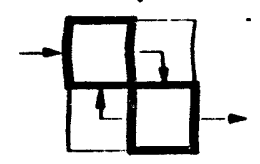


Figure 3-5. Functional Interface Diagram for Function 4.3.4, Determine Solid Waste Disposition Requirements

Iuputs

Solid Waste Characterization Information

w

\begin{tabular}{|c|c|c|c|}
\hline Information & $\begin{array}{l}\text { Compile } \\
\text { Imposed } \\
\text { Solid Waste } \\
\text { Requirements }\end{array}$ & $\begin{array}{l}\text { Disposition } \\
\text { Requirements List }\end{array}$ & \\
\hline NonCompliant Conditions & & $\begin{array}{c}\text { Evaluate } \\
\text { Solid Waste } \\
\text { Requirements } \\
\text { For Disposition }\end{array}$ & $\begin{array}{l}\text { Solid Waste } \\
\text { Disposition } \\
\text { Specifications }\end{array}$ \\
\hline & & & $\begin{array}{c} \\
\text { Prepare } \\
\text { Solid Waste } \\
\text { Disposition } \\
\text { Specifications }\end{array}$ \\
\hline
\end{tabular}

\section{Operations \& Capability} Needs

Requirements Requirng Resolution

Operations \& Capability Needs

Solid Waste Disposition

Requirements

Solid Waste Archive

Specifications

Transferrable Resources

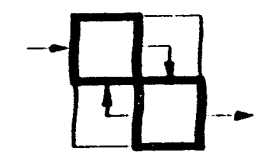


Figure 3-6. Functional Interface Diagram for

Function 4.3.5, Disposition Solid Waste

Qutputs

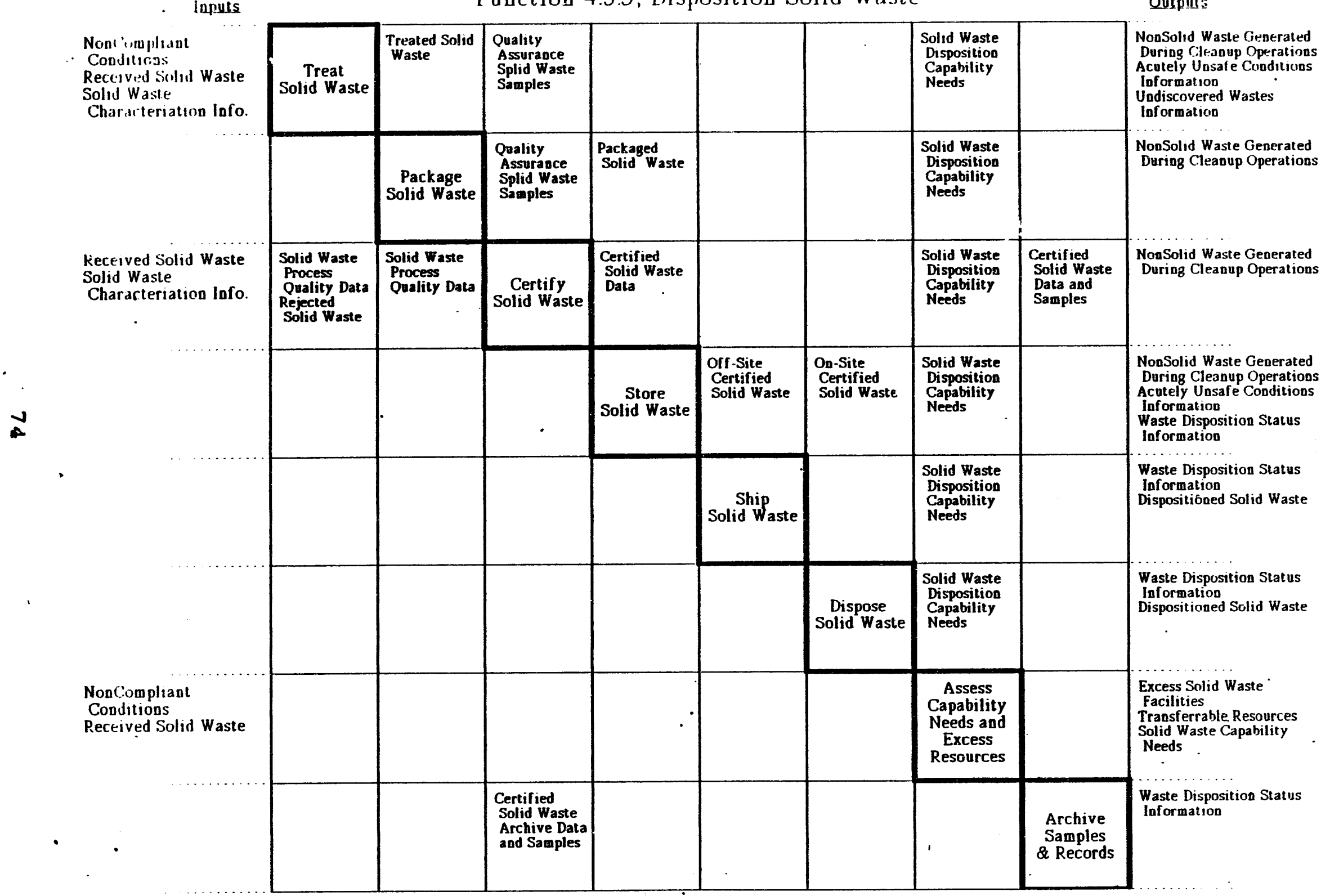




\section{WHC-SD-WM-RPT-060, REV 0 VOLUME 2}

\subsection{DEFINITIONS}

A list of commonly used words in this document have been defined for the reader. These definitions are based on referenced definitions to the maximum extent possible.

Category 1 Low-Level Waste - Low-level waste is waste that contains radioactivity and is not classified as high-level waste, transuranic (TRU) waste, or spent nuclear fuel or $11 E(2)$ byproduct material as defined by DOE Order 5820.2A. Test specimen of fissionable material irradiated for research and development only; and not for the production of power or plutonium, may be classified as LLW provided the concentration of transuranic is less than 100 $\mathrm{nC} i / \mathrm{g}$. If the radionuclide concentration does not exceed the value. in WHC-EP0063-4, Table 3-1, Column 1, the waste is considered Category 1 low-level waste. (Reference 3 ).

Category 3 Low-Level Waste - Low-level waste is waste that contains radioactivity and is not classified as high-level waste, transuranic (TRU). waste, or spent nuclear fuel or $11 E(2)$ byproduct material as defined by DOE Order 5820.2A. Test specimen of fissionable material irradiated for research and development only, and not for the production of power or plutonium, may be classified as LLW provided the concentration of transuranic is less than 100 $\mathrm{nC} \mathrm{i} / \mathrm{g}$. If the radionuclide concentration does not exceed the value in WHC-EP0063-4, Table 3-1, Column 2, the waste is considered Category 3 low-1eve1 waste. (Reference 3 ).

Greater Than Category 3 Low-Level Waste - Low-level waste is waste that contains radioactivity and is not classified as high-level waste, transuranic (TRU) waste, or spent nuclear fuel or $11 E(2)$ byproduct material as defined by DOE Order $5820.2 A$. Test specimen of fissionable material irradiated for research and development only, and not for the production of power or plutonium, may be classified as LLW provided the concentration of transuranic is less than $100 \mathrm{nCi} / \mathrm{g}$. If the radionuclide concentration exceeds the value in WHC-EP-0063-4, Tabie 3-1, Column 2, the waste is considered Greater Than Category 3 low-level waste. (Reference 3 ).

Certified Waste - Waste that has been confirmed to comply with disposal site waste acceptance criteria (e.g., the Waste Isolation Pilot Plant-Waste Acceptance Criteria for transuranic waste) under an approved certification program. (Reference 4)

Chemical Conversion - The action of substances undergoing chemical. change, or a process that produces change.

Closure - A. Operational Closure - Those actions that are taken upon completion of operations to prepare the disposal site or disposal unit for custodial care, (e.g., addition of cover, grading, drainage, erosion control). B. Final Site Closure - Those actions that are taken as part of a formal decommissioning or remedial action plan, the purpose of which is to achieve long-term stability of the disposal site and to eliminate to the extent 


$$
\text { WHC-SD-WM-RPT-060, REV } 0 \text { VOLUME } 2
$$

practical the need for active maintenance so that only surveillance, monitoring, and minor custodial care are required (Reference 4).

Contact-Handled Transuranic Waste - Packaged transuranic waste whose external surface dose rate does not exceed $100 \mathrm{mrem}$ per hour. This may be extended to $200 \mathrm{mrem}$ per hour on a case-by-case basis with the approval of the manager of Westinghouse Hanford Solid Waste Operations (Reference 5).

Combustible Material - Combustible materials are those materials which will sustain combustion in atmospneric air when exposed to an ignition source of 1475 degree Fahrenheit for a period of 5 minutes (Reference 6).

Dangerous Waste - Those wastes that are designated dangerous by Washington State Department of Ecology regulations (Reference 7).

Degradation - Conversion of a compound into a simpler compound, usually less noxious than the original compound.

Disposal - Emplacement of waste in a manner that assures isolation from the biosphere for the foreseeable future with no intent of retrieval and that requires deliberate action to regain access to the waste (Reference 4).

Disposal Facility - The land, structures, and equipment used for the disposal of waste (Reference 4).

Disposal Site - That portion of a disposal facility which is used to dispose of waste. For low-level waste, it consists of disposal units and a buffer zone (Reference 4).

Disposal Unit - A discrete portion (e.g., a pit, trench, tumulus, vault, or bunker) of the disposal site into which waste is.placed for disposal (Reference 4).

Engineered Barrier - A man-made structure or device that is intended to improve the performance of a disposal facility (Reference 4 ).

Hazardous Wastes - Those wastes that are designated hazardous by EPA regulations 40 CFR 261 (Reference 4).

Institutional Control - A period of time, assumed to be about 100 years, during which human institutions continue to control waste management facilities (Reference 4).

Long Term Storage - storage for a period of time greater than two years.

Low-Level Waste - Waste that contains radioactivity and is not classified as high-level waste, transuranic waste, or spent nuclear fuel or byproduct material. Test specimens of fissionable material irradiated for research and development only, and not for the production of power or 


\section{WHC-SD-WM-RPT-0 j0, REV 0 VOLUME 2}

plutonium, may be classified as low-level waste, provided the concentration of transuranium radionuclides is less than $100 \mathrm{nCi} / \mathrm{g}$ (Reference 4).

Monitoring - The making of observations and measurements to provide data to evaluate the performance of a waste management operation (Reference 4 ).

Mixed Waste - Waste containing both radioactive and dangerous waste components as defined by the Atomic Energy Act and the Washington State Dangerous Waste Regulations, respectively.

Near Surface Disposal - Disposal in the upper 30 meters of the earth's surface, (e.g., shallow land burtal) (Reference 4 ).

Processing - see Treatment, definition 2.

Radioactive Solid Waste - Solid waste that contains radionuclides regulated under the Atomic Energy Act of 1954, as amended and of negligible economic value, considering the costs of recovery. Solid wastes generated in radiologically controlled areas and contaminated above threshold limits are to be considered radioactive solid waste.

Radioactive Waste - Solid, liquid, or gaseous material that contains radionuclides regulated under the Atomic Energy Act of 1954, as amended and of negligible economic value considering costs of recovery (Reference 4).

Remote-Handled Transuranic Waste - Packaged transuranic waste whose external surface dose rate exceeds 200 mrem per hour. Test specimens of fissionable material irradiated for research and development purposes only and not for the production of power or plutonium may be classified as remotehandled transuranic waste (Reference 4).

Retrieval - The recovery of stored waste for the purpose of treatment and/or final disposal.

Solid Waste - Any discarded solid, semi-solid, or solidified liquid material such as garbage, refuse, sludge, or discarded commodity resulting from industrial, commercial, mining, agricultural, or community operations or activities that is not a primary product of such operations or activities. This includes solid materials, containerized liquid or semisolid materials, and containerized gaseous materials contained in drums, boxes, or other containers. The scope of solid waste within this document is any solid waste managed by the Restoration and Ungrades Program function within the Solid/Liquid Waste Remediation Division (Reference 5).

Stabilization - Any method, technique or process designed to prevent the migration of hazardous and/or radioactive constituents contained within a waste matrix.

Storage - Retrievable retention of waste pending disposal (Reference 4). 
WHC-SD-WM-RPT-060, REV 0 VOLUME 2

Storage Facility - Land area, structures, and equipment used for the storage of waste (Reference 4).

Storage Unit - A discrete part of the storage facility in which waste is stored (Reference 4).

Top Level - Pertains to high level topics related to the Solid Waste Program. This document is considered a top level document since it is written to assist the Solid Waste Program to perform the programmatic functions of solid waste scope development and defense to Westinghouse hianford higher management and to the DOE Field Office, Richland (Reference 5).

Transuranic Waste - Without regard to source or form, waste that is contaminated with alpha-emitting transuranium radionuclides with half-lives greater than 20 years and concentrations greater than $100 \mathrm{nCi} / \mathrm{g}$ at the time of assay (Reference 4).

Transuranium Radionuclide - Any radionuclide having an atomic number greater than 92 (Reference 4).

Treatment - 1. Any method, technique, or process designed to change the physical or chemical character of waste to render it less hazardous, safer to tranisport, store or dispose of, or reduce in volume (Reference 4). 2. Any method, technique or activity which is required for transport, storage, treatment, or disposal of waste regardless of whether the physical or chemical nature of the waste is changed.

Treatment Facility - The specific area of land, structures, and equipment. dedicated to waste treatment and related activities (Reference 4).

Waste Container - A receptacle for waste, including any liner or shielding material that is intended to accompany the waste in disposal (DOE $5820.2 \mathrm{~A})$. In the case of a contaminated, damaged, leaking, or breached containers, any overpack shall be considered the container, and the original container shall be considered part of the waste (Reference 6 ).

Waste Management - The planning, coordination, and direction of those functions related to generation, handi ing, treatment, storage, transportation, and disposal of waste, as well as associated surveillance and maintenance activities (Reference 4 ).

Waste Package - The waste, 'waste container, and any absorbent that are intended for disposal as a unit. In the case of surface contaminated, damaged, leaking, or breached waste packages, any overpack shall be considered the waste container, and the original container shall be considered part of the waste (Reference 4). 
WHC-SD-WM-RPT-060, REV 0 - VOLUME 2

\subsection{REFERENCES}

1: Hanford Mission Plan, Volume 1, Site Guidance, DOE-RL-93-08, Draft, Table 3-1, p. 3-2, March, 1993.

2. WHC-SP-0989, Solid Waste Program FY 1994 Multi-Year Program Plan, Phase

- 1 WBS \#1.2.1, M. M. McCarthy, June 1993.

3. WHC-EP-0063-3, September 1991, Hanford Site Solid Waste Acceptance. Criteria,N.P. Willis, G.C. Triner

4. DOE 5820.2A, September 26, 1988; Radioactive Waste Management.

5. WHC-EP-0363, Rev 1, August, 1991, Solid Waste Program Plan D.R. Duncan

6. WIPP/DOE-069, Rev 3, January 1989, IRU Waste Acceptance Criteria For The Waste Isolation Pilot Plant

7. WAC-173-303 Washington State Administrative Code, Chapter 303 Dangerous Waste Regulations, Part 040, Definitions

8. WHC-SD-ER-002, Rev. O, Hanford Restoration Basel ine Approach Interface Control Document, M. A. Casbon, October, 1993.

9. Immediate Action Directive No. 0511-21, Atomic Energy Commission, April, 1970. 
WHC-SD-WM-RPT-060, REV 0 VOLUME 2

This page intentionally left blank. 
WHC-SD-WM-RPT-060, REV O

Solid Waste Program

Technical Baseline Description

Volume 3: System Description 
WHC-SD-WM-RPT-060, REV 0 VOLUME 3

VOLUME 3. SYSTEM DESCRIPTION

Table of Contents

1.0 INTRODUCTION ....................... 1

1.1 BACKGROUND ....................... 1

1.2 PURPOSE ...................... 3

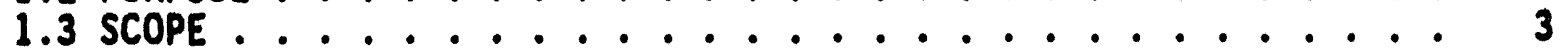

2.0 HANFORD SITE INVENTORY . . . . . . . . . . . . 6

2.I NATIONAL WASTE INVENTORIES .............. 7

2.2 CURRENT HANFORD SITE INVENTORY ............ 7

2.2.1 Low-Level Waste ................. 8

2.2.2 Low-Level Mixed Waste....... . . . . . . . . 9

2.2.3 Transuranic Waste ............... 10

2.2.4 Transuranic Mixed Waste .............. 11

2.2.5 Nonradioactive Hazardous Waste ........... 11

2.2.6 Material-Not-Categorized-as-Waste . . . . . . . 11

2.2.7 Historical Trends............... 12

2.3 PROJECTED INVENTORY . . . . . . . . . . . . 16

2.3.1 Low-Level Waste . . . . . . . . . . . . . . 17

2.3.2 Low-Level Mixed Waste . . . . . . . . . . . . 18

2.3.3 Transuranic Waste .................. 19

2.3.4 Transuranic Mixed Waste ............. 19

2.3.5 Nonradioactive Hazardous Waste ........... 20

2.3.6 Special Case Wastes ............. . 20

2.3.7 Material-Not-Categorized-As-Waste ........ 20

2.3.8 Waste Minimization ............ 20

2.4 HANFORD SITE SOLID WASTE UNCERTAINTIES .......... 22

2.4.1 Environmental Restoration And Decontamination And 22

2.4.2 Retrievably Stored Transuranic Waste . . . . . . . . 22

2.4.3 Tank Waste ................. 23

2.4.4 Additional Waste Generators . . . . . . . . . . . . 23

2.4 .5 Waste $\mathrm{Class}$.................. 23

2.4.6 Waste Forecast Accuracies .............. 23

2.5 REMOTE-HANDLED WASTE AND MATERIALS ............ 23

3.0 FACILITIES AND PROJECTS TO ACCOMPLISH MISSION . . . . . . . . . 25

3.1 RETRIEVAL . . . . . . . . . . . 26

3.1.1 Sol id Waste Retrieval Phase I (Project W-113) . . . 26

3.1.2 Alpha Caisson Retrieval (Project $W-156) \ldots 27$

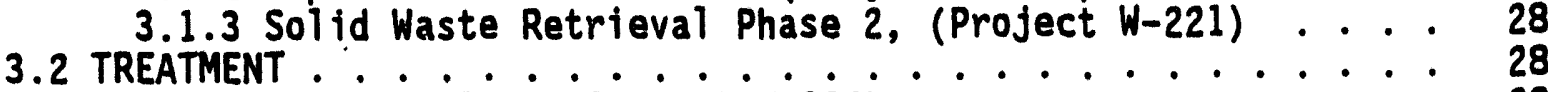

3.2.1 WRAP Module 1 (Project $W-026) \ldots \ldots$. . . . . . . 29

3.2.2 WRAP Module $2 A$ (Project $W-100$ ) .......... 30

3.2.3 WRAP Module 2B (Project W-255) ......... 31

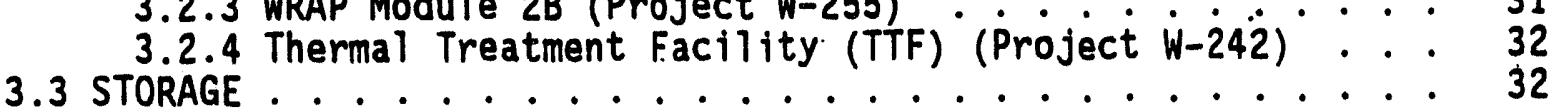




\section{WHC-SD-WM-RPT-060, REV 0 VOLUME 3}

3.3.1 Transurantc Assay and Storage Factlity (TRUSAF) (224-T) . . . . 33

3.3.2 Radtoactive Mixed Waste Storage Factitities (RMWSF) : 33

3.3.3 Enhanced Radioactive and Mixed Waste Storage Phase V Module (Project W-112) ............ 34

3.4 DISPOSAL . . . . . . . . . 35

3.4.1 Enhanced Sol id Low-Level Radioactive Waste Disposal (Project W-174)

3.4.2 Radioactive M1xed Waste Disposal, (Project W-025) ... 36

3.4.3 Sol id Low-Level Radioactive Waste Disposal . . . . . 37

4.0 SOLID WASTE PROGRAM FLOWSHEET . . . . . . . . . . . . 38

4.1 TRU WASTE ........................... 38

4.2 LOW-LEVEL MIXED WASTE ................. 39

4.3 LON-LEVEL WASTE . . . . . . . . . . . . . . . 40

4.4 SPECIAL CASE WASTE...$\ldots 41$

4.5 ENVIRONMENTAL RESTORATION WASTE ................... 41

5.0 REFERENCES . . . . . . . . . . . . . . . . 45

APPENDIX A. REMOTE-HANDLED WASTE AND MATERIALS INVENTORY ........ A-1 
WHC-SD-WM-RPT-060, REV 0 VOLUME 3

List of Tables

Table 2-1. Fraction of National U.S. Department of Energy Waste at the Hanford Site. . . . . . . 7

Table 2-2. Volume summary by Waste Category (Volumes in $\mathrm{m}^{3}$ ) $\ldots 16$

Table 2-3. Waste Minimization Goals ............. 21

\section{List of Figures}

Figure 1-1. Hanford Site Radioactive Solid Waste Current and

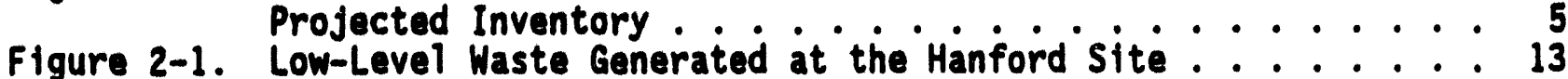

Figure 2-2. TRU Waste Generated at the Hanford S1te .......... 14

Figure 2-3. Low-Level Mixed Waste Generated at the Hanford Site . . . . . 15

Figure 4-1. Hanford Solid Waste Program Flowsheet ...........443

\section{List of Terms}

$\begin{array}{ll}\text { CFR } & \text { Code of Federal Regulations } \\ \text { CY } & \text { calendar year } \\ \text { DRD } & \text { decontamination and decommtssioning } \\ \text { DOE } & \text { U.S. Department of Energy } \\ \text { FY } & \text { fiscal year } \\ \text { GTC3 } & \text { Greater-Than-Category 3 } \\ \text { LLMW } & \text { low-level mixed waste } \\ \text { LLW } & \text { low-level waste } \\ \text { PCB } & \text { polychlorinated biphenyl } \\ \text { PNL } & \text { Pacific Northwest Laboratory } \\ \text { PUREX } & \text { Plutonium-Uranium Extraction } \\ \text { RCRA } & \text { Resource Conservation and Recovery Act of } 1976 \\ \text { SWITS } & \text { Solid Waste Information Tracking System } \\ \text { SWPM } & \text { Solid Waste Projection Model } \\ \text { TRU } & \text { transuranic } \\ \text { WAC } & \text { Washington (State) Administrative Code } \\ \text { Westinghouse Hanford } & \text { Westinghouse Hanford Company } \\ \text { WIPP } & \text { Waste Isolation Pilot Plant. }\end{array}$




\section{WHC-SD-WM-RPT-060, REV 0 VOLUME 3}

\subsection{INTRODUCTION}

This volume of the document provides a look at the system the Solid Waste Program has defined as its baseline approach for accomplishing its mission. The Solid Waste Program's system is defined in terms of the existing and projected inventory within its scope, the facilities and projects that the program has defined to accomplish its 'mission, and a flowsheet which describes the flow of the various wastes through each factlity and project.

This document provides a link between Solid Waste Program planning and site-wide planning under the auspices of the Hanford Mission Plan (Reference 1) and Systems Engineering for the Hanford Cleanup Mission (Reference 2). This document also provides a link between Solld Waste Program planning (Reference 3) and Solid Waste projects identified to perform the functions of the Solid Waste Program.

Many of Solid Waste Progran's projects and actions are in the development phase. As these projects become more defined, more precise information can be presented on the respective flow paths. Similarly, as programs outside the Solid Waste Program are better able to define the scope of their missions the uncertainty of projected waste forecasts is expected to diminish. Regulatory requirements are evolving for a number of the waste types handled by the Solid Waste Program and the program must change to stay in step with evolving requirements. For these reasons, this document is intended. to be a living document and thus updated to reflect the change to the scope and/or direction of the Solid Waste Program.

\subsection{BACKGROUND}

Solid waste currently exists and will continue to be generated at many locations throughout the Hanford Site; however, the majority of the operating or planned waste management facilities are in the 200 West Area, which is in the center of the Hanford Site. The principal facilities at the Hanford Site are grouped in "areas." The areas are as follows:

- The 100 Areas contain former nuclear material production reactors, which are no longer operational.

- The 200 Areas (200 East and 200 West) primarily contain nuclear material processing facilities and waste management facilities; most of the processing facilities are no longer operational or are being converted for waste cleanup missions.

- The 300 Area contains laboratory, service, and support facilities.

- The 400 Area contains the Fast Flux Test Facility and support facilities. The Fast Flux Test Facility is no longer operational.

- The 1100 and 3000 Areas contain administrative buildings and Site maintenance and vehicle storage. 
WHC-SD-WM-RPT-060, REV 0 VOLUME 3

- The 600 Area is the land between the other operational areas.

Other prominent features are the U.S. Ecology commercial low-level radioactive disposal site and the Washington Public Power Supply System reactor sites.

The following solid waste types ${ }^{1}$, are managed by the Solid Waste Program at the Hanford Site:

- LoW-Level Waste ${ }^{2}$ (LLW) which is radioactive waste that.

- has small amounts of radioactivity (less than $100 \mathrm{nCi} / \mathrm{g}$ ) from transuranic (TRU) elements

- is not high-level waste, spent nuclear fuel, or by-product material.

- Transuranic waste which is radioactive waste contaminated with alpha particle emitting TRU radionuclides with half-life periods greater than 20 years and TRU emission rates greater than 100 $\mathrm{nCi} / \mathrm{g}$.

- Mixed waste which is radioactive waste that is co-contaminated with dangerous waste as defined in Washington (State) Administrative Code (WAC) 173-303 (Reference 4). Washington is administrator for the dangerous waste program, as the State meets the requirements of the U.S. Environmental Protection Agency hazardous waste program. Mixed waste may be either LLW or TRU waste.

- Hazardous waste which is nonradioactive waste that is contaminated with dangerous constituents as defined in WAC 173-303.

Detailed definitions of each of these solid waste types are given in the Hanford Site Solid Waste Acceptance Criteria (Reference 5).

1

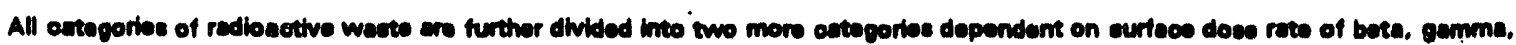

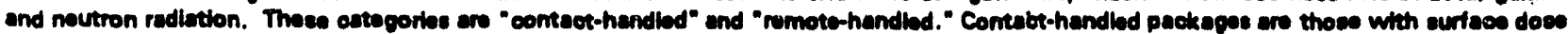
rates no grester than $100 \mathrm{mrom} / \mathrm{h}$ for nowly gonorated TRU wasto and etored LLW, and $200 \mathrm{mram} / \mathrm{h}$ for directly burbed LLW. Boforo 1992.

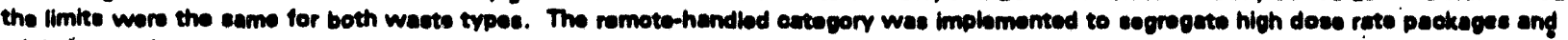
minimize worker exposurs.

2

LLW is further olaesified according to radionuelide concentration into Catogory 1, Category 3, and Greater Than Category 3. This syatem is similar to the U.S. Nuclear Regulatery Commiesion waste claseification eystem found in Titie 10 of the Code of Federal Regulationa (CFR). Part 61 (NAC 1990). This eategorization is adapted to fit isotopic and volume characteriaties of Hantord Site Waste. The higher the category number, the greater the activity and long-lived radionuellde concentration. This results in etrieter dieposal requirements. Small volumes of Category 2 waste at the Hanford Site led to an extension of the aetivity limite for Catogory 3 to onvelope Category 2. 


\section{WHC-SD-WM-RPT-060, REV 0 VOLUME 3}

The Solid Waste Program employs the use of solid waste inventory databases for existing and forecasted waste and waste volume throughput modeling to aid in defining the Solid Waste Program's system.

Strict accounting requirements for both radioactive and hazardous wastes require tracking systems from generation to disposal. The Sol id Waste Information Tracking System (SWITS), maintained by the Solid Waste Program, tracks each container of waste received for storage or disposal at the Hanford Site with a unique identification number and records location, physical attributes (e.g., weight, volume), chemical characteristics (e.g., presence of dangerous constituents), radionuclides, and other information (e.g., hazard classifications). The database has over 950,000 waste records dating from 1944.

The Solid Waste Projection Model (SWPM) (Reference 6) was developed for Westinghouse Hanford by Pacific Northwest Laboratory (PNL) to develop detailed projections of future wastes. In addition, the SWPM performs process flow modeling of waste volumes (including volume changes) through future waste handling facilities. Volume forecasts, including waste type, class, and physical and chemical descriptions, are prepared annually by generators for a 30-xear period. The most recent summary of waste volume forecast data (Reference 7) was published in August 1993.

\subsection{PURPOSE}

The purpose of this volume of the document is to provide a top-level description of the current direction of the Solid Waste Program in meeting its mission - receive, store, treat, and dispose of solid radioactive and nonradioactive wastes in a safe and environmentally compliant manner. (Reference 3) This document supports planning and analys is of top level inventory, functions, facilities and projects within the SoTid Waste Program that establish the program baseline.

Changing Hanford Site and U.S. Department of Energy (DOE) missions and changing cleanup requirements lead to uncertainties in the volumes and types of wastes expected in the future. The largest uncertainties are in the volumes and classification of waste from environmental restoration and decontamination and decommissioning (D\&D); much of the management of these wastes is beyond the scope of this document. Most of the other uncertainties can be accommodated by increased operating hours, longer facility operating lives, or capacity expansions. Time and national decisions are necessary to resolve all uncertainties.

\subsection{SCOPE}

The document compiles: 1) the volume of existing and projected radioactive solid waste inventory at Hanford, 2) Solid Waste .Program facilities and projects identified to manage the radioactive solid waste inventory, and 3) a flowsheet which describes how the solid waste under the 
WHC-SD-WM-RPT-060, REV 0 VOLUME 3

Solid Waste Program mission is managed. These three categories of information are combined to define the Solid Waste Program's technical system that has been developed to meet its mission.

The system description aids the Solid Waste Program in defining its role in the overall Hanford site mission of cleanup. In addition the flowsheet provides a link between Solid Waste Program planning and the specific projects identified to meet the Solid Waste Program mission.

Figure 1-1 graphically represents the existing inventory of solid waste currently at the Hanford site and the projected inventory of solid waste for the period fiscal year 1993 through fiscal year 2022. The Solid Waste Program manages the existing inventory of solid waste located in active burial grounds and Solid Waste Program managed facilities. The program also plans for management of projected solid waste forecasts. Figure 1-1 includes solid waste buried at the Hanford Site in inactive burial grounds that will be remediated by the Hanford Site Environmental Restoration (ER) Mission Area. The solid waste in the ER Mission Area is included in figure 1-1 to portray the entire inventory of existing solid waste buried at the Hanford site. 


\section{WHC-SD-WM-RPT-060, REV 0 VOLUME 3}

Eigure 1-1. Hanford Site Radioactive Solid Waste Current and Projected Inventory

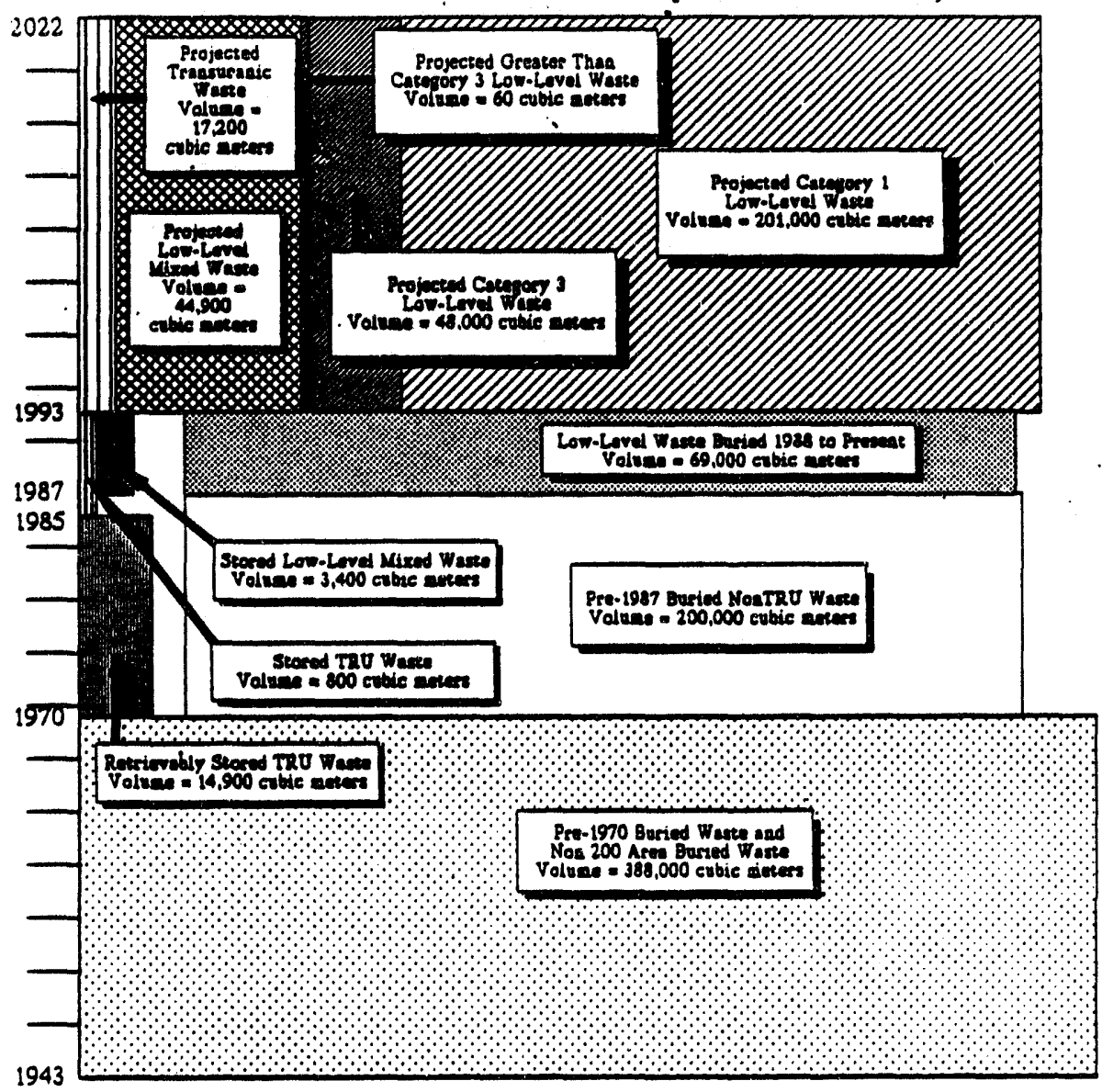

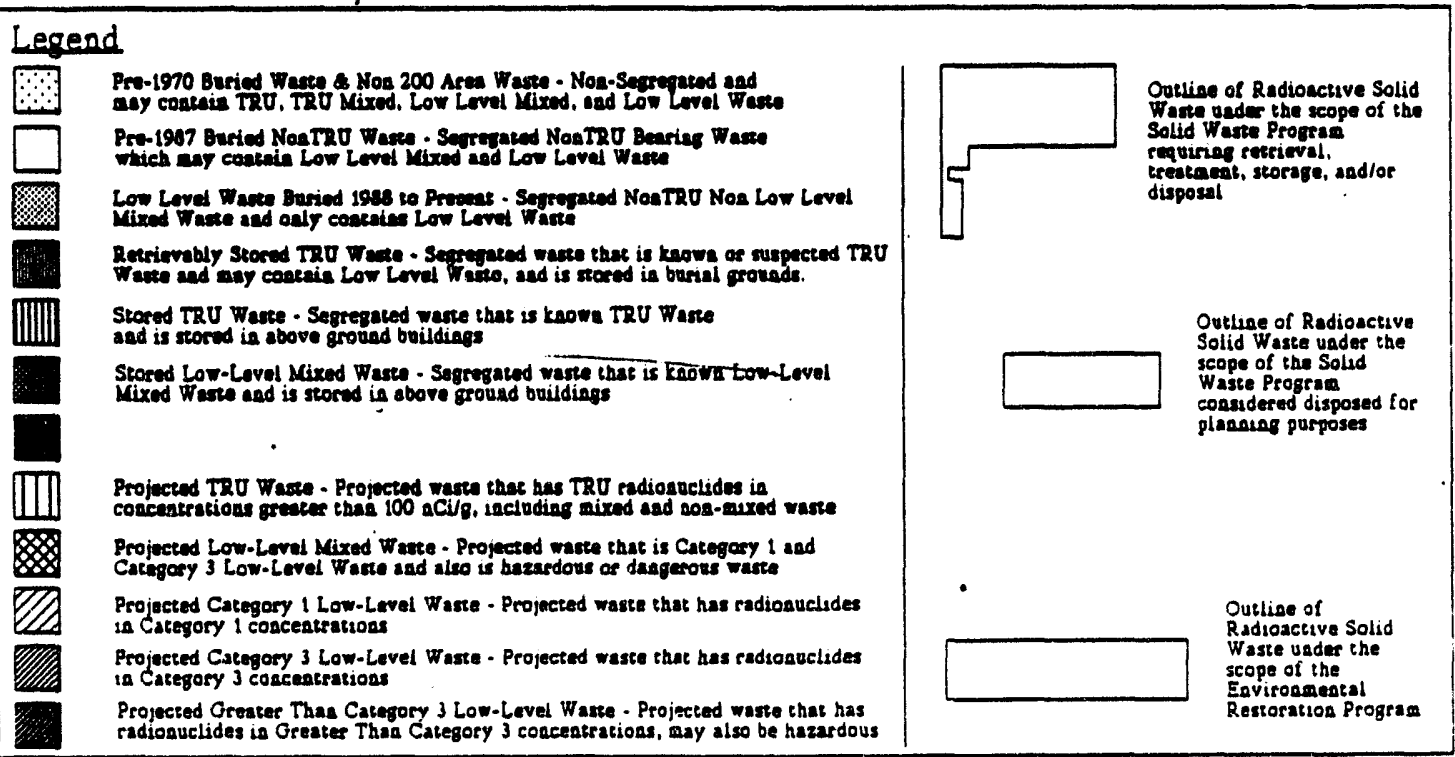


WHC-SD-WM-RPT-060, REV 0 VOLUME 3

\subsection{HANFORD SITE INVENTORY}

This section provides a summary of existing and projected solid waste at the Hanford Site until 2022, a 30-year waste forecast time frame. The following solid waste types are included:

- Low-level radioactive waste (LLW) (by category depending on radionuclide activity -- Calegory"1, Category 3, and greater-thanCategory 3 [GTC3])

- Transuranic (TRU) waste

- Radioactive mixed waste (mixed with hazardous components)

- Hazardous waste.

Radioactive waste originates from six major sources: (1) DOE-related activities, such as experimental reactors; (2) defense nuclear industry support; (3) institutions, such as hospitals, universities, and research foundations; (4) industrial uses of radioisotopes; (5) mining and milling of uranium ore; and (6) the commercial fuel cycle. Hanford Site solid waste within the scope of this report is principally from the first three sources. The defense nuclear materials production and breeder reactor program produced radioactive waste from the first two sources.

The Hanford Site has always had the responsibility to manage waste produced within its boundaries. An arid climate and large land area make the Site suitable for land disposal of radioactive waste. Thus, the DOE has accepted relatively small amounts of radioactive waste from institutions with no waste disposal capabilities since the 1960s. Other waste sources are either not received by the site or else not considered within the scope of the solid waste program. Tank wastes, cesium and strontium capsules, production and power reactor fuel, and residual special nuclear material (e.g., enriched uranium) are not included in the scope. Solid waste from all expected sources is discussed in this report. Major uncertainties and their relationship with waste volumes and planned or existing solid waste management facilities are al so discussed.

Solid wastes from environmental restoration and D\&D work are included in the inventories, al though little detail is known. These represent the largest volumes of waste that the Hanford Site will encounter. A division of responsibility for handling these wastes has recently been established. This document assigns responsibility for characterization, retrieval, storage, treatment, and in-place disposal of environmental restoration waste to the environmental restoration program of Westinghouse Hanford Company (Westinghouse Hanford). Solid Waste Management will have only disposal responsibility for environmental restoration waste that is sent to the 200 Areas (200 East and 200 West Areas). 


\subsection{NATIONAL WASTE INVENTORIES}

Hanford Site wastes are major portions of the national DOE waste inventory. The integrated database prepared annually by Oak Ridge National Laboratory (the latest volume (Reference 8 ) is current only through calendar year $[\mathrm{CY}]$ 1991) gives the following percentages.

Table 2-1. Fraction of National

U.S. Department of Energy Waste at the Hanford Site.

\begin{tabular}{|l|c|}
\hline \multicolumn{1}{|c|}{ Waste Type } & $\begin{array}{c}\text { Nation's waste } \\
\text { onsite (\%) }\end{array}$ \\
\hline Low-Level & 21 \\
\hline Transuranic & 16 \\
\hline Low-Level Mixed & 3 \\
\hline
\end{tabular}

The $L L W$ in the table is considered disposed. The TRU waste fraction is the retrievably stored portion. No buried TRU (waste with TRU elements buried before initiation of the TRU designation in 1970) was included. The volumes in Table 2-1 do not include any environmental restoration wastes that would increase volumes in each category by over an order of magnitude and cause the Hanford Site to hold the majority of each type of waste.

Shipments of waste to the Hanford Site in the past have occurred from many offsite generators, including such diverse entities as the International Atomic Energy Agency in Seibersdorf, Austria, and Ceer University in Puerto Rico as well as DOE factlities such as Argonne National Laboratory.

\subsection{CURRENT HANFORD SITE INVENTORY}

The current inventory of waste in this report is limited to that stored or buried in solid waste management facilities at the Hanford Site. These facilities will be identified and described in detail later. Projected inventory includes waste forecast to be sent to the Sol id Waste Program from onsite or offsite waste generators in the future and is discussed in the next chapter.

The current waste summary for the Hanford site is given in the next sections and is current as of the end of CY 1993. The critical feature of these wastes is the different storage, treatment, and disposal requirements. Waste volumes are rounded to the nearest $100 \mathrm{~m}^{3}$ for volumes of $1,000 \mathrm{~m}^{3}$ or greater and to the nearest 10 for volumes of less than $1,000 \mathrm{~m}^{3}$.

Both contact-handled and remote-handled waste are included in the summary. 
WHC-SD-WM-RPT-060, REV 0 VOLUME 3

\subsubsection{Low-Level Waste}

This waste type consists of the following:

- Trash from operating facilities

- Failed equipment

- Organic debris (e.g., tumbleweeds)

- Other materials with low levels of radioactive contamination

- Ion exchange resins

- Asbestos

- Classified waste packages

- Contaminated heavy equipment (e.g., cranes, grade-alls)

- Various process equipment (e.g., piping, valves)

- Laboratory wastes

- Hot cell wastes

- Miscellaneous contaminated items (e.g., paper, rubber, plastic and glass)

- Soil.

Packages that have been used to dispose of waste include self-contained items, plastic wrap, cardboard boxes, 55-gal drums, large metal boxes, concrete casks, and composite material containers. Some large items are not packaged but may be wrapped in plastic. Recent criteria preclude using waste packages that degrade and cause backfill subsidence, such as cardboard boxes. Among the larger packages to date are the Shippingport reactor pressure vesse1 and the steam generator from the Surree, Virginia, nuclear power plant. Before CY 1992 disposed LLW was not divided into the categories of Category 1 LLW and Category $3 \mathrm{LLW}$, as these classifications were not implemented until 1992.

Typically, LLW is buried in unlined trenches at the Hanford Site. A final strategy for Category 3 LLW management requires completion of a PA to verify acceptability of disposal practices; a draft of the PA has been completed. Until the PA is final, interim management practices (supported by the draft PA) for Category 3 LLW will include segregation and disposal in a modified waste form or a high integrity container. Currently, GTC3 LLW cannot be disposed in trenches and is in retrievable trench storage pending decisions on disposal. A probable disposal method would be a geologic repository. al though other alternatives may be chosen.

Since 1943, LLW has been disposed in direct shallow land burial in the $100,200,300$, and 600 Areas of the Hanford Site. There are 28 burial grounds in the 100 Area, which have been inactive since 1973. The 200 Areas have 43 active and inactive burial grounds and buildings where LLW (including LLMW) is either disposed or stored. A summary of all radioactive solid waste in the 100 Area can be found in Estimates of Solid Waste Buried in the 100 Area Burial Grounds (Reference 9). A similar document for the 200 Areas is Summary 
WHC-SD-WM-RPT-060, REV 0 VOLUME 3

of Radioactive Solid Waste Received in the 200 Areas During Calendar Year 1992 (Reference 10).

The LLW and TRU waste were not separated in the Hanford Site burial grounds until May 1, 1970, with the 1ssuance of the U.S. Atomic Energy Commission Immediate Action Directive 0511-21 (Reference 11). Before that date, all solid waste was disposed in shallow trenches. There was no distinction between LLW and LLMW before 1987 when Washington State began implementing the RCRA regulations. After 1987, waste with hazardous components was stored in above-ground bulldings that meet RCRA requirements. LLW buried before 1987 is considered to be disposed and is not considered mixed waste. Trenches containing such waste will be closed and monitored according to RCRA regulations..

A total of $595,000 \mathrm{~m}^{3}$ of LLW had been buried at the Hanford Site at the end of CY 1992. A small portion of the Hanford Site Category $1 \mathrm{LLW}, 190 \mathrm{~m}^{3}$ is stored; this waste is primarily organic liquids not subject to 1 and ban restrictions but not desirable to bury in trenches because of potential enhancement of radionuclide transport. Approximately $1,000 \mathrm{~m}^{3}$ of GTC3 LLW is stored pending national decisions necessary to permanently dispose of such waste. Waste consisting of defueled submarine reactor compartment sections $\left(24,000 \mathrm{~m}^{3}\right)$ is disposed in below-ground trenches in the 200 Area. This waste is mixed waste as the compartments contain lead and polychlorinated biphenyls, but the hazardous constituents are encapsulated within the heavy section steel compartments. The waste is considered low-level buried waste pending permit applications with the Washington State Department of Ecology.

\subsubsection{Low-Level Mixed Waste}

On May 18, 1987, DOE issued a rule under the Atomic Energy Act of 1954 clarifying DOE's obligations under RCRA. As a result, all DOE radioactive waste contaminated with hazardous waste under RCRA is termed mixed waste and subject to regulation by the DOE and the WAC. This created categories of waste that require separate waste management disposition and segregation. The procedure for determining if a radioactive solid waste is a mixed waste is in WAC 173-303-070 (Reference 4). Brief7y, waste is designated mixed if constituents from several 1 ists are present in sufficient concentrations or if the waste exhibits certain. characteristics, such as ignitability or corrosivity.

In 1987, the Hanford Site stopped disposing of mixed waste in unlined trenches and began to store these wastes in above-ground facilities. In January 1988, an agreement with the State stipulated that mixed waste with a dose rate less than $200 \mathrm{mrem} / \mathrm{h}$ would be retrievably stored and placed in a building that meets all of the Washington State storage requirements. Mixed waste with greater than $200 \mathrm{mrem} / \mathrm{h}$ (remote-handled) would be disposed of below ground to satisfy as low as reasonably achievable radiation safety requirements, assuming successful waiver applications. 
The inventory of stored LLMW at the end of calendar year 1992 is 3,400 $\mathrm{m}^{3}$. The LLMW is stored primarily in 19 above-ground buildings in the Central Waste Complex in the 200 Areas.

\subsubsection{Transuranic Waste}

The Atomic Energy Commission directed in Immediate Action Directive 0511-21 (Reference 11) on March 20, 1970, that after Apri1 30, 1970, al1 Atomic Energy Commission sites would segregate "waste with known or detectable contamination of transuranium nuclides" from other types of wastes. Such wastes were to be segregated, packaged, and stored in readily retrievable, contamination-free packages for up to 20 years. After 20 years, retrievability was to continue to be possible. This policy was because of the high toxicity and long half-life periods of TRU isotopes. The 20-year interim storage period was to allow time to study the best disposal alternative. The immediate action directive did not provide a detalled definition of TRU waste. Contractors to the Atomic Energy Commission implemented the policy as well as possible based upon analytical data, calculations, and process knowledge.

In 1973, the segregation limit for TRU waste was given a value of 10 $\mathrm{nCi} / \mathrm{g}$. This did not change waste handling practices because the amount of TRU was based on calculations and/or estimates. In 1982, the segregation 1imits were changed again, to $100 \mathrm{nCi} / \mathrm{g}$, reducing the volume of newly generated wastes-designated as TRU waste.

Retrievably stored TRU wastes have been placed in several different storage configurations at the Hanford Site. Initially, waste was placed horizontally in trenches with direct soil cover. Then, for a brief period of time, 1972-73, drums of TRU waste were placed in a concrete $V$ trench with a metal cover. After 1974, drums and boxes of contact-handled TRU waste were stored upright in trenches with either asphalt or plywood bottoms, plywood and plastic tarps covering the containers, and $4 \mathrm{ft}$ of earth over the tarp cover. In 1985, an above-ground building, the Transuranic Storage and Assay Facility (TRUSAF), was opened for storage of newly generated TRU waste and is currentiy used to store TRU waste with some containers having hazardous components. However, until 1989, some newly generated TRU was placed in trenches.

At the end of calendar year 1992, there is $15,500 \mathrm{~m}^{3}$ of contact-handled TRU waste in burial grounds and above-ground buildings. Because TRU definitions changed since 1970, approximately 50 percent of the waste now designated as stored TRU is expected to be $L L W$ when retrieved and analyzed. Remote-handled TRU waste amounts to approximately $200 \mathrm{~m}^{3}$ in two trenches and five cylindrical underground vaults, called caissons.

Approximately 97 percent of the retrievable stored TRU waste packages are 55-gal drums, with the remainder consisting of concrete, metal, plywood, or fiberglass-coated plywood boxes or other containers, such as high-efficiency particulate air filters. Because of their large size, however, the boxes contain nearly 50 percent of the stored TRU by volume. 
WHC-SD-WM-RPT-060, REV 0 VOLUME 3

The physical composition of the stored TRU is estimated as follows:

- 48 percent glass, metal, or similar solid noncombustibles

- 43 percent combustible

- 3 percent dirt, gravel, or asphalt

- 1 percent absorbed 1 iquids or sludges

- 1 percent filters or filter media

- 4 percent all other materials.

Before approximately 1978, essentially no data recording was required for waste form physical composition; data recording has steadily improved since 1978.

Because of the retrlevability requirements, more data are available on the nature of the TRU waste than the LLW. The waste characteristics are described in Contact-Handled Transuranic Waste Characterization Based on Existing Records (Reference 12).

\subsubsection{Transuranic Mixed Waste}

The total volume of TRU waste described above that is designated TRU mixed waste is $190 \mathrm{~m}^{3}$. Some is contained in buildings at the Central Waste Complex and the rest is in retrievable storage in trenches. All waste is contained within facilities with RCRA permits.

There was no requirement for listing hazardous components on waste disposal records before 1986; thus, all waste designated as TRU mixed waste is recent. Recent studies have shown that of all TRU waste generated since 1986, approximately $20 \%$ is mixed. It would be reasonable to assume that waste before 1986 has a similar mixed/nonmixed proportion, although it is not currentiy designated mixed.

\subsubsection{Nonradioactive Hazardous Waste}

Hazardous waste is accumulated at the source of generation and shipped to the 616 Nonradioactive Dangerous Waste Storage Facility for accumulation before offsite shipment or shipped directly offsite. Waste containing polychlorinated biphenyls with no other hazardous contaminants is stored in the 212-P Building before offsite shipment. Typically, hazardous wastes are soils and debris.

\subsubsection{Material-Not-Categorized-as-Waste}

There are large amounts of materials on the Hanford Site that are not currently designated as solid waste but may eventually be so designated and thus require waste management activities. A report was prepared recently summarizing these materials (Reference 13).

Much of these materials will probably be designated as high-level waste. Management of this waste could become a source for solid low-level or TRU 
WHC-SD-WM-RPT-060, REV 0 VOLUME 3

waste, however, which would be expected to appear in solid waste volume forecasts.

The reactor fuel basin sludges, lead bricks, and alkali metals would most likely become solid waste, although a beneficial use or customer may yet be found for the alkali metals. A small portion, approximately $10 \mathrm{~m}^{3}$, of the alkali metals was declared waste.

\subsubsection{Historical Trends}

Figures 2-1 through 2-3 show the annual receipts of LLW, LLMW, and TRU plus TRU mixed waste at the Hanford Site obtained from the SWITS database. The LLW disposal began in 1943. There is a significant spike in the LLW volume in 1969. This corresponds to the addition of the 300 Area burial grounds as anit to the database.

The spike in 1975 in Figure 2-2 (TRU and TRU mixed waste) is mostly gloveboxes and equipment from the cleanout of a plutonium production 1 ine (the Division of Military Applications line) in the Plutonium Finishing Plant. The lesser spike in 1980 is mostly boxed waste from the 231-2 Building, at that time a PNL plutonium metallurgy laboratory. The spike in 1981 was not caused by any single generator or event. The decrease from 1985 to 1986 is due to greater accuracy in assay techniques, when the TRUSAF became operational. Previousiy, inability to accurately assay to the $100 \mathrm{nCl} / \mathrm{g}$ TRU limit led to conservatism in assigning waste to the TRU category. 
WHC-SD-WM-RPT-060, REV 0 VOLUME 3

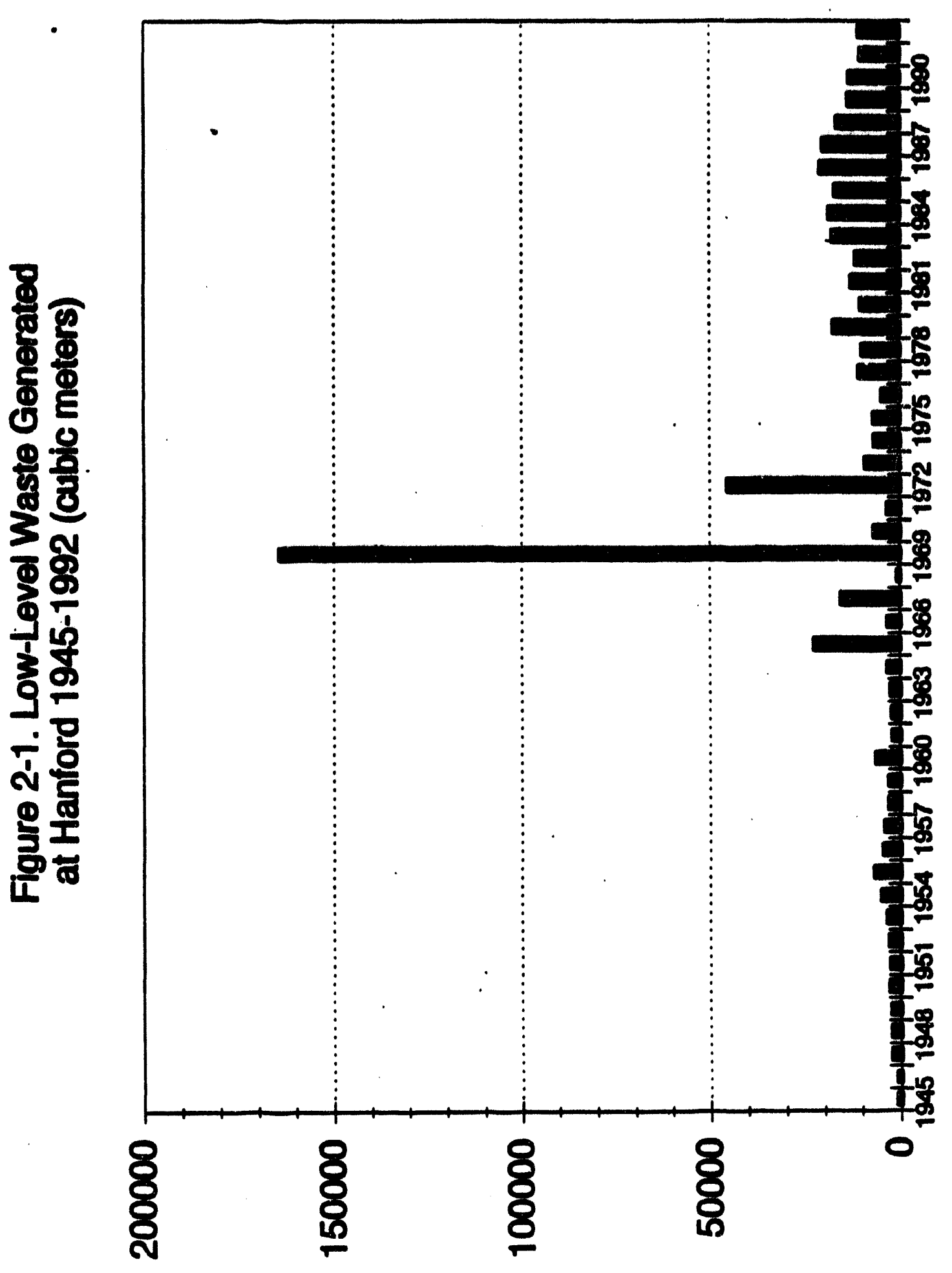


Figure 2-2. TRU Waste Generated at Hanford 1970-1992 (cubic meters)

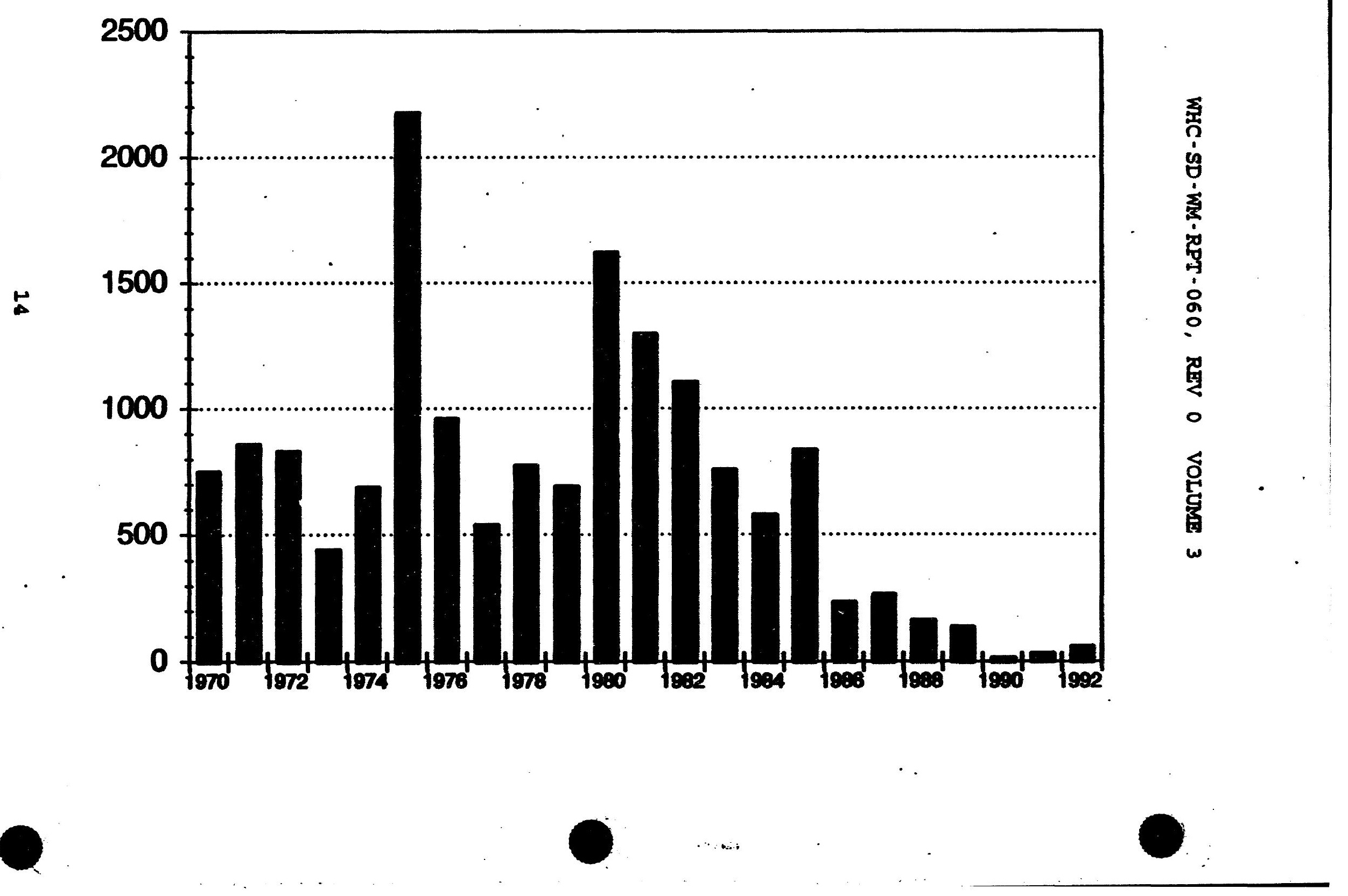


Figure 2-3. Low-Lovel Mbxed Wasto

at Hanford 1987-1992 (cubic meters)

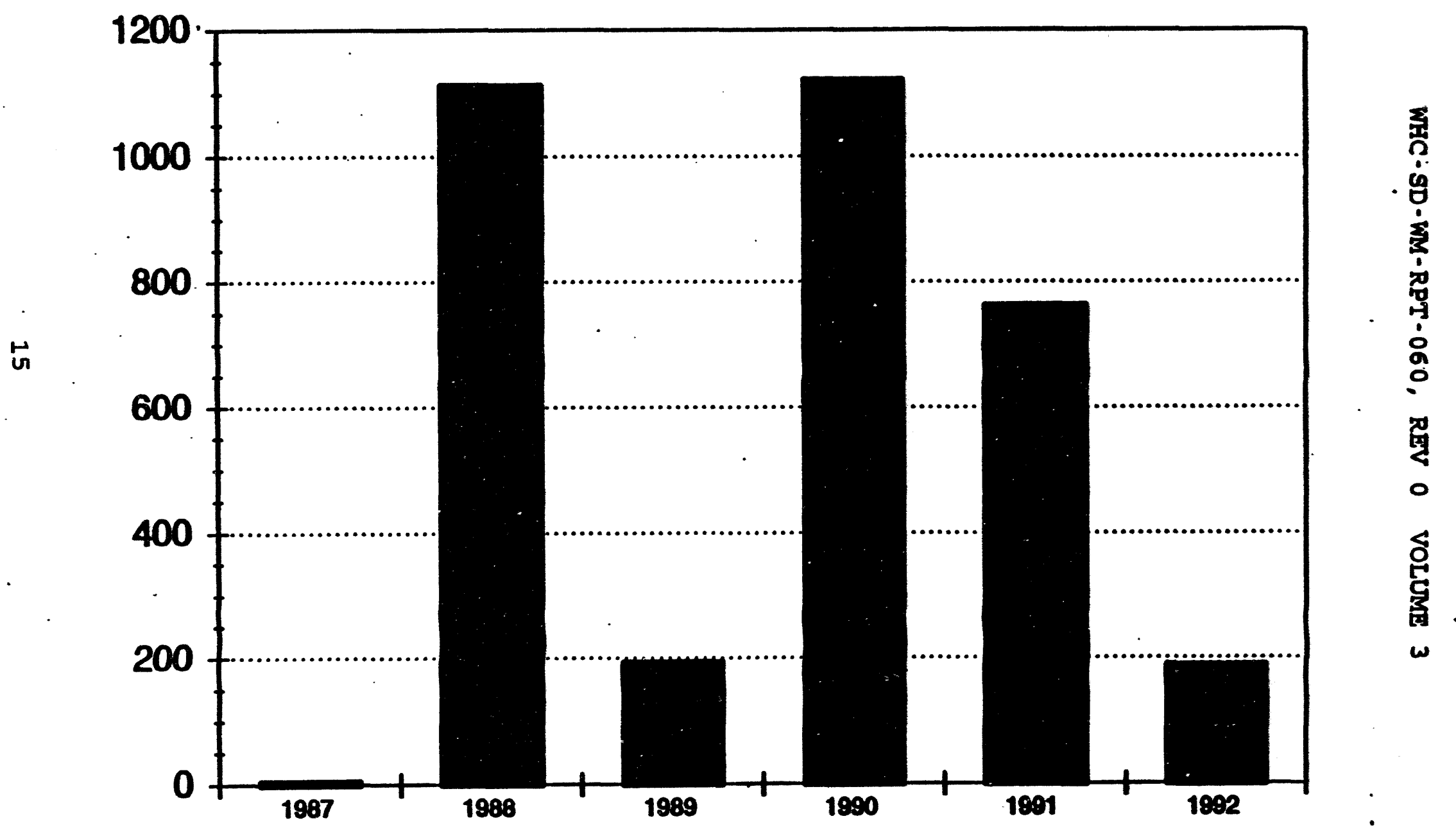




\subsection{PROJECTED INVENTORY}

This section deals with projected solid waste at the Hanford Site from fiscal year (FY) 1993 until FY 2022, a 30-year waste forecast time frame. The following solid waste types are included:

- Low-level radioactive waste (LLW) (by category depending on radionuclide activity -- Category 1 , Category 3 , and Greater-Than-Category 3 [GTC3])

- Transuranic (TRU) waste

- Radioactive mixed waste (mixed with hazardous components).

- Hazardous waste.

This section summarizes projected waste volumes and characteristics. The data are taken from the 1993 Solid Waste Reference Forecast Summary (Reference 7). A similar document is in preparation to update forecast figures for the time period from 1994-2023, but has not yet been published. Projected wastes are defined as those that are not in a facility managed by the Westinghouse Hanford solid waste organization but are expected to be received in the future. Projected waste in some cases may al ready have been generated and is being held until necessary planning and documentation is completed to certify that the waste will meet Westinghouse Hanford requirements. This applies to onsite and offsite generators.

The total volume of solid waste forecast for management at the Hanford Site (from FY 1993 to FY 2022) is approximately $320,000 \mathrm{~m}^{3}$. As shown in Table $2-2$, this waste is distributed among several waste categories.

Table 2-2. Volume Summary by Waste Category (Volumes in $\mathrm{m}^{3}$ )

\begin{tabular}{|l|r|c|}
\hline \multicolumn{1}{|c|}{ Waste Type } & Total Volume & Total Percent \\
\hline Low-level & 249,000 & 78.4 \\
\hline $\begin{array}{l}\text { Low-level } \\
\text { mixed }\end{array}$ & 44,900 & 14.2 \\
\hline Transuranic & 14,700 & 4.6 \\
\hline $\begin{array}{l}\text { Transuranic } \\
\text { mixed }\end{array}$ & 2,500 & 0.8 \\
\hline Hazardous & 6,300 & 2.0 \\
\hline Total & 317,400 & 100.0 \\
\hline
\end{tabular}




\section{WHC-SD-WM-RPT-060, REV 0 VOLUME 3}

The waste volumes do not include forecasts for environmental restoration activities; such volumes are projected to be as high as 21 million $\mathrm{m}^{3}$. The environmental restoration remedial action waste is destined for the Environmental Restoration Disposal Facility (ERDF). These wastes have not been characterized or forecast in as great a level of detall as the other wastes discussed in this section. However, they represent by far the largest volumes that the Site must manage. As stated earlfer in this report, the Solid Waste Program will only be responstble for disposing environmentả 1 restoration wastes shipped to the 200 Areas solid waste disposal facilities; these volumes have not been defined yet. As trench construction to accommodate disposal is relatively straight forward, ample time is avatlable to define such volumes before dates are needed for disposal.

Some small portions of D\&D wastes from surplus factlities are included in Table 2-2, but these are small fractions of the expected total of 1.51 million $\mathrm{m}^{3}$. Not enough detail is known about classification, particularly of the hazardous components, of the bulk of D\&D waste to incorporate it with the forecast waste in Table 2-2. The D\&D waste (with the possible exception of 100 Area production reactor large structural components) will be managed by - the Solid Waste Program for storage, treatment, and disposal similar to other waste generated onsite.

The LLW Category 1 will not require any treatment other than compaction before disposal. Other $L L W$ classes may require treatment to meet performance assessment requirements. The LLMW will require treatment before onsite disposal. The TRU and TRU mixed waste will require special handling and some processing before final offsite disposal at the WIPP. The hazardous waste : will be shipped offsite for treatment or disposal.

About 78 percent of the solid waste is LLW and will require little or no treatment before its disposal. However, nearly 20 percent of the solid waste will require treatment before disposal at the Hanford Site or shipment to the WIPP.

\subsubsection{Low-Level Waste}

Approximately $249,000 \mathrm{~m}^{3}$ (78.4 percent) of the total projected solid waste is LLW:

- 79 percent is contact-handled LLW 1

- 16 percent is contact-handled LLW 3

- 5 percent is distributed among other LLW Classes.

The LLW is as follows:

- 22 percent metal

- 34 percent compactible

- 20 percent particulate

- 24 percent has a variety of other physical characteristics. 


\section{WHC-SD-WM-RPT-060, REV 0 VOLUME 3}

A waste stream that has not been included in the preceding forecast volumes is a product of TRU retrieval operations. Retrieval of the stored TRU waste will result in LLW generation, as approximately 50 percent of the stored TRU is expected to become LLW after the repackaging and analysis necessary for shipment to the WIPP. This is because of the change of the radionuclide 1 imit for segregating TRU waste from LLW after 12 years of accumulation at the lower limit and the lack of accurate assay equipment during initial years of TRU segregation. The retrieved volume will be spread from 1999 to 2016.

The projected LLW is as follows:

- 37 percent in drums

- 47 percent in small boxes

- 16 percent in other containers.

\subsubsection{Low-Level Mixed Waste}

Approximately $44,900 \mathrm{~m}^{3}$ (14.2 percent) of the projected solid waste is LLMW. This is divided as follows:

- 96 percent contact-handled LLMW Category 1 and 3

- 4 percent remote-handled LLMW Category 1 and 3

The LLMW physical constituents are as follows:

- 77 percent liquid and siudige

- 10 percent metal

- 6 percent compactible

- 6 percent other characteristics

- 1 percent particulate.

Approximately 21 percent of the LLMW is forecast as "mixed" because of the expected presence of polychlorinated biphenyls. Approximately 65 percent of the hazardous constituents contained in the mixed waste were identified only as other regulated materials.

A majority of the liquids and sludges are expected from operations at the Liquid Effluent Treatment Facility. This is the first year solid waste forecast data has been received from the Liquid Effluent Treatment Facility, and the data may need to be updated after the facility has operated.

The projected LLiN is as follows:

- 86 percent in drums.

- 8 percent in other container types

- 6 percent in small boxes.

A significant portion of the drums will be from the Liquid. Effluent Treatment Facility. 


\section{WHC-SD-WM-RPT-060, REV 0 VOLUME 3}

\subsubsection{Transuranic Waste}

Approximately $14,700 \mathrm{~m}^{3}$ of the waste (4.6 percent) is expected to be TRU, 76 percent of which is contact-handled.

The TRU waste is expected to be as follows:

- 42 percent metal less than 1/2-in. thick

- 35 percent compactible

- 8 percent construction material

- 15 percent other physical characteristics.

The projected TRU is as follows:

- 67 percent drums

- 33 percent special containers, small boxes, and other containers

The special containers are most likely special transportation casks that were not described by the generators.

\subsubsection{Transuranic Mixed Waste}

Approximately $2,500 \mathrm{~m}^{3}$ ( 0.8 percent) will be TRU mixed waste; 35 percent of which is contact-handled.

Generators of TRU mixed waste include the Hanford Waste Vitrification Plant, PUREX Plant, the Plutonium Finishing Plant, and the Fuel Supply Building (e.g., Building 308), and PNL. Argonne National Laboratory is the sole offsite generator of TRU mixed waste included in the baseline forecast.

The Liquid Effluent Treatment Facility and retrieval operations at double-shell tanks significantly impact the expected physical characteristics of the TRU mixed waste. The projected TRU mixed waste is as follows:

- 57 percent liquid and sludge

- 28 percent metal greater than $1 / 2-i n$. thick

- 15 percent other characteristics.

The liquids and sludges will come from the Liquid Effluent Treatment Facility. The metal will come from retrieval operations at the double-shell tanks.

Much of the hazardous constituent information is unavailable. These constituents were either unspecified by the generators or identified as other regulated materials and not further defined by the generators.

The projected TRU mixed waste is as follows:

- 35 percerit 55-gal drums

- 65 percent in boxes and miscellaneous containers. 
The boxes will be used for the metals from the double-shell tanks. Some of the metals may be up to $18.3 \mathrm{~m}(60 \mathrm{ft})$ in length.

\subsubsection{Nonradioactive Hazardous Waste}

Approximately $6,300 \mathrm{~m}^{3}$, or only 2.0 percent of the total volume, will be nonradioactive hazardous waste. The generators of this waste are all located on the Hanford Site.

The major physical characteristics are as follows:

- 54 percent liquids and sludges

- 11 percent compactible

- 35 percent other forms.

'Much of the hazardous constituent information is unavailable. However, the following amounts are expected:

- 15 percent toxic materials

- 14 percent flammable liquids

- $\quad 9$ percent combustible liquids

- 7 percent are acidic materials

- 55 percent miscellaneous other materials.

\subsubsection{Special Case Wastes}

No such wastes have been forecast, although some generators are known to be initiating requests to ship such wastes to the Hanford Site.

\subsubsection{Material-Not-Categorized-As-Waste}

No such material has been included in the forecast.

\subsubsection{Waste Minimization}

In May 1990, the Hanford Site Waste Minimization and Pollution Prevention Awareness Plan was completed. This plan, updated for 1991 (Reference 14), provides the overall strategy for the Hanford Site and is supported by four plans for each of the Hanford Site contractors. In addition, a third tier of detalled plans for the larger generators has been developed by Westinghouse Hanford and PNL. There are currently 29 Westinghouse Hanford facility-specific and 8 PNL research-specific waste minimization plans.

The scope of the waste minimization program at the Hanford Site covers nonhazardous, hazardous, radioactive, and mixed wastes in addition to hazardous substances or products. The first priority is to reduce the amount and toxicity of waste via source reduction. For waste that is nevertheless 
WHC-SD-WM-RPT-060, REV 0 VOLUME 3

generated, the next priority is to recycle, the waste materials for reuse, if possible.

During $1992,804,000 \mathrm{~kg}$ of waste were avoided through source reduction and recycling efforts. This represents nearly a two-fold increase in waste avoided over the 1991 values. The primary contributions to this achievement were in RCRA hazardous waste, where $410,000 \mathrm{~kg}$ of excess chemicals were used . by offsite companies, and in mixed waste, where $109,000 \mathrm{~kg}$ of waste was avoided through segregation and recycling activities. Al though the total amount of waste generated during 1992 increased over 1991 quantities, waste. minimization activities in pre-job planning, use of nonhazardous substitutes, and recycling have significantly reduced the amount of waste requiring treatment and disposal. Goals from the Hanford Site Waste Minimization and Pollution Prevention Pian (Reference 14) are in Table 2-3.

A system to track waste by source is still being implemented. Once it is in place, waste generation can be adjusted for new activities and compared to the baseitine to determine if goals have been achieved.

Waste minimization should be considered when forecasting future waste volumes. However, there is no way to tell how amenable the currently forecast waste will be to minimization. The goals in Table 2-3 could apparently be expected to be met for hazardous waste. But the goals, even if met, will be less than the uncertainties in projected volumes of waste.

Table 2-3. Waste Minimization Goals

\begin{tabular}{|l|c|c|c|c|c|c|}
\hline \multirow{2}{*}{$\begin{array}{c}\text { Waste } \\
\text { Category }\end{array}$} & Baseline & \multicolumn{5}{|c|}{ Waste Minimization Goals } \\
\cline { 2 - 7 } & $\begin{array}{c}\text { (1990 Waste } \\
\text { Quantities } \\
(\mathrm{kg})\end{array}$ & 1991 & 1992 & 1993 & 1994 & 1995 \\
\hline $\begin{array}{l}\text { State or RCRA } \\
\text { hazardous }\end{array}$ & 778,700 & 5 & 10 & 10 & 5 & 5 \\
\hline Radioactive & $3,821,900$ & 5 & 5 & 5 & 3 & 2 \\
\hline Mixed & $11,917,000$ & 5 & 5 & 10 & 5 & 2 \\
\hline
\end{tabular}

RCRA = Resource Conservation and Recovery Act of 1976. 


\section{WHC-SD-WM-RPT-060, REV 0 VOLUME 3}

\subsection{HANFORD SITE SOLID WASTE UNCERTAINTIES}

The characteristics of current and projected waste inventories must be known with enough accuracy to permit adequate storage, treatment, and disposal facility planning. These facilities should not be undersized such that throughput and cleanup schedules are hampered, nor should they be oversized and, thus, inefficient and wasteful.

The major uncertainties can be summarized as follows:

- Standards for waste cleanup, characterization, treatment, or acceptance by offsite facilities (such as WIPP) are evolving, and changes during evolution will affect solid waste plans.

- Several waste classes (e.g., GTC3, alkali metals, miscellaneous radioactive materials) do not have clear decisions made on treatment and disposai. Some require decisions at a national level.

- Forecasts for volumes and other characteristics typically are less certain the longer the time frame: This is caused by uncertainty in $p l a n s$ and requirements. The impacts are the most significant on the waste handling facilities that require years of planning, design, and construction before operations.

- Waste component accuracies for stored waste become less reliable with age of the waste.

\subsubsection{Environmental Restoration And Decontamination And Decommissioning Waste}

The waste resulting from cleanup activities, environmental restoration activities (such as the pre-1970 buried waste expected to contain TRU radionuclides), and D\&D of non-operational reactor and processing sites is potentially the largest source of the Hanford Site solid waste. Table 2-4 is currently the best estimate of such potential wastes. Details of waste class or physical or hazardous constituents will be developed as specific decommissioning plans, RCRA closure plans, and Records of Decision for Comprehensive Environmental Response, Compensation, and Liability Act (CERCLA) remedial actions are developed.

\subsubsection{Retrievably Stored Transuranic Waste}

The integrity of retrievably stored TRU containers is uncertain after below-ground storage for up to 22 years. Breaches may cause more radionuclide and hazardous component spread during retrieval, leading to increased waste volumes and more extensive and expensive cleanup.

Requirements for completeness and accuracy of records were less stringent with older waste containers, leading to less accurate or complete waste contents descriptions. 
WHC-SD-WM-RPT-060, REV 0 VOLUME 3

\subsubsection{Tank. Waste}

The current estimates for tank wastes include external equipment from double-shell tanks to be removed before removing tank wastes.

Double-shell tank waste such as residual solids after tank waste removal, soils, tank shells, or waste (contaminated equipment and clothing) generated during cleanup have not been estimated.

Single-shell tank waste, such as residual solids after tank waste removal, solls from around or below the tanks, tank shells, or waste generated during cleanup, are considered environmental restoration wastes under environmental restoration.

\subsubsection{Additional Waste Generators}

Future decisions by DOE could add generators to those currently shipping waste from offsite to the Hanford Site, and future cleanup decisions at other sites could increase waste volumes from those currently forecast.

\section{$\equiv 2.4 .5$ Waste Class}

As waste sites are investigated and the waste characterized, estimates of waste classes may change. For instance, new estimates for radionuclide content of the LLW for a given waste stream may change the waste. from $L L W$ Category 1 to LLW Category 3; changing volume estimates in each category.

\subsubsection{Waste Forecast Accuracies}

An analysis of actual solid waste receipts versus forecast receipts has been performed for CY 1990 and CY 1991. For those years, the forecast contact-handled LLW was approximately twice the amount actually received. Low-level mixed waste forecasts and receipts were very similar. All receipts for TRU categories and remote-handled LLW were much less than forecasts by about an order of magnitude; although the total volumes of waste in each category were small, a few tens or hundreds of cubic meters.

With only two years of comparisons of waste receipts versus forecasts, reliable trends cannot be determined. Waste that was forecast and not shipped may still be shipped in a later year. The trends noted should be tracked for CY 1992 as well. Any consistent directions should then be factored into assessments of forecast accuracies.

\subsection{REMOTE-HANOLED WASTE AND MATERIALS}

A newly created milestone in the January 25, 1994 version of the TriParty Agreement calls for definition and justification of requirements for storage, processing and disposal of a number of materials and wastes to ensure integration of these needs across the Hanford Site. The milestone requires 
the submittal of a DOE-signed change package for acquisition of new facilities, modification of existing facilities, or modification of planned facilities for storage, processing and/or disposal of solid waste and materials by June 1995. The specific focus of this milestone has been remotehandled materials and waste such as: remote-handled alpha caisson waste, irradiated $N$ Reactor fuel, remote-handled D\&D wastes, 618-11 retrieval caisson waste, cesium and strontium capsules, remote-handled solid wastes, and other wastes and materials requiring remote management.

Alternative site configurations to take advantage of combining remotehandled capabilities for these wastes and materials will be investigated as part of the Tri-Party Agreement renegotiations. Alternatives looking at segregated processing (separate factilities), a single facility option, combined services with separate hot cell areas or other combinations may be examined. There is a potential for reduction in the total Hanford Site facility capital costs by combining various high gamma waste in a single high gamma facility capable of handiing the various materials and wastes.

Uncertainties related to the various streams include the full spectrum of solid waste issues: waste characterization, volume of waste, determination of waste definition (high level versus TRU versus Greater Than Category 3 lowlevel) presence of hazardous constituents and their effect on processing requirements, storage requirements, scheduling of when the waste will require treatment, packaging requirements for storage and shipping, final disposition of the waste.

Work on this milestone has been initiated by development of a table identifying solid waste and materials throughout the Hanford Site which may be affected by the scope of the milestone. Although the focus of the work will be on remote-handled materials the table provides information on TRU waste, low-level waste, low-level mixed waste, and materials. The tabulated data is compiled in Appendix A. 
WHC-SD-WM-RPT-060, REV O. VOLUME 3

\subsection{FACILITIES AND PROJECTS TO ACCOMPLISH MISSION}

The primary functions assoctated with management of radioactive solid waste are retrieval, storage, treatment, and disposal. Each type of waste has distinctive characteristics. Some of this waste (e.g., retrievably stored TRU) wi11 be retrieved. Storage for waste awaiting treatment will be required for some existing and projected waste. Treatment will be required for almost all waste categories (a large volume of Category 1 low-level waste will not be treated prior to disposal) managed by Solid Waste. Storage for treated waste awaiting disposal will be required for some waste. Disposal of waste will be required for all solid waste managed. The Solld Waste Program does not provide TRU or Greater Than Category 3 Waste disposal since these are DOE complex-level issues.

The Solid Waste Program must provide treatment and storage for the inventory of transuranic (TRU) waste and must also provide retrieval for the portion of the TRU inventory that has been retrievably stored since 1970. The Solid Waste Program will not provide for TRU disposal. The TRU waste will be disposed at WIPP.

For low-level mixed waste, the Solid Waste Program must provide storage, treatment, and disposal. The low-level mixed waste is currently stored in a manner that does not require a retrieval function.

The Solid Waste Program must provide treatment and disposal for lowlevel waste. Additionally, specific types of low-level waste (namely Greater Than Category 3 low-level waste) will require storage.

The special case waste inventory will require retrieval, treatment, and storage. The disposition of the special case waste will be addressed in the Hanford Irradiated Fuels-Environmental Impact Statement. The Solid Waste Program may provide the functions required to implement the record of decision of this EIS. In the interim, the Solid Waste Program will continue its existing storage management of the special case waste and may complete interim actions to continue safe management.

The Solid Waste Program is responsible for managing the facilities associated with the retrieval, treatment, storage, disposal, and handling of solid waste at Hanford (excluding those waste facilities under the control of. the generator of the waste). In addition, activities of the Solid Waste Program include the plant, process, and systems engineering necessary to support and optimize site operations, to identify and evaluate process improvements, and to evaluate and define requirements for future activities regarding solid waste. The principal solid waste types within the scope of the Solid Waste Program are: low-level waste, TRU waste, low-level mixed waste, nonradioactive hazardous waste, and irradiated material [special case waste]. All solid waste handled by the Solid Waste Program will be one of these types (Reference 15). The scope of this document is onty concerned with the radioactive solid waste within the scope of the Solid Waste Program. 


\section{WHC-SD-WM-RPT-060, REV 0 VOLUME 3}

Other solid wastes outside the Solid Waste Program have been discussed in Section 2.

Regulatory requirements presented in federal regulations and orders, Washington State and local regulations, and Westinghouse Hanford policles and manuals are the driving forces for management of solid waste. A 1isting of important documents is presented in the Solid Waste Program Plan.

\subsection{RETRIEVAL}

The Solid Waste Program must plan for and implement the retrieval of TRU waste stored in burial ground trenches and caissons since May 1, 1970. Since that date, waste suspected or known to contain TRU constituents has been segregated and retrievably stored pending a decision on management of the waste (Reference 11). This waste was to be stored as "retrievable waste." The waste was to be placed in contamination free packages and retrieved within a twenty year period. The Record of Decision for the Hanford Defense Waste Environmental Impact Statement (Reference 16) states that retrievably stored and newly generated TRU-contaminated solid waste will be retrieved, processed as necessary, and sent to WIPP for disposal.

The retrieval function will be split into two activities for TRU waste, retrieval of waste from burial ground trenches and retrieval of waste from burial ground alpha caissons. The trench waste retrieval function will provide for the retrieval of contact-handled suspect TRU waste in a variety of containers consisting mainly of 55-gallon drums. The caisson waste retrieval function will provide for the retrieval of remote-handled TRU waste stored in the dry waste alpha caissons. Remote-handled material whether in caissons or trenches will be retrieved only when treatment is directly available, no storage will be provided for remote-handled waste.

The solid waste program provides retrieval of the retrievably stored TRU waste in the 200 Areas of the Hanford site. The retrieval function has been separated into three distinct projects. General assumptions regarding retrieval are written below. Assumptions specific to a particular retrieval project are provided in the appropriate section. Assumptions of retrieval for radioactive solid waste under the Solid Waste Program are:

- TRI waste retrievably stored since May 1, 1970 will be retrieved (Reference 16).

- Special case waste stored in the burial grounds will be retrieved (Reference 15):

\subsubsection{Solid Waste Retrieval Phase I (Project W-113)}

Sol id Waste Retrieval Phase I will retrieve the TRU waste from Trench 4 of Burial Ground 218-W-4C. 
WHC-SD-WMM-RPT-060, REV 0 VOLUME 3

The following assumptions are specific to the Solid Waste Retrieval Phase 1 project:

- All waste containers retrieved will be from Trench 4 of Burial Ground 218-W-4C (Reference 17).

- Phase 1 retriteval operations will last six years (Reference 17).

- The total number of waste containers to be retrieved is 9,989 (Reference 17).

- The total waste volume to be retrieved is $2,397 \mathrm{~m}^{3}$.

- The waste containers are expected to be intact with no significant risk of questionable structural integrity causing contamination release to the environment (Reference 17).

- No facilities or equipment for clean-up, disposal, treatment, or storage of contaminated soil are included (Reference 17).

- Waste containers will be overpacked as part of the retrieval process (Reference 17).

\subsubsection{Alpha Caisson Retrieval (Project W-156)}

The alpha caisson retrieval project will involve removal of remote handled TRU waste stored in the dry waste caissons located in the 218-W-4B burial ground. Waste will be retrieved, packaged, surveyed, and transferred to the appropriate treatment function for treatment prior to disposal. project:

The following assumptions are specific to the alpha caisson retrieval

- Retrieval. operations will last 5 years (Reference 18).

- The total number of containers to be retrieved is 5,534.

- The total volume of waste placed in the alpha caissons and to be retrieved is $828 \mathrm{ft}^{3}$ [23.4 $\mathrm{m}^{3}$ ] (Reference 19 ).

- All containers retrieved will be non-contact [remote handled] sources (Reference 18).

- Waste will be loaded into a transportable cask and transported to WRAP 2B for treatment (Reference 18).

- All waste in caissons is considered TRU (Reference 18).

- Miscellaneous debris (plastiç sheeting, wrapping, etc.) waste volume is estimated at $5.7 \mathrm{~m}^{3}$. 


\section{WHC-SD-WM-RPT-060, REV 0 VOLUME 3}

\subsubsection{Solid Waste Retrieval Phase 2, (Project W-221)}

The retrieval project for retrievabiy stored TRU Waste, known as Phase 2 retrieval, will involve retrieval of the entire inventory of retrievably stored TRU waste (less that retrieved in Phase 1 and Alpha Caisson Retrieval) located in trenches in the burfal grounds. The container integrity for the waste that will be retrieved is expected to range from completely sound to totally degraded.

The following assumptions are specific to the full-scale retrieval, Phase 2 retrieval, project:

- The scope of Phase 2 retrieval is the entire inventory of retrievably stored TRU waste less the waste retrieved in Phase 1 and Alpha Caisson Retrieval.

- Containers retrieved intact will be overpacked.

- Retrieved waste in breached containers will be repackaged.

- Waste which was repackaged will not be overpacked.

\subsection{TREATMENT}

Treatment standards must be met for the various waste categories prior to waste disposal. Depending on the waste type and characteristics, various treatment subfunctions may be implemented including characterization, size reduction, physical segregation, separation, stabilization, chemical conversion, compaction and/or degradation of retrieved, stored or newly generated waste. These actions are taken to meet established treatment standards. A similar treatment subfunction may be required for different waste types but in order to avoid cross-contamination (TRU versus nonTRU, mixed versus nonmixed, etc.) of waste that subfunction may be duplicated for each waste type requiring its use.

The solid waste program provides treatment for inventories of currently managed and/or projected TRU, mixed, and low-level waste. The treatment function has been separated into five projects or facilities. General assumptions regarding treatment are written below. Assumptions specific to a particular treatment project or facility are provided in the appropriate section. Assumptions of treatment for radioactive solid waste under the Solid Waste Program are:

- Wastes banned from direct land disposal will be treated to meet disposal requirements.

- The Solid Waste Program will treat TRU waste within the program's scope requiring treatment prior to disposal. 
WHC-SD-WM-RPT-060, REV 0 VOLUME 3

- The Solid Waste Program will provide treatment for low-level mixed waste.

- The Solid Waste Program.will provide volume reduction for Category 1 low-level waste.

\subsubsection{WRAP Module 1 (Project W-026)}

The Record of Dectsion (ROD) for the Disposal of Hanford Defense HighLevel, Transuranic, and Tank Wastes, Hanford Site, Richland, Washington (Reference 16) states that "A facility will be designed, constructed and operated at Hanford to sort, process and repackage retrievabiy stored and newly generated TRU solid waste for shipment to the Waste Isolation Pilot Plant (WIPP)... The only pre-1970 buried suspect TRU-contaminated solld waste site outside the central (200 Area) plateau [618-11 burlal ground] will be removed to the 200 Area plateau for processing for disposal as solid TRU waste." The HOW-EIS states that "retrlevabiy stored and newly generated TRU solid waste would be sent to WIPP. The waste would first be processed and packaged... The waste processing factilty... would not...be sized for treatment of... remotely handled TRU waste" (Reference 16). This waste processing facility described in the HDW-EIS is known as WRAP Module 1. WRAP Module 1 will receive retrieved and newly generated solid contact-handled radioactive wastes in 55 gallon drums (some overpacked in salvage drums). Drums will be inspected, assayed, and opened if necessary. Waste contents can be sorted and segregated, empty drums and wastes compacted as appropriate, repackaged, certified and shipped to final disposal.

The following assumptions are specific to the WRAP Module 1 treatment project:

- WRAP Module 1 will have a design operating 1 ife of 30 years (Reference 20).

- WRAP Module 1 will operate on a one-shift per day basis.

- 6,825 drums of contact-handled waste wtll be received annually. This includes 2,100 drums of newly generated TRU/TRUMW, 2,625 drums of retrieved suspect TRU, and 2,100 drums of newiy generated LLW/LLMW. The facility shall also receive, certify, and ship 70 standard waste boxes of. contact-handled TRU annually (Reference 20).

- The 2,100 drums of newly generated TRU/TRUMW received annually will be comprised entirely of TRU/TRUMW (Reference 20).

- The 2,625 drums of retrieved suspect TRU received annually will be comprised of 50\% TRU and 50\% LLW (Reference 20).

- The 2,100 drums of newly generated LLW/LLMW received annually will be comprised entirely of LLW/LLMW (Reference 20). 
WHC-SD-WM-RPT-060, REV 0 VOLUME 3

- Module 1 shall be designed to be capable of accommodating the minimum required annual waste throughput in no more than 175 total operating days per year, with no more than five operating days per week. This is equivalent to $70 \%$, or 35 weeks, of the total 50 weeks in a normal operating year (Reference 20).

- TRU/TRUMW waste processed will meet TRUPACT II shipping requirements and the waste acceptance criteria for disposal at the Waste Isolation Pilot Plant (WIPP) (Reference 20).

WIPP will receive waste from WRAP Module 1 until 2018.

\subsubsection{WRAP ModuTe 2A (Project $W-100$ )}

On May 18, 1987 the DOE issued an interpretive rule under the Atomic Energy Act of 1954 clarifying DOE obligations under the RCRA, which is promulgated in Washington State by the "Dangerous Waste Regulat ions", Chapter 173-303 of the Washington Administrative Code (WAC). As a result, ail lowlevel radioactive waste contaminated with dangerous waste under the WAC is termed low-level mixed waste and subject to regulation by the DOE and. Washington State. This low-level mixed waste requires separate waste management, disposition, and segregation (Reference 15). The waste processing facility known as WRAP Module $2 A$ provides treatment to stored and projected contact-handled low-level mixed waste that does not require thermal treatment. project:

The following assumptions are specific to the WRAP Module $2 A$ treatment

- WRAP Module 2A will have a design operating life of 30 years (Reference 21).

- The treated waste will meet the waste acceptance criteria for disposal of mixed waste.

- WRAP Module 2A will provide treatment for solid wastes at Hanford determined to be contact-handled non-thermally treatable low-level hazardous radioactive mixed waste (RMW) (Reference 21).

- Waste forms expected for treatment include: ion exchange resin, sludges, solls, dry particulate, debris, dry active waste, metals, glass, and materials absorbed in an immobilization matrix (Reference 21).

- A total of $17,840 \mathrm{~m}^{3}$ of RMW is expected to be treated in module $2 \mathrm{~A}$ over its 30 year operational 1 ife (Reference 21).

- Waste processing will consist of: conditioning and deactivation and/or immobilization of ignitable materials not requiring thermal treatment, corrosives, inorganic wastes, resins, and other RMW, 
WHC-SD-WM-RPT-060, REV 0 VOLUME 3

encapsulation of lead shielding, special processing of small quantity wastes such as mercury-bearing RMW and reactive waste (Reference 21).

- Module $2 A$ w111 recetve waste in boxes and drums (Reference 21).

- WRAP 2A Will not treat radioactive mixed waste generated and stored at Hanford requiring thermal treatment.

- WRAP Module $2 A$ will be designed to process up to $820 \mathrm{~m}^{3}$ of mixed waste annually received from various sources (Reference 21 ).

\subsubsection{WRAP Module 28 (Project W-255)}

The HDW-EIS states that "the remotely handled TRU material would be processed on a much smaller scale, which favors use of a smaller facility using different technology. The waste would be processed in a new facllity of suitable size, possibly as an addition to the Waste Receiving and Processing facility." (Reference 16) This waste processing facility described in the HDW-EIS is known as WRAP Module 2B. WRAP Module 2B will receive retrieved and newly generated solid remote-handled radioactive wastes and will also receive oversized contact-handled radioactive wastes. WRAP Module 28 will be operated as a size reduction and repackaging facility for these wastes. project:

The following assumptions are specific to the WRAP Module 2B treatment

- The design operating life of WRAP Module $2 B$ is undetermined at this time. The design operating life will be established in the $\mathrm{W}-255$ functional design criteria.

- WRAP Module 2B will receive and treat remote-handled TRU waste. Waste volume will be quantified during project development.

- All stored oversized and contact-handled TRU waste in boxes will be processed in module 2B. Waste volume will be quantified during project development.

- Module 2B will be equipped to handle drums containing classified waste, contaminated soils, high efficiency particulate air (HEPA) filters, contact handled TRU boxes and other containers, and failed or contaminated equipment.

- Equipment from DST's as part of the tank clean-out, and PUREX tunnel and other canyon facility waste will be accepted for processing. 
WHC-SD-WM-RPT-060, REV 0 VOLUME 3

- TRU/TRUMW waste processed through WRAP Module 2B will meet the waste acceptance criteria for disposal at the Waste Isolation Pilot Plant (WIPP).

- WIPP will receive waste from WRAP Module 2B until 2018.

\subsubsection{Thermal Treatment Facility (TTF) (Project W-242)}

The discussion for WRAP Module $2 A$ regarding the need for separate waste management disposition and segregation of mixed waste (Reference 15) also applies to the Thermal Treatment Facility. The waste processing facility known as the Thermal Treatment Facility provides treatment for that portion of the low-level and TRU mixed waste that will require incineration as the technology-based standard for treatment. An acceptable alternative to the Thermal Treatment Facility would be use of an offsite vendor for any or all of the waste requiring thermal treatment. project:

The following assumptions are specific to the Thermal Treatment Facility

- Wastes treated at the TTF are both contact and remote handled (Reference 22).

- The TTF will treat low-level mixed waste and TRU mixed waste (Reference 22).

- The TTF will meet the minimum functional standards for an incinerator as required by Washington State regulations (Reference 4).

- Low-level mixed waste and TRU mixed waste will be treated in separate processing lines to reduce cross-contamination.

- Waste segregation is not performed within the TTF.

- Non combustible waste will be treated in the same manner as combustible waste.

- Residue will be treated in TTF or elsewhere.

\subsection{STORAGE}

Storage functions will encompass both interim and long term storage capabilities. The individual storage requirements are outlined by the specific waste types to be stored. Storage is necessary for contact-handled radioactive solid wastes received from offsite and onsite generators as well as waste recovered from retrieval operations. Interim and long term storage is required for TRU waste including TRU mixed waste and suspect TRU waste, low-level mixed waste, and low-level waste that is categorized as Category 3 


\section{WHC-SD-WM-RPT-060, REV 0 VOLUME 3}

waste and Greater Than Category 3 waste. The storage function will not provide for the storage of any remote-handled waste packages. Waste packages containing waste that is remote-handled is acceptable for storage in contacthandled waste packages.

The solid waste program provides storage for inventories of currently managed and/or projected TRU and mixed waste. The storage function has been separated into four projects or facilities. General assumptions regarding storage are written below. Assumptions specific to a particular storage project or facility are provided in the appropriate section. Assumptions of storage for radioactive solid waste under the Solid Waste Program are:

- Wastes that are determined mixed waste will be stored in compliance with dangerous waste storage requirements.

- Mixed waste that is remote-handled will. be buried in burial grounds or retrievable storage units to meet ALARA requirements.

- The Solid Waste Program will provide storage for TRU waste in contact-handled storage containers. .

- The Solid Waste Program will provide storage for low-level mixed waste in contact-handled storage containers.

\subsubsection{Transuranic Assay and Storage Facility (TRUSAF) (224-T)}

The 224-T TRUSAF primarily stores TRU waste that meets the Hanford Site Solid Waste Acceptance Criteria. In addition, other properly characterized and packaged low-level mixed waste could be accepted for storage.

The following assumptions are specific to the TRUSAF:

- TRUSAF has the capacity to store 1,800 55-gallon drums.

- In 1985 the 224-T Building modifications were complete to initiate storing TRU, TRU mixed, and low-level waste; the 224-T Building was redesignated as 224-T TRUSAF (Reference 23).

- Waste is received primarily in U.S. Department of Transportation approved or equivalent $17 \mathrm{C}$ or $17 \mathrm{H}$ 55-gallon (208 liter) containers or other U.S. Department of Transportation approved packages and overpacks (Reference 23).

\subsubsection{Radioactive Mixed Waste Storage Facilities (RMWSF)}

The Radioactive Mixed Waste Storage Facilities consist of a number of buildings, storage modules, and projects. Included among these facilities are twelve small radioactive mixed waste storage buildings (2402W, 2402WB, 2402WC, 2402WD, 2402WE, 2402WF, 2402WG, 2402WH, 2402WI, 2402WJ, 2402WK, 2402WL), 10Wflash-point mixed waste storage modules, one Plutonium/Polychlorinated 
WHC-SD-WM-RPT-060, REV 0 VOLUME 3

Biphenyl Mixed Waste Storage Building (2401W), Phase I-IV Radioactive Mixed Waste Storage (2403WA, 2403WB, 2403WC, 2403WD) and a mixed waste storage pad. These facilities provide interim storage of radioactive mixed waste awaiting appropriate treatment and disposal methods being developed for waste disposition.

The following assumptions are specific to the Radioactive Mixed Waste Storage Facility:

- All twelve small radioactive mixed waste storage buildings, the low-flash-point mixed waste storage modules, Plutonium/Polychlorinated Biphenyl Mixed Waste Storage Building, Phase I-IV Radioactive Mixed Waste Storage are currently operational.

- Each of the twelve storage facilities has the capacity store $220 \mathrm{~m}^{3}$ of waste.

- Each low-flash-point storage modules has the capacity to store 6.3 $\mathrm{m}^{3}$ of waste.

- Waste are segregated according to hazardous characteristics of ignitability, corrosivity, reactivity, and toxicity.

- Phase 1,3 , and 4 provide $34,000 \mathrm{ft}^{2}\left[3,200 \mathrm{~m}^{2}\right]$ of storage space each. Phase 1,3 , and 4 can accommodate 11,90055 gallon drums each.

- Phase 2 provides $55,250 \mathrm{ft}^{2}\left[5,100 \mathrm{~m}^{2}\right]$ of storage capacity. Phase 2 can accommodate $19,300,55$ gallon drums.

- The characteristic types of LLMW/TRUM stored will include acids, caustics, oxidizers, and Toxicity Characteristic Leaching Procedure (TCLP) toxic waste.

3.3.3 Enhanced Radioactive and Mixed Waste Storage Phase V Module (Project W112)

The Phase $V$ storage facility will store wastes and distribute waste to various radioactive solid waste treatment facilities. The I hase $V$ Module will provide interim and long term storage for waste.

The following assumptions are specific to Phase V Storage:

- Phase $V$ will store contact-handled solid wastes received from offsite and onsite generators (Reference 24).

- Low-level waste and low-level mixed waste will be transferred to onsite disposal facilities (Reference 24 ). 
WHC-SD-WM-RPT-060, REV 0 VOLUME 3

- Storage will be provided for 27,000 drum equivalents (55 gallon drums) $\left[5,616 \mathrm{~m}^{3}\right]$ of contact handled waste (Reference 24$)$.

- Phase V Storage will be able to accommodate Category 1 low-level waste, Category 3 low-level waste, Greater Than Category 3 lowlevel waste, Category 1 low-level mixed waste, Category 3 lowlevel mixed waste, Greater Than Category 3 low-level mixed waste, suspect TRU, TRU, and TRU mixed waste (Reference 24).

- Classified wastes will not be stored in the phase $V$ facility.

\subsection{DISPOSAL}

Disposal functions provide for the ultimate disposition of the radioactive solid waste both on and off the Hanford Site. Disposal facility performance is based on the level of containment required for the particular type of radioactive solid waste being dispositioned. Separate disposal functions are identified for TRU waste, low-level mixed waste, Category 1 lowlevel waste, and Category 3 low-level waste. The disposal function for TRU waste and Greater Than Category 3 low-level waste is outside of the scope of the Solid Waste Program.

The solid waste program provides disposal for inventories of currently managed and/or projected mixed and low-level waste. The disposal function has been separated into three projects or facilities. General assumptions regarding disposal are written below. Assumptions specific to a particular disposal project or facility are provided in the appropriate section. Assumptions of disposal of radioactive solid waste under the Solid Waste Program are:

- Disposal facility requirements (level of containment) will be based on the type/class of waste to be disposed.

- The Solid Waste Program will not provide a disposal facility for TRU waste. Disposal of TRU waste will be provided by a DOE complex wide disposal facility. Certified TRU waste will be shipped to WIPP through 2018. Any TRU waste at Hanford after 2018 will be disposed in a DOE complex wide disposal facility, but not necessarily WIPP.

- The DOE-RL has not determined whether the Solid Waste Program will provide a disposal facility for Special Case Waste.

- The Solid Waste Program has not determined whether the program is responsible for providing a disposal facility for Greater Than Category 3 low-level waste.

- The Solid Waste Program will provide a disposal facility for Category 1 low-level waste. 
WHC-SD-WM-RPT-060, REV 0 VOLUME 3

- The Solid Waste Program will provide a disposal facility for Category 3 low-level waste.

- The Solid Waste Program will provide a disposal facility for lowlevel mixed waste.

\subsubsection{Enhanced Solid Low-Level Radioactive Waste Disposal (Project W-174)}

The Enhanced Solid Low-Level Radioactive Waste Disposal facility will provide disposal capability for Category 3 low-level waste.

The following assumptions are specific to Enhanced Solid Low-Level Radioactive Waste Disposal:

- The disposal system will accommodate a total of $321,565 \mathrm{~m}^{3}$ of waste. This value is based on a thirty year operations forecast.

- The system will not be equipped or associated with a leachate collection system.

\subsubsection{Radioactive Mixed Waste Disposal, (Project W-025)}

The Radioactive Mixed Waste Disposal facility will provide permanent disposal capability for contact handled low-level mixed waste. A portion of the disposal system will also provide storage for remote handled mixed waste (RH MW). Disposal:

The following assumptions are specific to Radioactive Mixed Waste

- The disposal system will have-a design life of 50 years minimum, 20 years are required for the operational phase and 30 years for post closure monitoring (Reference 25).

- A total mixed waste volume of $3,133 \mathrm{~m}^{3}$ shall be used in the design of the disposal trenches (Reference 25).

- The non drag off disposal trench shall be designed to receive $1,870 \mathrm{~m}^{3}$ (Reference 25 ).

- The site selected for disposal of non drag off waste packages is the 218-W-5 burial ground (Reference 25).

- The Radioactive Mixed Waste Disposal system will meet the minimum functional standards for a dangerous waste landf 111 as required by Washington State regulations (Reference 4).

- The Radioactive Mixed Waste Disposal system will not address disposition of collected leachate from the system's leachate collection system (Reference 25). 
WHC-SD-WM-RPT-060, REV 0 VOLUME 3

- Drag off containers are not within the scope of this disposal system.

Waste projections and planned processing of mixed waste show that roughly $54,000 \mathrm{~m}^{3}$ of mixed waste wili require disposal. This projection and the design capacity of the mixed waste disposal system (above) are not in agreement. Additional capacity will be used to rectify the difference.

\subsubsection{Solid Low-Level Radioactive Waste Disposal}

The Sol id Low-Level Radioactive Waste Disposal burial grounds provide disposal capability for Category I low-level waste.

The following assumptions are specific to Solid Low-Level Radioactive Waste Disposal:

- The Solid Waste Program currently disposes of Category 1 low-level waste in burial grounds in the 200 Areas.

- The capacity of the disposal system is capable of accomnodating all forecasted Category 1 low-level waste. 
WHC-SD-WM-RPT-060, REV 0 VOLUME 3

\subsection{SOLID WASTE PROGRAM FLOWSHEET}

The Solid Waste Program identifies the programmatic functions of solid waste budget, scope, and schedule development and defense to Westinghouse Hanford higher management and to the DOE Operations Office, Richland (Reference 15). The flowsheet presented in Figure 4-1 helps in this programmatic function by showing the scope of each of the functions identified by the Solid Waste Program to handle the radioactive solid waste within its program.

The flowsheet identifies the projected direction of the current solid Waste Program. This direction is based on the current and forecasted inventory of solid waste to be managed by the Solid Waste Program, the functions identified to properly manage this inventory, and the goals, objectives, requirements, assumptions and definitions governing management of this waste. The flowsheet offers the reader clear and concise understanding of the solid waste mission by connecting functions through waste stream paths and providing an overall volume balance associated with each of the particular types of waste. Thus, the reader gains an appreciation for the magnitude of waste that will be handled by each function and the projected interaction of the functions.

The flowsheet is broken into the four top level program functions outlined previously: retrieval, treatment, storage, and disposal. The waste categories covered in the flowsheet are TRU, low-level mixed, and low-level waste. Each of these three waste categories is broken down into existing inventory and projected waste forecast for the 30 year period 1993-2022. The TRU waste inventory includes all contact-handled and remote-handled, mixed and non-mixed TRU inventory. The low-level mixed waste inventory includes all contact-handled and remote-handled, Category 1 and Category 3 low-level mixed waste. The low-level waste inventory includes contact-handled and remotehandled, Category 1, Category 3, and Greater Than Category 3 low-level waste. Greater Than Category 3 low-level mixed waste is included with the non-mixed Greater Than Category 3 waste.

\subsection{TRÚ WASTE}

The TRU waste inventory, for both current and projected waste, is 32,900 $\mathrm{m}^{3}$. This waste consists of the following:

- $\quad 14,900 \mathrm{~m}^{3}$ of waste that will require-retrieval (200 $\mathrm{m}^{3}$ of remote-handled and $14,700 \mathrm{~m}^{3}$ contact-handled)

- $800 \mathrm{~m}^{3}$ of contact handled waste that is stored awaiting treatment and/or certification

- $17,200 \mathrm{~m}^{3}$ of projected waste over the next thirty years $\left(5,100 \mathrm{~m}^{3}\right.$ remote-handled and $12,100 \mathrm{~m}^{3}$ contact-handled) 


\section{WHC-SD-WM-RPT-060, REV 0 VOLUME 3}

The $200 \mathrm{~m}^{3}$ existing and $5,100 \mathrm{~m}^{3}$ projected remote-handled waste will go directly to its treatment function (WRAP Module 2B) without going to storage. There is no planned storage function for remote-handled waste other than lag storage jncidental to the treatment function. The $15,500 \mathrm{~m}^{3}$ existing and $12,100 \mathrm{~m}^{3}$ projected contact-handled waste is sent to the Phase $V$ storage function awaiting treatment/certification. It should be noted that this volume of waste is received over a thirty year period and the required storage capacity depends on the expected quantity of waste requiring storage at any particular point in time.

A total of $6,600 \mathrm{~m}^{3}$ existing and $9,500 \mathrm{~m}^{3}$ of projected contact-handled waste is processed/certified in the WRAP Module 1 treatment function. The volume of waste is reduced during processing in WRAP Module 1 . The $6,600 \mathrm{~m}^{3}$ of retrievabiy stored waste processed becomes $1,100 \mathrm{~m}^{3}$ low-level waste, $400 \mathrm{~m}^{3}$ low-level mixed waste, and $3,100 \mathrm{~m}^{3}$ TRU waste following segregation and volume reduction. The $9,500 \mathrm{~m}^{3}$ of projected contact-handled waste is assumed to remain the same volume of waste after processing/certification. This accounts for 12,600 $\mathrm{m}^{3}$ of contact-handled TRU waste from WRAP 1 prepared for WIPP disposal. WRAP Module 1 also will ship to WIPP $15,600 \mathrm{~m}^{3}$ of contact-handled TRU waste processed in WRAP Module $2 B$. Total TRU waste shipments from WRAP Module 1 are $28,200 \mathrm{~m}^{3}$.

The WRAP Module $2 B$ treatment function will receive $8,300 \mathrm{~m}^{3}$ of existing and $2,200 \mathrm{~m}^{3}$ of projected contact-handled waste in boxes and other containers for treatment and/or certification. Of the $8,300 \mathrm{~m}^{3}$ of existing waste sent to WRAP $2 B$ for size reduction and repackaging, sorting will segregate TRU and low-level waste resulting in an estimated $12,800 \mathrm{~m}^{3}$ of TRU waste and $3,800 \mathrm{~m}^{3}$ of low-level waste. The 2,200 $\mathrm{m}^{3}$ of projected contact-handled waste in boxes and other containers will not be sorted prior to certification. This accounts for 2,600 $\mathrm{m}^{3}$ of contact-handled TRU waste in drums from WRAP 2B prepared for WIPP disposal. WRAP $2 B$ will also receive the $170 \mathrm{~m}^{3}$ of TRU, residue from the Thermal Treatment Facility for certification. The $15,600 \mathrm{~m}^{3}$ contact-handled TRU waste is sent to WRAP Module 1 for shipment to WIPP.

The WRAP Module $2 B$ treatment function will receive $200 \mathrm{~m}^{3}$ of existing and $5,100 \mathrm{~m}^{3}$ of projected remote-handled waste for treatment/certification. The $200 \mathrm{~m}^{3}$ of existing. and $5,100 \mathrm{~m}^{3}$ of remote-handled waste sent to WRAP 2B for treatment and repackaging will result in $7,000 \mathrm{~m}^{3}$ of remote-handled TRU waste prepared for WIPP disposal. This waste will be sent to WIPP directly rather than through WRAP 1 shipping.

\subsection{LOW-LEVEL MIXED WASTE}

The existing inventory of low-level mixed waste consists of $3,400 \mathrm{~m}^{3}$ of contact-handled waste exhibiting one or more characteristic and/or listed constituents of dangerous waste. The inventory of low-level mixed waste includes $44,900 \mathrm{~m}^{3}$ of projected waste over the next thirty years, of which $1,900 \mathrm{~m}^{3}$ is remote-handled and the remainder is contact-handled. 
WHC-SD-WM-RPT-060, REV 0 VOLUME 3

The $3,400 \mathrm{~m}^{3}$ of existing waste consists of $2,600 \mathrm{~m}^{3}$ of waste from cleanup of the 183-H solar evaporation basin and $800 \mathrm{~m}^{3}$ of various waste types and constituents. Examining records of the $800 \mathrm{~m}^{3}$ waste showed that $1 / 3$ can be treated through thermal treatment and $1 / 3$ could not, and the remaining $1 / 3$ could either be treated by stabilization or incineration. It is planned that the $183-\mathrm{H}$ solar evaporation basin and $2 / 3$ of the remaining $800 \mathrm{~m}^{3}\left(500 \mathrm{~m}^{3}\right)$ of existing waste would be treated in WRAP 2A. The other $300 \mathrm{~m}^{3}$ of existing waste would be thermally treated.

The $44,900 \mathrm{~m}^{3}$ of projected low-level mixed waste consists of $16,700 \mathrm{~m}^{3}$ of contact-handled sludge and resins from the 200 Area Effluent Treatment Facility, 6,500 $\mathrm{m}^{3}$ of contact-handled sludge and resins from the 300 Area Effluent Treatment Facility, $21,300 \mathrm{~m}^{3}$ contact-handled waste from varjous sources, and $1,900 \mathrm{~m}^{3}$ of remote-handled waste. Roughly $87 \%\left(37,400 \mathrm{~m}^{3}\right)$ of. the projected contact-hand] ed low-level mixed waste can be treated in WRAP $2 A$ and the remainder $\left(5,600 \mathrm{~m}^{3}\right)$ will be treated in the Thermal Treatment Facility. The $2,000 \mathrm{~m}^{3}$ of remote-handled waste will be treated in WRAP 2B.

In addition, 1,100 $\mathrm{m}^{3}$ of contact-handled low-level mixed waste generated from processing in WRAP Module 1 and WRAP. Module 2B will require treatment. It is assumed all this waste will receive treatment in WRAP $2 A$.

Combined existing and projected low-level mixed waste to be treated in WRAP $2 A$ is $42,200 \mathrm{~m}^{3}$. Combined exjsting and projected low-level mixed waste to be theimaliy treated is $6,300 \mathrm{~m}^{3}$. Treatment in WRAP Module $2 A$ will result in a doubling of the waste volume to be disposed. Treatment. in the Thermal, Treatment Facility will result in a five to one volume reduction to $1,300 \mathrm{~m}^{3}$ of waste to be disposed. The residue from thermal treatment will be certified in WRAP 2B. The $1,900 \mathrm{~m}^{3}$ of remote handled waste is assumed to produce 3,400 $\mathrm{m}^{3}$ of remote-handled waste for dispoşal. Total volume of low-level mixed. waste requiring disposal is $89,100 \mathrm{~m}^{3}$.

\subsection{LOW-LEVEL WASTE}

The existing inventory of low-level waste is $200 \mathrm{~m}^{3}$ of stored waste that is not in a form suitable for disposal. Projected low-level waste over the next thirty years includes $201,000 \mathrm{~m}^{3}$ Category $1,48,000 \mathrm{~m}^{3}$ Cątegory 3 , and $60 \mathrm{~m}^{3}$ Greater Than Category 3 low-level waste. The $201,000 \mathrm{~m}^{3}$ of Category 1 waste will be directly disposed.

The $48,000 \mathrm{~m}^{3}$ of Category 3 waste will be disposed as low-level waste on the Hanford site. No treatment of Category 3 waste has been identified prior to disposal. A performance assessment for Category 3 low-level waste is ongoing that will determine if more intensive management is necessary for disposal of Category 3 low-level waste in an Enhanced Solid Low-Level Radioactive Waste Disposal facility.

The Solid Waste Program will provide storage for the $60 \mathrm{~m}^{3}$ of projected Greater Than Category 3 low-level waste. The disposal facility for Greater 
WHC-SD-WM-RPT-060, REV 0 VOLUME 3

Than Category 3 waste is the responsibility of DOE and is not a function provided by the Solid Waste Program.

\subsection{SPECIAL CASE WASTE}

The solid waste burial grounds in the 200 Areas currently contain $160^{\circ} \mathrm{m}^{3}$ of special case waste mainiy consisting of trradiated materials from a number of experimental reactors. The disposition of this special case waste will be addressed in the Hanford Irradiated Fuels - Environmental Impact Statement. The Solid Waste Program may provide the functions required to implement the record of decision of this EIS. In the interim, the Solid Waste Program will continue its existing storage management of the spectal case waste.

\subsection{ENVIRONMENTAL RESTORATION WASTE}

The Environmental Restoration mission area at the Hanford Site is planning to design and construct an Environmental Restoration Disposal Facility (ERDF) that will be turned over to Solid Waste for pperation. The ERDF will provide disposal capability for up to $20,000,000 \mathrm{~m}^{3}$ of waste resulting from remediation actions. Until the ERDF can be built (expected to

: become operational in 1997), Environmental Restoration waste will be received for disposal at existing Solid Waste Program managed facilities. During the period 1994 to 1996 Solid Waste expects to receive $60,500 \mathrm{~m}^{3}$ of low-level mixed waste and $123,000 \mathrm{~m}^{3}$ of low-level waste for disposal. After 1996 , it is expected that up to $21,100,000 \mathrm{~m}^{3}$ of low-level waste and $480,000 \mathrm{~m}^{3}$ of low-

level mixed waste at the ERDF. 
WHC-SD-WM-RPT-060, REV 0 VOLUME 3

This page intentionally left blank. 
WHC-SD-WM-RPT-060, REV O VOLUME 3

Figure 4-1. Hanford Solid Waste Program Flowsheet

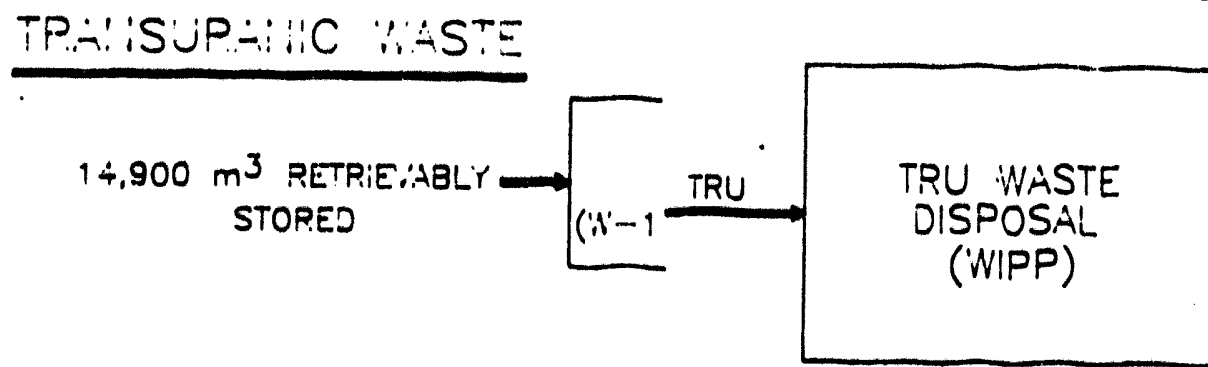

$800 \mathrm{~m}^{3}$ STORED
$17,200 \mathrm{~m}^{3}$ PROJECTED

$$
12,900 \mathrm{~m}^{3} \text { TRU }
$$

\section{LOW LEVEL}

MIXED WASTE

$3,400 \mathrm{~m}^{3}$ STORED $48,300 \mathrm{~m}^{3}$ $44,900 \mathrm{~m}^{3}$ PROJECTED

SPECIAL CASE WASTE h3 $160 \mathrm{~m}^{3}$ STORED

LOW LEVEL MIIXED WASTE DISPOSAL

LOW LEVEL WASTE $200 \mathrm{~m}^{3}$ STORED $249,000 \mathrm{~m}^{3}$ PROJECTED

ENVIRONMENTAL RESTORATION WASTE $21,763,500 \mathrm{~m}^{3}$ PROJECTED LEGEND:

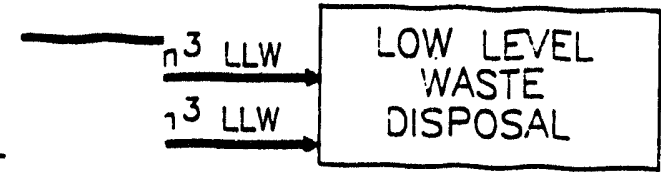

\footnotetext{
TRU WASTE

MIXED WASTE

LOW LEVEL WASTE

- SPECLAL CASE WASTE

DMMRONMEITAL RESTORATION WASTE

- VOLUME INCREASES/DECREASES ARE RERECTED FOR 'NRAP !, WRAP 2A, THERIMAL TREATAENT FAC

- total vo:use throvgh 2022
} 
WHC-SD-WM-RPT-060, REV 0 VOLUME 3

\subsection{REFERENCES}

$\therefore$ UOE/RL-93-08, Hanford Misston P1an, Volume 1, Site Guidance, August, 1993.

2. WHC-EP-0722, Draft, Systems Engineering Functions and Requirements for the Hanford Cleanup Mission: First Issue, December 1993.

3. WHC-SP-0989, Solid Waste Program FY 1994 Multi-Year Program Plan, Phase 1 WBS 1.2.1, M. M. McCarthy, June 1993.

4. "Dangerous Waste Regulations," Washington (State) Administrative Code Chapter 173-303, Washington State Department of Ecology, Olympia; Washington, 1991.

5. Hanford Site Solid Waste Acceptance Criteria, WHC-EP-0063-4, Westinghouse Hanford Company, Richland; Washington, 1993.

6. Solid Waste Projection Model System Overview, DOE/NBM-1070, U.S. Department of Energy, Richland, Washington, 1990.

7. 1993 Solid Waste Reference Forecast Summary, WHC-EP-0567-1, Westinghouse Hanford Company, Richl and, Washington, August, 1993.

8. Integrated Data Base for 1992: U.S. Spent Fuel and Radioactive Waste Inventories, Projections, and Characteristics, DOE/RW-0006, Rev. 8, U.S. Department of Energy, Washington, D.C, October, 1992.

9. Estimates of Solid Waste Buried in 100 Area Burial Grounds, WHC-EP-0087, Miller, R. L., and R. N. Wahlen, Westinghouse Hanford Company, Richl and, Washington, 1987.

10. Summary of Radioactive Solid Waste Received in the 200 Areas During Calendar Year 1992, WHC-EP-0125-5, Westinghouse Hanford Company, Richland, Washington, 1992.

11. Immediate Action Directive No. 0511-21, Atomic Energy Commission, Apri1, 1970.

12. Contact-Handled Transuranic Waste Characterization Based on Existing Records, WHC-EP-0225, Rev. 1, Westinghouse Hanford Company, Richland, Washington, 1991.

13. Material-Not-Categorized-As-Waste Survey for 1992, WHC-EP-0626, Westinghouse Hanford Company, Richland, Washington, July, 1993.

i4. Westinghouse Hanford Company Waste Minimization and Pollution Prevention Awareness Program Plan, WHC-EP-0496, Westinghouse Hanford Company, Richland, Washington, 1991 .

15. Sol id Waste Program P1an, WHC-EP-0363, Rev 1, D. R. Duncan, August, 1991. 
WHC-SD-WM-RPT-060, REV 0 VOLUME 3

16. Federal Register, Vol 53, No 72, Hanford Defense Waste Environmental Impact Statement, Record of Decision, Apri1 14, 1988.

17. WHC-SD-W113-FDC-001, Rev 2, Functional Design Criteria Solid Waste Retrieval Facility Phase 1, Project W-113, D.M. Johnson, 1993.

18. WHC-SD-WM-ES-181, Rev O, ECN, Retrieval of Waste From Aloha Caissons, $P$. R. Deichelbohrer, February 10, 1992

19. WHC-SD-WM-RPT-008, Rev 0, Alpha Caisson Data and Evaluation, P. R. Deichelbohrer, December, 1990.

20. WHC-SD-FDC-W026-001, Rev 2, Functional Design Criteria Waste Receiving and Processing (WRAP) Facility Module 1, B. A. Mayancsik, December, 1993.

21. WHC-SD-W100-FDC-001, Rev 2, Waste Receiving and Processing Facility Module 2A, Project $W-100$.

22. PNL-8162, Baseline Solid Waste Management System Description, L.L. Armacost et al, July 1992.

23. DOE/RL-91-51, Rev 0, Transuranic Storage and Assay Factlity (TRUSAF), Part B permit Application, June 30, 1992.

24. WHC-SD-W112-FDC-001, Rev 1, Functional Design Criteria For Entianced Radioactive and Mixed Waste Storage Phase V, K.D. Johnson, April 24, 1992.

25. WHC-SD-W025-FDC-001, Rev 1, Functional Design Criteria Interim RMW Disposal Facility, K.D. Johnson, May 22, 1992. 
WHĆ-SD-WM-RPT-060, REV 0 VOLUME 3

APPENDIX A. REMOTE-HANDLED WASTE AND MATERIALS INVENTORY

A-1 
WHC-SD-WM-RPT-060, REV 0 VOLUME 3

This page intentionally left blank.

A-2 
WHC-SD-WM-RPT-060, REV 0 VOLUME 3

A newly created milestone in the January 25,1994 version of the TriParty Agreement calls for definition and justification of requirements for storage, processing and disposal of a number of materials and wastes to ensure integration of these needs across the Hanford Site. The specific focus of this milestone has been remote-handled materials and waste such as: remotehandled alpha caisson waste, irradiated N Reactor fuel, remote-handled D\&D wastes, 618-11 retrieval caisson waste, cesium and strontium capsules, remotehandled solid wastes, and other wastes and materials requiring remote-handled management.

Work on this milestone has been initiated by development of the - table below identifying solid waste and materials throughout the Hanford Site which may be affected by the scope of the milestone. Although the focus of the work will be on remote-handled materials the table provides information on TRU waste, low-level waste, low-level mixed waste, and materials for completeness. 

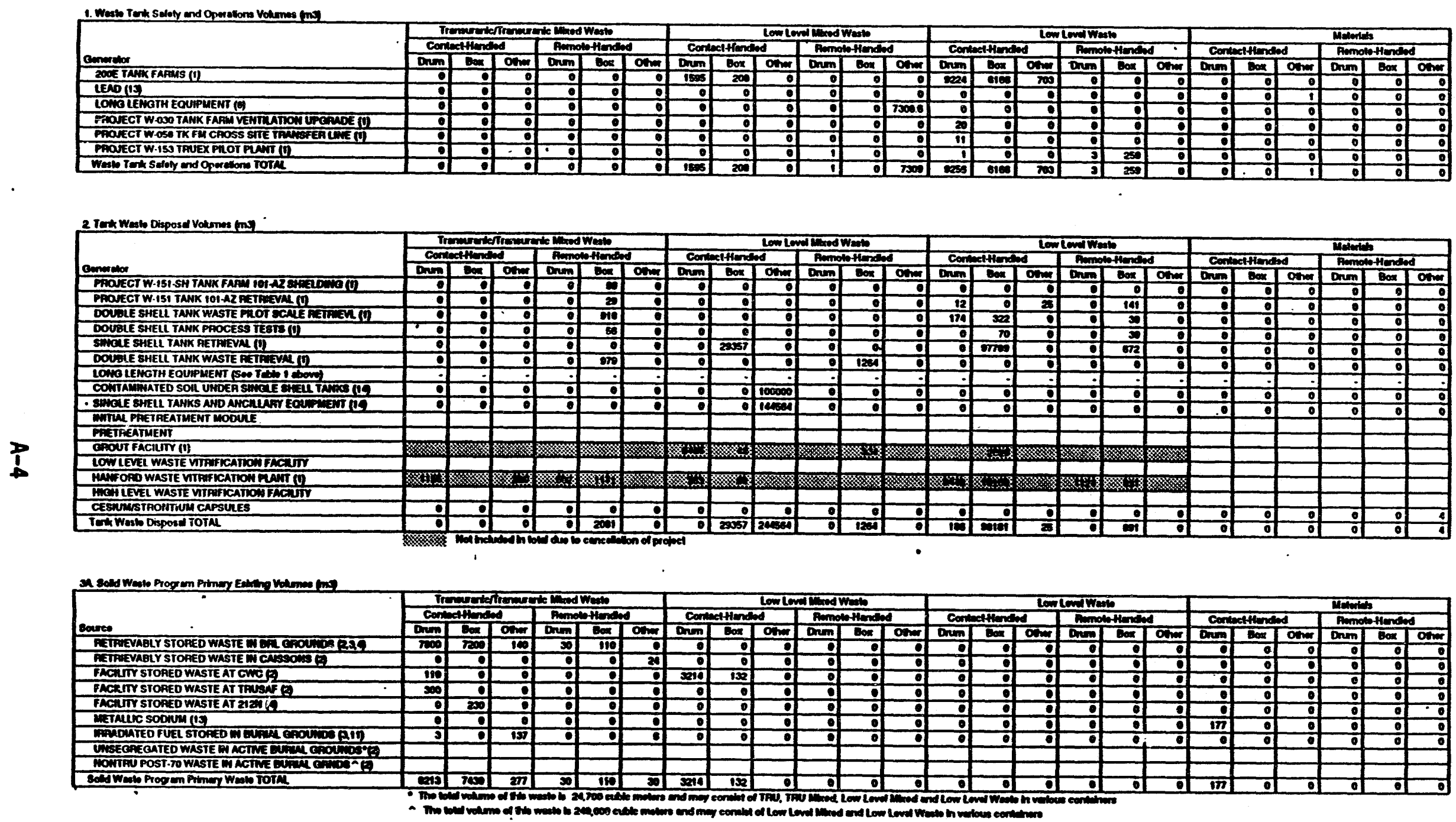


\section{-}
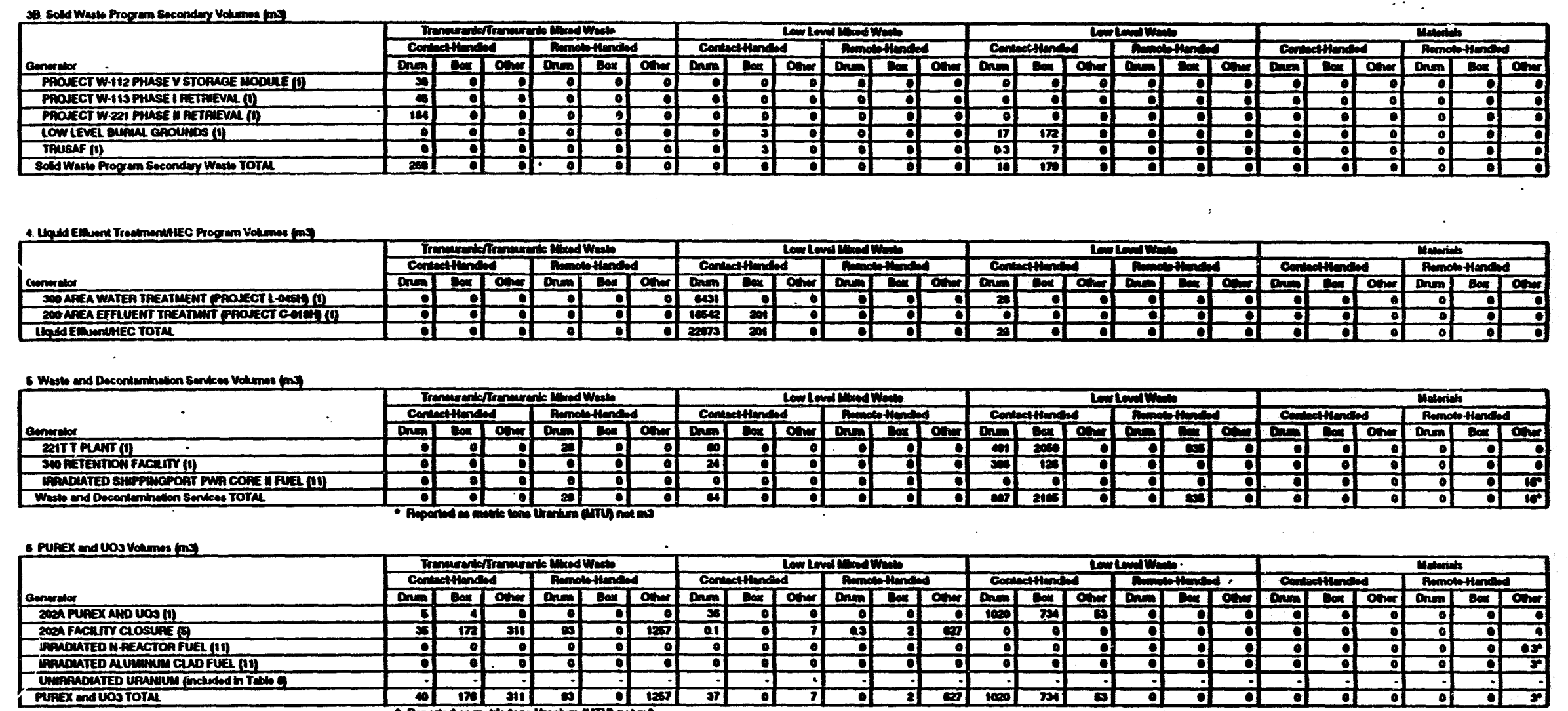

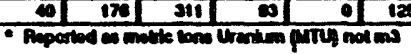

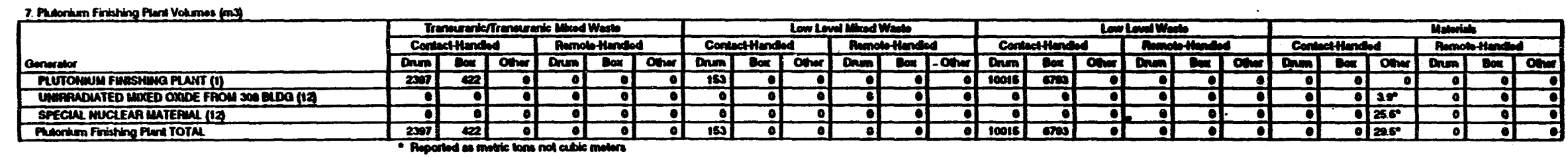



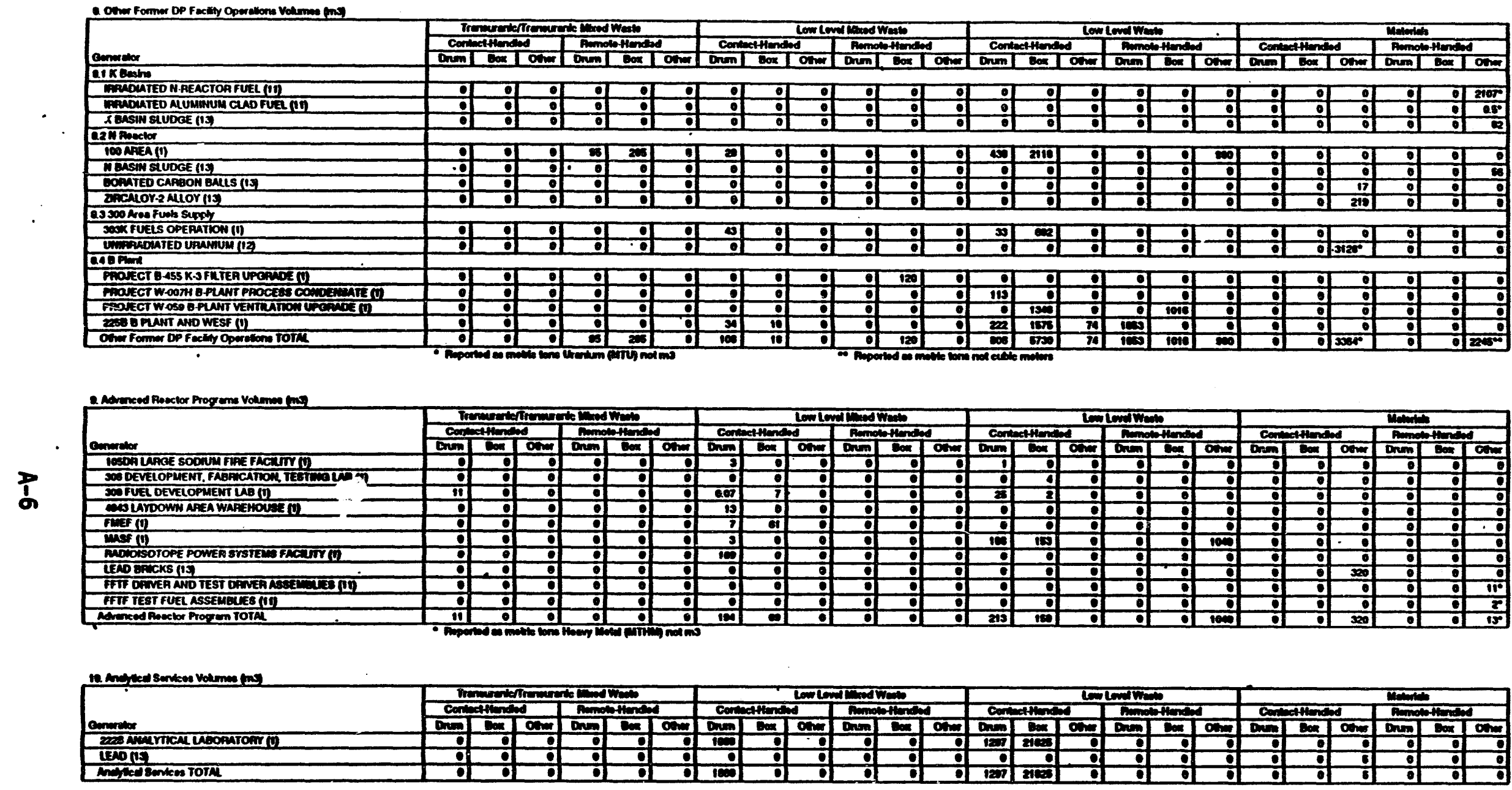

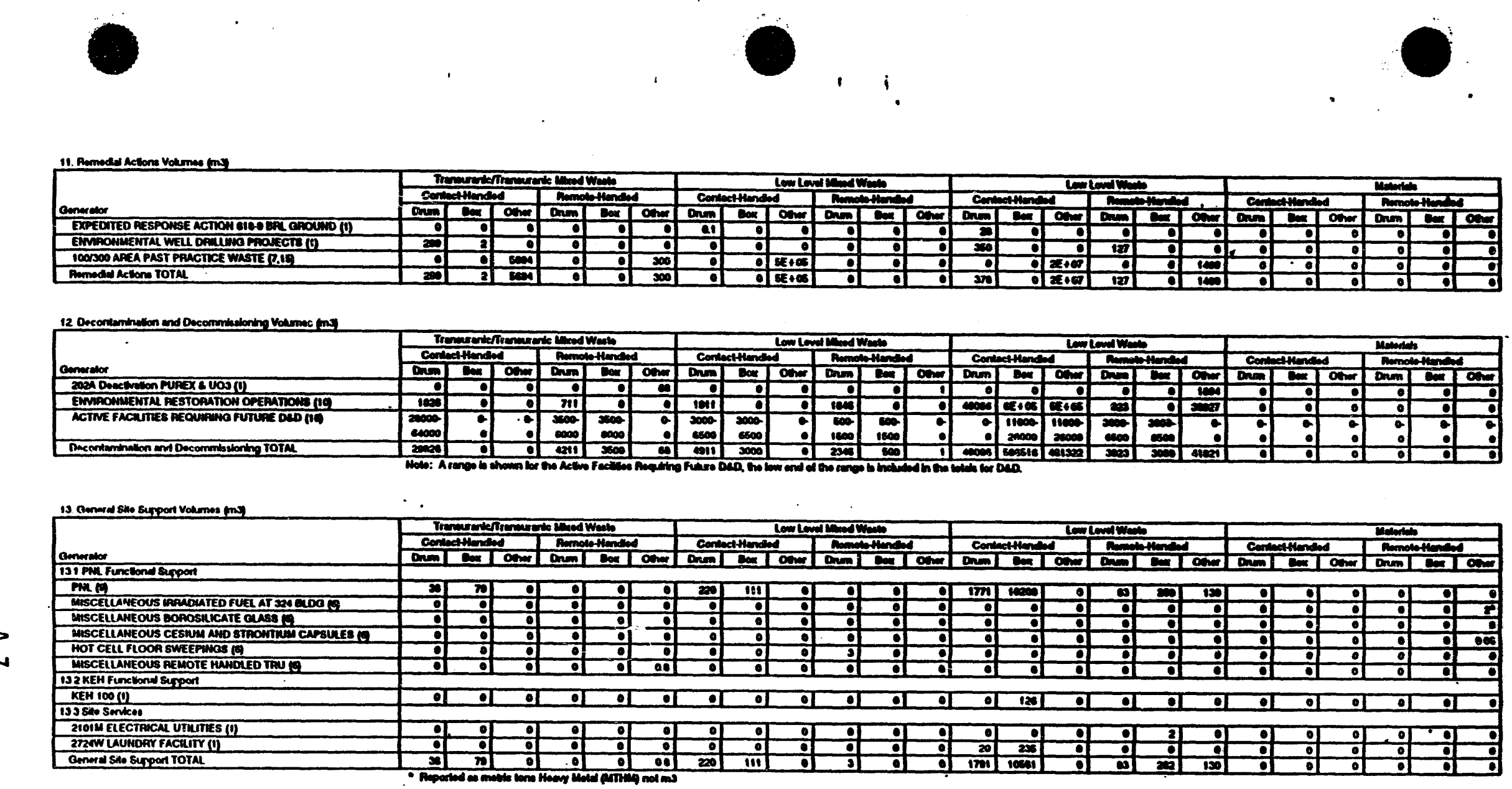

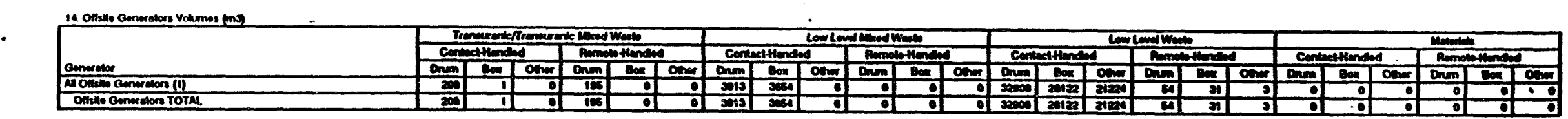


WHC-SD-WM-RPT-060, REV 0 VOLUME 3.
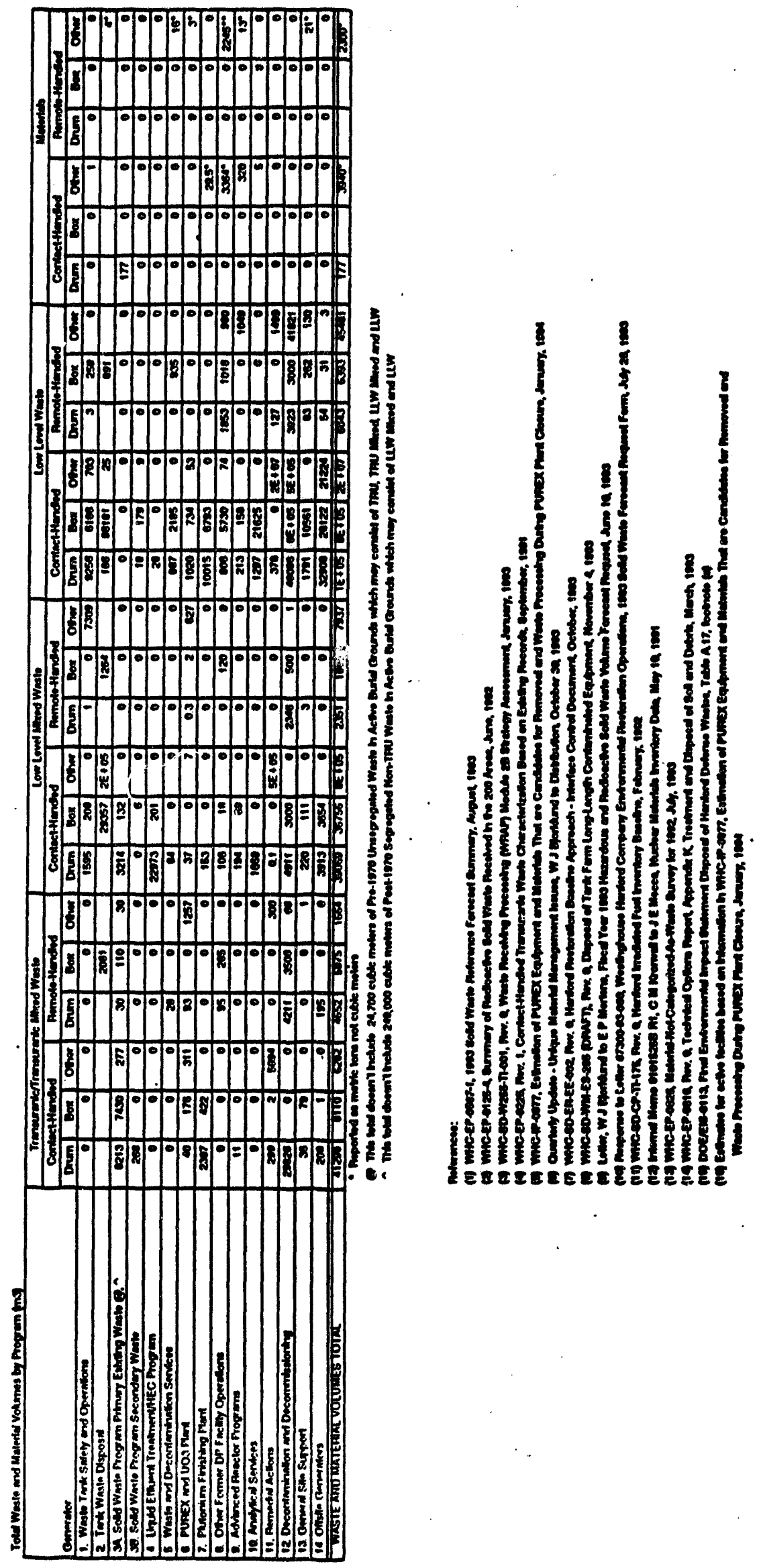


\section{WHC-SD-WM-RPT-060, REV 0}

Solid Waste Program

Technical Baseline Description

\section{Volume 4: Program Documentation}


WHC-SD-WM-RPT-060, REV 0 VOLUME 4

Table of Contents

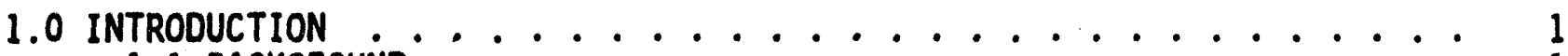

1.1 BACKGROUND .................... 1

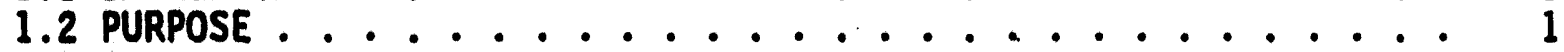

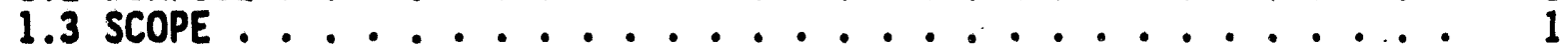

2.0 PROGRAM LEVEL DOCUMENTATION . . . . . . . . . . . 3

3.0 FACILITY AND PROJECT LEVEL DOCUMENTATION . . . . . . . . . 5

3.1 RETRIEVAL ....................... 10

3.1.1 Solid Waste Retrieval Phase 1 (Project $W-113$ ) .... 10

3.1.2 Solid Waste Retrieval, Phase 2 (Project W-221) .... 12

3.1.3 Alpha Caisson Retrieval (Project W-156) ........ 13

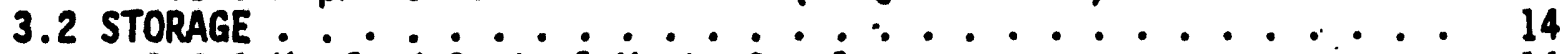

3.2.1 Hanford Central Waste Complex ......... 14

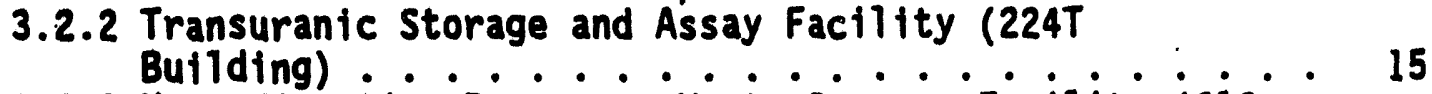

3.2.3 Nonradioactive Dangerous Waste Storage Facility $\left(616^{\circ}\right.$

3.2.4 Sodium Storage Units $\ldots 17$

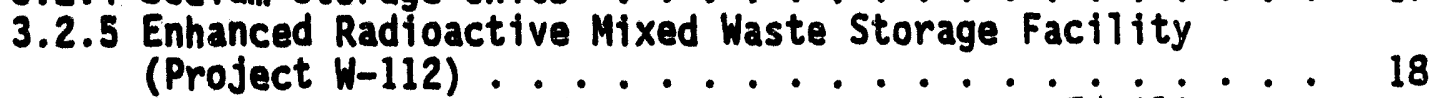

3.2.6 Special Case Solid Waste Temporary Storage Facility (Project W-272) $\ldots 20$

3.2.7 Radioactive Mixed Waste Storage (Project W-312) . . . 21

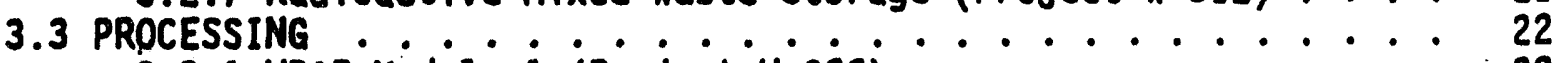

3.3.1 WRAP Module $\mathrm{i}$ (Project $W-026) \ldots \ldots . . \ldots 22$

3.3.2 WRAP Module $2 A$ (Project $W-100) \ldots \ldots 28$

3.3.3 WRAP ModuTe 2B (Project W-255) . . . . . . 32

3.3.4 Thermal Treatment Facility (Project W-242) ..... 34

3.4 DISPOSAL . . . . . . . . . . . . 35

3.4.1 Low-Level Waste Burial Grounds ........ 35

3.4.2 LoW-Level Mixed Waste Disposal (Project W-025) .... 36

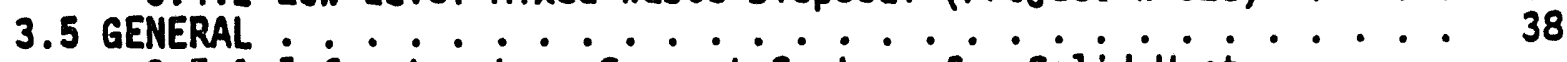

3.5.1 Infrastructure Support Systems for Sol id Waste Management Operations in the 200 Areas (Project W157) ...................... 38

3.5.2 Centrai Waste Support Complex (Project W-244) . . . . 39 
WHC-SD-WM-RPT-060, REV 0 VOLUME 4

List of Tables

Table 2-1. Documentation for Solid Waste Program. .......... 3

Table 3-1. Documentation for Solid Waste Retrieval Phase 1, Project $W-113 \ldots . . . . . . . . . . .10$

Table 3-2. Documentation for Solid Waste Retrieval Phase 2, Project $W-221 \ldots \ldots \ldots 12$

Table 3-3. Documentation for Aipha Caisson Retrieval, Project W-156 . . 13

Table 3-4. Documentation for Hanford Central Waste Complex ....... 14

Table 3-5. Documentation for Transuranic Storage and Assay Facility

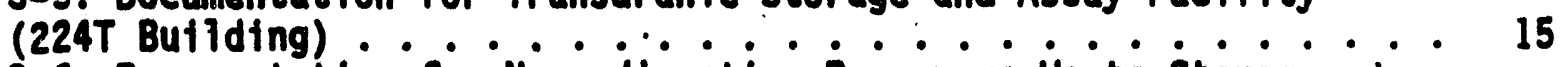

Table 3-6. Documentation for-Nonradioactive Dangerous Waste Storage . . 16

Table 3-7. Documentation for Sodium Storage Units ............. 17

Table 3-8. Documentation for Enhanced Radioactive Mixed Waste Storage Facility, Project $\mathrm{W}-112 \ldots \ldots 18$

Table 3-9. Documentation for Special Case Solid Waste Temporary Storage Facility, Project $W-272 \ldots . . . . .20$

Table 3-10. Documentation for Radioactive Mixed Waste Storage, Project $W-312$. . . . . . . . 21

Table 3-11. Documentation for Waste Receiving and Processing Module i, Project W-026 . . . . . . 22

Table 3-12. Documentation for Waste Receiving and Processing Module 2A, Project $W-100$. . . . . . 28

Table 3-13. Documentation for Waste Receiving and Processing Module 2B,

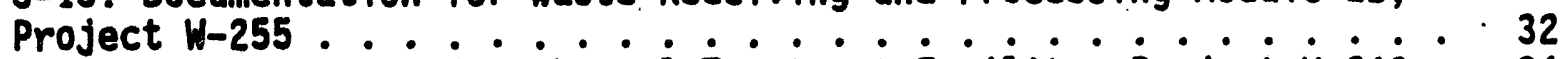

Table 3-14. Documentation for. Thermal Treatment Facility, Project W-242 . 34

Table 3-15. Documentation for Low-Level Waste Burial Grounds . . . . . 35

Table 3-16. Low-Level Mixed Waste Disposal, Project W-025 . . ..... 36

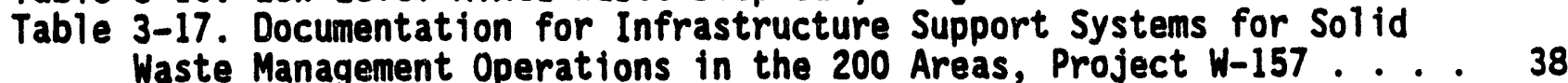

Table 3-18. Documentation for Central Waste Support Complex, Project W-244 ....................

\section{List of Figures}

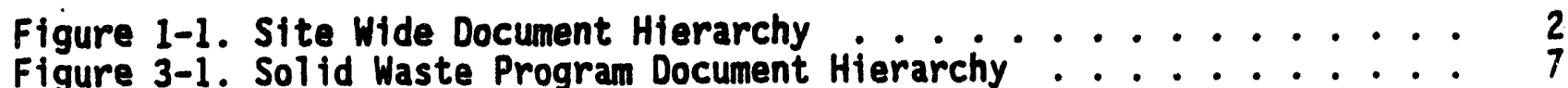

Figure 3-2. Solid Waste Facility/Project Document Status . . . . . . g 9 
WHC-SD-WM-RPT-060, REV 0 VOLUME 4

\subsection{INTRODUCTION}

\subsection{BACKGROUND}

A vast amount of analysis, study, design, evaluation, and planning, is required for the Solid Waste Program to satisfactorily accomplish its mission. This information is documented to meet requirements placed on the Solid Waste Program and to substantiate the technical baseline of the program. Figure 1-1 identifies the site wide hierarchy of documentation under which the Solid Waste program operates to accomplish its mission. External (to the Solid Waste Program) requirements are placed on the Solid Waste Program by regulatory considerations 1ike the Tri-Party Agreement and site-wide integration as described in the Hanford Mission Plan.

The Solid Waste program Identifies its role relative to other on site programs through interface control documents. The Solid Waste program identifies its own role at a summary level through the Solid Waste. Program Plan. The Solid Waste Program Plan describes at a summary level the current activities, strategy, schedule, and cost associated with solid waste management.

In support of the Solid Waste Program P1 an and interface control documents the program develops technical baseline documents. These documents provide technical basis which the program uses to support the strategy undertaken by the program in accomplishing its mission. These documents cover a variety of topics including waste acceptance criteria, studies and evaluations, waste characterization, waste forecasts, and computer models.

\subsection{PURPOSE}

The purpose of Volume 4, Program Documentation is to present a 1 isting of documentation necessary to establish the technical basis for the Solid Waste Program. This includes documents required at a programmatic level, a project level, and a facility level.

\subsection{SCOPE}

This volume of the covers that documentation necessary to establish the technical basis for the program and the projects and facilities under the direction of the program. 

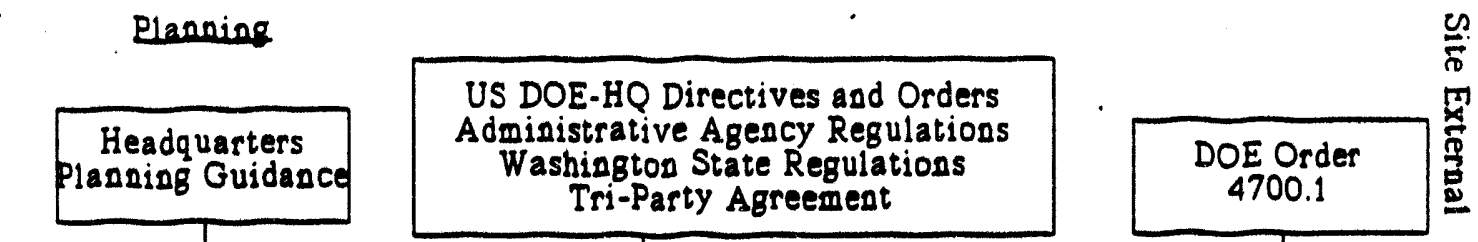

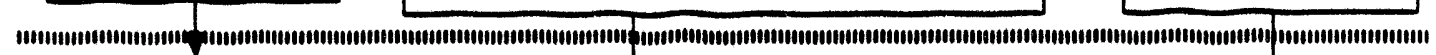
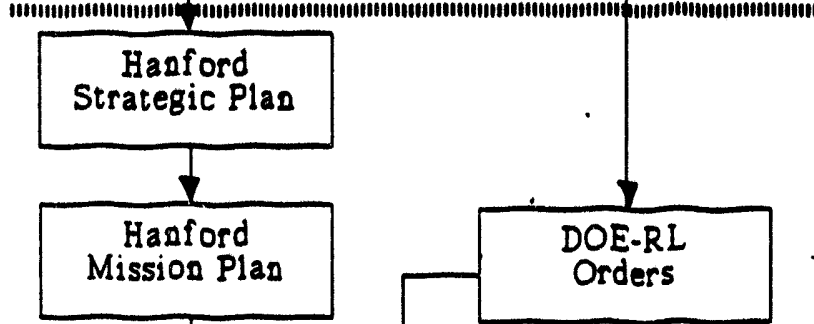

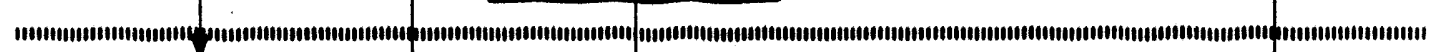
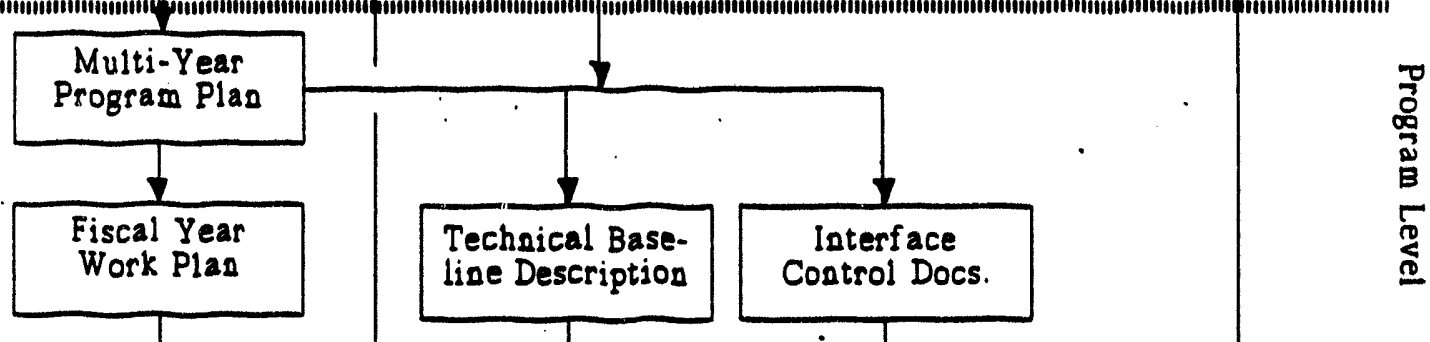

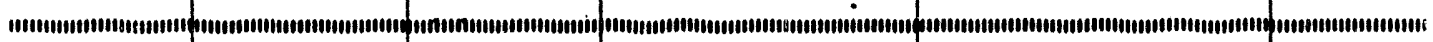

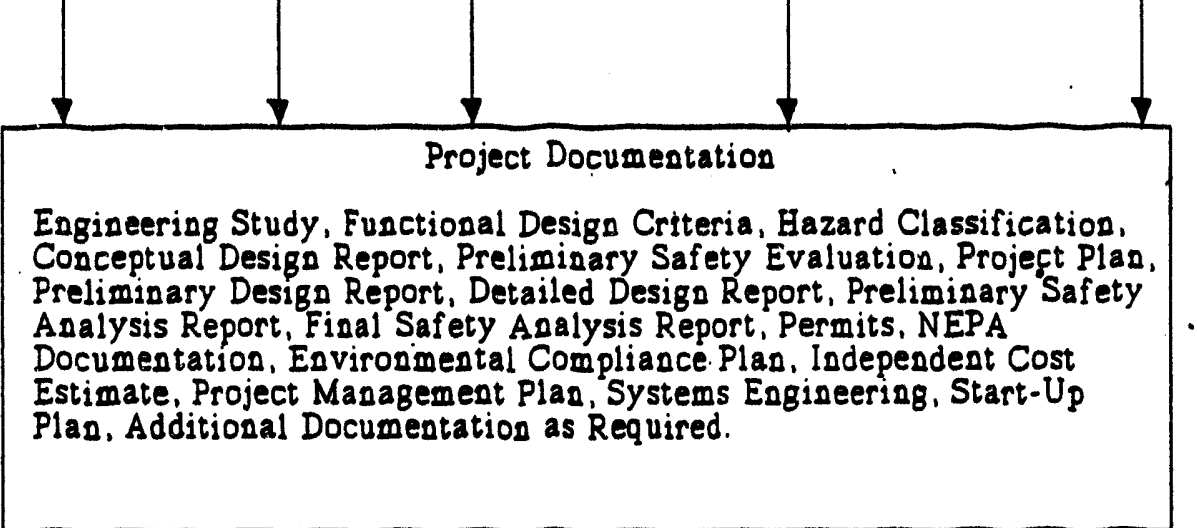

章. 
WHC-SD-WM-RPT-060, REV 0 VOLUME 4

\subsection{PROGRAM LEVEL DOCUMENTATION}

The Solid Waste Program must develop a number of programmatic documents in order to satisfy the requirements placed on the program. These include strategic planning documents, budget documents, interface control documents, and technical baseline documents as well as general supporting documents. Table 2-1 presents the baseline programmatic documentation for the Solid Waste Program. The documentation is categorized according to purpose of the document whether it be strategic planning, budgetary, interface controls, technical baseline or general support.

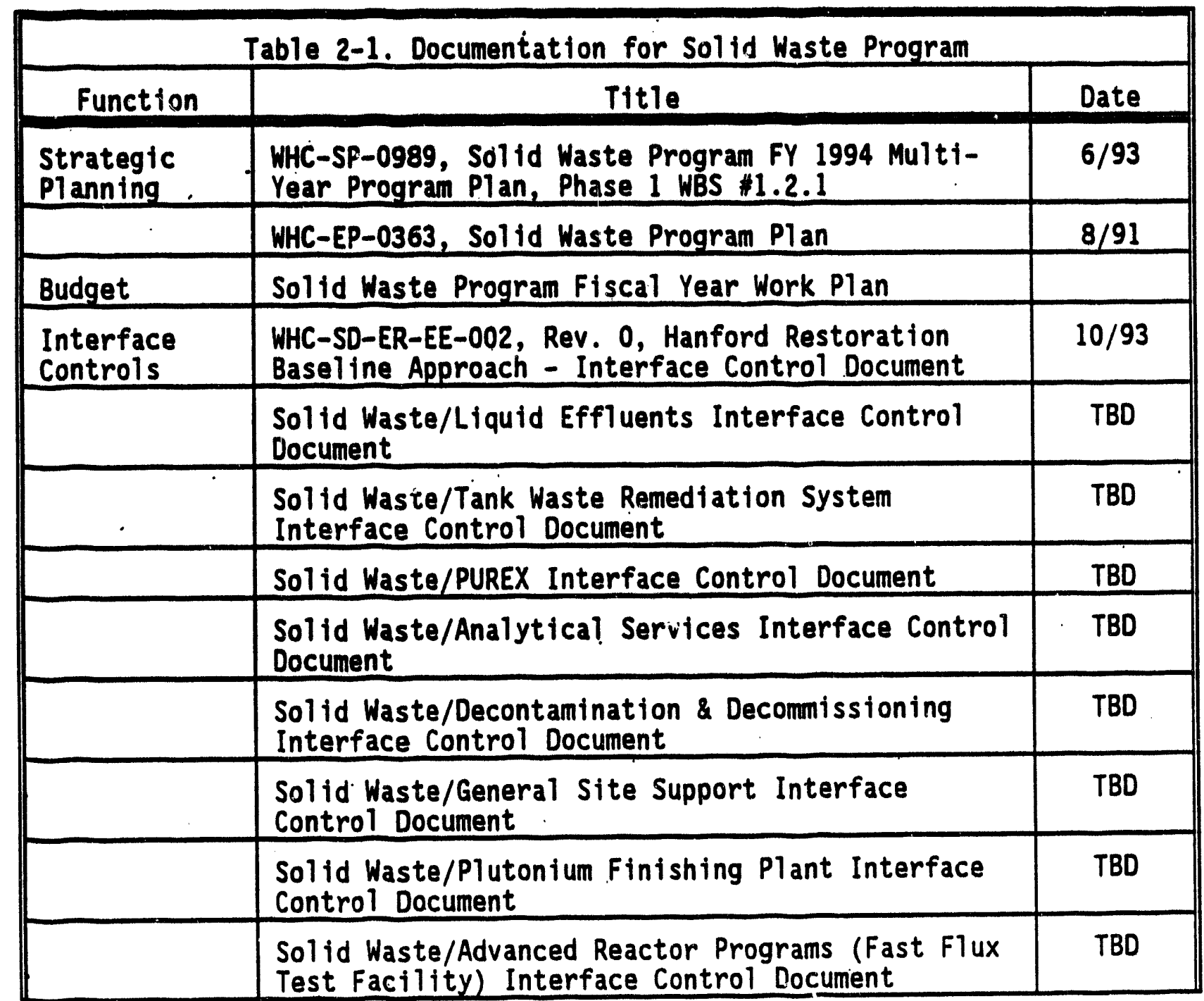



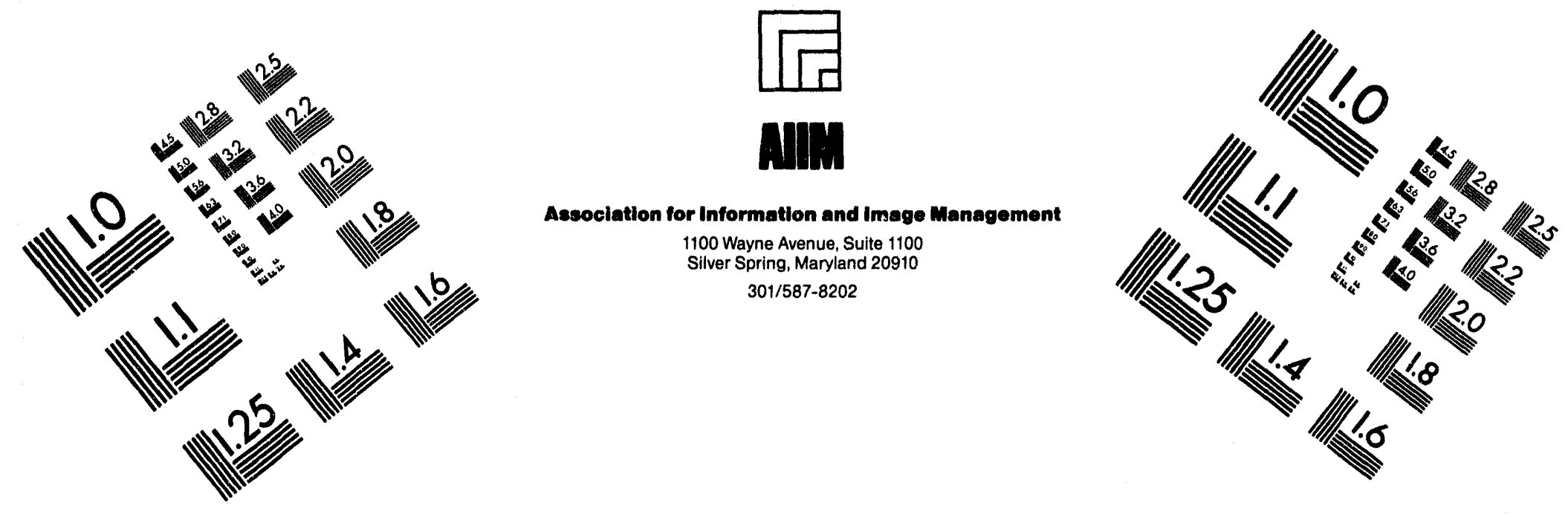

\section{Centimeter}

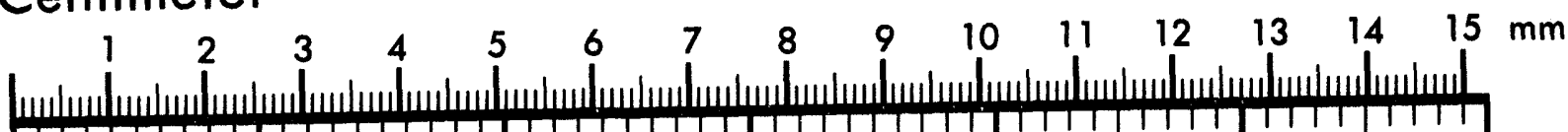
TITाTा Inches
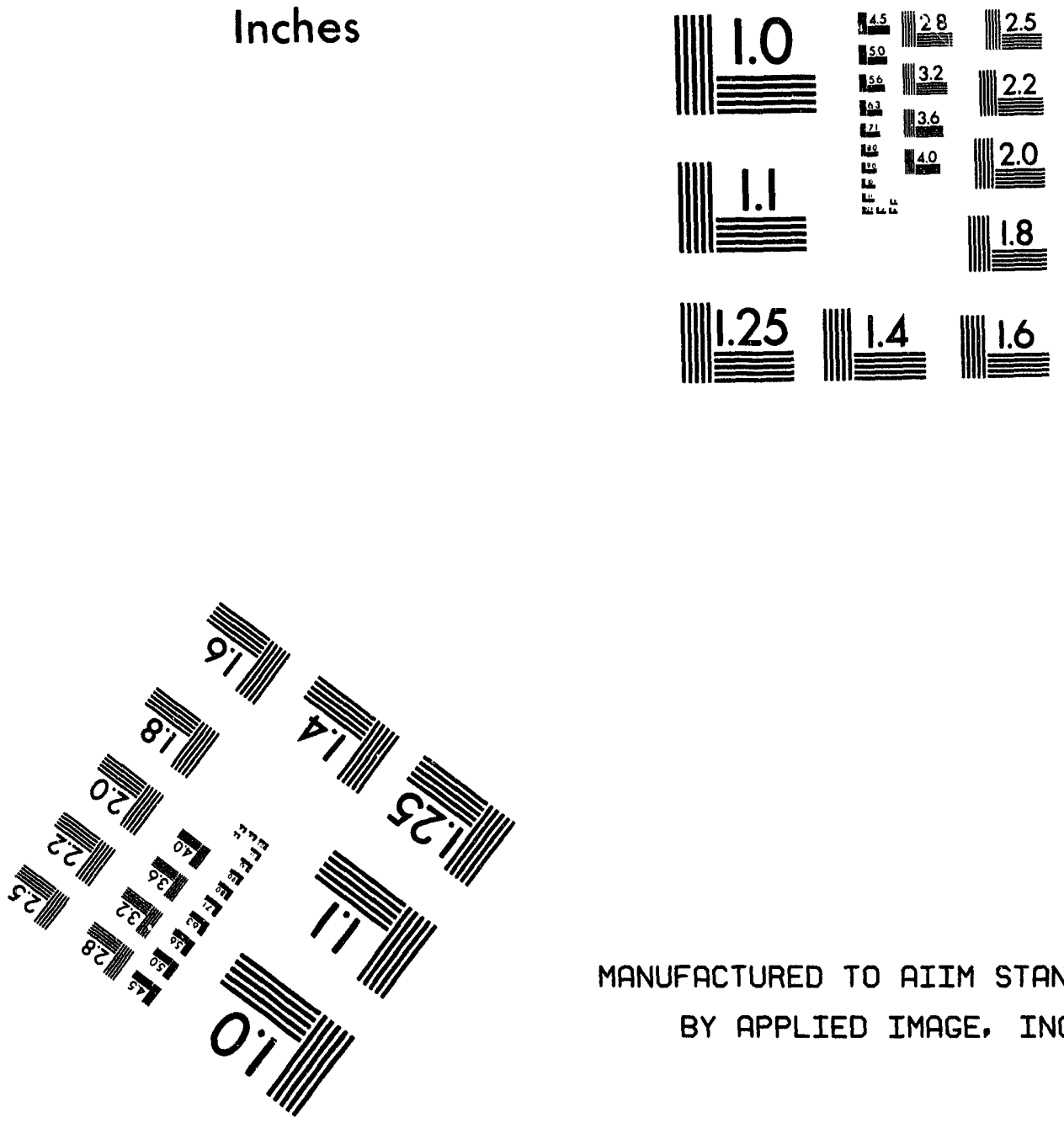

MANUFACTURED TO AIIM STANDARDS BY APPLIED IMAGE, INC.

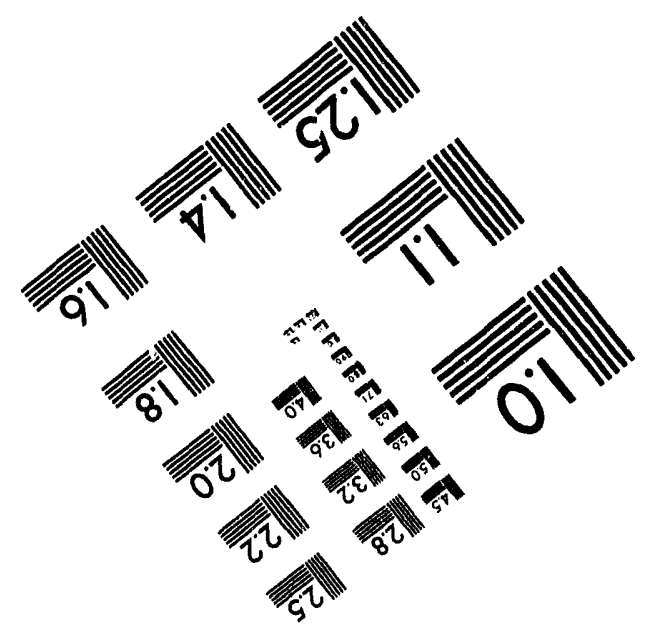



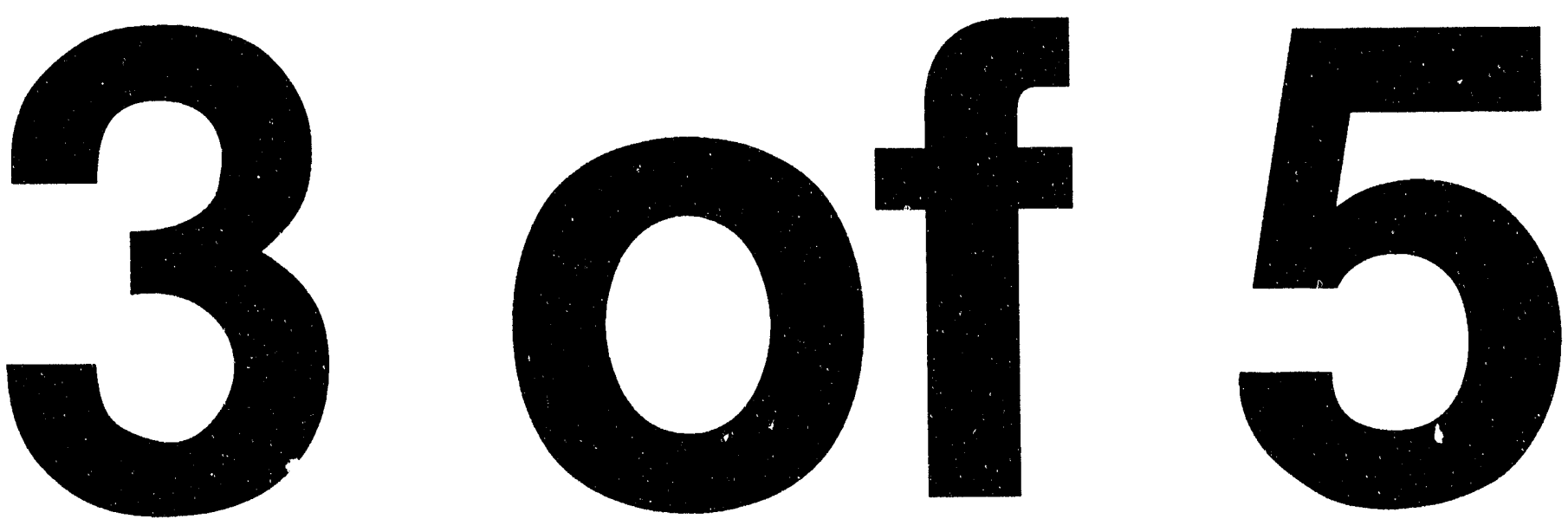
WHC-SD-WM-RPT-060, REV 0 VOLUME 4

\begin{tabular}{||c|l|c|}
\hline \multicolumn{3}{|l|}{ Table 2-1. Documentation for Solid Waste Program } \\
\hline Function & \multicolumn{1}{|c||}{ Title } & Date \\
\hline $\begin{array}{l}\text { Technical } \\
\text { Baseline }\end{array}$ & $\begin{array}{l}\text { WHC-SD-WM-RPT-060, Rev O, Solid Waste Program } \\
\text { Technical Baseline Description }\end{array}$ & $2 / 94$ \\
\hline & $\begin{array}{l}87330-93-W P G-026, \text { Solid Waste Projects } \\
\text { Nondestructive Assay/Nondestructive Examination } \\
\text { Review }\end{array}$ & $4 / 93$. \\
\hline & $\begin{array}{l}87330-93-J B M-021, \text { Results of Solid Waste } \\
\text { Operations Complex (SWOC) Office Administrative } \\
\text { Space Study }\end{array}$ & $3 / 93$ \\
\hline & $\begin{array}{l}\text { Hanford Solid Waste System - System Integration } \\
\text { Sunmary }\end{array}$ & $11 / 92$ \\
\hline $\begin{array}{l}\text { 1993 Basel ine Solid Waste Management System } \\
\text { Description }\end{array}$ & $12 / 93$ \\
\hline $\begin{array}{l}\text { General } \\
\text { Support }\end{array}$ & $\begin{array}{l}\text { WHC-EP-0063, Rev. 4, Hanford Site Solid Waste } \\
\text { Acceptance Criteria }\end{array}$ & $11 / 93$ \\
\hline $\begin{array}{l}\text { WHC-EP-0567-1, 1993 Solid Waste Reference } \\
\text { Forecast Summary }\end{array}$ & $8 / 93$ \\
\hline
\end{tabular}


WHC-SD-WM-RPT-060; REV 0 VOLUME 4

\subsection{FACILITY AND PROJECT LEVEL DOCUMENTATION}

Each project and facility under control of the Solid Waste program must develop a number of documents in order to satisfy the requirements placed on that project or facility. Depending on the scope of the project these requirements may include project management, system integration, environmental permitting and regulatory requirements, safety analysis, design, engineering and construction management, environmental, safety, health and qual ity assurance, operational interface, transportation, analytical requirements, among other requirements. Facilities likewise have requirements for operation such as safety analysis, permits, and operational safety requirements. The listing of documentation associated with each project under. the Solid Waste program is provided in Figure 3-1 below. Color coding is provided to illustrate the status of each of the documents for each project. The level of completion of this documentation is dependent upon the status and schedule of each project. A matrix showing the status, of major documents for each project and facility is provided in Figure 3-2.

A listing of documents which the Solid Waste Program has developed or is developing in support of its mission is tabulated for each project and facility identified below. 
. WHC-SD-WM-RPT-060, REV 0 VOLUME 4

This page intentionally left blank. 


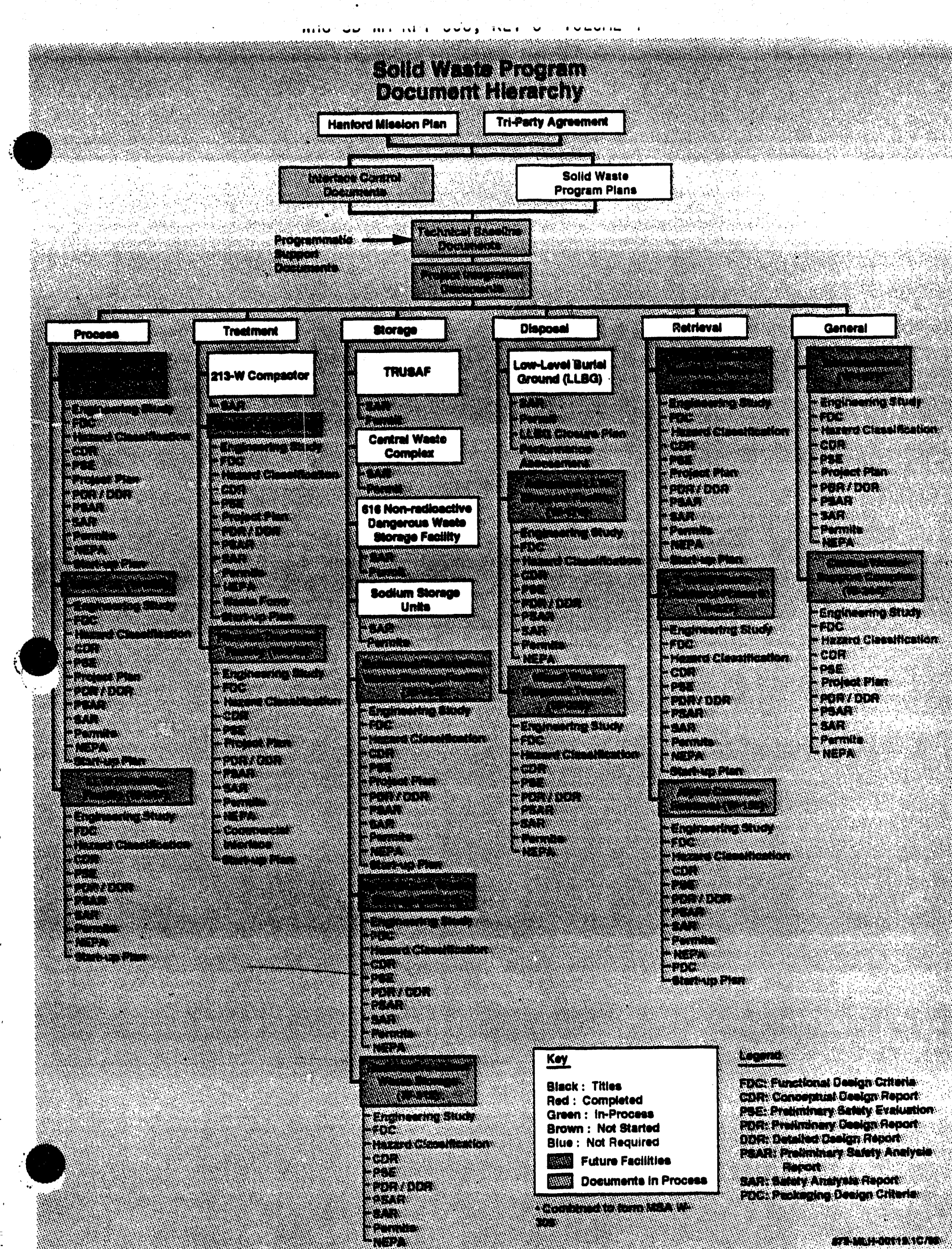


WHC-SD-WM-RPT-060, REV 0 VOLUME 4

This page intentionally left blank. 
Figure 3-2. Sol id Waste Facility/Project Document Status Matrix

\begin{tabular}{|c|c|c|c|c|c|c|c|c|c|c|c|c|}
\hline & $\begin{array}{l}\text { ENO } \\
\text { STUDY }\end{array}$ & FDC & $\begin{array}{l}\text { HAZ } \\
\text { CLASS }\end{array}$ & CDR & PSE & $\begin{array}{l}\text { PROJECT } \\
\text { PLAN }\end{array}$ & $\begin{array}{l}\text { PDR/ } \\
\text { DDR }\end{array}$ & PSAR & SAR & PERMITS & NEPA & $\begin{array}{l}\text { START-UP } \\
\text { PLAN }\end{array}$ \\
\hline \multicolumn{13}{|l|}{ RETRIEVAL } \\
\hline PHASE 1 & c & c & c & c & c & $\mathbb{P}$ & Ns & $\mathbb{P}$ & Ns & NS & $\mathbb{P}$ & Ns \\
\hline PHASE 2 & Ns & Ns & Ns & No & Ne & N8 & No & NS & N8 & No & N8 & Ns \\
\hline $\begin{array}{l}\text { ALPHA } \\
\text { CABBSON }\end{array}$ & c & $p$ & c & No & No & Na & No & No & Ns & Ns & N8 & NS \\
\hline \multicolumn{13}{|l|}{ STORAOE } \\
\hline Thusar & MA & $M$ & MA & MA & Ma & MA & MA & MA & $\dot{c}$ & $c^{\circ}$ & NA & iNA \\
\hline cwe & MA & NA & NA & MA & NA & NA & $M$ & MA & $c$ & $c^{\circ}$ & $\mathrm{MA}$ & NA \\
\hline Neowar & MA & MA & NA & MA & NA & $\mathrm{MA}$ & MA & MA & c & c & NA & NA \\
\hline PHASEV & c & c & c & c & c & $p$ & Ns: & $p$ & Ns & Ns & $\mathbb{P}$ & Ns \\
\hline $\begin{array}{l}\text { SPECIAL CASE } \\
\text { WASTE }\end{array}$ & c & c & c & $\boldsymbol{p}$ & $\boldsymbol{p}$ & NR & N8 & Ns & No & - NA & IP & NA \\
\hline $\begin{array}{l}\text { SOOIUM } \\
\text { stORACE }\end{array}$ & NA & NA & NA & MA & NA & MA & NA & MA & c & $c^{\circ}$ & NA & NA \\
\hline $\begin{array}{l}\text { RAD MIXED } \\
\text { WASTE }\end{array}$ & NR & $\mathbb{P}$ & c & No & No & $\mathrm{NR}$. & No & N8 & Ns & No & NS & NR \\
\hline \multicolumn{13}{|l|}{ Processawo } \\
\hline WRAP 1 & c & c & c. & c & $\dot{\mathbf{c}}$ & c & $p$ & IP & NS & ip & c & $\mathbb{P}$ \\
\hline WRAP $2 A$ & c & c & c & c & $\mathbb{P}$ & $\mathbb{P}$ & Ns & N8 & NS & NS & $\mathbb{P}$ & NS \\
\hline WAAP 28 & NS & Ns & NS & Ns & Ns & Ns & Ns & NS & N8 & NS & Ns & Ns \\
\hline $\begin{array}{l}\text { THEAMAL } \\
\text { TAEATMMENT }\end{array}$ & $\mathbb{P}$ & $\mathbb{P}$ & $\mathbf{P}$ & NS & NS & Ns & NS & NS & N8 & NS & Ns & Ns \\
\hline $\begin{array}{l}\text { 213-W } \\
\text { COMPACTOR }\end{array}$ & NA & NA & MA & NA & MA & MA & NA & NA & c & NA & NA & NA \\
\hline $\begin{array}{l}\text { LLW } \\
\text { HANDLINO } \\
\text { FACILITY }\end{array}$ & NS & No & NB & Ms & No & NA & No & NS & NS & NS & N8 & NS \\
\hline \multicolumn{13}{|l|}{ DISPOSAL } \\
\hline$\angle L B O$ & NA & MA & NA & MA & NA & MA & MA & MA & c & $c^{\circ}$ & NA & NA \\
\hline $\begin{array}{l}\text { AOVANCED } \\
\text { LLW DISPOSAL }\end{array}$ & $\mathbb{P}$ & Ns & NS & N8 & NS & NA & N8 & NS & NS & NS ${ }^{\circ}$ & NS & NA \\
\hline $\begin{array}{l}\text { MIXED WASTE } \\
\text { DISPOSAL }\end{array}$ & NA & c & c & c & c & NA & c & c & $\mathbb{P}$ & $\mathbb{P}$ & IP & NA \\
\hline \multicolumn{13}{|l|}{ GENERAL } \\
\hline $\begin{array}{l}\text { INFRASTRUC- } \\
\text { TURE }\end{array}$ & c & c & NR & c & c & $\mathbb{P}$ & NE & NS & NS & NA & $\mathbb{P}$ & NA \\
\hline cwsc & NR & $\mathrm{C}$ & NR & $c$ & $c$ & $\mathbb{P}$ & NS & NS & NS & NA & $\mathbb{P}$ & NA \\
\hline $\begin{array}{l}\text { C - Completed } \\
\text { IP - In Progreses } \\
\text { NS - Not Started } \\
\text { NR - Not Require } \\
\text { NA - Not Applios }\end{array}$ & & & $\cdot$ & & & & & & · & . & $\begin{array}{l}\text { Oper } \\
\text { RCRA ir }\end{array}$ & $\begin{array}{l}\text { ating Undor } \\
\text { nterim Status }\end{array}$ \\
\hline
\end{tabular}


WHC-SD-WM-RPT-060, REV 0 VOLUME 4

\subsection{RETRIEVAL}

A listing of documents which the Solid Waste Program has developed or is developing in support of each retrieval project is tabulated below.

\subsubsection{Solid Waste Retrieval Phase 1 (Project W-113)}

Table 3-1 presents the baseline documentation for Solid Waste Retrieval Phase 1, Project $W-113$. The documentation is categorized according to purpose of the document whether it be functional, design, planning, technical support, safety anaiysis, environmental, or engineering.

Table 3-1. Documentation for Solid Waste Retrieval Phase 1, Project W-113 [Part of Solid Waste Operations Complex (Project W-306)]

\begin{tabular}{|c|c|c|}
\hline Function & Title & Date \\
\hline \multirow[t]{2}{*}{$\begin{array}{l}\text { Functional } \\
\text { Criteria }\end{array}$} & $\begin{array}{l}\text { WHC-SD-W113-FDC-001, Rev 1, "Functional Design } \\
\text { Criteria Solid Waste Retrieval Phase 1, Project } \\
\text { W-113" }\end{array}$ & $4 / 92$ \\
\hline & $\begin{array}{l}\text { WHC-SD-W113-FDC-001, Rev 0, "Functional Design } \\
\text { Criteria Solid Waste Retrieval Phase 1, Project } \\
\text { W-113" }\end{array}$ & $5 / 91$ \\
\hline $\begin{array}{l}\text { Design } \\
\text { Requirements }\end{array}$ & $\begin{array}{l}\text { WHC-SD-W113-SDRD-001, Draft, "Supplemental Design } \\
\text { Requirements Document for Sol.id Waste Retrieval } \\
\text { Phase I" }\end{array}$ & TBD \\
\hline \multirow[t]{2}{*}{$\begin{array}{l}\text { Design } \\
\text { Reports }\end{array}$} & $\begin{array}{l}\text { WHC-SD-W113-ACDR-001, Draft, "Advanced Conceptual } \\
\text { Design Report, Sol id Waste Retrieval Facility } \\
\text { Phase 1, Project W-113" }\end{array}$ & TBD \\
\hline & $\begin{array}{l}\text { WHC-SD-W113-CDR-002, Rev 0, "Conceptual Design } \\
\text { Report, Solid Waste Retrieval Facility Phase 1, } \\
\text { Project W-113" }\end{array}$ & $10 / 92$ \\
\hline Planning & $\begin{array}{l}\text { "U. S. Department of Energy, Sol id Waste } \\
\text { Operations Complex (SWOC), Phase } 1 \text { Project 94-D- } \\
411 \text { Project Plan" }\end{array}$ & $12 / 93$ \\
\hline \multirow[t]{4}{*}{$\begin{array}{l}\text { Technical } \\
\text { Support }\end{array}$} & ACDR, Draft, "Box Overpack Design Criteria" & TBD \\
\hline & $\begin{array}{l}\text { ACDR, Draft, "Justification for Trench Weather } \\
\text { Enclosure" }\end{array}$ & TBD \\
\hline & $\begin{array}{l}\text { ACDR, Draft, "Equipment Functional Design for } \\
\text { NDE/NDA" }\end{array}$ & TBD \\
\hline & $\begin{array}{l}\text { WHC-SD-113-ES-003, Rev 0, "Project W-113 Drum } \\
\text { Venting and Head Gas Sampling Systems Equipment" }\end{array}$ & $4 / 93$ \\
\hline
\end{tabular}


WHC-SD-WM-RPT-060, REV 0 VOLUME 4

Table 3-1. Documentation for Solid Waste Retrieval Phase 1, Project W-113 [Part of Solid Waste Operations Complex (Project W-306)]

\begin{tabular}{|c|c|c|}
\hline Function & Title & Date \\
\hline \multirow[t]{4}{*}{$\begin{array}{l}\text { Technical } \\
\text { Support } \\
\text { (Continued) }\end{array}$} & $\begin{array}{l}\text { WHC-SD-W026-PAP-001, Rev 1, "Waste Receiving and } \\
\text { Processing/Sol id Waste (WRAP/SW) Engineering } \\
\text { Development Program Plan" }\end{array}$ & $2 / 93$ \\
\hline & $\begin{array}{l}\text { WHC-SD-W113-WP-001, Rev 0, "Advanced Conceptual } \\
\text { Design Work P1 an, Project W-113 Sol id Waste } \\
\text { Retrieval Factlity, Phase I" }\end{array}$ & $9 / 92$ \\
\hline & $\begin{array}{l}\text { WHC-SD-W113-ER-002, Rev 0, "Equipment Design For } \\
\text { NDE/NDA \& Gas Sampi ing for Phase I Retrieval" }\end{array}$ & $7 / 92$ \\
\hline & $\begin{array}{l}\text { WHC-SD-W113-PSAR-001, Draft, "Solid Waste } \\
\text { Retrieval Phase I Prel iminary Safety Analys is } \\
\text { Report" }\end{array}$ & TBD \\
\hline \multirow[t]{3}{*}{$\begin{array}{l}\text { Safety } \\
\text { Analysis }\end{array}$} & $\begin{array}{l}\text { WHC-SD-W1 13-PSE-001, Rev 0, "Sol id Waste } \\
\text { Retrieval Prel iminary Safety Evaluation (PSE) } \\
\text { Phase I" }\end{array}$ & $11 / 91$ \\
\hline & $\begin{array}{l}\text { WHC-SD-W113-HC-002, Rev 0, "Solid Waste Retrieval } \\
\text { Phase I Hazard Classification" }\end{array}$ & $10 / 91$ \\
\hline & $\begin{array}{l}\text { WHC-SO-W113-ES-002, Rev } 0 \text {, "Engineering Safety } \\
\text { Study for Project } W-113^{\prime \prime}\end{array}$ & $6 / 91$ \\
\hline Environmental & $\begin{array}{l}\text { Draft, "EA/FONSI: Solid Waste Retrieval Complex, } \\
\text { Phase I (W-113), and Enhanced Radioactive and } \\
\text { M1xed Waste Storage. Facility Phase V (W-112) }\end{array}$ & TBD \\
\hline $\begin{array}{l}\text { Engineering } \\
\text { Studies }\end{array}$ & $\begin{array}{l}\text { WHC-SD-W113-ES-001, Rev 0, "Engineering Study for } \\
\text { the Sol id Waste Retrieval; Project W-113" }\end{array}$ & $6 / 91$ \\
\hline \multirow[t]{4}{*}{$\begin{array}{l}\text { Technical } \\
\text { Studies }\end{array}$} & Draft, "Source Term Analysis" & TBD \\
\hline & $\begin{array}{l}\text { WHC-SD-W113-ER-001, Rev 0, "Prel iminary } \\
\text { Evaluation of Retrieval Systems Required for } \\
\text { Phase I Suspect TRU Sol id Waste" }\end{array}$ & $11 / 91$ \\
\hline & $\begin{array}{l}\text { SD-WM-TPP-028, Rev 0, "Technology Program P1an } \\
\text { (TTP) for Contact Handled Transuranic (CH-TRU) } \\
\text { Waste Retrieval" }\end{array}$ & $5 / 86$ \\
\hline & $\begin{array}{l}\text { SD-WM-TRP-002, Rev } 0 \text {, "Inspection of Retrievably } \\
\text { Stored Transuranic Waste Containers" }\end{array}$ & $8 / 82$ \\
\hline
\end{tabular}


WHC-SD-WM-RPT-060, REY 0 VOLUME 4

3.1.2 Solid Waste Retrieval, Phase 2 (Project W-221)

Table 3-2 presents the baseline documentation for Solid Waste Retrieval Phase 2, Project W-221. No documents have been identified to date since work has not begun on this project.

Table 3-2. Documentation for Solid Waste Retrieval Phase 2, Project W-221 Function Title Date

No documents identified to date. 
WHC-SD-WM-RPT-060, REV 0 VOLUME 4

\subsubsection{Alpha Caisson Retrieval (Project W-1.56)}

Table 3-3 presents the baseline documentation for Alpha Caisson Retrieval, Project W-156. The documentation is categorized according to purpose of the document whether it be functional, packaging, technical support, safety analysis, environmental, or engineering.

\begin{tabular}{|c|c|c|}
\hline Function & Title & Date \\
\hline $\begin{array}{l}\text { Functional } \\
\text { Criteria }\end{array}$ & $\begin{array}{l}\text { WHC-SD-W156-FDC-001, Draft, "Functional Design } \\
\text { Criteria Alpha Catsson Retrieval, Project W-156" }\end{array}$ & TBD \\
\hline $\begin{array}{l}\text { Packaging } \\
\text { Requitrements }\end{array}$ & $\begin{array}{l}\text { WHC-SD-TP-PDC-005, Rev 0, "Packaging Design } \\
\text { Criteria for the Alpha Caisson Packaging System" }\end{array}$ & $7 / 92$ \\
\hline \multirow[t]{2}{*}{$\begin{array}{l}\text { Safety } \\
\text { Analysis }\end{array}$} & $\begin{array}{l}\text { WHC-SD-W156-ES-001, Rev 0, "Engineering Safety } \\
\text { Study for Project W-156" }\end{array}$ & $1 / 92$ \\
\hline & $\begin{array}{l}\text { WHC-SD-W156-HC-001, Rev 0, "Hazard Classification } \\
\text { for W-156 Retrieval of Remote-Handled Transuranic } \\
\text { Waste from Alpha Caissons" }\end{array}$ & $.12 / 91$ \\
\hline \multirow[t]{2}{*}{ Environmental } & $\begin{array}{l}\text { WHC-SD-WM-RPT-051, Rev 0, "Alpha Caisson Air } \\
\text { Sampling" }\end{array}$ & 9/92 \\
\hline & $\begin{array}{l}\text { SD-WM-PAP-041, Rev 0, "Sol id Waste Burial Caisson } \\
\text { Plan for Transuranic (TRU) Wastes ("Alpha" } \\
\text { Caissons) }\end{array}$ & $9 / 85$ \\
\hline \multirow[t]{3}{*}{$\begin{array}{l}\text { Engineering } \\
\text { Studies }\end{array}$} & $\begin{array}{l}\text { WHC-SD-WM-ES-191, Rev 0, "Alpha Caisson Retrieval } \\
\text { Cask Engineering Study" }\end{array}$ & $1 / 92$ \\
\hline & $\begin{array}{l}\text { WHC-SD-WM-ES-181, Rev 0, "Engineering Study, } \\
\text { Retrieval of Waste from Alpha Caissons" }\end{array}$ & $10 / 91$ \\
\hline & $\begin{array}{l}\text { SD-WM-ES-102, Rev 0, "Remote Handling of } \\
\text { Transuranic and Low Level Waste in the Waste } \\
\text { Receiving and Processing Factlity" }\end{array}$ & $8 / 88$ \\
\hline \multirow[t]{4}{*}{$\begin{array}{l}\text { Technical } \\
\text { Studies }\end{array}$} & $\begin{array}{l}\text { WHC-SD-WM-RPT-008, Rev 0, "Alpha Caisson Data and } \\
\text { Evaluation" }\end{array}$ & $12 / 90$ \\
\hline & $\begin{array}{l}\text { SD-WM-ROB-005, Rev 0, "Retrieval of Waste Alpha } \\
\text { Caissons" }\end{array}$ & $10 / 85$ \\
\hline & $\begin{array}{l}\text { SD-WM-ROB-002, Rev 0, "Status at Termination, } \\
\text { Alpha Caisson Recovery Demonstration" }\end{array}$ & $3 / 85$ \\
\hline & $\begin{array}{l}\text { SD-WM-ROB-003, Rev 0, "Plan for Removing Remote } \\
\text { Handled Transuranic Waste from Alpha Caissons" }\end{array}$ & $5 / 85$ \\
\hline
\end{tabular}




\subsection{STORAGE}

A listing of documents which the Solid Waste Program has developed or is developing in support of its storage facilities and projects. is tabulated below.

\subsubsection{Hanford Central Waste Complex}

Table 3-4 presents the baseline documentation for the Hanford Central Waste complex. The documentation is categorized according to purpose of the document whether it be permitting or safety analysis related.

\begin{tabular}{||c|l|c|}
\hline \multicolumn{3}{|c|}{ Table 3-4. Documentation. for Hanford Central Waste Complex } \\
\hline Function & \multicolumn{1}{|c|}{ Title } & Date \\
\hline Permit & $\begin{array}{l}\text { DOE/RL-91-17, Rev 0, "Hanford Central Waste } \\
\text { Complex - Radioactive Mixed Waste Storage } \\
\text { Facility Dangerous Waste Permit Appl ication" }\end{array}$ & $10 / 91$ \\
\hline $\begin{array}{l}\text { Safety } \\
\text { Analysis }\end{array}$ & $\begin{array}{l}\text { WHC-SD-WM-SAR-049, Rev 0, "Central Waste Complex } \\
\text { Final Safety Analys is Report FSAR Upgrade" }\end{array}$ & $1 / 91$ \\
\hline
\end{tabular}


WHC-SD-WM-RPT-060, REV 0 VOLUME 4

3.2.2 Transuranic Storage and Assay Facility (224T Building)

Table 3-5 presents the baseline documentation for the Transuranic Storage and Assay Facility. The documentation is categorized according to purpose of the document whether it be permitting or safety analysis related.

\begin{tabular}{|l|l|c|}
\hline \multicolumn{2}{|c|}{ Table 3-5. Documentation for Transuranic Storage and Assay Factlity } \\
(224T Building)
\end{tabular}


WHC-SD-WM-RPT-060, REV 0 VOLUME 4

\subsubsection{Nonradioactive Dangerous Waste Storage Facility (616 Building)}

Table 3-6 presents the baseline documentation for the Nonradioactive Dangerous Waste Storage Facility. The documentation is categorized according to purpose of the document whether it be permitting or safety analysis related.

\begin{tabular}{||l|l|c||}
\hline \multicolumn{3}{|c|}{ Table 3-6. Documentation for Nonradioactive Dangerous Waste Storage } \\
Facility (616 Building)
\end{tabular}


WHC-SD-MM-RPT-060, REV 0 VOLUME 4.

3.2.4 Sodium Storage Units

Table 3-7 presents the baseline documentation for the Sodium Storage Units. The documentation is categorized according to purpose of the document whether it be permitting or safety analysis related.

\begin{tabular}{|l|l|c|}
\hline \multicolumn{3}{|c|}{ Table 3-7. Documentation for Sodium Storage Units } \\
\hline \multicolumn{1}{|c|}{ Title } & Date \\
\hline $\begin{array}{l}\text { Safetyctinn } \\
\text { Analysis }\end{array}$ & $\begin{array}{l}\text { WHC-SD-WM-SAR-049, Rev O, "Central-Waste Complex } \\
\text { Final Safety Analysis Report FSAD Upgrade" }\end{array}$ & $1 / 91$ \\
\hline Permit & $\begin{array}{l}\text { DoE/RL-91-17, Rev 0, "Hanford Central Waste } \\
\text { Complex - Radioactive Mixed Waste Storage } \\
\text { Facility Dangerous Waste Permit Application" }\end{array}$ & $10 / 91$ \\
\hline
\end{tabular}


WHC-SD-WM-RPT-060, REV 0 VOLUME 4

3.2.5 Enhanced Radioactive Mixed Waste Storage Facility (Project W-112)

Table 3-8 presents the baseline documentation for Enhanced Radioactive Mixed Waste Storage Facility Phase V, Project W-112. The documentation is categorized according to purpose of the document whether it be functional, design, planning, technical support, safety analysis, environmental, or engineering.

\begin{tabular}{|c|c|c|}
\hline Function & Title & Date \\
\hline \multirow[t]{2}{*}{$\begin{array}{l}\text { Functional } \\
\text { Criteria }\end{array}$} & $\begin{array}{l}\text { WHC-SD-W112-FDC-001, Rev } 1 \text {, "Functional Design } \\
\text { Criteria for Project W-112 Enhanced Radioactive \& } \\
\text { Mixed Waste Storage Phase V" }\end{array}$ & $4 / 92$ \\
\hline & $\begin{array}{l}\text { WHC-SD-W112-FDC-001, Rev } 0 \text {, "Functional Design } \\
\text { Criteria for Project W-112 Enhanced Radioactive \& } \\
\text { Mixed Waste Storage Phase } V "\end{array}$ & $8 / 91$ \\
\hline $\begin{array}{l}\text { Design } \\
\text { Requirements }\end{array}$ & $\begin{array}{l}\text { WHC-SD-W112-SDRD-001, Draft, "Supplemental Design } \\
\text { Requirements Document Enhanced Radioactive \& } \\
\text { Mixed Waste Storage Phase V" }\end{array}$ & TBD \\
\hline \multirow[t]{2}{*}{$\begin{array}{l}\text { Design } \\
\text { Reports }\end{array}$} & $\begin{array}{l}\text { WHC-SD-W112-ACDR-001, Draft, "Advanced Conceptual } \\
\text { Design Report for Project W-112 Enhanced } \\
\text { Radioactive \& Mixed Waste Storage Phase V" }\end{array}$ & TBD \\
\hline & $\begin{array}{l}\text { WHC-SD-W112-COR-001, Rev } 0, \text { "Conceptual Design } \\
\text { Report for Project" } W-112 \text { Enhanced Radioactive a } \\
\text { Mixed Waste Storage Phase } V "\end{array}$ & $8 / 92$ \\
\hline Plans & $\begin{array}{l}\text { Department of Energy, Draft, "U. S. Department of } \\
\text { Energy Sol id Waste Operations Complex (SWOC), } \\
\text { Phase } 1 \text { Project 94-D-411 Project P1an" }\end{array}$ & TBD \\
\hline \multirow{3}{*}{$\begin{array}{l}\text { Technical } \\
\text { Support }\end{array}$} & ACDR, Draft, "Automated. Drum Inspection" & TBD \\
\hline & ACDR, Draft, Site Plan Site Grading" & TBD \\
\hline & $\begin{array}{l}\text { WHC-SD-W026-PAP-001, Rev 1, "Waste Receiving and } \\
\text { Processing/Solid Waste (WRAP/SW) Development } \\
\text { Program Plan" }\end{array}$ & $2 / 93$ \\
\hline $\begin{array}{l}\text { Safety } \\
\text { Analysis }\end{array}$ & $\begin{array}{l}\text { WHC-SD-W112-PSAR-001, Draft, "Enhanced } \\
\text { Radioactive \& Mixed Waste Storage Phase V } \\
\text { Preliminary Safety Analysis Report" }\end{array}$ & TBD \\
\hline
\end{tabular}


WHC-SD-WM-RPT-060, REV 0 VOLUME 4

Table 3-8. Documentation for Enhanced Radioactive Mixed Waste Storage Facility, Project W-112

\begin{tabular}{|c|c|c|}
\hline Function & Title & Date \\
\hline \multirow[t]{3}{*}{$\begin{array}{l}\text { Safety } \\
\text { Analysis- } \\
\text { Continued } \\
\end{array}$} & $\begin{array}{l}\text { WHC-SD-W112-PSE-001, Rev 0, "Prel iminary Safety } \\
\text { Evaluation for Project W-112 Enhanced Radioactive } \\
\text { \& Mixed Waste Storage Phase V" }\end{array}$ & $11 / 91$ \\
\hline & $\begin{array}{l}\text { WHC-SD-W112-ES-002, Rev 0, "Engineering Safety } \\
\text { Study for Project W-112" }\end{array}$ & $7 / 91$ \\
\hline & $\begin{array}{l}\text { WHC-SD-W112-HC-002, Rev 0, "Hazard Classification } \\
\text { for Project } W-112 \text { Enhanced Radioact ive \& Mixed } \\
\text { Waste Storage Facility Phase V" }\end{array}$ & $6 / 91$ \\
\hline Environmental & $\begin{array}{l}\text { Draft, "EA/FONSI: Sol id Waste Retrieval Complex, } \\
\text { Phase I (W-113), and Enhanced Radioactive and } \\
\text { Mixed Waste Storage Factlity Phase V (W-112)" }\end{array}$ & TBD \\
\hline $\begin{array}{l}\text { Engineering } \\
\text { Studies }\end{array}$ & $\begin{array}{l}\text { WHC-SD-W112-ES-003, Rev 0, "Project W-112, } \\
\text { Enhanced Radioactive and Mixed Waste }- \text { Phase V, } \\
\text { Additional Studies for Project W-112" }\end{array}$ & $1 / 93$ \\
\hline 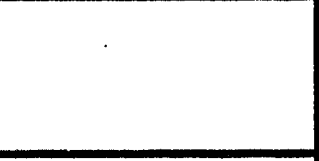 & $\begin{array}{l}\text { WHC-SD-W112-ES-001, Rev 0, "Project W-112 } \\
\text { Enhanced Radioactive \& Mixed Waste Storage Phase } \\
\text { V Engineering Study" }\end{array}$ & $3 / 91$ \\
\hline \multirow[t]{4}{*}{$\begin{array}{l}\text { Technical } \\
\text { Studies } \\
\end{array}$} & $\begin{array}{l}\text { WHC-SD-W112-ES-005, Draft, "Hanford Central Waste } \\
\text { Complex Maintenance Study" }\end{array}$ & TBD \\
\hline & $\begin{array}{l}\text { WHC-SD-W112-ES-004, Rev 0, "Hanford Waste } \\
\text { Vitrification P.1 ant Project Interim Storage } \\
\text { Facility for Hanford Waste Vitrification PIant } \\
\text { Canister Evaluation of Alternatives" }\end{array}$ & $2 / 93$ \\
\hline & $\begin{array}{l}\text { WHC-SD-W112-ER-002, Rev 0, "Witness Simulation } \\
\text { for Project } W-112^{N}\end{array}$ & 9/92 \\
\hline & $\begin{array}{l}\text { WHC-SD-W112-ER-001, Rev 0, "Material Flow } \\
\text { Simulation. Study for the Initial Phase of Phase V } \\
\text { Storage Operations Project W-112" }\end{array}$ & $5 / 92$ \\
\hline
\end{tabular}


WHC-SD-WM-RPT-060, REV 0 VOLUME 4

3.2.6 Special Case' Solid Waste Temporary Storage Factlity (Project W-272)

Table 3-9 presents the baseline documentation for Spectal Case Solid Waste Temporary Storage, Project W-272. The documentation is categorized according to purpose of the document whether it be functional, design, safety analysis, environmental, or engineering.

\begin{tabular}{||l|l|c|}
\hline \multicolumn{1}{|c|}{ Table 3-9. Documentation for Special Case Solid Waste Temporary Storage } \\
Facility, Project W-272
\end{tabular}




$$
\text { WHC-SD-WM-RPT-060, REV } 0 \text { VOLUME } 4
$$

.2.7 Radioactive Mixed Waste Storage (Project W-312)

Table 3-10 presents the basel ine documentation for Radioactive Mixed Waste Storage, Project W-312. The documentation is categorized according to purpose of the document whether it be functional or safety analysis.

\begin{tabular}{|l|l|c|}
\hline \multicolumn{3}{|c|}{ Table 3-10. Documentation for Radioactive Mixed Waste Storage, } \\
Project W-312
\end{tabular}


WHC-SD-WM-RPT-060, REV 0 VOLUME 4

\subsection{PROCESSING}

A listing of documents which the Solid Waste Program has developed or is developing in support of waste processing projects is tabulated below.

\subsubsection{WRAP Module 1 (Project W-026)}

Table 3-11 presents the basel ine documentation for Waste Receiving and Processing Module 1, Project W-026. The documentation is categorized according to purpose of the document whether it be functional, design, planning, technical support, specifications, safety analysis, environmental, permitting or engineering.

Table 3-11. Documentation for Waste Receiving and Processing Module 1, Project $W-026$

\begin{tabular}{|c|c|c|}
\hline Function & Title & Date \\
\hline \multirow[t]{3}{*}{$\begin{array}{l}\text { Functional } \\
\text { Criteria }\end{array}$} & $\begin{array}{l}\text { WHC-SD-W026-FDC-001, Rev 1, "Functional Design } \\
\text { Criteria Waste Receiving and Processing (WRAP) } \\
\text { Facility Module } 1\end{array}$ & $9 / 91$ \\
\hline & $\begin{array}{l}\text { WHC-SD-W026-FDC-001, Rev 0, "Functional Design } \\
\text { Criteria Waste Receiving and Processing (WRAP) } \\
\text { Facility Module } 1\end{array}$ & $9 / 88$ \\
\hline & $\begin{array}{l}\text { SD-WM-TI-291, Rev 0, "Waste Receiving and } \\
\text { Processing (WRAP) Facility Draft Functional } \\
\text { Design Criteria" }\end{array}$ & $3 / 87$ \\
\hline \multirow[t]{3}{*}{$\begin{array}{l}\text { Design } \\
\text { Requirements } \\
\end{array}$} & $\begin{array}{l}\text { WHC-SD-W026-SDRD-001, Rev 2, "Supplemental Design } \\
\text { Requirements Document, Project W-026" }\end{array}$ & $10 / 92$ \\
\hline & $\begin{array}{l}\text { WHC-SD-W026-SDRD-001, Rev 1, "Supplemental Design } \\
\text { Requirements Document, Project W-026" }\end{array}$ & $3 / 92$ \\
\hline & $\begin{array}{l}\text { WHC-SD-W026-SDRD-001, Rev 0, "Supplemental Design } \\
\text { Requirements Document, Project } \mathrm{W}-026 " \text {. }\end{array}$ & $10 / 91$ \\
\hline \multirow[t]{4}{*}{$\begin{array}{l}\text { Design } \\
\text { Reports }\end{array}$} & $\begin{array}{l}\text { UE\&C, Rev 0, "Waste Receiving and Processing } \\
\text { Facility Module I Detailed Design Report" }\end{array}$ & $3 / 93$ \\
\hline & $\begin{array}{l}\text { UE\&C, Rev 0, "Waste Receiving and Processing } \\
\text { Facility Module } 1 \text { Preliminary Design Report" }\end{array}$ & $3 / 92$ \\
\hline & $\begin{array}{l}\text { SD-W026-CDR-001, Rev 0, "Conceptual Design Report } \\
\text { for Project W-026 Waste Receiving and Processing } \\
\text { Facility Module 1" }\end{array}$ & $6 / 89$ \\
\hline & $\begin{array}{l}\text { SD-WM-TI-263, Rev } 0 \text {, "Waste Receiving and } \\
\text { Processing (WRAP) Facility Conceptual Design } \\
\text { Report (CDR)" . }\end{array}$ & $8 / 86$ \\
\hline
\end{tabular}


Table 3-11. Documentation for Waste Receiving and Processing Module 1, Project W-026

\begin{tabular}{|c|c|c|}
\hline Function & Title & Date \\
\hline Planning & $\begin{array}{l}\text { "U. S. Department of Energy Waste Receiving and } \\
\text { Processing Module I W-026 Project Plan" }\end{array}$ & $2 / 92$ \\
\hline \multirow[t]{14}{*}{$\begin{array}{l}\text { Design } \\
\text { Support } \\
\end{array}$} & $\begin{array}{l}\text { WHC-SD-W026-ES-009, Rev 0, "WRAP Module 1, } \\
\text { Characterization and Process Alternat ives Study" }\end{array}$ & $11 / 92$ \\
\hline & $\begin{array}{l}\text { UEaC Preliminary Design Report, Rev 0, "HVAC } \\
\text { Confinement Study" }\end{array}$ & $3 / 92$ \\
\hline & $\begin{array}{l}\text { UE\&C Prel iminary Design Report, Rev 0, "Degree of } \\
\text { Automation within Containment Study" }\end{array}$ & $12 / 91$ \\
\hline & $\begin{array}{l}\text { UEaC Prel iminary Design Report, Rev 0, "Material } \\
\text { Handl ing Opt imization Study" }\end{array}$ & $11 / 91$ \\
\hline & $\begin{array}{l}\text { UEaC Prel iminary Design Report, Rev 0, "Hardware } \\
\text { for Characterization of Waste Study" }\end{array}$ & $10 / 91$ \\
\hline & $\begin{array}{l}\text { UE\&C Prel Iminary Design Report, Rev } 0 \text {, "Waste } \\
\text { Processing Systems Layout \& Configuration Study" }\end{array}$ & $10 / 91$ \\
\hline & $\begin{array}{l}\text { UE\&C Prel iminary Design Report, Rev 0, "Bagless } \\
\text { Transfer System" }\end{array}$ & $9 / 91$ \\
\hline & $\begin{array}{l}\text { UESC Preliminary Design Report, Rev 0, "ALARA } \\
\text { Assessment Study" }\end{array}$ & $9 / 91$ \\
\hline & $\begin{array}{l}\text { UEaC Prel iminary Design Report, Rev 0, "CDR } \\
\text { Technical Assessment" }\end{array}$ & $8 / 91$ \\
\hline & $\begin{array}{l}\text { UE\&C Preliminary Design Report, Rev 0, "83 Gallon } \\
\text { Drum Overpack Study" }\end{array}$ & $8 / 91$ \\
\hline & $\begin{array}{l}\text { UEaC Prel iminary Design Report, Rev 0, "Drum and } \\
\text { Box Lag Storage Study" }\end{array}$ & $8 / 91$ \\
\hline & $\begin{array}{l}\text { UE\&C Preliminary Design Report, Rev 0, "Methods. } \\
\text { of Waste Entry Into Containment" }\end{array}$ & $8 / 91$ \\
\hline & $\begin{array}{l}\text { UE\&C Prel iminary Design Report, Rev 0, } \\
\text { "Compaction Cptimization Study" }\end{array}$ & $8 / 91$. \\
\hline & $\begin{array}{l}\text { UE\&C Preliminary Design Report, Rev 0, "Waste } \\
\text { Minimization Study" }\end{array}$ & $8 / 91$ \\
\hline
\end{tabular}


- WHC-SD-WM-RPT-060, REV 0 VOLUME 4

Table 3-11. Documentation for Waste Receiving and Processing Module 1, Project W-026

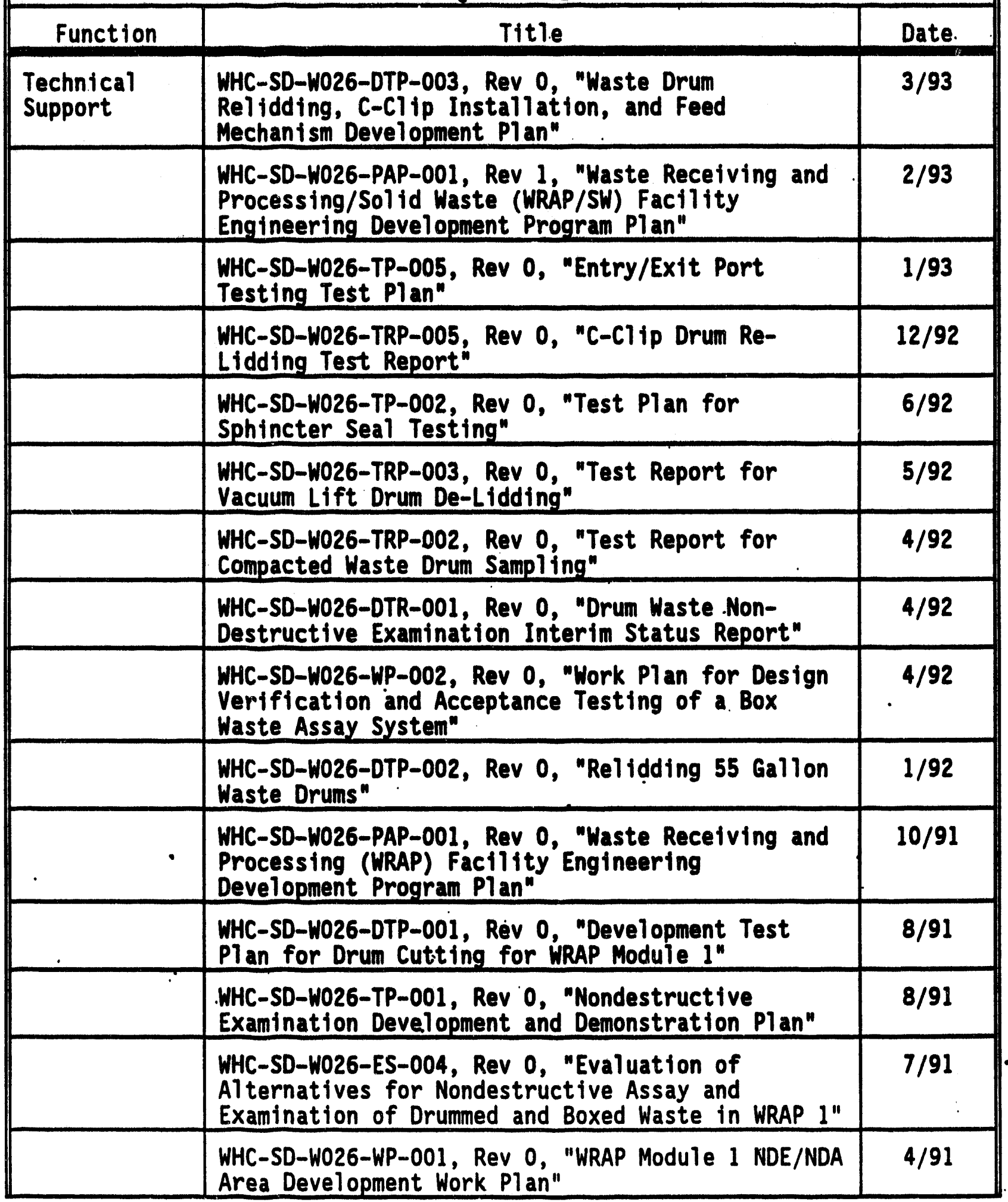


WHC-SD-WM-RPT-060, REV 0 VOLUME 4

\begin{tabular}{|c|c|c|}
\hline Function & Title & Date \\
\hline \multirow[t]{4}{*}{ Speciftcation } & $\begin{array}{l}\text { WHC-S-003, Rev 3, "Specification for Box Waste } \\
\text { Assay System" }\end{array}$ & $9 / 92$ \\
\hline & $\begin{array}{l}\text { WHC-S-003, Rev 2, "Specification for Box Waste } \\
\text { Assay Systen" }\end{array}$ & $11 / 90$ \\
\hline & $\begin{array}{l}\text { WHC-S-003, Rev 1, "Specification for Box Waste } \\
\text { Assay System" }\end{array}$ & $9 / 90$ \\
\hline & $\begin{array}{l}\text { WHC-S-003, Rev 0, "Spectfication for Box Waste } \\
\text { Assay System" }\end{array}$ & $2 / 90$ \\
\hline \multirow[t]{4}{*}{$\begin{array}{l}\text { Safoty } \\
\text { Analysis }\end{array}$} & $\begin{array}{l}\text { WHC-SO-W026-SAR-001, Draft, Rev F-1, "Waste } \\
\text { Receiving and Processing Facility Module 1 (WRAP) } \\
\text { Preliminary Safety Analysis Report" }\end{array}$ & $2 / 93$ \\
\hline & $\begin{array}{l}\text { WHC-SD-W026-PSE-001, Rev 0, "Hazard } \\
\text { Classification and Prel iminary Safety Evaluation } \\
\text { for Waste Receiving and Processing Facility } \\
\text { Module } 1 \text { Project W-026" }\end{array}$ & $5 / 91$ \\
\hline & $\begin{array}{l}\text { WHC-SD-W026-ER-001, Rev 0, "Safety Class } \\
\text { Determination for the Boxed Waste Assay System to } \\
\text { be Installed in the WRAP Facility" }\end{array}$ & $7 / 90$ \\
\hline & $\begin{array}{l}\text { WHC-SD-W026-PSH-001, Rev 0, "Prel iminary Safety } \\
\text { Evaluation for WRAP Module } 1 \text { - Project W-026" }\end{array}$ & $5 / 89$ \\
\hline \multirow[t]{4}{*}{ Environmental } & $\begin{array}{l}\text { DOE/EIS-0113-FS/SA2, "Supplement Analysis of the } \\
\text { Environmental Effects of Changes in DOE's } \\
\text { Proposed Action to Construct and Operate the } \\
\text { Waste Receiving and Processing Facility Module 1" }\end{array}$ & $5 / 93$ \\
\hline & $\begin{array}{l}\text { WHC-SD-W026-TI-005, Rev 0, "Hanford Waste } \\
\text { Receiving and Processing Facil ity Module } 1 \\
\text { Technical Background Document for Best Available } \\
\text { Control Technology for Toxics Demonstration" }\end{array}$ & $3 / 93$ \\
\hline & $\begin{array}{l}\text { WHC-SD-W026-TI-004, Rev 0, "Waste Receiving and } \\
\text { Processing Module i Facility Technical Background } \\
\text { Document for Best Available Radionuclide Control } \\
\text { Technology Demonstration" }\end{array}$ & $3 / 93$ \\
\hline & $\begin{array}{l}\text { DOE/RL-93-15, Rev 0, "Radioactive Air Emissions } \\
\text { Notice of Construction for the Waste Receiving } \\
\text { and Processing Facility" }\end{array}$ & $2 / 93$ \\
\hline
\end{tabular}


WHC-SD-WM-RPT-060, REV 0 VOLUME 4

\begin{tabular}{||l|l|c||}
\hline \multicolumn{2}{|c|}{ Table 3-11. Documentation for Waste Receiving and Processing Module 1, } \\
\hline Project W-026
\end{tabular}




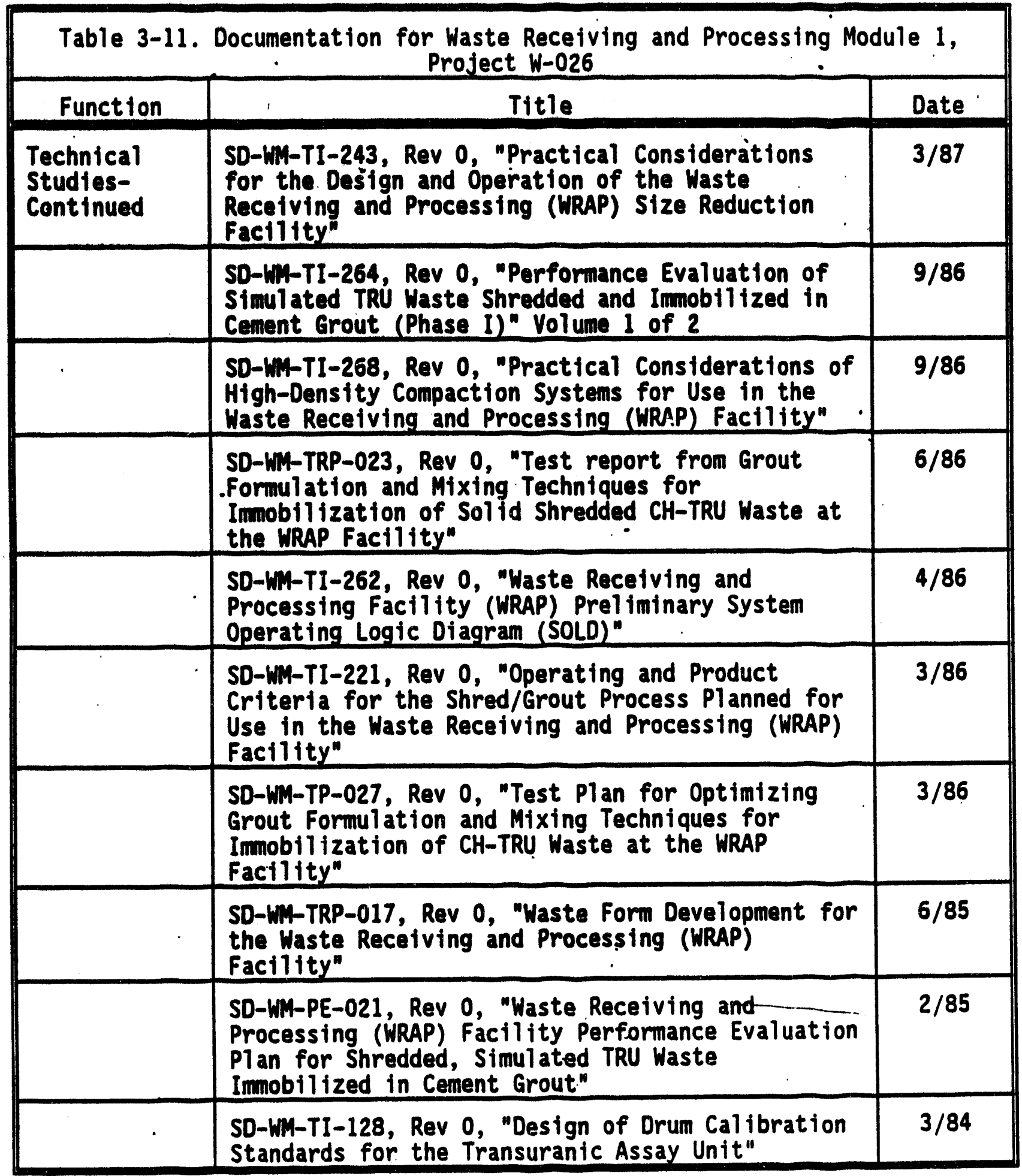




\section{WHC-SD-WM-RPT-060, REV 0 VOLUME 4}

\subsubsection{WRAP Module 2A (Project $W-100$ )}

Table 3-12 presents the baseline documentation for Waste Receiving and Processing Module 2A, Project W-100. The documentation is categorized according to purpose of the document whether it be functional, design, planning, technical support, safety analysis, environmental, or engineering.

\begin{tabular}{|c|c|c|}
\hline Function & Title & Date \\
\hline \multirow[t]{2}{*}{$\begin{array}{l}\text { Functional } \\
\text { Criteria }\end{array}$} & $\begin{array}{l}\text { WHC-SD-W100-FDC-001, Rev 1, "Functional Design } \\
\text { Criteria Project W-ioo Waste Receiving and } \\
\text { Processing (WRAP) Facil ity Module 2A" }\end{array}$ & $7 / 92$ \\
\hline & $\begin{array}{l}\text { WHC-SD-W100-FDC-001, Rev 0, "Functional Design } \\
\text { Criteria Project W-ioo Waste Receiving and } \\
\text { Processing (WRAP) Facil ity Module 2A } \\
\end{array}$ & $1 / 92$ \\
\hline $\begin{array}{l}\text { Design } \\
\text { Requirements }\end{array}$ & $\begin{array}{l}\text { WHC-SD-W100-SDRD-001, Draft, "WRAP Module 2A } \\
\text { Supplemental Design Requirements Document, } \\
\text { Project W-100" }\end{array}$ & TBD \\
\hline \multirow[t]{3}{*}{$\begin{array}{l}\text { Design } \\
\text { Reports }\end{array}$} & $\begin{array}{l}\text { UE\&C, Draft, "Advanced Conceptual Design Report } \\
\text { for Project W-100 Waste Receiving and Processing } \\
\text { Facility Module } 2 A^{\circ} \\
\end{array}$ & TBD \\
\hline & $\begin{array}{l}\text { UE\&C, Rev } 0 \text {, "Conceptual Design Report for } \\
\text { Project W-100 Waste Receiving and Processing } \\
\text { Facility Module } 2 A^{*} \\
\end{array}$ & $7 / 92$ \\
\hline & $\begin{array}{l}\text { SD-WM-TI-263, Rev } 0 \text {, "Waste Receiving and } \\
\text { Processing (WRAP) Facility Conceptual Design } \\
\text { Report (CDR)" }\end{array}$ & $8 / 86$ \\
\hline Plans & $\begin{array}{l}\text { Department of Energy, Draft, "U. S. Department of } \\
\text { Energy Solid Waste Operations Complex (SWOC), } \\
\text { Phase 1 Project 94-D-411 Project Plan" } \\
\end{array}$ & TBD \\
\hline \multirow[t]{2}{*}{$\begin{array}{l}\text { Technical } \\
\text { Support }\end{array}$} & UE\&C 1604-10, Draft, "Process Sampling" & TBD \\
\hline & UERC 1604-6, Draft, "Sludge Repackaging" & TBD \\
\hline . & $\begin{array}{l}\text { UE\&C 1604-5, Draft, "Open/Sort/Size/Reduction } \\
\text { Evaluation" }\end{array}$ & TBD \\
\hline & UE\&C 1604-3, Draft, "Waste Mixing Evaluation" & TBD \\
\hline & $\begin{array}{l}\text { UE\&C 1604-2, Draft, "Waste Form Qualification } \\
\text { Treatability Study Impacts" }\end{array}$ & TBD \\
\hline
\end{tabular}


Table 3-12. Documentation for Waste Receiving and Processing Module 2A, Project W-100

\begin{tabular}{|c|c|c|}
\hline Function & Title & Date \\
\hline $\begin{array}{l}\text { Technical } \\
\text { Support- } \\
\text { Continued }\end{array}$ & UE\&C 1604-1, Draft, "Single Immobilization" & - TBD \\
\hline & $\begin{array}{l}\text { WHC-SD-W100-TP-006, Draft, "Rotary Shredder Test } \\
\text { P1an" }\end{array}$ & TBD \\
\hline & $\begin{array}{l}\text { WHC-SD-W100-TP-004, Draft, "WRAP 2A Thermosetting } \\
\text { Polymer Waste Form Test PI an" }\end{array}$ & TBD \\
\hline & $\begin{array}{l}\text { UE\&C, Rev 0, "WRAP } 2 \text { Pre-conceptual Design, } \\
\text { Additional Follow-on Activities" }\end{array}$ & $4 / 93$ \\
\hline & $\begin{array}{l}\text { WHC-SD-W100-TI-003, Rev 0, "WRAP Module 2A Waste } \\
\text { Form Qual ification Status Report" }\end{array}$ & $4 / 93$ \\
\hline & $\begin{array}{l}\text { WHC-SD-W100-TP-003, Rev 0, "WRAP 2A Mixing } \\
\text { Equipment" }\end{array}$ & $3 / 93$ \\
\hline & $\begin{array}{l}\text { WHC-SD-W100-TP-002, Rev 0, "Waste Receiving and } \\
\text { Processing - Waste Form Qualification Plan" }\end{array}$ & $2 / 93$ \\
\hline & $\begin{array}{l}\text { WHC-SD-W100-LL-001, Rev 0, "Review of Cement- } \\
\text { Based Immobilization Processes at DOE Sites" }\end{array}$ & $2 / 93$ \\
\hline & $\begin{array}{l}\text { WHC-SD-W026-PAP-001, Rev 1, "Waste Receiving and } \\
\text { Processing/Solid Waste (WRAP/SW) Facility } \\
\text { Engineering Development Program Plan" }\end{array}$ & $2 / 93$ \\
\hline & $\begin{array}{l}\text { WHC-SD-W100-WP-002, Rev } 1 \text {, "Cement Immobilization } \\
\text { Technology Work Plan Waste Qual ification Testing" }\end{array}$ & $2 / 93$ \\
\hline & $\begin{array}{l}\text { WHC-SD-W100-TI-004, Rev 0, "Chemistry of the WRAP } \\
2 A \text { Polymer Immobilization Study" }\end{array}$ & $1 / 93$ \\
\hline . & $\begin{array}{l}\text { WHC-SD-W100-TA-002, Rev 0, "Special Wastes } \\
\text { Treatment Development and Demonstration } \\
\text { Requirements" }\end{array}$ & $1 / 93$ \\
\hline & $\begin{array}{l}\text { WHC-SD-W100-WP-002, Rev 0, "Cement Immobilization } \\
\text { Technology Work Plan Waste Qual ification Testing" }\end{array}$ & $12 / 92$ \\
\hline & $\begin{array}{l}\text { WHC-SD-W100-TI-002, Rev } 0 \text {, "Waste Water } \\
\text { Generation for WRAP 2A" }\end{array}$ & $3 / 92$ \\
\hline & $\begin{array}{l}\text { WHC-SD-W100-TP-001, Rev 0, "WRAP 2A Polymer } \\
\text { Immobilization Technology Demonstration Test } \\
\text { Plan" }\end{array}$ & $2 / 92$ \\
\hline
\end{tabular}


WHC-SD-WM-RPT-060, REV 0 VOLUME 4

Table 3-12. Documentation for Waste Receiving and Processing Module 2A, Project $W-100$

\begin{tabular}{|c|c|c|}
\hline Function & Title & Date \\
\hline $\begin{array}{l}\text { Technical } \\
\text { Support- } \\
\text { Continued }\end{array}$ & $\begin{array}{l}\text { WHC-SD-W026-PAP-O01, Rev 0, "Waste Receiving and } \\
\text { Processing (WRAP) Facil ity Engineering } \\
\text { Development Program Plan" }\end{array}$ & $10 / 91$ \\
\hline \multirow[t]{3}{*}{$\begin{array}{l}\text { Safety } \\
\text { Analysis }\end{array}$} & $\begin{array}{l}\text { WHC-SD-W100-PSE-002, Rev 0., "Hazard } \\
\text { Classification and Preliminary Safety Evaluation } \\
\text { for Waste Receiving and Processing Facil ity } \\
\text { Module } 2 A \text { Project W-100" }\end{array}$ & $8 / 92$ \\
\hline & $\begin{array}{l}\text { WHC-SD-W100-PSE-001, Rev 0, "Hazard } \\
\text { Classification and Prel iminary Safety Evaluation } \\
\text { for Waste Receiving and Processing (WRAP) Module } \\
\text { II" }\end{array}$ & $11 / 91$ \\
\hline & $\begin{array}{l}\text { WHC-SD-W100-PSH-001, Rev 0, "Prel iminary Safety } \\
\text { Evaluation for WRAP Module 2A - Project W-100" }\end{array}$ & $2 / 89$ \\
\hline Environmental & $\begin{array}{l}\text { TBD, Draft, "Analysis of the Environmental } \\
\text { Effects of the Waste Receiving and Processing } \\
\text { Facility Module 2A (WRAP 2A)" }\end{array}$ & TBD \\
\hline \multirow[t]{2}{*}{$\begin{array}{l}\text { Engineering } \\
\text { Studies }\end{array}$} & $\begin{array}{l}\text { SD-W100-ES-001, Rev 0, "Engineering Study for } \\
\text { Waste Receiving and Processing (WRAP) Facility } \\
\text { Module 2" }\end{array}$ & $3 / 90$ \\
\hline & $\begin{array}{l}\text { SD-RE-ES-017, Rev } 1 \text {, "Waste Receiving and } \\
\text { Processing (WRAP) Facility Engineering Study" }\end{array}$ & $9 / 85$ \\
\hline \multirow[t]{5}{*}{$\begin{array}{l}\text { Technical } \\
\text { Studies }\end{array}$} & $\begin{array}{l}\text { WHC-SD-WM-ES-108, Draft, "WRAP Decontamination \& } \\
\text { Repairs Options" }\end{array}$ & TBD \\
\hline & $\begin{array}{l}\text { WHC-SD-W100-TA-001, Rev 0, "Suitability of WRAP } \\
2 A \text { for Treatment of Sol id Contact-Handled Low } \\
\text { Level Category } 3 \text { Waste" }\end{array}$ & $11 / 93$ \\
\hline & $\begin{array}{l}\text { WHC-SD-W100-ES-005, Rev 0, "Strategy Assessment } \\
\text { for Project W-100 Waste Receiving and Processing } \\
\text { Module 2" }\end{array}$ & $11 / 91$ \\
\hline & $\begin{array}{l}\text { WHC-SD-W100-ES-003, Rev 0, WRAP Potential Waste } \\
\text { Feed Streams from Factlity Closures \& HWVP } \\
\text { Project Operation" }\end{array}$ & $10 / 91$ \\
\hline & $\begin{array}{l}\text { WHC-SD-W100-ES-004, Rev } 0 \text {, "Application of } \\
\text { Thermal Processing in WRAP 2" }\end{array}$ & $10 / 91$ \\
\hline
\end{tabular}


Table 3-12. Documentation for Waste Recieiving and Processing Module 2A, Project $W-100$

\begin{tabular}{|c|c|c|}
\hline Function & Title & Date \\
\hline \multirow{10}{*}{$\begin{array}{l}\text { Technical } \\
\text { Studies- } \\
\text { Continued } \\
\end{array}$} & $\begin{array}{l}\text { WHC-SD-W100-DP-001, Rev 0, "WRAP } 2 \text { Radiological } \\
\text { Inventories" }\end{array}$ & . $7 / 91$ \\
\hline & $\begin{array}{l}\text { SD-WM-TI-265, Rev 0, "Performance Evaluation of } \\
\text { Simulated TRU Waste Shredded and Immobilized in } \\
\text { Cement Grout (Phase II) "Volume } 2 \text { of } 2\end{array}$ & $9 / 88$ \\
\hline & $\begin{array}{l}\text { SD-WM-TI-243, Rev 0, "Practical Considerations } \\
\text { for the Design and Operation of the Waste } \\
\text { Receiving and Processing (WRAP) Size Reduction } \\
\text { Factilty" }\end{array}$ & $3 / 87$ \\
\hline & $\begin{array}{l}\text { SD-WM-TI-264, Rev 0, "Performance Evaluation of } \\
\text { Simulated TRU Waste Shredded and Immobilized in } \\
\text { Cament Grout (Phase I)" Volume } 1 \text { of } 2\end{array}$ & $9 / 86$ \\
\hline & $\begin{array}{l}\text { SD-WM-TI-268, Rev 0, "Practical Considerations of } \\
\text { High-Density Compaction Systems for Use in the } \\
\text { Waste Receiving and Processing (WRAP) Facility" }\end{array}$ & $9 / 86$ \\
\hline & $\begin{array}{l}\text { SD-WM-TI-262, Rev 0, "Waste Receiving and } \\
\text { Processing Facility (WRAP) Prel iminary System } \\
\text { Operating Logic Diagram (SOLD)" }\end{array}$ & $4 / 86$ \\
\hline & $\begin{array}{l}\text { SD-WM-TI-221, Rev 0, "Operating and Product } \\
\text { Criteria for the Shred/Grout Process Planned for } \\
\text { Use in the Waste Receiving and Processing (WRAP) } \\
\text { Factlity" }\end{array}$ & $3 / 86$ \\
\hline & $\begin{array}{l}\text { SD-WM-TP-027, Rev 0, "Test Plan for Optimizing } \\
\text { Grout Formulation and Mixing Techniques for } \\
\text { Immobilization of CH-TRU Waste at the WRAP } \\
\text { Faclitity" }\end{array}$ & $3 / 86$ \\
\hline & $\begin{array}{l}\text { SD-MM-TRP-023, Rev 0, "Test report from Grout } \\
\text { Formulation and Mixing Techniques for } \\
\text { Immobilization of Solid Shredded CH-TRU Waste at } \\
\text { the WRAP Factifity" }\end{array}$ & $6 / 86$ \\
\hline & $\begin{array}{l}\text { SD-WM-TRP-017, Rev 0, "Waste Form Development for } \\
\text { the Waste Receiving and Processing (WRAP) } \\
\text { Facility" }\end{array}$ & $6 / 85$ \\
\hline $\begin{array}{l}\text { Technical } \\
\text { Studies- } \\
\text { Continued }\end{array}$ & $\begin{array}{l}\text { SD-WM-PE-021, Rev 0, "Waste Receiving and } \\
\text { Processing (WRAP) Facility Performance Evaluation } \\
\text { Plan for Shredded, Simulated TRU Waste } \\
\text { Immobilized in Cement Grout" }\end{array}$ & $2 / 85$ \\
\hline
\end{tabular}


WHC-SD-WM-T.PT-060, REV 0 VOLUME 4.

\subsubsection{WRAP Module 2B (Project W-255)}

Table 3-13 presents the baseline documentation for Waste Receiving and Processing Module 2B, Project W-255. The documentation is categorized according to purpose of the document whether it be technical support, engineering or technical studies.

\begin{tabular}{||c|l|c|c||}
\hline \multicolumn{2}{||c|}{ Table 3-13. Documentation for Waste Receiving and Processing Module 2B, } \\
\hline Project W-255
\end{tabular}


WHC-SD-WM-RPT-060, REV 0 VOLUME 4

Table 3-13. Documentation for Waste Receiving and Processing Module 2B, Project W-255

\begin{tabular}{|c|c|c|}
\hline Function & Title & Date \\
\hline \multirow[t]{5}{*}{$\begin{array}{l}\text { Technical } \\
\text { Studies - } \\
\text { Continued }\end{array}$} & $\begin{array}{l}\text { SD-WM-TRP-023, Rev 0, "Test report from Grout } \\
\text { Formulation and Mixing Techniques for } \\
\text { Immobilization of Solid Shredded CH-TRU Waste at } \\
\text { the WRAP Factlity" }\end{array}$ & $6 / 86$ \\
\hline & $\begin{array}{l}\text { SD-WM-TI-262, Rev 0, "Waste Recelving and } \\
\text { Processing Factlity (WRAP) Prel iminary System } \\
\text { Operating Logic Diagram (SOLD)" }\end{array}$ & $.4 / 86$ \\
\hline & $\begin{array}{l}\text { SD-WM-TI-221, Rev 0, "Operating and Product } \\
\text { Criteria for the Shred/Grout Process Planned for } \\
\text { Use in the Waste Receiving and Processing (WRAP) } \\
\text { Facility" }\end{array}$ & $3 / 86$ \\
\hline & $\begin{array}{l}\text { SD-WM-TP-027, Rev 0, "Test Plan for Optimizing } \\
\text { Grout Formulation and MIxing Techniques for } \\
\text { Immobilization of CH-TRU Waste at the WRAP } \\
\text { Facility" }\end{array}$ & $3 / 86$ \\
\hline & $\begin{array}{l}\text { SD-WM-TRP-017, Rev 0, "Waste Form Development for } \\
\text { the Waste Receiving and Processing (WRAP) } \\
\text { Facility" }\end{array}$ & $6 / 85$ \\
\hline & $\begin{array}{l}\text { SD-WM-PE-021, Rev 0, "Waste Receiving and } \\
\text { Processing (WRAP) Facility Performance Evaluation } \\
\text { Plan for Shredded, Simulated TRU Waste } \\
\text { Inmobilized in Cement Grout" }\end{array}$ & $2 / 85$ \\
\hline
\end{tabular}


WHC-SD-WM-RPT-060, REV 0 VOLUME 4

\subsubsection{Thermal Treatment Facility (Project W-242)}

Table 3-14 presents the baseline documentation for Thermal Treatment Facility, Project W-242. The documentation is categorized according to purpose of the document whether it be functional, technical support, safety analysis, or engineering.

\begin{tabular}{||l|l|c|}
\hline \multicolumn{1}{|c|}{ Table 3-14. Documentation for Thermal Treatment Facility, Project W-242 } \\
\hline Function & \multicolumn{1}{|c|}{ Title } & Date \\
\hline $\begin{array}{l}\text { Functional } \\
\text { Criteria }\end{array}$ & $\begin{array}{l}\text { WHC-SD-W242-FDC-001, Draft, "Functional Design } \\
\text { Criteria, Thermal Treatment Facility, Project W- } \\
\text { 242" }\end{array}$ & TBD \\
\hline $\begin{array}{l}\text { Safety } \\
\text { Analysis }\end{array}$ & $\begin{array}{l}\text { WHC-SD-W242-HC-001, Draft, "Hazard Classification } \\
\text { for the Thermal Treatment Facility, Project W242" }\end{array}$ & TBD \\
\hline $\begin{array}{l}\text { Engineering } \\
\text { Study }\end{array}$ & $\begin{array}{l}\text { WHC-SD-W242-ES-001, Draft, "Hanford Site-Specific } \\
\text { Engineering Study for the W-242 Thermal Treatment } \\
\text { Facility" }\end{array}$ & TBD \\
\hline $\begin{array}{l}\text { Technical } \\
\text { Study }\end{array}$ & $\begin{array}{l}\text { SAIC-91/1278, "Assessment of High Temperature } \\
\text { Thermal Treatment Alternatives for Inclusion into } \\
\text { the Scope of the Hanford Waste Receiving and } \\
\text { Processing (WRAP) Facility" }\end{array}$ & $10 / 91$ \\
\hline
\end{tabular}


WHC-SD-WM-RPT-060, REV 0 VOLUME 4

\subsection{DISPOSAL}

A listing of documents which the Solid Waste Program has developed or is developing in support of its disposal facilities and projects is tabulated below.

\subsubsection{Low-Level Waste Burial Grounds}

Table 3-15 presents the basel ine documentation for Low-Level Waste Burial Grounds. The documentation is categorized according to purpose of the document whether it be permitting or safety analysis related.

\begin{tabular}{|c|c|c|}
\hline Function & Title & Date \\
\hline \multirow[t]{6}{*}{$\begin{array}{l}\text { Safety } \\
\text { Analysis }\end{array}$} & $\begin{array}{l}\text { WHC-SD-WM-SAR-053, Draft, "Low-Level Burial } \\
\text { Grounds Safety Analysis Report" }\end{array}$ & TBD \\
\hline & $\begin{array}{l}\text { WHC-SD-WM-SAR-038, Addendum 6, Draft, "Final } \\
\text { Safety Analysis for Contact-Handled Transuranic } \\
\text { Unvented Waste Drum and Box In-Situ Inspection } \\
\text { and Unvented Drum Retrieval" }\end{array}$ & TBD \\
\hline & $\begin{array}{l}\text { WHC-SD-WM-SAR-038, Addendum 4, Draft, "FinaL } \\
\text { Safety Analysis for Contact-Handled, Transuranic } \\
\text { Wastes Drum In-Situ Inspection and Vented Drum } \\
\text { Retrieval" }\end{array}$ & TBD \\
\hline & $\begin{array}{l}\text { WHC-SD-WM-SAR-047, Rev 0, "Retrieval Storage of } \\
\text { Irradiated Fuels in the Solid Waste Burial } \\
\text { Grounds" }\end{array}$ & $7 / 92$ \\
\hline & $\begin{array}{l}\text { WHC-SD-WM-SAR-038, ECN 106628, Rev 0, } \\
\text { "Shippingport Reactor Pressure Vessel Burial" }\end{array}$ & $3 / 89$ \\
\hline & $\begin{array}{l}\text { WHC-SD-WM-SAR-038, Rev 0, "Active and Retired } \\
\text { Radioactive Sol id Waste Burial Grounds Safety } \\
\text { Analysis Report" }\end{array}$ & $3 / 84$ \\
\hline Permit & $\begin{array}{l}\text { DOE/RL-88-20, Rev 0, "Low-Level Burial Grounds } \\
\text { Dangerous Waste Permit Application" }\end{array}$ & $12 / 89$ \\
\hline
\end{tabular}


WHC-SD-WM-RPT-060, REV 0 VOLUME 4

3.4.2 Low-Level Mixed Waste Disposal. (Project W-025)

Table 3-16 presents the baseline documentation for Low-Level Mixed Waste Disposal, Project $W-025$. The documentation is categorized according to purpose of the document whether it be functional, design, technical support, specifications, safety analysis, environmental, or engineering.

\begin{tabular}{|c|c|c|}
\hline Function & Title & Date \\
\hline \multirow[t]{2}{*}{$\begin{array}{l}\text { Functional } \\
\text { Criteria } \\
\end{array}$} & $\begin{array}{l}\text { WHC-SD-W025-FDC-001, Rev 1, "Functional Design } \\
\text { Criteria Interim Ruw Disposal Facility" }\end{array}$ & $4 / 88$ \\
\hline & $\begin{array}{l}\text { WHC-SD-W025-FDC-001, Rev 0, "Functional Design } \\
\text { Criteria Interim RMin Disposal Factlity" }\end{array}$ & $11 / 87$ \\
\hline \multirow[t]{2}{*}{$\begin{array}{l}\text { Design } \\
\text { Reports }\end{array}$} & $\begin{array}{l}\text { WHC-SD-W025-FDR-001, Rev 0, "Design Report } \\
\text { Project W-025 Radioactive Mixed Waste (RMW) Land } \\
\text { Disposal Facility Non-Drag-0ff" }\end{array}$ & $8 / 90$ \\
\hline & $\begin{array}{l}\text { WHC-SD-W025-CDR-001, Rev 0, "Conceptual Design } \\
\text { Report for Radioactive Mixed Waste Disposal } \\
\text { Facility" }\end{array}$ & $8 / 88$ \\
\hline \multirow[t]{3}{*}{$\begin{array}{l}\text { Technical } \\
\text { Support }\end{array}$} & $\begin{array}{l}\text { WHC-SD-W025-ATP-001, Rev 0, "W-025, Acceptance } \\
\text { Test Procedure" }\end{array}$ & $8 / 92$ \\
\hline & $\begin{array}{l}\text { WHC-SD-WO25-TRP-001, Rev 0, "Geosynthetic } \\
\text { Liner/Leachate Compatibility Testing in Support } \\
\text { of Project W-025 Radioactive Mixed Waste Land } \\
\text { Disposal Facility" }\end{array}$ & $10 / 91$ \\
\hline & $\begin{array}{l}\text { WHC-SD-W025-ER-001, Rev 0, "Alternate Operational } \\
\text { Backfill Material Study for W-025 Landfil1" }\end{array}$ & $10 / 91$ \\
\hline Specification & $\begin{array}{l}\text { WHC-S-045, Rev 0, "Material Specifications and } \\
\text { Construction Requirements for the Radioactive } \\
\text { Mixed Haste Land Disposal Facility Non-Drag-Off" }\end{array}$ & $? ? ?$ \\
\hline \multirow[t]{2}{*}{$\begin{array}{l}\text { Safety } \\
\text { Analysis } \\
\end{array}$} & $\begin{array}{l}\text { WHC-SD-WM-SAR-053, Draft, "Low-Level Burtal } \\
\text { Grounds Safety Analysis Report" }\end{array}$ & TBD \\
\hline & $\begin{array}{l}\text { WHC-SD-W025-PSAR-001, Rev O, "Mixed Waste Lined } \\
\text { Landfil1 (Project W025) Prei iminary Safety } \\
\text { Analysis Report" }\end{array}$ & $5 / 92$ \\
\hline Environmental & $\begin{array}{l}\text { Draft, "Disposal of. Waste in Low-Level Burial } \\
\text { Grounds (W025) }\end{array}$ & $? ? ?$ \\
\hline $\begin{array}{l}\text { Engineering } \\
\text { Study. }\end{array}$ & $\begin{array}{l}\text { WhC-SD-WM-ES-094, Rev 0, "Engineering Study for } \\
\text { Interim Radioactive Mixed Waste (RMW) Disposal. } \\
\text { Facility Leachate Control System" }\end{array}$ & $1 / 88^{\circ}$ \\
\hline
\end{tabular}


WHC-SD-MN-RPT-060, REV O VOLUAE- 4

\begin{tabular}{|c|c|c|}
\hline Function & Title & Date \\
\hline \multirow[t]{5}{*}{$\begin{array}{l}\text { Technical } \\
\text { Studies }\end{array}$} & $\begin{array}{l}\text { WHC-SD-W025-AP-001, Rev } 1 \text {, "Response Action P1 an } \\
\text { Project W-025 Landfi11, Hanford Site, Washington" }\end{array}$ & $3 / 93$ \\
\hline & $\begin{array}{l}\text { WHC-SD-W025-AP-001, Rev O, "Response Action Plan } \\
\text { Project W-025 Landfill, Hanford S1te, Washington" }\end{array}$ & $? ? ?$ \\
\hline & $\begin{array}{l}\text { WHC-SD-W025-PO-001, Rev 0, "L/ner Performance } \\
\text { Operating Life Study Project W-025 Landfili" }\end{array}$ & $10 / 91$ \\
\hline & $\begin{array}{l}\text { WHC-SD-W025-SE-001, Rev 0, "Stte Investigation } \\
\text { Report Mon-Drag-0ff Landfil1 Stte Low-Level } \\
\text { Burtal Area Mo. } 5 \text { West Area" }\end{array}$ & $7 / 90$ \\
\hline & $\begin{array}{l}\text { WHC-SD-W025-DRR-001, Rev 0, "Project w025 } \\
\text { Functional Design Criterta Design Review Report" }\end{array}$ & $3 / 88$ \\
\hline
\end{tabular}




\section{.3 .5 GENERAL}

3.5.1 Infrastructure Support Systems for Solid Waste Management Operations in the 200 Areas (Project W-157)

Tabie 3-17 presents the baseline documentation for Infrastructure Support for Solid Waste Management Operations in the 200 Areas, Project H-157. The documentation is categorized according to purpose of the document whether it be functional, design, planning, technical support, safety analysis, environmental, or engineering.

Table 3-17. Documentation for Infrastructure Support Systems for Solid Waste Management Operations in the 200 Areas, Project W-157

\begin{tabular}{|c|c|c|}
\hline Function & Title & Date \\
\hline $\begin{array}{l}\text { Functional } \\
\text { Criteria }\end{array}$ & $\begin{array}{l}\text { WHC-SD-W112-FDC-001, Rev } 1 \text {, "Functional Design } \\
\text { Criteria for Project W-112 Enhanced Radioactive a } \\
\text { Mixed Waste Storage Phase V" }\end{array}$ & $3 / 92$ \\
\hline $\begin{array}{l}\text { Design } \\
\text { Requirements }\end{array}$ & $\begin{array}{l}\text { WHC-SD-W112-SDRD-001, Draft, "Supplemental Design } \\
\text { Requirements Document Enhanced Radioactive \& } \\
\text { Mixed Waste Storage Phase V" }\end{array}$ & TBD \\
\hline $\begin{array}{l}\text { Design } \\
\text { Reports }\end{array}$ & $\begin{array}{l}\text { WHC-SD-W112-ACOR-001, Draft, "Advanced Conceptual } \\
\text { Design Report for Project W-112 Enhanced } \\
\text { Radioactive \& Mixed Waste Storage Phase V" }\end{array}$ & TBD \\
\hline & $\begin{array}{l}\text { WHC-SD-W112-CDR-001, Rev } 0 \text {, "Conceptual Design } \\
\text { Report for Project W-112 Enhanced Radioactive \& } \\
\text { Mixed Waste Storage Phase } V "\end{array}$ & $6 / 92$ \\
\hline Plans & $\begin{array}{l}\text { Department of Energy, Draft, "U. S. Department of } \\
\text { Energy Sol id Waste Operat fons Complex (SWOC), } \\
\text { Phase } 1 \text { Project } 94-0-411 \text { Project Plan" }\end{array}$ & TBD \\
\hline $\begin{array}{l}\text { Safety } \\
\text { Analysis }\end{array}$ & $\begin{array}{l}\text { WHC-SD-W112-PSAR-001, Oraft, "Enhanced } \\
\text { Radioactive \& Mixed Waste Storage Phase V } \\
\text { Preliminary Safety Analysis Report" }\end{array}$ & TBD \\
\hline$\cdot$ & $\begin{array}{l}\text { WHC-SD-W112-PSE-001, Rev } 0 \text {, "Prel iminary Safety } \\
\text { Evaluation for Project W-112 Enhanced Radioact ive } \\
\text { \& Mixed Waste Storage Phase V" }\end{array}$ & $11 / 91$ \\
\hline Environmental & $\begin{array}{l}\text { Draft, "EA/FONSI: Sol id Waste Retrieval Complex, } \\
\text { Phase I (W-113), and Enhanced Radioactive and } \\
\text { Mixed Waste Storage Facility Phase } V(W-112) " \\
\end{array}$ & TBD \\
\hline $\begin{array}{l}\text { Technical } \\
\text { Study }\end{array}$ & $\begin{array}{l}\text { WHC-SD-W112-ES-005, Draft, "Hanford Central Waste } \\
\text { Complex Maintenance Facility Study" }\end{array}$ & TBD \\
\hline
\end{tabular}


WHC-SD-MM-RPT-060, REV O. VOLUME 4

3.5.2. Central Waste Support Complex (Project W-244)

Table 3-18. presents the baseline documentation for Central Waste Support Complex, Project W-244. The documentation is categorized according to purpose of the document whether it be functional, design, planning, technical support, safety analysis, environmental, or engineering.

\begin{tabular}{|c|c|c|}
\hline Function & Title & Date \\
\hline \multirow[t]{3}{*}{$\begin{array}{l}\text { Functional } \\
\text { Criteria }\end{array}$} & $\begin{array}{l}\text { WHC-SO-W112-FDC-001, Rov } 1 \text {, "Funct tonal Design } \\
\text { Criterta for Project W-112 Enhanced Radioactive \& } \\
\text { Mixed Waste Storage Phase V" }\end{array}$ & $3 / 92$ \\
\hline & $\begin{array}{l}\text { WHC-SD-W244-FDC-001, Rev 0, "Functional Design } \\
\text { Criterta for Project W-244 Central Waste Support } \\
\text { Complex" }\end{array}$ & $1 / 92$ \\
\hline & $\begin{array}{l}\text { WHC-SD-W114-FDC-001, Rev 0, "Functional Design } \\
\text { Criteria - Hanford Central Waste Complex Support } \\
\text { Factlity" }\end{array}$ & $7 / 91$ \\
\hline $\begin{array}{l}\text { Design } \\
\text { Requitrenents }\end{array}$ & $\begin{array}{l}\text { WHC-SD-W112-SDRD-001, Draft, "Supplemental Design } \\
\text { Requirements Document Enhanced Radioactive \& } \\
\text { Mixed Waste Storage Phase V" }\end{array}$ & TBD \\
\hline \multirow[t]{2}{*}{$\begin{array}{l}\text { Design } \\
\text { Reports } \\
\end{array}$} & $\begin{array}{l}\text { WHC-SD-W112-ACDR-001, Draft, "Advanced Conceptual } \\
\text { Design Report for Project W-112 Enhanced } \\
\text { Radtoactive \& Mixed Waste Storage Phase V" }\end{array}$ & TBD \\
\hline & $\begin{array}{l}\text { WHC-SD-W112-CDR-001, Rev 0, "Conceptual Design } \\
\text { Report for Project W-112 Enhanced Radioactive \& } \\
\text { Mixed Waste Storage Phase V" }\end{array}$ & $6 / 92$ \\
\hline Planning & $\begin{array}{l}\text { Department of Energy, Draft; "U. S. Department of } \\
\text { Energy Sol id Waste Operations Complex (SWOC), } \\
\text { Phase } 1 \text { Project } 94-0-411 \text { Project P1 an" }\end{array}$ & TBD \\
\hline \multirow[t]{2}{*}{$\begin{array}{l}\text { Safety } \\
\text { Analysis }\end{array}$} & $\begin{array}{l}\text { WHC-SD-W112-PSAR-001, Draft, "Enhanced } \\
\text { Radioactive \& MHxed Waste Storage Phase V } \\
\text { Preliminary Safety Analysis Report" }\end{array}$ & TBD \\
\hline & $\begin{array}{l}\text { WHC-SD-W112-PSE-001, Rev 0, "Prel Iminary Safety } \\
\text { Evaluation for Project W-112 Enhanced Radioactive } \\
\text { \& Mixed Waste Storage Phase V" }\end{array}$ & $11 / 91$ \\
\hline Environmental & $\begin{array}{l}\text { Draft, "EA/FONSI: Solid Waste Retrieval Complex, } \\
\text { Phase I (W-113), and Enhanced Radioactive and } \\
\text { Mixed Waste Storage Factlity Phase V (W-112)" }\end{array}$ & TBD \\
\hline
\end{tabular}


WHC-SD-WM-RPT-060, REV ' 0 VOLUME 4

Table 3-18. Documentation for Central Waste Support Complex, Project W-244

\begin{tabular}{||l|l|c|}
\hline \multicolumn{1}{|c|}{ Function } & \multicolumn{1}{|c|}{ Title } & Date \\
\hline $\begin{array}{l}\text { Engineering } \\
\text { Study }\end{array}$ & $\begin{array}{l}\text { WHC-SD-W114-ES-001, Rev 0, "Engineering Study } \\
\text { Hanford Central Waste Support Complex" }\end{array}$ & $12 / 90$ \\
\hline $\begin{array}{l}\text { Technical } \\
\text { Study }\end{array}$ & $\begin{array}{l}\text { WHC-SD-W112-ES-005, Draft, "Hanford Central Waste } \\
\text { Complex Maintenance Facility Study" }\end{array}$ & TBD \\
\hline
\end{tabular}


WHC-SD-WM-RPT-060, REV 0

Solid Waste Program

Technical Baseline Description

Volume 5: Facility and Project Bases 
Table of Contents

1.0 INTRODUCTION

1.1 PURPOSE

1.2 SCOPE

1.3 BACKGROUND

1.3.1 Generation

1.3.2 Retrieval

1.3.3 Storage

1.3.4 Treatment

1.3.5 Disposal

1.4 SOLIO WASTE MANAGEMENT STRATEGY $\ldots \ldots$

2.0 RETRIEVAL FACILITIES AND PROJECTS . . . . . . . . . . . . 4

2.1 SOLID WASTE RETRIEVAL, PHASE $1 \ldots \ldots$.......... 4

2.1.1 Project Identification ............. 4

2.1.2 Project Scope .................. 6

2.1.2.1 Waste Types .............. 6

2.1.2.2 Interfaces ............ 8

2.1.2.2:1 Facilities . . . . . . . 8

2.1.2.2.2. Vehicles . . . . . . . . 8

2.1.2.2.3 Containers .......... 9

2.1.2.3 Project Size . . . . . . . . . . . . . 9

2.1.2.4 Project Schedule ........... 18

2.1.2.5 Retrieval Rate .............. 18

2.1.2.6 Facility Expansion .......... 20

2.1.3 Project Functions ................. 20

2.1.3.1 Waste Characterization ......... 20

2.1.3.2 Excavation of Trench .......... 20

2.1.3.3 Waste Handling ............ 22

2.1.3.3.1 Crane ............ 22

2.1.3.3.2 Forklift . . . . . . . . . 22

2.1.3.3.3 Drums .............. 22

2.1.3.3.4 Boxes .............. 23

2.1.3.3.5 Oversize Drums .......... 23

2.1.3.3.6 Overpacks ............. 23

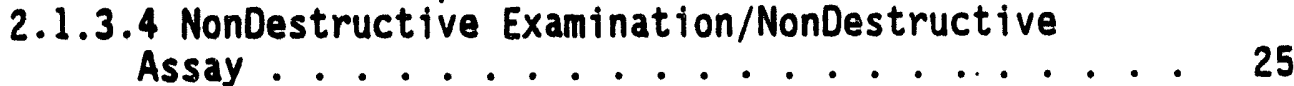

2.1.3.5 Transportation ........... . 26

2.1 .4 Project Requirements .............. 27

2.2 SOLID WASTE RETRIEVAL, PHASE $2 \ldots \ldots$

2.2.1 Project Identification ............. 33

2.2.2 Project Scope . . . . . . . . . . . . 33

2.2.3 Project Functions ............... 33

2.2.4 Project Requirements .............. 33

2.3 ALPHA CAISSON RETRIEVAL . . . . . . . . . . . . . . 34

2.3.1 Project Identification ............. 34

2.3.2 Project Scope . . . . . . . . . . . . . . . . 34

2.3.3 Project Functions ................ . . 34

2.3 .4 Project Requirements .............. 34 
WHC-SD-WM-RPT-060, REV 0 VOLUME 5

Table of Contents (Continued)

3.0 STORAGE FACILITIES AND PROJECTS . . . . . . . . . . . . 35

3.1 HANFORD CENTRAL WASTE COMPLEX - RADIOACTIVE MIXED WASTE

STORAGE FACILITY . . . . . . . . . . . . 35

3.1.1 Mixed-Waste Storage Buildings . . . . . . . . . 36

3.1 .1 .1 Facility Identification ......... 36

3.1 .1 .2 Facility Scope .............. 36

3.1.1.3 Facility Functions ............ 36

3.1.1.4 Factlity Requirements ........... 36

3.1.2 Large Mixed-Waste Storage Facility, Phases I-IV ... 36

3.1.2.1 Facility Identification ........ 36

3.1.2.2 Facility Scope ............. 36

3.1.2.3 Facility Functions . . . . . . . . . . 37

3.1.2.4 Facility Requirements . . . . . . . . 37

3.1.3 Plutonium/Polychlorinated Biphenyl Mixed Waste
Storage Building ... 37

3.1.3.1 Facility Identification ........ 37

3.1.3.2 Facility Scope ............ 37

3.1.3.3 Facility Functións . . . . . . . . . . 37

3.1.3.4 Facility Requirements ......... 37

3.1.4 Flammable Mixed-Waste Storage Modules . . . . . . . 37

3.1.4.1 Facility Identification ......... 37

3.1.4.2 Facility Scope ............. . 37

3.1.4.3 Facility Functions . . . . . . . . . . 37

3.1.4.4 Facility Requirements . . . . . . . . . 37

3.1.5 Waste Receiving and Staging Area ........... 37

3.1.5.1 Facility Identification ........ 37

3.1.5.2 Facility Scope ............. 38

3.1.5.3 Facility Functions . . . . . . . . . . 38

3.1.5.4 Facility Requirements . . . . . . . . . 38

3.1 .6 Mixed-Waste Storage Pad .............. 38

3.1.6.1 Facility Identification ........ 38

3.1.6.2 Facility Scope .............. 38

3.1.6.3 Facility Functions . . . . . . . . . 38

3.1.6.4 Facility Requirements . . . . . . . . 38

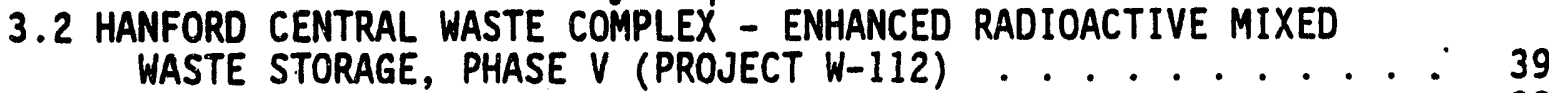

3:2.1 Project Identification . . . . . . . . . . 39

3.2.2 Project Scope .................. 41

3.2.2.1 Waste Types ............. . 41

3.2.2.2 Interfaces . . . . . . . . . 46

3.2.2.2.1 Facilities. . . . . . . . . . 46

3.2.2.2.2 Vehicles............ 47

3.2.2.2.3 Containers . . . . . . . . . . 47

3.2.2.3 Project Size .............. . 48 48

3.2.2.4 Project Schedule . . . . . . . . . . . . 51

3.2.2.5 Facility Expansion . . . . . . . . . . 51

3.2 .3 Project Requirements . . . . . . . . . . . 52

3.2.3.1 Permitting . . . . . . . . . . 52 


\section{WHC-SD-WM-RPT-060, REV 0 VOLUME 5}

Table of Contents (Continued)

3.2.3.2 Inspections ............. 52

3.2 .4 Project Functions ............... . 53

3.2.4.1 Waste Segregation ........... 53

3.2.4.2 Shipping/Receiving ......... 54

3.2.4.3 Available Storage in the Facility ..... 54

3.2.4.4 Waste Characterization ......... 55

3.2.4.5 Waste Handling Automated Stacker/Retriever System (AS/RS) . . . . . 56

3.3 TRANSURANIC STORAGE AND ASSAY FACILITY. . . . . . . . . 58

3.3.1 Facility Identification . . . . . . . . . 58

3.3.2 Facility Scope ................ 58

3.3.3 Facility Functions ................ 58

3.3.4 Facility Requirements ........... 58

4.0 TREATMENT FACILITIES AND PROJECTS ............... 59

4.1 WRAP MODULE $1 \ldots . . . . . . . . . . .59$

4.1.1 Project Identification ............. 59

4.1 .2 Project Scope ................ 59

4.1.2.1 Waste Types .............. 59

4.1.2.2 Interfaces .............. 62

4.1.2.3 Project Size . . . . . . . . . . . . 66

4.1.2.4 Project Schedule ............. 69

4.1.2.5 Throughput .............. 69

4.1.2.6 Facility Expansion ........... 73

4.1.3 Project Functions ............... 74

4.1.3.1 Waste Sorting ............ 74

4.1.3.3 Packaging .............. 82

4.1.3.4 Waste Characterization .......... 83

4.1.3.5 Storage ............... 86

4.1.3.6 Liquid Wastes ............. 86

4.1.3.7 NDA/NDE Systems ............. 88

4.1.3.8 Data Systems . . . . . . . . . . . 90

4.1.4 Project Requirements .............. . 91

4.1.4.1 Permits . . . . . . . . . . . . 91

4.1.4.2 Nuclear Safety. . . . . . . . . . . 92

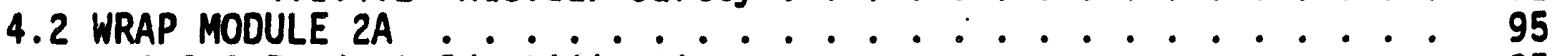

4.2.1 Project Identification ........... 95

4.2.2 Project Scope ................ . 98

4.2.2.1 Waste Type . . . . . . . . . . . . 98

4.2.2.2 Interfaces . . . . . . . . . . 101

4.2.2.3 Project. Size . . . . . . . . . . . 102

4.2.2.4 Project Schedule . . . . . . . . . . 103

4.2.2.5 Process Rate . . . . . . . . . . . . 104

4.2.2.6 Facility Expansion .......... 104

4.2.3 Project Functions . . . . . . . . . . . 104

4.2.3.1 Waste Characterization ......... 104

4.2.3.2 Waste Storage . . . . . . . . . 105

4.2.3.3 Waste Sorting . . . . . . . . . 105 
WHC-SD-WM-RPT-060, REV 0 VOLUME 5

Table of Contents (Continued)

4.2.3.4 Waste Treatment . . . . . . . . . 106

4.2.3.5 Waste Packaging ........... . 107

4.2.3.6 NonDestructive Assay/NonDestructive

Examination . . . . . . . . 107

4.2:3.7 Liquid Wastes . . . . . . . . . . . 108

4.2.4 Project Requirements ............... . . . . . . . . . .

4.2.4.1 Permits .............. 109

4.3 WRAP MODULE $2 B \ldots \ldots \ldots \ldots$

4.3.1 Project Identification .............. 115

4.3.2 Project Scope ............... 115

4.3.2.1 Waste Types ............... 115

4.3.2.2 Interfaces ............. . 115

4.3.2.3 Project Size ............ 115

4.3.2.4 Project Scheduie ............ 115

4.3.3 Project Functions ............... 115

4.3.4 Project Requirements .............. 115

4.4 THERMAL TREATMENT FACILITY .............. 116

4.4.1 Project Identification .............. 116

4.4.2 Project Scope ............... 116

4.4.2.1 Waste Types .............. 116

4.4.2.2 Interfaces ............ 116

4.4.2.3 Project Size ............. 116

4.4.2.4 Project Schedule ........... 116

4.4.3 Project Functions .............. 116

4.4.4 Project Requirements ............ 116

5.0 DISPOSAL FACILITIES AND PROJECTS $\ldots \ldots \ldots \ldots \ldots$

5.1 LOW-LEVEL WASTE BURIAL GROUNDS . . . . . . . . . . . . 117

5.1.1 Facility Identifieacion . . . . . . . . . . 117

5.1 .2 Facility Scope . . . . . . . . . . . . . 117

5.1.3 Facility Functions .............. 117

5.1.4 Facility Requirements ............. 117

5.2 LOW-LEVEL MIXED WASTE DISPOSAL . . . . . . . . . . 118

5.2.1 Project Identification ............. 118

5.2 .2 Project Scope ............... 125

5.2.2.1 Waste Types . . . . . . . . . . . 125

5.2.2.2 Interfaces . . . . . . . . . . . 128

5.2.2.2.1 Facilities . . . . . . . . . 128

5.2 .2 .2 .2 Vehicles ............ 129

5.2.2.2.3 Containers . . . . . . . . . . 129

5.2.2.3 Project Size ............. 129

5.2 .2 .4 Project Schedule . . . . . . . . . 130

5.2.2.5 Facility Expansion .......... 130

5.2 .3 Project Functions . . . . . . . . . . 131

5.2.3.1 Trench Description . . . . . . . . . 131

5.2.3.2 Trench Liner System . . . . . . . . . . 131

5.2.3.3 Leachate Collection System . . . . . . . 132

5.2.4 Project Requirements .............. 132 
WHC-SD-WM-RPT-060, REV 0 VOLUME 5

Table of Contents (Continued)

5.2.4.1 Permits . . . . . . . . . . . 132

5.2 .4 .2 Inspections ............. 136

6.0 REFERENCES ........................... 137 
WHC-SD-WM-RPT-060, REV 0 VOLUME 5

List of Tables

Table 2-1. Comparison of Alternatives Examined in W-113 Engineering

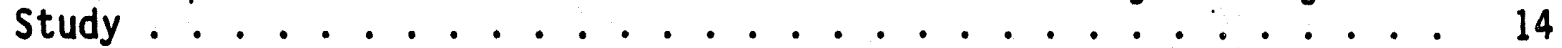

Table 2-2. Comparison of Retrieval Projects at Hanford, Savannah River,

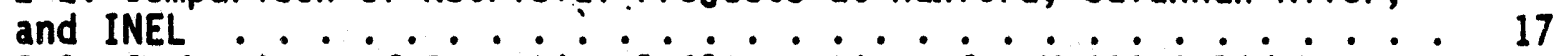

Table 2-3. Comparison of Operational Alternatives for $W-113$ Solid Waste Retrieval Facility ............... 19

Table 3-1. Radionuclide Concentration Limits ............ 42

Table 3-2. Alternative Comparison Between Manual and Manual/Automated Systems . . . . . . . . . . . . . . 57

Table 4-1. WRAP i Interfaces - Facilities . . . . . . . . . . 63

Table 4-2. WRAP 1 Interfaces - Containers ............. 64

Table 4-3. WRAP 1 Interfaces - Vehicles ............. 65

Table 4-4. Butlding System Historical Overview ........... 68

Table 4-5. WRAP 1 Annual Throughput Historical Overview . . . . . . 71

Table 4-6. Facility Expansion Historical Overview . . . . . . . . . 73

Table 4-7. WRAP I Waste Sorting Historical Overview . . . . . . . . 75

Table 4-8. WRAP I Waste Treatment Historical Overview . . . . . . . . 77

Table 4-9. WRAP I Waste Packaging Historical Overview .......... 82

Table 4-10. WRAP 1 Waste Characterization Historical Overview . . . . 85

Table 4-11. WRAP I Liquid Waste Historical Overview ........... 87

Table 4-12. WRAP I NDA/NDE Historical Overview ............ 89

Table 4-13. Radionuclide Concentration Limits ........... 100 


\subsection{PURPOSE}

\subsection{INTRODUCTION}

The purpose of the Facility and Project Bases volume is to describe the bases for the configuration of the Solid Waste projects and facilities which provide the capability for the Solid Waste Program to accomplish its mission.

\subsection{SCOPE}

The projects and facilities have been categorized according to the primary function they provide, namely retrieval, storage, treatment, or disposal. For each facility and project the following information is provided:

- identified purpose (what does the particular project or facility fulfill in meeting the Solid Waste mission)

- scope (what waste types are handled, the interfaces with the project or facility, the physical characteristics, project schedule, capacities, etc.)

- functions performed (specific functions the project or facility carries out to provide the necessary capability [i.e., retrieval, storage, treatment, or disposal])

- requirements (requirements and permits under which the project or facility operates)

\subsection{BACKGROUND}

Waste generation began coincident with the defense materials production mission initiated at the Hanford Site in 1944. From then until 1970, virtually all solid wastes were disposed of through ground burial. Beginning in 1970, wastes containing transuranic materials were segregated and temporarily stored awaiting future retrieval and treatment before final disposal. In 1985, nonradioactive hazardous waste was no longer accepted for burial in a central landfill; since then, all such waste has been and will continue to be shipped off-site for treatment and final disposal. Starting in 1987, low-level waste containing hazardous constituents was segregated and is temporarily stored awaiting future treatment before final on-site disposal.

\subsubsection{Generation}

Initially, waste is characterized by determining several physical and chemical properties in order to assign to the categories of LLW, LLW mixed, TRU, TRU-mixed, or hazardous. All radioactive waste is further segregated into contact-handled ( $200 \mathrm{mrem} / \mathrm{hr}$ ) and remote-handled ( $>200 \mathrm{mrem} / \mathrm{hr}$ ) waste. Low- level waste is also categorized according to radionuclide concentrations. These classifications are all done according to DOE Orders 5820.2A (LLW) and 5820.1 (TRU), WAC 173-303 (hazardous), 40 CFR 761 (toxic substances), and WHCEP-0063 and WHC-CM-6-16 (internal manuals). 
WHC-SD-WM-RPT-060, REV 0 VOLUME 5

\subsubsection{Retrieval}

The Solid Waste Program must plan for and implement the retrieval of TRU waste stored in burial ground trenches and caissons since May 1, 1970. Since that date, waste suspected or known to contain TRU constituents has been segregated and retrievably stored pending a decision on management of the waste (Reference 1). This waste was to be stored as "retrievable waste." The waste was to be placed in contamination free packages and retrieved within a twenty year period. The Record of Decision for the Hanford Defense Waste Environmental Impact Statement (Reference 2) states that retrievably stored and newly generated TRU-contaminated solid waste will be retrieved, processed as necessary, and sent to WIPP for disposal.

\subsubsection{Storage}

Storage is performed according to appilicable regulations for the waste type. TRU is stored in the transuranic Storage and Assay Facility (TRUSAF) or near-surface trenches. Low-level mixed waste is stored in the Hanford Central Waste Complex awaiting further on-site treatment. Hazardous waste is temporarily stored in the Nonradioactive Dangerous Waste Storage Facility awaiting shipment to off-site treatment and disposal facilities.

\subsubsection{Treatment}

Compaction of LLW is currently provided in the Compactor Facility. Treatment of most low-level mixed waste will be performed at. the Waste Receiving and Processing (WRAP) facilities. WRAP 1 will have the capability to certify retrieved and newly generated contact-handled TRU and TRU mixed waste as well as low-level and low-level mixed waste. WRAP 2A and 2B will process contact- handled and remote-handled wastes, respectively.

\subsubsection{Disposal}

Disposal of LLW continues in unlined burial trenches. Category 3 waste is segregated from Category 1 waste to provide added protection and control. Treated contact-handled mixed waste will be disposed of in a RCRA-permitted lined trench. Remote-handled mixed waste is being disposed in deep trenches on a case-by-case basis. Disposal of TRU and TRU mixed waste is planned for the WIPP site in New Mexico. Disposal of nonradioactive hazardous waste in accomplished in off-site commercial facilities.

\subsection{SOLID WASTE MANAGEMENT STRATEGY.}

The management of solid waste at Hanford must be performed in direct. response to the current regulatory climate. Consequently, the course of solid waste management strategy for the future is set in a broad sense.

The Hanford site has initiated a site-wide strategic analysis and. planning effort that will examine, from a broad view, end use of 1 and at the 
WHC-SD-WM-RPT-060, REV 0 VOLUME 5

Hanford site. This analysis and planning will culminate in a top-level technical plan and an integrated plan that will envelope a.11 Hanford Site activities. At a lower level, such as the Solid Waste mission level, detailed plans will still be developed that interface with those top-level plans.

Reduced to a single basic component, the Hanford Site solid waste management strategy is a "cradle-to-grave" tracking and management system. The specific activities within the "cradle (waste generators) and prior to and at the "grave" (disposal facilities) are dictated by priorities within the regulatory environment.

The initial tactic of Solid Waste management is to ensure the greatest accuracy in the forecasts and descriptions of Hanford site solid wastes. This is necessary to accurately size factilties and processes to handle the expected waste volumes within the required time frames, while at the same time avolding unneeded processing capability.

Storage tactics include continuing an assessment of the interface requirements and throughput requirements for moving stored and newly generated TRU waste from storage areas through the WRAP facilities to the WIPP Site. This necessitates knowledge of the required annual throughput to work off TRU waste prior to WIPP closure, and design and construction of necessary capacity in storage and WRAP facilities. Low-level mixed waste requires accurate forecasting of mixed waste volumes and characteristics to ensure design and construction of adequate RCRA-compliant storage facilities. Storage accommodates generated waste until work-off can begin. Land disposal restricted mixed waste will continue to be stored pending availability of appropriate treatment capability.

Treatment technologies will be selected on the basis of ability to meet RCRA requirements, if fe-cycle cost, and acceptance by the public and regulatory agencies.

Tactics for disposal at Hanford include elimination of land disposal of untreated mixed waste by use of appropriate treatment and disposal in permitted facilities. Transuranic waste, including mixed TRU, will be shipped to the WIPP. Low-level waste will continue to be disposed in near-surface trenches. Designs for future trenches will depend on the results of performance assessments now being carried out.

These activities are part of an integrated and consistent approach toward implementation of solid waste activities at the Hanford Site leading to final waste disposal. 


\subsection{RETRIEVAL FACILITIES AND PROJECTS}

The Solid Waste Program must $p l a n$ for and implement the retrieval of TRU waste stored in burial ground trenches and caissons since May 1, 1970. Since that date, waste suspected or known to contain TRU constituents has been segregated and retrievably stored pending a decision on management of the waste (Reference 1). This waste was to be stored as "retrievable waste." The waste was to be placed in contamination free packages and retrieved within a twenty year period. The Record of Decision for the Hanford Defense Waste Environmental Impact Statement (Reference 2) states that retrievably stored and newly generated TRU-contaminated solid waste will be retrieved, processed as necessary, and sent to WIPP for disposal.

The retrieval function has been split into three activities for retrievably stored TRU waste: (1) Phase 1 which will be a full-scale retrieval project to address retrieval of a portion of the waste that is expected to be intact, stored in a single burial ground trench, (2) Phase 2 retrieval to handle the remainder of retrievabiy stored waste in trenches, and (3) Alpha Caisson Retrieval for retrieval of remote-handled waste from burial ground alpha caissons. The trench waste retrieval functions (Phase 1 and Phase 2) will provide for the retrieval of mainly contact-handled suspect TRU waste in 55-gailon drums but a variety of containers and some remote-handled waste will be encountered. The caisson waste retrieval function will provide for the retrieval of remote-handled TRU waste stored in the dry waste alpha caissons. Remote-handled material whether in caissons or trenches will. be retrieved only when treatment is directly avallable, no storage will be provided for remote-handled waste.

\subsection{SOLID WASTE RETRIEVAL, PHASE $1 \cdot($ Project W-113)}

This project provides Phase 1 retrieval for one of 25 trenches of stored transuranic wastes. This project is required to support TRU retrieval, processing, and eventual waste shipment to the Waste Isolation Pilot Plant (WIPP). If not funded, TRU wastes stored in the burial grounds will continue to degrade resulting in safety concerns and environmental contamination.

\subsubsection{Project Identification}

Basis: Hanford Defense Waste Environmental Impact Statement Record of Decision

Source: $\quad$ Solid Waste Retrieval Facility, Phase 1, Conceptual Design Report, (WHC-SD-W113-CDR-002, Rev.0); Hanford Defense Waste Environmental Impact Statement Record of Decision (HDW-EIS ROD); Engineering Study for Waste Receiving and processing (WRAP) facility Module 2

The Hanford Defense Waste Environmental Impact Statement (HDW-EIS) Record of Decision (Reference 2) stated the Department of Energy's intent to proceed with removal of retrievably stored TRU waste at the Hanford Site. 
WHC-SD-WM-RPT-060, REV 0 VOLUME 5

Retrievably stored TRU-contaminated solid waste will be retrieved, processed as necessary, and sent to WIPP for disposal.

The following description is excerpted from the WRAP 2 Engineering Study (Reference 3).

Under DOE regulations (DOE Order 5820.2A, Radioactive Waste Management), radioactive solid waste is divided into transuranic (TRU), which primarily includes low dose rate waste with long lived alpha enitting radiolsotopes, - high level waste (HLW), which primartly includes the high dose rate waste produced directly in fuel reprocessing that contains both transuranic and fission products, and low lovel waste (LLW), which includes everything that is not TRU, HLW, spent nuclear fuel, or byproduct material.

Historically, only HLW was segregated for advanced treatment and disposal. In Aprif 1970, the predecessor to the U.S. Department of Energy (DOE), the Atomic Energy Commission, issued immediate Action Directive No. 0511-21, which directed Hanford (and other DOE sites) to begin temporarlly storing all suspect TRU solid waste "in such a fashion that they can be readily retrievable as contamination-free packages within an interim. period of 20 years." Initially, the definition of TRU included any waste with suspect alpha contanination. This definition was later (1972) changed to include only those wastes containing $>10 \mathrm{nCi} / \mathrm{gram}$ alpha emitting isotopes with half-lives $>20$ years; and still later (1982) changed again to include only wastes with $>100 \mathrm{nCi} / \mathrm{gram}$ of TRU nuclides.

Prior to 1970, TRU wastes were not segregated and were buried at Hanford commingled with LLW. Disposition of TRU wastes buried prior to 1970 was deferred in the HOW-EIS Record of Decision. Since 1970, it has been the policy of DOE that TRU wastes will be retrieved, treated (as required), certified, and transferred to the Waste Isolation Pllot Plant (WIPP) repository in New Mexico for permanent disposal. Because existing technology in the 1970s could not determine the concentration of TRU radionuclides at 10 or evan $100 \mathrm{nCl} / \mathrm{gram}$, any solid waste that was suspected to be TRU was placed in retrievable storage. As a result, it is anticipated that a large fraction of the waste placed into storage at Hanford as "suspect TRU" will actually be determined to be $L L W$ after retrieval and assay. It is al so known that some of the waste stored as suspect TRU has radioactive and hazardous mixed waste (RMW) components, in both the TRU and LLW fractions.

Retrievably stored suspect TRU and other waste types are stored in a variety of container types including 55 gallon, 30 gallon, and 85 gallon steel drums; fiberboard boxes; steel boxes; plywood boxes; fiberglass reinforced plywood (FRP) boxes; concrete boxes; casks; and others. Most of the containers in which suspect contact-handled (CH) TRU is stored were intended to have a minimum expected 1 ife of 20 years, al though there is little documentation concerning design life expectations for specific containers. At any rate, the storage of suspect CH TRU waste at. Hanford began in May 1970, and it is therefore anticipated that many containers may be extensively deteriorated. 
WHC-SD-WM-RPT-060, REV 0 VOLUME 5

Solid Waste Retrieval, Phase 1 will be a full-scale retrieval project to address retrieval of a portion of the waste that is expected to be intact. This will result in retrieving roughly one-third of all retrievably stored drums since 1970. These drums are stored in a single burial ground trench. The retrieval function will provide for the retrieval of mainily contacthandied suspect TRU waste in 55-gallon drums but a variety of containers will be encountered.

\subsubsection{Project Scope}

The discussion on the scope of the Solid Waste Retrieval Phase 1 project will cover waste types, interfaces, project size, project schedule, retrieval rate, and facility expansion.

Sol id Waste Retrieval Phase 1 will retrieve the TRU waste from Trench 4 of Burlal Ground 218-W-4C in the 200 West Area. The following assumptions are specific to the Solid Waste Retrieval, Phase 1 project:

- All waste containers retrieved will be from Trench 4 of Burial Ground 218-W-4C (Reference 4).

- Phase 1 retrieval operations will last approximately up to three and one-quarter years (Reference 4).

- The total number of waste containers to be retrieved is 9,989 (Reference 4).

- The total waste volume to be retrieved is $2,397 \mathrm{~m}^{3}$.

- The waste containers are expected to be intact with no significant risk of questionable structural integrity causing contamination release to the environment (Reference 4).

- No facilities or equipment for clean-up, disposal, treatment, or storage of contaminated soil are included (Reference 4).

- Waste containers will be overpacked as part of the retrieval process (Reference 4).

\subsubsection{Waste Types}

Basis: U.S. Atomic Energy Commission Immediate Action Directive 0511-21. Hanford Defence Waste Environmental Impact Statement (HDW-EIS).

Source: Solid Waste Program Plan (WHC-EP-0363)

The Solid Waste Retrieval Facility, Phase 1, Project W113 provides facilities and equipment for retrieval of the waste located in Trench 04 of the 218-W-4C Burial Ground located in the 200 West Area of the Hanford Site. 
WHC-SD-WM-RPT-060, REV 0 VOLUME 5

Trench 04 is reported to contain approximately 9,894 55-gallon and 57 110gailion drums, 37 metal boxes, and 1 fiberglass reinforced plywood box of suspect TRU waste. Emplacement of waste in Trench 04 began in 1978, and the last waste package was placed into the trench in 1985. The containers in Trench 04 are expected to be intact with no significant degradation (Reference 4).

The U.S. Atomic Energy Commission (AEC) directed [Immediate Action Directive 0511-21] that after Aprl1 30, 1970, AEC sites segregate "waste with known or detectable contamination of transuranium nuclides" from other types of wastes. Such wastes were to be packaged and stored to be readily retrievabie as contamination-free packages within 20 years. After 20 years, retrievability was to continue to be possible. This policy was formulated in consideration of the long half-lives of TRU isotopes. The 20 year-interim storage period was stipulated to allow time to study the best disposal alternative.

The Immediate Action Directive (IAD) did not provide a detailed definition of TRU waste. Contractors to the AEC implemented the IAD as well as possible within the iimits of detection equipment. After this directive, all solid radioactive waste was designated either TRU or LLW.

Segregated TRU wastes were placed in storage configurations specified by each site. Hanford Site interim storage areas consisted of shallow land trenches, concrete 1 ined " $V$ " trenches, and earth-covered asphalt pads and caissons.

Handling and shipping practices for TRU waste containers with high surface dose rates differed, because of the necessity of avoiding personnel exposure. Wastes that required shipment by shielded cask were placed in caissons (underground concrete or metal cylindrical structures). This practice occurred prior to 1970 and did not change after the 1970 IAD segregation limit. This resulted in a division into contact-handled (CH) and remote-handled (RH) waste, with the separation occurring at a $200-\mathrm{mrem} / \mathrm{hr}$ dose rate at the container surface.

The segregation limit for TRU waste was changed with the 1973 ișsuance of the Atomic Energy Comission Manual, Chapter 0511, "Radioactive Waste Management" to material contaminated with certain alpha-emitting radionuclides and activity greater than $10 \mathrm{nCi} / \mathrm{g}$. The radionuclides included were $23 \mathrm{U}$ plus its daughter products, plutonium, and trans-plutonium nuclides with the exception of ${ }^{238} \mathrm{Pu}$ and ${ }^{241} \mathrm{Pu}$.

In 1982, the TRU waste segregation 1 imits were changed to $100 \mathrm{nCi} / \mathrm{g}$ by U.S. Department of Energy (DOE) Order 5820.1, Management of Transuranic Material, [U.S. Department of Energy Headquarters (DOE-HQ) 1982]. This caused no change in waste handling practices other than decreasing the relative volume of radioactive waste designated as TRU waste. 
Storage practices for TRU waste were changed at the Hanford Site in FY 1985 in response to DOE Order 5820.2, Radioactive Waste Management (DOE-HQ 1984) in order to facilitate. requirements for offsite shipment and geologic disposal at the Waste Isolation Pilot Plant (WIPP) Site. When certification to the WIPP waste acceptance was approved in 1986, newly generated CH TRU drum waste began to be stored above ground at the Hanford Site in the Transuranic Storage and Assay Facility (TRUSAF) in preparation for shipment to the WIPP Site. This practice will continue with the expected addition of new storage facilities for $\mathrm{CH}$ waste that cannot be handled in TRUSAF, as a result of space limitations, floor-loading restrictions, and lack of generator certification plans. This implements the "Hanford Defense Waste Environmental Impact Statement Record of Decision" [Environmental Protection Agency (EPA) 1988], to ship newly generated TRU waste, along with retrievable stored TRU waste, to WIPP. The TRU waste and assoclated contaminated soil volumes in pre-1970 burial grounds (termed buried waste) will require additional evaluation as stated in the Record of Decision before decisions regarding disposal are made.

\subsubsection{Interfaces}

Basis: $\quad$ Solid Waste Program Plan

Source: Engineering Study for Phase 1 Retrieval

Description of interfaces with facilities, vehicles, and shipping containers is provided below.

2.1.2.2.1 Facilities. The Phase 1 retrieval Facility will be required to ship drums and boxes in a manner that is acceptable to the following facilities at a minimum:

- Phase V Storage Facility

- Waste Receiving and Processing (WRAP) Module 1

- Waste Receiving and Processing (WRAP) Module 2A

The Phase V storage Facility will receive the overpacked waste from the Phase 1 Retrieval Facility and store the waste until WRAP is prepared to receive and process the waste. .

2.1.2.2.2 Vehicles. The Phase 1 Retrieval facility will need to have a loading area for the vehicles that will transport the overpacked waste to Phase V Storage. Phase I Retrieval will also need to recefve new and reconditioned overpacks. Because of the uneven nature of retrieval trench, automated guided vehicles are not currently planned for inclusion in the scope of the Phase 1 Retrieval Project. Phase 1 retrieval will require; a forklift for drum handling in the trench, a crane for movement of boxes and top tier drums, a van for transportation of the drums from the trench to Phase $V$ storage, and a flat-bed truck for transportation of boxes from the trench to Phase V'storage. The vehicles used to transport waste containers from the 


\section{WHC-SD-WM-RPT-060, REV 0 VOLUME 5}

trench to Phase $V$ will be coordinated with Phase $V$ to ensure that the containers can be off-loaded.

2.1.2.2.3 Containers. Because of the questionable integrity of the containers in the trench Phase 1 Retrieval will need to overpack waste drums and boxes. The overpacks for drums are $83 \mathrm{gall}$ on drums and for boxes are larger metal boxes. The sizes and weights of these overpacks will need to comply with size and weight restrictions applicable to Phase $V$ Storage and WRAP Modules 1 and 2. The current plan for 83-gal overpacks and variously sized box overpacks will be coordinated with the other facilities.

\subsubsection{Project Size}

Basis: Solid Waste Program Plan, Schedules for WRAP Modules 1 and 2

\section{Source: COR Section I}

Project W-113 will retrieve solid waste suspected of containing transuranic (TRU) radionuclide material. Waste is currently classified as TRU if it contains $100 \mathrm{nCt} / \mathrm{gram}$ or more of transuranic elements. Prior to 1982, TRU was classified as any waste containing $10 \mathrm{nCi} / \mathrm{gram}$ or more of transuranic elements. Since waste emplacement in Trench 04 began in 1978, it is likely that some of the waste packages will not contain TRU waste as it is currently defined, but will be determined to be low-level waste. Project $W-113$ will provide the facilities and equipment to retrieve the waste located in Trench 04 of the 218-W-4C burial ground within the 200-West Area.

Trench 041 ies south of 19th Street and east of Dayton Avenue. Trench 04 is approximately 24 feet wide and approximately 600 feet long. The bottom of the trench is covered with an asphalt pavement to provide easy access and a firm base for stacking and ultimate removal of the drums and boxes. The trench contains 19 storage modules: two have drums stacked five tiers high and the remaining 17 have drums stacked four tiers high. A tier contains a maximum of 144 drums arranged 12 by 12 with supporting plywood sheets between each tier. There are two sizes of drums: 55 and 110 gallon.

Waste boxes and 110-gallon drums were interspersed in the storage modules. The modules were covered with plastic tarpaulins and additional sheets of treated plywood before being backfilled and mounded over with the natural sand and gravel excavated from the trench. A system to vent moisture from around the drums and boxes was installed and a 3- to 5-ft layer of backfill was placed over the modules.

The waste in Trench 04 is covered with a minimum of $4 \mathrm{ft}$ of soil. The height of the overburden covering the waste extends above the existing grade in some places, creating a berm. The berm is approximately $12 \mathrm{ft}$ above existing grade at the east end of the trench.

Project W-113 will include the construction of several buildings to accomplish waste recovery. The conceptual design report for Project $W-113$ 
WHC-SD-WM-RPT-060, REV 0 VOLUME 5

lists five specific facilities: a general office building, retrieval staff change building, trench enclosure building, trench operation building, nondestructive examination/nondestructive assay building. Since the conceptual design report was issued in October, 1992 informally proposed changes to Project $W-113$, Solid Waste Retrieval Facility have been identified based on preliminary safety evaluations and advanced conceptual design report studies in progress. Below is a listing of proposed changes to the project since the CDR was issued:

- NDA/NDE facility deleted in favor of mobile units

- Only Passive-Active Neutron (PAN) counting performed in Project W113, Gamma Energy Analysis (GEA) is el iminated.

- Tota $\mathrm{X}$-ray/assay equipment requirement reduced to one unit each

- Operations enclosure requirements relaxed (no airlocks, leak tightness not required, HEPA filtration not required)

- Lag storage reduced from 48 to 12 drums and box 1 ag storage eliminated.

An independent review (internal memo 22180-93-001, March 31, 1993, from Process Analysis to R.J. Roberts) identified that GEA should remain in the scope of the Solid Waste Retrieval Facility to determine TRU/fissile content as required for packaging and shipping requirements and that the PAN. is not necessary to make this determination.

\section{General Office Building}

The building will be constructed of two 14-foot wide by 66-foot long portable trailers, and will be occupied by seven personnel. The building will include office space, a manager's private office, a conference room, a lunch room, and restrooms. Total gross square feet for the building is 1,835. (Phase 1 Retrieval Facility Conceptual Design Report (CDR), WHC-SD-W113-CDR002, Rev. O, K.E. Smith, October 5, 1992)

A support building separate from the operations enclosure building is required to provide general office space for administrative staff (manager, . technical staff, and clerical staff), rest rooms, lunch room, and conference room. This building is planned for future use during retrieval at other trenches (Phase 1 Retrieval Facility Functional Design Criteria (FDC), WHC-SDW113-FDC-001, Rev 1, D.E. Johnson, January 2, 1992).

A study evaluating what office, administrative and other non-process areas should be inside of the various Solid Waste Operations Complex (SWOC) facilities was undertaken (Results of SWOC Office and Administrative Space Study, internal memo 87330-93-JBM-021, J.B. Meyers to J.G. Riddelle, March 29, 1993). The results suggest that the distance (l mile) of the Sol id Waste Retrieval Facility from general support buildings of the SWOC (Project W-112 


\section{WHC-SD-WM-RPT-060, REV 0 VOLUME 5}

Support Buildings) makes centralization of space for essential personnel with the general support buildings of the SWOC impractical. However, the study suggests centralization of all common facilities (such as lunch rooms) within the Solid Waste Retrieval Facility to the General Office Building and elimination of all other Solid Waste Retrieval Facility common areas. This approach of consolidation of common areas is appropriate for the Solid Waste Retrieval Facility.

Based on having essential personnel (operations manager, cognizant engineer, data entry personnel, clerical support) at the retrieval site and having common areas for personnel to eat lunch and hold meetings a General office Building at the retrieval site is justified.

\section{Retrieval Staff Change Building}

The building will be a pre-engineered metal structure totalling 3900 $\mathrm{ft}^{2}$. The functional design criteria state change rooms, showers, personnel decontamination, and staff radiological survey stations are to be separate from the trench enclosure building. The men's and women's change-rooms will provide separate accommodations for personnel to dress in either blues or special work permit clothing. Support area in the building include office space, a control room, a communications room, a lunchroom, storage rooms for soiled laundry and for clean laundry, a health physic technician's office, restrooms, locker rooms, decontamination shower, and a janitor's closet. This building is planned for future use during retrieval at other trenches.

The independent review found that the personnel decontamination shower within the change building is not technically justified and should be deleted from the proposed scope. The estimated frequency of contaminations during retrieval operation has not been established but the expectation of intact drums would lead to the hypothesis that contaminations would be infrequent. Current outdoor operations at the Hanford site (tank farm operations) do not have personnel decontamination available at change building locations, rather if someone does become contaminated the person is transported to an existing decontamination station within the area. With the exception of personnel decontamination showers and common areas (lunch room and office should be consolidated with General office Building) a change building is justified to eliminate transporting personnel in special work permit clothing to a fixed facility to change to street clothes.

\section{Nondestructive Examination/Nondestructive Assay (NDE/NDA) Building}

The NDE/NDA building is a permanent pre-engineered metal building with overall dimensions of $130^{\prime}$ by $151^{\prime}$. The building includes office space for administration, a lunchroom, a control room, a change-room (blues only), showers, NDE, NDA, shipping, a truck drive-through, two 1-hour fire-rated enclosed lag staging rooms for drums, and a shielded storage area for eight 200-Mrem/hour drums. The total gross square feet for the building is 15,140. 


\section{WHC-SD-WM-RPT-060, REV 0 VOLUME 5}

The engineering study included asserts that the historical record information on the waste containers would need to be augmented with real time radiography (RTR) as part of retrieval. Due to the large drum. weights, the presence of lead in some drums, and the size of some of the storage boxes a very powerful radiography $(X$-ray) system was anticipated to "see through" all drums and boxes. The system recommended in the engineering study is a linear accelerator (1 inac). Linear accelerators produce high levels of radiation while operating and the shielding required to reduce personnel exposure is significant. Aithough it is not clearly stated in the engineering study, it is assumed that the requirement for a permanent NDE/NDA facility as opposed to mobile NDE/NDA equipment was driven by the need for a large amount of shielding associated with the linac and the convenience of a truck drivethrough for box NDE/NDA. The study was based on using a centralized facility for retrieval operations in seven trenches.

The current scope of the retrieval project is retrieval in only one trench. In addition, a lower power $X$-ray system is now anticipated to be sufficient for the current project scope. With only one trench being excavated as opposed to seven, the NDE/NDA throughput rate will also be reduced. Solid Waste personnel are evaluating whether the characterization of the waste boxes in the trench to be excavated in the $W-i 13$ project is sufficient to preclude the need for NDE/NDA. For these reasons Solid Waste personnel are reevaluating whether the NDE/NDA function required for the Solid. Waste Retrieval Facility could be accomplished by mobile equipment in the trench, potentially eliminating the permanent NDE/NDA facility.

\section{Trench Operation Building}

The building will be adjacent to the Trench Enclosure Building and will be a pre-engineered metal structure totalling $3000 \mathrm{ft}^{2}$. The building will include a small office, tool crib area, battery charging area, and lag staging area. The tool crib area, battery charging area, and lag staging area provide a location near the trench for maintenance and non-process operations (such as electrical equipment recharging) without being in the trench enclosure building which potentialily could become contaminated. The building supports operations within the Trench Enclosure Building and appears to be justified.

\section{Trench Enclosure Building}

The building will be a pre-engineered modular metal building: The enclosure will be erected in modules that are $20 \mathrm{ft}$ long by $42 \mathrm{ft}$ wide to cover $360 \mathrm{ft}$ of the approximately $600 \mathrm{ft}$ long trench 04 of burial ground 218W4C. The building cross section dimensions were determined by minimum requirements for handling of boxes by the gantry crane. Once the contents of the first half of the trench have been retrieved the modules will be disconnected and relocated to cover the unexcavated portion of the trench. The enclosure will be placed over the retrieval area to protect operations from wind, rain, or other inclement conditions (Phase 1 Retrieval FDC). 


\section{WHC-SD-WM-RPT-060, REV 0 VOLUME 5}

The Phase 1 Retrieval Facility Engineering Study compared alternatives to perform retrieval of seven trenches containing containers that were assumed essentially intact. One of these trenches includes trench 04 of burial ground $218 \mathrm{~W}-4 \mathrm{C}$, the scope of the Solid Waste Retrieval Facility. The study is somewhat unique in that the final selection of the facility that will retrieve the Phase 1 trenches was recommended on the basis of both technical and cost merits, safety considerations (yet to be completed), and management judgement as to the best alternative. Three basic options were investigated: operation in the open air without any weather or confinement enclosure (assuming the effective year was only seven months long), operation with a weather enclosure (permitting operations over a full calendar year), and operation with a weather enclosure plus an inner confinement enclosure (providing year round operation with a degree of continuous contamination control).

Two alternatives were considered for open air operation: without a shed roof (Alternative 6) and with a shed roof (Alternative 5). Four alternatives were considered for operation in an enclosure: modular metal shell preengineered weather protection building (Alternative 1), air supported fabric weather protection building (Alternative 2), fabric construction weather protection bullding (Alternative 3 ), modular metal shell pre-engineered weather protection building covering three trenches (Alternative 4). Three alternatives were considered for weather enclosure plus inner confinement: total confinement within weather enclosure alternatives (Alternatives 1-4), total confinement in lieu of a weather enclosure, modification of Alternatives 1-4 to provide a high-hazard inner core structure for Phase 2 Retrieval activities.

Weighted criteria were established to select a preferred alternative. All alternatives were compared to each other as measured by the criteria guidelines. A summary of the results is provided in the table 2-1 below.

The result of the engineering study showed that open air retrieval is the preferred alternative based on evaluation of alternatives. Both open air retrieval options ranked highest followed by the weather enclosure alternatives and finally the containment alternatives.

It is not clear that a justification exists for providing a weather enclosure for retrieval operations. The preliminary safety evaluation (Solid Waste Retrieval Phase 1 Preliminary Safety Evaluation (PSE), WHC-SD-W113-PSE001 , Rev 0, K.E. DeWitt, November 4; 1991 with Engineering Change Notices \# 173277 and 173298) determined consequences of potential accidents without benefit of a weather enclosure and found in all-cases operations and accidents were within acceptable limits. 
WHC-SD-WM-RPT-060, REV 0 VOLUME 5

\begin{tabular}{|c|c|c|c|c|c|c|c|c|c|}
\hline Criteria & Weight & $\begin{array}{c}\text { Alt } 1 \\
\text { (Metal } \\
\text { Enclocure) }\end{array}$ & $\begin{array}{c}\text { Ait } 2 \\
\text { (Air } \\
\text { Enclosure) }\end{array}$ & $\begin{array}{c}\text { Att } 3 \\
\text { (Fobric } \\
\text { Enolosure) }\end{array}$ & $\begin{array}{c}\text { Aft } 4 \\
\text { (3 Tronoh } \\
\text { Enclosure) }\end{array}$ & $\begin{array}{c}\text { Alt } 5 \\
\text { (Open w/ } \\
\text { Roof) }\end{array}$ & $\begin{array}{c}\text { Alt } 6 \\
\text { (Opon Air) }\end{array}$ & $\begin{array}{c}\text { Att } 7 \\
\text { (Inside } \\
\text { Confminnt) }\end{array}$ & $\begin{array}{l}\text { Alt } \\
\text { Continmnt }\end{array}$ \\
\hline PERFORMANCE & & & & & & & & . & \\
\hline $\begin{array}{l}\text { 1. Meots } \\
\text { Aequiromonts }\end{array}$ & $5 \%$ & 5 & 4 & 5 & 5 & $\mathbf{5}$ & $\mathbf{5}$ & 5 & 5 \\
\hline $\begin{array}{l}\text { 2. Change to } \\
\text { Inereased } \\
\text { Confinomont }\end{array}$ & $2 \%$ & 2 & 0 & 1 & 1 & 0 & 1 & 2 & 2 \\
\hline $\begin{array}{l}\text { 3. Smooth flow of } \\
\text { diums and boxes }\end{array}$ & $3 \%$ & 32 & 1 & 3 & 3 & 3 & 3 & 1 & 1 \\
\hline $\begin{array}{l}\text { 4. Leck of } \\
\text { Imterforenos w/ } \\
\text { Phace } 2\end{array}$ & $5 \%$ & 23 & 3 & 1 & 2 & 2 & $\mathbf{5}$ & 4 & 4 \\
\hline $\begin{array}{l}\text { 5. Eace of } \\
\text { decontamination }\end{array}$ & $3 \%$ & 21 & 2 & 2 & 1 & 2 & 3 & 2 & 2 \\
\hline $\begin{array}{l}\text { 6. Space for } \\
\text { oporotions } 8 \\
\text { equipmam }\end{array}$ & $3 \%$ & 33 & 3 & 3 & 3 & 3 & 3 & 1 & 2 \\
\hline $\begin{array}{l}\text { 7. Abillty for } \\
\text { additional grounth }\end{array}$ & $2 \%$ & 22 & 1 & 1 & 1 & 2 & 2 & $\mathbf{0}$ & 1 \\
\hline $\begin{array}{l}\text { 8. Erection, } \\
\text { oportion, tear } \\
\text { down }\end{array}$ & $3 \%$ & 33 & 3. & 3 & 1 & 3 & 3 & 1 & 1 \\
\hline $\begin{array}{l}\text { 9. Enclosure } \\
\text { durability }\end{array}$ & $4 \%$ & 44 & 2 & - 2 & 4 & 4 & 4 & 4 & 4 \\
\hline $\begin{array}{l}\text { PEAFORMANCE } \\
\text { SUBTOTAL }\end{array}$ & $30 \%$ & 24 & 10 & 21 & 20 & 24 & 28 & 20 & $\begin{array}{l}22 \\
\cdots\end{array}$ \\
\hline SCHEDULE & & & & & & & & & \\
\hline $\begin{array}{l}\text { 1. Meete } 2008 \\
\text { Completion } \\
\text { Schedule }\end{array}$ & $20 \%$ & 16 & 16 &.$^{16 .}$ & 15 & 16 & 20 & 9 & 10 \\
\hline $\begin{array}{l}\text { 2. Drum a box } \\
\text { deltivery floxibility }\end{array}$ & $10 \%$ & 8 & 7 & 7. & 7 & 6 & 10 & 2 & 2 \\
\hline $\begin{array}{l}\text { SCHEDULE } \\
\text { SUBTOTAL }\end{array}$ & $30 \%$ & 22 & 22 & 23 & 23 & 21 & 30 & 11 & 12 \\
\hline $\begin{array}{l}\text { LIFE CYCLE } \\
\text { COSTS }\end{array}$ & & & & & & & & & \\
\hline 1. Capital Coste & $15 \%$ & $\begin{array}{c}11 \\
(\$ 234 M)\end{array}$ & (\$231 M) & $\begin{array}{c}12 \\
(1233 \mu)\end{array}$ & $\stackrel{8}{(\$ 237 ~ M)}$ & $\begin{array}{c}13 \\
(\$ 191 \mathrm{M})\end{array}$ & $\begin{array}{c}15 \\
(\$ 188 M)\end{array}$ & $\begin{array}{c}6 \\
(1258 M)\end{array}$ & $\begin{array}{c}6 \\
(\$ 288 M)\end{array}$ \\
\hline 2. Expense Costs & $25 \%$ & 22 & 21 & 10 & 16 & 23 & 25 & 4 & 7 \\
\hline $\begin{array}{l}\text { LIFE CYCLE } \\
\text { COSTS SUBTOTAL }\end{array}$ & $40 \%$ & 33 & 34 & 31 & 25 & 36 & 40 & 10 & 13 \\
\hline $\begin{array}{l}\text { TOTAL FOR ALL } \\
\text { SECTIONS }\end{array}$ & $100 \%$ & 79 & 75 & 74 & 68 & 81 & 98 & 41 & 47 \\
\hline
\end{tabular}


The functional design requirements stating that the enclosure shall be able to maintain a negative pressure differential at least 0.1 inch water gage and that the design shall meet the requirements to be leak tight as identified in the first paragraph of DOE Order 6430.1A Section 1161-2 "Construction" are overstated for the purpose of providing a weather enclosure. Truck and personnel airlocks, and ventilation system with HEPA filtration are also unnecessary for providing a weather enclosure. The stated requirement for a leak tight enclosure complete with airlocks and ventilation/HEPA filtration is currentiy being evaluated.

The justification for a weather enclosure is being evaluated as part of the work in an advanced conceptual design workplan (WHC-SD-W113-WP-001, Rev. 0, K.E. Smith, September 18, 1992). A description of the task is taken from the reference, "Operational/Economic Basis for Heather Enclosure - A third party review of the functional criteria for the Phase 1 Retrieval Project has questioned the justification for a weather enclosure and the attendant infrastructure such as ventilation and complicated fire protection systems. Value engineering of the requirement was recommended. This task will include documentation of site meteorological records pertaining to days per year that conditions exist that preclude excavation or waste container handling in the LLW burial grounds. Work schedule strategies can then be developed to attain a rate of retrieval that best meets the WRAP 1 requirement while minimizing impacts to storage requirements. The cost/benefit impacts can then be evaluated and documented to support a final recommendation.

As part of the workplan mentioned in the last paragraph, an Operational/Economic Basis for Heather Enclosure study has been undertaken. The study will evaluate site meteorological records pertaining to days per year that conditions exist that preclude excavation or waste container handling in the LLW burial grounds. Work schedule strategies can then be developed to attain a retrieval rate that best meets WRAP 1 requirements. The Operational/Economic Basis for Weather Enclosure study has not been completed, but will provide a final recommendation whether a weather enclosure is justified.

Except for drum venting and headspace gas sampling, the Solid Waste Retrieval Facility closely parallels INEL drum retrieval experience (INEL Transuranic Storage Cell Penetration and Inspection, TREE-1311, J.R. Bishoff, January 1979, and Initial Drum Retrieval Final Report, TREE-1286, K.B. McKinley and J.D. McKinney, August, 1978) and it appears that systems similar to those used at INEL may be appropriate. The first reference describes pilot scale recovery of one hundred drums from a storage module similar to Trench 04 without the aid of a weather enclosure. Retrieval was accomplished without breaching the integrity of any waste containers. The second reference describes recovery of twenty thousand drums in a more unfavorable array (drums placed horizontaliy, earth covered, and overrun by heavy machinery) under an air-supported structure for weather protection. Approximately $2.4 \%$ of the drums were breached and of those breached roughly $1 / 3$ leaked free liquids. During the $31 / 2$ year retrieval operation, no serious injury or significant increase to body burden of radioisotopes was experienced by retrieval personnel and no contamination was spread to the environment.

As part of the independent review referred to in the paragraphs above, Contacts at Idaho National Engineering Laboratory (INEL) and Savannah River Plant (SRP) were interviewed to discuss information provided by Hanford site personnel regarding similarities and differences between the Hanford Solid 


\section{WHC-SD-WM-RPT-060, REV 0 VOLUME 5}

Waste Retrieval Facility and similar projects at INEL and SRP. Table 2-2 compares the ongoing projects at each of the three sites. Comparison of similar functions between the Hanford project and similar projects at SRP and INEL to determine relative cost for waste retrieva? has been performed by the Solid Waste Retrieval Facjlity project engineer.

The following changes to project scope were made by the project engineer to compare the SRP and Hanford retrieval projects on similar terms. The SRP retrieval project, TRU Waste Facility Retrieval Phase, (preliminary TEC of \$7 million) does not include: $x$-ray \& assay facility and equipment, change room and office trailer, box retrieval equipment \& overpacks. For comparing similar work scopes, the Hanford project comes in at $\$ 11$ million compared to Savannah River's $\$ 7$ million. Unlike SRP Hanford's wastes are buried below grade and sheet piling must be installed to prevent soil cave-in ( $\$ 1$ million). Eliminating this from Hanford's scope would reduce the project to $\$ 10$ million. Assuming the enclosure will, be used on two additional trenches the cost of retrieving about $210,000 \mathrm{ft}^{3}$ of waste equates to roughly $\$ 48 / \mathrm{ft}^{3}$. Preliminary studies have shown that if Hanford were to reduce the trench enclosure building length such that it would be moved four times during operations, the project cost savings would be around $\$ 1.5$ million. The cost of retrieving about $210,000 \mathrm{ft}^{3}$ of waste under this scenario would be $\$ 40 / \mathrm{ft}^{3}$. Cost for SRP would be $\$ 35 / \mathrm{ft}^{3}$.

The following changes to project scope were made by the project engineer to compare the INEL and Hanford retrieval projects on similar terms. The INEL retrieval project, TRU Storage Area Enclosure, does not include: $x$-ray \& assay facility and equipment, office space, box overpacks, drum venting and gas analysis equipment. For comparing similar work scopes, the Hanford project omitting the above items comes in at $\$ 10$ million. Assuming the enclosure will be used on two additional treaches the cost of retrieving about $210,000 \mathrm{ft}^{3}$ of waste equates to roughly $\$ 48 / \mathrm{ft}^{3}$. Preliminary studies have shown that if Hanford were to reduce the trench enclosure building length such that it would be moved four times during operations, the project cost savings would be around $\$ 1.5$ million. The cost of retrieving about $210,000 \mathrm{ft}^{3}$ of waste under this scenario would be $\$ 40 / \mathrm{ft}^{3}$. This compares to INEL removing $1,470,000 \mathrm{ft}^{3}$ at a cost of $\$ 51$ million for $\$ 35 / \mathrm{ft}^{3}$. 


\section{WHC-SD-WM-RPT-060, REV 0 VOLUME 5}

\begin{tabular}{|c|c|c|c|}
\hline & $\begin{array}{l}\text { Henford - Solld Weate Rotriovel } \\
\text { Faolinty }\end{array}$ & $\begin{array}{l}\text { Sovemanch Rhrer - ThU Warte Fuelliey } \\
\text { Rotroval Phace }\end{array}$ & INEL - ThU Storace Arse Enclocurs \\
\hline Type of Conteninere & 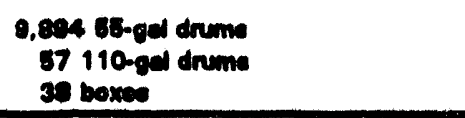 & 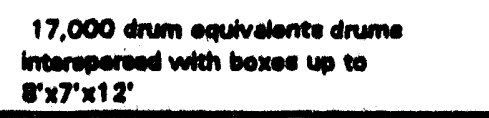 & $\begin{array}{l}200,000 \text { drum equivelente of drume } \\
\text { and boxos }\end{array}$ \\
\hline Burled Configuration & 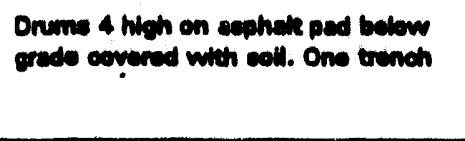 & 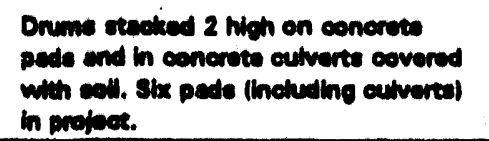 & $\begin{array}{l}\text { Drums ateoked } 8 \text { high on } 3 \\
\text { condouous pede and covered with } \\
\text { soll. }\end{array}$ \\
\hline Westher Enclosure & $\begin{array}{l}\text { Metal etructure covering 1/2 the } \\
\text { trinch. Encloum is } 17,000 \mathrm{nt}^{2} \text {. }\end{array}$ & 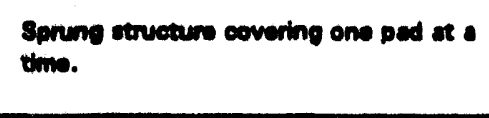 & $\begin{array}{l}\text { Motel atruoture covering entire } \\
\text { notrioval erea. Pad wres is 238,000 } \\
t^{2} \text {. }\end{array}$ \\
\hline $\begin{array}{l}\text { Drum Venting } \\
\text { Equipment }\end{array}$ & $\begin{array}{l}\text { Porteble venting and ges eampling } \\
\text { equipment ineluded in cost of project. }\end{array}$ & $\begin{array}{l}\text { Porteble venting and gas sampling } \\
\text { equipment included in cost of projoet. }\end{array}$ & $\begin{array}{l}\text { Fixod venting and gae sempling } \\
\text { equipment provioualy supplied. }\end{array}$ \\
\hline NDEMOA & 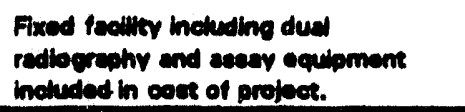 & Exioting squipment alroedy supplied. & Exioting equipment atready supplied. \\
\hline Support Fualltides & $\begin{array}{l}\text { Portable offlice and chence foelintioe } \\
\text { inoluded in coet of project. }\end{array}$ & Exioting foclititioe oxiot new project. & $\begin{array}{l}\text { Chenoe faelitities included in } \\
\text { enclocurs. }\end{array}$ \\
\hline $\begin{array}{l}\text { Throughpus decign } \\
\text { rate }\end{array}$ & 1900 drume per year & $\begin{array}{l}8 \text { drume per doy } 11760 \text { drume por } \\
\text { yeart }\end{array}$ & 10,000 drum equivalente per year \\
\hline Throughput bateis & $\begin{array}{l}\text { Dosigned to matoh WRAP } 1 \\
\text { throughput deaign for retrieved wasto }\end{array}$ & $\begin{array}{l}\text { Baced on pertormence requirements of } \\
\text { the project }\end{array}$ & $\begin{array}{l}\text { Rotrieval to support shipment of } \\
200,000 \text { drum equivalents to WIPP in } \\
\text { WIPP operating window. }\end{array}$ \\
\hline Projset cost & $\begin{array}{l}\text { - } 28 \text { Mullon Total Eotmated Cspleal } \\
\text { Cost } \\
\text { 147.5 Million Total Project Cont }\end{array}$ & $\begin{array}{l}\text { Functonat Doaign Crteria oxiat but no } \\
\text { Concoptual Design for Eatimate Badis }\end{array}$ & $\begin{array}{l}\text { - } 51 \text { Million Total Estimated Capital } \\
\text { Cont }\end{array}$ \\
\hline
\end{tabular}


WHC-SD-WM-RPT-060, REV 0 VOLUME 5

\subsubsection{Project Schedule}

Basis: Solid Waste Program Plan, WRAP Module 1 and 2 Schedules

Source: Phase I Retrieval Conceptual Design Report

Solid Waste Retrieval Phase 1 is an integral part of the overall Hanford Site solid waste planning. The Phase 1 Retrieval schedule is planned to coincide with the schedules of other projects such as WRAP Module 1 and Enhanced Radioactive Mixed Waste Storage, Phase V. These two will provide processing and storage respectively for the retrieved waste.

Complete schedule development is ongoing. Information will be made available as the material is developed. The project schedule can be broken into the following four areas:

- DESIGN - The design currently is ongoing and tentatively scheduled to be completed by April 1995. Engineering inspection which has been included as a part of the design phase will continue through June of 1997.

- PROCUREMENT - Procurement of materfals is tentatively scheduled to begin in June 1995 and be completed by December 1996.

- CONSTRUCTION - Construction activities are tentatively scheduled to begin in July of 1995 and the final tie-ins are scheduled to be completed by March 1997.

- PROJECT INTEGRATION - Project integration activities are currently ongoing and tentatively scheduled to be completed in April 1998.

\subsubsection{Retrieval Rate}

Basis: The retrieval rate is driven by WRAP Modules 1 and 2 Schedules.

Source: Phase 1 Retrieval Conceptual Design Report (CDR), Phase 1 Retrieval Functional Design Criteria (FDC)

The retrieval operation consists of: removal of overburden from the trench and storage modules, retrieval of stored containers, collection of drum head gas samples, overpacking of retrieved containers, examination of the overpacked containers by assay and $x$-ray, coding, storage of characterization data generated in the solid waste retrieval facility, and preparation of the retrieved suspect TRU waste packages for transport. The design retrieval rate for the Solid Waste Retrieval Facility was originally 1900 drums per year if boxes are not being retrieved.

In response to questions during independent review an analys is was performed to determine if the life cycle cost could be reduced by changing the 


\section{WHC-SO-WM-RPT-060, REV 0 VOLUME 5}

retrieval rate. It was determined that the bottleneck in the retrieval operation was the headspace gas sampling. The baseline operating scenario (1900 drums per year for a six year duration) was compared to two al ternatives (option 2 and 3) each of three year duration ( 3800 drums per year) and two alternatives (options 4 and 5) each of two year duration (5700 drums per year). Option 2 uses an additional venting and gas sampling unit. Option 3 performs addittonal venting and gas sampling on a second shift. Option 4 adds two venting and sampling units and one PAN unit. Option 5 adds one venting and sampling units use on two shifts and one PAN unit. A comparison of operating, equipment and total costs for the five options is shown in Table 2-3 below. It was determined that adequate storage space will be available for retrieved waste to complete the Solid Waste Retrieval (Project W-113) operations in either two or three years, therefore additional storage capacity in the SWOC is not requited.

\begin{tabular}{|l|c|c|c|}
\hline \multicolumn{2}{|c|}{ Table 2-3. Comparison of Operational Alternatives for $\mathrm{W}-113$ Sol Id } \\
Waste Retrieval Facil ity
\end{tabular}

Comparison of these alternatives shows that with no additional capital cost, total life cycle cost savings of $\$ 3.6$ million could be realized using the existing venting and gas sampling unit on a second shift. This would increase the design rate to 3800 drums per year. If it is expected that retrieval rates can be increased to 3800 drums per year head gas sampling should be increased to a two-shift operation to reduce retrieval operations to 3 years.

The baseline equipment cost is $\$ 2.5$ million for one PAN (\$1 million), one drum venting and head-gas sampling unit $(\$ 750,000)$ and one radiography unit with digital linear array $(\$ 750,000)$. Basel ine operating personnel are one supervisor, six technicians, six operators, and four health physic technicians. 
WHC-SD-WM-RPT-060, REV 0 VOLUME 5

\subsubsection{Facility Expansion}

Basis: Solld Waste Program Plan

Source: Engineering Study, FDC, CDR

The scope of Phase 1 Retrieval Facility (Project W-113) includes only the retrieval of the suspect TRU waste in trench 04 of the 218-W-4C Burfal Ground. There is no current plan to expand the scope of Project W-113 to include additional retrievably stored suspect TRU waste. Other waste to be retrieved w111 be retrieved under another project.

Although expansion of the scope of the Phase 1 Retrieval Project is not within current planning, some of the buildings included in the scope of the Phase 1 Retrieval Project will be reused in later retrieval projects.

\subsubsection{Project Functions}

\subsubsection{Waste Characterization}

Basis: Hanford Site Solid Waste Acceptance Criteria (WHC-EP-0063), RCRA, WAC 173-303

Source: $\quad$ Phase 1 Retrieval Engineering Study, Phase 1 Retrieval Functional Design Criteria (FDC), Phase 1 Retrieval Conceptual Design Report (CDR)

In order to comply with the requirements of WAC 173-303, and RCRA, the waste retrieved under Project $W-113$ will need to be characterized before it can be received ințo Phase $V$ storage or WRAP Module 1. To supplement the written record of the contents of the waste drums and boxes in Trench 04, the Phase 1 Retrieval Facility will include non-destructive examination/nondestructive assay (NDE/NDA) equipment. The NDE/NDA equipment, described in detail in the NDE/NDA section below, provides the characterization required for acceptance of the waste into Phase $V$ storage and WRAP Module 1.

\subsubsection{Excavation of Trench}

Basis: The basis for the excavation of the trench is the need to remove the overburden to allow access to the waste.

\section{Source: Phase I Retrieval Conceptual Design Report}

Trench 04 is approximately 24 feet wide and approximately 600 feet long. The bottom of the trench is covered with an asphalt pavement to provide easy access and a firm base for stacking and ultimate removal of the drums and boxes. The trench contains 19 storage modules: two have drums stacked five tiers high and the remaining 17 have drums stacked four tiers high. A tier contains a maximum of 144 drums arranged 12 by 12 with supporting plywood sheets between each tier. There are two sizes of drums: 55 and $110 \mathrm{gallon}$. 
WHC-SD-WM-RPT-060, REV 0 VOLUME 5

Waste boxes and 110-galion drums were interspersed in the storage modules. The modules were covered with plastic tarpaulins and additional sheets of treated plywood before being backfilled and mounded over with the natural sand and gravel excavated from the trench. A system to vent moisture from around the drums and boxes was installed and a 3- to 5-ft layer of backfll1 was placed over the modules.

The waste in Trench 04 is covered with a minimum of $4 \mathrm{ft}$ of soll. The helght of the overburden covering the waste extends above the existing grade in some places, creating a berm. The berm is approximately $12 \mathrm{ft}$ above existing grade at the east end of the trench.

The COR contains the following:

The soll overburden will be removed to within $1 \mathrm{ft}$ of the waste in the trench before the bullding is erected. The soil will be placed in a plle away from the trench. The soll will be sampled for contamination before it is removed and the spolls pile will be sampled after it is deposited. Once the bullding is erected, the soll will be removed by a vacuum system, one module at a time. The plle will be placed alongside the adjacent trench. Large rocks that cannot be vacuumed will be placed in a pile for removal by a skip loader.

In order to provide access to the waste in the trench, the overburden will need to be removed. Current planning calls for a two step process for removal of the overburden; the 3 to $31 / 2 \mathrm{ft}$ of soil is to be removed with a back-hoe or similar type of heavy earth-moving equipment, the final 6 to 12 inches of soll will be removed with a portable soil vacuum system. Section IV.D.3 of the CDR includes the following description of this equipment:

A portable vacuum system will be used to remove the overburden from each storage module. The vacuum unit will be powered by a 150-hp diesel engine located outside the Trench Enclosure Building. The unit will be capable of removing 32 tons of soil per hour. A 10-in. suction line from centrifugal separator and vacuum unit will penetrate the wall of the Trench Enclosure Bullding at predetermined points to connect to the vacuum manifold in the trench. Four 4-in. Tines will be connected to the manifold and operated from the service bridge or from the floor of the trench. The soil from the separator will be deposited into a hopper and fed onto a conveyor for deposit onto the spoils pile. The air exhaust will be filtered twice: first to remove large particles and then through a HEPA filter to remove small particles before the air exhaust is discharged to the atmosphere. The vacuum system, diesel engine, and hopper will be mounted on a trailer for portability.

With the overburden around the modules to be removed by the soil vacuum system, a determination has been made that the dust control 
WHC-SD-WM-RPT-060, REV 0 VOLUME 5

requirements will be minimized. To mitigate dust generation, the ramp, the trench floor, and the walkways will be cleaned, as needed by the soll vacuum system. Additional dust control measures may be provided at the discretion of the operating contractor.

It may be possible to remove all of the overburden with the vacuum system, which would eliminate the need to have heavy equipment near the. trench.

\subsubsection{Waste Handling}

Basis: Process Control, Safety, ALARA

\section{Source: Phase 1 Retrieval Conceptual Design Report}

After the final overburden has been removed from the trench over a module with the soll vacuum system, the plywood and tarpaul in will also be removed from the module exposing the top tier of waste. At this point the waste packages (drums or boxes) will be retrieved from the stack with a crane or forklift, the head-gas in the package will be sampled, the waste package will be overpacked, the overpacked waste will be examined in the NDE/NDA facility, and finaliy the waste is coded and transported to Phase $V$ Storage. With the exception of the crane and forklift, all of the waste handling equipment has been or will be discussed in other sections of this document. Section IV.D.3 of the Phase 1 Retrieval CDR contains the following description of the crane and fork 1 ift:

2.1.3.3.1 Crane. An electrically-powered 15-ton gantry crane will provide the majority of the container removal work in the trench. The crane will move on rails that run the length of the trench. The crane will remove the drums with drum grappling equipment and boxes with spreader bars, cables, or straps. The crane will also handle and assemble the overpack lid for the overpack boxes.

2.1.3.3.2 Forklift. An electric forklift, with a 12,000 ib lifting capacity, will be used for moving the portable shoring, for box and drum handiing, and for housekeeping activities in the Trench Enclosure and the Trench Operations Building.

2.1.3.3.3 Drums. After the overburden is removed from a module of drums, the portable shoring will be put in place to keep the drums from falling in the event of a DBE (Design Basis Earthquake) or an accident during waste retrieval. The drum grappling equipment will be attached to the crane to remove drums from the module. A person in the aerial work platform will visually inspect the drums to be moved for signs of deterioration. For drums of suspect integrity, ultra-sonic testing will be done to determine the drum wall thickness. If it safe to move the drum, the grapple will then be attached. The crane will remove the drum from the module for further inspection, bar code application, and insertion into an overpack drum. 


\section{WHC-SD-WM-RPT'-060, REV 0 VOLUME 5}

Deteriorated drums will be removed from the stack and overpacked on a case by case basis depending upon the magnitude of the deterioration and the contents of the drum. When the overpack drums are full, they will be moved to the drum venting station.

The overpacked drum with its top exposed will be placed inside the cage of the head-gas sampling unit. The cage will mitigate the effects of any explosion during the head-gas sampling operation. The head-gas sampling unit will puncture the top of the 55-gal waste drum, perform an on-1 ine analysis, and procure one gas sample for archive purposes. The drum will be purged with nitrogen, if necessary, and w111 have a flltered vent installed. After removal from the sampling station, the overpack 1 id will be installed. The overpacked drum will be placed on a tratler by the crane for shipment to lag staging area or to the NDE/NDA Buflding. The tratlers will be towed to the NDE/NOA Bullding by an electrically-powered tug.

2.1.3.3.4 Boxes. When boxes are to be removed from a module, a tractortrailer rig will back down into the trench, the trailer will be detached, and the iractor driven out. The overpack box will be on the trailer. The top of the overpack will be removed and disassembled for later use. The base will remain on the trailer. Spreader bars and rigging attached to the crane to remove the boxes will be moved over a box, lowered and attached. The person in the aerial work platform will inspect the boxes, apply bar codes, and set the rigging. The box will then be removed from the module, moved over the trailer containing the overpack base, rotated if necessary, and lowered onto the overpack base. While reassembling and replacing the top of the overpack, dunnage will be placed around the box to keep it from shifting. The tractor will be backed down again and attached to the trailer to transfer the load to the NDE/NOA Building.

2.1.3.3.5 Oversize Drums. The outer containers of the 1-10 containment system are 110-gal drums capable of handling objects up to $5 \mathrm{ft}$ long. The 110-gal drum is designed to remain unsealed. These drums will be visually inspected and ultrasonically tested before being removed from the module with a grapple and placed in box overpacks.

2.1.3.3.6 Overpacks. [Basis: The basis for the overpacks is driven by the need to provide contamination free waste containers to Phase $V$ Storage Facility. Source: Phase 1 Retrieval Facility Engineering Study] The Phase 1 Retrieval Facility Engineering Study includes the following overpack discussion (Engineering Study for the Solid Waste Retrieval, Project W-113, WHC-SD-W113-ES-001, Rev. 0, June 1991):

the current direction of the project requires that transfer of the waste packages from the retrieval location to WRAP or another onsite destination will require over-packing in a packaging system approved for such a purpose. The initial engineering study has concluded that four packaging systems will be needed for over-packing the retrieved waste packages for transport. The designs have been conceptualized for this purpose to cover all the foreseen payloads. They are: 
WHC-SD-WM-RPT-060, REV 0 VOLUME 5

- 83-gal double-1id drum

- 16,000 lb capacity box (BM-14/S)

-. 45,000 lb capacity box (BM-36/S)

- 85,000 lb capacity box (BM-68/S)

These packaging systems wil? be designed to meet Hanford onsite requirements for transport of radioactive material. It was assumed that the contact dose rate of the payload materials will be such as not to require shielding. Table 1 presents some basic design data for the four systems. All the dimensions are subject to revision based on optimization of the designs which will occur continuously through the design process.

TABLE 1

OVERPACKS

\begin{tabular}{|c|c|c|c|}
\hline PACKAGING & $\begin{array}{c}\text { MAXIMUM PAYLOAD } \\
\text { CAPACITY/GROSS } \\
\text { WT (LB) }\end{array}$ & $\begin{array}{l}\text { MINIMUM PAYLOAD } \\
\text { CAVITY DIMENSIONS }\end{array}$ & $\begin{array}{c}\text { MAXIMUM EXTERIOR } \\
\text { DIMENSIONS }\end{array}$ \\
\hline $\begin{array}{c}\text { Drum, } 83 \text {-gal } \\
\text { Double Lid } \\
\end{array}$ & $\begin{array}{l}3000 \\
3100 \\
\end{array}$ & $\begin{array}{l}36 \text { in. (h) } \\
26 \text { in. (d) } \\
\end{array}$ & $\begin{array}{l}36.5 \text { in. (h), } \\
26.5 \text { in. (d) }\end{array}$ \\
\hline Box BM-14/S & $\begin{array}{l}16,000 \\
30,000\end{array}$ & $\begin{array}{l}12.3 \mathrm{ft}(1), \\
7.3 \mathrm{ft}(\mathrm{w}), \\
7.3 \mathrm{ft} \mathrm{(h)}\end{array}$ & $\begin{array}{l}13.0 \mathrm{ft}(1), \\
8.0 \mathrm{ft}(w), \\
8.0 \mathrm{ft}(\mathrm{h})\end{array}$ \\
\hline Box BM-36/S & $\begin{array}{l}45,000 \\
80,000\end{array}$ & $\begin{array}{l}20.5 \mathrm{ft} \mathrm{(1),} \\
12.0 \mathrm{ft}(w), \\
13.0 \mathrm{ft}(\mathrm{h})\end{array}$ & $\begin{array}{c}22.0 \mathrm{ft}(1), \\
13.0 \mathrm{ft}(\mathrm{w}), \\
14.5(\mathrm{~h})\end{array}$ \\
\hline Box $B M-68 / S$ & $\begin{array}{l}85,000 \\
130,000\end{array}$ & $\begin{array}{l}20.0 \mathrm{ft} \mathrm{(1),} \\
9.0 \mathrm{ft}(w), \\
12.0 \mathrm{ft}(\mathrm{h})\end{array}$ & $\begin{array}{l}21.3 \mathrm{ft}(1), \\
10.3 \mathrm{ft}(w), \\
14.0 \mathrm{ft}(\mathrm{h})\end{array}$ \\
\hline
\end{tabular}

Use of the 83-gal, double-lid drum is currently being evaluated in conjunction with design activities related to WRAP and its basic features will be similar to the 110-gal double-lid drum currently available. the drum body and cover will be made of steel sheet. It will be equipped with a minimum of three rolling hoops and with the necessary features to facilitate the double-lid loading system interface. The scope of project $W-113$ will be limited to qualification of the drum for transportation purposes; WRAP will prepare the design (in conjunction with their glove box-to-drum interface activities).

The overpack boxes are of the same basic design. they consist of a cover assembly which is lowered onto a base assembly to form the 


\section{WHC-SD-WM-RPT-060, REV 0 VOLUME 5}

containment. The cover consists of a stainless steel inner shell and a carbon steel outer shell. The annulus between the inner and outer shells is filled with polyurethane foam with a thin layer of ceramic fiber insulation between the foam and the steel surfaces. A seal flange equipped with two independent gaskets provides the interface with the base assembiy. the base assembly consists of a stainless steel base plate supported by an impact resistant spacer and an I-beam frame. The frame is equipped with holes for attaching lifting rigging and forklift pockets. The cover assembly is held to the base by a series of locking bars which rotate and index with mating surfaces on the cover. The locking bars will rotate downward to allow for ease in loading operations. The base assembly will be equipped with interfacing hardware to provide a ramp to allow for dragging of waste packages onto the base (as an alternative to lifting the waste box and lowering it in place on the base).

The packaging will be designed and qualified to meet Hanford onsite packaging requirements. These requirements are currently under development and are expected to be issued via a Hanford site transportation safety manual later this year. The basic design goal will be that the packaging will maintain containment in accident conditions with no measurable leakage based on an acceptable leak detection sensitivity.

\subsubsection{NonDestructive Examination/NonDestructive Assay}

Basis: Hanford Site Solid Waste Acceptance Criteria, Resource Conservation and Recovery Act (RCRA), Washington State Administrative Code (WAC) 173-303

Source: $\quad$ Engineering Study; FDC; CDR

Non-destructive assay (NDA) refers to the measurement of the fission and activation products as well as the actinide contents of solid radioactive waste. Non-destructive means that the waste is not altered as it would be if a physical sample were to be taken for chemical of other analysis. For NDA to be successful, the waste must be characterized. There are two methods of NDA planned for the Solid Waste Operations Complex, Gamma Energy Analys is (GEA) and Passive-Active-Neutron Analysis (PAN). GEA is not practical for making the determination whether waste is LLW or TRU because the quantity of plutonium present is typically in the milligram region and too few gammas are emitted to be accurately measured. GEA measurements for TRU, using a segmented gamma scanner, are best made when the TRU quantity is greater than 1.0 gram. The PAN approach, provides the best estimate of the amount of TRU present at the LLW/TRU levels.

Non-destructive examination in this application refers to the use of various techniques to examine the contents of the container without opening it. The purpose of NDE is to minimize the chances that a drum contains undetected free liquids, flammable vapors, powders, potentially explosive 


\section{WHC-SD-WM-RPT-060, REV 0 VOLUME 5}

pressurized gas cylinders or other non-compliant items. NDE in this

investigation refers to Head Gas Sampling and Real Time Radiography. Head Gas Sampling refers to the sampling and analysis of gases in the head space of waste containers for volatile organic compounds. Real Time Radiography (RTR) applies $X$-ray fluoroscopy to the imaging of drums of waste. The output of an $X$-ray source is passed through a drum and onto a fluoroscopic screen. The resulting image is observed in real time as the drum is rotated and incremented vertically past the source. "The operator is able to "jog" the drum by starting. and stcpping rotation. This permits the viewing of free liquids as they slosh about. A video tape of the scanning process is provided along with voice annotation as a permanent record. These RTR systems provide high resolution and excellent penetration capability.

- W-113 Solid Waste Retrieval Facility - 2 Passive-Active-Neutron Systems (PAN), 2 Gamma Energy Analysis Systems (GEA), Real Time Radiography systems (RTR), and 1 Head gas sampling system

The basis for each of these NDE/NDA functions in each facility is listed below (Internal Memo (Draft), Solid Waste Projects NDA/NDE Review, W.P. Gilles to W.H. Hamilton et al, February 12, 1993):

- Head Gas Sampling - compliant storage of waste in Phase V Storage Facility, acceptance of waste into WRAP 1, and stabilization of flammable or potentially explosive drums

- PAN - TRU fissite content determination for 85-galion drum overpack specification, compliant storage of waste in Phase $V$ Storage Facility, acceptance of waste into WRAP 1

- GEA - TRU fissile content determination for 85-gallon drum overpack specification, compliant storage of waste in Phase $V$ Storage Facility, acceptance of waste into WRAP 1

- RTR - compliant storage of waste in Phase V Storage Facility, acceptance of waste into WRAP 1

\subsubsection{Transportation}

Basis: $\quad$ The need to move the waste packasas from the retrieval site to Phase V Storage.

Source: Engineering Study; Conceptual Design Report (CDR)

The Phase V Engineering Study includes the following:

No special equipment is currently expected to be required to transport the loaded overpacks; available equipment will be utilized to perform this function. Transport of the loaded overpacks will be accomplished by means of an enclosed van similar 
WHC-SD-WM-RPT-060, REV 0 VOLUME 5

to the PFP process trucks currently used to move similar materials onsite at Hanford.

Transport of the loaded drum overpacks will likely be accomplished by means of an enclosed van similar to the "PFP process trucks" currently used to move similar materials onsite at Hanford. Railcar or tractor/trailer will be the two primary options for transparting the loaded box overpacks. Almost all the loaded overpacks will have a gross weight under the normal over-the-road weight 1 imit, but a few will exceed this value. Most of the boxes can be transported on a standard trailer with the heavy overpacks requiring special vehicles. The burial grounds currently utilize at least one 100-ton "lowboy" trailer. The final transport method will depend on the capabilities of the available trailers, the road way, and other factors.

The boxes will most likely be transported one at a time and the trailer will be weighed to determine the box weight. The enclosed vans used to transport the overpacked drums will have the capacity to carry approximately 14 drums per trip.

U.S. Department of Transportation (DOT) requirements for shipping of waste do not apply to transfers of material or waste on the Hanford Site, although some the DOT requirements will be used as a basis for the waste overpack design. DOT regulations are not in general applicable on the Hanford Site because the roadways are not public.

\subsubsection{Project Requirements}

Basis: Resource Conservation and Recovery Act (RCRA), WAC 173-303

Source: Phase 1 Retrieval Functional Design Report (FDC), Phase 1 Retrieval Facility Conceptual Design Report (CDR)

The Functional Design Criteria (WHC-SD-W113-FDC-001, Rev. 1, D.M. Johnson, section 5.1.3) includes the following:

\section{Environmental Protection}

The project $(W-113)$ will be evaluated for environmental requirements and permit applicability, complying with the National Environmental Policy Act (NEPA), Resource Conservation and Recovery Act (RCRA), National Emission Standards for Hazardous Air Pollutants permits, Clean Air Act, Department of Social and Health Services, and Washington Administrative Code 173-303 "Dangerous Waste Regulations" during design. Al1 NEPA documentation required for new facility construction or modification, as identified in WHC-CM-7-5 "Environmental Compliance Manual", and permit applications will be prepared by the Operating Contractor in conjunction with the Design Contractor. Permit applications shall be in compliance with current applicable revision of the Hanford Federal Facility Agreement and Consent Order. 
WHC-SD-WM-RPT-060, REV 0 VOLUME 5

The Conceptual Design Report (WHC-SD-W113-CDR-002, Rev.0, Sections VI.H and VI.I) for Phase 1 Retrieval identified the following Environmental Compliance and permitting issues:

The latest edition of all codes and standards shall be used at the start of definitive design. Subsequent changes to regulations, codes, or standards which affect the design shall be evaluated and controlled in accordance with WHC-CM-6-1, EP-2.2 "Engineering Document Change Control".

The design and construction of project $W-113$ will comply with the following list of environmentally oriented orders, codes, and regulations in addition to the list provided in the FDC.

\section{Executive Orders}

- E.0. 11514, "Protection and Enhancement of Environmental Quality".

- E.0. 11991, "Protection and Enhancement of Environmental Quality".

- E.0. 12088, "Federal Compliance with Pollution Control Standards".

- E.0. 12580, "Superfund Implementation".

\section{U.S. Department of Energy Orders}

- DOE 5400.1, "General Environmental Protection Program".

- RLIP 5400.1, "General Environmental Protection Program".

- DOE 5400.2A, "Environmental Compliance Issue Coordination".

- DOE 5400.3, "Hazardous and Radioactive Mixed Waste Program".

- DOE 5400.4, "Comprehensive Environmental Response Compensation and Liability Act Requirements".

- DOE 5400.5, "Radiation Protection of the Public and the Environment".

- RL 5440.1A, "Implementation of the National Environmental Policy Act at the Richland Operations Office".

- RL 5480.1, "Environmental Protection, Safety, and Health Protection Program for Richland Operations".

- RL 5480.1A, "Environment, Safety, and Hea7th Program for Department of Energy Operations for Richland Operations". 
WHC-SD-WM-RPT-060, REV 0 VOLUME 5

- DOE 5480.1B, "Environment, Safety, and Health Program for Department of Energy Operations".

- DOE 5480.3, "Safety Requirements for the Packaging and Transportation of Hazardous Materials, Hazardous Substances, and Hazardous Wastes".

- DOE 5480.4, "Environmental Protection, Safety, and Health Protection Standards".

- RL 5480.4B, "Environmental Protection, Safety, and Health Protection Standards for RL".

- DOE 5482.1B, "Environment, Safety, and Health Appraisal Program".

- RL 6430.1C, "Hanford Plant Standards (HPS) Program".

\section{Code of Federal Regulations}

- 36 CFR 800, "Protection of Historic and Cultural Properties".

- $\quad 40$ CFR 50, "National Primary and Secondary Ambient Air Quality Standards".

- $\quad 40$ CFR 116, "Designation of Hazardous Substances" .

- 40 CFR 117, "Determination of Reportable Quantities for Hazardous Substances".

- 40 CFR 131, "Water Quality Standards".

- 40 CFR 133, "Secondary Treatment Regulation".

- 40 CFR 141, "National Primary Drinking Water Regulations".

- $\quad 40$ CFR 142, "National Primary Drinking Water Regulations Implementation".

- $\quad 40$ CFR 191, "Environmental Radiation Protection Standards for Management and Disposal of Spent Nuclear Fuel, High-Level and Transuranic Radioactive Wastes".

- 40 CFR 260, "Hazardous Waste Management System: General".

- 40 CFR 261, "Identification and Listing of Hazardous Waste".

- $\quad 40$ CFR 263, "Standards Applicable to Transporters of Hazardous Waste". 
WHC-SD-WM-RPT-060, REV 0 VOLUME 5

- 40 CFR 264, "Standards for Owners and Operators of Hazardous Waste Treatment, Storage and Disposal Facilities".

- 40 CFR 265, "Interim Status Standards for Owners and Operators of Hazardous Waste Treatment, Storage and Disposal Facilities".

- 40 CFR 270, "EPA Administered Permit Programs: The Hazardous Waste Permit Program".

- $\quad 40$ CFR 300, "National 011 and Hazardous Substances Pollution Contingency Plan".

- 40 CFR 302, "Designation, Reportable Quantities, and Notification".

- 40 CFR 370, "Hazardous Chemical Reporting: Community Right-toKnow".

- $\quad 40$ CFR 372, "Toxic Chemical Release Reporting; Community Right-toKnow".

- 40 CFR 1501, "NEPA and Agency Planning".

- 40 CFR 1502, "Environmental Impact Statement".

- 43 CFR 7, "Protection of Archaeological Resources".

- 50 CFR 17, "Endangered and Threatened Wildlife and Plants".

\section{Federal Regulations}

- Resource Conservation and Recovery Act of 1976, Public Law 94-580, 90 Stat. 2795 (42 USC 6901 et seq.); and as amended by the Hazardous and Soljd Waste Amendments of 1984.

- Safe Drinking Water Act, Public Law 93-523 (42 USC 201 et seq.).

- National Environmental Policy Act of 1970, Public Law 91-190, 83 Stat. 852 ( 42 USC 4341).

- Title 40, U.S.C., 9601-9675, (Superfund), Comprehensive Environmental Response, Compensation, and Liability Act of 1980: 9620.

- U.S.C. 6601-6610, Public Law 101-508, Pollution Prevention Act of 1990 .

- PSD-X80-14, Approval of Application to Construct, EPA Region. 


\section{WHC-SD-WM-RPT-060, REV 0 VOLUME 5}

\section{Washington Administrative Code}

- WAC 173-200, "Water Quality Standards for Groundwater of the State of Washington."

- WAC 173-240, "Submission of Plans and Reports for Construction at Waste'Water Facilities".

- HAC 173-303, "Dangerous Waste Regulations".

- WAC 173-460, "Controls for New Sources of Toxic Air Pollutants".

- WAC 173-470, "Ambient Air Quality Standards for Particulate Matter".

- WAC 173-474, "Ambient Air Quality Standards for Sulfur Oxides".

- WAC 173-475, "Ambient Air Quality Standards for Carbon Monoxide, Ozone, and Nitrogen Dioxide".

- WAC 173-480, "Ambient Air Quality Standards and Emission Limits for Radionuclides".

- WAC 173-481, "Ambient Air Quality and Environmental Standards for Fluorides."

- WAC 173-490, "Emission Standards and Controls for Sources Emitting Volatile Organic Compounds (VOC)".

- WAC 173-802, "SEPA Procedures".

- WAC 197-11, "SEPA Rules".

- WAC 246-272, "On Site Sewage Systems".

\section{Local Codes}

General Regulations 80-7, Benton-Frankl in-Walla Walla Counties Air Pollution Control Authority.

Westinghouse Hanford Company Documents

- Hazardous Classification, "Project W-113 Hazardous Classification," prepared by M. R. Harker Westinghouse Hanford Company, Document No. WHC-SD-W113-HC-002, 1991.

- Engineering Study, "Engineering Safety Study for Project $W-113$," prepared by M. R. Harker, Westinghouse Hanford Company, Document No. WHC-SD-W113-ES-002, 1991. 
WHC-SD-WM-RPT-060, REV 0 VOLUME 5

- Program PIan, "Sorid Waste Management Program Plan", prepared by Westinghouse Hanford Company, Document No. WHC-EP-0363, 1990.

- WHC-CM-1-3, "Management Requirements and Procedures".

The operating contractor will identify; permits required to construct and operate the facility, a strategy to acquire the permits, associated cost and schedule requirements, and resulting constraints. 
WHC-SD-WM-RPT-060, REV 0 VOLUME 5

\subsection{SOLID WASTE RETRIEVAL, PHASE 2}

The retrieval project for retrievably stored TRU Waste, known as Phase 2 retrieval, will involve retrieval of the entire inventory of retrievably stored TRU waste (less that retrieved in Phase 1 and Alpha Caisson Retrieval) located in trenches in the burial grounds. The container integrity for the waste that will be retrieved is expected to range from completely sound to totally degraded.

The following assumptions are specific to the full-scale retrieval, Phase 2 retrieval, project:

- The scope of Phase 2 retrieval is the entire inventory of retrievably stored TRU waste less the waste retrieved in Phase 1 and Alpha Catsson Retrieval.

- Containers retrieved intact will be overpacked.

- Retrieved waste in breached containers will be repackaged.

- Waste which was repackaged will not be overpacked.

\subsubsection{Project Identification}

This project is at too early a stage to provide an established identification of the project.

\subsubsection{Project Scope}

This project is at too eariy a stage to provide an established scope.

\subsubsection{Project Functions} functions.

This project is at too early a stage to provide established project

\subsubsection{Project Requirements}

This project is at too early a stage to provide an established set of project requirements. 


\section{WHC-SD-WM-RPT-060, REV 0 VOLUME 5}

\subsection{ALPHA CAISSON RETRIEVAL}

The alpha caisson retrieval project will involve removal of remote handled TRU waste stored in the dry waste caissons located in the 218-W-4B burial ground. Waste will be retrieved, packaged, surveyed, and transferred to the appropriate treatment function for treatment prior to disposal. project:

The following assumptions are specific to the alpha caisson retrieval

- Retrieval operations will last 5 years (Reference 5).

- The total number of containers to be retrieved is 5,534.

- The total volume of waste placed in the alpha caissons and to be retrieved is $828 \mathrm{ft}^{3}\left[23.4 \mathrm{~m}^{3}\right]$ (Reference 6 ).

- All containers retrieved will be non-contact [remote handled] sources (Reference 5).

- Waste will be loaded into a transportable cask and transported to WRAP 2B for treatment (Reference 5).

- All waste in caissons is considered TRU (Reference 5).

- Miscellaneous debris (plastif sheeting, wrapping, etc.) waste volume is estimated at $5.7 \mathrm{~m}^{3}$.

\subsubsection{Project Identification}

This project is at too early a stage to provide an established identification of the project.

\subsubsection{Project Scope}

This project is at too early a stage to provide an established scope.

\subsubsection{Project Functions} functions.

This project is at too early a stage to provide established project

\subsubsection{Project Requirements}

This project is at too early a stage to provide an established set of project requirements. 


\section{WHC-SD-WM-RPT-060, REV 0 VOLUME 5}

\subsection{STORAGE FACILITIES AND PROJECTS}

Storage functions will encompass both interim and long term storage capabilities. The individual storage requirements are outlined by the specific waste types to be stored. Storage is necessary for contact-handled radioactive solid wastes received from offsite and onsite generators as well as waste recovered from retrieval operations. Interim and long term storage is required for TRU waste including TRU mixed waste and suspect TRU waste, low-level mixed waste, and low-level waste that is categorized as Category 3 waste and Greater Than Category 3 waste. The storage function will not provide for the storage of any remote-handled waste packages. Waste packages containing waste that is remote-handled is acceptable for storage in contacthandled waste packages.

\subsection{HANFORD CENTRAL WASTE COMPLEX - RADIOACTIVE MIXED WASTE STORAGE FACILITY}

The Hanford Central Waste Complex is an existing and planned series of facilities that will centralize the management of solid waste operations at a single location on the Hanford Site. The Hanford Central Waste Complex includes the Radioactive Mixed Waste Storage Facility and the Waste Receiving and Processing Factitity.

The radioactive component of mixed waste stored at the Radioactive Mixed Waste Storage Facility is, or will be, either low-level waste, contact-handled transuranic waste (including transuranic plutonium/polychlorinated biphenyl waste), or contact-handled suspect transuranic waste. Mixed waste. low-level waste, and transuranic waste are received at the Waste Receiving and Staging Area or the Mixed Waste Storage Pad. From there, the waste packages are distributed to the appropriate storage, treatment or disposal unit.

The Radioactive Mixed Waste Storage Facility began operations in 1988. This storage unit, classified as container storage, will be permitted under Washington State Department of Ecology Dangerous Waste Regulations, Washington Administrative Code 173-303-806. The Radioactive Mixed Waste Storage Facility consists of multiple storage structures that store radioactive and/or mixed waste before the waste has been processed or certified for final disposal. The Radioactive Mixed Waste Storage Facility provides the capacity to store both onsite and offsite waste.

On final completion, the Radioactive Mixed Waste Storage Facility is roughly estimated to have the capacity to store $88,13655-g a l l o n$ drums and to have approximately 300,000 square feet of storage space. Currently, drums are stored in metal buildings or on storage pads. The drums are placed on wooden pallets that can be handled by a forklift truck. A maximum of four drums can be stored on each pallet, and stacking of pallets allows for a maximum of 12 drums per stack, three drums in height. Heavier drums are rotated to the bottom of the stack to ensure a stable center of gravity for each stack. The concrete floors of the storage buildings and storage pads have provisions for secondary containment. In addition the entire floor areas of these structures 
WHC-SD-WM-RPT-060, REV 0 VOLUME 5

are covered with an epoxy-based coating to aid in spill cleanup and to prevent the penetration of any radioactive and/or mixed waste to the ground. following:

The Radioactive Mixed Waste Storage Facility currently consists of the

- Plutonium/Polychlorinated Biphenyl Mixed Waste Storage Building

- Low-Flash-Point Mixed Waste Storage Modules

- Radioactive and/or Mixed Waste Storage Buildings

- Large Mixed-Waste Storage Facility, Phases I-IV

- Waste Receiving and Staging Area

- Mixed-Waste Storage Pad

In addition the Enhanced Radioactive and Mixed Waste Storage Building, Phase $V$ is planned to provide storage space. The above storage buildings and the Mixed Waste Storage Pad and the Enhanced Radioactive and Mixed Waste Storage Building provide, or will provide, storage space for approximately 88,136 55gallon (or equivalent) waste containers. Storage buildings with physical features that provide for segregated storage areas are operated to maintain appropriate separation hetween arrays of incompatible waste.

\subsubsection{Mixed-Waste Storage Buildings}

\subsubsection{Facility Identification}

Tó be drafted.

\subsubsection{Facility Scope}

To be drafted.

\subsubsection{Facility Functions}

To be drafted.

\subsubsection{Facility Requirements}

To be drafted.

\subsubsection{Large Mixed-Waste Storage Facility, Phases I-IV}

\subsubsection{Facility Identification}

To be drafted.

\subsubsection{Facility Scope}

To be drafted. 
WHC-SD-WM-RPT-060, REV 0 VOLUME 5

3.1.2.3 Facility Functions

To be drafted.

3.1.2.4 Factlity Requirements

To be drafted.

3.1.3 Plutonfum/Polychlorinated Biphenyl Mixed Waste Storage Building

\subsubsection{Factitty Identification}

To be drafted.

\subsubsection{Facility Scope}

To. be drafted.

\subsubsection{Facility Functions}

To be drafted.

3.1.3.4 Facility Requirements;

To be drafted:

3.1.4 Flammable Mixed-Waste Storage Modules

3.1.4.1 Facility Identification

To be drafted.

3.1.4.2 Facility Scope

To be drafted.

3.1.4.3 Facility Functions

To be drafted.

3.1.4.4 Facility Requiremențs

To be drafted.

3.1.5 Waste Receiving and Staging Area

3.1.5.1 Facility Identification

To be drafted. 
WHC-SD-WM-RPT-060, REV 0 VOLUME 5

3.1.5.2 Facility Scope

To be drafted.

3.1.5.3 Facility Functions

To be drafted.

3.1.5.4 Facility Requirements

To be drafted.

\subsubsection{Mixed-Waste Storage Pad}

3.1.6.1 Facility Identification

To be drafted.

3.1.6.2 Facility Scope

To be drafted.

3.1.6.3 Facility Functions

To be drafted.

3.1.6.4 Facility Requirements

To be drafted. 
WHC-SD-WM-RPT-060, REV 0 VOLUME 5

\subsection{HANFORD CENTRAL WASTE COMPLEX - ENHANCED RADIOACTIVE MIXED WASTE STORAGE, PHASE V (PROJECT W-112)}

\subsubsection{Project Identification}

Basis: Hanford Mission Plan, Solid Waste Program Plan

Source: W-112 Engineering Study (WHC-SD-W112-ES-001, Rev. 0), W-112 Conceptual Design Report (WHC-SD-W112-CDR-001, Rev.0̣).

The W-112 Engineering Study listed the following requirement for the Enhanced Radioactive and Mixed Waste Storage, Phase V facility:

Current safety analyses 1 imit the amount of plutonium and/or fission products that can be stored in the type of waste storage (low hazard) currently available or being constructed at the Hanford site. The amount of waste that will require a more protective type storage facility (moderate hazard) is supported by the 1989 solid Waste Forecast Data.Summary Report (Anderson 1990). Phase V Storage will provide the appropriate mitigating features to permit safe storage of the following waste streams and WRAP facility process support storage requirements:

(1) Category 3 low-level mixed-waste storage

(2) Greater than category 3 (GTC3) low-level waste storage

(3) RSTRU waste storage (Recovered Suspect Transuranic)

(4) Newly generated TRU and TRUM waste storage

(5) WRAP Facility process support storage

The engineering study estimated that a peak storage volume requirement of 55,000 drum equivalents would occur in the year 2000. This peak volume includes waste streams $1,2,3,4$, and 5 . The estimated storage volume was based on the best waste forecasts available at the time the engineering study was written. Although the forecasts used were the best available at the time, they were thought to be somewhat inaccurate (Current peak volume estimates suggest that the peak volume may be as high as 80,000 drum equivalents). It was considered preferable to have an undersized facility designed for easy expansion as opposed to an oversized facility. For these reasons, the Phase $V$ Storage Facility was designed with a storage capacity of 27,000 drum equivalents rather than 55,000 drum equivalents.

Small volumes (not addressed in the previous paragraph for clarity) of the same waste streams that are classified as remote handled are included in this peak volume. These wastes will be shielded down to contact-handled levels. the peak storage volume is generated because mixed-waste treatment will not occur in WRAP Module 2 unti1 the year 2000. Hence, the key to Phase $V$ storage sizing is the start of treatment and disposal of all mixed waste.

Section III of the $W-112$ CDR includes the following justification: 
WHC-SD-WM-RPT-060, REV 0 VOLUME 5

Approximately 75,000 drum equivalents (DE) $\left(545,000-\mathrm{ft}^{3}\right)$ of suspect TRU waste have been placed in retrievable underground burial areas at the Hanford Site since 1970. The waste is contained in over 38,000 containers which had an expected life of approximately 20 years when buried. Degradation of the containers will continue to pose a risk of loss of containment (as defined in WAC 173-303).

Waste generation will exceed the existing storage capacity and additional storage buildings will be required to achieve compliance with $E P A, D O E$ and WAC storage requirements. The Phase $V$ facility will provide the required containment and temporary storage appropriate for the inventoried radiological and hazardous waste, while awaiting the waste's final disposition.

A compliant storage facility is required to store wastes until permitted disposal or shipment to the WIPP can be achieved. Long-term storage of greater than Category 3 waste, low-level mixed waste, and greater than Category $3 / 10 w-1$ evel mixed waste is required.

The Hanford Defense Waste Environmental Impact Statement (HDW-EIS) (DOE 1987) was issued by the U.S. Department of Energy Field Offices, Richland (DOE-RL), in December 1987. The purpose of the HDW-EIS was "to provide environmental input into the selection and implementation of final disposal actions for high-level, transuranic, and tank wastes located at the Hanford Site, Richland Washington, and into the construction, operation, and decommissioning of waste treatment facilities that may be required in implementing waste disposal alternatives".

The decision, documented in the Record of Decision (ROD) (DOE 1988), was to implement the preferred alternative discussed in the HDW-EIS. That alternative included retrieval and processing of all TRU and suspect TRU which has been retrievably stored at the Hanford Site since 1970. The Phase V storage facility is required for $1 \mathrm{ag}$ and surge storage of the retrieved and newly generated TRU, Suspect TRU, and low-level mixed waste after retrieval/generation and receipt at the Central Waste Complex (CWC).

For the purpose of this document lag storage is defined as the Phase $V$ waste container storage provided for WRAP processing activities. Lag storage is distinguished by both waste package availability (first-in-first-out capabilities) and short duration (measured in days or weeks) storage. These waste containers will be partially processed through WRAP (Modules 1 and 2), returned to Phase V Storage, and held prior to subsequent laboratory or engineering disposition.

Surge storage is defined as the Phase $V$ waste container storage provided before or following WRAP processing activities. Surge storage is designed to provide continuity of operations for the treatment and shipping of TRU and low-level mixed waste containers. Surge storage is perceived to house waste for up to 60 days prior to treatment, and up to 60 days after treatment. 
Long-term storage is defined as waste storage for wastes that require storage time frames longer than surge storage. Typical waste types stored in long-term storage are GTC3, which has no approved treatment or disposal methods, and Remote handled waste which requires treatment in WRAP Module $2 B$.

Phase $V$ Storage is also required to store processed waste awaiting shipment to the Waste Isolation Pilot. Plant (WIPP) for TRU waste or Iand disposal on the Hanford site for LLMW.

\subsubsection{Project Scope}

\subsubsection{Waste Types}

Basis: Hanford Site Solid Waste Program Plan

Source:- Engineering study, FDC, CDR

Solid Wastes that are candidates for storage in the Phase $V$ storage facility are newly generated wastes from on or offsite generators, and waste retrieved from TRU retrieval projects $(W-113$, and $W-221)$. Two broad classifications of waste were used to evaluate the project scope: contacthandled and remote-handled. Contact-handled wastes include those with radioactive dose rates below $200 \mathrm{mrem} / \mathrm{hr}$. Remote-handled waste is waste with radioactive dose rates of $200 \mathrm{mrem} / \mathrm{hr}$ and higher. "All low-level

(radioactive) waste shall be classified according to Category 1,3 , and greater than Category 3 concentration limits defined in table $3-1$. Also the radioactive component of all mixed waste shall be classified according to this classification system. Waste shall then be segregated prior to shipment to the burial grounds." (Hanford Site Solid Waste Acceptance Criteria, WHC-EP0063-3, Willis and Triner, September 1991, page 4-3). 
WHC-SD-WM-RPT-060, REV 0 VOLUME 5

Table 3-1. Radionuclide Concentration Limits

\begin{tabular}{|c|c|c|c|}
\hline Radionuclide & Half-life (yr) & $\begin{array}{c}\text { Column } 1 \\
\text { Category } 1 \\
\text { Hanford limit } \\
\mathrm{Ci} / \mathrm{m}^{3}\end{array}$ & $\begin{array}{c}\text { Column } 2 \\
\text { Category } 3 \\
\text { Hanford limit } \\
\mathrm{Ci} / \mathrm{m}^{3}\end{array}$ \\
\hline${ }^{3} H$ & 1.2E+01 & $5 E+00$ & - \\
\hline${ }^{14} \mathrm{C}$ & $5.7 E+03$ & $6 E-04$ & $8 E+00$ \\
\hline${ }^{14} \mathrm{i}$ (aect. metal) & $5.7 E+03$ & $6 E-04$ & $8 E+01$ \\
\hline${ }^{60} \mathrm{Co}$ & $5.3 E+00$ & $3 E+02$ & $-\dot{0}$ \\
\hline${ }^{59} \mathrm{Ni}$ (eot. motall & $8.0 E+04$ & $3 E+00$ & $2.2 E+02$ \\
\hline${ }^{63} \mathrm{Ni}$ & $9.2 E+01$ & $2 E+00$ & $7 E+02$ \\
\hline${ }^{63} \mathrm{Ni}$ (eact. motall & $9.2 E+01$ & $2 E+01$ & $7 E+03$ \\
\hline${ }^{90} \mathrm{Sr}$ & $2.8 E+01$ & $5 E-03$ & $7 E+03$ \\
\hline${ }^{94} \mathrm{Nb}$ & $2.0 E+04$ & $8 E-04$ & $2 E-01$ \\
\hline${ }^{99} \mathrm{TC}$ & $2.1 E+05$ & $7 E-03$ & $3 E+00$ \\
\hline${ }^{129} I$ & $1.2 E+07$ & $1 E-03$ & $8 \mathrm{E}-02$ \\
\hline${ }^{137} \mathrm{Cs}$ & $3.0 \mathrm{E}+01$ & $2 E-02$ & $4.6 E+03$ \\
\hline${ }^{249} \mathrm{Pu}$ & $1.3 E+01$ & $5 E+01^{b}$ & $3.5 E+03^{b}$ \\
\hline${ }^{242} \mathrm{Cm}$ & $4.4 E-01$ & $2 E+03^{b}$ & $2 E+04^{b}$ \\
\hline${ }^{79} \mathrm{Se}$ & $6.5 \mathrm{E}+04$ & $7 E-03$ & $7 \mathrm{E}-02$ \\
\hline $\begin{array}{l}\text { Alpha-emitting } \\
\text { transuranic. } \\
\text { nuclides }\end{array}$ & $>5$ & $10^{b, e}$ & $100^{b, c}$ \\
\hline
\end{tabular}

"A dash indicates no values are provided.

bexpressed in units of nanocuries per gram of waste.

'Number selected in accordance with already-established limits and definitions.

NOTE: This table is modeled on the waste classification system developed by the NRC in 10 CFR 61 (NRC 1990). These values are upper limit concentrations of specific radionuclides for the INVERSE computer model developed by the NRC. The actual concentration limits for Column 1 are also based on the internal dose models, ICRP-30 and ICRP-48, which have been adopted by DOE for all radiation exposure calculations for internally deposited radionuclides. These limits are numerically smaller than the NRC limits, in part, because the NRC limits are based on the earlier internal dose model ICRP-2. The list of nuclides includes ${ }^{79} \mathrm{Se}$, which may occur in significant amounts in deferise waste, but is insignificant in commercial waste. Values for other radionuclides may be identified during the development of the Hanford Site PAs for disposal of waste in these classifications. 
WHC-SD-WM-RPT-060, REV 0 VOLUME 5

Section 5.1.1. of the Engineering Study for $W-112$ states the following:

The Phase V Storage must store waste from new generators and suspect TRU waste retrieval activities. The storage activities can be classified into lag storage, surge storage, and long-term storage for GTC3 (Greater Than Category 3) wastes. The classifications include the following:

- Lag storage for waste containers from WRAP Module 1 awaiting treatment in Module 2 and treated Module 2 wastes awaiting assay in Module 1.

- Surge storage for waste containers awaiting entry into Module 1, containers awaiting entry into Module 2, and containers awaiting shipment to WIPP from Module 1.

- Long-term storage for mixed-wastes awaiting Module 2 treatment and GTC3 wastes.

All waste containers must be certified relative to TRU content. Suspect retrieved TRU waste containers will be certified in the retrieval process or in WRAP Module 1 and newly generated waste packages are certified by the generator and will be verified in WRAP Module 1. In addition to TRU content, RSTRU waste containers must also be characterized for hazardous waste constituents. The process will include visual as well as analytical tests. The analytical process results will supplement the TRU certification process.

The following paragraphs describe the waste container flow $p$ ths $p$ lanned for Phase $V$ Storage as well as develop basic information on the waste containers:

- RSTRU - Retrieved suspect TRU waste will enter Phase V Storage and be heid in surge storage. From surge storage, RSTRU will be sent to WRAP Module 1 for characterization. Lag storage will be provided in Phase $V$ storage between any in-process steps that are required to certify the waste for disposal. Retrieved suspect TRU could be split into any number of waste streams and then appropriately stored or pro ssed. If certified WIPP-compliant, the waste will go into lag storage for a waiting period prior to the head gas test. Upon successful completion of the test, it will then go to surge storage to await staging and transportation to WIPP from WRAP.

The RSTRU waste containers planned to be stored in Phase $V$ Storage are in drums or boxes. All RSTRU waste drums will be received in overpack, double-lidded, salvage drums. The maximum recorded weight for stored suspect TRU drums is 2,810 1b. Phase V Storage facilities can handle a limited number of heavier drums (drums 
that exceed $2,810 \mathrm{lb}$ ). However, due to the payload limitations of the handling equipment, a 4,000-1b maximum drum weight is placed on Phase $V$ storage. Retrieved suspect TRU waste boxes also will be received in overpack boxes. The overpack size restriction is 8-ft wide by 13-ft long by 8-ft high with the weight not to exceed $80,000 \mathrm{~Tb}$.

The size requirement of $8-\mathrm{ft}$ wide by $13-\mathrm{ft}$ 10ng by $8-\mathrm{ft}$ high is based on waste container dimensions up to 7-ft wide by 12-ft long by 7-ft high. The additional foot in each dimension is an al lowance for the overpack. This size limitation for RSTRU boxes is selected because it can be readily handled in the box storage building, within the transfer corridor, and by container handling equipment. Boxes that are larger than the above sizes can be selectively scheduled for retrieval following WRAP Module 2(B) becoming operational. These containers can be received directly into WRAP Module 2(B) for size reduction and/or treatment. Should selective retrieval be unattractive, a new project could be provided that would add a storage module to the transfer corridor or adjacent to WRAP Module 2(B) (if boxes are too large for the transfer corridor) for storage of the larger-sized boxes.

This paragraph provides insight for the box sizing limitations previously identified for phase $V$ Storage. A portion of WHC-IP0590, Study of Existing Records for Contact-Handled Transuranic Waste (Anderson et a1. 1989) identifies bases data for suspect TRU containers to be retrieved. Other details such as different box construction types are contained in WHC-IP-0590. The total piece count found for box waste in WHC-IP-0590 is 1,003 pieces. Of the 1,003 pieces, 541 pieces were identified as to their construction medium and outside dimensions. Regarding dimensional description, no effort was made to relate the dimensions to length, width, or height. It was noted in the previous paragraph that a box size of $7 \mathrm{ft} \times 12 \mathrm{ft} \times 7 \mathrm{ft}$ was selected as the optimum size box for Phase $v$ Storage. This optimum size was selected from calculations performed on several different trial sizes.

An estimated two-thirds of the 541 suspect. TRU boxes to be retrieved can be stored in Phase $V$ Storage. In terms of cubic feet of waste, this capability supports only one-fifth of the cubic feet. This low percentage is due to the small number of very large boxes of known dimensions, which Phase $V$ will not accommodate. As previously noted, Phase V Storage provides adequate storage based on the premises that RSTRU boxed waste can be selectively retrieved (i.e. larger RSTRU boxes can be selectively retrieved following the start of WRAP 2 (B) operation).

- NEW TRU - Newly generated TRU waste will enter Phase V Storage and be sent to WRAP Module 1 where the certification will be verified and unacceptable packages returned to the generator. From there; 
the acceptable waste containers will go into lag storage to await head gas testing and then go to surge storage to await transportation to WIPP.

- NEW TRUM - Newly generated TRUM waste will enter Phase $V$ Storage and be sent to WRAP Module 1 for characterization verification. If the waste stream meets the waste acceptance criteria for WIPP, the waste container will go into lag storage to await the head gas test and then into surge storage to await shipment to WIPP. If non-compliant, the waste will go into surge storage (or long-term storage if before the year. 2002) and wait for treatment in WRAP Module 2(B). After treatment, the TRUM waste will go into 1 ag storage until it can be staged through WRAP Module 1 for compliance verification. After compliance verification, the waste will follow the same path as the compliant waste.

- NEW LLMW - New LLMW will enter Phase V Storage and go into surge storage (or long-term storage if before the year 1999) to await treatment and certification in WRAP Module 2(A). After treatment and certification, the waste will go into 1 ag storage to await shipment to a LLMW disposal area. This waste will be contained in 55 gallon drums, and will be well characterized.

- NEW GTC3 - New GTC3 waste will enter Phase V Storage and then go into long-term storage until a treatment or disposal method is identified. Some of this category will be "discovered," identified, packaged, and certified in WRAP Module 1 . In each case, the GTC3 is well characterized.

- NEW REMOTE SHIELDED WASTE - New remote shielded (Waste which is itself remote handled, but which has shielding as a part of its packaging which reduces the dose rate on the surface of the waste package to less than $200 \mathrm{mrem} / \mathrm{hr}$ ) waste will enter Phase $V$ Storage and then go into surge storage (or long-term storage if before the year 2002) to await treatment in WRAP Module $2(B)$. After treatment, the waste will be able to be contact handled and will go into lag storage. The waste will be staged through either WRAP Module 1 or WRAP Module 2(A) for certification, and then follow the routing for the appropriate waste type. Low-level wastes generated as a result of WRAP processes are also packaged in WRAP and staged through Phase $V$ Storage for disposal with the appropriate waste type.

- OVERSIZED WASTE - Oversized packages of waste will enter through WRAP Module 2(B) for treatment and size reduction. Upon leaving WRAP Module 2(B), the packages will be contact handled and will go into 1 ag storage. The waste then will be staged through WRAP Module 1 in the appropriate category and will follow that particular type of waste route. Low-level wastes generated as a 
WHC-SD-WM-RPT-060, REV 0 VOLUME. 5

result of WRAP processes exit Phase V Storage shipping to disposal.

- REMOTE WASTE - Remote waste will enter through WRAP Module 2(B) for treatment. Following treatment, the waste will be able to be contact-handled and go into lag storage from where it will stage through WRAP Module 1 in the appropriate category and follow that particular type of waste route.

A portion of the newly generated streams identified above includes those waste containers that comprise the small generator certification stream. The following are included among these containers:

- Newly generated waste in 55-gal drums (nominally less than 1,000 16 , though a few up to 4,000-1b gross weight drums can be accommodated) from small generators.

- Newly generated waste in SWB (not exceeding 4,000 1b) and B-25 boxes (not exceeding 4,000-1b gross weight) from small generators.

Retrieved suspect TRU boxes, capable of being individualiy retrieved, will be stored in the Phase V Storage. Waste containers must be individuaily retrievable because of the treatment and certification processes that are conducted in WRAP. Treatment is anticipated to be conducted in a batch process; thus when a particular type of waste is being treated, those containers containing that. waste must be retrievable from storage.

\subsubsection{Interfaces}

Basis: Hanford Site Solid Waste Program Plan

Source: $\quad$ FDC Section 3.3.14

3.2.2.2.1 Facilities. Physical integration, which includes buildings/utilities and waste treatment process trans ars, will be with the WRAP Modules and other future treatment facilities. Phase V Storage and WRAP Module buildings may be physically connected with common walls, utilities (including sanitary waste collection, treatment, and disposal), corridors, etc. Waste treatment processing transfers will include waste package resident time in the Phase V Storage buildings. Waste packages transferred between Phase V Storage and the WRAP treatment facilities will require lag, surge, and long-term storage and container equalization/head gas sampling. Transfers will be via forklift, AGVs, air-cushion transporter, or other conveyance systems. These transfers will be tracked by an in-plant computer communications system, which will be linked with the site network system.

As well as interfacing directly with WRAP and other future treatment facilities, Phase $V$ Storage will be required to receive waste from both new generators and from retrieval, and to ship waste to RCRA compliant disposal facilities such as WIPP. As stated above all waste received into Phase $V$ 
Storage will be characterized for TRU and hazardous material content and will have a dose rate at all locations on the packaging of less than $200 \mathrm{mrem} / \mathrm{hr}$.

Phase V Storage will provide lag, and long-term storage for retrieved suspect and newly generated TRU waste awaiting treatment in WRAP Module 1 or Module 2B. Phase V Storage will also provide lag and surge storage for lowlevel mixed waste exiting WRAP Module 1 and Module $2 B$ or which has been received from waste generators and is awaiting treatment in WRAP Module $2 A$. Waste which has undergone treatment and certification in WRAP Modules $1,2 A$, and $2 B$ or other future treatment facilities will be stored in Phase $V$ Storage awaiting shipment to RCRA compliant disposal.

3.2.2.2.2 Vehicles. Automated Guided Vehicles (AGVs) are included in the scope of several of the Hanford Site Central Waste Complex-projects. Specifically, WRAP Module 1 uses AGVs for in-process drum transfers between the receiving area and the NDA/NDE portions of the facility. Automated guided vehicles are also used in all process areas of WRAP Module $2 A$. Phase $V$ storage also includes AGVs, which will be used to transfer drums from the Automated Stacker/Retriever Building along the transfer corridor to WRAP Module 1, WRAP Module 2A, WRAP Module 2B, and possibly the Thermal Treatment Facility. AGVs are also included in the design of the WRAP $2 A$ facility.

No technical justification was specifically provided in the Phase $V$ Storage Engineering study for the use of AGVs. The use of AGVs in WRAP Module $2 A$ is based on the justification of AGVs for drum transfers in the NDA/NDE and process areas of WRAP Module 1 (Material Handling Optimization Study, WRAP Facility, Rev. B, United Engineers and Constructors, Project No. 6237.001, November 1, 1991). The referenced study recommended AGVs for future interfacing with WRAP Module $2 A$ and Phase $V$ storage.

An interface will be required, and has been included in the design of the WRAP Module 2A Facility, to transfer drums from the Phase $V$ transfer corridor AGVs to the transfer systems in WRAP Module $2 A$. A battery powered Fork 1 ift Truck is used to unload pallets of four waste drums and boxes from the Phase $V$ AGV.

Forklifts will be used to transfer drums, boxes, and pallets in all areas of the Phase V Storage Facility except in the Automated Stacker/Retriever (AS/RS) Building and in the transfers of pallets from the AS/RS to WRAP Modules 1 and 2 through the Transfer Corridor Building.

3.2.2.2.3 Containers. The Phase V Storage Facility is sized to receive waste drums $(55,83$, and 110 gallon) and boxes. The receiving equipment for Phase V Storage will need to be sized in order to receive drums in sizes from 55 to 110 gallons, and boxes with dimensions up to $13-\mathrm{ft}$ wide $x$ 22-ft long $x$ 14.5-ft high. Since waste will be shipped to WIPP and burial in 55 gallon drums only, the shipping equipment will need to be sized for 55 galion drums on $1 y$. 
WHC-SD-WM-RPT-060, REV 0 VOLUME 5

\subsubsection{Project Size}

Basis: WRAP Facilities needs, Waste Volume Forecast

Source: FDC, CDR Section IV.B.1

The engineering study estimated that a peak storage volume requirement of 55,000 drum equivalents would occur in the year 2000. The estimated storage volume was based on the best waste-forecasts available at the time the engineering study was written. Although the forecasts used were the best available at the time, they were thought to be somewhat inaccurate (Current peak volume estimates suggest that the peak volume may be as high as 80,000 drum equivalents). It was considered preferable to have an undersized facility designed for easy expansion as opposed to an oversized facility. For these reasons, the Phase V Storage Facility was designed with a storage capacity of 27,000 drum equivalents rather than 55,000 drum equivalents.

The Phase V Storage Facility will be initially capable of storing the equivalent of 27,000 drums of contact-handled solid waste. Of this total, manual storage for 5,700 drum equivalents of waste in boxes will be provided and the remaining 21,300 drum equivalents will be comprised of storage for 55gallon drums and 83-gallon overpacks of solid waste. The drum storage consists of a minimum of 7,000 drum equivalents of automated storage with the remaining 14,300 drum equivalents in manual storage. Manual storage refers to drums that will reside in Phase V Storage without transfers for more than two years. Phase V Storage Facility includes the need for the following drum lag storage:

- Automated Stacker/Retriever System (AS/RS) to provide incoming waste lag storage (retrieved and newiy generated wastes), intermediate lag storage for waste being transferred between processing facilities (WRAP 1, WRAP 2A, Head Gas Sampling Building), and outgoing waste lag storage (waste awaiting approval to be shipped to disposal). The AS/RS storage module will be designed to store a minimum of 7,000 (55- and 83- ga1) drums.

- Lag storage for off-loading incoming waste in shipping/receiving prior to transfer to the AS/RS and for on-loading outgoing waste in shipping/receiving for transfer to disposal. The shipping and receiving module will be designed to accommodate receipt of four truck loads and shipment of eight truck loads of drums per day (18 to 20 drums per truck load).

Lag storage capacity was not specifically identified in the Phase V Storage Facility functional design criteria for the Head Space Gas Sampling Building operation but lag storage for 44 drums has been included in the conceptual design report.

The Phase V Storage Facility consists of five detached and five attached pre-engineered metal buildings. . The five detached buildings are the Box 


\section{WHC-SD-WM-RPT-060, REV 0 VOLUME 5}

Storage Builiding, three Long-Term Drum Storage Buildings, and the Ignitable Waste Storage Bullding. The five attached bulldings ate the Administration, Shipping/Receiving, Transfer Corridor, Head-Gas Sampling, and

Stacker/Retriever Buildings. Two of the five attached buildings will be occupied while the remaining three attached buildings will be unoccupied except when inspections are required. None of the five detached buildings will be occupied.

A brief description of the function of each butlding follows:

ADMINISTRATION BUILDING - The Administration Building is designed to support eight office personnel. The administration area will provide a hard wall office for a shift supervisor. Work stations with chairs, desks, and storage cabinets are provided for HPTs, quality assurance personnel, plant technicians, and a clerk. This building will also include a 20-person lunch room, central control room, restrooms, motor control room, fire riser room, and telecommunications room.

SHIPPING/RECEIVING BUILDING - The Shipping/Receiving Butlding adjacent to the Administration Building and the Transfer Corridor Bullding will support 12 operators, including a dock foreman. The Shipping/Receiving Building will provide delivery points for loading and unloading covered vans, flatbed trucks, tractor trailers, and low-boy trailers. A truck slip is included inside the shipping and receiving area for unloading special waste containers from casks. The Shipping/Receiving Building will provide the primary interface with the Transfer Corridor Building. The Shipping/Receiving Building will include a battery recharging area. The battery recharging area will provide space for night time parking of battery-operated vehicles that are being recharged.

TRANSFER CORRIDOR BUILDING - The Transfer Corridor Building will be the primary interface and distribution area for incoming and outgoing materials, and staging waste packages while awaiting transfer between the Shipping/Receiving, WRAP or other treatment, Head-Gas Sampling, and Stacker/Retriever Buildings. The Transfer Corridor Building is designed to support two-way movement of waste packages. The Transfer Corridor building will have a smooth concrete floor with appropriate divider barriers to eliminate collision potential where automated Guided Vehicles (AGV) and warehouse forklifts are used with two-way traffic patterns.

STACKER/RETRIEVER BUILDING - The Stacker/Retriever Building will be constructed utilizing a metal rack and structural building support system. The Stacker/Retriever Building will include an. automated stacker/retriever system (AS/RS) with positions for 7000 drums. The Stacker/Retriever Building will also include a 
WHC-SD-WM-RPT-060, REV 0 VOLUME 5

maintenance area and fire riser room located at opposite ends of the building. Personnel access to these areas is provided.

HEAD-GAS SAMPLING BUILDING - The Head-Gas Sampling Building will be occupied building containing a small sampling area to test gas accumulation in the drums.

IGNITABLE WASTE STORAGE BUILDING - The Ignitable Waste Storage Building is designed to provide segregated areas and cell s for 1,000 drums. Segregated storage wi11 be divided into two areas, one for two hundred 55-gal drums of fully characterized ignitable waste, and one for eight hundred 83-gal overpack drums of less than fully characterized suspect ignitable waste from retrieval operations. The two segregated areas will be divided into eight cells in order to meet segregation requirements for the various levels of waste packages to be stored. The interior walls between each cell will be two hour fire rated. The interior floors of each cell will be sloped and drain to a spilled liquids collection box located near the center of each cell. The waste packages in each cell will be loaded and unloaded with battery-powered forklifts.

LONG-TERM STORAGE BUILDINGS - The Long-Term Drum Storage Buildings will consist of three identical, unoccupied, storage modules. Loading and unloading areas will be included at both ends of each building. The interior floors will be sloped and drain to central spilled liquids collection boxes.

BOX STORAGE BUILDING - The Box Storage Building will be provided with a loading and unloading area at both ends of the building. Boxes will be loaded and unioaded from a flatbed trailer using a 50-ton overhead crane. The building will be unoccupied. The interior floor will be sloped and drain to a central spilled liquids collection bax.

In addition to the buildings the scope of the Phase $V$ Storage facility also includes the following infrastructure upgrades:

- Improved or new utilities systems (Water, Sewer, Power, Telecommunications...) These upgrades will support the Hanford Site Central Waste Complex and not only Phase $V$ Storage.

- Road and Rail systems to provide access to the Hanford Site Central Waste Complex. 
WHC-SD-WM-RPT-060, REV 0 . VOLUME 5

\subsection{2:4 Project Schedule}

Basis: The basis for the project schedule of the Phase V Storage facility is driven by WRAP Modules 1 and 2 and Burial Ground closure schedules.

\section{Source: CDR Appendix D}

The project schedule can be broken into the following four areas:

- DESIGN - The design currently is ongoing and tentatively scheduled to be completed by April 1995. Engineering inspection which has been included as a part of the design phase will continue through May of 1997.

- PROCUREMENT - Procurement of materials is tentatively scheduled to begin in January 1995 and be completed by august 1996.

- CONSTRUCTION - Construction activities are tentatively scheduled to begin in December of 1994 and be completed by March 1997.

- PROJECT INTEGRATION - Project integration activities are current7y ongoing and tentatively scheduled to be completed in May 1997.

Complete schedule development is ongoing. Information will be made available as the material is developed.

\subsubsection{Facility Expansion}

Basis: Hanford Site Solid Waste Program Plan, "Soft" Waste Volume Forecasts

\section{Source: $\quad$ FDC Section 2.4}

The FDC includes the following requirement: The project shall be designed and constructed in such a manner which will not hinder future expansion.

The modular facility design in the conceptual design report lends itself well to future expansion of the facility. It is important to understand that facility expansion is accomplished by building additional long-term storage modules. The design of any new modules should be identical to the long-term storage buildings (Ignitable Waste Storage Building, Long-Term Drum Storage Buildings, and Box Storage Building) in the initial project scope. The Automated stacker/Retriever, office buildings, and utilities will most likely not require expansion or significant upgrade to accommodate additional storage capacity. 

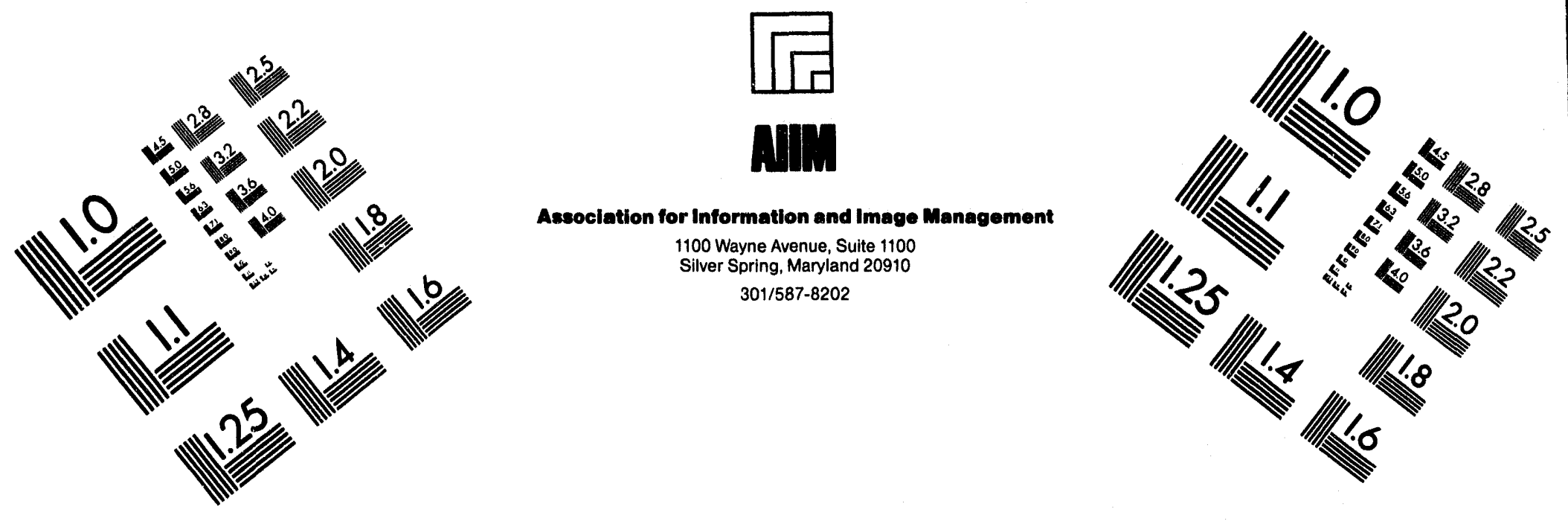

\section{Centimeter}

$\begin{array}{llllllllllllllll}1 & 2 & 3 & 4 & 5 & 6 & 7 & 8 & 9 & 10 & 11 & 12 & 13 & 14 & 15 & \mathrm{~mm}\end{array}$

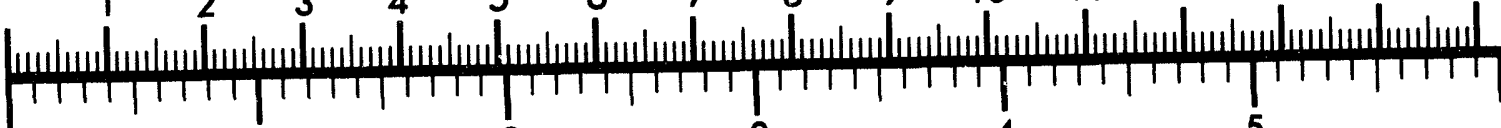
Inches
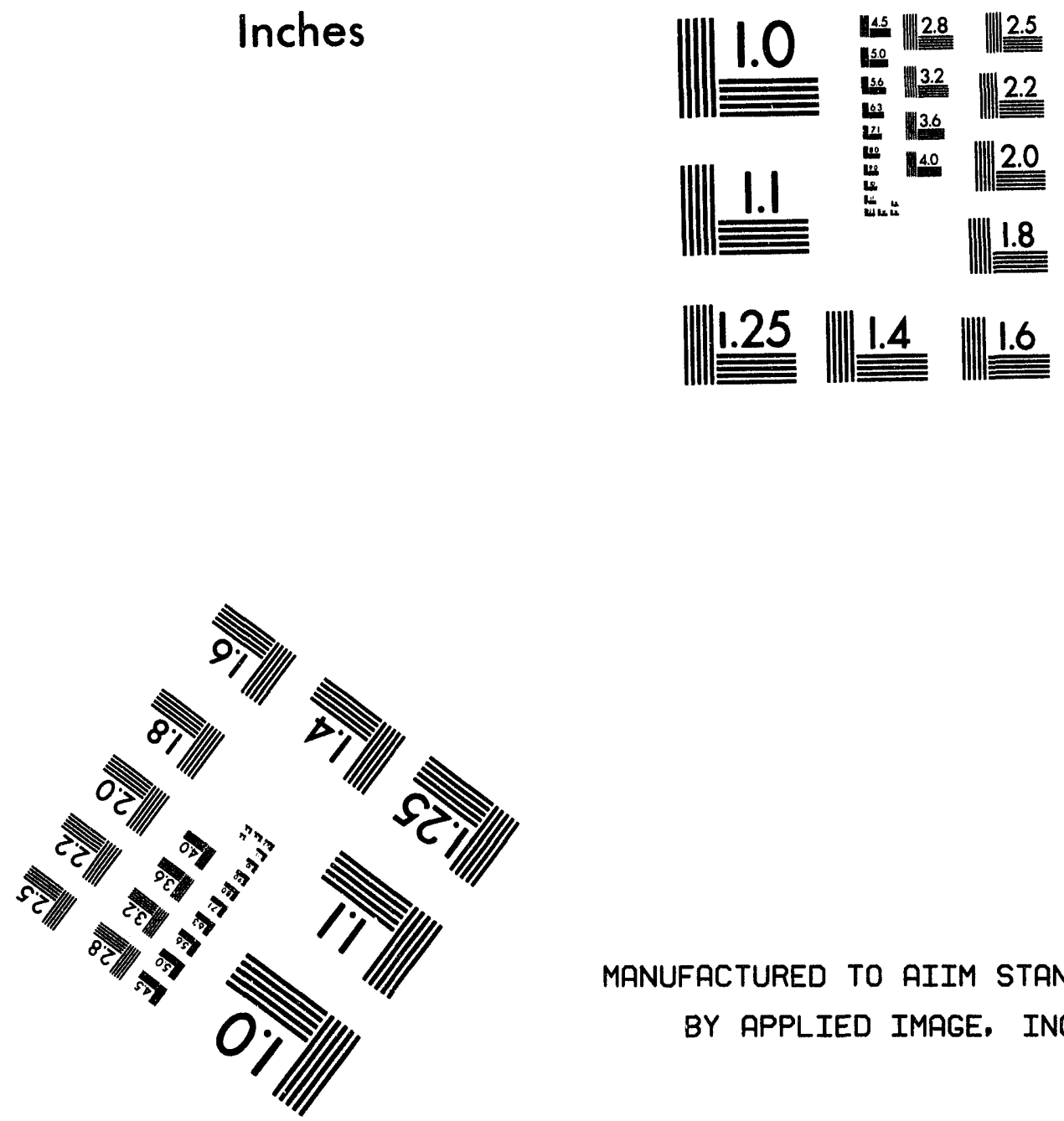

MANUFACTURED TO AIIM STANDARDS BY APPLIED IMAGE, INC.

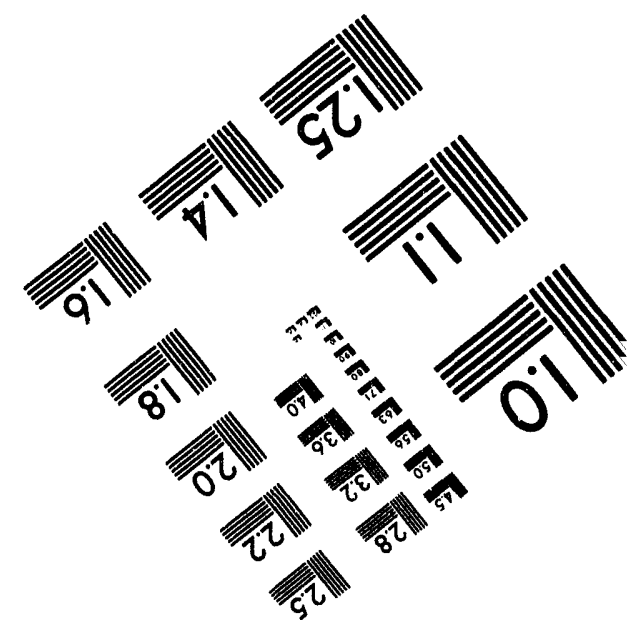



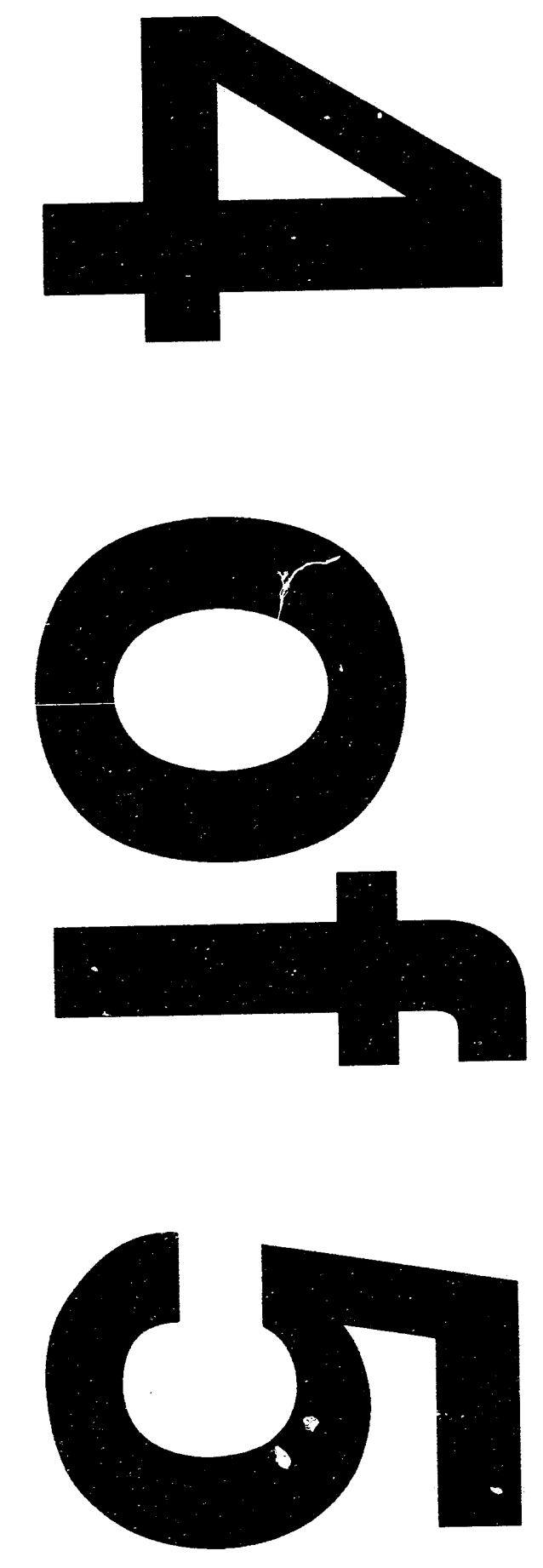
WHC-SD-WM-RPT-060, REV 0 VOLUME 5

\subsubsection{Project Requirements}

\subsubsection{Permitting}

Basis:- Resource Conservation and Recovery Act (RCRA); Washington State Administrative Code (WAC) 173-303

Source: $\quad$ CDR Section VI.I

Section VI.I of the CDR states the following:

- Project W-112 will be included in the HCWC RCRA Part B permit application.

- Project $W-112$ will also require air emissions and sewage permits.

In addition to these permitting requirements, the $W-112$ Project will need to comply with and be governed by DOE Orders, Washington State and U.S. federal codes and regulations, local government codes, and Westinghouse Hanford Company Plans, Procedures, and Manuals. A complete listing of these governing requirements and regulations can be found in section VI. $H$ of the Phase V Storage CDR.

\subsubsection{Inspections}

Basis: Washington State Administrative Code (WAC) 173-303

\section{Source: $\quad$ Project W-112 Engineering Study}

The Enhanced Radioactive Mixed Waste Storage, Phase V (Project W-112) scope includes an automated weekly inspection system.

The frequency of inspection is detailed by. Washington Administrative Code (WAC-173-303-630, "Use and Management of Containers") "(5) Management of Containers, (6) Inspections. At least weekly, the owner or operator must inspect areas where containers are stored, looking for leaking containers and for deterioration of containers and the containment system caused by corrosion, deterioration, or other factors."

The "Enhanced Radioactive and Mixed Waste Storage Phase V Engineering Study" evaluated only an automated inspection system. The study results were included in the functional design criteria. The engineering study assumed that off-the-shelf technology. was available for this type of inspection system. The "Spimaster" system specified in the conceptual design report was used as a basis for a rough cost estimate of an automated inspection system. However, evidence does not exist to indicate that off-the-shelf technology such as the. "Spimaster" has been applied specifically to drum inspections.

A work plan dated March 4, 1993 titled "Work Plan for WRAP V Automated Drum Inspection System" describes work which will identify and evaluate 
WHC-SD-WM-RPT-060, REV 0 VOLUME 5

commercially available solutions to implementing an automated drum inspection system. This study will cover the following areas:

- Sensor System - Techniques for detecting damaged leaking drums equivalent to human visual inspection.

- Positioning System - A robotics system that will operate in the planned facility. It shall provide maximum access to drums for inspection and not interfere with the stacker/retriever.

- Pallet Options - Identify constraints to pallet design features that would optimize drum evaluation.

Technical justification has not been prepared for use of automated drum inspection rather than manual drum inspection. However, an automated drum inspection system is beneficial from a personnel safety stand-point because of the reduction in dose to personnel by eliminating drum inspection in the Phase $V A S / R S$ and long term storage areas. Rough order of magnitude dose estimates for the AS/RS have shown a dose rate of $14.5 \mathrm{mrem} / \mathrm{hr}$. Assuming an occupancy factor of $1 / 2$ to attain drum inspections, the dose rate to an operator transferring drums out of a configuration similar to the AS/RS would be 290 $\mathrm{mrem} /$ week, $1.1 \mathrm{rem} / \mathrm{month}$, and $14 \mathrm{rem} /$ year. The WHC accepted dose rates are 20 $\mathrm{mrem} /$ week and $1 \mathrm{rem} /$ year. Although this is not an ALARA assessment, it appears this would justify the use of an automated drum inspection system. The $\$ 300,000$ capital cost of a "Spimaster" system in the conceptual design report would replace roughly one operator dedicated to drum inspection at a cost of approximately $\$ 100,000$ per year. Maintenance cost for the automated inspection system is not known.

\subsubsection{Project Functions}

\subsubsection{Waste Segregation}

Basis: $\quad$ Resource Conservation and Recovery Act (RCRA), Washington State Administrative Code (WAC-173-303)

Source: Engineering Study; FDC; and CDR

As previously stated, all waste will be characterized before acceptance into the Phase V Storage Facility. The Phase V Storage facility will have available storage areas for short-term storage ( $1 \mathrm{ag}$ and surge storage), of drums and boxes, and for long-term storage of wastes. The short term storage will be primarily for waste received into Phase $V$ Storage while treatment facilities are in operation and ready to receive and treat the waste. Longterm storage is for waste received before facilities are ready to receive and treat the waste. As mentioned previously the storage areas are; the Automated Stacker/Retriever System (AS/RS) Building, Long-Term Drum Storage Buildings, Box Storage Building, and Ignitable Storage Building. 
WHC-SD--WM-RPT-060, REV 0 VOLUME 5

L...n receipt into Phase $V$ Storage, the waste will be segregated and transferred into the appropriate facility to await appropriate treatment, certification, and disposal.

\subsubsection{Shipping/Receiving}

Basis: Hanford Site Solid Waste Program Plan

Source: $\quad$ FDC Section 3.3.6.1:/CDR Section VI.B.1

The Shipping/Receiving building will have the capability for loading, unloading and staging up to two truckloads (18 to 20 drums or 2 B-25 boxes per truck) simultaneously per hour. The Shipping and Receiving Building will be designed to accommodate receipt of 7 truck loads ( 4 drum and 3 box) and shipment of 8 truck loads per day. This same area, which includes laden areas for cask lids and other appropriate support hardware during loading or unloading, shall have the flexibility to handle vertical casks. The staging area shali be supported by a pelletizing station for shipments received without pallets.

Forklifts and an overhead crane shall be utilized for loading and unloading operations. An appropriate number of forklift to Automated Guided Vehicle (AGV). transfer stations will be required. These stations allow the unloading of vehicles to be dedicated to the Shipping and Receiving area. AGVs and forklifts (as appropriate) will be dedicated to the transferring of drums and box. waste packages to and from storage. The Phase $V$ Storage Shipping and Receiving Building shall be designed to accommodate space for 150 drum equivalents, which includes space for staging loads received or about to be shipped, staging drums for pelletizing, and space for holding non-compliant waste packages.

The Shipping/Receiving Building will provide delivery points for loading and unloading covered vans, flatbed trucks, tractor trailers, and low-boy trailers. A truck slip is included inside the shipping and receiving area for unloading special waste containers from casks. The Shipping/Receiving Building will provide the primary interface with the Transfer Corridor Building.

\subsubsection{Available Storage in the Facility}

Basis: Hanford Site Solid Waste Program Plan

\section{Source: $\quad F D C / C D R$}

The Phase V Storage Facility will be initially capable of storing the equivalent of 27,000 drums of contact-handled solid waste. Of this total, manual.storage for 5,700 drum equivalents of waste in boxes will be provided and the remaining 21,300 drum equivalents will be comprised of storage for 55gallon drums and 83-gallon overpacks of solid waste. The drum storage consists of a minimum of 7,000 drum equivalents of automated storage with the 
WHC-SD-WM-RPT-060, REV 0 VOLUME 5

remaining 14,300 drum equivalents in manual storage. Manual storage refers to drums that will reside in Phase $V$ Storage without transfers for more than two years. Phase $V$ Storage Facility includes the need for the following drum lag storage:

- Automated Stacker/Retriever System (AS/RS) to provide incoming waste lag storage (retrieved and newly generated wastes), intermediate 1 ag storage for waste being transferred between processing facilities (WRAP 1, WRAP 2A, Head Gas Sampling Building), and outgoing waste lag storage (waste awaiting approval to be shipped to disposal). The AS/RS storage module will be designed to store a minimum of 7,000 (55- and 83- gal) drums.

- Lag storage for off-loading incoming waste in shipping/receiving prior to transfer to the AS/RS and for on-loading outgoing waste in shipping/receiving for transfer to disposal. The shipping and receiving module will be designed to accommodate receipt of four truck loads and shipment of eight truck loads of drums per day (18 to 20 drums per truck load).

Lag storage capacity was not specifically identified in the Phase V Storage Facility functional design criteria for the Head Space Gas Sampling Building operation but 1 ag storage for 44 drums has been included in the conceptual design report (SK-2-58813).

The Phase $V$ Storage Facility consists of five detached storage buildings and one attached storage building. The five detached storage buildings are the Box Storage Building, three Long-Term Drum Storage Buildings, and the Ignitable Waste Storage Building.

\subsubsection{Waste Characterization}

Basis: $\quad$ Resource Conservation and Recovery Act (RCRA), Washington State Administrative Code (WAC) 173-303

\section{Source: Engineering Study/FDC/CDR}

As previously mentioned, in order to be accepted all waste entering Phase $V$ Storage will be fully characterized for TRU and hazardous material content.

For compliance with the WIPP Waste Acceptance Criteria (WIPP-WAC), the head gas in all drums will need to be sampled prior to certification. In order to fulfil requirement, there is a head gas sampling building included within the scope of the Phase V Storage Facility. Head Gas Sampling refers to the sampling and analysis of gases in the head space of waste containers for volatile organic compounds. The Head-Gas Sampling Building will be an occupied building containing a small sampling area to test gas accumulation in the drums. 
WHC-SD-WM-RPT-060, REV 0 VOLUME. 5

3.2.4.5 Waste Handling Automated Stacker/Retriever System (AS/RS)

Basis: Hanford Site Solid Waste Program Plan, ALARA, WRAP facility processing needs

Source: Engineering Study/FDC

The AS/RS in the Phase $V$ Storage Facility is designed to store 7,000 drums or approximately $\mathbf{8 . 8 \%}$ of the Central Waste Complex (including Phase $V$ Storage Facility) total storage of 79,500 drums. The Phase $V$ Storage Facility AS/RS stacks and retrieves pallets of waste drums supporting lag storage for: incoming waste from onsite/offsite generators and from the $W-113$ retrieval project, waste returned from initial treatment awaiting subsequent processing or results of laboratory analysis, and outgoing waste awaiting certification and batching for final disposal.

The Phase V Storage Facility AS/RS consists of vertical and horizontal conveyors which pick up and deliver pallets (four drum locations per pallet) to designated locations within a storage rack or take and deliver pallets from the storage rack for transport. The AS/RS is computer controlled. The computer controls the movement of the stacker/retriever and provides container traceability. The AS/RS will also be able to assemble batches of waste drums stored in these pallets for waste processing or disposal. Batches are typically made up of drums of compatible waste. Batches can be made up from one or more drums from several pallets. The computer is able to track drums, pallets, and batches.

The Phase V Storage Facility AS/RS performs the following functions:

- enables remote operation

- handle and store palletized drums (four drums to a pallet) of waste awaiting processing in WRAP Module 1, WRAP Module 2A or Head Gas Sampling and waste awaiting shipment for disposal

- aids weekly drum inspection

- segregates waste packages (by waste characteristics)

Enhanced Radioactive and Mixed Waste Storage Phase V Engineering Study considered two alternatives for waste storage and transfer equipment. The first alternative was a completely manual system and the second was the use of the combined automated and manual systems. The combined automated and manual system looked at the use of an AS/RS along with AGVs. The system was evaluated as a complete system rather than an individual storage system and an individual transfer system. The recommendation from the engineering study is based on the complete system rather than individual automated storage and transfer systems.

The following measures were used to compare the two waste handling and transfer equipment alternatives considered in the engineering study: maintainability, expansion capability, availability, handling errors, package retrievability, ALARA, life-cycle cost. Each selection measure was assigned a 
WHC-SD-WM-RPT-060, REV 0 VOLUME 5

weight based on relative importance. If one alternative was clearly superior to the other, the superior alternative scored a three (3) and the inferior scored a one (1). If neither alternative was clearly superior, then both scored a two (2). Table 3-2 gives the outcome of the comparison.

The partially automated system was the preferred alternative and scored higher in the availability, handling errors, ALARA, and life-cycle cost measures. Capital cost for the automated drum storage facility and material handling equipment was $\$ 20.8$ million while capital cost for the manual drum storage and material handling equipment was $\$ 23.4$ million. Comparison of dose estimates for alternatives was not presented in the engineering study but an AS/RS would have no dose to operators during normal operations unlike a manual system. The AS/RS would only have dose to operators during maintenance.

The engineering study only identified and evaluated one automation al ternative, the stacker/retriever with automated guided vehicles, that was chosen for inclusion in the Phase V Storage Facility.

A statement of work for the Phase V Storage Facility was issued to Los Alamos Technical Associates (LATA) to: identify the technical drivers for automation, evaluate automation al ternatives, and critique integration of automation with respect to the phasing of Solid Waste projects. A letter report reviewed the findings of the engineering study and agreed with the results that automation was justified. The work regarding automation a) ternatives and integration of automation is underway.

Table 3-2. Alternative Comparison Between Manual and Manual/Automated Systems

\begin{tabular}{|c|c|c|c|c|c|}
\hline \multirow{2}{*}{$\begin{array}{l}\text { Handiling Equipment } \\
\text { Seloction Criteria }\end{array}$} & \multirow{2}{*}{ Woight } & \multicolumn{2}{|c|}{ Manual Syotem } & \multicolumn{2}{|c|}{ Combined system } \\
\hline & & Score & $\begin{array}{c}\text { Woighted } \\
\text { Score }\end{array}$ & Score & $\begin{array}{l}\text { Woighted } \\
\text { Score }\end{array}$ \\
\hline Maintainabillity & 1 & 2 & 2 & 2 & 2 \\
\hline Expansion Capebillty & 2 & 3 & 6 & 1 & 2 \\
\hline Availability & 2 & 1 & 2 & 3 & 8 \\
\hline Hendling Error & 2 & 1 & 2 & 3 & 6 \\
\hline Packege retriovebility & 2 & 2 & 4 & 2 & 4 \\
\hline ALARA & 3 & 1 & 3 & 3 & 9 \\
\hline Lifo-Cyade Cost & 3 & 1 & 3 & 3 & 9 \\
\hline Total woighted score & - & - & 22 & .. & 38 \\
\hline
\end{tabular}


WHC-SD-WM-RPT-060, REV 0 VOLUME 5

3.3 TRANSURANIC STORAGE AND ASSAY FACILITY -

3:3.1 Facility Identification

To be drafted.

3.3.2 Facility Scope

To be drafted.

3.3.3 Facility Functions

To be drafted.

3.3.4 Facility Requirements

To be drafted. 
WHC-SD-WM-RPT-060, REV 0 VOLUME 5

4.0 TREATMENT FACILITIES ANDD PROJECTS

\subsection{WRAP MODULE 1}

\subsubsection{Project Identification}

The Disposal of Hanford Defense High-Level, Transuranic, and Tank Wastes, Hanford Site, Richland, Washington; Record of Decision (Reference 2) promulgates the Department of Energy's decision to implement the "Preferred Alternative" as discussed in the Disposal of Hanford Defense High-Level, Transuranic, and Tank Wastes Environmental Impact Statement (Reference 7). As part of the preferred alternative the Department of Energy decided that "A facility will be designed, constructed and operated at Hanford to sort process and repackage retrievabiy stored and newly generated TRU solid waste for shipment to the Waste Isolation Pilot Plant (WIPP) located approximately 26 miles from Carlsbad, New Mexico." (Reference 2)

The Waste Receiving and Processing (WRAP) facilities provide characterization, treatment, and repackaging of radioactive solid wastes at Hanford. WRAP Module 1 (WRAP) will process only TRU waste that can be handled without radiation shielding. WRAP I was a 1992 Line Item; definitive design began in January 1992 and completed in 1993. Construction is planned to begir. in 1994 and be completed in 1996. Operation is planned for 1997.

Some operations at Hanford over the years produced waste containing small amounts of plutonium. This radioactive waste, called TRU waste, was kept separate from other waste and was put for the most part, into steel drums. Some pieces of broken equipment were put into larger boxes. All of this waste produced since 1970 has been stored on asphalt pads and covered with dirt. The HDW-EIS describes $\mathrm{plans}$ for this waste to be removed and shipped to New Mexico for burial deep in salt formations. The WRAP facilities provide the means to safely prepare the waste for disposal.

\subsubsection{Project Scope}

\subsubsection{Waste Types}

Basis: DOE ORDER 5820.2A

HDW-EIS Record of Decision

Source: FDC Section 2.0.

Solid wastes that are candidates for treatment in the WRAP facility include wastes now in storage, wastes added to storage prior to WRAP start-up, and wastes to be generated after WRAP start-up.

Two broad waste classifications of waste were used to evaluate the WRAP project scope: contact-handled and remote-handled. Contact-handled wastes include those with radioactive dose rates less than $200 \mathrm{Mr} / \mathrm{hr}$ at any point on 
WHC-SD-WM-RPT-060, REV O VOLUME 5

the waste container. Remote-handled waste is waste with radioactive dose rates $200 \mathrm{mrem} / \mathrm{hr}$ and greater at any point on the waste container.

Beginning in 1970, TRU waste was segregated from other waste types and placed into retrievably stored units. The Atomic Energy Commission issued Immediate Action Directive No. 0511-21 that directed Hanford (and other sites) to begin temporarily storing all suspect TRU solid waste. The waste was to be stored "in such a fashion that it can be retrievable as contamination-free packages within an interim period of 20 years." Special provisions were made at Hanford for retrievable storage of high activity TRU WASTE. Thus, not only has the TRU waste been segregated from other types, but contact-handled TRU has been kept separate from remote-handled TRU. DOE Order 5820.2A defines transuranic, low-level and high-level wastes.

TRU waste is defined as containing plutonium or other "transuranic" naterials. This waste is given a special category by the Department of Energy primarily because it is an "alpha emitter." That is, its radioactivity is mostly alpha particles. This type of radiation is easily stopped by the skin or even a piece of newspaper. It is much more dangerous if it gets inside the body. Although is it usually safe to handle this type of waste without shielding from radiation, it does require precautions to keep from breathing small particles of the radioactive material. Much of the material that contains TRU waste also has waste that emits gamma and beta radiation:

Records maintained on the TRU waste show more than 38,700 containers (over 37,600/55-gallon drums) in contact-handled retrievable storage. Over $485 \mathrm{~kg}$ of plutonium is on record in these containers. About 1,200 cubic feet of remote-handled TRU waste is in retrievable storage. The waste that was retrievably-stored does not meet disposal packaging criteria. It must be repackaged.

The waste forecast shows that between 1997 and 2018 approximately 15,900 $\mathrm{m}^{3}$ of contact-handled TRU waste will be received for treatment in WRAP.

The HDW-EIS outlined the Department of Energy plan for the disposal of Hanford's TRU wa'ste. Several alternatives were considered: Geologic Disposal, In-place Stabilization and Disposal, Reference Alternative, and No Disposal Action.

The Geologic Disposal alternative inciuded, for the TRU solid waste as well as other waste classifications, retrieval, processing and packaging, and shipment of the waste to the Waste Isolation Pilot Piant in New Mexico for disposal. The In-place Stabilization and Disposal alternative involved nearsurface disposal of the solid TRU waste, including in-place compaction of waste containers to preclude subsidence at.some future date. The waste would be covered with a protective barrier and marker system. The Reference Alternative included retrieval, processing and packaging, and shipment to the Waste Isolation Pilot Plant only the retrievably-stored TRU waste. The No Disposal Action alternative (continued storage) for the TRU solid waste 


\section{WHC-SD-WM-RPT-060, REV 0 VOLUME 5}

included monitoring, surveillance, and maintenance of the existing storage locations.

The Preferred Alternative for TRU waste includes retrieval, processing and packaging, and shipment to the Waste Isolation Pilot Plant for disposal. Both contact- and remote-handled TRU wastes are identified in this action.

LLW solid waste was not included in the HOW-EIS evaluations. Disposal of LLW solid radioactive waste can be accomplished in accordance with the requirements of RCRA or CERCLA. LLW solid waste at Hanford that has been put into trenches is now, by definition, disposed.

Mixed Low-Level Waste (MLLW) contains hazardous constituents, as defined by the Resource Conservation and Recovery Act (RCRA). Treatment requirements for the large number of hazardous waste categories are also given by RCRA. Generally, these treatment requirements for disposal are more extensive than those required by the WIPP-WAC for TRU waste. Incorporating the RCRA MLLW technologies with WRAP I was evaluated. The evaluation determined that a separate MLLW facility would be more effective in managing that specific class of waste.

The remote-handled TRU solid waste at Hanford includes two general types of waste. These types represent different handling and processing considerations. One type includes physically-large waste items, e.g. containers up to 2000 cubic feet volume and failed equipment up to 60 feet long, with moderate dose rates (although definitely greater than $200 \mathrm{Mr} / \mathrm{hr}$ ). The other type includes those containers and items with very high (up to 2000 $\mathrm{R} / \mathrm{hr}$ ) dose rates. Decidedly different techniques and technologies are needed for the remote-handled TRU solid waste than for contact-handled containers.

The WRAP 2 Engineering Study evaluated the feasibility of including with the WRAP scope, waste other than contact handled TRU. The results of the evaluation concluded that WRAP should not be designed and constructed as one facility, but rather built in modules. The portions of the processes that were well understood and well defined would be placed into WRAP Module 1: assay and inspection, certification and shipping for contact handled TRU and LLW in drums.

Future WRAP modules would provide Size Reduction; Remote Handling, Low Level Mixed Waste, and Decontamination facilities. The sampling requirements and specific analyses for mixed waste characterization were not well defined; WRAP throughput and storage needs could not be well enough established to provide a basis for design at the time of the evaluation. Remote handled TRU processing, potentially in existing facilities, and transportation, such as fissile material allowances, requirements al so were insufficient to allow for design configurations. Capability to assay large containers, currently in storage, was non-existent. All of these items could affect facility sizing, lag storage, and throughput requirements. 
WHC-SD-WM-RPT-060, REV 0 VOLUME 5

Thus, the scope of the WRAP Module I facility, contact-handled TRU solid waste, was established based upon the HDW-EIS Preferred Alternative, the unique characteristics of TRU solid waste, the ability to shallow-land dispose of LLW solid waste, the technology development requirements for remote-handled TRU sol id waste, and the relative large quantity of contact-handled TRU solid waste at Hanford.

References: WHC-EP-0225, Section 3 of "Waste Volume Forecast and Projections" WHC-SD-W100-ES-001, WRAP 2 Engineering Study WRAP 1 Engineering Study

\subsubsection{Interfaces}

\section{Bases: $\quad$ Solid Waste Program Plan}

Sources: FDC Section 1.2; SDRD Sections 3.0 and 4.0.

Although Module 1 is a "stand alone" facility, it will interface in many ways with several facilities. These are summarized in table 4-1. Waste will be received in either drums or small boxes from the Central Waste Complex Phase I through IV buildings by transport motor vehicle or forklift type vehicle. Phase $V$ storage will be connected with Module 1 to permit the use of automated guided vehicles for transport of drummed waste. Other containers, small boxes or standard waste boxes, from Phase $V$ storage will be received by forklift vehicles. WRAP Module 1 container interfaces are presented in table. 4-2. Waste in drums from other locations may be received by motor vehicle.

Module 1 will also interface with other WRAP modules for transport of drummed waste requiring additional processing and for receipt of waste in drums requiring certification for shipping.

Waste for treatment and/or disposal offsite will be shipped from Module 1. TRU waste for disposal at WIPP will be shipped in TRUPACT II containers; this motor vehicle transport system has been specialiy designed for shipment of TRU wastes. Both drums and standard waste boxes may be shipped in TRUPACT II containers. Shipment of LLW will be accomplished by motor vehicle. No rail transportation facilities are provided. Shipment of shielded casks is not a part of Module 1. WRAP Module 1 vehicle interfaces are shown in table 4-3.

The WRAP 1 Conceptual Design Report identified that Module 1 would provide shipping functions for other WRAP Modules for contact handled TRU and contact handled LLW standard waste boxes. Rail access was identified in this report as "likely" to be provided by later modules.

Module 1 , in the Conceptual Design Repor: , was not $p 1$ anned to have storage capability, other than might be required for direct process support. The storage function was described as being provided by existing or new facilities. 
WHC-SD-WM-RPT-060, REV 0 VOLUME 5

\begin{tabular}{|c|c|c|c|c|c|}
\hline & $\begin{array}{l}\text { Proporem: } \\
\text { Plien }\end{array}$ & $\begin{array}{l}\text { URAP } 1 \text { Eng } \\
\text { Study }\end{array}$ & $\begin{array}{c}\text { Coneeptual } \\
\text { Deetign } \\
\text { Report }\end{array}$ & $\begin{array}{l}\text { WRAP: } 2 \text { Eng } \\
\text { Study }\end{array}$ & $\begin{array}{l}\text { Title: } 1 \\
\text { Deafign }\end{array}$ \\
\hline $\begin{array}{l}1 . \text { Centrat } \\
\text { Cosete } \\
\text { Conelex } \\
\text { storegos }\end{array}$ & - & - & $x$ & $x$ & - \\
\hline $\begin{array}{l}\text { z. Rotrieval } \\
\text { Trench }\end{array}$ & $x$ & 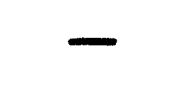 & - & - & - \\
\hline $\begin{array}{l}\text { 3. Phase v } \\
\text { Storage }\end{array}$ & - & - & - & - & $x$. \\
\hline 4. map 2 & - & - & $x$ & $x$ & - \\
\hline $\begin{array}{l}\text { 5. Weste } \\
\text { Isolution } \\
\text { Pillot Plent } \\
.\end{array}$ & $x$ & $x$ & $x$ & $x$ & $x$ \\
\hline 6. TRUSAF & $x$ & $x$ & - & - & - \\
\hline $\begin{array}{l}\text { 7. Orsposel } \\
\text { Trencht }\end{array}$ & - & $x$ & $x$ & $x$ & $x$ \\
\hline
\end{tabular}

NOTES: $\quad$ 1. The WRAP facility interface with disposal activities-either the Hanford burial grounds for LLW or the Waste Isolation Pilot Plant for TRU waste has not changed over the conceptual life of the facility.

2. The interface with TRUSAF, Central Waste Complex Storage, the retrieval trenches, and othei WRAP modules was replaced with a single facility--the Phase $V$ Storage facility, as the Solid Waste strategy developed over the years. 
WHC-SD-WM-RPT-060, REV 0 VOLUME 5

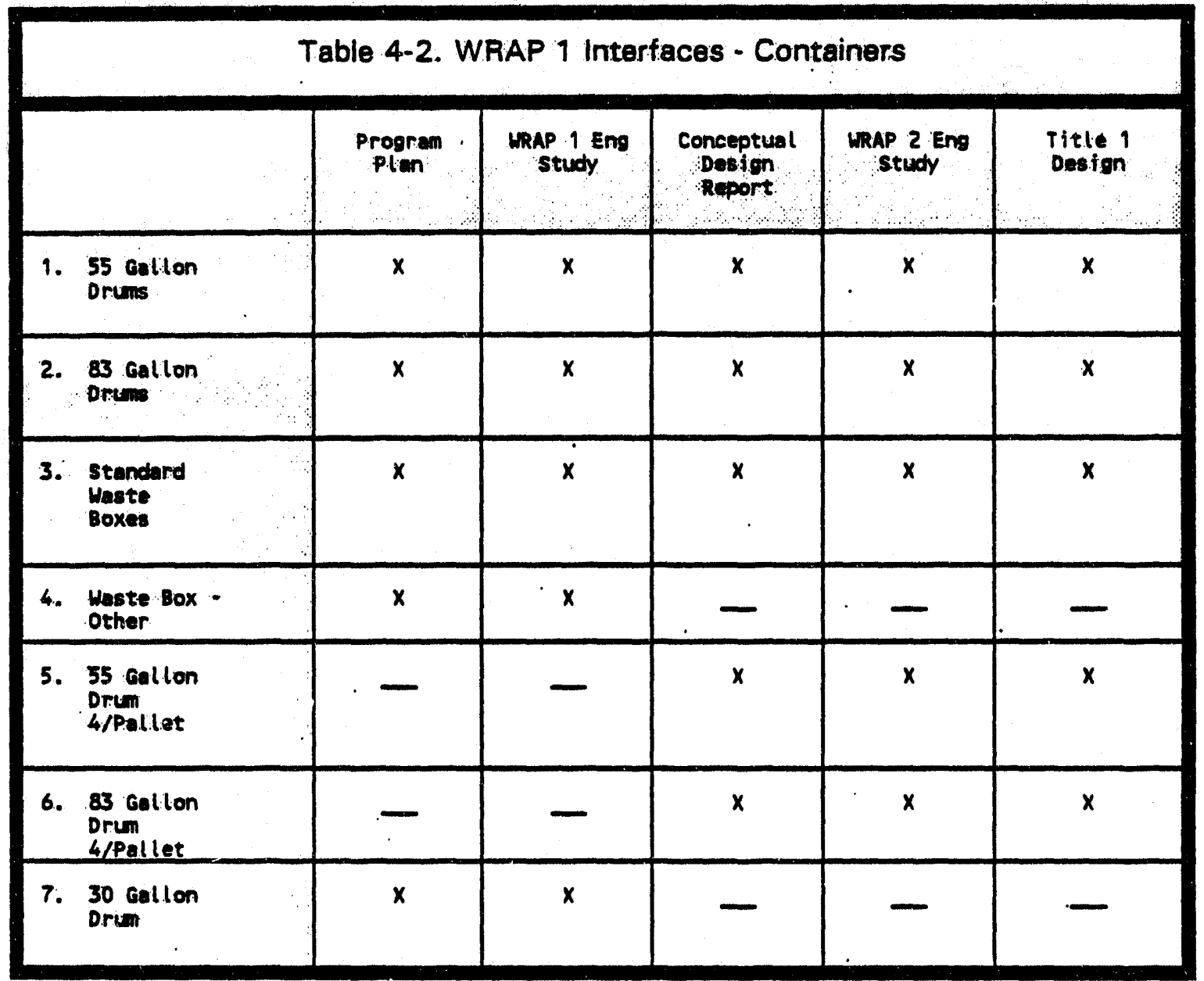


WHC-SD-WM-RPT-060, REV 0 VOLUME 5

Table 4-3. WRAP 1 Interfaces - Vehicles

\begin{tabular}{|c|c|c|c|c|c|}
\hline & $\begin{array}{l}\text { Propreal } \\
\text { Plent } \\
\end{array}$ & $\begin{array}{l}\text { WRAP } 1 \text { Eng } \\
\text { Study }\end{array}$ & $\begin{array}{l}\text { Conceptual } \\
\text { Desfion } \\
\text { Report }\end{array}$ & $\begin{array}{l}\text { Wrap } 2 \text { Eng } \\
\text { study }\end{array}$ & $\begin{array}{r}\text { Titele } 1 \\
\text { Design } \\
\vdots\end{array}$ \\
\hline 1. Truak & $x$ & $x$ & $x$ & $x$ & $x$ \\
\hline 2. pontht & $y$ & 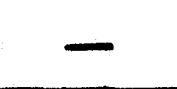 & $x$ & $x$ & $x$ \\
\hline 3. Train & $x$ & $x$ & & & 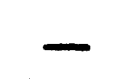 \\
\hline $\begin{array}{l}\text { 4. Autconted Gutded } \\
\text { Vehicte }\end{array}$ & 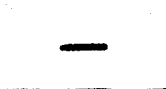 & 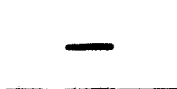 & 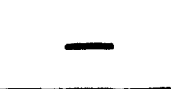 & - & $x$ \\
\hline 5. "TRUPACT" & $x$ & $x$ & 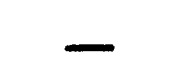 & - & - \\
\hline 6. MTRUPAgR IL & 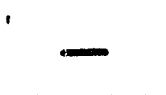 & & $x$ & $x$ & $x$ \\
\hline
\end{tabular}

References: WHC-SD-W-100-ES-001, Engineering Study for Waste Receiving and Processing (WRAP) Facility, Module 2.

WHC-SD-H-025-CDR-001, Conceptual Design Report, Waste Receiving and Processing Facility Module 1, Project W-026.

WHC-EP-0363, Solid Waste Program Plan.

WRAP Module 1 will also interface with communications systems for transfer of information regarding waste processing, sampling, certification, etc. (Source: FDC Section 2.2.10). Some of these interfaces are listed below:

Hanford Local Area Metwork (HLAN)

WHC-SD-WM-TI-291, WRAP Draft FDC, Section 3.6, Process Control and Data Acquisition.

Solid Waste Information Tracking System (SWITS)

WHC-SD-WM-TI-291, WRAP Draft FDC, Section 3.6, Process Control and data Acquisition.

Shipping and Receiving

WHC-SD-WM-TI-291, WRAP Draft FDC, Section 3.5.

Automated Guided Vehicles

No information available prior to Title 1 design (PCDR) 
WHC-SD-WM-RPT-060, REV 0 VOLUME 5

Box Assay System

WHC-SD-WM-TI-291, WRAP Draft FDC, Section 3.2.1

Telecommunications

WHC-SD-WM-TI-291, WRAP Draft FDC, Section 4.10.1, Telecommunications.

Video/Audio Archive of NDE/NDA Data

No information available prior to Title 1 design (PCDR)

Portable Bar Code Reader and Transmission of Data to Control Room

WRAP Engineering Studies, Vol.V, UE\&C, 12/91, Waste Processing System

Functional Analysis Study, P.9, 5.2.1 "The code is read again so that a

cross check... and the computer concurs with the tracking of that drum."

Process Control Annunciation

WHC,SD-WM-TI-291, WRAP Draft FDC, Section 3.6, Process Control and Data Acquisition.

HVAC

WHC-SD-WM-TI-291, WRAP Draft FDC, Section 4.3 .

Uninterruptable Power Supply Systems

WHC-SD-WM-TI-291, WRAP Draft FDC, Section 3.6, Process Control and Data Acquisition and Section 2, Proposed changes to draft FDC.

WHC-SD-W026-CDR-001, CDR WRAP Module 1, Project W-026, page 41.

4.1.2.3 Project Size

Basis: $\quad$ Preliminary Safety Analysis, DOE Order 6430.1A, Throughput Requirements

Source: FDC Sections 2.1.1, 5.1.

The Module 1 is located about 800 feet northwest of the intersection of Dayton Avenue and 23rd Street in the 200 West Area. The site area is now developed. Natural grasses and sagebrush are the prevalent vegetation. The site development will include construction of two new access roads, parking area for 60 automobiles, and a paved area for truck maneuvering. Two roads for truck access are separate from the automobile and bus route to the facility.

The building is designed as a 51,736 square foot structure with 44,296 square feet of space on the first floor and 7,440 square feet on the second. There are four primary areas within the building: Shipping and Receiving, NDA/NDE, Process, and Administrative. The second floor contains the Plant Control Room, Computer room, and some of the heating, ventilating, and air conditioning equipment. Three zones of HVAC confinement in the processing areas are provided, with progressive negative pressures to assure flow of air from potentially lower contamination locations to potentially higher contamination locations. 


\section{WHC-SO-WM-RPT-060, REV 0 VOLUME 5}

The design life of the facility is 30 years. It is designated a radioactive solid waste facility, classified as non safety class in accordance with DOE Order 6430.1A. The structure is designed to SDC-4.1

The building enclosure will be of the beam-and-column type that is typically supplied by pre-engineered metal building manufacturers. The exterior skin consists of preinsulated, prefinished metal, interlocking roof and wall sandwich panels. Some spectal structural design is required as a result of the second floor loads and the bridge crane in the Shipping and Receiving area. .

The building system is not required to contribute to the mitigation of accident conditions. Analyses of credible accidents, including the maximum credible accident, show that the effects of the accidents are within the risk acceptance guidelines without consequence reduction from the building structure. The structural design guidelines of SDC-4.1 for natural phenomenon provide for the WRAP 1 building, confinement barriers, and confinement enclosures to preclude unacceptable safety consequences of non-routine process upset conditions.

Five alternative facility configurations and processes were evaluated in the WRAP 2 Engineering Study: two for TRU in drums, five for TRU in boxes and other containers, two for remote handled TRU, three for LLW, and five for MLLW. All of the alternatives included receiving/shipping with attendant storage for incoming and outgoing containers. The need for a new facility for TRU waste treatment and certification was established in 1983 by DOE in the Defense Waste Management Plan. This was reaffirmed in the HDW-EIS and the resulting Record of Decision. Table 4-4.

A building system historical overview for WRAP Module 1 is presented in 
WHC-SD-WM-RPT-060, REV 0 VOLUME 5

Table 4=4. Building System Historical Overviow

\begin{tabular}{|c|c|c|c|c|c|}
\hline . & $\begin{array}{l}\text { Program } \\
\text { Plan }\end{array}$ & $\begin{array}{l}\text { WRAP. } 1 \\
\text { Eng } \\
\text { study }\end{array}$ & $\begin{array}{l}\text { Conceptual } \\
\text { Design } \\
\text { Report }\end{array}$ & $\begin{array}{l}\text { WRAP } 2 \text { Eng } \\
\text { Study }\end{array}$ & $\begin{array}{l}\text { Title } 1 \\
\text { Design }\end{array}$ \\
\hline 1. Pre-Engineered Structure & & & & & $x$ \\
\hline 2. Concrete Structure & & & & & \\
\hline 3. Double Containment & & $x$ & & & \\
\hline 4. Safety Class & & & & & $\begin{array}{l}\text { Non sefety } \\
\text { clase }\end{array}$ \\
\hline 5. Building size & & 28,000 & & $52,000 \mathrm{ft}^{2}$ & $51,736+t^{2}$ \\
\hline 6. Location & & $\begin{array}{l}200 \mathrm{~W} \\
\text { Area }\end{array}$ & & & $\begin{array}{l}\text { Central } \\
\text { Weste } \\
\text { Complex } \\
200 \mathrm{~W} \\
\text { Area }\end{array}$ \\
\hline $\begin{array}{l}\text { 7. Number of } \\
\text { Functional Areas }\end{array}$ & 6 & $?$ & & & 7 \\
\hline 8. HVAC Zones & & & & $3 \cdot(?)$ & 2 \\
\hline
\end{tabular}

References: WHC-SD-W-026-PSE-001, Rev 0, Preliminary Safety Evaluation W026 Waste Receiving and Processing Facility Module 1, .

.DOE Order 6430.1A

WHC Internal Memo, R. J. Roberts to J. A. Swenson, "WRAP 1 Throughput," dated 3-27-91.

The Defense Waste Management PIan, DOE/DP-0015, U.S.

Department of Energy, Washington, D.C., 1983.

HDW-EIS, Record of Decision, Apri1 14, 1988

HDW-EIS 


\subsubsection{Project Schedule}

Basis: HDW-EIS Record of Decision, WIPP Schedule, Tri-Party Agreement

Source:. Restoration and Upgrade Programs Five-Year Plan Budget Activity Data Sheet 2220-01-AA.

A plan was prepared for disposing of the TRU solid wastes stored at Hanford. The Final Environmental Impact Statement, "Disposal of Hanford. Defense High-Leve1, Transuranic, and Tank Wastes," (HDW-EIS) gave the public the outline of this plan. The WRAP modules are a part of it. The Record of Decision, April 14, 1988, for the HDW-EIS states that these TRU wastes at Hanford would be disposed of in the Waste Isolation Pilot Plant (WIPP) in New Mexico.

Funding identified on Activity Data Sheet, 'Task Description Document 2220-1-AA, established WRAP 1 as a 1992 Line Item. The Hanford Facility Agreement and Consent Order (TRI-PARTY Agreement) committed the WRAP Module 1 facility to be operational in 1997; Milestone M-18-00. The design, environmental permitting, safety documentation, and technology/equipment develop schedules all support the TRI-PARTY Agreement milestone.

The WIPP is designed to accept TRU waste for disposal for a period of only 25 years. The test phase of WIPP, involving now waste from Hanford, is scheduled to begin in CY 1993 and continue for at least five years. The earliest that WIPP could accept waste from Hanford would then be 1998, assuming complete success of the test phase. WIPP operations is now scheduled to stop receiving waste in the year 2018, leaving a maximum of 20 years for shipment from Hanford.

\section{References: TRI-PARTY Agreement Letter, WIPO}

\subsubsection{Throughput}

\section{Bases: Inventory and Forecast, WIPP Schedule}

Source: FDC Section 2.0.

The Department of Energy made a commitment to the state of New Mexico that Hanford TRU waste would be shipped in tune with the WIPP schedule. WRAP Module 1 must have the capacity to process the TRU waste in accordance with these plans. It will take several years to get all of the TRU waste that is stored at Hanford ready for processing in WRAP. New waste will be sent in for many years and the stored waste will be retrieved over the space of several years. WRAP operation must be integrated with the waste forecasts and retrieval as well as with WIPP plans. Only in this way can there be a successful program of TRU waste disposal. 


\section{WHC-SD-WM-RPT-060, REV 0 VOLUME 5}

The Waste Isolation Pilot P]ant plans show operation for 25 years, with a currently projected cilosure date of 2018. The WIPP Test Phase, involving no Hanford waste, is to begin in CY 1993 and will last at least five years (the Test Phase is included in the 25 year WIPP lifetime. The earliest then that WIPP could receive Hanford waste would be CY 1998.

The "Inventory and Projections" Section identifies the waste streams and volumes that are available for treatment in Module 1. Contact handled TRU waste is retrievably stored on site and more is to be received from off site. The DOE has established the Waste Isolation Pilot Plant as the repository ior TRU waste from al1 DOE sites. WRAP Module 1 is to prepare Hanford contact handled TRU waste for shipment to WIPP.

The Preferred Alternative in the Hanford Defense Waste Environmental Impact Statement designated TRU waste disposal in the Waste Isolation Pilot Plant. The Record of Decision for this EIS supported this alternative. The WIPP schedule includes receiving waste from the various sites over a 25 year period. The current closure date for WIPP is established as the year 2018. All of the retrievably stored TRU and that planned to be received must be processed and shipped prior to the WIPP closure date.

The entire WRAP schedule, including throughput rates of Module 1, supports the WIPP closure date for the currently planned TRU waste volume. Using one shift per day for processing, Module 1 will initially handle the TRU waste stored above ground. Newly received TRU waste will begin to be processed early in the operation, also. As the retrievably stored TRU becomes available, that stream will be added.

The planned use of one shift operation for the WRAP 1 facility provides for operating flexibility in dealing with unforseen circumstances without sacrificing design and construction efficiencies. The factlity size, configuration, processing lines, shipping and receiving, and administrative areas are all necessary to support the basic WRAP 1 operation. These attributes are not sensitive to the number of operating shifts. They all do, however, support multiple shift operation. No significant changes in the project design would be undertaken if the baseline operation were, for example, two shifts a day.

An annual throughput historical overview for WRAP Module 1 is presented in Table 4-5. 
Table 4-5. WRAP 1 Annual Throughput Historical Overview

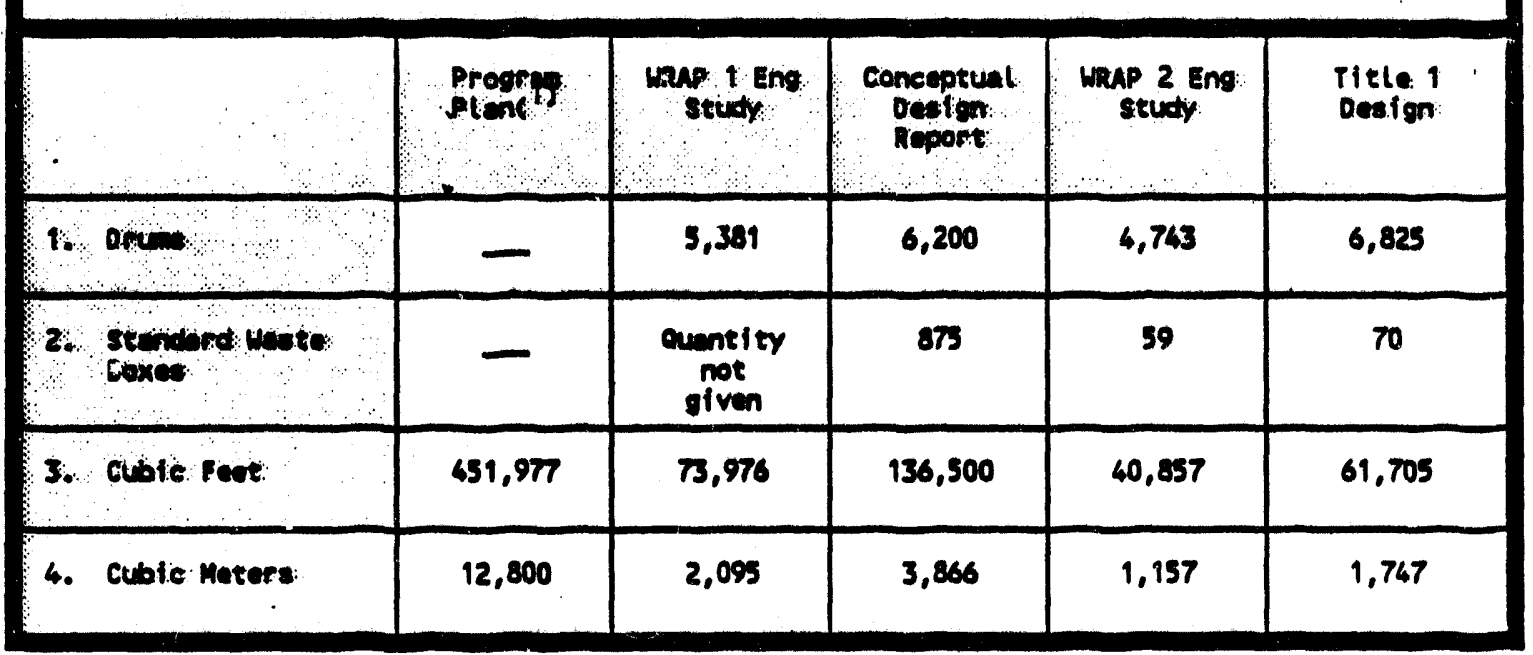

NOTES: - 1. The Program Plan included retrievably stored TRU only. No estimate was given for newly generated TRU to be received/processed.

2. The WRAP 1 Conceptual Design Report included nondestructively examining, assaying, and certifying approximately 875 boxes per year. Included were 118 newly generated $\mathrm{CH}-$ TRU boxes at 68 cubic feet each and 455 newly generated $\mathrm{CH}-\mathrm{LLW}$ boxes at 128 cubic feet each; after WRAP 2 startup, an additional 262 standard waste boxes of $\mathrm{CH}-\mathrm{TRU}$ and 40 boxes of $\mathrm{CH}-\mathrm{LLW}$ were processed annually. Thus, about 46,500 cubic feet of boxed $\mathrm{CH}-$ TRU was planned to be processed each year.

In 1989 the required WRAP throughput of contact handled TRU was estimated. About $560,000 \mathrm{cu} f t$ of suspect TRU were placed in retrievable storage between 1970 and 1988 .

- Included $280,000 \mathrm{cu} \mathrm{ft}$ of $\mathrm{CH}$ boxes and $280,000 \mathrm{cu} \mathrm{ft}$ of $\mathrm{CH}$ in drums $(38,000$-drums). About 18 years of operation of WRAP 1 (start up was scheduled for CY 1995) would be available before closure of WIPP in the year 2013.

NOTE: The WIPP closure date changed to 2018 in CY 1992; the WRAP start up date changed to CY 1997 from the CY 1995 projected in 1989. 
- With the eighteen years of WRAP operation, about 2000 drums of retrievabiy stored TRU waste would need to be processed per year to meet the WIPP schedule requirenent.

- The waste volume forecast, Revision 0 , in 1987, identified about $300,000 \mathrm{cu} \mathrm{ft} / \mathrm{yr}$ of $\mathrm{LLW}$ to be put in storage. It was assumed that quality verification checks of about ten percent of the newly generated waste would be required. However, about one half of the forecasted LLW was soils, not needing examination or verification of contents of drums. Thus, about 15,000 cu ft; or about 2000 drums per year would be verified in WRAP 1 .

- Revision 0 of the waste volume forecast also identified about $280,000 \mathrm{cu} \mathrm{ft}$ of newly generated CH TRU waste to be received by WRAP, or roughly 38,000 drums. Processing at an annual rate of 2000 drums would work off this projected inventory prior to WIPP closing.

- Therefore, annual throughput requirements for WRAP were estimated, in 1988, at about 6000 drums of waste per year.

Current waste volume forecasts show that about $272,000 \mathrm{cu} \mathrm{ft}$ of retrievably stored TRU in drums will be designated for WRAP 1; about 170,000 cu ft of newly generated TRU drums will be received; about 1850 newly generated TRU boxes will be received. About $270,000 \mathrm{cu}$ ft of $L L W$ will be over checked in WRAP 1.

Thus: Retrievably stored TRU - 35,700 drums or about 1985 per year. Newly generated TRU - 22,300 drums or about 1250 per year. LLW verification $\quad-35,500$ drums or about 1970 per year. TRU in SWB's $s^{\circ} \quad-1,850$ boxes or about 100 per year.

NOTE: The conversion from forecasted cubic feet to containers assumes that each drum contains 7.61 cubic feet of waste and each standard waste box contains 67.2 cubic feet. Less than ideal loadings of waste into the containers could increase the total number of containers received by WRAP 1.

WRAP 1 will process 2,625 drums of retrieved wastes and 4,200 drums of newiy generated waste per year, with a $50 \%$ split on LLW and TRU, for a total of 6825 drums total per year. NDA/NDE of 70 newly generated TRU standard waste boxes (no other processing activity for boxes is included in WRAP 1) per year. WRAP 1 Shipping and Receiving can receive 6,825 drums and 70 boxes per year or 40 drums per day and two boxes per week.

\section{References: WHC-SD-W026-FDC-001, Rev 1, Functional Design} Criteria, WRAP Module 1.

Hanford Defense Waste Environmental Impact Statement Letter, RL to WHC, WIPP Closure

Memo, BA.Mayancsik, "WRAP Throughput" 
WHC-SD-WM-RPT-060, REV 0 VOLUME 5

\subsubsection{Facility Expansion}

\section{Bases: WRAP 2 Engineering Study}

Source: FDC Section 3.11; SDRD Section 2.8.2.1.

Module 1 is the first of the WRAP facilities. The design and construction are to be able to acconmodate either expansion of the basic building or connection to future modules or waste storage/handling buildings. The design will permit using Moduie 1 in shared operations, such as examinatian, certification, and shipping.

As the additional treatment and storage facilities become more defined, and as technologies evolve, the Module 1 will have flexibility, primarily in the area of the process functions, to be modified to expand and/or accept different equipment. The outer wall adjacent to the process 1 ines fronts oniy outside space, not other equipment or necessary operating areas. Thus, modifications to the facility structure and primary processing areas could be accomplished with a minimum of both expansion costs and schedule impacts. A facility expansion historical overview for WRAP Module 1 is presented in Table 4-6.

Table 4-6. Factlity Expansion Historical Overview

\begin{tabular}{|c|c|c|c|c|c|}
\hline & $\begin{array}{c}\text { Progeren } \\
\text { Ptenn }\end{array}$ & $\underset{\text { Study }}{\operatorname{manp}} 1 \mathrm{Em}$ & $\begin{array}{l}\text { Conceptual } \\
\text { Depigan } \\
\text { Report }\end{array}$ & $\begin{array}{l}\text { WRAP } 2 \text { Eng } \\
\text { Study }\end{array}$ & $\begin{array}{l}\text { Title } 1 \\
\text { Design }\end{array}$ \\
\hline 1. Expansion & - & - & & - & $x$ \\
\hline 2. Commection & - & - & & $x$ & $x$ \\
\hline & & & & & \\
\hline & & & & & \\
\hline & & & & & \\
\hline & & & & & \\
\hline
\end{tabular}

The WRAP 2 Engineering Study evaluated the feasibility of including with the WRAP scope, waste other than contact handled TRU. The results of the 
evaluation concluded that WRAP should not be designed and constructed as one facility, but rather built in modules. The portions of the processes that were well understood and well defined would be placed into WRAP Module 1: assay and inspection, certification and shipping for contact handled TRU and LLW in drums.

Future WRAP modules would provide Size Reduction, Remote Handling, Low Level Mixed Waste, and Decontamination facilities. The sampling requirements and specific analyses for mixed waste characterization were not well defined; WRAP throughput and storage needs could not be well enough estabilished to provide a basis for design at the time of the evaluation. Remote handled TRU processing, potentially in existing facilities, and transportation, such as fissile material allowances, requirements also were insufficient to allow for design configurations. Capability to assay large containers, currently in storage, was non-existent.

All of these items could affect facility sizing, 1ag storage, and throughput requirements.

References: WHC-SD-W-100-ES-001, Engineering Study for Waste Receiving, and Processing (WRAP) Facility, Module 2.

\subsubsection{Project Functions}

\subsubsection{Waste Sorting}

Basis: WIPP Waste Acceptance Criteria, RCRA, TRAMPAC

Source: FDC Section 2.2.5 and 2.2.7.

Requirements have been placed upon the disposal of TRU waste at the Waste Isolation Pilot Plant (WIPP) in salt formations in New Mexico. All of these rules are to make sure that the waste will be safely disposed of for at least 10,000 years. These requirements have been written into a document called the "Waste Acceptance Criteria" (WIPP WAC). The WIPP WAC establishes at least 16 criteria that must be met before waste will be accepted for disposal. At least four define the need to sort the TRU waste:

1) no free liquids are allowed;

2) pyrophorics must be stabilized;

3) explosives or compressed gases are not allowed;

4) corrosives must be neutralized.

WRAP 1 has sorting tables within Waste Processing enclosures to sort the TRU wastes. The drum is transferred to the sorting table after the drum lid has been removed. The contents of the drum are then emptied onto the sorting table. Items identified as not suitable for WIPP disposal during the nondestructive examination will be removed. The. separated items will be sent to the Radioactive Mixed Waste processing line. The remaining contents will be placed back into the drum. A waste sorting historical overview for WRAP Module 1 is presented in Table 4-7. 
WHC-SD-WM-RPT-060, REV 0 VOLUME 5

Table 4-7. WRAP I Waste Sorting Historical Overview

\begin{tabular}{|c|c|c|c|c|c|}
\hline & $\begin{array}{l}\text { Progren } \\
\text { Ptex }\end{array}$ & $\begin{array}{l}\text { map I Eng } \\
\text { study }\end{array}$ & $\begin{array}{l}\text { Conecpetuat } \\
\text { Desien } \\
\text { Report }\end{array}$ & $\begin{array}{c}\text { Whap } 2 \text { Eng } \\
\text { study }\end{array}$ & $\begin{array}{l}\text { ritele } 1 \\
\text { oesten }\end{array}$ \\
\hline 1. Wesandive & $x$ & $x$ & & $x$ & $x$ \\
\hline 2. Merdifsoft: & $x$ & $x$ & . & $x$ & 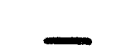 \\
\hline 3. metals & $\underline{x}$ & $x$ & 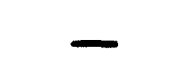 & $x$ & 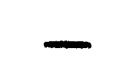 \\
\hline 4. Undafined: & & & $x$ & & \\
\hline
\end{tabular}

COR: $\quad$ Conceptual Design Report, WHC-SO-W026-CDR-001.

ENG STY: WRAP 2 Engineering Study, WHC-SD-W100-ES-001.

TITLE I: WRAP Facility Module 1 Preliminary Design Report.

Comments:

1. In-drum compaction of TRU waste as envisioned in the CDR and Engineering Study was replaced with supercompaction and core sampling in the Title 1 design.

2. Treatment of pyrophoric material was anticipated in the CDR, but in the Title 1 design, such material would be removed from WRAP 1.

3. Aerosol can liquids were to be treated in the CDR but are removed to storage in the Title 1 design.

4. Lead decontamination was eliminated in the Title 1 design in favor of storage and treatment in WRAP-2A.

5. No mention of treatment of reactive materials by a liquid reagent was given in the CDR.

6. A shred/grout alternative was considered in the WRAP 2 Engineering Study but was not chosen for WRAP I implementation due to higher costs, added waste material, and added mechanical complexity.

The COR states:

55- and 83-gallon drums; lifted by power grapple; tilted, contents spread on table; liquids collected in holding tank; manually sorted; TRU to clean 55-gallon drum for compaction; LLW to 
WHC-SD-WM-RPT-060, REV 0 VOLUME 5

refilled drum for supercompaction and placement in 83-gallon drums.

Capacity - 6.9 TRU and 8.7 LLW drums opened per shift.

The engineering study states:

Separate enclosures for TRU and LLW drums; drums

deheaded and tipped on vibratory table; manually

sorted; TRU to 55-gallon drum for compaction, 500

pounds limit; LLW supercompacted and loaded in 83-

gallon drums, 1000 pounds 7 imit.

Capacity - 8.1 TRU and 7.2 LLW drums opened per day.

Title 1 design states:

55- or 83-gallon drums; lifted; by scissor 1ift; drums

lids cut off, drum placed on tipper and contents

dumped on table; TRU back to drum for supercompaction;

LLW to RMW glovebox.

Capacity - 8 TRU and 8 LLW drums per day.

References: Conceptual Design Report, WHC-SD-W026-CDR-001.

WRAP 2 Engineering Study, WHC-SD-W100-ES-001.

WRAP Facility Module 1 Preliminary. Design Report.

\subsubsection{Waste Treatment}

Basis: $\quad$ RCRA, WAC 173-303, WIPP-WAC, TRUPACT-II

Source: $\quad F D C$ Section $2.0 ; 2.2,2.2 .7$

The WIPP WAC set requirements for how the waste must be treated before it can be buried. In most cases, the waste just cannot be dumped into a can. The waste must be processed to a form that assures that problems will not develop during 10,000 years.

The TRU waste is going to be shipped by truck from Hanford to New Mexico. Shipping requirements for the waste relate to treatment of the waste. These requirements are specified in the TRUPACT-II Transportation Criteria. These treatments are identified to assure that the waste can.be shipped safely under all foreseeable circumstances.

Module I waste treatment processes currently include sorting, volume reduction, and non-compliant waste stabilization. Sorting is identified as a separate key project item in this report. Waste treatments have been reviewed during the design evolution of Module I. A waste treatment historical overview for WRAP Module 1 is presented in Table 4-8. 
- sundp uolleb-sg u!

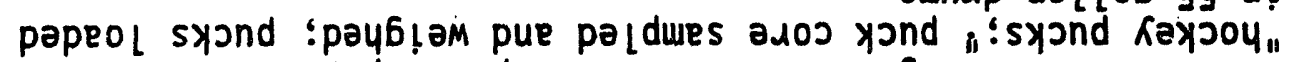
oqu! pazoedwosdadns pue sundp uolle6-ss u! papeol nyl

[ $371 I \perp$

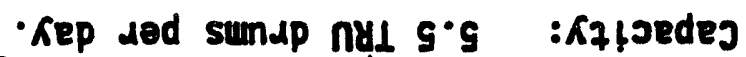

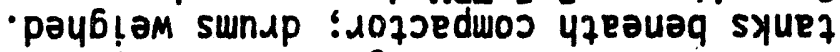

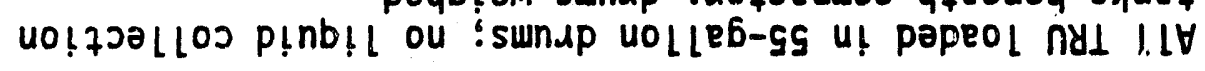
AONLS ONZ

-7ft4s dad sunap nat $99^{\circ} 1$ : K7toedeg -payb!am sunap ؛

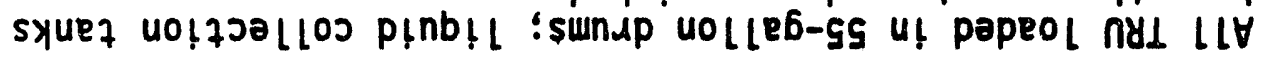
yoj NOIIJBdWOJ nषI

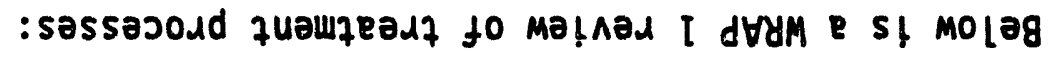

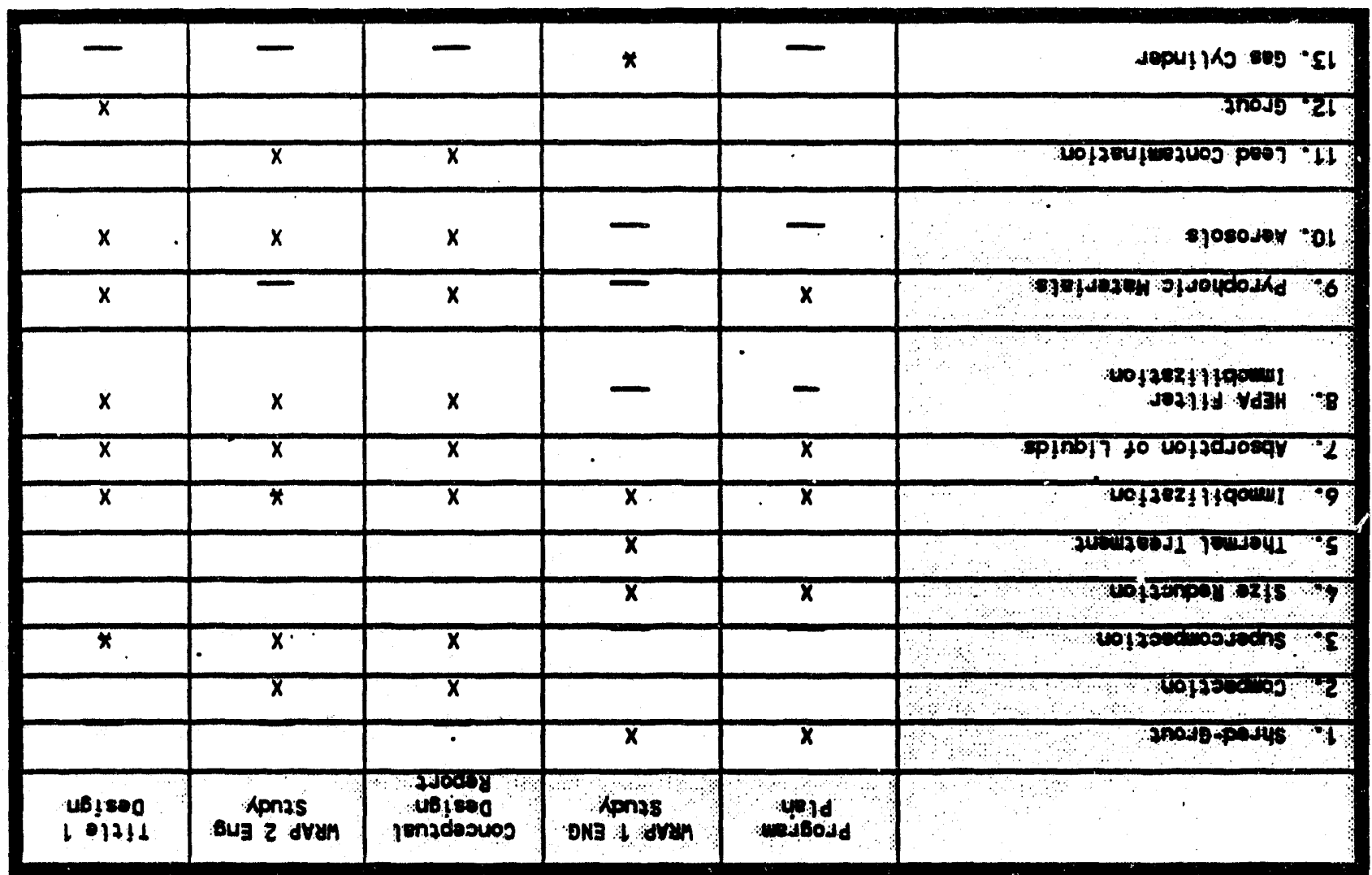

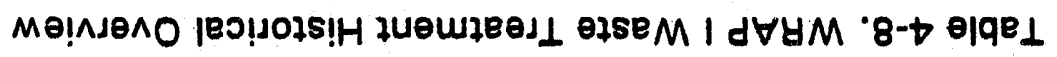


WHC-SD-WM-RPT-060, REV 0 VOLUME 5

LLW COMPACTION

CDR LLW loaded into 55-gallon drums and supercompacted; - 1 iquid collection tanks beneath compactor; loaded into 83-gallon drums; drums weighed.

ENG STUDY LLW supercompacted and loaded into 83-gallon drums; 1 iquid collection tank beneath compactor; drums weighed.

TITLE 1 LLW loaded into 83-gal1on drums and supercompacted; drums weighed.

\section{PARTICULATE IMMOBILIZATION}

CDR

Particles sampled and characterized; mixed with

solidification agent (e.g. Portland cement) in small

container; cured; packaged in 55-gallon drum.

Capability: Particles below 10 micrometers and more than $1 \%$ of waste or if below 200 micrometers and more than 15\%. of waste; two containers per shift.

ENG STUDY Particles sampled and characterized; mixed with

immobilization agent (e.g. cement, Envirostone) in 1-2 liter container; cured; packaged in 55-gallon drum.

Capability: Glovebox sweepings or soil; two containers per day.

TITLE 1 Particles mixed with cement additives and

immobilized in sealed container.

Capability: Not given.

\section{LIOUID NEUTRALIZATION/ABSORPTION/SOLIDIFICATION}

CDR

Small amounts (< 1 gallon) of corrosive

liquids and sludges neutralized with soda

ash or sulfamic acid; mixed to provide

blending; neutralized aqueous or organics

absorbed with solidification agent (e.g.

cement or Envirostone); cured; packaged in

55-gallon drum.

Capability: Amount not given; neutralizing agents chosen to minimize overheating and fume generation.

ENG STUDY Small amounts (<1 gallon) of corrosive

liquids neutralized with soda ash or sulfamic acid; mixed; placed in 1-2 liter container; neutralized aqueous or organics absorbed with solidification agent (e.g. cement or Envirostone); cured; packaged in 55-galion drum. 
WHC-SD-WM-RPT-060, REV 0 VOLUME 5

Capability: Up.to eight 2 liter containers per day; maximum volume ratio of $2: 1$ solidification agent to liquid.

TITLE 1 Liquids neutralized; mixed with cement additives; sealed in small container; rotated using jar mill; cured; packaged in 55-galion drum.

Capability: Not given.

\section{HEPA FILTER IMMOBILIZATION}

CDR Immerse in plasticizer; cure.

Capability: Filters < i $\mathrm{ft}^{3} ; 1$ filter per shift.

ENG STUDY Only shred/grout was considered for inmobilization even though the shred/grout process was not chosen for WRAP 1 use. Capability: Filters < $1 \mathrm{ft}^{3}$; no rate given.

TITLE 1 Immobllized using a fixative and disposed as TRU or TRU mixed waste.

Capability: None given.

\section{PYROPHORIC MATERIAL IREATMENT}

CDR

Combine material with cement in small mixer; store until cured.

ENG STUDY No consideration given to pyrophoric material handling.

TITLE 1 Pyrophoric material is to be removed from WRAP I without processing.

AEROSOL CAN HANDLING

CDR

Puncture to depressurize; collect liquid in polyethylene container; treat in liquid sorption process described above; drained cans treated as other waste.

ENG STUDY Puncture to depressurize; treat in liquid sorption process described above; drained cans treated as other waste.

TITLE 1 Puncture and drain; send collected liquids and gases for storage outside WRAP 1; drained cans treated as other waste. 
WHC-SD-WM-RPT-060, REV 0 VOLUME 5

\section{LEAD DECONTAMINATION}

CDR Lead bricks or small sheets transferred in a 55-gallon drum with a handling basket;

cleaned in wash down chamber.

ENG STUDY Small items of lead transferred via a

"French can" into decontamination area for

cleaning with high pressure water, steam, chemicals, and wiping materials.

TITLE 1 Lead decontamination was eliminated in design in favor of storage and treatment in WRAP $2 A$.

\section{REACTIVE MATERIALS}

CDR Not mentionęd.

ENG STUDY Not mentioned.

TITLE 1 Reactive materials rendered nonreactive by a reaction with a liquid reagent.

Neutralized liquid handled the same as other liquids described above.

\section{SHRED-GROUT}

CDR

Not mentioned:

ENG STUDY

Considered as an alternative but not chosen for WRAP 1 due to higher costs, added waste material and added mechanical complexity.

WIPP will accept only TRU waste. Any container that does not contain at least $100 \mathrm{nCi} / \mathrm{gram}$ TRU will not be accepted. About 45 .percent of the retrievabiy-stored containers are suspected to contain less than $100 \mathrm{ncj} / \mathrm{gram}$. The waste in these containers becomes a candidate for LLW disposal on the Hanford site. Waste Acceptance Criteria also exist for this disposal.

Free liquids are not allowed for disposal in LLW at Hanford. LLW containing hazardous components is cấiegorized as mixed waste and subject to mixed waste requirements as well.

Waste drums processed in WRAP Module 1 determined to contain restricted, regulated, or unknown waste will be opened with that waste removed and sampled; as required. Depending upon the nature of these wastes, it may be managed in WRAP Module 1 on a limited basis or repackaged for storage pending availability of treatment or disposal facilities." 
WHC-SD-WM-RPT-060, REV 0 VOLUME 5

Any treatment used in WRAP Module 1 will be performed in the Restricted Waste Management (RWM) glovebox. These treatments consist of small scale liquid and corrosive material neutralization, liquid absorption or solidification, particulate immobilization, HEPA filter encapsulation, and reactive materials neutralization. Standard techniques that will be used in these processes in WRAP Module 1 include the following operations.

Acidic or alkaline liquids and corrosive materials, as determined by prior sampling and analysis, are transferred to the RWM glovebox. A predetermined amount of neutralizing reagent is added to the container and mixed with the liquid or corrosive materlal to neutralize it. The attainment of a neutral $\mathrm{pH}$ is verified using a $\mathrm{pH}$ meter inside the glovebox.

Neutralized aqueous 1 iquids and dry cement are added to a plastic container in predetermined proportions for solidification. After mixing, the plastic containers are allowed to stand for final curing of the solidified waste. After curing, selected containers are physicaliy inspected to verify that the liquid has solidified. The treated waste product is then roaded out of the glovebox and routed directly to NDA/NDE as part of certification prior to shipment.

If the aqueous liquid is determined from laboratory analysis not to be amenable to solidification using cement, it is mixed with a solid absorbent using the same process equipment and materials used for absorbing organic liquids. The product is then shipped to continued storage until treatment capabilities exists.

Organic liquids are mixed with absorbent solids, such as vermiculite, diatomaceous earth, or conwed pads. The treated waste product is loaded out of the glovebox and shipped to continued storage until a treatment capability exists.

Particulates such as diatomaceous earth, ash, and soil are received in the RWM glovebox and mixed with water and dry cement. The treated waste product is loaded out and routed directly to NDA/NDE as part of certification prior to shipment.

The HEPA filters are macro-encapsulated in the RWM gloveboxes. After curing of the encapsulation agent, the treated waste product is loaded out and routed directly to NDA/NDE as part of certification before shipment.

Any reactive materials will be routed to the RWM glovebox and.reacted using the appropriate technique. After the material has been reacted, it will be loaded out of the glovebox and routed directly to NDA/NDE as part of certification before shipment.

References: SD-W026-FDC-001 Rev 1, WRAP Module 1 Functional Design Criteria; WRAP Module I Preliminary Design Report; WHC-SD-W026-SDRD-001, Supplemental Design Requirements Document Project W026; WHC-SD-W026-SAR-001, WRAP Module 1 Preliminary Safety Analysis Report. 
WHC-SD-WM-RP'T-060, REV 0 VOLUME 5

\subsubsection{Packaging}

Basis: $\quad$ TRUPACT-II, 49 CFR 173, WIPP WAC

Source: $\quad$ FDC Section 2.0, 2.2.1, 2.2.8

The WRAP Module 1 facility will, be capable of handling 55 gallon drums, drum overpacks, Standard Waste Boxes (SWBs) and other small waste boxes (such as a B-25 burial box). The containers will be shipped meeting requirements of the TRUPACT II Safety Analysis Report and transportation requirements specified in 49 CFR Transportation requirements. The facility will have the capabilities to load and unload TRUPACT II trailers, trucks, and vans.

The certified TRU 55 gallon waste drums will be assembled into seven packs and loaded into a TRUPACT II cask, 2-seven packs per cask. The SWBs will be loaded into TRUPACT II casks, 2-SWBs per cask. The LLW/LLMW waste drums and boxes will be loaded on trucks and sent to long term storage el sewhere or for on-site disposal. A waste packaging historical overview for WRAP Module 1 is presented in Table 4-9.

Table 4-9. WRAP 1 Waste Packaging hilstorical Ovoniew

\begin{tabular}{|c|c|c|c|c|c|}
\hline & $\begin{array}{l}\text { Progran } \\
\text { P Plan }\end{array}$ & $\begin{array}{l}\text { Mip } 1 \text { Eng } \\
\text { study }\end{array}$ & $\begin{array}{l}\text { Conceptuel } \\
\text { Desfen } \\
\text { Report }\end{array}$ & 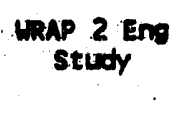 & $\begin{array}{l}\text { Title } 1 \\
\text { Desion }\end{array}$ \\
\hline 1. Dor 55 eallen. & $x$ & 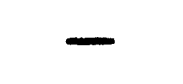 & $x$ & 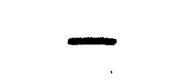 & $x$ \\
\hline 2. TRUPACT & $x$ & $x$ & - & - & - \\
\hline 3. TRUPACT II & - & 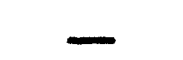 & $x$ & $x$ & $x$ \\
\hline $\begin{array}{l}\text { 4. Standard Maste } \\
\text { Box }\end{array}$ & $x$ & - & $x$ & $x$ & $x$ \\
\hline 5. 330 Galtion TYpe & $x$ & $x$ & & & • \\
\hline 6. $\begin{array}{l}\max \\
12 \times 12 \times 6.5 \\
\text { foet }\end{array}$ & $?$ & $x$ & & _ & 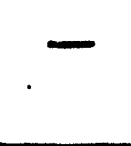 \\
\hline $\begin{array}{l}\text { 7. } 83 \text { Gallon } \\
\text { Overpack }\end{array}$ & $\dot{-}$ & _. & $x$ & $x$ & $x$ \\
\hline
\end{tabular}


WHC-SD-WM-RPT-060, REV 0 VOLUME 5

References: TRUPACT II Safety Analys is Report for Packaging 49 CFR 173

SD-W026-FDC-001 Rev 1, WRAP Module 1 Functional Design

Criteria

WHC-SD-W026-SDRD-001 Supplemental Design Requirements

Document

WIPP WAC

\subsubsection{Waste Characterization}

- Basis: WIPP WAC, TRUPACT-II, RCRA

Source: FDC Section 2.2.7; SDRD Section 3.3

Before the wastie will be accepted for shipment, the shipper requires that the waste be carefully identified. The TRUPACT-II Transportation Criteria are very specific about how the waste is to be described and identified. Before the Waste Isolation.P1lot Plant w11l bury the waste every precaution must be taken to assure that the waste meets their requirements. The WIPP-WAC also are very specific about identifying what is in the waste containers.

Characterization is the process of obtaining enough information about the waste to properly classify, certify, and transport the waste. The primary methods of characterization are:

1) Process History (existing records).

2) Non-Destructive Assay (random sample).

3) Non-Destructive Examination (Radiography, again random sample). This stage will also provide data to justify extending the time that $\mathrm{CH}$-TRU waste can be stored.

4) Head Space Gas Analysis

5) Remote Detection (Ramon Spectroscopy and Laser Ablation Techniques are proposed.

6) Physical Sampling and Laboratory Analysis. Contents are oper.3d in a glovebox (if required) and the examination would include segregation, weighing, chemical analysis, and inspections required to further quantify the waste attributes.

Certification has been an integral part of WRAP I since its inception. By definition, certification incorporates procedures and criteria to document waste type, labeling and packaging prior to disposal (or long-term storage 20 years - until a disposal site is available). A waste characterization historical overview for WRAP Module 1 is presented in Table 4-10.

Sampling of wastes will be in accordance with EPA SW 846. The objective of the WRAP Module I is to certify $\mathrm{CH}$ drums and boxes to the applicable waste acceptance criteria for transport and disposal (CH-TRU at WIPP and LLW at Hanford). Incoming drums that cannot be certified to each of these criteria will be opened in WRAP I, and the contents sorted, characterized and 


\section{WHC-SD-WM-RPT-060, REV 0 VOLUME 5}

repackaged into new drums. Incoming SWB's (Standard Waste Boxes) that cannot be certified will be returned to the generator for storage until WRAP 2A (or 2B) is operational.

Physical Sampling Purpose:

1) Provide statistical confirmation of the capabilities of other characterization methods, especially remote sensing. This should be accomplished through random sampling of the first 100 drums processed by WRAP I, and maintained by random sampling of an estimated $1 \%$ of remaining drums.

2) Provide quantitative analysis of "authoritative" samples, where remote methods leave unanswered questions. An authoritative sample, as defined by EPA SW-846, is not a random sample. In this casse, it is a sample from a specifically identified package for which more information is needed. Samples of this type should be anticipated for fewer than one-half of $1 \%$ of all drums processed. 
WHC-SD-WM-RPT-060, REV $O$ VOLUME 5

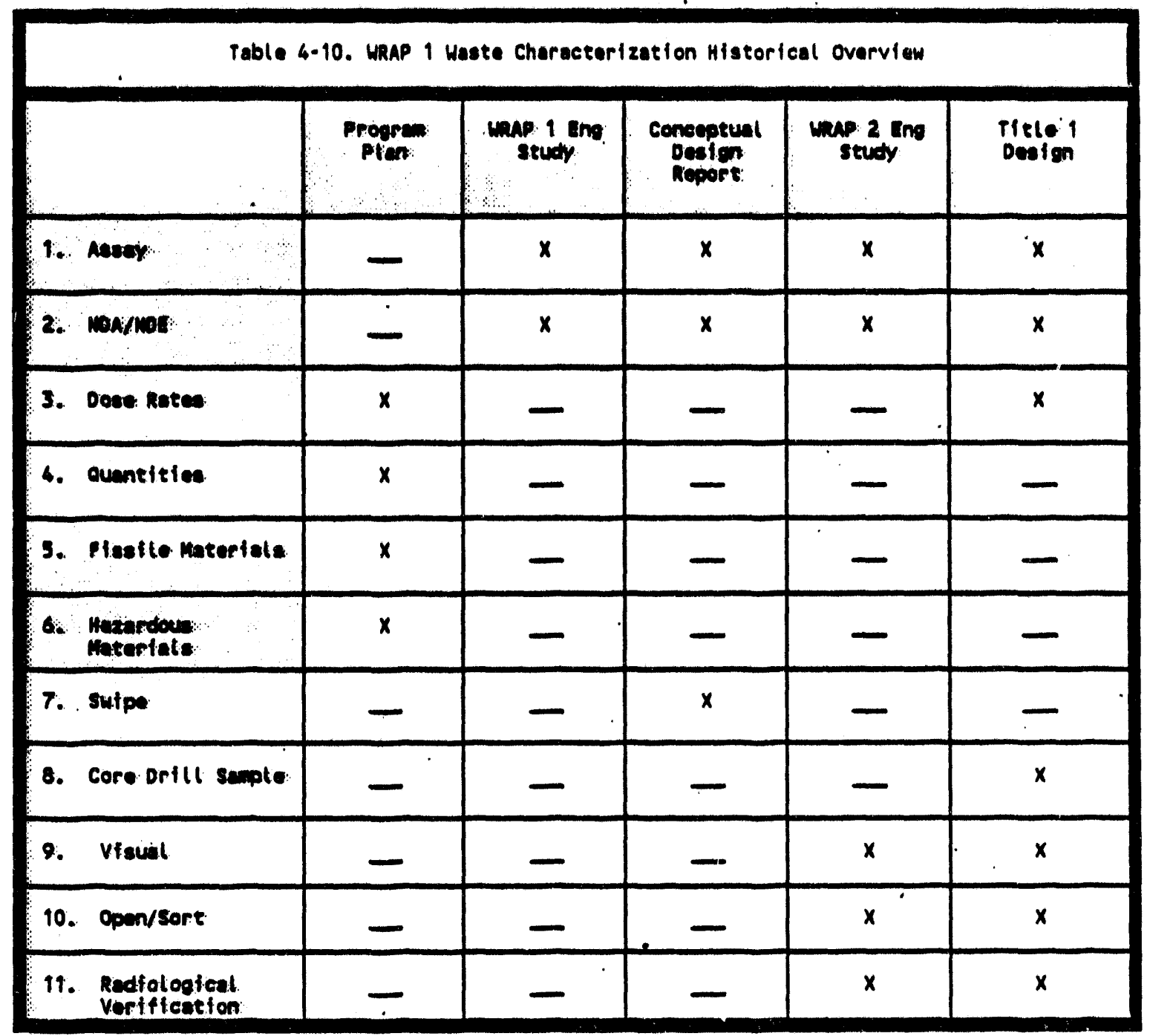

References: WIPP/DOE-069 ReV 03 TRU Waste Acceptance Criteria for the Waste Isolation Plant.

Washington Administrative Code 173-303, Dangerous Waste

Regulations.

NUPAC TRUPACT II-SAR, ReV 01, Pg. 8.

WHC-EP-0223 (1989) Stored. Contact Handled Transuranic Waste Characterization Plan. WHC Richland, WA. 
WHC-SD-WM-RPT-060, REV 0 VOLUME 5

\subsubsection{Storage}

Bases: $\quad$ Solid Waste Program P1an, WHC-EP-0063

Sources: FDC Section 2.2.1 and 2.2.8

Storage is provided within the WRAP 1 facility for both incoming and outgoing containers in the Receiving/Shipping area. Provisions are made for a total of 213 drums (either 55 gallon or overpacked in salvage drum) and 14 boxes (no larger than $8^{\prime} L \times 5^{\prime} W \times 4^{\prime} H$ ). A further breakdown of this total shows 100 incoming drums and 4 incoming boxes; outgoing quantities of 63 drums of TRU (may be in seven packs), 50 drums of LLW, 8 standard waste boxes of TRU and 2 standard waste boxes of LLW.

The expected incoming (receiving) load size is 18 drums or two boxes. The outgoing (shipping) load size for TRU is 42 drums ( 6 seven-packs) or 6 standard waste boxes. The outgoing load size for LLW is 18 drums or two standard waste boxes. Storage capacity is then provided for four loads of incoming drums plus a cushion of 28 drums, two loads of incoming boxes, one load of TRU drums plus a cushion of one-half a load, one load of TRU standard waste boxes plus one-third of a load, two and two-thirds loads of LLW drums, and one load of LLW boxes.

Five alternative facility configurations and processes were evaluated in the WRAP 2 Engineering Study: two for TRU in drums, five for TRU in boxes and other containers, two for remote handled TRU, three for LLW, and five for MLLW. All of the alternatives included receiving/shipping with attendant storage for incoming and outgoing containers. It was not deemed feasible to transfer containers to/from WRAP for receiving/shipping.

References: Nupac TRUPACT II-SAR, Rev 01. TRUPACT II Safety Analysis Report for Packaging WHC-EP-0063 WHC-SD-W-100-ES-001, Engineering Study for Waste Receiving and Processing (WRAP) Facility, Module 2.

\subsubsection{Liquid Wastes}

Bases: HDW-EIS, WRAP 1 Conceptual Design Report

Source: FDC Section 2.2.9.

The WRAP-1 factlity is designed to handle solid TRU waste; therefore, no liquids are expected to be a part of the input waste stream makeup. However, liquids could be introduced to the process system through maintenance of equipment, leaks of equipment that may contain 1 iquids, decontamination agents, fire protection systems, and the like, many of which were considered in the Conceptual Design Report and subsequent preliminary design activities. 
WHC-SD-WM-RPT-060, REV 0 VOLUME 5

As part of the preliminary design efforts, a Waste-Minimization Study was included as part of the assessment process. This study examired the various potential liquid waste streams and made the following recommendations:

1. Eliminate the Decontamination Process enclosure in favor of using manual decontamination methods which "obviate the need for many services including process steam, a large quantity of process water, decontamination chemicals, waste water treatment chemicals and the collection, storage and treatment systems that they demand."

2. El Iminate the floor drain collection system used for fire protection and cleaning water in favor of a "mopping up" mothodology in case of inadvertent water from sprinklers, roof leaks, or factlity cleaning efforts.

The design criteria have been altered to consider these recommendations.

The basis for eliminating or minimizing liquid waste is given in State and Federal laws requiring or requesting waste minimization, and the need for this approach is given in the Conceptuai Design Report, Functional Design Criteria, and Supplemental Design Requirements. A liquid waste historical overview for WRAP Module 1 is presented in. Table 4-11.

Table 4-11. WRAP 1 Liquid Waste Histortcal Overview

\begin{tabular}{|c|c|c|c|c|c|}
\hline & $\begin{array}{l}\text { Progrem } \\
\text { Plen }\end{array}$ & $\begin{array}{l}\text { mep it ens } \\
\text { study }\end{array}$ & $\begin{array}{l}\text { Conceptual } \\
\text { Design } \\
\text { Report }\end{array}$ & $\operatorname{map}_{\text {study }} 2$ the & $\begin{array}{l}\text { Prele } 1 \\
\text { Deaign }\end{array}$ \\
\hline 1. Proceses & $x$ & $x$ & $x$ & $x$ & $x$ \\
\hline 2. Generate & - & - & $x$ & $x$ & - \\
\hline 3. Ship & 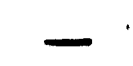 & 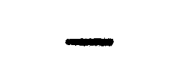 & $x$ & 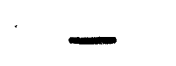 & $x$ \\
\hline
\end{tabular}

References: WHC-SD-W-026-PSE-001. Rev O. Prel iminary Safety Evaluation W-026 Waste Recetving and Processing Facility Module 1. DOE Order $6430.1 \mathrm{~A}$

WRAP 1 Title 1 Design Report

WRAP 2 Engineering Study

WHC Internal Memo. dated 3-27-91, R. J. Roberts to J. A. Swenson, "WRAP 1 THROUGHPUT,". 


\section{WHC-SD-WM-RPT-060, REV 0 VOLUME 5}

Since the WRAP-1 design will not include processing liquid wastes, any such wastes generated (or discovered in the waste stream) are action planned as follows (in order of preference):

1. Collect and dispose waste into the Tank Farms liquid waste system.

2. Collect and store for processing in the WRAP-2 modules.

3. Solidify and dispose through the WRAP-1 module.

\subsubsection{NDA/NDE Systems}

\section{Bases: $\quad$ DOE Order 5820.2A, WIPP Waste Acceptance Criteria}

Source: FDC Sections 2.2.3 and 2.2.4.

A prime mission of the WRAP factlity is to characterize and certify waste. This work is primarily accomplished through non-destructive examination and assay (NDE/NDA) techniques. The original study for the use of such equipment was done in 1988 by WHC (Gilles), and the equipment was specified during the design phase by United Engineers and Constructors (UE\&C). UE\&C also completed a NDA/NDE technology assessment on the chosen equipment which examined uncertainties and alternatives. The description below summarizes this.

TRU waste is defined as waste containing certain alpha emitters which requires special disposal techniques. The oniy practical method of determining the amounts of such materials is with non-destructive analyses. The requirements for such determinations come through DOE Order 5820.2A, Radioactive Waste Management, and through WIPP-DOE-069, IRU Waste Acceptance Criteria (WAC) for the Waste Isolation Pilot Plant.

All drums and boxes will be scanned through both NDE and NDA systems. In the case of drum assays, all activities are automated using an automated guided vehicle which guides the drum from receiving or storage through the NDE and two-phase NDA scanning to either waste processing or back to storage. In the case of box scanning, boxes are transferred from receiving or storage to the NDE unit, between NDE and NDA units, and from the NDA unit to waste processing or back to storage manually forklift.

- Drum and box NDE will use real time radioscopy (RTR) to ascertain the material contents of the waste. The drum units will handle 55- as well as 85gallon drums. The box unit is for boxes up to $4^{\prime} \times 4^{\prime \prime} \times 7^{\prime}$. The RTR system consists of an $X$-ray generation unit and a high-resolution imaging system, manipulation system, radiation shielded enclosure, transport system, and control console, which is interfaced for remote operation from the plant control room. This system will be used to ascertain non-compliant waste such as free liquids and compressed gas cylinders. Video and audio records are made during the NDE.

Drum and box NDA consists of two measurement elements. First, the drum will be measured on a Passive Active Neutron counter where passive neutron 
WHC-SD-WM-RPT-060, REV 0 VOLUME 5

counting is used to detect and measure the quantities of uranium, plutonium, cerium and Californium isotopes. The second assay station used gamma energy analysis to match the gamma ray energies. High resolution germanium detectors measure the gamma ray attenuations for determining uranium-233, plutonium-238, neptunium-237. Americium-241, Americium-243, and fisston activation products. Counting data are automaticaliy stored using bar code scanning for identification.

A nondestructive assay/nondestructive examination historical overview for WRAP Module 1 is presented in Table 4-12.

Table 4-12. WRAP I NDA/NOE Hfstortcal Overview

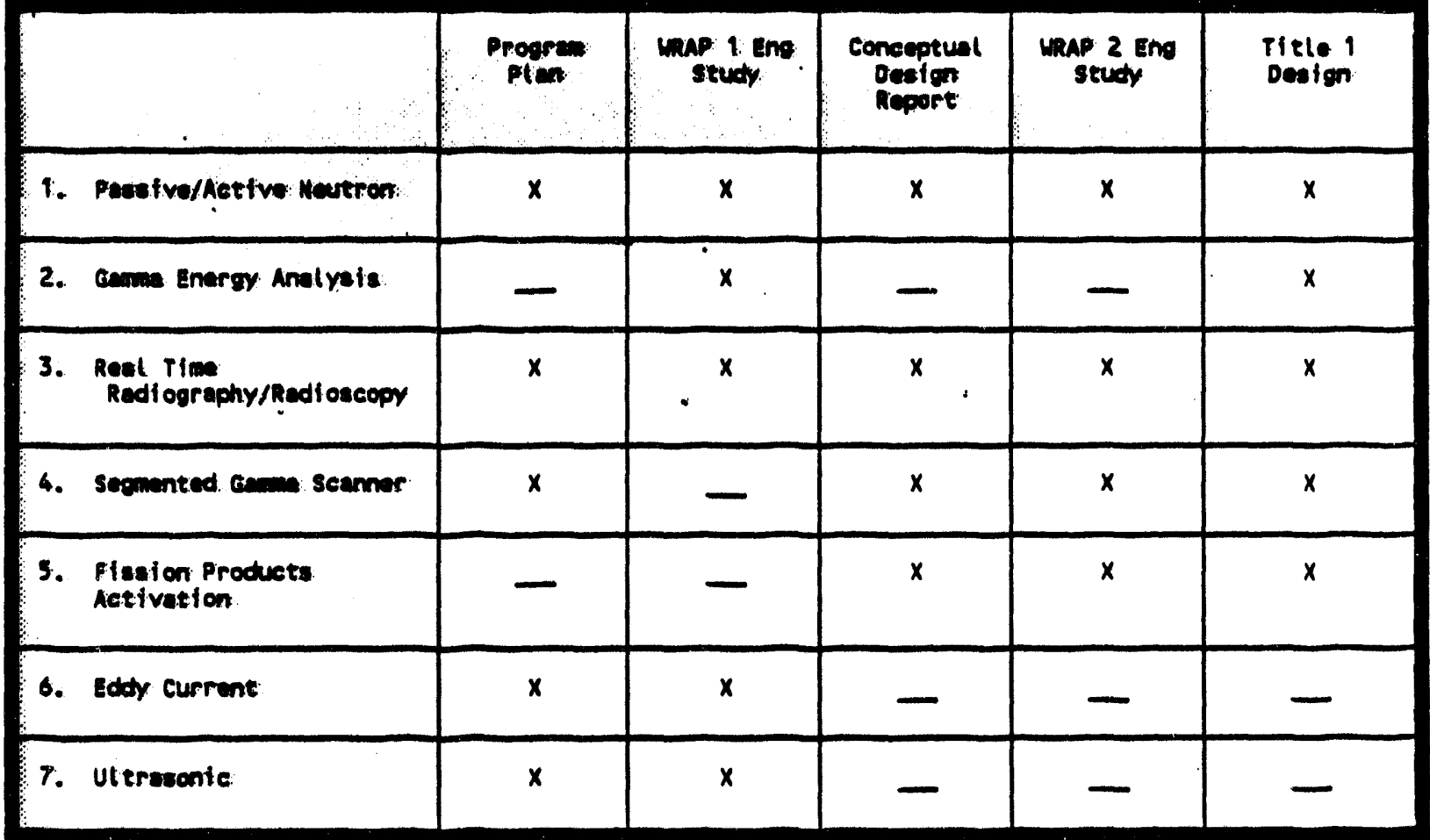

References: $H H C-S D-H-025-C D R-001$, Conceptual Design Report, Waste Receiving and Processing Facility Module 1, Project W-026. DOE Order 5820.2A, Radioactive Waste Management WIPP-DOE-069, TRU Waste Acceptance Criteria for Waste Isolation Pilot Plant. 


\subsubsection{Data Systems}

Source: FDC Section 2.2.10.

Distributed Control Computer System

WHC-SD-WM-TI-291, WRAP Draft FDC, Section 3.6, Process Control and Data Acquisition

WHC-SD-W026-CDR-001, CDR WRAP Module 1, Project W-026, page 54-58

WHC-SD-W026-CDR-001, CDR WRAP Module 1, Project W-026, Appendix C.

\section{Instrumentation and Central Control Area}

WHC-SD-WM-TI-291, WRAP Draft FDC, Section 3.6, Process Control and Data Acquisition

WHC-SD-W026-CDR-001, CDR WRAP Module d, Project W-026, page 54-58

WHC-SD-W026-CDR-001, CDR WRAP Module 1, Project W-026, Appendix C.

NDE/NDA

WHC-SD-WM-TI-291, WRAP Draft FDC, Section 3.2.

WHC-SD-W026-CDR-001, CDR WRAP Module 1, Project W-026, page 52-53. WHC-SD-W026-CDR-001, CDR WRAP Module, Project W-026, Appendix C.

Data Logging and Acquisition. Bar Code Reader/Labeler

WHC-SD-WM-TI-291, WRAP Draft FDC, Section 3.1, 3.2.

WHC-SD-W026-CDR-001, CDR WRAP Module 1, Project W-026, page 54-58, Appendix $C$.

WHC-SD-W026-CDR-001, CDR WRAP Module 1, Project W-026, Appendix C.

Characterization Data Control and Validation

WHC-SD-WM-TI-291, WRAP Draft FDC, Section 3.6, Process Control and Data Acquisition.

WHC-SD-W026-CDR-001, CDR WRAP Module 1, Projject W-026, page 54-58.

Automated Stacker/Retriever

No information available prior to Title 1 design (PCDR).

Computerized Supervisory Process Control (Process Automation) Process Management System (PMS)

WRAP Engineering Studies, Vol.V, UE\&C, 12/91, Waste Processing

System Functional Analys is Study, P.9, 5.1.16 "Appropriate

information may be electronically transferred"

WHC-SD-WM-TI-291, WRAP Draft FDC, Section 3.6, Process Control and data Acquisition and Section 2, Proposed changes to draft FDC.

WHC-SD-2026, page 54-58.

WHC-SD-W026-CDR-001, CDR WRAP ModuTe 1, Project W-026, Appendix C. 
WHC-SD-WM-RPT-060, REV 0 VOLUME 5

\subsubsection{Project Requirements}

\subsubsection{Permits}

Basis: $\quad$ RCRA, WAC 173-303, 40 CFR 61, WAC 246-247, WAC 173-400, WAC $173-460$

Source: $\quad$ FDC Section $2.0,2.1 .3,2.2: 7,3.10$

TRU solid waste is a category of waste not included within the jurisdiction of RCRA/WAC 173-303. The Washington State Department of Ecology does not define specific requirements for the disposal of TRU solid waste; Department of Energy Order 5820.2A defines disposal requirements for this waste.

The WRAP Module 1 facility will provide capabilities to perform nondestructive examination, non-destructive assay, drum opening and contents sorting, waste volume reduction via compaction, processing and 1 imited treatment to meet regulatory requirements for waste disposal. To operate, the WRAP Module 1 facility must comply with the treatment regulations of RCRA/WAC 173-303 and environmental impacts or air emissions regulations per WAC 246-247, WAC 173-400, WAC 173-460, and 40 Code of Federal Regulations (CFR) 61. The TRU waste feed for WRAP 1 was retrievably stored and not disposed. Thus, handling of the waste is not under the jurisdiction of CERCLA requirements.

A11 retrieved waste received at WRAP Module 1 will be characterized for dangerous and radionuclide constituents per RCRA and WAC 173-303 regulations. Limited treatment will be provided on non-compliant or regulated waste in the Restricted Waste Management (RWM) glovebox. The treatments will be conducted in accordance with the WRAP Module 1 Part B Permit.

Because drums are opened in gloveboxes, most of the airborne contaminants produced within WRAP Module 1 are expected to be generated in the process gloveboxes. Four gloveboxes are located within the process area and consist of TRU and LLW process lines and TRU and LLW RWM gloveboxes. Since the RWM gloveboxes are the only place where individual waste packages will be opened and waste items treated, it is anticipated that the majority of the toxic air emissions will be generated in the RWM enclosures. Radioactive air emissions are expected to emanate from all gloveboxes.

The glovebox structures and penetrations are designed to confine the contaminants within Zone 1 . Zone 1 along with the Zone 2 exhausts are ducted to their own HEPA filtration banks, each consisting of two stages of HEPA filters, before being combined and subsequently discharged to the atmosphere through the exhaust stack. Exhaust air from the gloveboxes will also flow through push-pull filters prior to passing through the two staged HEPA filters. 


$$
\text { WHC-SD-WM-RPT-060, REV } 0 \text { VOLUME } 5
$$

The exhaust stack will be the emission point for ventilation Zone 1 (gloveboxes) and Zone 2 (process area room). All of the ventilation air that has the potential to contain contaminants will be exhausted through the exhaust stack.

References: SD-W026-FDC-001 Rev 1, WRAP Module 1 Functional Design Criteria WHC-SD-WO26-SDRD-001 Supplementa1 Design Requirements Document

WRAP Module 1 TAPs Notice of Construction WRAP Module 1 RAEP Notice of Construction WRAP Module 1 NESHAPS Notice of Construction WRAP 1 Title 1 Design Report

\subsubsection{Nuclear Safety}

Basis: DOE Order 6430.1A, DOE Order 5400.5, DOE Order 5480.11

Source: FDC Section 5.0

The WRAP 1 Facility will contain radioactive, including fissile, material. Protection of the public, on-site personnel, and facility workers from the consequences of systems or component failures is required. Unacceptable safety consequences for the facility include:

Nuclear criticality

Instantaneous release of radioactivity in excess of limits Exposure of personnel to ionizing radiation in excess of limits.

DOE Orders establish limits for individual and population exposure limits for credible accident conditions:

Analyses of postulated WRAP 1 accidents with inventory, location, meteorology, and population considerations show:

Worker exposure limits, established by WHC-CM-4-46:

Analysis of the WRAP 1 design and operation shows:

Inadvertent criticality is unacceptable. Analysis of the WRAP 1 design and operation. shows that the potential for such an event is acceptably low, falling well within the risk acceptance criteria as given in DOE Order $X X X X . X X$. 
WHC-SD-WM-RPT-060, REV 0 VOLUME 5

The following is a reference collection for the project bases information presented for WRAP Module 1. These references have not been called out in the reference section of this volume, rather they are listed here.

WRAP 1 Project Bases Refẹence List

HHC-SD-H-026-PSE-001, Rev 0, Prel iminary Silfety Evaluation W-026 Waste Receiving and Processing Facility Module 1, .

D.OE Order $6430.1 \mathrm{~A}$

WHC Internal Memo, R. J. Roberts to J. A. Swenson, "WRAP I Throughput," dated 3-27-91.

WHC-SD-H-100-ES-001, Engineering Study for Waste Receiving and Processing (WRAP) Facility, Module 2.

SD-W026-FDC-001 Rev 1, WRAP Module 1 Functional Design Criteria.

WHC-SD-W026-SDRD-001 Supplemental Design Requirements Document, Project W 026.

Nupac TRUPACT II-SAR. ReV 01. TRUPACT II Safety Analys is Report for Packaging

WIPP/DOE-069 ReV 03 TRU Waste Acceptance Criteria for the Waste Isolation Plant.

Washington Administrative Code 173-303, Dangerous Waste Regulations.

WHC-EP-0223 (1989) Stored Contact Handled Transuranic Waste Characterization Plan. WHC Richland. WA.

DOE/EIS-0113, Final Environmental Impact Statement, Disposal of Hanford Defense High-Level, Transuranic and Tank Wastes, December 1987

Letter, RL to WHC, WIPP Closure

Memo, BA Mayancsik, "WRAP Throughput"

WHC-EP-0063-2, Hanford Site Radioactive Solid Waste Acceptance Criteria.

Hanford Federal Facility Agreement and Consent Order, Vol 1 and 2 , Washington State Department of Ecology, U.S. Environmental Protection Agency, U.S. Department of Energy (TRI-PARTY Agreement).

DOE Order 5820.2A, Radioactive Waste Management

49 CFR 173 . 


\section{WHC-SD-WM-RPT-060, REV 0 VOLUME 5}

WRAP I Project Bases Reference List .(Continued)

WHC-EP-0225, Rev 1, Contact-Handled Transuranic Waste Characterization Based on Existing Records, 9-91.

WHC-SD-W026-SAR-001, WRAP Module 1 Preliminary Safety Analysis Report

The Defense Waste Management Plan, DOE/DP-0015, U.S. Department of Energy, Washington, D.C., 1983.

HDW-EIS, Record of Decision, April 14, 1988.

WHC-EP-0363, Solid Waste Program Plan. 


\section{WHC-SD-WM-RPT-060, REV 0 VOLUME 5}

\subsection{WRAP MODULE 2A}

\subsubsection{Project Identification}

Source: WRAP 2A.CDR Volume 1, section 3.0, WRAP 2 CDR, Tri-Party Agreement Milestone M-19-00

The following is the Background section from the current WRAP 2A Conceptual Design Report (WRAP Facility, DOE-RL, DE-AC06-91RL11946, United Engineers and Constructors, Project No. 6237.006):

The Hanford Defense Waste Environmental Impact Statement (HDW-EIS) (DOE 1987) was issued by the U.S. Department of Energy Field Offices, Richiand (DOE-RL), in December 1987. The purpose of the HDW-EIS was "to provide environmental input into the selection and implementation of final disposal actions for high-level, transuranic, and tank wastes located at the Hanford Site, Richland Washington, and into the construction, operation, and decommissioning of waste treatment facilities that may be required in implementing waste disposal alternatives".

To comply with the Council on Environmental Quality guidance, the HDWEIS was written early in the decision-making process and before completion of detailed design for the Waste Receiving and Processing Facility (WRAP). The decision, documented in the Record of Decision (ROD) (DOE 1988), was to implement the preferred alternative discussed in the HDW-EIS. That alternative included design, construction, and operation of a facility to sort, process, and repackage retrievabiy stored and newly generated contact-handled (CH) transuranic (TRU) solid waste for shipment to the Waste Isolation Pilot Plant (WIPP) located near Carlsbad, New Mexico (DOE 1987). In addition to constructing the CH-TRU WRAP facility, the HDW-EIS also recommended a separate facility for the handling, processing, and certification of remote-handled (RH) TRU waste (DOE 1987).

The DOE, the Washington State Department of Ecology (Ecology), and the U.S. Environmental Protection Agency (EPA) reached an agreement in 1989 that established milestones for completion of certain activities addressed in the HDW-EIS (Ecology 1989a). This agreement, commonly referred to as the tri-party agreement, includes a modular approach for the WRAP. Facility. Current planning is to construct the WRAP Facility in two princtple modules. Module 1 i.s a validated 1991 Line Item under project $\mathrm{W}-026$ and is scheduled to become operational in 1997 . Module 2 consists of two functional elements: Module $2 A$ is a proposed 1994 Line Item under Project $W-100$ which is scheduled to become operational in 1999, and module 2B is a proposed 1996 Line Item under Project W-255 which is scheduled to become operational in 2002.

The primary functions of Module $2 \mathrm{~A}$ include processing, packaging, and certification of retrieved and newly generated contact handled 


\section{WHC-SD-WM-RPT-060, REV 0 VOLUME 5}

radioactive mixed waste (RMW). The primary functions of Module 2B include processing, packaging, and certification of retrieved and newly generated RH-TRU wastes, retrieved and newly generated remote handled radioactive mixed waste, and handling, processing, repackaging, and certification for retrieved and newly generated CH-TRU waste that cannot be processed in Module 1.

While the combined Module 1 and Module 2 facilities are intended to be the functional equivalent of the CH-TRU WRAP facility and RH-TRU Waste Processing Facility described in the HDW-EIS, the Module 2 concept has undergone several changes since the publication of the HDW-EIS because of Hanford Waste Management mission changes. All retrieved TRU waste is suspect TRU waste which is likely to contain some low-level waste (LLW), which must be segregated as part of the processing. Similarly, newly generated waste will be a combination of TRU and LLW. In both cases, the LLW could be mixed with RCRA hazardous constituents to classify them as low-level radioactive mixed waste (LLRMW).

The existing HDW-EIS has been considered adequate to envelope the current WRAP 2A mission and a revision of the HDW-EIS is not proposed at this time.

The Hanford Defense Waste Environmental Impact Statement did not specifically address the retrieval or treatment of radioactive mixed waste (RMW), however low-level wastes specifically resulting from the processing of TRU wastes were included. The retrieval of RMW is assumed to be incidental during retrieval and assay of the TRU waste and suspect TRU waste. The WRAP Module 2 CDR. (WHC-SD-W100-CDR-001, Rev 0), which was written prior to WRAP Module 2 being divided into two functional elements, includes the following paragraph (underline added):

It is known that some of the TRU waste stored at Hanford contains both radioactive and hazardous mixed waste components. In June 1987, DOE relinquished the byproduct exclusion for regulation of mixed waste (MW), making the treatment, storage, and disposal of MW subject to regulation under RCRA. However, none of the solid waste below ground (and some above ground) storage configurations currently used at Hanford meet the minimum RCRA technical requirements for MW storage. Therefore, it is certain that all stored suspect TRU waste will have to be retrieved, treated (as required), and placed into RCRA compliant storage or disposal facilities (e.g. WIPP). However, Hanford does not have facilities capable of providing the necessary treatment to enable Dlacing stored wastes in RCRA compliant storage or disoosal configurations.

The "Strategy Assessment Project W100, Waste Receiving and Processing (WRAP) Module 2" document (WHC-SD-W100-ES-005, Rev 0, D.L. Lamberd, Westinghouse Hanford Company, October 1991) recommended that the WRAP Module 2 Facility be divided into smaller functional projects. WRAP Module 2 was split 
WHC-SD-WM-RPT-060, REV O. VOLUME 5

into WRAP Module 2A and WRAP Module 2B. These Modules will have the functions listed in the paragraph above.

The WRAP 2A Conceptual design report section 5 paragraph 13 reads as follows (comments added\}:

13. The justification for WRAP Module $2 A$ can be summarized as follows:

a. Low level MW volume currently in storage and forecasted as. being generated over the next 30 years totals approximately 820,000 cubic feet of which about 590,000 cubic feet, or about 72 percent, can be treated, certified by WRAP Module 2A for permanent disposal.

b. Due to the deteriorated state of the $\mathrm{CH}$ MW waste drum inventory at Hanford, the WRAP $2 A$ facility is required to mitigate any further impacts to the Hanford reservation environment and subsequent increased exposure to personnel during retrieval and handling operations.

c. Between 1992 and the year 2021 (the last year included in the solid waste generation forecasts, WHC 1991b and 1991d), projected solid waste generation includes over 520,000 cubic feet of CH MW. WRAP Moduie $2 A$ is required now to el iminate double handling of this large solid volume in as much as these wastes do not have to be put in RCRA compliant storage for an indefinite period of time and then later retrieved for treatment and final disposal when a facility like WRAP $2 A$ is built in the distant future.

d. Low level MW is accumulating in storage at Hanford because there is no treatment available for this waste at the present time and it cannot be disposed of without treatment. WRAP Module $2 A$ is the proposed facility that would provide the necessary treatment to reduce the toxicity and mobility of this waste, allowing its disposal in compliance with Washington State/RCRA hazardous waste regulatory requirements.

e. The HDW-EIS ROD (DOE 1988C) identified WRAP as the preferred alternative for treatment of waste stored at Hanford, and committed DOE to building WRAP Module 2A. Note: The. EIS only addressed low-level waste that specifically resulted from the processing of TRU waste. While this is an important feed stream to WRAP Module 2A, it is by no means the only feed stream. Furthermore, DOE was committed to a WRAP Module 2 type facility in the ROD and not specifically WRAP Module 2A. Operation of WRAP Module 2A will not satisfy DOE's commitment under the ROD to retrieve and treat TRU waste for disposal. If WRAP Module $2 A$ is delayed, implementation of this ROD and fulfillment of DOE's obligations will be delayed. 


\section{WHC-SD-WM-RPT-060, REV 0 VOLUME 5}

f. The Tri-Party Agreement (TPA 1989) also committed Hanford and DOE to building WRAP Module 2A. Note: The Tri-Party agreement Milestone $M-19$ requires completion of WRAP Module 2 by. September 1999. A change has been requested to delay Completion of WRAP Module 2B unt i7.2002, however as the Tri-Party Agreement currently stands, WRAP Module 2A will not completely satisfy the M-19 Milestone. If WRAP. Module $2 A$ is delayed, implementation of this agreement will also be delayed.

g. Secondary solids from Hanford LETFs \{Liquid Effluent Treatment Facilities\}, the highest volume (55 percent) waste feedstream for WRAP Module 2A, will soon begin accumulating in storage at Hanford because there is no treatment available for this waste. It cannot be disposed without treatment. WRAP Module $2 A$ is the proposed facility that would provide the necessary treatment to reduce the toxicity and mobility of this waste by encapsulation, and thus allowing its disposal in compliance with environmental laws and regulations.

The justification for treating low-level radioactive mixed waste is driven by the need to provide a RCRA compliant disposal for the 590,000 cubic feet of waste which is currently in storage or will be generated over the 30 life of the WRAP $2 A$ facility.

\subsubsection{Project Scope}

\subsubsection{Waste Type}

\section{Source: $\quad$ FDC (ECN \#130502)}

Solid Wastes that are candidates for treatment in the WRAP facilities include wastes now in storage, wastes added to storage prior to WRAP start-up, and wastes to be generated after WRAP start-up.

Two broad classifications of waste were used to evaluate the WRAP project scope: contact-handled and remote-handled. Contact-handled wastes include those with radioactive dose rates below $200 \mathrm{mrem} / \mathrm{hr}$. Remote-handled waste is waste with radioactive dose rates of $200 \mathrm{mrem} / \mathrm{hr}$ and higher.

Originally, the scope of WRAP module 2 project included solid waste characterization and size reduction capability for transuranic (TRU) and suspect TRU waste and treatment for contact handled low level radioactive mixed waste. Due to the uncertainties associated with the design of a facility to process TRU waste for disposal at WIPP, WRAP module 2 was divided into two smaller projects, WRAP $2 A$ and WRAP $2 B$.

The WRAP module $2 A$ facility is designed to receive and process contacthandled radioactive mixed waste. This consists of waste which is hazardous and also radioactive. This does not include TRU waste which contains at least $100 \mathrm{nCi} / \mathrm{gram}$ of transuranic elements ( $\mathrm{Np}, \mathrm{Pu}, \mathrm{Am}, . .$.$) . Contact handled TRU.$ 
WHC-SD-WM-RPT-060, REV 0 VOLUME 5

waste drums will be processed and packaged for shipment to WIPP in WRAP 1. Remote handled TRU waste and large TRU waste will be processed and packaged for shipment to WIPP in WRAP $2 B$.

"All low-level (radioactive) waste shall be classified according to Category 1, 3, and greater than Category 3 concentration 1 imits defined in table 4-13. Also the radioactive component of all mixed waste shall be classified according to this classification. system. Waste shall then be segregated prior to shipment to the burial grounds." (Hanford site Solid Waste Acceptance Criteria, WHC-EP-0063-3, Wi11 is and Triner, September 1991, page 4-3). All waste in WRAP module 2A will be classifled into the three categories above and segregated for disposal. Segregation of the waste exiting WRAP 2A for RCRA compliant disposal is accomplished by Non-Destructive Assay (NDA) equipment. After treatment in WRAP 2A, segregation of the waste may no longer be required.

As part of the ACDR work plan, the Solid Waste Program has completed a preliminary review of NOA requirements and has identified potential changes to the NDA capabilities. The review suggests that WRAP 2A PAN and GEA be eliminated. This is based on the assumption that distinction between Category 1 and Category 3 low level mixed waste need not be made for disposal requirements since the disposal facility would perform adequately for both waste types. 
WHC-SD-WM-RPT-060,. REV O VOLUME 5

Table 4-13. Radionuclide Concentration Limits

\begin{tabular}{|c|c|c|c|}
\hline Radionuclide. & Half-life (yr) & $\begin{array}{l}\text { Column 1 } \\
\text { Catogory } \\
\text { Hanford limit } \\
\mathrm{Ci} / \mathrm{m}^{3}\end{array}$ & $\begin{array}{l}\text { Column } 2 \\
\text { Catogory } 3 \\
\text { Hanford } 1 \text { Imit } \\
\mathrm{Ci} / \mathrm{m}^{3}\end{array}$ \\
\hline${ }^{3} \mathrm{H}$ & $1.2 E+01$ & $5 E+00$ & - \\
\hline${ }^{14} \mathrm{C}$ & $5.7 E+03$ & $6 E-04$ & $8 E+00$ \\
\hline${ }^{14} \mathrm{C}$ reor. motall & $5.7 E+03$ & 6 E-04 & $8 E+01$ \\
\hline${ }^{60} \mathrm{Co}$ & $5.3 E+00$ & $3 E+02$ & - \\
\hline${ }^{59} \mathrm{Ni}$ (ect. motell) & $8.0 E+04$ & $3 E+00$ & $2.2 E+02$ \\
\hline${ }^{63} \mathrm{Ni}$ & $9.2 E+01$ & $2 E+00$ & $7 \mathrm{E}+02$ \\
\hline${ }^{63} \mathrm{Ni}$ locer. motell & $9.2 E+01$ & $2 E+01$ & $7 E+03$ \\
\hline${ }^{90} \mathrm{Sr}$ & $2.8 E+01$ & $5 E-03$ & $7 \mathrm{E}+03$ \\
\hline $94 \mathrm{Nb}$ & $2.0 E+04$ & $8 E-04$ & $2 E-01$ \\
\hline${ }^{99} \mathrm{TC}$ & $2.1 E+05$ & $7 E-03$ & $3 E+00$ \\
\hline${ }^{129} \mathrm{I}$ & $1.2 E+07$ & $1 E-03$ & $8 E-02$ \\
\hline${ }^{137} \mathrm{Cs}$ & $3.0 E+01$ & $2 E-02$ & $4.6 E+03$ \\
\hline${ }^{249} \mathrm{Pu}$ & $1.3 \cdot E+01$ & $5 E+01^{b}$ & $3.5 E+03^{b}$ \\
\hline - $\quad{ }^{242} \mathrm{Cm}$ & $4.4 E-01$ & $2 E+03^{b}$ & $2 E+04^{b}$ \\
\hline${ }^{79} \mathrm{Se}$ & $6.5 E+04$ & $7 E-03$ & $7 E-02$ \\
\hline $\begin{array}{c}\text { Alpha-emitting } \\
\text { transuranic } \\
\text { nuclides }\end{array}$ & $>5$ & $10^{b . c}$ & $100^{6, e}$ \\
\hline
\end{tabular}

"A dash indicates no values are provided.

bxpressed in units of nanocuries per gram of waste.

Number selected in accordance with already-established limits and definitions.

NOTE: This table is modeled on the waste classification system developed by the NRC in 10 CFR 61 (NRC 1990). These values are upper limit concentrations of specific radionuclides for the INVERSE computer model developed by the NRC. The actual concentration limits for column 1 are also based on the internal dose models, ICRP-30 and ICRP-48, which have been adopted by DOE for all radiation exposure calculations for internally deposited radionuclides. These limits are numerically smaller than the NRC limits, in part, because the NRC 1 imits are based on the earlier internal dose model ICRP-2: The list of nuclides includes ${ }^{79} \mathrm{Se}$, which may occur in significant amounts in defense waste, but is insignificant in commercial waste. Values for other radionuclides may be identified during the development of the Hanford Site PAs for disposal of waste in these classifications. 


\subsubsection{Interfaces}

Source:- WRAP 2A Conceptual Design Report, Volume 1 section 6.4

Section 6.4 of the COR reads as follows:

1. WRAP Module 2A forms and integral part of the overall solid waste management. strategy at Hanford. Other factlittes that are a part of this strategy include:

a. Hanford Contral Waste Complex, Mixed Waste Storage Facility (W016);

b. Mixed Waste Disposal Factlity (W-025);

c. Enhanced Radioactive and Mixed Haste Storage Phase V (W-112);

d. WRAP Module 1 ( $(W-026)$;

e. HRAP Module $2 B(\mathrm{H}-255)$;

f. Thermal Treatment Facility (W-242);

g. Liquid Effiuent Treatment Factlities (Projects $\mathrm{C}-018 \mathrm{H}$ and $\mathrm{L}-045 \mathrm{H}$ )

2. The Hanford Central Waste Complex (HCWC), Projects W-112 and W-016 provide buffer and lag storage for waste transfer to and from Module $2 A$.

3. WRAP Module 1 is currently in the detall design phase and provides characterization and certification of $C H$ TRU and LLW, which is either newly generited or has come from the Retrieval Project. WRAP 1 waste determined to contain hazardous waste fractions requiring immobilization and which are determined to be non-TRU will be treated in WRAP 2A.

Other LLMW will be stored for treatment in other future facilities.

4. WRAP Module $2 B$ is a future facility which will provide characterization and certification of TRU and LLW which is too large, too great in radiation levels, or too heavy for WRAP Module 1 processing.

5. The Thermal Treatment Facility is a future facility which will provide thermal treatment of waste requiring such treatment, in accordance with Washington State Administrative Codes (WAC) 173-303. The ash residues from this facility will be treated in WRAP Module 2A.

6. The Liquid Effiuent Treatment Factlity (LETF) is a future factlity which will treat liquid effluents from miscellaneous Hanford facilities. Secondary solids from the LETF will be treated in WRAP Module 2A.

7. The interface between Module $2 A$ and the facilities described above is the shipping and recelving area in the southeast corner of the facility with - the W-112 transfer corridor. Through this corridor all waste will enter and leave Module 2A. This transfer corridor is extended along the south side of Module $2 A$ to allow future connection of Module $2 A$ to handle Category $3 \mathrm{LLW}$ or Module $2 \mathrm{~B}$ and other future waste treatment modules. Waste movements within this transfer corridor are currently planned to be by fork lift truck and AGV (computer controlled, 
WHC-SD-WM-RPT-060, REV 0 VOLUME 5

Automated Guided Vehicles), the waste having been delivered to the module $2 A / W-112$ interface by the $W-112$ transfer system. Consideration should be given to the integration and optimization of this overall transfer system.

8. Module $2 A$ will tie-in to appropriate utilities at locations supplied by the Hanford Site Utility Upgrade Project, W-112.

9. Liquid wastes generated within the Module $2 A$ process will consist of potentially radioactively contaminated, and non-contaminated effluents. The conceptual design maximizes the internal recycle of radioactively contaminated and non-contaminated liquids by utfifzation of such liquids within the process to achieve a zero discharge mode during normal operations. As an option during non-normal operating conditions, such as fire conditions, there will be provision for the radioactively contaminated waste stream to be containerized and shipped to the Liquid Effluent Treatment Facility (LETF), if necessary. A tank truck connection point will be provided at the southeast corner of the bullding, in the area where trucks arrive to unload new drums for the process. Non-contaminated liquid effluents which contain hazardous materials will be segregated and collected within the process and will be routed into 55-gailon drums, within the AMU area to be transferred off-site for necessary treatment and disposal.

\subsubsection{Project Size}

\section{Source: WRAP 2A CDR Section 6.2}

The. WRAP Module $2 A$ facility will be housed within a pre-engineered metal building, measuring approximately $250 \mathrm{ft}$. X $180 \mathrm{ft}$. External storage is provided for new drums entering the process and for the bulk constituents of the cement grout and polymer encapsulation process.

The facility will be divided into distinct areas to accommodate functional and safety requirements. These areas are:

\section{a. Office Administration/Facility Support Area \\ b. Process Area \\ c. Process Support Area}

The office administration and factlity/personnel support area will include 21,240 square feet of programmable space excluding circulation, and occupies the north end of the facility which provides general traffic access and parking. The office administration area will consist of a lobby and reception area, offices for management/engineering/clerical personnel, RPT office, records management, storage rooms, conference room, rest rooms, and a lunch room. The facility/personnel support areas include personnel change rooms, janitorial area, laundry, telecommunications room, SWP area, and 
separate mechanical, HVAC, and electrical equipment rooms. Spaces are also provided for uninterruptible power supply and HVAC equipment room HEPA filters and exhaust fans. The office administration area will be located adjacent to the main entry and personnel support areas. Personnel flow to the process areas will be through the change rooms to provide a single point of access, radiation monitoring, and rogulated entry. The office administration and factlity support areas occupy the entire north end of the factlity.

The process area will provide 16,321 square feet of area excluding circulation space and is located at the south end of the facility with future expanstion provistons to the west side. Connection to WRAP Module 1, Project W112 for shipping and receiving of waste, potentlal expansion of WRAP Module $2 A$ to include other waste treatment processes, and future WRAP modules will be through the $20 \mathrm{ft}$ wide transfer corridor running the entire south side of the factlity. The process area includes a open/sort/repack area where all incoming waste drums are opened, the contents inspected for irregularities, appropriately size reduced in shredders, and repacked in new drums in preparation for the encapsulation process. Adjacent to this area is the large tem breakdown area where large boxes and drums are opened, sortad, and size reduced. Repackaged drums are non-destructively assayed at the NDA area and forwarded to either the grouting enclosure or the polymer enclosure for final immobilization prior to shipping for disposal. There is also a special waste processing area to deal with waste forms that need pre-treatment and stabilization prior to being size-reduced and immobilized. Other process operations include areas for verification/process sampling, liquid waste (as generated by various processes) treatment, lead/lag storage for waste drums, and decontamination of enclosures and equipment. Process areas are appropriately isolated by walls, enclosures, and airlocks.

The process support will provide 12,497 square feet of area excluding circulation space; and consists of the shipping/receiving area, new drum storage, grout preparation area, aqueous make-up, transfer corridor, control room, computer room, and operations supervisor office. Shipping/receiving area will provide space for unloading, survey and staging of incoming waste as well as transportation of immobilized outgoing waste. All receipt and shipment of waste is accomplished through the radioactive and mixed waste storage factlity, Project $W-112$, via the transfer corridor. Supplies to new drum storage and exterior storage of bulk material is accomplished by-trucks. (AMU) will provide bulk storage and dilution of concentrated acids and caustics for process control.

\subsubsection{Project Schedule.}

Source: WRAP 2A CDR Volume II, Section 6 and 7

A complete schedule breakdown is included in sections 6 and 7 of volume II of the WRAP 2A CDR. The three primary schedule categories are:

1. Engineering and Design which was already begun and is scheduled to be completed March 1996. 
WHC-SD-WM-RPT-060, REV 0 VOLUME 5

2. Building construction which is scheduled to begin in April 1996 and be completed by August 1998.

3. Process Equipment procurement and installation which is scheduled to begin in April 1996 and be completed by September 1998.

\subsubsection{Process Rate}

Source: WRAP 2A CDR, Volume 1, Section 6.5, FDC.

As previously stated approximately 590,000 cublc feet of solid, radioactive mixed waste are planned to be processed through WRAP 2A over the thirty year 1 ife of the facility. The 590,000 cubic feet of waste corresponds to about 80,00055 gallon drums of waste. A minimum process rate of approximately 2,700 drums per year will be required to complete the processing within 30 years.

The shredder and repacl. enclosure processes 3,445 waste drums into 6693 new drums per year. The pug mill enclosure processes 596 drums into 1,171 new drums per year. Additionaliy, as many as 1,218 waste drums per year will be processed in the special waste enclosure. WRAP 2A will have the process capacity to achieve a throughput rate of as high as 5,259 waste drums per year. Additional specific information about the processes in each enclosure will be included later in this document.

\subsubsection{Facility Expansion}

Source: $\quad$ FDC Section 3.11

"The WRAP Module 2A is the second module to the WRAP facilities, and therefore shall be designed and constructed in such a manner as to facilitate expansion or connection to future modules or waste storage buildings as much as practical. The facility shall maintain one open wall in the process areas and support ares to accommodate potential expansions."

This requirement for expansion has been reflected in the COR (see the interfaces item above for details).

\subsubsection{Project Functions}

\subsubsection{Waste Characterization}

\section{Source: $\quad$ FDC Section 1.1}

All the waste received at the WRAP Module $2 A$ facility will be characterized for dangerous and radionuclide constituents, as per WAC 173-303 and other regulations, prior to receipt. All outgoing waste shall be certified for disposal in RCRA approved land disposal. The certification of outgoing waste will be done as necessary using NDE/NDA (see NDE/NDA section of this report) equipment in the WRAP Module $2 A$ facility. 


\subsubsection{Waste Storage}

Source: $\quad F D C / C D R$

WRAP $2 A$ functional design criteria includes the need for the following lag storage capability:

- Lag storage space for receipt of waste to support two days of verification sampling and treatment operations (110 drums)

- Two days lag storage and visual inspection of curing treated waste ( 74 drums of polymer product and 36 drums of grout product)

- Lag storage space-for at least 20 drums in the specialty enclosure

- Receipt and covered storage for new containers and supplies needed to support two weeks of operation (544 new drums)

- Lag storage for receipt and shipping of at least one day of (waste) containers (i.e., one day incoming waste (30 drums) and one day outgoing waste ( 54 drums))

WRAP $2 A$ conceptual design has approximately 300 drums of waste drum lag storage in various locations in the facility (shipping/receiving, processing, lag storage) and 528 drums of 1 ag storage for new empty containers for operations. This equates to one day storage of incoming drums in shipping/receiving ( 30 drums), two days storage of waste awaiting stabilization/encapsulation (1.08 drums), two days storage of curing waste after stabilization/encapsulation (108 drums), one day storage of waste outgoing waste in shipping/receiving (54 drums). These are relatively small lag storage capabilities that allow for decoupling of WRAP $2 A$ processing. For example the waste size reduction and repackaging and sampling activities in WRAP $2 A$ and the grout stabilization and polymer encapsulation activities do not have to operate simultaneousiy in order to operate at $100 \%$ efficiency. This allows for more efficient operation by building up an inventory of material so grout stabilization and polymer encapsulation can continue to operate if size reduction and repackaging equipinent is unavailable for short periods of time or vise versa. Similarly, lag storage in shipping/receiving allows for accumulation of waste without requiring immediate transfer between WRAP $2 A$ and Phase $V$ Storage.

\subsubsection{Waste Sorting}

Source: FDC Section 2.2.1

As stated above, the facility operation is based on all entering waste being characterized by the generator. WRAP module $2 A$ personnel shall segregate the entering waste into campaign lots of 1 ike material in storage prior to transportation to WRAP 2A. Representative sampling of packages constituting a lot shall be performed to verify characterization data and supply process information to adjust and control the treatment processes in WRAP Module 2A. A lot of waste shall not be mixed with other lots but the treatment process shall be controlled to comply with the operating ranges determined for that lot of waste. Representative samples shall be taken of 
WHC-SD-WM-RPT-060, REV 0 VOLUME 5

each treated lot to verify successful treatment and provide radioisotope distribution information to support the low-level waste assay performed in WRAP Module 2A. The treated waste shall reside in storage until it is sufficiently cured and certified via sampling and WRAP Module $2 A$ assay for disposal.

\subsubsection{Waste Treatment}

Source: FDC Section 2.2.1, CDR Volume 1 Section 6

WRAP Module $2 A$ shall provide the non-thermal treatment necessary to enable certification of solid contact-handled low-level categories 1 and 3 radioactive mixed waste for permanent disposal. The process features provided to accomplish this mission are: verification of entering waste characteristics, immobilization; encapsulation and deactivation treatments for radioactive mixed waste, non-destructive assay to determine low-level waste. category, and a specialty processing capability to perform custom treatment of small volume wastes.

The radioactive mixed waste treatment area shall provide treatment for low-level contact-handled radioactive mixed waste to enable disposal of the treated waste in accordance with all applicable DOE, EPA, and WDOE regulations. The area shall have at a minimum two separate enclosures, one housing the main process lines of encapsulation, immobilization and deactivation and a second housing a specialty treatment capability. The process enclosure provides receipt and exiting of waste, verification and certification sampling capability, destructive examination, conditioning of the waste for treatment (e.g. shredding and screening), deactivation treatment, lead encapsulation treatment, and immobilization and solidification treatment. The specialty enclosure shail provide the capability to treat small waste streams requiring special treatment for disposal or additional treatment in the main process enclosure. The facility shall be capable of handling and treating waste that has been previously supercompacted or. immobilized.

The specific treatments which have been identified are size reduction, immobilization, encapsulation, and special waste treatments.

The size reduction treatment for drums consists of shredding and repacking the waste into new drums for dry waste or treatment in a pug mill for the sludge type waste and repacking the waste into new drums.

Size reduction of special waste will also be accomplished in the special waste enclosure. (Special waste is waste which is contaminated with mercury, lead, or reactive metals (e.g. alkali and alkali earth metals). These waste streams will be processed on a campaign basis. This enclosure is capable of simultaneously processing lead and mercury waste drums. The special waste enclosure contains equipment for load out of lead bricks, size reduce (with shredders) lead or mercury contaminated solids, amalgamate elemental mercury, recover mercury from solids using evaporation, and load out waste into new 


\section{WHC-SD-WM-RPT-060, REV 0 VOLUME 5}

drums for immobilization at the polymer enclosure. After all the mercury and lead waste drums have been treated, some equipment can be stripped out and replaced with new equipment that will deactivate reactive metal waste drums if. this waste feedstream is identified.

All incoming waste drums, after being emptied, àre also shredded and repackaged in new drums for eventual encapsulation in grout.

Immobilization consists of filling the new drums with polymer. This is the technology based standard to permit RCRA compliant disposal of some of the waste (primarily lead and mercury).

Encapsulation consists of filling the new drums with grout. The grout wi11. prevent migration of the waste from the drums, and allow RCRA compliant disposal for most of the waste.

\subsubsection{Waste Packaging}

\section{Source: CDR Volume V Section 1}

The waste entering WRAP Module $2 A$ will be packaged in 55 or 83 gallon drums or boxes of various size. As part of the processing in WRAP the waste will be emptied from the existing containers, size reduced (Shredded or sent through a pug mill), and repackaged in new 55 gallon drums. The new drums will be filled with polymer or grout, allowed to cure, and then shipped out for eventual disposal.

\subsubsection{NonDestructive Assay/NonDestructive Examination}

Source: FDC Section 2.2.2

Non-destructive assay (NDA) refers to the measurement of the fission and activation products as well as the auctioned contents of solid radioactive waste. Non-destructive means that the waste is not altered as it would be if a physical sample were to be taken for chemical of other analysis. For NDA to be successful, the waste must be characterized. There are two methods of NDA planned for WRAP 2A, Gamma Energy Analysis (GEA) and Passive-Active-Neutron Analysis (PAN). GEA is not practical for making the determination whether waste is LLW or TRU because the quantity of plutonium present is typically in the milligram region and too few gammas are emitted to be accurately measured. GEA measurements for TRU, using a segmented gamma scanner, are best made when the TRU quantity is greater than $1.0 \mathrm{gram}$. The PAN approach, provides the best estimate of the amount of TRU present at the LLW/TRU levels.

The following NDA requirement was listed in the WRAP 2A FDC:

"A NDA capability shall be provided to determine the radionuclide inventory and assign the low-level waste category of all drums exiting the WRAP module $2 A$ facility for disposal. It is expected that treatment will cause some of the waste entering as low-level category 3 to be 
WHC-SD-WM-RPT-060, REV 0 VOLUME 5

redesignated as category 1 at exit. The NDA capability shall possess the capacity and capability needed to reassign the low-level waste category to 1 for waste that is low-level category 3 at entrance.

The NDA capability will use information from.the waste generator and/or laboratory results. The NDA shall measure the key gamma and neutron emitters and calculate the total radionuclide inventory of a waste drum to: determine whether the container is to be classified as category 1 or 3 per the requirements of WHC-EP-0063 and certify the TRU, fission, and activation product contents of the drum prior to disposal.

The NDA shall assay 55 gallon drums weighing as much as 3,000 pounds. Also capability to determine the weight of each drum shall be provided."

In order to meet this requirement, the $W-100$ WRAP $2 A$ conceptual design report included the following NDA systems:

- 1 Passive-Active-Neutron system

- 1 Gamma Energy Analysis system.

Both of these systems are needed to certify outgoing waste as category one or category three.

As part of the ACDR work plan, the Solid Waste Program has completed a preliminary review of NDE/NDA requirements and has identified potential changes to the NDA capabilities. The review suggests that WRAP $2 A$ PAN and GEA be eliminated. This is based on the assumption that distinction between Category 1 and Category 3 low level mixed waste need not be made for disposal requirements since the disposal facility will perform adequately for both waste types.

\subsubsection{Liquid Wastes}

Source: FDC Section 1.1/CDR Volume 1, Section 6.4.9

Project W-100 shall provides the capability to collect RMW and liquid hazardous wastes generated from the facility operations. Radioactively contaminated liquid wastes shall be recycled. for use in the treatment process to the maximum extent possible, however a backup capability to transport to the $\mathrm{C}-018 \mathrm{H}$ LETF located in the 200 East Area for treatment shall also be provided. The non-radioactively contaminated liquid shall be collected separately for disposal.

Liquid wastes generated within the Module $2 A$ process will consist of potentially radioactively contaminated, and non-contaminated effluents. The conceptual design maximizes the internal recycle of radioactively contaminated and non-contaminated liquids by utilization of such liquids within the process to achieve a zero discharge mode during normal operations. As an option during non-normal operating conditions, such as fire conditions, there will be 
WHC-SD-WM-RPT-060, REV 0 VOLUME 5

provision for the radioactively contaminated waste stream to be containerized and shipped to the Liquid Effluent Treatment Facility (LETF), if necessary. A tank truck connection point will be provided at the southeast corner of the building, in the area where trucks arrive to unload new drums for the process. Non-contaminated liquid effluents which contain hazardous materials will be segregated and collected within the process and will be routed into 55-gallon drums, within the AMU area to be transferred off-site for necessary treatment and disposal.

\subsubsection{Project Requirements}

\subsubsection{Permits}

Source: $\quad$ WRAP 2A CDR, Volume 1, Section 9.9

WRAP CDR, Volume 1, Section 9.9 reads as follows:

1. The construction and operation of the WRAP Module $2 A$ facility is subject to several sets of regulations concerning the management of solid wastes. The primary state and federal regulations include the following:

- Dangerous waste regulations

- Atr emission regulations

- Ottier environmental regulations

2. Section 9.9.1 describes the state and federal waste regulations, section 9.9.2 describes the permitting requirements for a Treatment, Storage and Disposal Facility (TSD), section 9.9.3 describes the air emission regulations and section 9.9.4 lists other environmental regulations applicable to the WRAP Module $2 A$ facility.

\subsubsection{State and Federal Dangerous Waste Requlations}

1. The WRAP Module $2 A$ factlity provides the capability to receive containers of contact handled (CH) solid low-level mixed waste (MW) and treat these wastes as necessary to allow certification and permanent disposal in accordance with all applicable DOE orders and other 1 aws, codes and regulations including: WAC 173-303, RCRA, and Hanford site radioactive sol'id waste acceptance criteria, WHC-EP-0063.

2. The WRAP Module $2 A$ facility will be treating and storing dangerous waste, therefore, the facility sill be subject to the state and federal dangerous waste regulations contained in the Washington Administrative Code (WAC) 173-303 Dangerous Waste Regulations and related federal requirements included in title 40 of the Code of Federal Regulations ( 40 (FR). The state of Washington, Department of Ecology has been granted the authority to enforce both the state and federal regulations for solid waste management. 
WHC-SD-WM-RPT-060, REV 0 VOLUME 5

3. Both 40 CFR part 261 and WAC $173-303$ contain lists of chemical compounds or common industrial waste solutions that if present in a solid waste make that solid waste a dangerous waste. The characteristics of dangerous waste include:

- Ignitability

- Corrosivity

- Reactivity

- Toxicity

4. Many of the compounds present in the WRAP Module $2 A$ feedstream exhibit one or more of the dangerous waste characteristics. The disposal of dangerous waste is strictly regulated.

\subsubsection{ISD Facility Pemitting}

1. WRAP Module $2 A$ facility is a new TSD facility which will be treating dangerous waste, as such it must receive an interim status permit before any physical construction can start and a final status operating permit before beginning any treatment, storage or disposal activities. The process for both applying for these permits and for the state of Washington approval is described in WAC 173-303-806. Once granted, DOE owned facilities must operate in accordance with all final status requirements in particular the following:

\section{WAC 173-303-600 Final Facility Standards}

WAC 173-303-610 Closure and Post Closure Care

WAC 173-303-630 Use and Management of Containers

WAC 173-303-640 Tank Systems

WAC 173-303-645 Releases from Solid Waste Management Units

2. The WRAP Facility Part B Dangerous Waste permit application is contained in DOE-RL-91-16. This document mainly describes the WRAP Module 1 facility at the present time. This permit application will be modified in accordance with the requirements identified in WAC-173-303830 as WRAP 2A facility design information becomes available. The data required for the permit modification will be prepared by the operating contractor in conjunction with the design contractor.

3. The WRAP Facility Part B permit application consists of 15 chapters:

- Introduction (Chapter 1.0)

- Facility Description and General Provisions (Chapter 2.0)

- Waste Characteristics (Chapter 3.0)

- Process Information (Chapter 4.0)

- Groundwater Monitoring (Chapter 5.0)

- Procedures to Prevent Hazards (Chapter 6.0)

- Contingency Plan (Chapter 7.0)

- Personnel Training (Chapter 8.0)

- Exposure Information Report (Chapter 9.0)

- Waste Minimization Plan (Chapter 10.0) 
WHC-SD-WM-RPT-060, REV 0 VOLUME 5

- Closure and Postclosure Requirements (Chapter 11.0)

- Report and Recordkeeping (Chapter 12.0)

- Other Relevant Laws (Chapter 13.0)

- Certification (Chapter 14.0)

- References (Chapter 15.0)

4. a brief description of the chapters of the Part B.permit application is provided below:

a. Eacility Descriotion and General Provisions (Chapter 2.0) This chapter provides a general description of the WRAP facllity. A brief description of the Hanford Site and the Hanford Factlity also are provided.

b. Haste Characteristics (Chaoter 3.0) This chapter describes the physical, chemical, and biological characteristics of the dangerous waste to be treated or stored at the WRAP facility. A waste analysis plan is included that provides the methodology for determining waste types. Although radionuclide components are not within the scope of the Dangerous Waste Regulations, the information is provided for general knowledge where appropriate.

c. Process Information (Chapter 4.0) This chapter provides a detailed discussion of the processes and equipment of the WRAP facility.

d. Groundwater Monitoring (Chapter 5.0) This chapter explains that the WRAP Facility will not be operated as a dangerous waste surface impoundment, waste pile, land treatment unit, of 1 andfill. Therefore, groundwater monitoring is not required.

e. Procedures to Prevent Hazards (Chapter 6.0) This chapter discusses hazard prevention and emergency preparedness equipment, structures, and procedures.

f. Contingency Plan (Chapter 7.0) This chapter provides information on contingency planning to ensure the safety of the WRAP facility employees whose primary duties will be identified as being associated with dangerous waste management.

9. Exposure Information Report (Chapter 9.0) This chapter explains that the WRAP facility will not store, treat, or dispose of dangerous waste in a surface impoundment or a landfill. Therefore, exposure information is not required.

h. Waste Minimization Plan (Chapter 10.0) This chapter discusses the program to minimize the volume or quantity and toxicity of waste generated at the WRAP facility. The regulatory basis for, and objectives of, the waste minimization program are discussed. Waste generation is described and specific procedures for minimizing waste are discussed. 
WHC-SD-WM-RPT-060, REV 0 VOLUME 5

i. Closure and Postclosure Requirements (Chapter 11.0) This chapter describes the planned activities for closing the WRAP facility. The WRAP facility is to be clean closed; therefore, no postclosure plan is included.

j. Reporting and Recordkeeping (Chapter 12.0) This chapter summarizes commitments for reporting and recordkeeping that will be applicable to the WRAP facility.

k. Other Relevant Laws (Chapter 13.0) This chapter discusses the federal and state laws that wil1 govern the operation of the WRAP facility, other than the RCRA, as amended, and the State of Washington Hazardous Waste Management Act of 1976, as amended.

1. Certification (Chapter 14.0) This chapter contains the required certification signed by officials of the U.S. Department of Energy (DOE) Field Office, Richland (RL) and Westinghouse Hanford Company indicating that the information provided is true, accurate, and complete.

m. References (Chapter 15.0) References used throughout the Part B permit application are listed in this chapter. All references which generally are not available from other sources, will be made available for review, upon request, to any regulatory agency or public commenter. References can be obtained by contacting the following:

Administrative Records Specialist

Public Access Room H4-22

Westinghouse Hanford Company

PO Box 1970

Richland, WA 99352

\subsubsection{Air Emissions Requlations}

1. Emissions from the WRAP Module $2 A$ facility will be subject to state and federal regulations governing radioactive and non-radioactive air emissions from processing facilities. Air emissions will also be subject to DOE Orders and WHC policy, which reflect the appropriate local, state and federal regulations.

\section{a. General Requlations}

1) Federal air emission regulations have been implemented in Washington through Chapters 173-400, 173-403, 173-480, and 402-80 WAC. In general, new or significantly modified sources of air emissions at Hanford must file notices of construction (NOCs) with the Department of Social and Health Services (DSHS), Ecology, and Tri-County Air Pollution Control Authority (TCAPCA) before constructing a new or modified source of air emissions. 
WHC-SD-WM-RPT-060, REV 0 VOLUME 5

2) The NOCs will be reviewed to ensure that the proposed facility complies with any applicable New Source Performance Standards (NSPS) . contained in 40 CFR Part 60, with applicable National Emission Standards for Hazardous Air Pollutants (NESHAPs) found in 40 CFR Part 61, and the Best Avallable Control Technology (BACT), Best Available Radionuclide Control Technology (BARCT), and Best Available Control Technology for Toxics (T-BACT) have been applied for emissions control. Within 30 days, the appropriate authorities will make a preliminary determination. on the acceptability of the proposed new source, and after an appropriate pubilic comment period, authorize construction to proceed. Major stationary sources may enit regulated air pollutants including particulates, nitrogen oxides, volatile organic compounds, sulfur dioxide, or reduced sulfur compounds including $\mathrm{H}_{2} \mathrm{~S}$ in excess of threshold levels, so the major stationary sources must receive a -Prevention of Significant Deterioration (PSD) permit from ecology.

3) A NOC will be required for construction of the WRAP 2A facility, as it will lead to increased air emissions. A PSD permit may be required if sulfide or sulfur dioxide emissions exceed threshold levels.

b. Mational Emission Standards for Emissions of Radionuclides Other than Radon from Department of Energy Facilities

1) Radionuclide emissions from DOE facilities are subject to the NESHAP contained in 40 CFR Part 61 Subpart $H$, which 1 imits emissions from all sources at a DOE site to an effective offsite dose equivalent of 10 millirem per year (mrem/yr). Subpart $H$ also requires that specific monitoring and sampling systems be used for compliance monitoring. This requirement is also reflected in DOE Order 5400.5, Radiation Protection of the Public and Environment.

2) The WRAP Module $2 A$ facility process will be designed and operated to ensure that., as a whole, emissions from the Hanford site do not exceed the $10 \mathrm{mrem} / \mathrm{yr} 1$ imit. Emission monitoring systems must meet the standards specified in 40 CFR Part 61 Subpart H.

\section{c. Washington State Toxic Air Pollutant Regulations}

1) Chapter 173-460 WAC contains limits on emissions of toxic air pollutants (TAPs) from new sources; permission to operate a new source of toxic air pollutants is granted by review of an NOC as described in section 2.2.1. Proposed sources of toxic air pollutants must show, through system mass balances and/or dispersion modeling, that emissions will not violate ambient source impact levels (ASILs) specified in Chapter $173-460$.

2) 40 CFR 264 Subpart AA regulates air emissions from process vents in facilities which treat solutions containing greater than 10 ppmw VOCs by the following processes: distillation, thin-film evaporation, fractionation, solvent extraction, air stripping, or steam stripping. A 
WHC-SD-WM-RPT-060, REV 0 VOLUME 5

process vent is defined and "any open-ended pipe or stack that is vented to the atmosphere either directiy, through a vacuum producing device, of through a tank (e.g., distillate receiver, condenser, bottoms receiver, surge control tank, separator tank, of hot well)..." Volatile organic emissions from all process vents must be reduced to 1 ess than $1.4 \mathrm{~kg} / \mathrm{hr}$ and $2.8 \mathrm{Mg} / \mathrm{yr}$, or by 95 weight percent through installation of a closed vent system and/or control device. If a closed vent system and control device are installed; the device must meet the performance requirements stipulated in 40 CFR 264.1033. All facilities subject to the process vent regulations must meet the monitoring, recordkeeping, and reporting requirements found in 40 CFR 264.1034 through 40 CFR 264.1036.

3) 40 CFR 264 Subpart BB regulates air emissions from equipment leaks in facilities which manage hazardous wastes containing greater than 10 ppmw VOCs. Standard design features, routine maintenance, inspection, and recordkeeping requirements are incorporated into subpart BB for such items as pumps, compressors, pressure relief devices, sampling stations, and valves. Subpart BB also establishes maximum allowable time frames for repairs to leaking equipment after such leaks are detected.

4) Regulations proposed by EPA in July 1991 (Federal Register, Volume 56, Number 140, July 22, 1991) may eventually limit VC emissions from tanks, surface impoundments, and containers at RCRA TSD facilities. Under these proposed regulations, any TSD facility which handles hazardous wastes which contain more than 500 ppmw of VOCs must use covered tanks, containers, or surface impoundments, and must route all emissions from these sources to a control device which produces nondetectable VOC content of the waste. This is to be evaluated at the point of generation, or the point where the waste may first come into contact with the air.

\subsubsection{Other Environmental Requlations}

1. The WRAP Module $2 A$ facility will also be required to comply with the following other federal environmental laws:

- Atomic Energy Act of 1954

- Clean Air Act of 1977

- Clean Water Act of 1977

- Endangered Spectes Act of 1973

- Fish and Wildlife Coordination Act of 1934

- National Historic Preservation Act of 1966

- Toxic Substances Control Act of 1976

- Wild and Scenic Rivers Act of 1968 


\section{WHC-SO-WM-RPT-060, REV 0 VOLUME 5}

\subsection{WRAP MODULE 2B}

\subsubsection{Project Identification}

To be drafted.

\subsubsection{Project Scope}

To be drafted.

\subsubsection{Waste Types}

To be drafted.

\subsubsection{Interfaces}

To be drafted.

\subsubsection{Project Size}

To be drafted.

\subsubsection{Project Schedule}

To be drafted.

\subsubsection{Project Functions}

To be drafted.

\subsubsection{Project Requirements}

To be drafted. 
WHC-SD-WM-RPT-060, REV 0 VOLUME 5

\subsection{THERMAL TREATMENT FACILITY}

\subsubsection{Project Identification}

To be drafted.

\subsubsection{Project Scope}

To be drafted.

\subsubsection{Waste Types}

To be drafted.

\subsubsection{Interfaces}

To be drafted.

\subsubsection{Project S1ze}

To be drafted.

\subsubsection{Project Scheduie}

To be drafted.

\subsubsection{Project Functions}

To be drafted.

\subsubsection{Project Requirements}

To be drafted. 
WHC-SD-WM-RPT-060, REV 0 VOLUME 5

\subsection{OISPOSAL FACILITIES AND PROJECTS}

5.1. LOW-LEVEL WASTE BURIAL GROUNDS

\subsubsection{Factlity Identification}

To be drafted.

\subsubsection{Factlity Scope}

To be drafted.

\subsubsection{Factlity Functions}

To be drafted.

\subsubsection{Facility Requirements}

To be drafted. 
WHC-SD-WM-RPT-060, REV 0 VOLUME 5

\subsection{LOW-LEVEL MIXED WASTE DISPOSAL}

\subsubsection{Project Identification}

Basis: $\quad$ Resource Conservation and Recovery Act (RCRA)

Source: Engineering Study for Waste Receiving and processing (WRAP) facility Module 2; WRAP Modu'le 2A Conceptual Design Report; WRAP Module 2 Conceptual Design Report; Final Environmental Impact Statement, Disposal of Hanford Defense High-Level, Transuranic, and Tank Wastes (HDW-EIS) (U.S. DOE 1987); Hanford Federal Facility Agriement and Consent Order (Tri Party Agreement) (Ecology et: al. 1989), Milestone M-19-00

The justification for butlding a RCRA compliant radioactive mixed waste disposal facility is driven by the need to provide a RCRA compliant disposal for the 110,000 cubic feet of radioactive mixed waste which is currently in storage at Hanford and the additional estimated 480,000 cubic feet of radioactive mixed waste which is projected to be generated over the next 30 years.

A portion of the radioactive mixed waste to be generated will come from retrieval for Waste Receiving and Processing (WRAP) Module 1. WRAP Module 1 will treat and certify for disposal in the Waste Isolation Pilot Plant (WIPP) contact-handlad (CH) transuranic (TRU) Waste. One source of the waste to be treated in WRAP Module 1 will be retrievably stored suspect TRU waste. Some of the waste retrieved for treatment will be non-TRU low level radioactive waste which also contains hazardous constituents, or has hazardous characteristics. This radioactive and hazardous mixed waste (RMW) Will require treatment and certification for disposal in compliance with RCRA.

The information below states the identified need for the WRAP 2A Facility. The WRAP Module 2A Facility will treat and prepare for disposal low-level radioactive mixed waste. A disposal facility is needed to accept the prepared waste from the WRAP Module 2A. The identified need as stated in the WRAP 2 Engineering Study (WHC-SD-W100-ES-001, Section 1.0, T.R. PauTy, March 1990) is as follows:

Radioactively contaminated solid waste has been generated during routine defense materials production, research, and waste management activities at Hanford since it began operations in the early 1940s, and the regulations for treatment and disposal of these wastes have evolved along with the nuclear industry. Early regullations were concerned primarily with protecting the workers who were handling these wastes. from the hazards associated with ionizing radiation emitted by the waste. As waste management knowledge, technology, and awareness evolved, the regulations became increasingly more detailed and began to emphasize protection of the environment, and stability of the waste form. 
WHC-SD-WM-RPT-060, REV 0 VOLUME 5

Under DOE regulations (DOE Order 5820.2A, Radioactive Waste Management), radioactive solid waste is divided into transuranic (TRU), which primarily includes low dose rate waste with long iived alpha emitting radioisotopes, high level waste (HLW), which primarily includes the high dose rate waste produced directly in fuel reprocessing that contains both transuranic and fission products, and low level waste (LLW), which includes everything that is not TRU, HLW, spent nuclear fuel, or byproduct material.

Historically, only HLW was segregated for advanced treatment and disposal. In Apri1 1970, the predecessor to the U.S: Department of Energy (DOE), the Atomic Energy Commission, issued Immediate Action Directive No. 0511-21, which directed Hanford (and other DOE sites) to begin temporarily storing all suspect TRU solid waste "in such a fashion that they can be readily retrievable as contamination-free packages within an interim period of 20 years." Initially, the definition of TRU included any waste with suspect alpha contamination. This definition was later (1972) changed to include only those wastes containing $>10$ nCi/gram alpha emitting isotopes with half-7ives $>20$ years; and still later (1982) changed again to include only wastes with $>100 \mathrm{nCi} / \mathrm{gram}$ of TRU radionuclides.

Prior to 1970, TRU wastes were not segregated and were buried at Hanford commingled with LLW. Those TRU wastes buried prior to 1970 are considered disposed and are not candidates for retrieval. Since 1970, it has been the policy of DOE that. TRU wastes will be retrieved, treated (as required), certified, and transferred to the Waste Isolation Pilot Plant (WIPP) repository in New Mexico for permanent disposal. Because existing technology in the 1970s could not determine the concentration of TRU radionuclides at 10 or even $100 \mathrm{nCi} / \mathrm{gram}$, any sol id waste that was suspected to be TRU was placed in retrievable storage. As a result, it is anticipated that a large fraction of the waste placed into storage at Hanford as "suspect TRU" wi11 actually be determined to be LLW after retrieval and assay... It is also known that some of the waste stored as suspect TRU has radioactive and hazardous mixed waste (RMW) components, in both the TRU and LLW fractions.

Prior to acceptance at WIPP, each TRU waste package must be certified by the shipper as being in compliance with the Waste Acceptance Criteria (WAC) established for the WIPP. In this usage, certification means a signed statement that the waste package complies with all pertinent WAC. Certification also includes all necessary elements of an auditable program designed to ensure and prove compliance with the WAC. It is assumed that WIPP will accept properly characterized and treated TRU RMW for permanent disposal.

The WIPP WAC have been evolving since 1978; and even more restrictive requirements will be imposed by the evolving WIPP transportation system, the Transuranic Package Transporter 2 (TRUPACT-2): Still another change that has occurred since suspect CH TRU was placed in storage at Hanford 
is that the regulation governing the disposal of radioactive components in this waste, DOE Order 5820.2A, now imposes more restrictive requirements on the disposal of LLW.

The impact of all these changes will be that stored waste that may have complied with the applicable requirements at the time of emplacement may now not comply with (or cannot be proven to comply with) transportation and disposal requirements. Another important result of these changes is that Hanford currently has RMW (both TRU and LLW fractions) in storage configurations that do not meet the RCRA Minimum Technical Requirements for hazardous waste storage.

Historically, low level RMW was disposed intermingled with LLW at Hanford using shallow land burial techniques since there was no requirement to characterize or segregate the hazardous components in radioactive waste. In 1979, DOE prohibited the burial disposal of liquid organic materials. Since that time, TRU and low level liquid organic waste have been packaged in drums and stored intermingled with $\mathrm{CH}$ TRU waste for later retrieval and treatment. In June 1987, DOE relinquished the byproduct exclusion for regulation of RMW, making the treatment, storage, and disposal of all RMW subject to regulation under the Resource Conservation and Recovery Act (RCRA), and the Hazardous Solid Waste Amendments (HSWA) which established the Land Disposal Restrictions.

All low level RMW at Hanford since that decision has been stored for later retrieval and treatment. Initially low level RMW was stored in trenches similar to $\mathrm{CH}$ TRU storage; in 1987 Hanford began constructing a series of buildings for storing these wastes. All RMW stored in trenches and buildings at Hanford will be retrieved when permitted treatment and disposal facilities are available.

In 1988, DOE revised Radioactive Waste Management Order 5820.2A. This order established new criteria that requires each site to develop a specific Performance Assessment (PA) for $L L W$, and it is anticipated that the Hanford LLW PA, when completed, will identify specific radionuclides and activity concentrations that require more intensive management techniques (e.g. stabilization and advanced disposal configurations). DOE Order $5820.2 \mathrm{~A}$ also requires that each LLW package be characterized, to identify treatment and disposal methodologies, and certified as meeting al1 transportation and disposal requirements.

The DOE Defense Waste Management Plan (DOE/DP-0015) established WRAP as the facility that would provide the necessary treatment for certification of contact handled (CH) TRU waste at Hanford. In April 1988, the Hanford Defense Waste Environmental Impact Statement (HDW-EIS) Record of Decision (ROD) was issued. The HDW-EIS ROD committed DOE to build WRAP at Hanford and initiate retrieval and treatment of TRU waste stored at Hanford for emplacement in the WIPP. In 1989, the Hanford Federal Facility Agreement and Consent Order, or Tri-Party Agreement, 


\section{WHC-SD-WM-RPT-060, REV 0 VOLUME 5}

was signed by the U.S. Environmentat Protection Agency (EPA), the State of Washington Department of Ecology (WDOE), and the U.S. Department of Energy (DOE). This further reinforced DOEs commitment to build the WRAP facility at Hanford. The Tri-Party Agreement also specified WRAP as the Hanford facility that would provide necessary treatment for low level RMW in addition to TRU waste.

Suspect CH TRU waste is stored at Hanford in the 224-T Building, in Burial Grounds in the 200 West and 200 East Areas; and in the 212-N and 212-P Buildings in the 200 North Area. As of January 1989, approximately 544,500 cubic feet of suspect TRU waste containing over 480,000 grams of transuranic radionuclides had been $p 1$ aced in storage at Hanford 200 Areas in over 38,700 containers. The HDW-EIS preferred alternative also recommends retrieval of the 618-11 Burial Ground in the 600 Area (the 618-11 Burial Ground was formerly called the "Wye" burial ground and is located in the vicinity of WNP-2), and additional TRU waste will result from that operation.

In addition to suspect TRU, containers of several other types of radioactive waste have been intermingled in storage with suspect CH TRU waste. These other types include shielded remote handled (RH) waste, commercially generated Greater Than Class C (GTCC) LLW, classified DOE waste, irradiated fuel and hardware from the Experimental Breeder Reactor II (EBR-II), and LLW RMW such as containerized liquid organic waste.

Suspect TRU and other waste types are stored in a variety of container types including 55 gallon, 30 gallon, and 85 gallon steel drums; fiberboard boxes; steel boxes; plywood boxes; fiberglass reinforced plywood (FRP) boxes; concrete boxes; casks; and others. Most of the containers in which suspect $\mathrm{CH}$ TRU is stored were intended to have a minimum expected life of 20 years, although there is little documentation concerning design life expectations for specific containers. At any rate, the storage of suspect $\mathrm{CH}$ TRU waste at Hanford began in May 1970, and it is therefore anticipated that many containers may be extensively deteriorated.

The WRAP 2A Conceptual Design Report (WRAP Facility, DOE-RL, DE-ACG691RL11946, United Engineers and Constructors, Project No. 6237.006) ident ified the need for the WRAP $2 A$ facility, (and by inference radioactive mixed waste disposal) as follows:

The Hanford Defense Waste Environmental Impact Statement (HDW-EIS) (DOE 1987) was issued by the U.S. Department of Energy Field Offices, Richland (DOE-RL), in December 1987. The purpose of the HDW-EIS was "to provide environmental input into the selection and implementation of final disposal actions for high-level, transuranic, and tank wastes located at the Hanford Site, Richland Washington, and into the construction, operation, and decommissioning of waste treatment 


\section{WHC-SD-WM-RPT-060, REV 0 VOLUME 5}

facilities that may be required in implementing waste disposal alternatives".

To comply with the Council on Environmental Quality guidance, the HDWEIS was written early in the decision-making process and before completion of detailed design for the Waste Receiving and Processing Facility (WRAP). The decision, documented in the Record of Decision (ROD) (DOE 1988), was to implement the preferred alternative discussed in the HDW-EIS. That alternative included design, construction, and operation of a facility to sort, process, and repackage retirievably stored and newly generated contact-handled (CH) transuranic (TRU) solid waste for shipment to the Waste Isolation Pilot Plant (WIPP) located near Carlsbad, New Mexico (DOE 1987). In addition to constructing the CH-TRU WRAP facility, the HDW-EIS aiso recommended a separate facility for the handiing, processing, and certification of remote-handled (RH) TRU waste (DOE 1987).

The DOE, the Washington State Department of Ecology. (Ecology), and the U.S. Environmental Protection Agency (EPA) reached an agreement in 1989 that established milestones for completion of certain activities addressed in the HDW-EIS (Ecology 1989a). This agreement, commoniy referred to as the tri-party agreement, includes a modular approach for the WRAP Facility. Current planning is to construct the WRAP Facility in two principle modules. Module $l$ is a validated 1991 Line Item under project W-026 and is scheduled to become operational in 1997 . Module 2 consists of two functional elements: Module 2A is a proposed 1994 Line Item under Project $W-100$ which is scheduled to become operational in 1999, and module 2B is a proposed 1996 Line Item under Project W-255 which is scheduled to become operational in 2002.

The primary functions of Module $2 \mathrm{~A}$ include processing, packaging, and certification of retrieved and newly generated contact handled radioactive mixed waste (RMW). The primary functions of Module $2 B$ include processing, packaging, and certification of retrieved and newly generated RH-TRU wastes, retrieved and newly generated remote handled radioactive mixed waste, and handling, processing, repackaging, and certification for retrieved and newly generated $\mathrm{CH}$-TRU waste that cannot be processed in Module 1.

While the combined Module 1 and Module 2 facilities are intended to be the functional equivalent of the CH-TRU WRAP facility and RH-TRU Waste Processing Facility described in the HDW-EIS, the Module 2 concept has undergone several changes since the publication of the HDW-EIS because of Hanford Waste Management mission changes. All retrieved TRU waste is suspect TRU waste which is likely to contain some low-level waste (LLW), which must be segregated as part of the processing. Similarly, newly generated waste will be a combination of TRU and LIW. In both cases, the LLW could be mixed with RCRA hazardous constituents to classify them as low-level radioactive mixed waste (LLRMW). 
WHC-SD-WM-RPT-060, REV 0 VOLUME 5

The existing HOW-EIS has been considered adequate to envelope the current WRAP $2 A$ mission and a revision of the HDW-EIS is not proposed at this time.

The retrieval of RMW is assumed to be incidental during retrieval and assay of the TRU waste and suspect TRU waste. The Hanford Defense Waste Environmental Impact Statement does not specifically call for the retrieval or treatment of radioactive mixed waste (RMW), however low-level wastes specifically resulting from the processing of TRU wastes are included. The WRAP Module 2. CDR (WHC-SD-W100-CDR-001, Rev 0), which was written prior to WRAP Module 2 being divided into two functional elements, includes the following paragraph (underline added):

It is known that some of the TRU waste stored at Hanford contains both radioactive and hazardous mixed waste components. In June 1987, DOE relinquished the byproduct exclusion for regulation of mixed waste (MW), making the treatment, storage, and disposal of MW subject to regulation under RCRA. However, none of the solid waste below ground (and some above ground) storage configurations currently used at Hanford meet the minimum RCRA technical requirements for MW storage. Therefore, it is certain that all stored suspect TRU waste will. have to be retrieved, treated (as required), and placed into RCRA compliant storage or disposal facilities (e.g. WIPP). However, Hanford does not have facilities capable of providing the necessary treatment to enable lacing stored wastes in RCRA compliant disoosal configurations.

The "Strategy Assessment Project W100, Waste Receiving and Processing (WRAP) Module 2" document (WHC-SD-W100-ES-005, Rev 0, D.L. Lamberd, Westinghouse Hanford Company, October 1991) recommended that the WRAP Module 2 Facility be divided into smaller functional projects. WRAP Module 2 was split into two separate projects; WRAP Module 2A, and WRAP Module 2B. The primary reason for the split was the large uncertainty regarding WIPP acceptance of the remote-handled TRU waste to be treated in WRAP module 2 . In the current concept WRAP Module 2A will treat non-TRU contact-handled radioactive mixed waste, and WRAP Module 2B will treat remote-handled TRU, remote-handled mixed waste, and pieces too large for WRAP Module 1. Building WRAP Modules $2 A$ and $2 B$ witl satisfy the requirements of the HDW-EIS.

The WRAP $2 A$ Conceptual design report section 5 paragraph 13 reads as follows \{added comments are indented\}:

13. The justification for WRAP Module $2 A$ can be summarized as follows:

a. Low level MW volume currently in storage and forecasted as being generated over the next 30 years totals approximately 820,000 cubic feet of which about 590,000 cubic feet, or about 72 percent, can be treated, certified by WRAP Module 2A for permanent disposal.

b. Due to the deteriorated state of the $\mathrm{CH}$ MW waste drum inventory at Hanford, the WRAP $2 A$ facility is required to mitigate any further 


\section{WHC-SD-WM-RPT-060, REV 0 VOLUME 5}

impacts to the Hanford reservation environment and subsequent increased exposure to personnel during retrieval and handling operations.

c. Between 1992 and the year 2021 (the last year included in the solid waste generation forecasts, WHC $1991 \mathrm{~b}$ and 1991d), projected solid waste generation includes over 520,000 cubic feet of CH MW. WRAP Module 2A is required now to eliminate double handling of this. large solid volume in as much as these wastes do not have to be put in RCRA compliant storage for an indefinite period of time and then later retrieved for treatment and final disposal when a facility like WRAP $2 A$ is built in the distant future.

d. Low level MW is accumulating in storage at Hanford because there is no treatment available for this waste at the present time and it cannot be disposed of without treatment. WRAP Module 2A is the proposed facility that would provide the necessary treatment to reduce the toxicity and mobility of this waste, allowing its disposal in compliance with Washington State/RCRA hazardous waste regulatory requirements.

e. The HDW-EIS ROD (DOE 1988C) identified WRAP as the preferred alternative for treatment of waste stored at Hanford, and committed DOE to building WRAP Module 2A.

Note: This paragraph from the CDR needs clarification. The EIS only addressed low-level mixed waste that specifically resulted from the processing of TRU waste. While this is an important feed stream to. WRAP Module 2A, it is by no means the only feed stream and therefore, the current scope of the WRAP Module 2A Facility is not justified solely based on the HDW-EIS ROD. In order to comply with RCRA however, it is critical to treat all non-TRU low-level mixed waste retrieved as suspect TRU for WRAP 1. There is no available treatment capability at Hanford which will allow RCRA compliant storage or disposal for low-level mixed waste. Furthermore, although DOE was committed to a WRAP Module 2 type facility in the ROD and not specifically WRAP Module 2A, Operation of both WRAP Modules. $2 A$ and $2 B$ will satisfy DOE's commitment under the ROD. The ROD was written before WRAP 2 was divided into two distinct projects.

If WRAP Module 2A is delayed, implementation of this ROD and fulfillment of DOE's obligations will be delayed.

f. The Tri-Party Agreement (TPA 1989) al so committed Hanford and DOE to building WRAP Module $2 A$.

Note: The Tri-Party agreement Milestone $M-19$ requires completion of WRAP Module 2 by September 1999. A change has been requested to divide WRAP Module 2 into 2 projects and delay Completion of WRAP Module $2 B$ until 2002. As the Tri-Party Agreement currently stands however, WRAP Module $2 A$ will satisfy only part of the M-19 
WHC-SD-WM-RPT-060, REV 0 VOLUME 5

Milestone. The milestone will still require completion of WRAP Module $2 B$.

If WRAP Module $2 \mathrm{~A}$ is delayed, implementation of this agreement will also be delayed.

g. Secondary solids from Hanford LETFs [Liquid Effluent Treatment Facilities), the highest volume (55 percent) waste feed stream for WRAP Module 2A, will soon begin accumulating in storage at Hanford because there is no treatment available for this waste. It cannot be disposed without treatment. WRAP Module $2 A$ is the proposed facility that would provide the necessary treatment to reduce the toxicity and mobtlity of this waste by encapsulation, and thus allowing its disposal in compliance with environmental laws and regulations.

WRAP Module $2 A$ is required to treat low-level radioactive and hazardous mixed waste currently in storage and which is forecast to be generated over the next 30 years. The treated waste from WRAP Module $2 \mathrm{~A}$ will require a disposal site.

\subsubsection{Project Scope}

\subsubsection{Waste Types}

Basis: Resource Conservation and Recovery Act (RCRA); Washington State Administrative Code (WAC) 173-303.

Source: Radioactive Mixed Waste Land Disposal Facility FDC

The waste to be disposed in the Radioactive Waste Land Disposal Facility will consist of radioactive mixed waste which has been prepared for disposal in WRAP Module 2A. The WRAP module 2A facility is designed to receive and process contact-handled radioactive mixed waste. This consists of waste which is hazardous and also radioactive. This does not include TRU waste which contains at least $100 \mathrm{nCi} / \mathrm{gram}$ of transuranic elements ( $\mathrm{Np}, \mathrm{Pu}, \mathrm{Am}, \ldots$ ). Contact handled TRU waste drums will be processed and packaged for shipment to WIPP in WRAP 1. Remote handled TRU waste, remote handled RMW, and TRU waste too large for treatment in WRAP Module 1 will be processed and packaged for shipment to WIPP in WRAP Module 28.

"Al1 low-level (radioactive) waste shall be classified according to Category 1, 3, and greater than Category 3 concentration 1 imits defined in table 5-1. Also the radioactive component of all mixed waste shall be classified according to this classification system. Waste shall then be segregated prior to shipment to the burial grounds." (Hanford Site Solid Waste Acceptance Criteria, WHC-EP-0063-3, Will is and Triner, September 1991, page 4-3). All waste in the Hanford Site Central Waste Complex (CWC) will be classified into the three categories above and segregated for disposal. Categories 1 and 3 RMW will be treated in WRAP Module 2A. Segregation of the 


\section{WHC-SD-WM-RPT-060, REV 0 VOLUME 5}

waste exiting WRAP 2A for RCRA compliant disposal is accomplished by NonDestructive Assay (NDA) equipment.

The Hanford classification system (category 1, category 3 , and greater than category 3 ) is loosely modeled on the U.S. Nuclear Regulatory Commission (NRC) $s$ waste classification system ( $C l$ ass $A, c l a s s ~ C$, and greater than class C) (10 CFR 61). The Hanford classification system is based on the preliminary. performance assessment (PA) for the Hanford Site, and may be modified when the final-PA is issued. Also, some nuclides may be added to the list with speciric concentration limits if these nuclides occur in sufficient quantities in the waste streams to be disposed. If such is the case, these limits will be indicated in the appropriate storage/disposal approval records (SDARs). Future revisions of the Hanford Site Solid Waste Acceptance Criteria will reflect these changes. Only radioisotopes with half-lives greater than 5 years will have Category 3 limits. Radioisotopes with half-lives less than 5 years will be considered Category 1 for all curie concentrations.

Only Hanford classification category 1 and category 3 waste is scheduled for treatment in WRAP Module $2 A$ and disposal in Radioactive Mixed Waste Land Disposal Facility. Greater than category 3 waste will be treated and disposed of in other facilities.

After treatment in WRAP Module 2A, segregation of the waste may no longer be required. As part of the Advanced Conceptual Design Report work plan submittal, rev. 1, (United Engineers \& Constructors, Project No. 6237.008. , January 26, 1993) the Solid Waste Program has completed a: preliminary review of NDA requirements and has identified potential changes to the NDA capabilities. The review suggests that WRAP 2A PAN and GEA be eliminated. This is based on the assumption that distinction between Category 1 and Category 3 low level mixed waste need not be made for disposal requirements since the disposal facility would perform adequately for both waste types. 
WHC-SD-WM-RPT-060, REV 0 VOLUME 5

Table 5-1. Radionuclide Concentration Limits.

\begin{tabular}{|c|c|c|c|}
\hline Radionuclide & Half-life $(y r)$ & $\begin{array}{l}\text { Column } 1 \\
\text { Category } 1 \\
\text { Hanford } 1 \text { imit } \\
\mathrm{Cl} / \mathrm{m}^{3}\end{array}$ & $\begin{array}{c}\text { Column } 2 \\
\text { Category } 3 \\
\text { Hanford } 1 \text { imit } \\
\mathrm{Ci} / \mathrm{m}^{3}\end{array}$ \\
\hline$\cdot$. & $1.2 E+01$ & $5 E+00$ & -0 \\
\hline${ }^{14} \mathrm{C}$ & $5.7 E+03$ & $6 E-04$ & $8 E+00$ \\
\hline${ }^{16} \mathrm{C}$ (eot. motel) & $5.7 E+03$ & $6 E-04$ & $8 E+01$ \\
\hline${ }^{60} \mathrm{Co}$ & $5.3 E+00$ & $3 E+02$ & - \\
\hline${ }^{59} \mathrm{Ni}$ (eot. moted) & $8.0 E+04$ & $3 E+00$ & $2.2 E+02$ \\
\hline${ }^{63} \mathrm{NI}$ & $9.2 E+01$ & $2 E+00$ & $7 E+02$ \\
\hline${ }^{63} \mathrm{Ni}$ (ect. motell & $9.2 E+01$ & $2 E+01^{\circ}$ & $7 E+03$ \\
\hline${ }^{90} \mathrm{Sr}$ & $2.8 E+01$ & $5 E-03$ & $7 E+03$ \\
\hline${ }^{94} \mathrm{Nb}$ & $2.0 E+04$ & $8 E-04$ & $2 E-01$ \\
\hline${ }^{99} \mathrm{TC}$ & $2.1 E+05$ & $7 E-03$ & $3 E+00$ \\
\hline${ }^{129}$ I & $1.2 E+07$ & $1 E-03$ & $8 E-02$ \\
\hline${ }^{137} \mathrm{Cs}$ & $3.0 E+01$ & $2 E-02$ & $4.6 E+03$ \\
\hline${ }^{241} \mathrm{Pu}$ & $1.3 E+01$ & $5 E+01^{b}$ & $3.5 E+03^{b}$ \\
\hline${ }^{242} \mathrm{Cm}$ & $4.4 E-01$ & $2 E+03^{b}$ & $2 E+04^{b}$ \\
\hline${ }^{79} \mathrm{Se}$ & $6.5 E+04$ & $7 E-03$ & $7 E-02$ \\
\hline $\begin{array}{c}\text { Alpha-emitting } \\
\text { transuranic } \\
\text { nuclides }\end{array}$ & $>5$ & $10^{b, 0}$ & $100^{b .0}$ \\
\hline
\end{tabular}

A dash indicates no values are provided.

'Expressed in units of nanocuries per gram of waste.

oNumber selected in accordance with already-established limits and definitions.

NOTE: This table is modeled on the waste classification system developed by the NRC in 10 CFR 61 (NRC 1990). These values are upper limit concentrations of specific radionuclides for the INVERSE computer model developed by the NRC. The actual concentration limits for Column 1 are also based on the internal dose models, ICRP-30 and ICRP-48, which have been adopted by DOE for all radiation exposure calculations for internally deposited radionuclides. These limits are numerically smaller than the NRC 1 imits, in part, because the NRC limits are based on the earlier internal dose model ICRP-2. The list of nuclides includes ${ }^{79} \mathrm{Se}$, which may occur in significant amounts in defense waste, but is insignificant in commercial waste. Values for other radionuclides may be identified during the development of the Hanford Site PAs for disposal of waste in these classifications. 
WHC-SD-WM-RPT-060; REV 0 VOLUME 5

\subsubsection{Interfaces}

Basis: Hanford Site Solid Waste Program Plan (WHC-EP-0363)

Source: Radioactive Mixed Waste Land Disposal Facility

5.2.2.2.1 Facilities. Radioactive Mixed Waste Land Disposal Facility will receive packaged waste from Phase $V$ Storage which has been stabilized and packaged in WRAP Module 2A. The Radioactive Mixed Waste Land Disposal Facility is an integral part or the overall solid waste management strategy at Hanford. Other facilities that are a part of this strategy include:

- Hanford Central Waste Complex, Mixed Waste Storage Facility (Project W-016);

- Mixed Waste Disposal Facility (Project W-025);

- Enhanced Radioactive and Mixed Waste Storage Phase V (Project W112);

- $\quad$ WRAP Module 1 (Project W-026);

- WRAP Module 2A (Project W-100);

- WRAP Module 2B (Project W-255);

- Thermal Treatment Facility (Project W-242);

- Liquid Effluent Treatment Facilities (Projects $\mathrm{C}-\mathrm{O}$ - $8 \mathrm{H}$ and $\mathrm{L}-\mathrm{O} 45 \mathrm{H}$ )

The Hanford Central Waste Complex (HCWC), Projects W-112 and W-016 provide buffer and lag storage for waste transfer from WRAP Module $2 A$.

WRAP Module 1 is currently in the detail design phase and provides characterization and certification of CH TRU and LLW, which is either newly. generated or has come from the Retrieval Project. WRAP 1 waste determined to contain hazardous waste fractions requiring immobilization and which are determined to be non-TRU will be treated in WRAP 2A and disposed in Radioactive Mixed Waste Land Disposal Facility. Other LLMW will be stored for treatment in other future facilities.

WRAP Module $2 B$ is a future facility which will provide characterization and certification of TRU and LLW which is too large, too great in radiation levels, or too heavy for WRAP Module 1 processing. WRAP 2B will also process radioactive mixed waste which cannot be handled in WRAP Module $2 \mathrm{~A}$. After processing in WRAP Module 2B the stabilized and packaged radioactive mixed waste is disposed in the Radioactive Mixed Waste Land Disposal Facility.

The Thermal Treatment Facility is a future facility which will provide thermal treatment of waste requiring such treatment, in accordance with 
WHC-SD-WM-RPT-060, REV 0 VOLUME 5

Washington State Administrative Codes (WAC) 173-303. The ash residues from this facility will be treated in WRAP Module $2 A$ and disposed in Radioactive Mixed Waste Land Disposal Facility.

The Liquid Effluent Treatment Factlity (LETF) is a future factlity which will treat 1 iquid effluents from miscellaneous Hanford facilities. Secondary solids from the LETF will be treated in WRAP Module 2A and disposed in Radioactive Mixed Waste Land Disposal Facility.

The interface between the factlittes above and Radioactive Mixed Waste Land Disposal Facilitty is the shipping and receiving area of the Phase $V$ Storage Factlity (W-112 Project).

5.2.2.2.2 Vehicles. Shipments of processed waste from WRAP Modules 2A and $2 B$ will be received from Phase $V$ Storage. This waste will be disposed in the Radioactive Mixed Waste Land Disposal Facility. Coordination between the two facilities will ensure that the vehicle on and off-loading equipment is capable of handling the same waste packages.

5.2.2.2.3 Containers. Current planning calls for all waste treated in WRAP Module $2 A$ to be repackaged into 55 gallon drums. Presumably the 55 gallon drum size for all waste will also be true for WRAP Module 2B. Therefore, all waste received for disposal in the Radioactive Mixed Waste Land Disposal Facility is assumed to be in 55 gallon drums. As stated above the receiving equipment at the disposal site will be sized for 55 gallon drums.

\subsubsection{Project Size}

Basis: $\quad$ The Project size is driven by the volume of material to be disposed.

Source: $\quad$ Radioactive Mixed Waste Land Disposal Facility FDC; Design Report Project W-025 Radioactive Mixed Waste Land Disposal Facility Non-Drag-Off

Radioactive Mixed Waste Land Disposal Facility Functional Design Criteria (FDC) (WHC-SD-WO25-FDC-001, R.A. Cartson, November 1987) Includes the following in Section 1.2:

Project $W-025$ includes design analysis and design report preparation to support future RCRA Part B permit applications for RMW disposal facilities for the following areas: run-on/run-off management, waste disposal cells (trenches), double-liner systens, leachate collection systems, and facility layout. Project $W-025$ also includes civil construction and inspection, liner/waste compatibility, site geotechnical testing analysis and report preparation, liner fabrication/installation, and groundwater well installation. The number of new groundwater wells may be reduced for sites selected within burial grounds covered by the Phase I. groundwater well construction project. 
WHC-SD-WM-RPT-060, REV 0 VOLUME 5

Design and construction of leachate treatment or disposal facilities is not part of project $W-025$

A total required volume of $3,133 \mathrm{~m}^{3}\left(110,600 \mathrm{ft}^{3}\right)$ was 1irted in the FDC. The total required volume was split into two separate trenches, drag-off trench and non-drag-off trench, as a part of the Radioactive Mixed Waste Land Disposal Facility. The non-drag-off disposal trench was required to hold a minimum of $1,870 \mathrm{~m}^{3}\left(66,000 \mathrm{ft}^{3}\right)$ of waste, and The drag-off trench $1,263 \mathrm{~m}^{3}$ $\left(44,600 \mathrm{ft}^{3}\right.$ ) of waste (FDC Section 2.2). The total volume required in the FDC was based on the best available waste volume projections at the time the FDC was written. Since that time the estimated total waste volume to be disposed has increased. The size of the disposal trench has also changed to $7,860 \mathrm{~m}^{3}$ $\left(277,500 \mathrm{ft}^{3}\right)$ to better reflect the current estimates. The current estimate of $277,500 \mathrm{ft}^{3}$ of total storage is conservative and it may be possible to increase the total volume by changing the slope of the trench or by reducing the amount of fill material placed between tiers of drums.

\subsubsection{Project Schedule}

\section{Basis: Hanford Site Solid Waste Program Plan}

Source: Radioactive Mixed Waste Land Disposal Facility FDC; Design Report Project H-025 Radioactive Mixed Waste Land Disposa 1 Facility Non-Drag-Off

The engineering of the Radioactive Mixed Waste facility is currently nearing completion. A bid package will be prepared starting in September 1993 with the bid being opened in November 1993. Construction of the trench will occur starting in February 1994 and is scheduled to be completed by the end of 1994. The readiness review process will begin following the completion of the construction and is expected to take about six months to complete.

Radioactive Mixed Waste Land Disposal Facility is scheduled to be ready to begin accepting waste in mid 1995. A 32 year factlity 1 ife was 1 isted for the Radioactive Mixed Waste Land Disposal Facility in the FDC. Of the 32 years, 2 years were for accepting waste and 30 years were post closure monitoring. Since the Radioactive Mixed Waste Land Disposal Facility will begin accepting waste approximately 4 years prior to the start-up of WRAP Module 2A. The facility life will need to be lengthened to accommodate WRAP Module $2 A$ schedule.

\subsubsection{Facility Expansion}

There are no current designs to expand the scope of Project W-025 to include other trenches. If other trenches are required for radioactive mixed waste disposal following the closure of Project $W-025$, these trenches will be developed and constructed under other project $(s)$. 
WHC-SD-WM-RPT-060, REV 0 VOLUME 5

\subsubsection{Project functions}

\subsubsection{Trench Description}

Bas1s: Solid Waste Program Plan, Solid Waste Forecasts

Source: Radioactive Mixed Waste Land Disposal Factlity FOC; Design Report Project W-025 Radioactive Mtxed Waste Land Disposal Factlity Mon-Drag-off

The Design Report Project W-025 Radtoactive Mtxed Waste Land D1sposal Facility Non-Drag-Off (Golder Associates Inc., Richland Washington, 15 June 1990) includes the following description:

The Non-Drag-Off Landf 111 will be located in the northwest corner of the 200 West Area in the 218-W-5 Burlal Ground between future burial trenches 39 and 47 . The overall factlity measures approximately 450 feet by 300 feet with the landfill's long axis trending east-west. The excavated depth will range from approximately 25 feet at the east end of the floor to nearly 35 feet at the west end. To prevent windblown soll from being deposited in the landfill, the excavation stockplle will be located north of the landfill downwind of the prevatling wind direction. Temporary admix preparation areas will be located south and west of the 1 andfill in proximity to the 1 andfill access ramp during construction.

The trench will be double lined and will include a leachate collection s.ystem in each of the liners. The trench liner and leachate collection system will be discussed in the next two sections of this document.

\subsubsection{Trench liner Systam}

Basis: Resource Conservation and Recovery Act (RCRA); Washington State Administrative Code (WAC) $173-303$

Source: Radioactive Mixed. Waste Land Disposal Facility FDC; Design Report Project W-025 Radioactive Mixed Waste Land Disposal Factlity Non-Drag-Off

The FDC included a requirement that the trenches be double lined. The liner is to be designed, constructed, and installed to prevent any migration of wastes out of the landfill to the adjacent subsurface soli, groundwater, or surface water at anytime during the active and postclosure period of the landfi11. The liner will consist of the following layers from top to bottom:

- Primary Leachate Collection System

- Primary High Density Polyethylene Liner

- Secondary Leachate Collection System

- Secondary High Density Polyethylene Finer

- Secondary admix liner 
WHC-SD-WM-RPT-060, REV D VOLUME 5

WAC 173-303 requires that a mixed waste disposal facility have a liner and double collection system. The primary and secondary liners and leachate collection system are designed to prevent any liquid which leaks into the disposed waste from reaching the surrounding anvironment.

High Density Polyethylene was selected as the liner material because it has the highest chemical resistance of commercially-available liner materials, has been widely used in similar facilities, and has a high level of regulatory acceptance.

\subsubsection{Leachate Collection System}

Basis: Washington State Administrative Code (WAC) 173-303-640

Source: Design Report Project W-025 Radioactive Mixed Waste (RMW) Land Disposal Facility Non-Drag-Off.

The leachate collection and removal system consists of a sump in the polyethylene liner which will collect any liquid which drains into the Land Disposal Facility. Any liquid which collects in the sumps will be drained via a system of pumps to a temporary leachate receiver tank. For most of the life of the waste disposal facility the flow of leachate is expected to be very low, however in the "twenty-four, twenty-five-year" storm the amount of liquid may be significant.

Under normal conditions, the leachate collection system sump will be empty. During precipitation events the sump may fill.

\subsubsection{Project Requirements}

\subsubsection{Permits}

Basis: $\quad$ Resource Conversation and Rec:overy Act (RCRA), and - Washington State Administrat ive Code (WAC) 173-303

Source: WRAP 2A CDR, Volume 1, Section 9.9

The permitting requirements established for WRAP Module $2 A$ will also be applicable to the Radioactive Mixed Waste Land Disposal Facility. WRAP Module 2A CDR, Volume 1, Section 9.9 reads' as follows:

1. The construction and operation of the WRAP Module 2A facility (and Radioactive Mixed Waste Disposal Facility) is subject to several sets of regulations concerning the management of solid wastes. The primary state and federal regulations include the following:

- Dangerous waste regulations

- Air emission regulations

- Other environmental regulations 


\section{WHC-SD-WM-RPT-060, REV 0 VOLUME 5}

2. Section 9.9.1 describes the state and federal waste regulations, section 9.9.2 describes the permitting requirements for a Treatment, Storage and Disposal Facility (TSD), section 9.9.3 describes the air emission regulations and section 9.9.4 1ists other environmenta] regulations applicable to the WRAP Module $2 A$ facility.

\section{State and Federal Dangerous Waste Requlations}

1. The WRAP Module 2A facility (and Radioactive Mixed Waste Disposal Facility) provides the capability to receive containers of contact handled (CH) solid low-level mixed waste (MW) and treat these wastes as necessary to allow certification and permanent disposal in accordance with all applicable DOE orders and other laws, codes and regulations including: WAC 173-303, RCRA, and Hanford site radioactive solid waste acceptance criteria, WHC-EP-0063.

2. The WRAP Module $2 A$ facility will be treating and storing dangerous waste, (and the Radioactive Mixed Waste Disposal Facility will be disposing dangerous waste), therefore, the facility sill be subject to the state-and federal dangerous waste regulations contained in the Washington Administrative Code (WAC) 173-303 Dangerous Waste Regulations and related federal requirements included in title 40 of the Code of Federal Regulations (40 CFR). The state of Washington, Department of Ecology has been granted the authority to enforce both the state and federal regulations for solid waste management.

3. Both 40 CFR part 261 and WAC 173-303 contain lists of chemical compounds or common industrial waste solutions that if present in a solid waste make that solid waste a dangerous waste. The characteristics of dangerous waste include:

- Ignitability

- Corrosivity

- Reactivity

- Toxicity

4. Many of the compounds present in the WRAP Module 2A feedstream exhibit one or more of the dangerous waste characteristics. The disposal of dangerous waste is strictly regulated.

\section{TSD Facility Permitting}

1. WRAP Module 2A facility (and Radioactive Mixed Waste Disposal Facility) is a new TSD facility which will be treating dangerous waste, as such it must receive an interim status permit before any physical construction can start and a final status operating permit before beginning any treatment, storage or disposal activities. The process for both applying. for these permits and for the state of Washington approval is described in WAC 173-303-806. Once granted, DOE owned facilities must operate in accordance with all final status requirements in particular the following: 
WHC-SD-WM-RPT-060, REV 0 VOLUME 5

WAC 173-303-600 Final Facility Standards

WAC 173-303-610 Closure and Post Closure Care

WAC 173-303-630 Use and Management of Containers

WAC 173-303-640 Tank Systems

WAC 173-303-645 Releases from Solid Waste Management Units

\section{Air Emissions Requlations}

1. Emissions from the WRAP Module $2 A$ facility (and Radioactive Mixed Waste Disposal Facility! will be subject to state and federal

regulations governing radioactive and non-radioactive air emissions from processing facilities. Air emissions will also be subject to DOE Orders and WHC policy, which reflect the appropriate local, state and federal regulations.

\section{a. General Regulations}

1) Federal air emission regulations have been implemented in Washington through Chapters 173-400, 173-403, 173-480, and 402-80 WAC. In general, new or significantly modified sources of air emissions at Hanford must file notices of construction (NOCs) with the Department of Social and Health Services (DSHS), Ecology, and Tri-County Air Pollution Control Authority (TCAPCA) before constructing a new or modified source of air emissions.

2) The NOCs will be reviewed to ensure that the proposed facility complies with any applicable New Source Performance Standards (NSPS) contained in 40 CFR Part 60, with applicabie National Emission Standards for Hazardous Air Pollutants (NESHAPs) found in 40 CFR Part 61, and the Best Available Control Technology (BACT), Best Available Radionuclide Control Techinology (BARCT), and Best Available Control Technology for Toxics (T-BACT) have been applied for emissions control. Within 30 days, the appropriate authorities will make a preliminary determination on the acceptability of the proposed new source, and after an appropriate public comment period, authorize construction to proceed. Major stationary sources may emit regulated air pollutants including particulates, nitrogen oxides, volatile organic compounds, sulfur dioxide, or reduced sulfur. compounds including $\mathrm{H}_{2} \mathrm{~S}$ in excess of threshold levels, so the major stationary sources must receive a Prevention of Significant Deterioration (PSD) permit from ecology.

3) A NOC will be required for construction of the WRAP 2A facility, as it will lead to increased air emissions. A PSD permit may be required if sulfide or sulfur dioxide emissions exceed threshold levels.

b. National Emission Standards for Emissions of Radionuclides

Other than Radon from Department of Energy Facilities 
WHC-SD-WM-RPT-060, REV 0 VOLUME 5

1) Radionuclide emissions from DOE facilities are subject to the NESHAP contained in 40 CFR Part 61 subpart $H$, which limits emissions from all sources at a DOE site to an effective offsite dose equivalent of 10 milli irem per year (mrem/yr). Subpart $H$ al so requires that specific monitoring and sampling systems be used for compliance monitoring. This requirement is aiso reflected in DOE Order 5400.5, Radiation Protection of the Public and Environment.

2) The WRAP Module 2A facility (and Radioactive Mixed Waste Disposal Facility) process will be designed and operated to ensure that, as a whole, emissions from the Hanford site do not exceed the $10 \mathrm{mrem} / \mathrm{yr}$ limit. Emission monitoring systems must meet the standards specified in 40 CFR Part 61 Subpart $H$.

\section{c. Washington State Toxic Air Pollutant Regulations}

1) Chapter 173-460 WAC contains limits on emissions of toxic air pollutants (TAPs) from new sources; permission to operate à new source of toxic air pollutants is granted by review of an NOC as described in section 2.2.1. Proposed sources of toxic air pollutants must show, through system mass balances and/or dispersion modeling, that emissions will not violate ambient source impact levels (ASILs) specified in Chapter 173-460.

2) 40 CFR 264 Subpart. AA regulates air emissions from process vents in facilities which treat solutions containing greater than 10 ppmw VOCs by the following processes: distillation, thin-film evaporation, fractionation, solvent extraction, air stripping, or steam stripping. A process vent is defined and "any open-ended pipe or stack that is vented to the atmosphere either directly, through a vacuum producing device, of through a tank (e.g., distillate receiver, condenser, bottoms receiver, surge control tank, separator tank, of hot we11)..." Volatile organic emissions from all process vents must be reduced to less than $1.4 \mathrm{~kg} / \mathrm{hr}$ and $2.8 \mathrm{Mg} / \mathrm{yr}$, or by 95 weight percent through installation of a closed vent system and/or control device. If a closed vent system and control device are installed, the device must meet the performance requirements stipulated in 40 CFR 264.1033. A11 facilities subject to the process vent regulations must meet the monitoring, recordkeeping, and reporting requirements found in 40 CFR 264.1034 through 40 CFR 264.1036.

3) 40 CFR 264 Subpart BB regulates air emissions from equipment leaks in facilities which manage hazardous wastes containing greater than $10 \mathrm{ppmw}$ VOCs. Standard design features, routine maintenance, inspection, and recordkeeping requirements are incorporated into Subpart BB for such items as pumps, compressors, pressure relief devices, sampling stations, and valves. Subpart BB also establishes maximum allowable time-frames for repairs to leaking equipment after such leaks are detected. 
WHC-SD-WM-RPT-060, REV 0 VOLUME 5

4) Regulations proposed by EPA in July 1991 (Federal Register, Volume 56, Number 140, July 22, 1991) may eventually limit VC emissions from tanks, surface impoundments, and containers at RCRA TSD facilities. Under these proposed regulations, any TSD facility which handles hazardous wastes which contain more than 500 ppmw of VOCs must use covered tanks, containers, or surface impoundments, and must route a 11 emissions from these sources to a control device which produces non-detectable VOC content of the waste. This is to be evaluated at the point of generation, or the point where the waste may first come into contact with the air.

\section{Other Environmental Regulations}

1. The WRAP Module 2A facility (and Radioactive Mixed Waste Disposal Facility) will also be required to comply with the following other federal environmental laws:

- Atomic Energy Act of 1954

- Clean Air Act of 1977

- Clean Water Act of 1977

- Endangered Species Act of 1973

- Fish and Wildi ife Coordination Act of 1934

- National Historic Preservation Act of 1966

- Toxic Substances Control Act of 1976

- Wild and Scenic Rivers Act of 1968

\subsubsection{Inspections}

Basis: Resource Conservation and Recovery Act (RCRA); Washington State Administrative Code (WAC) 173-303.

Source: Radioactive Mixed Waste Land Disposal Facility FDC; Design Report Project W-025 Radioactive Mixed Waste Land Disposal Facility Non-Drag-0ff

WAC 173-303-665 Requires that Land Disposal Systems must have a liner with a leachate collection and removal system capable of collecting and controliting at least the water from a "twenty-four-hour, twenty-five-year storm. The liner and leachate collection system in the Radioactive Mixed Waste Land Disposal Facility are expected to be operational for a minimum of 30 years following closure of the facility. Inspection of the leachate collection sumps and sensing equipment will be required following closure as well as during operation. 


\section{WHC-SD-WM-RPT-060, REV 0 VOLUME 5}

\subsection{REFERENCES}

1. Immediate Action Directive No. 0511-21, Atomic Energy Commission, Apri1, 1970.

2. Disposal of Hanford Defense High-Leve1, Transuranic, and Tank Wastes, Hanford Site, Richland, Washington; Record of Decision (ROD), Federal Register Volume 53, p. 12449, Apri1 8, 1988.

3. WHC-SD-W100-ES-001, WRAP 2 Engineering Study, Section 1.0, T.R. Pauly, March 1990.

4. WHC-SD-W113-FDC-001, Rev. 2, Solid Waste Retrieval Facility Phase 1, Project W-113, D. M. Johnson, July 1993.

5. WHC-SD-WM-ES-181, Rev O, ECN Feb 10, 1992, Retrieval of Waste From Alpha Caissons, P. R. Deichelbohrer

6. WHC-SD-WM-RPT-008, Rev 0, Aipha Caisson Data and Evaluation, P. R. Deichelbohrer, December 1990.

7. DOE/EIS-113, Disposal of Hanford Defense High-Level, Transuranic, and Tank Wastes, December, 1987. 
- yuelq qfol KLleuo!quaqu! ә6ed s!4L

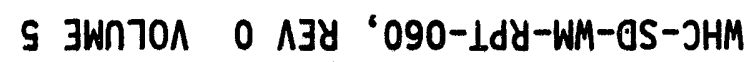


WHC-SD-WM-RPT-060, REV 0

Solid Waste Program

Technical Baseline Description

Volume 6: Uncertainties 


\author{
WHC-SD-WM-RPT-060, REV 0 VOLUME 6 \\ Table of Contents
}

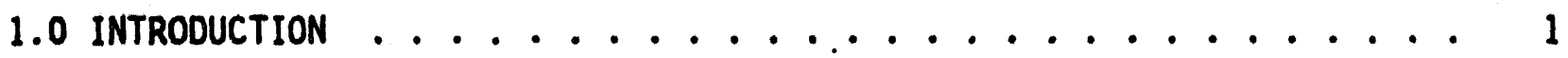

2.0 DOE SYSTEM LEVEL UNCERTAINTIES . . . . • . . . . . . . 6

2.1 DOE POLICY ON THERMAL TREATMENT VERSUS ALTERNATIVE TREATMENT • 6

2.2 LOW LEVEL MIXED WASTE INTEGRATED DEMONSTRATION. . . . . . . 6

2.3 WIPP WASTE EMPLACEMENT..$\cdot \cdot 7$

2.3.1 WIPP Opening Date and Initial Acceptance of Hanford

Waste ............... 7

2.3.2 WIPP Volume Aliocation 8

2.3.3 WIPP Waste Acceptance Rates ..... . ...... 9

2.3.4 WIPP Waste Acceptance Criteria ........... 10

2.3.5 WRAP 1 Operation Before WIPP Certification ...... 11

2.3.6 WIPP Remote Handled Waste Uncertainties ........ . 12

2.3.7 Remote-Handled TRU Waste Storage-Post Treatment . . . . 12

2.3.8 WIPP Alternative Remote-Handled TRU Emplacements . . . 13

2.3.9 Remote-Handled TRU Transportation Casks . ....... 14

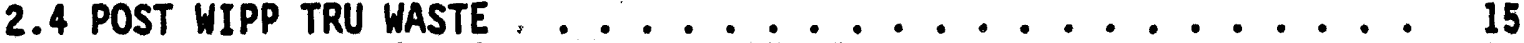

2.5 AVAILABILITY OF CERTIFIED LABORATORIES $\ldots 16$

2.6 FUTURE NATIONAL ENVIRONMENTAL POLICY ACT DECISIONS $\ldots . . . . .16$

3.0 DOE HANFORD SITE LEVEL UNCERTAINTIES . . . . . . . . . . . . 17

3.1 REMOTE HANDLED WASTE AND MATERIALS . . . . . . . . . . . 17

3.2 DOUBLE AND SINGLE SHELL TANK (DST/SST) WASTES . . . . . . . . 19

3.3 WASTE FORECASTS . . . . . . . . . 21

3.4 COMMERCIAL THERMAL TREATMENT FACILITY . . . . . . . . . . 22

4.0 SOLID WASTE PROGRAM LEVEL UNCERTAINTIES . . . . . . . . . . . . 24

4.1 PERFORMANCE ASSESSMENT ................... 24

4.2 "SPECIAL WASTE" .................... 26

4.3 STORAGE CAPACITY ................... 27 

solqe! to 7517

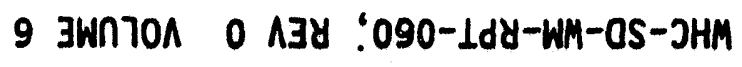


WHC-SD-WM-RPT-060, REV 0 VOLUME 6

\subsection{INTRODUCTION}

This volume addresses uncertainties that were compiled in mid-1993. The status of some of the uncertainties reported herein may have changed since then. As with any large activity, there are many uncertainties, some of which are a major concern requiring immediate action, ranging down to uncertainties that will be addressed during the actual Treatment, Storage and Disposal (TSD) activities in the Solid Waste Program facilities discussed herein. This volume addresses those that are Identifled that require some near term management action, or near term cognizance (should action not be required right away). It should be noted that "uncertaintfes" includes "unknowns" as weil as "alternatives" on which a decision has not yet been made.

The volume is segregated into three sections based on the categorization of the uncertainties. Uncertainties exist at a DOE Complex level, at the Hanford Site level, and at the Sol id Waste Program level. The uncertainties presented here have been organized according to these three levels.

Chapter 2 addresses the uncertainties related to the overall DOE solid waste complex problems as they may impact our planning: For the most part, Hanford staff cannot control these uncertainties, but will react to changes to current assumptions, 1 aws, regulations and guidelines. Hanford staff may be involved in plans to address these uncertainties, but for the most part, Hanford TSD actions will be 1 imited to being cognizant of the decisions made by external (to the Solid Waste Program) influences and adapting to make any required changes. An example of a DOE complex uncertainty would be the potential for changes in the WIPP-WAC to require treatment of mixed waste to land disposal restriction requirements. This change would impact the WRAP Module 1 and WRAP Module 2B scope of work.

Chapter 3 addresses the uncertainties related to Hanford site alternatives. These uncertainties deal with alternatives that are within the control of Hanford, but cross current organizational boundaries. Effort will be required by Sol id Waste staff to resoive these uncertainties, in either a leadership. role or as a team participant. An example of this class of uncertainty would be whether a single facility or multiple facilities to handle all the types of remote-handied wastes and materials that exist at the Hanford Site.

Chapter 4 addresses the uncertainties related to areas within the Solid Waste Program operational scope. The uncertainties include items within a particular project, as well as crossing the boundaries so that two or more projects are involved. Effort will be required by Solid Waste staff to resolve these uncertainties. An example of a Solid Waste Program uncertainty is the Performance Assessment (PA) currently underway for the low level waste burial grounds. Results of the PA will determine what, if any, special disposal methods are required for Category 3, low-level waste. Until the PA is complete, plans for any treatment and disposal of Category 3, low-level waste are uncertain. 
WHC-SD-WM-RPT-060, REV 0 VOLUME 6

Following is a table identifying current waste streams, the primary facility for managing them, and backup plans. This tabulation is provided for both the "baseline" streams and those with more difficult Treatment, Storage, or Disposal requirements. This table is provided here for reference and for review of the potential uncertainties, if any, associated with each of those waste streams. Some of the streains are very small, e.g. the 12 drums of "Pu238." Others are also addressed in specific sections of this Volume.

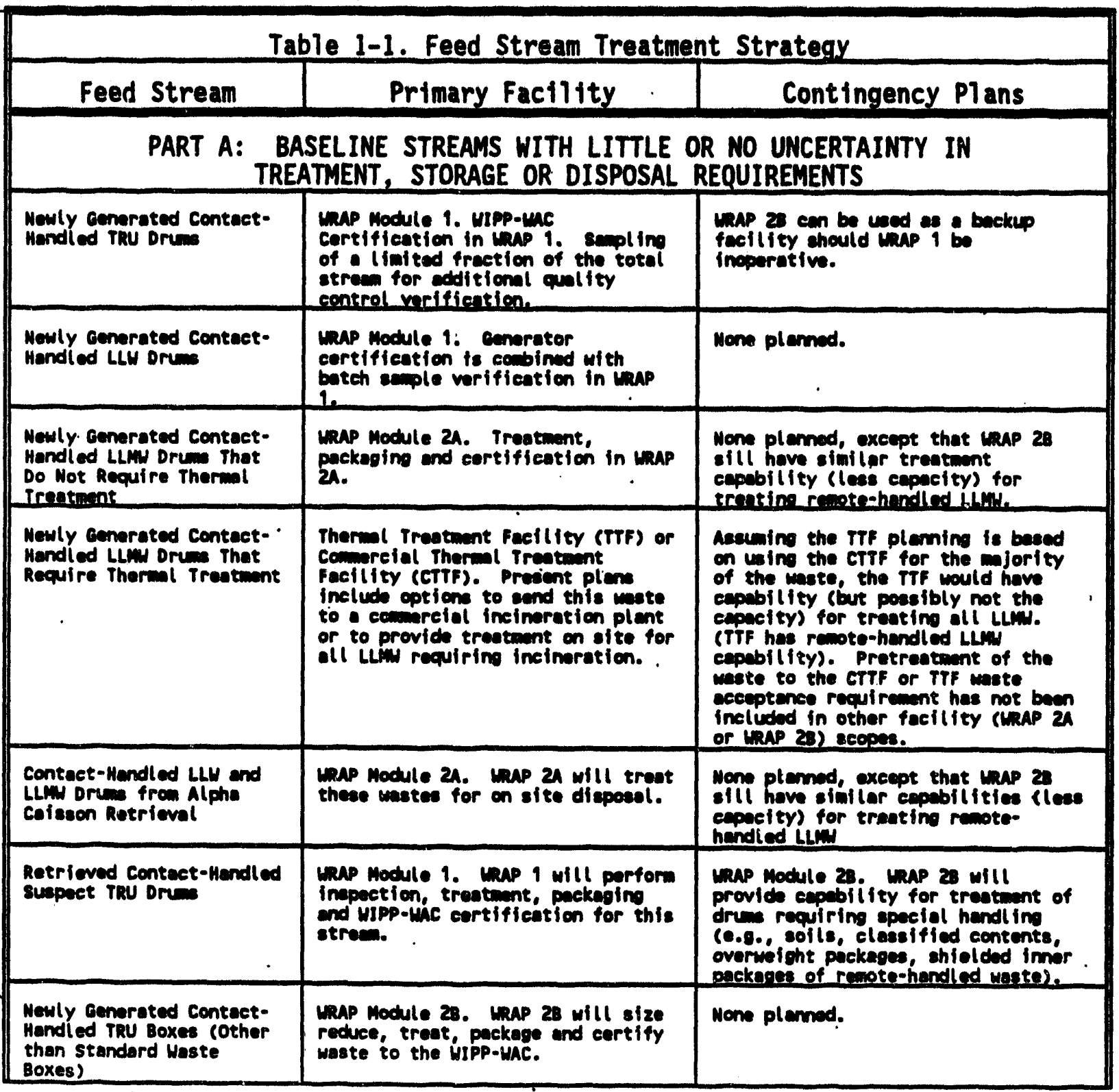




\section{WHC-SD-WM-RPT-060, REV 0 VOLUME 6}

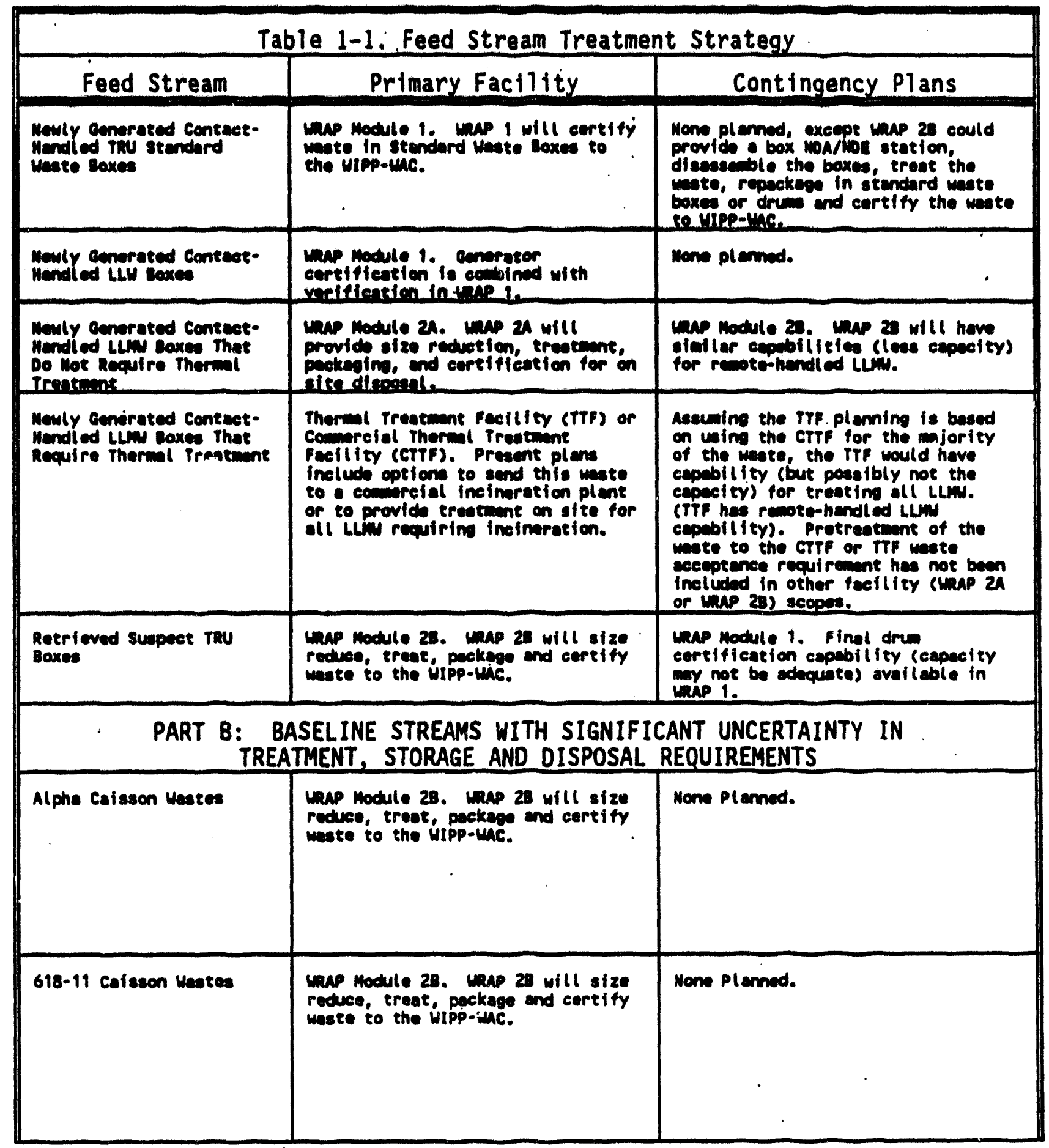




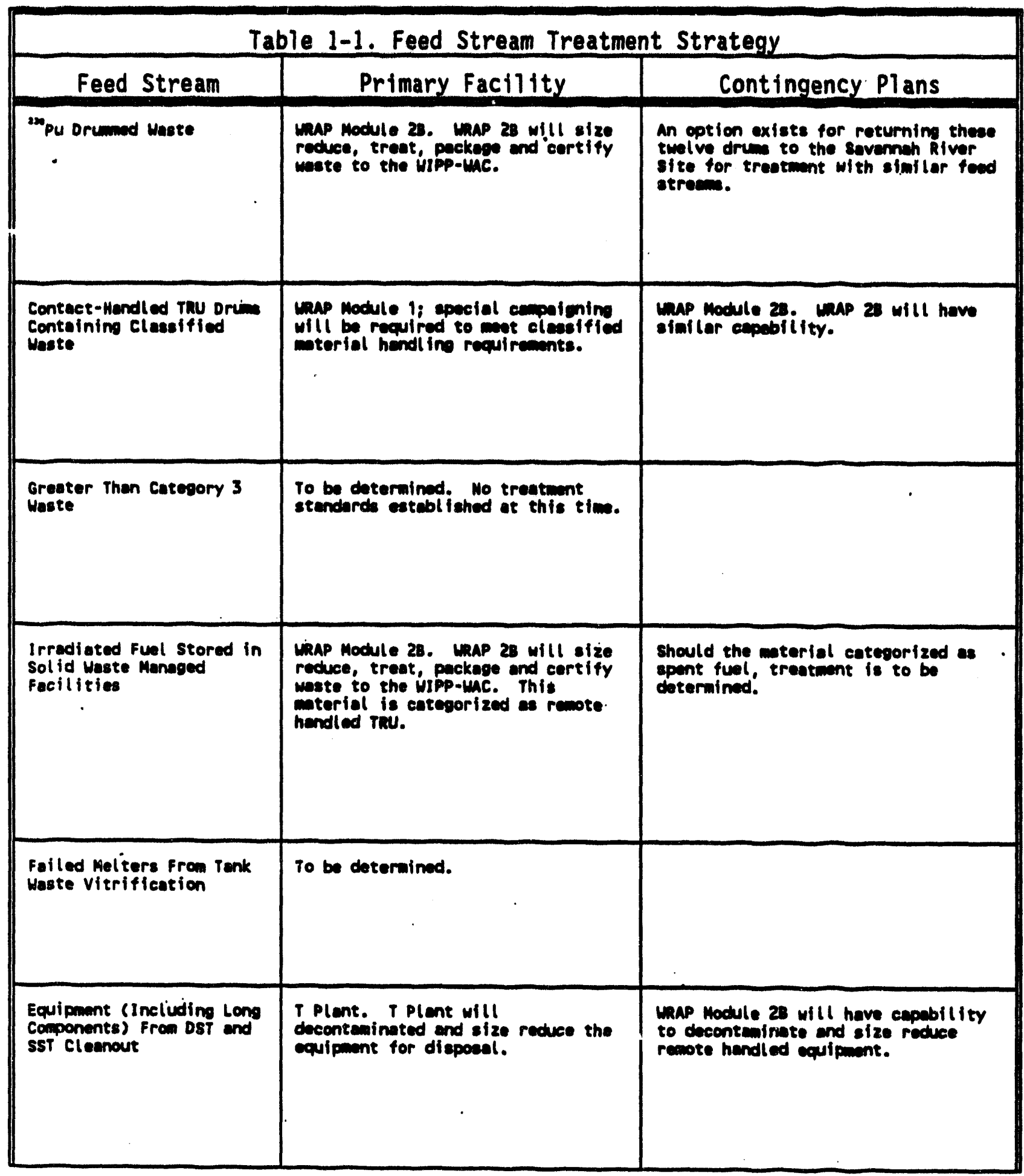


WHC-SD-WM-RPT-060, REV 0 VOLUME 6

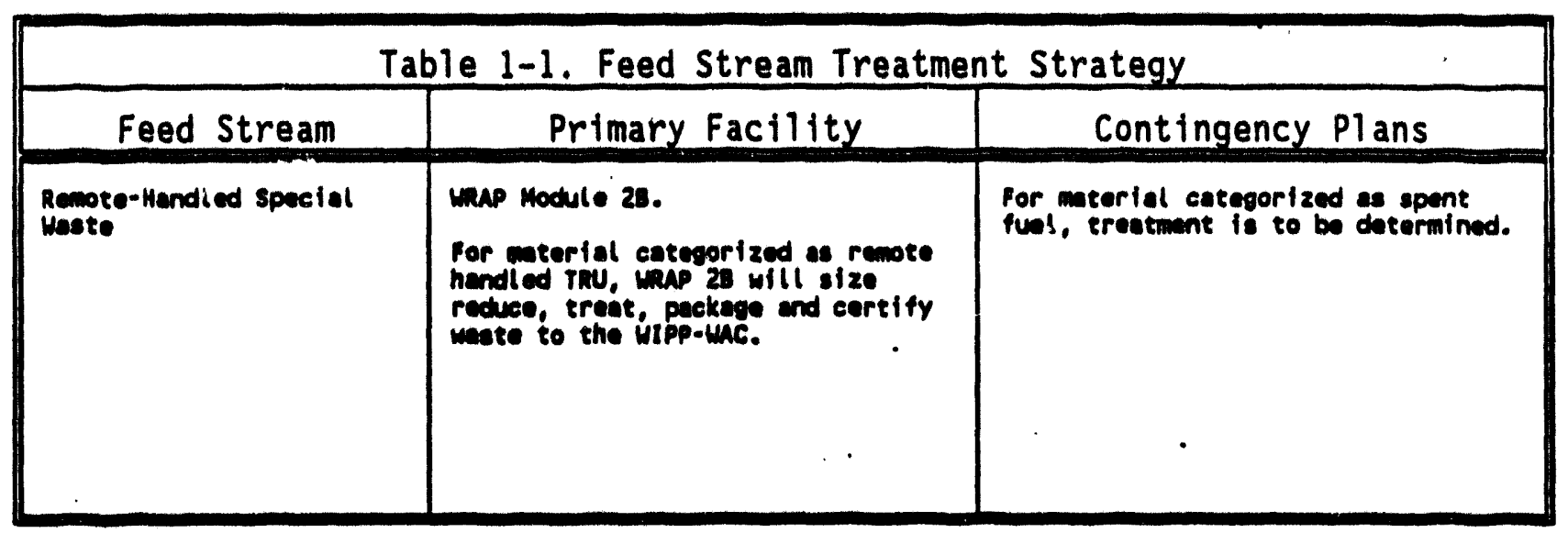



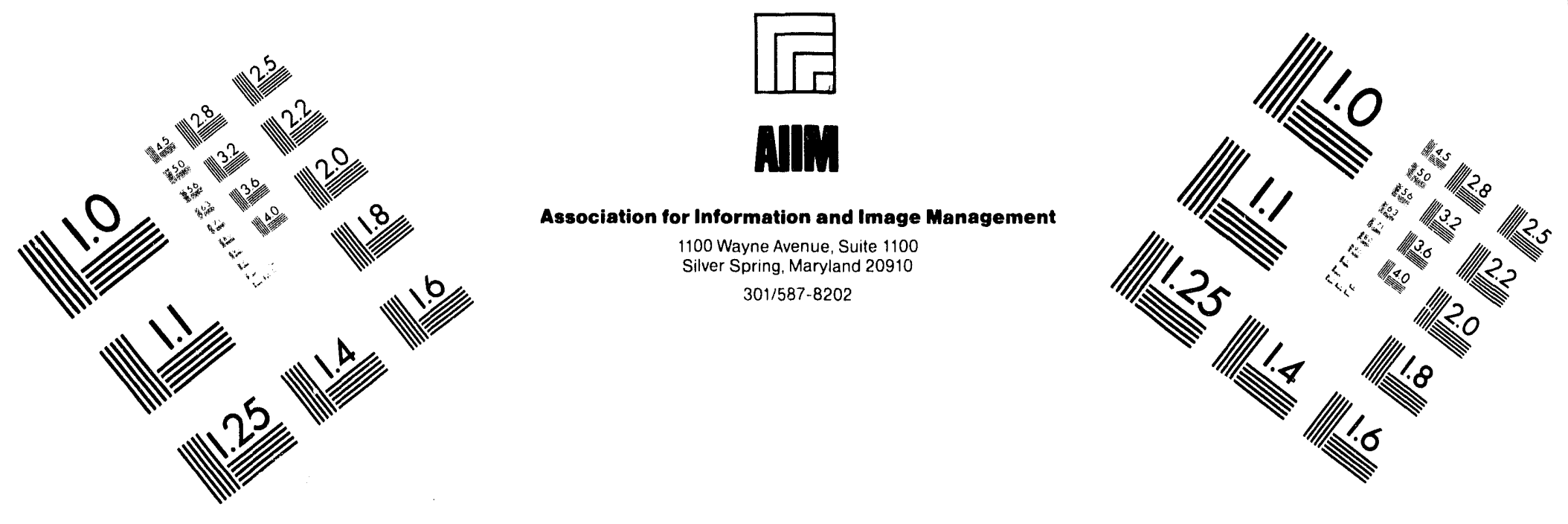

\section{Centimeter}

$\begin{array}{llllllllllllllll}1 & 2 & 3 & 4 & 5 & 6 & 7 & 8 & 9 & 10 & 11 & 12 & 13 & 14 & 15 & \mathrm{~mm}\end{array}$

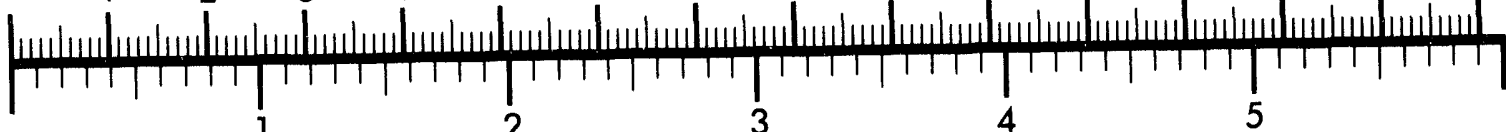

Inches
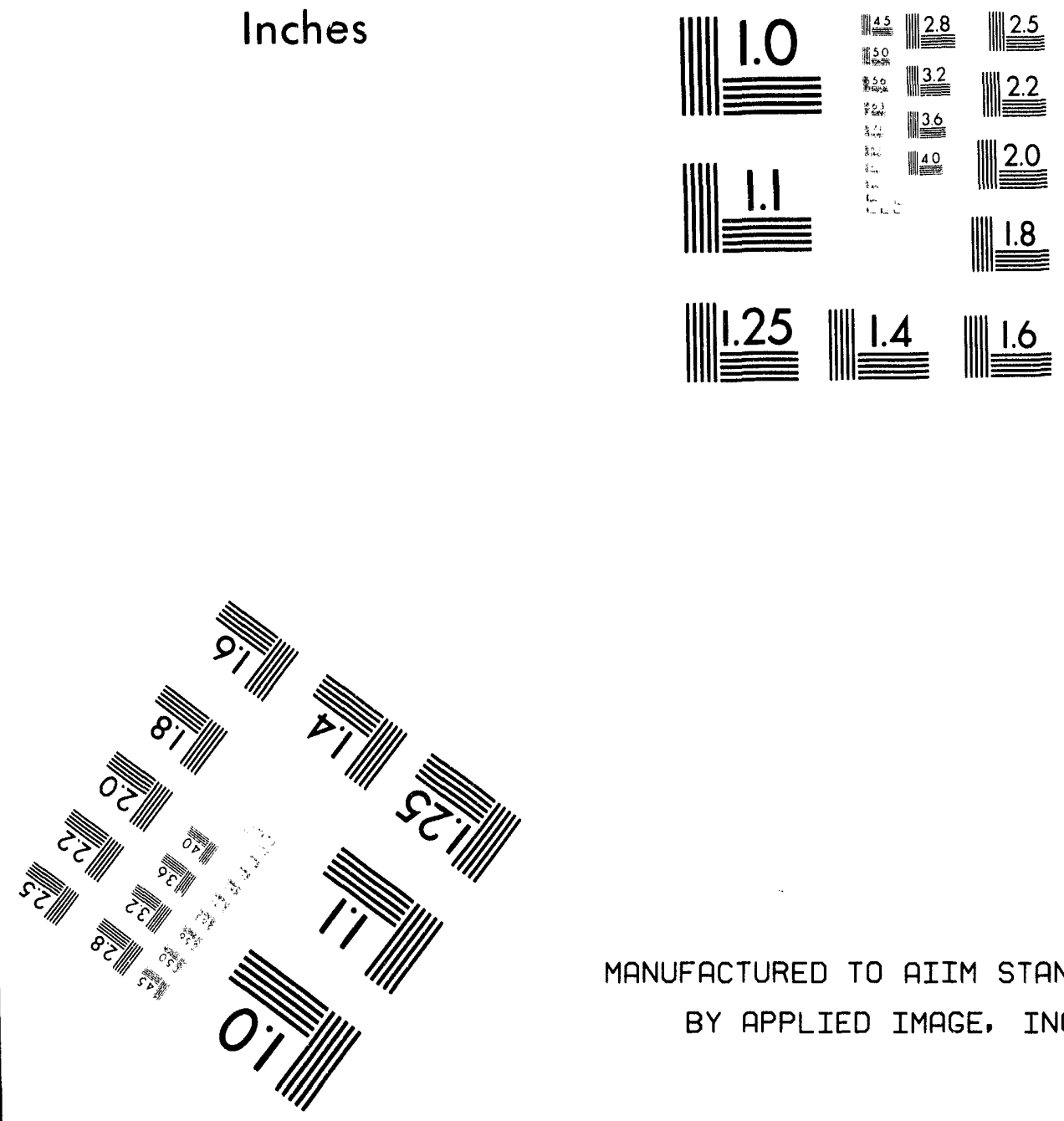

MANUFACTURED TO AIIM STANDARDS

BY APPLIED IMAGE, INC.

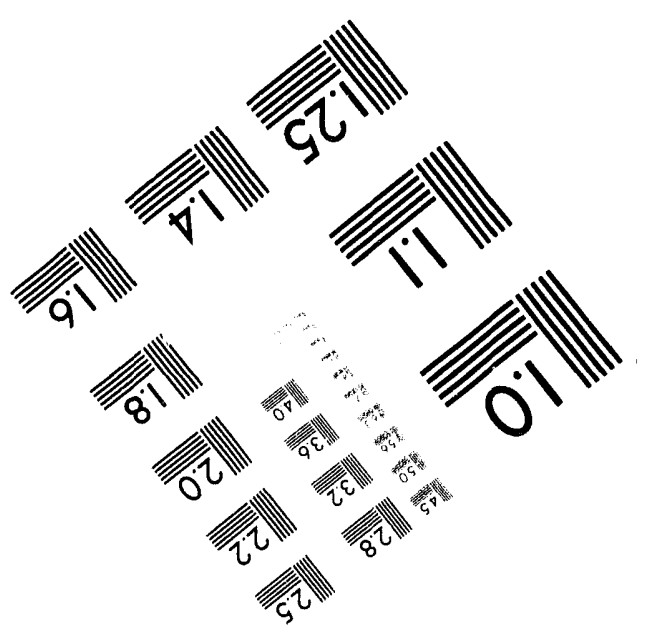



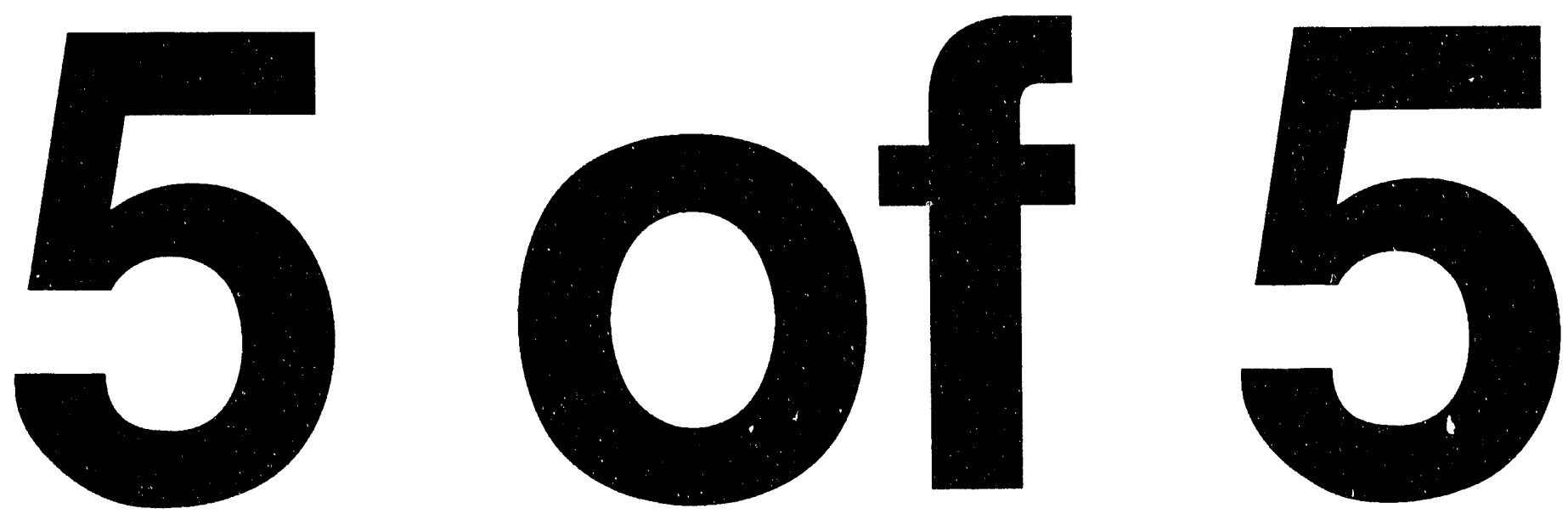
WHC-SD-WM-RPT-060, REV 0 VOLUME 6

\subsection{DOE SYSTEM LEVEL UNCERTAINTIES}

This section summarizes the uncertainties that deal with DOE complex wide solid waste issues. Included in this grouping are alternatives that may be determined by the DOE, WIPP, EPA, WDOE and other outside organizations.

\subsection{DOE POLICY ON THERMAL TREATMENT VERSUS ALTERNATIVE TREATMENT}

\section{Discussion}

The EPA regulations on hazardous wastes require some form of treatment for wastes restricted from direct 1 and disposal in an approved 1 andfill. The treatment depends on the specific hazardous constituent(s) present, but in general terms, treatment can be broadly grouped into thermal destruction of the hazardous constituent or stabilization of the waste to reduce the risk of the contaminant harming the environment. Each hazardous contaminant has at least one treatment code, some have more than one option. The latter option allows the waste treatment organization to select the one that best meets the kind of processing capability that they possess, and which is the most cost efficient.

The DOE Mixed Waste Program Office is in the process of deciding on the national policy that will become a site wide guidance. At this time, the DOE is leaning toward the destruction alternative, in the expectation that this is the alternative that will be received with the maximum amount of support by all the stakeholders in the mixed waste issue. Assuming this.policy is promulgated, then the sites will be required to structure their treatment plans to maximize, to the extent possible by the treatment codes, the thermal destruction of ali LLMW.

Hanford Solid Waste Disposal planning has reviewed both maximizing the thermal destruction and maximizing stabilization approaches. At this time, stabilization is the option being pursued.

\section{Decision Timeline}

No data are currently available as to the DOE decision timeline. Since the TTF is now planned as a '98 or ' 99 Line Item, there are several years before a policy decision would have a cost impact on the TTF financial baseline.

\subsection{LOW LEVEL MIXED WASTE INTEGRATED DEMONSTRATION}

\section{Discussion}

The DOE has several technology demonstration programs underway, one of which is a LLMW Integrated Demonstration. As in all the Integrated Demonstrations, promising technologies related to the TSD activities on the 


$$
\text { WHC-SD-WM-RPT-060, REV } 0 \text { VOLUME } 6
$$

target wastes are evaluated in field demonstrations. Based on this work, recommendations on appropriate technologies for use in treatment and disposal of specific contaminants will be made. It is not known to what degree the application of the recommended technologies will be enforced, but it, is likely that considerable support for the recommended technologies will be forthcoming.

Assuming the extreme, that the recommended technologies will become manuatory, ther it is possible that the sites, including Hanford, will be required to revise their LLMW treatment and disposal plans. The actual degree of variance of Hanford plans from what will result from the Integrated Demonstrations is not possible to forecast.

\section{Decision Timeline}

No data are available as to when, or by how much, the Integrated Demonstration results will impact Hanford TSD planning. Hanford solid waste staff specializing in LLMW TSD planning must keep in communication with the Integrated Demonstration activities and the DOE staffs involved so as to be knowledgeable as to the technologies in demonstration and policy trends.

Any significant redirection will have some impact on WRAP $2 A$. An early redirection would have impacts limited to some cost impact, but later redirection would also impact cost and schedule.

\subsection{WIPP WASTE EMPLACEMENT}

Several uncertainties related to the Waste Isolation Pilot Plant directly impact the Solid Waste Program at Hanford. This section addresses the WIPP opening date, Waste Acceptance Criteria, waste acceptance rates, capacity allocation for Hanford, and WIPP not opening.

\subsubsection{WIPP Opening Date and Initial Acceptance of Hanford Waste}

\section{Discussion}

Based on latest Land Withdrawal Act requirements, the earliest WIPP will be able to accept waste is December, 1999. Recognizing that this is the earliest, and that both internal DOE and external forces may result in a delay, the date for actual waste shipment becomes somewhat questionable. Additionally, the Rocky Flats Plant (RFP) and INEL may receive higher priority in determining waste acceptability for the WIPP site, suggesting that when the plant actually opens, Hanford would not be shipping waste as soon as RFP and INEL.

Using the dates presently in WIPP planning, Hanford is now assuming that WIPP will open to Hanford waste starting after the year 2000. 
Decision Timeline

No immediate action is required by Hanford staff.

\section{Potential Solid Waste Disposal Action}

There are alternatives, but it appears premature to devote much attention to addressing them at this point in the approval of WIPP as a TRU disposal site. The SWPM is the analytical tool that can be used to perform "what-if's" and evaluate alternatives once the alternatives are better defined.

There is some concern that WIPP may not open on the current schedule, or in the extreme case, may never open to accept waste. It might open for some wastes, but not for a 11 wastes. It may open for waste from some sites, but not for wastes from Hanford. All these possibilities exist, with varying degrees of probability.

To evaluate the possible impacts of any delays in accepting Hanford wastes, a "no-WIPP" study is being accomplished. The study will be performed to evaluate the impacts to Hanford if the WIPP site (1) delays opening another 5 years, (2) a total of 10 years or (3) cannot be forecasted to open within our planning window. This study will provide some insight into the alternatives that must be considered in structuring the design and operation of WRAP 1 and WRAP 2B. The study will use the SWPM as an analytical tool to evaluate the effects of delays on SWD areas such as additional storage requirenents.

Once the reference study is completed, it may be appropriate to build in some backup design features or operational plans into the WRAP 1 and WRAP 2B scope.

\subsubsection{WIPP Volume Allocation}

\section{Discussion}

In late 1992, WIPP made an allocation of their 6.2 million cu ft capacity to the various waste shippers. The allocation to Hanford was 868,000 cu ft: Latest SWPM forecasts show that Hanford is essentially at the limit. These forecasts do not include likely major streams, e.g., Plutonium Finishing Plant, PUREX and other canyon building clean out, tank farm cleanup, D\&D wastes, and ER wastes, all of which are potential TRU waste generators.

\section{Decision Timeline}

None required with respect to an allocation change. This is beyond the control of Hanford staff. 
WHC-SD-WM-RPT-060, REV 0 VOLUME 6

\section{Potential Sol id Waste Disposal Action}

New TRUCON codes should be prepared for approval (by WIPP and the NRC) as soon as possible so as to permit WRAP l packaging planning to address the increased $\mathrm{Pu}$ allowed in a drum. The WRAP 1 and WRAP $2 \mathrm{~B}$ staff must be alert to the potential need to minimize the number of drums to be shipped to WIPP. Segregation and selective drum packaging capability, real time assay to improve segregation of LLW from TRU, improved assay accuracy - these are the kind of systems that may be required.

\subsubsection{WIPP Waste Acceptance Rates}

\section{Discussion}

The WIPP facility, like all plants, has a processing throughput $p l$ an and the facility design and equipment capability is targeted to meeting the acceptance and emplacement rates included in the facility planning. WIPP is also chartered with the task of developing and providing the transportation fleet that will receive waste (at the sites like Hanford) and deliver the waste to WIPP.

On the supply side of the equation, sites like Hanford are planning treatment facilities with throughput capacities that are reasonable from the standpoint of site clean out schedules, coupled with an operating window for acceptance of waste by WIPP. The shipping facilities have to have the necessary capability to package and ship their waste to WIPP in a timely manner. The shippers and WIPP must coordinate their efforts to reach a satisfactory solution.

With the changing WIPP schedules, plus changing treatment facility operational schedules (impacted, for example, by funding scenarios at the sites), it is possible that the waste generation rates, and the timing of waste becoming available for shipment, i.e., the Hanford TRU waste workoff plan, may not correspond to the equivalent workoff plans by the other generating sites and the WIPP acceptance plan.

\section{Decision Timeline}

The WIPP acceptance planning is not yet available. It is not possible to evaluate the potential courses of actions with either a waste acceptance rate or transportation availability until WIPP information and plans become firm. It is important the Hanford staff involved in coordination with WIPP matters integrate the SWD workoff plan with the WIPP acceptance plan. The sooner the WIPP planning work is completed, the easier it will be to evaluate our local options and mesh our waste generation with their waste acceptance. This has potential for impacting TRU waste storage capacity. 
WHC-SD-WM-RPT-060, REV 0 VOLUME 6

\section{Potential Solid Waste Disposal Action}

It is not appropriate to produce in-dept planning on the alternatives that may have to be followed should the waste generation time and rate not match the waste acceptance rate by WIPP and it's transportation system. The Hanford Solid Waste Projection Model (SWPM) provides insight into the requirements for acceptance of waste from Hanford, given no restriction by WIPP. The SWPM analytical tool can be used to perform "what-if's" on alternate waste acceptance rates, all of which are likely to increase the need for local storage of TRU drums and SWB's. When WIPP starts addressing the TKU waste work-off planning, Hanford will be an active participant in the planning and negotiation of TRU volume allocations, and acceptance rates.

In the interim, the planning for shipping rates is based on essentially unlimited WIPP transportation capability and receipt rates (i.e., WIPP will accept the waste at the rate it is generated). Facility treatment, storage, and shipping rates are continually reviewed with the use of the SWPM to evaluate the treatment rates versus the inventory and work-off planning.

\subsubsection{WIPP Waste Acceptance Criteria}

\section{Discussion}

WIPP will conduct an extensive test phase prior to opening the facility. WIPP is also having a Performance Assessment prepared (by Sandia National Laboratory specialists). To date, the emphasis by the PA team has been to evaluate the site from the standpoint of release of radionuclides to the environment. One current assumption made by WIPP, and reflected in the latest revision to the WIPP-WAC (Rev. 4) is that WIPP will accept all hazardous co-contaminates with some limited qualifications.

Just recently, Sandia started to evaluate, in the Performance Assessment evaluation, the release of hazardous contaminates to the environment. The initial results strongly suggest that there may be changes required in the waste form or in the facility design, to address release of hazardous contaminants in the long range intrusion scenario (where, after closure, someone drills into or through the salt bed in search of a commercially attractive resource). This suggests that there may be some changes in the future related to waste form, the most likely change being a reduction in the waste that causes gas to be generated.

\section{Decision Timeline}

There is no definite time for any decision to be made with respect to major changes in the WIPP-WAC. Minor changes can be expected on a routine basis up to WIPP startup, but major changes, such as the elimination of metals from the waste form, are not likely to be announced for several years. 
WHC-SD-WM-RPT-060, REV 0 VOLUME 6

\section{Potential Solid Waste Disposal Action}

SWD staff involved in WIPP must keep abreast of the developments in the WIPP-WAC so as to allow Hanford the opportunity to be a constructive participant in any major changes to the WIPP-WAC. Evaluations of the impacts of the waste form uncertainties at WIPP is currently being updated by Solid Waste Programs. This study is expected to be completed by the end of July 1993. The results will be integrated in Solid Waste Disposal planning.

\subsubsection{WRAP 1 Operation Before WIPP Certification}

\section{Discussion}

The current WIPP planning and operations is dedicated to starting up the disposal facility as early as possible, under the latest Congressional mandate, the Land Withdrawal Act for.WIPP. This act has a series of requirements that must be met before WIPP can commence operations. The earliest that WIPP can now accept waste is 12/99. Accordingly, the WIPP staff has discontinued the generator certification program and will not institute it until about a year. before WIPP will start accepting waste from each generator site.

WRAP 1 is scheduled to start operations in 3/97. Two of the three streams that are treated, packaged, certified and shipped are TRU wastes, one being newly generated TRU (.in drums and SWB's), the other being retrieved suspect TRU in drums. The third stream is LLW.

Given that there is no reason to send the newly generated TRU through a WIPP-WAC certification process that does not have WIPP approval, the newly generated TRU drums will simply sit in storage until they can be routed to WRAP 1 for certification. There are no other logical alternatives for the newly generated TRU waste.

\section{Retrieved TRU Alternatives}

Alternative 1 assumes that the WIPP-WAC (in place at the time of initial WRAP 1 operations) will remain valid and it is acceptable to proceed with treating to the then current WIPP-WAC. It assumes that the WIPP will accept the treatment documentation obtained during treatment as acceptable to the latest acceptance criteria.

Alternative 2 assumes that it would be beneficial to perform a sorting and characterization activity on the retrieved drums, as preparation for final treatment. This alternative has the advantage of obtaining further characterization data (which may be required for long term storage in $W-112$ ) and would provide segregation of the TRU wastes into groups more readily suitable for future treatment (e.g., segregate out al1 metals). Additional operational experience in the glovebox system will be obtained. 
Alternative 3 assumes that no suspect TRU (retrieved) drums will be routed through WRAP 1 until the WIPP-WAC is finalized and WRAP I certification is obtained. In this alternative, the retrieved drums are stored in $\mathrm{W}-112$ until treatment is possible. This alternative still allows start up of operation of the glovebox line for equipment checkout and hot startup testing and the operational "ramp up" using newly generated TRU drums.

\section{Decision Timeline}

There is no pressing need to make a policy decision on this uncertainty. No facility design implications are involved. It is important that the policy decision be made well enough in advance of WRAP 1 startup so that the SWD waste work-off planning (as provided in the SWPM) can accurately reflect these decisions.

\subsubsection{WIPP Remote Handled Waste Uncertainties}

\section{Discussion}

The WIPP issues of acceptance criteria, acceptance rates, operational probability, and volume allocation, discussed with respect to contact-handled TRU wastes, apply to the remote-handled TRU wastes as well.

\section{Decision Timeline}

The WRAP 2B facility will be tasked with the task of treating, packaging, certifying and shipping remote-handled TRU waste to WIPP. Additionaliy, as discussed in Section 3.2, the MPSC may accept the task of processing a fraction of the remote-handled TRU waste for disposal at WIPP.

In general, because of the later validation, design, construction and startup of these two facilities (as compared to WRAP 1 processing contacthandled TRU waste), the impact of the uncertainties will be reduced over that presented to the contact-handled TRU waste streams.

\subsubsection{Remote-Handled TRU Waste Storage-Post Treatment}

\section{Discussion}

Storage for treated remote-handled TRU waste needs to be addressed. An evaluation of the amount of storage required for waste that has been treated and is essentially ready to ship to WIPP, should WIPP be delayed, will be required. The amount and type of storage will be a function of:

- the startup time of WRAP 2B (which impacts the waste generation rate to treat the waste within the WIPP receipt window)

- the ability of WIPP to provide shipping casks and trucks the ability of WIPP to accept waste

- the on-site storage of remote-handled waste at WIPP, prior to emplacement the WIPP acceptance window 


\section{WHC-SD-WM-RPT-060, REV 0 VOLUME 6}

- other waste generators and their shipping plans and capabilities and their interferences with our shipments

- projected remote-handled TRU volume

This section assumes that a system study will be conducted to evaluate the alternatives identified herein, plus others that may be developed. The size of the required storage will have to be addressed via a coordinated effort with WIPP staff.

\section{Alternatives}

Alternative 1 provides the necessary storage of canisters and drums within the WRAP $2 B$ facility. This has the advantages of close coupling the treatment, certification, packaging, lag storage and shipping function.

Alternative 2 provides the necessary storage as a separate facility. This has the disadvantages associated with decoupling the storage, but it has a contractual advantage in that the decision on comparatively simple storage can be deferred somewhat over that of the very complex WRAP 2B facility (which will take much longer to design, construct and get operational).

Alternative 3 assumes that the MPSC can be outfitted with the necessary 1 ag storage capability. The MPSC would, under some operational scenarios, have remote-handled TRU shipping capability. The added scope would be simple storage and an added shipping rate capability, but no new basic functions to the facility.

Decision Timeline

With the current DOE and WIPP staff concentration on contact-handled waste, there are no data on when a resolution on the on-site storage needs can be developed.

\section{Potential Solid Waste Disposal Action}

From the standpoint of SWD, the most pressing issue is the definition of the scope of the MPSC, Alternate 3. There is a question as to how much additional information would be required to properly scope the MPSC to fulfill the storage and shipping role. By coordinating with the MPSC staff, development of modularized storage capability, or other built-in facility flexibility, could provide viable management capabilities for this waste stream.

\subsubsection{WIPP Alternative Remote-Handled TRU Emplacements}

\section{Discussion}

The design of the WIPP facility is based on a series of emplacement rooms with each emplacement rooms having the remote-handled TRU waste inserted into the room side walls, followed by filling the room itself with contacthandled TRU waste. The remote-handled waste must be emplaced prior to the 
WHC-SD-WM-RPT-060, REV 0 VOLUME 6

contact-handled waste. The remote-handled TRU program is receiving very little priority within DOE; concentration is on startup with contact-handled TRU wastes. Accordingly, all activities that support contact-handled waste initial emplacement reduces the capacity of the current WIPP reduction in the remote-handled allocation to Hanford.

WIPP is cognizant of the problem and is, on a low priority basis, considering alternatives, including alternate emplacement designs, additional emplacement rooms and the like. Some alternatives may involve revising the remote-handled TRU packaging concepts (e.g., handling drums as opposed to the current plan to handle drums packaged within a canister). No alternatives are being considered at this time that will increase the total remote-handled TRU volume above the current $250,000 \mathrm{cu} f \mathrm{ft}$ limit.

\section{Decision Timeline}

Little action need be taken by Hanford on this issue except to maintain a presence in the remote-handled TRU Task Force and related remote-handled TRU study teams. Hanford has a presence in the Task Force at this time and will maintain this involvement. Studies on some likely alternatives could be conducted as noted above, in anticipation that some action will be required.

\subsubsection{Remote-Handied TRU Transportation Casks}

\section{Discussion}

The WIPP had embarked on a transportation cask for the remote-handled TRU waste. The cask that has been designed (but not approved by NRC) is a cask that holds a remote-handled TRU canister, which in turn holds either 3 drums or undrummed waste of equal volume. The cask is designed to shield the contents radiation to acceptable transportation levels with the canister having hot spots no greater than $1000 \mathrm{R} / \mathrm{hr}$. The canister and the remote welding system to place the head on the canister after loading the waste has been designed and tested (at Hanford by RHO staff). The cask itself and the truck-trailer system have had much work completed on it, but it is not ready for submission to the sites for comment, nor ready for submission to NRC for approval. This work is deferred as WIPF concentrates on contact-handled issues.

Assuming this transportation system is eventually pursued, then the user sites, WRAP $2 B$ and possibly the MPSC at Hanford, will have to provide the appropriate interfaces for receive, operate and load the cask.

Decontamination and servicing of the cask will be necessary, as required.

The cask holds 3 drums of waste. The latest SWPM data suggests that with unlimited transportation and WIPP support, Hanford will have several years of shipping casks at the rate of 600 shipments per year. If WRAP 2B only operates at the $70 \%$ availability factor, this is a rate of 3.5 per day. 
WHC-SD-WM-RPT-060, REV 0 VOLUME 6

Most of the waste is much lower in radiation levels than the cask is designed to accommodate. Accordingly, the remote-handled TRU Task Force Team has recommended that a lower radiation level drum cask be provided. The threshold recommended in $30 \mathrm{R} / \mathrm{hr}$ and the minimum capacity recommended in 6 drums, with 12 drums per shipment desirable. This cask would permit much more efficient loading and shipping of remote-handled TRU drums.

This alternative cask would add a significant amount of additional work on WIPP to redesign their system to accommodate the new cask and drum handling concepts. Nevertheless, since the WIPP is not designed to accept waste at the rate Hanford alone generates remote-handled TRU drums, plus the remote-handled TRU from the other DOE sites, the adaptation to a second cask option may be attractive to WIPP as well.

\section{Decision Timeline}

Should this cask recommendation be pursued by WIPP, then there will have to be two cask interfaces developed, one for the current canister cask concept and one for the new drum cask concept. These interfaces will have to be developed in time to incorporate them into the Title I design requirements for the WRAP. 2B, and possibly for the MPSC.

\subsection{POST WIPP TRU WASTE}

\section{Discussion}

WIPP, by definition, is a pilot scale program designed to evaluate the bedded salt deposits as a final repository for radionuclidic contaminated wastes. It is specifically targeted to TRU waste. WIPP is planning a 20 year operation lifetime, which based on current schedules, stops receiving waste in the year 2018. Cleanup of the Hanford site is likely going to extend beyond 2018. This suggests that there may be TRU waste generated after WIPP closure.

Another geological repository may become available. Above ground storage may be required if another repository is not available. Alternative local treatments (e.g., in-situ encapsulation of canyon buildings) may be acceptable for selected TRU wastes. There are a large number of potential alternatives that will be evaluated in the out years (or if WIPP itself becomes questionable for technical or political reasons).

\section{Decision Timeline}

No immediate action is necessary. Hanford staff involved in TRU planning at the DOE levels should be alert to the possibility that Hanford may have to change treatment planning to a new waste acceptance criteria, or that additional storage may be required until another repository comes on line. 


\subsection{AVAILABILITY OF CERTIFIED LABORATORIES}

\section{Discussion}

Sufficient laboratory capacity, certifiable to WIPP standards, does not now exist within the DOE complex to support the planned storage, treatment and disposal activities. A complex-wide certification plan for upgraded facilities needs to be developed to meet the criteria established by regulators and WIPP. This would allow development, at least on an interim basis, capability of meeting near term neeas. A national strategy for laboratory support needs to be established and implemented.

\section{Decision Timeline}

Operating efficiencies of the solid waste management facilities could be seriously impacted without the availability of certified laboratory facilities. Operation of WRAP I could be impacted, beginning in March 1997. Sample analysis availability may very well be the limiting factor in processing rates.

\subsection{FUTURE NATIONAL ENVIRONMENTAL POLICY ACT DECISIONS}

\section{Discussion}

The "Programmatic Environmental Impact Statement" (PEIS) development that is underway within the DOE complex could provide direction different from that currently within the budget and planning cycles. This potentially impacts all DOE sites, not just Hanford. 
WHC-SD-WM-RPT-060, REV 0 VOLUME 6

\subsection{DOE HANFORD SITE LEVEL UNCERTAINTIES}

This chapter summarizes the uncertainties that deal with Hanford Site issues and the solid waste TSD activities.

\subsection{REMOTE HANDLED WASTE AND MATERIALS}

\section{Discussion}

Baseline pllanning assumes that the four alpha caissons in the 200 West Area that contain TR'S material would be retrieved, processed within WRAP Module 2B and disposed of at WIPP. This material is hot cell waste from research operations on fuel and includes some irradiated fuel elements, irradiated $c l a d d i n g$ and other fuel hardware, plus related hot cell equipment waste contaminated with this high gamma waste. The maximum surface dose rate is reported to be in the range of $1800 \mathrm{R} / \mathrm{hr}$ (at emplacement time).

Project $W-156$ is identified as the retrieval project for the alpha caissons. Historical records indicate that the caissons contain the waste, plus a substantial amount of plastic sheeting that was used in the emplacement process. Latest plans on this project scope include a segregation process prior to shipping the waste to the treatment plant, the sheeting being packaged separately and sent to WRAP $2 A$ (assuming that it is not sufficiently contaminated to be either remote-handled or TRU) and the target waste being routed to WRAP $2 B$ for treatment, packaging, certification and shipping to WIPP.

In the current baseline planning, treatment of this waste stream would be accomplished in WRAP 2B. Project W-156 would fund the development of a single drum transportation cask that would be used to ship the loaded 55 gal drum between the retrieval cell (located over the caisson) and WRAP 2B. Retrieval and shipping would be based on a "pull" concept, in which WRAP 2B operational schedules would set the rate at which the waste left W-156 and went to WRAP 2B. This "pull" approach eliminates the need for above ground storage of the loaded cask and minimizes the number of casks that will be required.

WRAP 2B would be outfitted with the high gamma cells, remote-handled NDE/NDA equipment, remote-handled TRU containerizing equipment and remotehandled TRU cask shipping capability. This equipment would be sized to accommodate all the remote-handled TRU waste forecasted to be treated and shipped to WIPP, not just the much smaller stream from the alpha caissons. The impact of the alpha caisson waste on WRAP $2 B$ is to increase the shielding necessary for handling waste whose radiation level is expected to be up to 100 $\mathrm{R} / \mathrm{hr}$ to a level of up to $2000 \mathrm{R} / \mathrm{hr}$ wherever the high dose rate drums are handled.

Alternatives to the current WRAP 2B scope may evolve from renegotiations of the Tri-Party Agreement. A newly created milestone in the January 25, 1994 


\section{WHC-SD-WM-RPT-060, REV 0 VOLURE 6}

version of the Tri-Party Agreement calls for definition and justification of requirements for storage, processing and disposal of a number of materials and wastes to ensure integration of these needs across the Hanford Site. Specific attention has been paid to remote-handled materials and waste such as: remote-handled alpha caisson waste, irradiated $N$ Reactor fuel, remote-handled D\&D wastes, 618-11 retrieval caisson waste, cesium and strontium capsules, remote-handled solid wastes, and other wastes and materials requiring remote management.

Alternative site configurations to take advantage of combining remotehandled capabilities for these wastes and materials will be investigated as part of the Tri-Party Agreement renegotiations. Alternatives looking at segregated processing (separate facilities), a single facility option, combined services with separate hot cell areas or other combinations may be examined. There is a potential for reduction in the total Hanford Site facility capital costs by combining various high gamma waste in a single high gamma facility capable of handling the various materials and wastes.

Uncertainties related to the various streams include the full spectrum of solid waste issues: waste characterization, volume of waste, determination of waste dofinition (high level versus TRU versus Greater Than Category 3 lowlevel) presence of hazardous constituents and their effect on processing requirements, storage requirements, scheduling of when the waste will require treatment, packaging requirements for storage and shipping, final disposition of the waste.

\section{Alternatives}

Alternative 1 assumes the decision is made to send Solid Waste Program managed remote-handled wastes to WRAP $2 B$. These wastes include the alpha caisson wastes and any forecast remote-handled waste. Alternative 1 also assumes all other programs (Environmental Restoration, Facility Operations, Tank Waste Remediation System) are responsible for providing their own remote-handled storage and processing capability.

Alternative site configurations to take advantage of combining remotehandled capabilities for wastes and materials will be investigated to determine if reduction in the total Hanford Site facility capital costs can be realized.

Alternative 2 assumes a separate remote-handied facility be built for each waste type (high-level, TRU, spent fuel, Greater-Than-Category 3 lowlevel) requiring processing and/or storage.

Alternative 3 assumes a centralized processing facility for all waste types with common use areas and separate processing cells for each waste type.

Alternative 4 assumes a centralized processing facility for all waste types with a multiple-use hot cell area that could be modified to accommodate the various wastes and materials. 
WHC-SD-WM-RPT-060, REV 0 VOLUME 6

\section{Decision Timeline}

A newly created milestone in the January 25, 1994 version of the TriParty Agreement calls for definition and justification of requirements for storage, processing and disposal of a number of materials and wastes to ensure integration of these needs across the Hanford Site. The milestone requires the submittal of a DOE-signed change package for acquisition of new facilities, modification of existing facilities, or modification of planned facilities for storage, processing and/or disposal of solid waste and materials by June 1995 .

\subsection{DOUBLE AND SINGLE SHELL TANK (DST/SST) WASTES}

\section{Discussion}

The cleanout of the DST and SST tanks to remove the liquid and sludge wastes is the responsibility of the TWRS organization. As part of the cleanout, there a many pieces of internal tank equipment that is removed and will need treatment and disposal. This equipment is characterized by being quite long (up to about $60^{\prime}$ in length), frequently quite small in diameter (inches), with internal tubing and piping, contaminated with tank wastes that will result in at least some of the equipment, once it is size reduced to normal waste package size, being a mix of contact-handled and remote-handled wastes in both LLW, LLMW and TRU mixed waste classes. Some equipment consists of pumps and these are similar in length and contamination levels to the thin items, but can be several feet in diameter and much heavier.

The last DST feed stream input to the Solid Waste annual forecast was in 1990; it has not been updated since that time. A comparatively small quantity was estimated. Since then, it is determined that the SST tanks will be Cleaned out as well and the latest estimates of the total number of compunents, including spent pumps used in the cleanout process, will total in the range of 500 units.

The processing of these wastes will take a very large facility, with shielding to levels required to handle components in the $100 \mathrm{R} / \mathrm{hr}$. range. The receiving bay, hot cell airlocks and cutup cells required (in any alternative) will be very large, and therefore capital intensive. It is estimated that up to 500 or so pieces of equipment are-involked in the cleanout, which with a 35 week working year and a work off period of 15 years, is a rate of 1 per week. Simply put, the DST \& SST equipment activity will be a major effort for the selected treatment plant.

\section{Alternatives}

Alternative 1 looks at providing treatment in WRAP 2B. As a remotehandled solid waste, and potentially a TRU waste, the DST wastes are targeted 


\section{WHC-SD-WM-RPT-060, REV 0 VOLUME 6}

to be treated in WRAP 2B. Assuming this is the treatment plant, the wastes would be packaged at the tank farm for long term storage in the 200 West Area storage complex, and later, sent to WRAP 2B for treatment.

Within WRAP 2B, the component will be size reduced, waste characterized, segregated, treated and packaged per the waste class of the component segment in question. The remote-handled TRU fracticn and any contact-handled TRU fraction will be packaged and shipped to WIPP. Any LLW/LLMW fraction (contact-handled and remote-handled) will be treated in WRAP 2B (to the LDR requirements for LLMW) and sent to disposal. (Current WRAP 2A scope has a small volume stream of contact-handled LLMW arriving from WRAP 2B for treatment in WRAP 2A. The projected volume is quite small and since WRAP 2B must have the LLMW capability anyway to address remote-handled LLMW, WRAP 2B scope will assume all this waste is treated in-plant. Later updates of the WRAP 2A streams will delete the feed from WRAP 2B.)

Alternative 1 al so requires the DST/SST components to be packaged for long term storage. The storage will take place in. the Central Waste Complex, specifically Phase I through V storage buildings.

An uncertainty that needs to be addressed is the scope of storage required for these components. This will be a function of the total quantity of components generated and time of generation of the waste, the selected storage location and the treatment facility option selected. Alternative 1 may have the latest startup date of the alternatives now under consideration (about 2006). This would suggest. Alternative 1 might require the largest storage capacity for the DST \& SST components. (The Solid Waste Projection Model [SWPM] is the analytical tool that will evaluate the storage capacity question, once the feedstock volume and timing is supplied by TWRS.)

Alternative 2 looks at providing treatment at the MPSC. The DST and SST equipment can be routed to the MPSC for storage and treatment. The treatment plans would be similar to that described in Alternative 1, except that the contact-handled TRU and remote-handled LLMW streams would, when segregated from the other. waste fractions, be sent to WRAP $2 B$ for final treatment. Any contact-handled LLMW fraction would be sent to WRAP 2A for treatment. Any LLW fraction would be sent direct to the disposal trench (after packaging per WHC-EP-0063).

This alternative would el iminate a substantial feed stream from WRAP 2B, a significant factor not in terms of volume per se, but in terms of facility size.

Presentations by MPSC staff suggest that their proposed plant will be on-line to accept the DST \& SST wastes without requiring any storage. At least until the MPSC comes on line, this is not the case (three components are already in the CWC storage and more have been identified for the near term). The SWPM is the analytical tool to evaluate the alternatives with respect to impacts on storage with the MPSC providing treatment. 


\section{WHC-SD-WM-RPT-060, REV 0 VOLUME 6}

Alternative 3 looks at providing treatment at T-Plant. T-Plant is being proposed to treat some waste, with a particular emphasis on coming on line within the next year or two to address the DST and SST wastes, thereby minimizing the need for providing extra storage capability in the CWC. Assuming alternative 3 is selected, there still are questions that need to be answered dealing with the scope of the treatment versus the total forecasted inventory.

Subsets to this alternative that could be investigated include:

- Operate T-Plant until MPSC comes on line

- Operate T-Plant until WRAP 2B comes on line

- Operate T-Plant until all the waste is treated

- Operate T-Plant to completely process the waste

- Operate T-Plant to perform size reduction function only (see below)

At one time, the T-Plant was also being considered as a preliminary treatment plant, restricted to size reduction, so that the DST/SST components would be packaged in boxes for long term storage, boxes whose size would not require the huge airlocks implied by handling full size components. With the recent identification of hundreds of components, this 1 imited scope

alternative is no longer being actively considered, but should be included in a new overall alternatives evaluation.

As in the other alternatives, the SWPM is the analytical tool that can be used to evaluate the impact on storage (and facility throughput) with the T-Plant alternative.

\section{Decision Timeline}

An Interface Control Document needs to be completed in a time frame that allows the feedstreams and project scope for the facilities be defined to support the Solid Waste Program planning through the budget process.

\subsection{WASTE FORECASTS}

\section{Discussion}

Each year, SWD issues a data call letter to all known or potential suppliers of waste to the SWD operations. One of the purposes of the call letter is obtaining near term information on which to plan next year's operations.

The out-year forecasts are used by SWD to plan the storage, treatment and disposal facility capacities. The analytical tool used in making capacity judgements is the SWPM. The feedstock information used in the SWPM is a combination of actual inventory (the SWITS database) plus the 30 year forecasts. 


\section{WHC-SD-WM-RPT-060, REV 0 VOLUME 6}

Forecasts are "soft" data, as many things can change the waste generation rate. Mission plan changes and funding profile changes are major perturbation over which the forecaster may or may not have any insight.

Future decisions by DOE could add generators to those currently shipping waste from offsite to the Hanford Site, and future cleanup decisions at other sites could increase waste volumes from those that are currently forecast. Standards for waste cleanup, characterization, treatment, or acceptance by offsite facilities are evolving, and changes during the evolution will affect solid waste management plans.

The forecasts for volumes and other characteristics typically are less certain the longer the time frame. With the budget cycle for projects requiring several years froin inception to completion, uncertainties in waste volume forecasts tend to have far reaching effects.

An analysis of actual solid waste receipts versus forecast receipts has been performed for $C Y 1990$ and 1991. For those years, the actual contact-handled LLW receipts were only about one-half of the amount forecast. Low level mixed waste forecasts and receipts were very similar. All receipts for TRU categories and remote handled LLW were much less than forecasts; the total volumes of waste in each category were small, in the tens or hundreds of cubic meters.

With only two years of comparisons of waste receipts versus forecasts, reliable trends cannot be determined at this point. Waste that was forecast, but not shipped, may still be shipped at a later date. The analysis should continue on a yearly basis and consistent directions factored into assessments of forecast accuracies.

Knowledge of the waste characterization has improved markedly during the time period of receiving waste volume forecasts. Additional characterization information is being requested to further refine the expected waste streams. An aggressive "Generator Assistance" program is being employed to further develop knowledge about the potential waste and its characteristics as well as to reduce uncertainties about projected volumes, waste types, and receipt times.

\subsection{COMMERCIAL THERMAL TREATMENT FACILITYY}

\section{Discussion}




\section{WHC-SD-WM-RPT-060, REV 0 VOLUME 6}

An effort is underway to evaluate the option of using a commercial plant to treat LLMW. There are uncertainties related to this potential treatment option; two examples:

1. Will the CTTF accept alpha bearing wastes, or just beta-gamma wastes (which is typical of commercial nuclear operations that may desire or require thermal treatment)?

2. Assuming a CTTF, will this be a viable option for all of the LLMW for as long as we need these services, or will the CTTF only treat a limited amount of LLMW?

Assuming there is a CTTF, additional questions arise:

1. Will the CTTF receive waste "as-is" or will pretreatment be required?

2. What will the CTTF do with material that is not thermally treatable? Return to Hanford? Process it themselves and send it to a commercial disposal site?

3. Will the CTTF return the ash/residue for treatment by Hanford, or will they treat this waste for disposal (at Hanford or at a commercial site)?

4. Will the CTTF accept remote-handled and TRU wastes?

5. Will Hanford thermally treat the maximum amount of waste, or just that required by LDR regulations?

\section{Alternatives}

Alternative 1 is that the CTTF will be viable. It seems appropriate to assume that, given a major capital expenditure to come on line, that the CTTF will be operational for the necessary duration required to treat all the thermally treatable waste at Hanford. It is also assumed that to make this contract attractive, Hanford is sending the maximum amount of material to the CTTF, minimizing the feedstock to WRAP $2 A$ and the TTF.

Alternative 2 assumes that the CTTF does not become viable. In this alternative, the DOE facility will process the thermally treatable waste. off-site.

Alternative 3 uses a regional thermal treatment plan, presumed to be 


\section{WHC-SD-WM-RPT-060, REV 0 VOLUME 6 \\ 4.0 SOLID WASTE PROGRAM LEVEL UNCERTAINTIES}

This chapter summarizes the uncertainties that deal with alternatives under consideration at the Program (i.e., SWD) level.

\subsection{PERFORMANCE ASSESSMENT}

\section{Discussion}

LLW Class III is a LLW that has radionuclide contamination levels that may exceed that allowed on the Hanford site solid waste burial grounds shallow land trenches. The DOE orders require site-specific evaluations of the burial grounds and Hanford has embarked on the necessary 200 West Area burial ground Performance Assessment (PA). Until this is completed, with d 11 appropriate internal and external reviews, there remains an uncertainty as to the viability of using the same disposal methods as LLW-I.

Tentative data suggests that the Hanford arid site will require some special handling of LLW-III wastes. The preliminary data suggest that some combination of deep trenches (the top of the waste being $>5$ meters below the surface), trench covers and waste treatment to stabilize the waste will be required. The preliminary data also suggest that there may be benefits to reactivating a waste class, LLW-II, which be allowing selective contaminants, may be disposed of without any special handling other than placing this waste at the bottom of a LLW-I trench.

Recognizing that the PA is not complete, current practice is to bury the LLW- III wastes in a High Integrity Container (HIC), the HIC providing a minimum of 300 year barrier from water reaching the waste. The HIC containers are costly and consume additional waste trench acreage, so are undesirable from a life- cycle cost basis.

Once the PA is complete, the plans for any treatment and disposal of LLW-III can be completed. For reference, LLW-III stream has been forecasted to be about $1 / 5$ that of the LLW-I volume. It is forecasted to be somewhat greater than the LLMW volumes. WHC-SWD-W100-TA-001 is a study that considered incorporating a LLW-III treatment capability into WRAP 2A. These data may prove useful in evaluating the alternatives. In summary, the uncertainty deals with the question as to the extent of any treatment or special disposal requirements that will be required to meet the Hanford site specific performance requirements.

\section{Alternatives}

Alternative 1 assumes that the PA will show that no special TSD operations are required of LLW-III. Once approved, the waste can be handled like LLW-I, and the use of HIC's discontinued. 


\section{WHC-SD-WM-RPT-060; REV 0 VOLUME 6}

Alternative 2 assumes that the PA will show that special TSD is required, and that the selected treatment is the continuation of the use of HIC's. Generator operations can reduce the volume of waste requiring HIC's to those radionuclides that require HIC's.

Alternative 3 assumes that the PA will show that special TSD is required, and that the selected treatment is stabilization of those wastes requiring extra treatment. As above generator operations can reduce the volume of waste requiring HIC's to those radionuclides that require the stabilization treatment. Alternate 3 assumes that the WRAP 2A facility will be able to process this extra stream volume, probably on off-shifts (with the baseline LLMW being treated on the normal single shift capacity).

Alternate 4 is the same as alternative 3 except that treatment is added to WRAP 2B (because WRAP 2A's capacity is fully utilized with other streams).

Alternative 5 and 6 deal with options related to disposal. Alternative 5 assumes that the waste does not require any special treatment, but must be disposed of in a trench whose upper waste surface is at least 5 meters below grade. Alternative 6 assumes that a closure cover will suffice for the additional protection required.

Alternative 7 is a combination of treatment plus a cover and/or burial below 5 meters.

The PA discussed above may recommend that Hanford re-instate the LLW-II class. By restricting the LLW-II class to selected radionuclides and concentrations, preliminary data suggests that disposal of this waste can be accomplished in a LLW-I trench, but limited to the bottom layer of waste in the trench. By locating the waste there, the intrusion scenarios, plus the waste details, plus the location, may show acceptable results.

Should this be acceptable, then the generators will have the option of further segregation of their LLW into I, II and III classes. This

segregation, coupled with lower waste acceptance costs for the lower classes of waste, will offset segregation costs. The LLW-II waste would require more specialized treatment in the trench disposal operations, but the overall costs would be lower than that required by the deep trench required of LLW-III. These possibilities can be addressed if and when the PA is approved with this alternative provided as an option to disposal. No additional consideration need be given to the LLW-II waste classification at this time.

Decision Timeline

There is no set timeline for resolution of this uncertainty. One can simply continue to operate as-is until the PA is approved and the DOE determines which alternative should be selected.

The PA task force is currently planning to release the initial draft of the report for peer review by early summer 1993. Assuming a reasonably prompt 
WHC-SD-WM-RPT-060, REV 0 VOLUME 6

response and some additionally analytical studies, the PA could be released for DOE consideration a year later. Action by DOE could be forecasted to take some time, say a year, or by the start of FY 1996.

At this time, should the selected alternative involve disposal options (Alternatives $1,2,5 \& 6$ ), these would be implemented without impacting a treatment plant. Should the selected alternative involve treatment, WRAP 2A will be quite far along in design and it is unlikely that the treatment capability would be incorporated into that facility. This suggests that the LLW-III treatment would be incorporated into WRAP $2 B$.

The treatment might be incorporated into WRAP $2 A$ if the required treatment uses essentially the same technology and equipment as that already in the facility for the LLMW treatment. In this case, the LLW-III volumes could be incorporated into the WRAP $2 A$ waste stream, with the extra workload being addressed via operation of the WRAP $2 A$ facility on a multi-shift basis. (It is just this kind of situation that prompts Hanford to initially scope the facilities on a single shift, 5 day a week basis. Waste volume is more likely to grow than to reduce and multi-shift operations can increase the plant real capacity (over the single shift nameplate value) by a factor up to $420 \%$.

\section{2 "SPECIAL WASTE"}

\section{Discussion}

The waste discussed herein is waste from the 300 Area hot cell laboratories that is contaminated with residue from the fuel research operations, experimental waste from waste treatment research activities, and irradiated fissile material used in research and development activities. This has been called "Special Waste", primarily because it is a mix of materials. The waste is characterized by having a high gamma dose rate and will require significant amounts of shielding, once it is removed from the hot cells. It is all remote handled waste.

Project W-272, "Special Case Waste Storage," is a storage system that provides the design for an above ground storage complex for this material. It consists of a pad, plus the design for the actual waste canister, canister welding system, canister transportation system and the storage module. Oniy the pad is provided in the project; the rest of system is selected (a specific vendor and design), but not provided. Some equipment, such as the transporter, could be leased from the selected vendor.

With the waste being a mixture of various wastes, identification of the canisters will allow segregation of the waste for storage. Transfer, then, of specific canisters on a case-by-case basis could be easily accomplished from the storage pad to an appropriate treatment facility. 
WHC-SD-WM-RPT-060, REV 0 VOLUME 6

\section{Decision Timeline}

The decision on the destination of this waste for treatment, will be determined when the treatment approach is defined.

\subsection{STORAGE CAPACITY}

\section{Discussion}

The current data resulting from the SWPM analyses suggests that the peak storage needs will exceed the combined capacity provided in the SWOC. In addition, some of the potential waste streams are not well identified at this time. There is an uncertainty regarding the ER and D\&D activities and the potential for SWD to receive some of that waste. It is very possible that the rate of waste acceptance will exceed the ability of the treatment plants to process the waste.

SWPM evaluations of multi-shift operations of the treatment plants served to mitigate some of the storage problems, but a dominant factor in storage needs is the startup dates for WRAP $2 B$ and for the TTF.

The duration required for characterization sample analys is turnaround time is extremely important to the operational planning for the Solid Waste Operations Complex, especially storage capacity. For example, consider this operational scenario:

1. Waste batch is made up on the basis of SWITS records.

2. Selection is made of the drums from which the batch contents verification is to be made.

3. Selected drums sent to WRAP 2A for sampling.

4. Samples taken and sent. to laboratory for analysis.

5. Drums repackaged, returned to $W-112$ for storage.

6. Sample data is obtained at the target 100 days after receipt at the laboratory. This is almost 5 months after the batch makeup was prepared.

7. The entire batch can now be schedule for treatment in WRAP $2 A$ (assuming the samples verify the manifest contents).

8. Waste batch sent to WRAP 2A.

9. Waste is grouted. Grout samples taken for QC verification of process control. Samples cured standard 38 days, then sent to Taboratory.

10. Grouted drums stored for several days in WRAP 2A, then sent to $W-$ 112 for long term storage pending results of grout sample.

11. Grout samples run through QC tests, including long term leach test.

12. Samples approved. Batch released.

13. Grouted drums pulled from storage and sent to LLMW trench. 


\section{WHC-SD-WM-RPT-060, REV 0 VOLUME 6}

This kind of operational scenario suggests that a batch of waste could be in storage for almost a year, most of the time awaiting data from the laboratory. Obviously any reduction in laboratory turnaround time will have a significant impact on the need for storage support.

\section{Decision Timeline}

An evaluation of the impacts of the laboratory turnaround time should be accomplished as early as possible. Based on the current SWPM data, refined data on storage will be needed within a couple of years.

Current data suggests that new storage will be required in the 2005 time frame and a ' 99 Line Item is suggested as appropriate for the additional buildings. This allows a few years to continue to evaluate the waste arrivals and waste forecasts, and generally refine our modeling and forecasting abilities. 

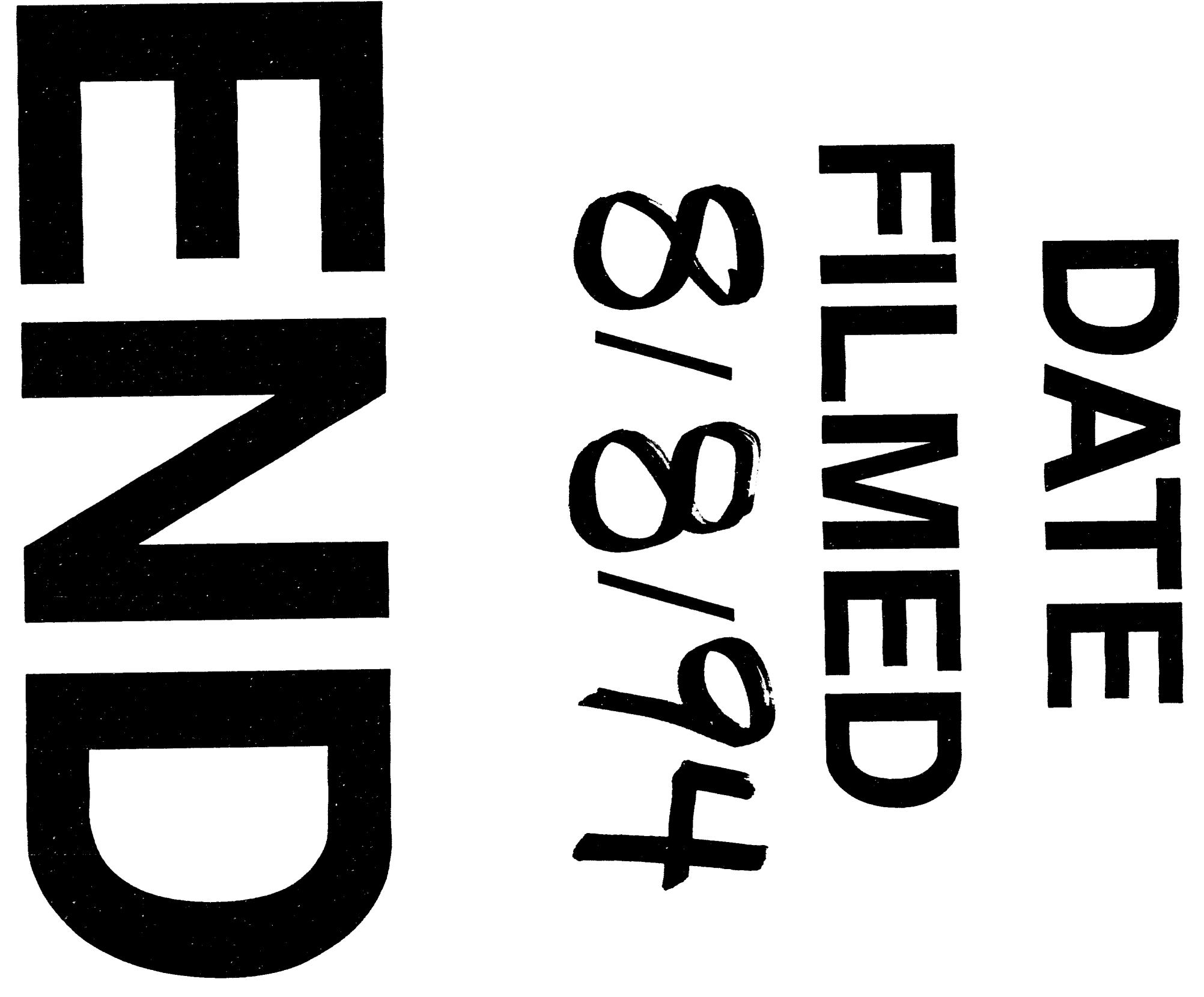
